Central European Jewish Émigrés and the Shaping of Postwar Culture: Studies in Memory of Lilian Furst (1931-2009)

Edited by

Julie Mell and Malachi Hacohen

Printed Edition of the Special Issue "Between Religion and Ethnicity:

Twentieth-Century Jewish Émigrés and the Shaping of Postwar Culture"

Published in Religions

www.mdpi.com/journal/religions 
Julie Mell and Malachi Hacohen (Eds.)

Central European Jewish Émigrés
and the Shaping of Postwar Culture:
Studies in Memory of Lilian Furst (1931-2009) 
This book is a reprint of the special issue that appeared in the online open access journal Religions (ISSN 2077-1444) in 2012 (available at:

http://www.mdpi.com/journal/religions/special_issues/jewish-emigres).

Guest Editors

Julie Mell

North Carolina State University, History Department

Raleigh, NC, USA

Malachi Hacohen

Duke University, History Department

Durham, NC, USA

Editorial Office

MDPI AG

Klybeckstrasse 64

Basel, Switzerland

Publisher

Shu-Kun Lin

Production Editor

Martyn Rittman

\section{Edition 2014}

MDPI • Basel • Beijing

ISBN 978-3-906980-57-7

(C) 2014 by the authors; licensee MDPI, Basel, Switzerland. All articles in this volume are Open Access distributed under the Creative Commons Attribution 3.0 license (http://creativecommons.org/ licenses/by/3.0/), which allows users to download, copy and build upon published articles even for commercial purposes, as long as the author and publisher are properly credited, which ensures maximum dissemination and a wider impact of our publications. However, the dissemination and distribution of copies of this book as a whole is restricted to MDPI, Basel, Switzerland. 


\section{Table of Contents}

List of Contributors

Malachi Hacohen (Ed.)

Preface IX

\section{Daniel Bessner}

Rather More than One-Third Had No Jewish Blood": American Progressivism and German-Jewish Cosmopolitanism at the New School for Social Research, 1933-1939

Reprinted from Religions 3 (2012): 99-129; doi:10.3390/rel3010099 1 http://www.mdpi.com/2077-1444/3/1/99

\section{Matthias Bormuth}

Meaning in History-A Comparison Between the Works of Karl Löwith and Erich Auerbach

Reprinted from Religions 3 (2012): 151-162; doi:10.3390/rel3020151 33 http://www.mdpi.com/2077-1444/3/2/151

\section{Malachi Haim Hacohen}

Typology and the Holocaust: Erich Auerbach and Judeo-Christian Europe Reprinted from Religions 3 (2012): 600-645; doi:10.3390/rel3030600.... 45 http://www.mdpi.com/2077-1444/3/3/600

\section{Avihu Zakai and David Weinstein}

Erich Auerbach and His "Figura": An Apology for the Old Testament in an Age of Aryan Philology

Reprinted from Religions 3 (2012): 320-338; doi:10.3390/rel3020320 92 http://www.mdpi.com/2077-1444/3/2/320

\section{Adi Gordon and Udi Greenberg}

The City of Man, European Émigrés, and the Genesis of Postwar Conservative Thought

Reprinted from Religions 3 (2012): 681-698; doi:10.3390/rel3030681 http://www.mdpi.com/2077-1444/3/3/681 


\section{Julie Mell}

Twentieth-Century Jewish Émigrés and Medieval European Economic History

Reprinted from Religions 3 (2012): 556-587; doi:10.3390/rel3030556

http://www.mdpi.com/2077-1444/3/3/556

\section{David Kettler and Volker Meja}

Karl Mannheim's Jewish Question

Reprinted from Religions 3 (2012): 228-250; doi:10.3390/rel3020228 163

http://www.mdpi.com/2077-1444/3/2/228

\section{Arie M. Dubnov}

What is Jewish (If Anything) about Isaiah Berlin's Philosophy?

Reprinted from Religions 3 (2012): 289-319; doi:10.3390/rel3020289 186

http://www.mdpi.com/2077-1444/3/2/289

\section{Ofer Ashkenazi}

Homecoming as a National Founding Myth: Jewish Identity and German Landscapes in Konrad Wolf's I was Nineteen

Reprinted from Religions 3 (2012): 130-150; doi:10.3390/rel3010130

http://www.mdpi.com/2077-1444/3/1/130

\section{Birgit Lang}

Haunted Encounters: Exile and Holocaust Literature in German and Austrian Post-war Culture

Reprinted from Religions 3 (2012): 424-440; doi:10.3390/rel3020424 238 http://www.mdpi.com/2077-1444/3/2/424

\section{Lilian R. Furst and Anabel Aliaga-Buchenau}

Growing up in Wartime England-A Selection from "The Rachel Chronicles: A Kind of Memoir" 


\section{List of Contributors}

Ofer Ashkenazi is a senior lecturer in the Department of History and the School of Arts at the Hebrew University, and the director of the Richard Koebner Minerva Center for German History. He is the author of Weimar Film and Modern Jewish Identity (PalgraveMacmillan, 2012) and A Walk into the Night: Reason and Subjectivity in Weimar Film (Am-Oved, Hebrew, 2010).

Daniel Bessner is currently Assistant Professor in the Henry M. Jackson School of International Studies at the University of Washington. He received a Ph.D. in history from Duke University in 2013, and his forthcoming book manuscript, currently titled "The Rise of the Defense Intellectual: Hans Speier and the Transatlantic Origins of the Cold War", is under contract with the United States in the World series at Cornell University Press.

Matthias Bormuth, born 1963, is Heisenberg-Professor for Comparative Intellectual History at the Institute for Philosophy at Oldenburg University, Germany. He is the author of Life Conduct in Modern Times: Karl Jaspers and psychoanalysis (Springer, 2006) and Mimesis und der christliche Gentleman: Erich Auerbach schreibt an Karl Löwith (Keicher, 2006).

Anabel Aliaga-Buchenau is Associate Professor of Comparative Literature and German at UNC Charlotte. She currently serves as Associate Chair of the Department of Languages and Culture Studies. She works on narratives of nineteenth-century German immigrants to the Americas.

Arie M. Dubnov is a Senior Lecturer at the School of History and the Department of General History at the University of Haifa, Israel. Dubnov holds a Ph.D. from the Hebrew University of Jerusalem, is a past George L. Mosse Fellow at the University of WisconsinMadison, and prior to his arrival to Haifa had taught at Stanford University. Dubnov's fields of expertise are modern Jewish and European intellectual history, with a subsidiary interest in nationalism studies. He is the author of Isaiah Berlin: The Journey of a Jewish Liberal (Palgrave Macmillan, 2012), and he also edited the collection [in Hebrew] Zionism - A View from the Outside (The Bialik Institute, 2010), seeking to put Zionist history in a 
larger comparative trajectory. In addition, Dubnov has published essays in journals such as Nations \& Nationalism, Modern Intellectual History, History of European Ideas, The Journal of Israeli History.

Lilian Furst (1931-2009) was the Marcel Bataillon Professor of Comparative Literature at the University of North Carolina Chapel Hill until her retirement in 2005. Among her many publications are Before Freud: hysteria and hypnosis in later nineteenth-century psychiatric cases (2008), Romanticism in Perspective: A Comparative Study of aspects of the Romantic Movements in England, France, and Germany (1969), and her fatherdaughter memoir Home is Somewhere Else (1994). As a Central European émigré whose intellectual work helped shape the field of comparative literature, her unpublished memoirs are included here in the volume dedicated to her memory.

Adi Gordon teaches Jewish and intellectual history at Amherst College. He is the author of "In Palestine. In a Foreign Land": The Orient. A German-Language Weekly between German Exile and Aliyah (Jerusalem 2004 [Hebrew]) and the editor of Brith Shalom and Bi-National Zionism: “The Arab Question” as a Jewish Question (Jerusalem 2008 [Hebrew]). His peer reviewed publications include articles in The Journal of Contemporary History, The Leo Baeck Institute Year Book, and the Tel Aviver Jahrbuch für deutsche Geschichte. His forthcoming book is an intellectual biography of Hans Kohn.

Udi Greenberg is an assistant professor of European history at Dartmouth College. He is the author of The Weimar Century: German Émigrés and the Ideological Foundations of the Cold War (Princeton University Press, 2014). He is also the author of several essays on European thought, the Cold War, and film. He is currently working on a book length project on the transformation of European Christianity and decolonization.

Malachi Haim Hacohen is Bass Fellow \& Associate Professor of History, Political Science and Religion, as well as Chair of the Council for European Studies, at Duke University. He has published on the Central European Jewish intelligentsia, Cold War liberalism, nation state and empire in Jewish history, and cosmopolitanism and Jewish identity. His Karl Popper - The Formative Years, 1902-1945 (Cambridge University Press, 2000; paperback 2002) won the Herbert Baxter Adams Prize of the AHA for the best book in European History and the Austrian Victor Adler State Prize. He has published essays in The Journal of Modern History, The Journal of the History of Ideas, History and 
Theory, History of Political Economy, Jewish Social Studies, and numerous other journals and collections. He is completing a book: "Jacob \& Esau between Nation and Empire: A Jewish European History." He has been a recipient of the Frederick Burkhardt Fellowship from the ACLS, as well as of Fulbright, Mellon, and Whiting fellowships and a number of teaching awards. He was a fellow at the Center for Advanced Studies in the Behavioral Sciences in Stanford, the National Humanities Center and at the IFK (Internationales Forschungszentrum Kulturwissenschaften) in Vienna.

David Kettler, born 1930 in Leipzig, Germany, emigrated to the United States in 1940. $\mathrm{He}$ is Research Professor in Social Studies at Bard College (New York) and Professor Emeritus in Political Studies at Trent University (Ontario). Apart from a specialized series on Eighteenth-Century Scottish moral philosophy and another on the politics of labor law, Kettler's publications deal with the "Weimar generation" of social theorists in Germany and in exile, notably Karl Mannheim and Franz L. Neumann. The unifying theme is the problem of intellectuals as a distinct historical social formation, especially the special characteristics of its styles of thought.

Birgit Lang is Senior Lecturer in German at the School of Languages and Linguistics at the University of Melbourne. She has published widely in the fields of German cultural history and literature, with a special focus on and exile and émigré literature and culture and on the history of sexuality. Her her publications include the monograph Eine Fahrt ins Blaue: Deutschsprachiges Theater und Kabarett im australischen Exil und Nach-Exil (1933-1988) (Weidler, 2006). She has held research and lecturing positions at Duke University, Oxford University, and the IFK (International Research Centre for Cultural Studies) in Vienna, and is a co-editor of Limbus: Australian Yearbook of German Literary and Cultural Studies.

Volker Meja was born in Berlin in 1940 and studied sociology, economics, and philosophy at the University of Frankfurt. He has a Ph.D. in sociology from Brandeis University and is Professor Emeritus of Sociology at the Memorial University of Newfoundland (Canada). Meja has published several books on the sociology of knowledge and science, on Knowledge and Politics, on Karl Mannheim, and on Modern German Sociology. He is also co-editor (in German and English) of Karl Mannheim's previously unpublished manuscripts, Structures of Thinking and Conservatism. 
Julie Mell is Associate Professor of History at North Carolina State University. Her research focuses on medieval Jewish history with particular emphasis on economic and religious life. Her forthcoming monograph Which is the merchant, and which the Jew? The Myth of the Medieval Jewish Moneylender (Palgrave, 2015) challenges commonplace narratives about Jews and their moneylending function in the commercialization of Europe. She has published articles in Jewish History, Jewish Historical Studies, and the Wiener Jahrbuch für Jüdische Geschichte Kultur und Museumswesen, and received fellowships from the Yad HaNadiv, the Memorial Foundation for Jewish Culture, and the American Association of University Women.

David Weinstein is Professor of Politics and International Affairs, Wake Forest University; Honorarprofessor, Universität Oldenburg, Germany and Plumer Research Fellow, St. Anne's College, Oxford, UK. His is author of Equal Freedom and Utility (Cambridge University Press, 1998) and Utilitarianism and the New Liberalism (Cambridge University Press, 2007). He is also co-author with Avihu Zakai of Exile and Interpretation, forthcoming.

Avihu Zakai, Department of History, the Hebrew University of Jerusalem, is the author of eight books and over one hundred articles. Soon will be published his study of Erich Auerbach's Mimesis, which for the first time analyzes the whole chapters of this celebrated work. 


\section{Preface}

This volume grew out of a conference on "Jewish Émigrés and the Shaping of Postwar Culture," organized by the Triangle Intellectual History Seminar and the Duke-UNC Jewish Studies Seminar to commemorate the late Lilian Renée Furst (1931-2009), the Marcel Bataillon Professor of Comparative Literature at the University of North Carolina, Chapel Hill. The conference was held at the National Humanities Center on April 3, 2011. Furst grew up in Vienna, and emigrated with her parents to England, via Belgium, after the German annexation of Austria in 1938. The family spent World War II in Manchester, England. Furst earned her BA in Modern Languages from the University of Manchester and went on to Cambridge to complete a doctorate in German in 1957. She taught for more than a decade at Queen's University in Belfast, and then became the head of the Comparative Literature Program in Manchester. After her mother passed away in 1969, she moved with her father to the U.S., and taught in several programs, holding, among others, visiting appointments in leading universities. She ended up, in 1986, at the University of North Carolina at Chapel Hill, where she taught until her retirement in 2005. Brought up in a traditional Jewish family, Furst was never a practicing Jew, or a member of the Jewish community, but she retained a robust sense of her Jewish identity and fate. An intellectual adventurer, whose work tied together diverse academic cultures and national literatures, Furst found no intellectual home. In Home is Somewhere Else: An Autobiography in Two Voices (1994), she paired her memories of emigrating from Austria to England with those of her father. The Autobiography became the most widely read of her more than twenty books, which ranged from Romanticism and Naturalism to illness in modern literature.

Furst's story is one of a generation of Central European émigrés who became the makers of postwar culture, and of the alienation from home and nation that was the source of their innovation. She was a pioneer of comparative literary studies, and hoped that U.S. academic life would help her break out of the confines of national culture she experienced in Austria and even in Britain. She broke through professionally, but, personally, the U.S. academy never became a home. After her father passed away in 1983, a group of friends, students, and a family of teddy bears she collected and named were her closest company. A genetic illness, impacting also her vision, made her final years difficult, but she carried through with her usual dignity and good humor. She was buried next to her father according to Jewish rite but without a funeral. This writer may be the single reciter of kadish and yizkor after her.

The nexus between innovative intellectual contributions and the émigré experience was at the center of the conference in Furst's memory. European Jewish émigrés from Nazi Germany and Europe have become in the last two decades a major interdisciplinary research field, and their contributions to twentieth-century culture are well known. This conference focused on the émigrés' role in the formation of postwar trans-Atlantic culture. We asked: How, why, 
and in what fashion did émigré dislocation, identity dilemmas, and Holocaust experience shape intellectual paths and utopias promising new homes that have, ironically, become highlights of European culture? We were mindful that we needed to explore religion and ethnicity among mostly secular intellectuals, who often no longer identified themselves as Jewish. We anticipated receiving a range of answers to the "Jewish Question": a series of explorations of the Jewish European disaster, ending with portrayals of prospective new homes, whether in Europe, the U.S. or Israel, whether on Popper's model of an Open Society, or on Furst's model of home is somewhere else. Unexpectedly, the vision of Judeo-Christian civilization emerged as a focal interest for participants, reflecting the contemporary European search for identity and the historical interest in Jewish Catholics. We hope that we have provided in this volume new ways for understanding religion and ethnicity among the Jewish émigrés, and new directions for searching for the émigré impact on the shaping of postwar culture.

David Kettler and Volker Meja's essay on sociologist Karl Mannheim pointedly raises the question bedeviling émigré scholars: Mannheim made social location determinative of ideology yet he never contemplated that his own Jewish origins had a role in shaping his sociology of knowledge. How does one illuminate the impact of unacknowledged, and even rejected Jewishness? Kettler and Meja use the assimilation theory advanced by Mannheim's student, historian Jacob Katz, to explain Mannheim's ideal of a "free floating intelligentsia." Assimilation consisted, among others, in the formation of groups of intellectuals who relinquished their particular (religious) identities, at least in public debate. Mannheim was committed to such groups, to intellectuals bracketing their own (Jewish) identities, so they can negotiate among ideological standpoints. Writers in this volume deploy diverse stratagems in attempts to decode elusive Jewishness that is neither religious nor ethnic or national nor entirely a product of antisemites marking assimilated Jews as Jewish.

Daniel Bessner's essay on the New School for Social Research queries the silence of both its founder, Alvin Johnson, and the émigrés appointed as faculty on their Jewish origin. The University in Exile accepted more German and European exiles than any other American institution of higher education, yet the most open statement on their background insisted that "a full one third had no Jewish blood." Bessner suggests that shared transnational interests and cosmopolitan values created a common academic agenda for American progressives and German-Jewish intellectuals. They knew all too well that this agenda was only marginally acceptable to current antisemitic academic culture and preferred not to burden it with the Jewish Question. American progressives helped Jews wishing to escape their Jewishness create a trans-Atlantic academic culture that "solved" the Jewish Question by pretending that it did not exist outside Nazi Germany.

Erich Auerbach (1892-1957) is the subject of three of the volumes' essays, reflecting his stature as a leading intellectual émigré, the recognition of his Mimesis (1946) as an epochal work, and recent interest in Judeo-Christian visions of European culture. Matthias Bormuth 
highlights the differences between Karl Löwith and Auerbach's responses to modernity. Löwith, nominally a Protestant, viewed the French Revolution negatively as reflecting secularization of Christian eschatology, and sought escape in Goethe's self-cultivation. Auerbach, who remained Jewish, bemoaned secularization's dissolution of the Christian worldview but implicated Goethe's rejection of the French Revolution in Germany's failure to confront modernity. The "Jewish" Jew was more a Christian and a democrat than the "Christian" one. Malachi Hacohen, Avihu Zakai and David Weinstein look at Mimesis and "Figura" as a response to Nazi racialized Europe, which endeavored to reintegrate the Jews into European civilization as progenitors of Christianity. Whereas Zakai \& Weinstein regard the project as Jewish (as does the majority of Auerbach scholars), Hacohen views Auerbach as a cultural Christian. While perusing biographies and works for hints of the Jewish experience, he argues, we must not reify the "Jewishness" of German acculturated intellectuals - it could be Christian in character.

If "Figura" and Mimesis presaged postwar Judeo-Christian visions of Europe, The City of Man, published in 1940 by a group of American public intellectuals and European émigrés, did so for the U.S. The group included, among others, Reinhold Niebuhr and Lewis Mumford among the Americans, and Thomas Mann, Hermann Broch, Hans Kohn, and Oscar Jaszi among the émigrés. They urged an isolationist U.S. to assume global leadership in the struggle against fascism and communism and lead a spiritual transformation of democracy into a modern political religion. They called for a rejuvenation of conservative values, anchored in the Judeo-Christian tradition, in support of a global reconstruction of modernity, threatened by totalitarianism. The pamphlet signaled, say Adi Gordon and Udi Greenberg, the first act of postwar conservatism, and the trans-Atlantic making of Cold War culture.

Julie Mell's essay sketches the intellectual work of five émigrés investigating the origins of European capitalism. She illuminates how their formative works in the fields of Jewish history, economic history, and economic sociology were shaped by the crisis of WWII, their Jewish identities and their émigré experiences during and after the war. The two openly Jewish protagonists, Guido Kisch and Toni Oelsner, sparred over the legacy of the German Historical School and the Jews' role in the rise of capitalism: Kisch affirmed it and Oelsner denied it as an antisemitic construct. The two assimilated Jewish intellectuals, Robert Lopez and Michael Postan, fashioned the Cambridge Economic History and elaborated the concept of the "medieval commercial revolution," which had little need for the Jews at all. Finally, the Protestant Jew, Karl Polanyi, presented capitalism as a historically aberrant and catastrophic attempt to free the market from its social embeddedness.

The final three essays represent "homecomings" of the Jewish émigrés and analyze the shaping of utopias that re-envision Jewish integration. Ofer Ashkenazi explores the manipulation of Heimat (homeland) images in the postwar films of Konrad Wolf, a high profiled East-German filmmaker who returned from his WWII Moscow exile as a Red Army soldier. In the autobiographical film I was Nineteen (1968), Wolf documented his return, and 
Ashkenazi sees his exposition of the violence embedded in Heimat imagery as a plea for a new society united by a universalist ideology, providing a home for Jews that the national community of Heimat could not.

Unlike Wolf, remigrés to Austria could not even pretend that their country was making a fresh start. Friedrich Torberg and Hilde Spiel availed themselves of the Central European past to elaborate visions of Austrian literature that, contrary to their own expectations, became blueprints for a new European culture. They mourned the loss of Central European Jewry but neither, says Birgit Lang, endeavored to represent the Holocaust. They seemed free of the tensions that noble-prize winner, Imre Kertész, discerned in Jewish intellectuals' postwar use of German. Kertész himself was able to confront the linguistic conundrum of Jewish use of German by self-conscious depiction of the émigré experience of language loss (which he discovered in Jean Améry). Torberg and Spiel's depictions of a Golden Age gone did not reflect this survivor's experience of linguistic loss.

Arie Dubnov ponders the leading postwar liberal thinker, Isaiah Berlin's ambivalent stance towards nationalism. To Berlin, nationalism constituted, at one and the same time, a threat to liberty and a desired community. Having immigrated to England as a boy from Riga, Latvia, Berlin cultivated the persona of a Russian Jew and supported Zionism. Diaspora Zionism was his solution to the nationalist riddle, and to the problems of an Oxford Don, who wished to live as an admired Jewish outsider, support Israel, yet remain the Queen's loyal and knighted subject. Good nationalism was a Diasporic national community, pluralizing the postwar nation state and enabling a Jew to be a British Zionist.

An unpublished autobiographical excerpt on growing up in wartime England, pulled from Lilan Furst's archives, and introduced by her literary executor, Anabel Aliaga-Buchenau, completes the collection. Furst shows a very different path of Jewish acculturation in Britain from that of Berlin, one that led to Cambridge, but never made the British academy a home. Home is somewhere else, perhaps in heavenly Jerusalem. The Shoah Foundation's visual history archive contains a spectacular interview with Lilian Furst, recounting her life, in speech and pictures: http://vha.usc.edu.proxy.lib.duke.edu/login.aspx

The Girton College archive at Cambridge has Furst's remaining personal papers, including the manuscript of the excerpt published here:

http://janus.lib.cam.ac.uk/db/node.xsp?id=EAD\%2FGBR\%2F0271\%2FGCPP\%20Furst

I wish to thank my colleagues Yaakov (Kobi) Ariel of UNC - Chapel Hill, coordinator of the Duke-UNC Jewish Studies Seminar, K. Steven Vincent of NCSU - Raleigh, coordinator of the Triangle Intellectual History Seminar, and Sandi Payne, coordinator of the Carolina Seminars for their support in organizing the conference. Thanks go also to Madeline Levine of UNC - Chapel Hill for opening the conference with a biographical and historical memoir of Lilian Furst; to the National Humanities Center for hosting the conference; to Peter 
Kaufman of the University of Richmond, Editor-in-Chief of Religions, for proposing that Julie Mell \& I edit a special issue of Religions with the conference papers; and to Jerry Zhang, Managing Editor of Religions, for working on the issue, and suggesting that it now be published as a book. All contributed to bringing together three generations of scholars - the younger émigrés, mid-career historians, and rising academic stars - to show that the fascinating story of the outcasts of Europe who have helped reinvent trans-Atlantic culture continues to capture academic minds, young and old.

Malachi Haim Hacohen

Guest Editor

Jerusalem, 13 July 2014 

Reprinted from Religions. Cite as: Bessner, D. "Rather More than One-Third Had No Jewish Blood": American Progressivism and German-Jewish Cosmopolitanism at the New School for Social Research, 1933-1939. Religions 2012, 3, 99-129.

Article

\title{
"Rather More than One-Third Had No Jewish Blood": American Progressivism and German-Jewish Cosmopolitanism at the New School for Social Research, 1933-1939
}

\section{Daniel Bessner}

Henry M. Jackson School of International Studies at the University of Washington

Received: 5 January 2012; in revised form: 7 March 2012 / Accepted: 7 March 2012 /

Published: 16 March 2012

\begin{abstract}
The New School for Social Research's University in Exile accepted more German and European exiled intellectuals than any other American institution of higher education. This paper argues that transnational, cosmopolitan ideological and interestbased affinities shared by left-leaning American progressives and German-Jewish intellectuals enabled the predominantly Jewish University in Exile to become a vibrant intellectual space accepted by the community of largely anti-Semitic American academics. These affinities also illuminate why, despite the fact that the émigrés' exile was in large part the result of National Socialist hatred of Jews, Alvin Johnson (the founder of the University in Exile) and the faculty members that comprised it seldom discussed the University's Jewish demographics. The Jewish faculty members ignored the relationship between their ethnicity and exile because to focus on it would have been to admit that the cosmopolitan project they had embraced in Central Europe had failed. Johnson ignored the faculty's Jewish heritage for two reasons. First, he endorsed a cosmopolitan American nationalism. Second, he understood that the generally antiSemitic community of American academics would have rejected the University in Exile if he stressed the faculty's Jewishness. In ignoring the University in Exile's Jewish demographics, Johnson and the University's faculty successfully adhered to a strategy designed to foster the exiles' entrance into the American intellectual community. Thus, while cosmopolitanism failed in Germany and Central Europe, the exiles' later influence on the American academy indicates that it partially succeeded in the United States.
\end{abstract}


Keywords: New School for Social Research; University in Exile; Graduate Faculty of

Political and Social Science; Alvin Johnson; Emil Lederer; John Dewey; German Jewry; cosmopolitanism; exile

\section{Introduction}

Of all American institutions of higher education, the New School for Social Research in New York City accepted the largest number of German and European intellectual exiles during the era of National Socialism [1]. Founded in 1933 and soon renamed the "Graduate Faculty in Political and Social Science" (Graduate Faculty), this "University in Exile" served as the wartime home to 184 exiled scholars, seventy-four of whom hailed from Germany [2]. It was at the New School that a full one-quarter of all intellectual émigrés to the United States worked. The University in Exile saved several of the most influential academics of the twentieth century, including Hans Kelsen, Claude Lévi-Strauss, Bronislaw Malinowski, Leo Strauss, and Max Wertheimer [3]. Several future policymakers, including Karl Brandt, Gerhard Colm, and Hans Speier, also made this institution their home. The story of the New School in the 1930s is one central to twentieth century American and transatlantic intellectual history.

The University in Exile has been the exclusive subject of one scholarly monograph, ClausDieter Krohn's Intellectuals in Exile [4]. Krohn's work is a complete account of the gestation, founding, and influence of the Graduate Faculty, particularly its economists, on American social science. However, in explaining how the New School thrived in the 1930s and 1940s, Krohn focuses almost exclusively on structural factors, particularly the relationship between the University in Exile and its financial backers. This work assumes that securing funds was the most crucial factor in enabling the Graduate Faculty to find an intellectual home in America. While Krohn relates how Alvin Johnson, the individual behind the University in Exile, recruited politically and culturally like-minded scholars to the New School, Intellectuals in Exile generally ignores the role ideas played in allowing the University in Exile to thrive in its early years.

This paper augments Krohn's structural account by demonstrating how transnational ideological and interest-based affinities shared by left-leaning American progressives and German-Jewish intellectuals enabled the predominantly Jewish University in Exile to become a vibrant intellectual space accepted by anti-Semitic American academics [5]. I argue that both groups-American progressives and European Jewish exiles-embraced complementary cosmopolitan ideologies. Left-leaning progressives like Johnson subscribed to a social vision that sought to reinvigorate American nationalism by incorporating ideas and traditions from European cultures [6]. They thus supported the possible contributions European exiles could make in America. This idea was accepted, and indeed embraced, by the German-Jewish intellectuals who comprised much of the Graduate Faculty. These individuals were the inheritors of a post-emancipation German and Central European Jewish intellectual tradition that sought to deny the importance of Jewish ethnicity in favor of a secular and cosmopolitan intellectual identity. Both Johnson and the members of the University in Exile adhered to ideologies that embraced the notion of an international Republic of Letters in which intellectuals from any nation could contribute positively 
to a society's development. The cosmopolitan affinities shared by Johnson and the faculty members explain why the New School functioned smoothly as an institution, with Johnson and faculty members rarely disagreeing as to the University in Exile's American mission.

These affinities also illuminate why, despite the fact that the émigrés' exile was the result of National Socialist hatred of Jews, Johnson and the faculty members seldom discussed the University in Exile's Jewish demographics. The Jewish faculty members ignored the relationship between their ethnicity and exile because to focus on it would have been to admit that the cosmopolitan project they had embraced had failed. Moreover, in both the European and American contexts, integration was at stake. Therefore, when the émigrés first came to America, they continued in the same mode they had in Europe. At the same time, if Johnson mentioned the faculty's Jewish heritage, the largely anti-Semitic community of American academics would have rejected his own cosmopolitan undertaking. In ignoring the University in Exile's Jewish demographics, Johnson and the faculty successfully adhered to a strategy designed to foster the exiles' entrance into the American intellectual community. Each had an interest in promoting the University in Exile's scholarship and eliding the émigrés' Jewishness was central to this goal. Indeed, in the late-1930s, collections published by the University in Exile received almost uniformly positive reviews, indicating that the faculty was not "tainted" by its Jewish makeup. By the end of the decade, however, the Jewish members of the Graduate Faculty could no longer ignore the special place occupied by Jews in the National Socialist imagination. In "Forms and Features of Anti-Judaism," a biting essay released in 1939, Erich Kahler explicitly rejected the cosmopolitan project embraced by his colleagues. This essay inaugurated New School scholars' new focus on Jewish issues. With the failure of the European cosmopolitan project, the University in Exile's faculty turned to examining what they had so long ignored: their Judaism. Their ability to do so, however, indicated the American achievement of their cosmopolitan goals.

\section{The Founding of the University in Exile}

In 1919, a group of well-known liberals, radical democrats, and philanthropists that included Charles A. Beard, John Dewey, Horace M. Kallen, Thorstein Veblen, and Felix Frankfurter founded the New School for Social Research. These liberal progressives created the New School in response to Columbia University president Nicholas Murray Butler's dismissal of several professors for refusing to take a loyalty oath to the American government and opposing U.S. engagement in World War I [7]. Angered at Butler's stifling of intellectual expression, these intellectuals formed the New School as a self-conscious bastion of academic freedom, partially modeled on the German Volkshochschulen dedicated to adult and worker education [8]. Similar to many American educational progressives of the day, these intellectuals hoped to use social science to achieve liberal socioeconomic goals [9].

Alvin Johnson, the central force behind the creation of the University in Exile, was one of the New School's founders. Johnson was born and raised in Nebraska, the son of Danish immigrants. He served in the U.S. Army during the Spanish-American War, and at the end of the war matriculated as a graduate student in economics at Columbia University. At Columbia, he studied under E.R.A. Seligman and Franklin Giddings and received his Ph.D in 1902 [10]. Johnson worked in academia until 1915, when Herbert Croly, the founder of The New Republic, invited him to join 
the magazine as an assistant editor [11]. Johnson accepted the offer, and through The New Republic became involved with the progressive New York intellectual circle that founded the New School. He was naturally attracted to John Dewey's progressive educational philosophy and eagerly accepted a position as one of the New School's first faculty members. By the early 1920s, Johnson had become the New School's first president. For the next decade, he improved the institution's finances, enlarged its scholarly focus from the policy and social sciences to the humanities, and built its reputation as a local leader in arts education.

Transatlantic connections forged in the 1920s became the seeds of the University in Exile's germination. Johnson was fluent in German and had since the beginning of his career been interested in German academia [12]. In 1924, Johnson and the Jewish financier-statesmen Bernard Baruch traveled to Germany to study the hyperinflation and derive lessons for how American policymakers could avoid a similar economic crisis. On this trip, Johnson made the acquaintance of Emil Lederer, a Jewish economist and member of the Sozialdemokratische Partei Deutschlands (SPD) then teaching at the University of Heidelberg. Johnson and Lederer retained their friendship and continued to correspond throughout the 1920s. In 1927, Johnson accepted Seligman's offer to serve as associate editor of an American encyclopedia of the social sciences modeled on the Handwörterbuch der Staatswissenschaften. Upon doing so, he asked Lederer to recommend German colleagues to contribute [13]. Over the next several years, Lederer recommended numerous German academics that wound up contributing to the encyclopedia. By the time the Encyclopedia of eventually fifteen-volumes began to appear in the 1930s, several future members of the University in Exile, including Lederer, Gerhard Colm, Fritz Lehmann, and Hans Speier, had written entries.

These positive experiences with German academia generally, and Lederer specifically, enlarged Johnson's already considerable respect for German social science. As he watched the rise of National Socialism from abroad, Johnson began to recognize that, if Hitler triumphed, many left wing and Jewish academics would require a home in exile. Soon after Hitler's seizure of power in January 1933, Johnson began to create an institution dedicated to preserving the German academic tradition he correctly believed the Nazis would destroy. He hoped that this new "University in Exile" would serve "as a liaison between American university culture and the pre-Nazi German university culture [14]." Echoing his colleague Dewey's idea of developing an "international nationalism," Johnson maintained that providing a safe haven for German academics would be beneficial not only to the rescued Germans, but to American society and intellectual culture as well. This intellectual migration, Johnson hoped, would reinvigorate American social science and provide it with the necessary tools to affect social change.

Lederer was centrally involved in the University in Exile's creation. In February 1933, Harold Butler, the Director of the International Labor Office, invited Lederer to participate in a Parisian conference on the relationship between technological progress and unemployment. After leaving Germany to attend the conference, Lederer never returned, immigrating instead to London. This was a prescient decision, as Lederer was one of the first professors the Nazis intended to dismiss, likely due to his socialism. From the beginning, Johnson had intended Lederer to be the major German intellectual force behind his envisioned institution. In early 1933, he approached Lederer about his plans "to get ten or a dozen [German professors] to the U.S. to set up a German university 
in exile [15]." Lederer quickly accepted Johnson's request and turned down a position at the University of Manchester to move to New York [16]. According to Lederer's student, Hans Speier, who himself became the youngest founding member of the University in Exile, Lederer "was impressed by Johnson's pragmatic liberalism and considered work at a new free university, which in the prevailing circumstances could become a political symbol, to be more worthwhile than joining a well-established institution [17]." In joining the University in Exile, Lederer symbolically demonstrated to the German and international academic community that, despite the attempts of domestic political reactionaries, academic freedom would always find an international home.

Throughout the spring and summer of 1933, Johnson diligently worked to raise funds for his institution [18]. By May 13, he had collected \$120,000 from the Jewish philanthropist Hiram Halle and the Rockefeller Foundation, which allowed him to fund fifteen professorships at a salary of $\$ 4,000$ per year [19]. To win American intellectual support for his and Lederer's venture, Johnson drafted a letter signed by several hundred social scientists supporting the University in Exile's founding [20]. In June of that year, Johnson applied for and received a provisional charter from the Board of Regents of New York State [21].

At Lederer and Johnson's request, throughout the summer of 1933, Speier, who was a Lutheran (although married to a Jewish pediatrician), traveled back and forth between London and Germany with contracts for the University's founding members. Over that summer, Johnson, Lederer, and Speier successfully recruited ten academics to found the University in Exile. In the schema of earlyto mid-twentieth century United States immigration law, intellectuals were considered "non-quota" immigrants and could thus immigrate more easily than members of other social groups [22]. The ten founding members of the University in Exile were Karl Brandt (agricultural science); Gerhard Colm (economics); Arthur Feiler (economics); Eduard Heimann (economics); Erich von Hornbostel (sociology of music); Herman Kantorowicz (law); Lederer (economics); Speier (sociology); Max Wertheimer (Gestalt psychology); and Frieda von Wunderlich (social policy). The progressive Johnson recruited these scholars because each "supported the democratic government under the Weimar constitution [23]." Additionally, most were Social Democrats or held social democratic sympathies, were empirically oriented social scientists, and were associates of Lederer [24]. The New School scholars hailed primarily from three institutions: the University of Frankfurt, the Kiel Institute for World Economics, and the Berlin-based Hochschule für Politik (College for Politics) [25]. Most importantly for Johnson and Lederer, each New School member was an intellectual concerned with using social science as a means to reach social and economic progressive ends [26].

With the faculty and funding in place, the University in Exile - renamed the Graduate Faculty of Political and Social Science because the New York State Department of Education would not allow an institution with only a single faculty to call itself a "university"-opened its doors in October 1933 [27]. The Graduate Faculty grew significantly over the next few years. In the spring of 1934 there were 18 faculty members; by the summer of 1939, there were 33. After Germany's defeat of France in the summer of 1940, many more came. Student enrollment also increased as the Graduate Faculty's reputation rose in the 1930s. In the fall of 1933, the University in Exile had only 92 students; by 1940 that number had risen to 520 [28]. As these numbers indicate, the Graduate Faculty flourished in the 1930s and 1940s. 


\section{The Presentation of the University in Exile, 1933-1939}

Two-thirds of the Graduate Faculty's founding members were Jewish [29]. Many more Jewish academics came to the New School as the Nazi era wore on. However, throughout the 1930s, Johnson, Lederer, and the rest of the New School faculty refused to present the University in Exile as a haven for German Jews. They instead offered the New School as an institution dedicated to defending intellectual freedom and the best aspects of the pre-Nazi German academic tradition. There was very little talk of Judaism or the role the faculty's ethnicity played in their immigration. At first, such a position was defensible, as the Nazis' initial program was premised upon removing political as opposed to racial enemies. Nevertheless, by April 1933, the Nazis had begun to strip Jews of their rights and it was clear that the Jews were no longer welcome in Germany.

This unwillingness or inability to discuss the New School scholars' Jewish identity had two intellectual sources, each of which hailed from one side of the transatlantic divide. The first was an American progressive vision, argued most explicitly by John Dewey, which sought to incorporate European intellectual, social, and cultural traditions into a reinvigorated American nationalism. Dewey, Johnson, and other left-leaning progressives believed that they must work to create a new "international nationalism" that was nevertheless American. This international nationalism, they hoped, would result in a cultural exchange that would undergird a progressive American future [30].

Nonetheless, this ideology did not necessarily mean that Johnson had to deny completely the faculty's Judaism. He could have mentioned their ethnicity but downplayed it. I argue that Johnson's total elision of the faculty member's Jewish heritage was both a consequence of his progressive commitments and a strategy designed to avoid the anti-Semitism that permeated American higher education during the interwar period. Johnson hoped that American academics would accept the University in Exile as a peer institution. At the time, however, many American universities were permeated with anti-Semitism. Most, including almost all of the elite colleges, had imposed strict quotas on Jewish students and faculty. Johnson was very much aware of educational anti-Semitism and railed against it from his position as president of the American Section of the International League for Academic Freedom [31]. He had himself received criticism from colleagues who believed that there was no room for Jews in American academia [32]. If Johnson had stressed the faculty's Judaism, he would have alienated his academic peers.

The post-emancipation German-Jewish embrace of the universalist Bildung educational philosophy constituted the second, European intellectual source of the New School's position regarding its Jewish demographics. Traditional Bildung referred to the idealist-romantic process of "cultivating" oneself through extensive reading in classical texts of the Greco-Roman and German traditions and the conduct of original research in one's Wissenschaft (science). Engagement with Bildung and Wissenschaft was supposed to engender a coherent Weltanschauung (worldview) in a student [33]. As one scholar notes, the "pursuit of truth was to lead to something like integral insight and moral certainty" [34]. In the late-nineteenth and early-twentieth centuries, Central European Jewish intellectuals believed that participation in Bildung was the key to their acceptance by secular society. This Jewish embrace of Bildung, however, came at the expense of particularist Jewish identities. Jews denied their Judaism and appropriated the cosmopolitanism of Bildung. This was 
Jewish intellectuals' strategy of assimilation and acceptance (ironically, this cosmopolitanism was primarily about Jewish integration into a national community). By ignoring their Judaism in the 1930s, the majority of faculty members did the same in America as they had in Germany, defining themselves as secular intellectuals, not Jews [35]. With this vision, they believed they could contribute positively to society's advance while fostering their own acceptance into the American intellectual community.

In the 1930s, the New School's University in Exile was an institutional site that saw the merging of two coherent and complementary philosophies. Both the left-leaning American progressive and Central European Jewish traditions were cosmopolitan in character. As we will see, even in the face of the Nazi threat, Johnson, Lederer, and the majority of the New School scholars remained silent about the faculty's Judaism. This helped engender their acceptance into American academia. It was not until 1939, when it had become too clear to deny that Hitler and the National Socialists posed an existential threat to European and world Jewry, that faculty members began to address their Judaism.

\section{Johnson and Judaism}

In the Graduate Faculty's first course catalogue, which was almost certainly written by Johnson (perhaps with minor aid from Lederer and other faculty members), there was no mention of National Socialist racial policy nor the regime's specific animosity toward Jews [36]. Johnson justified the creation of the University in Exile with reference only to "the reorganization of German university life under the National Socialist revolution." Because of Nazi political regulations, Johnson continued, scholars of "international reputation have been dismissed" or given indefinite furloughs from teaching. He declared that the Nazis denied politically problematic scholars "academic liberty" and, as "an American institution," the New School was obligated "to express by word and act its own faith" in intellectual freedom [37]. Throughout the catalogue, Johnson continued to downplay the faculty's Judaism. His only critique of Nazi racism occurred within a discussion of the regime's educational policy. According to the catalogue, all faculty members believed "that real education begins where racial, religious and political intolerance ends." A salient display of Johnson's general unwillingness to underline the unique position occupied by Jews in the Nazi racial imagination was the fact that the catalogue never mentioned the word "Jew." He instead repeatedly referred to the faculty as comprising only "German professors." Johnson thus presented the founding of the University in Exile as a defense of democracy and intellectual freedom, not a rejection of Nazi racism [38].

Theoretically, in the first months of Hitler's rule, one could have argued that the Nazis mainly were persecuting political enemies. By the autumn of 1933, however, the National Socialist perspective regarding Jews was very clear. Events such as the April 1, 1933 boycott of Jewish businesses, the April passing of laws that banned Jews from serving as civil servants (including university professors), lawyers, or editors - and which also enacted Jewish student quotas - and the thousands of anti-Semitic references that recurred throughout Nazi speeches, propaganda, and publications made the degraded position that Jews now occupied in Germany clear. In spite of these obvious signals, however, this first course catalogue presented the University in Exile as a space where liberal German professors could teach "German methods" and the "German point of 
view" (both of which were, in actuality, the German-Jewish point of view) to American students. It was Nazi "political requirements," not racial hatred, which had resulted in the dismissal of the new faculty members [39]. Throughout the 1930s, Johnson offered similar claims in Social Research (the journal created to popularize the Graduate Faculty's work in America), for example referring to the National Socialist triumph solely as a "political" revolution [40].

In the first course catalogue, Johnson repeatedly appealed to the language of international scientific cosmopolitanism when discussing why a university in exile was "an institution long overdue in the modern world [41]." When praising German universities, for example, Johnson singled out for special admiration the fact that earlier in history German universities retained "a highly international" character [42]. When discussing Social Research, he declared that it would focus exclusively on "international tendencies" in the social sciences [43]. In the first issue of the journal, he similarly stated that the knowledge produced by the Graduate Faculty was "of the world at large [44]." Declarations that "scholarship is international" and that all defenders of intellectual freedom, particularly Americans, who "justly clai[m] a position of leadership in civilization," must work together to create institutions dedicated to serving exiles for the purpose of reinvigorating American culture, peppered his writings. Such claims mirrored typical left-leaning progressive language. Echoing Dewey and other leftist progressives, in Johnson's conception the international, European contributions of the New School would contribute to the renewal of American life. Eventually, this would benefit not only America, but the world.

Johnson thus presented a vision of a world characterized by an international society at the center of which stood the American nation. This society, he declared, must become the haven for all intellectuals rejected by their homelands. Anyone dedicated to democratic values, whether from Europe or America, could help create new, practical, and progressive knowledge. In the post World War I era of crisis, Americans must incorporate exiles' ideas to aid in their quest for a progressive future.

The desire to elide the faculty's Judaism was made starkly clear in Johnson's 1935 declaration that:

The men who compose this German faculty were expelled from their posts essentially for one reason only. They chose to be free. In the majority of cases the official ground for dismissal was 'political unreliability.' They could not consent to stultify themselves by accepting the official political and social doctrines and thereby forfeit their scholarly right to follow the truth wherever it might lead. They regarded liberty as worth whatever sacrifices it might entail, and therewith placed themselves in the honored company of the [American] men who, by their readiness to endure sacrifice, won liberty for the English-speaking peoples [45].

This is an astonishing passage. In presenting the search for intellectual freedom and adherence to democratic political values as the reasons for the Graduate Faculty's exile, Johnson downplayed the importance of the race-based dogmatisms of National Socialism. Although it was true that many of the faculty were politically unacceptable to the Nazis, being socialists, fellow travelers, or liberals, many left for racial reasons. Even Speier, a non-Jew, fled Germany because he was married to a Jewish woman. Yet in Johnson's presentation, it was only intellectual and political, not racial, considerations that necessitated the University in Exile's creation. Johnson's denial of the ethnic heritage of the faculty members was further evident in the historical precedents for the 
Graduate Faculty that he cited. For instance, he referred to the University in Exile as the intellectual-institutional heir of the University of Padua, which was founded in the early 13th century in response to political oppression experienced at the University of Bologna. This ignored cases to which the University in Exile was truly analogous, such as Puritan exiles' founding of Harvard in 1636. Johnson asserted that what the Nazis rejected was "liberalism," not Judaism [46].

Johnson's most outrageous denial of the faculty members' Judaism came in the section of a 1935 report to the New School's trustees entitled "Racial and Political Constitution of the Faculty." Here, Johnson explicitly disavowed the Jewish character of the Graduate Faculty. As he said, "[t]here is a prevalent conception that the German professors expelled from their chairs were all either 'Marxians' or Jews. This conception is not valid so far as the Graduate Faculty is concerned. In selecting scholars for the faculty," Johnson continued, "no attention was given to such irrelevant matters as race and religion" [47]. He stressed that "rather more than one-third [of the faculty] had no Jewish blood at all and of the others several could be classed as non-Aryan only by virtue of the 'grandparent clause [48]."' Johnson took pains to portray the faculty as specifically non-Jewish, as only Jewish under the ridiculous laws of the Nazis. The University in Exile was not to be tainted publicly by the Jewish blood that did in fact comprise it.

Johnson's presentation of the University in Exile as a cosmopolitan intellectual haven for political refugees closely mirrored John Dewey's educational philosophy and views of cultural immigration. Johnson and Dewey were colleagues who belonged to the same progressive New York intellectual circles. Dewey and Johnson also worked together at the New School, and Dewey was on the University in Exile's board. The respect Johnson had for Dewey was clearly reflected in his helping to found the John Dewey Society, an organization devoted to progressive education and educational philosophy, in 1935 [49]. Moreover, at Dewey's ninetieth birthday, Johnson was invited to give a tribute to him, a favor which Dewey repaid at Johnson's seventy-fifth birthday [50]. Later in life, Johnson would designate Dewey as one of the "great men" of twentieth century American thought [51]. In addition to these personal connections, Dewey's philosophy strongly influenced Johnson, which one sees when comparing the former's work with the latter's presentation of the University in Exile.

In the pre-World War I era, many progressives believed that the large number of European immigrants who began settling in America in the nineteenth century needed to undergo a process of "Americanization [52]." Right-leaning progressives such as Theodore Roosevelt adopted an avowedly nationalistic perspective that advocated immigrants' complete divestment of their European cultural heritage and full embrace of "American" values. Many other progressives, such as Jacob A. Riis, similarly believed that one must work to dissolve and replace the ethnic heritages of European immigrants. Dewey and other left-leaning progressives rejected these arguments. They instead advocated for immigrants to retain aspects of their cultural heritages and inject them into American life [53]. Dewey and others believed these cosmopolitan injections would lead to a rejuvenated "cosmopolitan American nationalism" that would support the achievement of progressive goals [54].

Thus, before 1918, Dewey wanted to create a new, international American nationalism, undergirded by core American ideals but enriched by European cultures [55]. A number of well-known progressives advocated a similar position, including Horace Kallen (the immigrant son of an orthodox rabbi who 
taught at the New School in the interwar years), Jane Addams, Emily Greene Bach, and Randolph Bourne [56]. However, after World War I, many left-leaning progressives abandoned this cultural focus in favor of highlighting American economic injustice [57]. When in the early-1930s Johnson advocated the use of the New School as a means to create an international American culture, he was somewhat of an atavism. But, unlike most progressives, Johnson had since 1924 been very much concerned with German developments, particularly the rise of National Socialism. This likely led him to be more sensitive to cultural issues than his economically focused contemporaries. Indeed, progressives would re-embrace cultural arguments in the 1930s and 1940s, as Nazi and Soviet successes re-indicated the important role culture played in modern life.

Johnson's cosmopolitan presentation of the German exiles as strengthening American social science with their own European intellectual traditions mirrored Dewey's philosophy of international American nationalism. But why, then, did Johnson downplay the faculty's Judaism while stressing their German-ness? In theory, he could have highlighted the faculty's ethnic identity while maintaining that, once the best parts of this identity were assimilated, it would be transcended. The answer to this question lies in the prevalent anti-Semitism of the American university system in the interwar period. The problem of Jewish quota systems at major universities was well known at the time, with a variety of newspaper and magazine articles addressing the subject [58]. Although elite, American protestant culture had long been defined by what scholars have termed "genteel anti-semitism" - a type of polite, non-violent, yet pervasive distrust and fear of Jews - it was only in the interwar years that Protestant-dominated American colleges and universities began to engage in serious efforts to limit Jewish enrollment [59]. Johnson, a college president interested in educational administration and philosophy, was very aware of this issue. To overcome it and reach his cosmopolitan goals, Johnson strategically ignored the faculty's Judaism. This, he hoped, would foster their American acceptance.

Johnson was also likely worried about the New School's standing as an elite institution. Since its founding as a progressive offshoot of Columbia, the New School had attempted to position itself as an alternative to other elite American universities. The fact that Columbia president Nicholas Murray Butler and Harvard president Abbott Lawrence Lowell had made clear their belief that Jewish enrollment would endanger Anglo-Saxon protestant culture must have strengthened Johnson's commitment to ignoring the exiles' Judaism.

Various trends bolstered American academics' fear of Jews in the 1920s and impelled the creation of the quota system. There was worry over immigration (which manifested in the 1924 Immigration Act) and the concomitant rise of nativism and racial science. Protestant elites also feared that they could not compete with Jews academically and that Jewish business success (enabled by education) would lead to the erosion of their own economic standing and social prestige. In addition to such academic and economic anxieties, protestant elites shared the cultural fear that the infiltration of supposedly effeminate Jews into the American aristocracy would attenuate the masculinity of the next generation of elites [60]. The ancient religious charge that the Jews were the murderers of Jesus Christ fortified these anti-Semitic impulses. The process of American universities' democratization also strengthened these economic and cultural fears [61]. In the 1920s and 1930s, then, many American Protestant intellectuals considered the Jews as economic and cultural challengers who must be prevented from entering the American elite [62]. 
Such attitudes manifested in the quota systems, limiting Jewish student enrollment and faculty appointments. In the interwar years, many universities, including Adelphi, Barnard, Brown, Cincinnati, Columbia, Cornell, Dartmouth, Duke, Harvard, Johns Hopkins, Illinois, Kansas, Minnesota, New York, Northwestern, Ohio State, Penn State, Princeton, Rutgers, Texas, Virginia, Washington, Washington and Lee, and Yale, imposed quotas on Jewish students and faculty [63]. Yale did not promote a Jew to the position of full professor until 1946. The humanities, in particular, were bastions of anti-Semitic prejudice [64]. In their anti-Semitism, American protestant intellectuals echoed more general social attitudes toward Jews [65]. Unique among immigrant groups, the more Jews succeeded in American society the more Americans resented them [66]. Presenting the New School as a Jewish institution in an overtly anti-Semitic educational environment would have made it difficult, if not impossible, for Johnson to achieve his cosmopolitan goal of popularizing German academia among American intellectuals. Had he stressed the faculty's Judaism, he would have done little but contribute to their American alienation.

The argument that Johnson's ignoring of the ethnic identities of the Graduate Faculty was a strategy designed to increase the likelihood of their American success is bolstered by the fact that Johnson was by no means an anti-Semite and was quite attuned to Jew hatred. In addition to his personally saving more than one hundred European-Jewish scholars, Johnson repeatedly devoted himself to fighting educational anti-Semitism. He did so throughout the 1930s as a member and president of the American Section of the International League for Academic Freedom. Later, in 1946, he helped found the New York State Committee against Discrimination in Education specifically to fight the Jewish quota system [67]. Johnson was very clearly not an anti-Semite. However, given the interwar climate of intellectual and university-associated anti-Semitism, it would have been an imprudent strategy for Johnson to focus on, or even acknowledge, the faculty's Jewish identity. This could have, in theory, alienated not only fellow academics but also some of the non-Jewish associated funding sources upon which the Graduate Faculty relied. Indeed, representatives of the Rockefeller Foundation had made disparaging remarks about Jews in the past [68]. Doing anything to limit exiles' acceptance into American academia would have been foolhardy [69]. For cosmopolitanism, Johnson denied the faculty's Jewish demographics.

\section{The Graduate Faculty and Judaism}

The fact that Jewish New School scholars similarly kept silent about their Judaism facilitated the Graduate Faculty's success and aided Johnson's strategy of assimilation. Like Johnson, the Graduate Faculty publicly denied that the creation of the University in Exile had anything to do with Nazi racial policy. As a collective they first displayed this belief in their academic constitution. Mirroring Johnson's language, the University in Exile's constitution declared that the Graduate Faculty was primarily "founded upon the principles of academic freedom" [70]. The only mention of race or religion came in a sub-clause that forbade discriminating against a potential hire for "scientifically irrelevant considerations." As late as 1939, when National Socialist persecution of German Jews had become incontrovertible, the Graduate Faculty still refused to mention their Judaism in official reports to the New School's board and donors (implying that fears of pulled funding contributed to their denial of Judaism) [71]. In no way did faculty members wish publicly to portray the University in Exile as a Jewish institution. 
To understand how Jewish New School scholars portrayed themselves to the outside world, one must examine the articles they wrote for Social Research. Although the journal was intended to promote not only faculty scholars', but also other exiles' work, for its first few years the majority of Social Research contributors were members of the University in Exile. Johnson and the faculty were fairly successful in disseminating Social Research: by September 1936, the journal had 523 American and 114 foreign subscribers [72]. What is most striking about 1930s articles from Social Research is the almost complete lack of discussion regarding Judaism, Jews, and the German and European Jewish problem. Throughout the mid-1930s, the word "Jews" was mentioned in only 21 Social Research articles and book reviews; "Jewish" in 16; "Judaism" in six; variations on "anti-Semitism" in six; variations on "anti-Semitic" in five; and "Jew" in four. Many of these terms were used in the same articles. Zionism was not mentioned at all [73]. Compare this to the fact that the term "intellectual" was used in 111 articles and book reviews.

When Jewish New School scholars did discuss Judaism, it was primarily in an oblique, passing fashion. In 1935, for example, Albert Salomon briefly referred to "the pariah existence of the Jews" in an essay that discussed Max Weber's sociology [74]. Arthur Feiler made a similar fleeting reference to Jews in 1937, declaring that the "great changes" in social life that occurred under German fascism came from "the degradation of Jews, socialists, liberals, Catholics, Protestants and women [75]." The fact that Feiler mentioned Jews as the first group in a series of those persecuted by fascism implied he understood Jews occupied a special place in the Nazi racial pantheon. He did not, however, engage in a protracted analysis or discussion of the Jews' position.

The few articles that did discuss Jewish issues at some length submerged these discussions within other subjects. In an essay on "Education in Nazi Germany," Frieda Wunderlich mentioned that in the National Socialist imagination, political and civil rights were "derived from the folk," a "mystic community of blood" from which the Jews were excluded [76]. Wunderlich further underlined that a major goal of the National Socialists was to awaken "sound racial forces [77]". In a later book review, she argued that racial restrictions had led to a decline in the quality of German scholarship, while elsewhere she emphasized that the Nazis considered the Jews to be their major enemy [78]. However, Wunderlich's statements were made with reference to a specific topic, be it Nazi education or philosophical justice. Her essays indicate that she was well aware of the special place Jews occupied in the Nazi imagination, but she remained unwilling to discuss the Jewish problem at length.

The example of Wunderlich demonstrates that faculty members were aware of the centrality of the Jewish question to the Nazi project. For the most part, however, the Graduate Faculty ignored Judaism, even in instances where it would have made sense to mention it. When talking about the loss of liberty under dictatorships, Lederer argued that every autocracy prosecuted "a 'purge' eliminating all those who dare to resist" [79]. He made no mention of Judaism. Of course, few Jews resisted National Socialism, and Lederer's 1937 remarks make little sense. Moreover, his description of dictatorship included no mention of the racial aspects upon which Nazi autocracy rested. He simply declared that dictatorships "extol violence and brutality, they appeal to the ferocious instincts, they build up a sinister mythology of national pride and superiority, and establish crude standards of discipline and of stereotyped thinking to which everyone must conform [80]." Lederer could have added that the German dictatorship was premised upon racial exclusion, an exclusion 
that caused his own and his colleagues' exiles. The fact that he did not demonstrates his unwillingness to address the Jewish issue [81].

Between 1933 and 1939, the Graduate Faculty spent no time discussing the peculiar features of modern German anti-Semitism or the Jewish nature of their exile. Faculty members did, however, collectively define themselves as cosmopolitan intellectuals. That the Jewish scholars of the New School identified strongly as intellectuals may first be seen in the fact that one of their major proffered explanations for Nazism's success was that intellectuals had failed in their duty to defend Weimar democracy [82]. Lederer blamed intellectuals — and hence himself and his colleagues — for failing to overcome the German labor movement's inherent wariness of them. Lederer maintained that because intellectuals were unaware that policy was not a completely rational phenomenon, but depended on the manipulation of emotions, they were unable to speak to German workers in an effective manner [83]. Without intellectuals, workers, who did not understand the world's complexity, were unable to seize power [84]. Eduard Heimann similarly maintained that Weimar intellectuals were unwilling to develop a philosophical principle that had the capacity to unite the disparate elements of the German nation and thus organize an anti-reactionary political bloc able to seize and retain power. Heimann further declared that intellectual democrats were unable to use education to give students a coherent Weltanschauung that would have allowed them to reject National Socialist appeals [85]. Adolf Löwe also blamed the German university system for failing to provide students with a "social consciousness" that had at its center the defense of democracy. Without such a social consciousness, Löwe retrospectively argued, the interwar explosion of academic unemployment was bound to result in a general social upheaval that found academics serving as the "propagandists and officers of the counterrevolution [86]." Wunderlich and Colm echoed this latter viewpoint [87].

In blaming intellectuals for democracy's failure, the Jewish New School scholars were implicitly placing responsibility for Weimar's collapse on themselves. Yet they were also signaling to American audiences that they identified primarily as intellectuals, not Jews. Faculty members' self-identification as intellectuals was further displayed in their strong advocacy of intellectual involvement in American life. Throughout the 1930s, Lederer argued that science was integral to political life, and that exiled intellectuals like himself and his colleagues must do what they could to have their work speak to the contemporary problems of their adopted homeland. Without social science, "complicated procedures of government and administration, of business, industry, commerce, journalism," could not possibly be performed [88]. This was doubly true during the Great Depression, which many of the faculty members - reflecting their German experiences-believed threatened democracy. In Lederer's opinion, the basic calling of modern intellectual life, especially for exile intellectuals denied academic freedom in their homeland, was to defend democratic values. Intellectuals must become men of action, "uniting and giving strength" to liberty's defense [89]. These actions, however, had nothing to do with overcoming the racial hatred that led to their exile.

Other Jewish faculty members echoed this appeal to intellectual engagement in social and political life. Salomon declared that periods of economic and political crisis like the 1930s created the social conditions that allowed intellectuals to "arrive at definite insights into the primordial phenomena of social life and the intellectual connection of antagonistic concepts within a higher spiritual unity [90]." He argued that European exile intellectuals, who retained a deeper philosophical knowledge than pragmatic American colleagues, must remove religious, moral, and social values 
from dogmatism. Doing so enabled societies to rediscover universal humanism, the philosophical basis of Western civilization [91]. Without such an attitude, democratic political life could not be maintained. Salomon argued that by promoting humanism, intellectuals enabled "the statesman to gain from philosophy a spiritual and intellectual power which enables him to suffer the adversities of political and social life with calmness of soul [92]". This resulted in political moderation, the sine qua non of democracy. As with Lederer, the goal remained defending democracy, not combating anti-Semitism [93].

Gerhard Colm similarly emphasized that exiled social scientists had a "social responsibility" to defend democratic values. Academic work, while objective, retained within it an "element of responsible decision." Social science must speak to "the task it has to fulfill in a specific historical situation," which in the 1930s centered upon defending democracy and fighting fascism. Like Salomon, Colm argued that moments of crisis allowed intellectuals to revise traditional assumptions, enabling them to reach greater insights than in the past and prepare the way for a civilized future [94]. In addition to Lederer, Salomon, and Colm, Wunderlich maintained that social scientists must dedicate themselves to preventing fascism's spread, while Löwe declared that intellectuals must seek, through creativity and rationalism, to "satisfy the social and spiritual demands" that led people to dictators by fostering "a new spirit of conscious cooperation and solidarity" dedicated to social reconstruction [95]. The Jewish New School scholars discussed themselves and their social mission with reference to their intellectual identity and need to defend democracy. There was little to no discussion of Jewish issues.

In these ways the graduate faculty identified with democratic cosmopolitanism while dismissing the role anti-Semitism played not only in modern life but also in their own experiences of exile. What explains this lacuna? The New School scholars' impulse to ignore their Jewish identity and stress their collective belonging to an intellectual Republic of Letters reflected a defining cultural characteristic of the post-emancipation German-Jewish intelligentsia. Since the nineteenth century, many Jews had rejected their Jewish identity and replaced it with German Bildung [96]. In an attempt to navigate a middle path between Judaism and particularist German nationalism while becoming part of the German cultural community, German Jews seized upon Bildung and membership in the Bildungsbürgertum (educated middle class) as a replacement identity [97].

This embrace led Jewish intellectuals to advocate the primacy of Kultur over race. In the fin-de-siècle, Jewish intellectuals hoped joining the Bildungsbürgetum indicated wider German society's acceptance of them as Germans. This was especially true amongst left-leaning Jews like those who joined the Graduate Faculty. As several scholars have argued, this (incorrect) belief impelled Jews, during the rise and triumph of National Socialism, to project "their ideals of a tolerant Germany onto a quite different, far more brutal reality [98]". The Graduate Faculty's essays reflect this phenomenon. Accepting this perspective entailed willfully ignoring the anti-Semitic undercurrents permeating late-19th and early-20th century German society. Throughout the Wilhelmine era, for example, the terms "cosmopolitan," citoyen du monde, and Weltbürger developed anti-Semitic overtones [99]. Anti-Semites regularly mocked the Jews' for their cosmopolitan dreams [100]. Nevertheless, the desire to be exiled for what you thought, as opposed to who you were, led many Jewish intellectuals to ignore the realities of racialist National Socialism. As evidenced above, this 
denial continued during many intellectuals' first years in exile. Lederer and his colleagues believed that, first and foremost, they were intellectuals, not Jews. The Nazis, however, thought differently.

This belief in universal, cosmopolitan intellectualism was not confined to German Jewish culture. It was also a characteristic of Central European Jewish intellectual culture generally. During the interwar years, throughout Central Europe, particularly in the areas formerly united into the Austro-Hungarian Empire, Jewish intellectuals maintained that each had a "universal intellectual self" that enabled them to belong to a "cosmopolitan scholarly community [101]." As the majority of non-Jews abandoned whatever allegiance they may have had to cosmopolitanism, German-speaking Jewish intellectuals continued to uphold and defend this ideology. In Austria, Czechoslovakia, and the other areas of Central European Jewish settlement, Jews, caught between various ethnonationalistic particularities, declared their membership in an imagined, supranational intellectual community [102]. Like their German counterparts, this led Jews stubbornly to ignore the realities of radical, racialist nationalism. Thus, when non-German Jewish intellectuals came to find safe haven at the University in Exile from the mid-1930s onward, their intellectual identities overlapped with their German antecedents. In sum, the belief in a universal, cosmopolitan intellectual identity led the Jewish members of the Graduate Faculty to downplay their Judaism in their first years of exile. The exiles also, of course, hoped to be accepted by the American academy, and eliding their Judaism contributed to this goal. The émigrés' ideology and interests thus overlapped with Johnson's.

Their cosmopolitan dreams and hopes for acceptance led Johnson and the Jewish members of the Graduate Faculty to deny the faculty's Jewish demographics. Johnson hoped to use the European exiles to reinvigorate American life. The only way to do so was to have the exiles' scholarship accepted by an anti-Semitic American intellectual community. To foster this acceptance, Johnson ignored the faculty's Jewish heritage. The Jewish faculty members, for their part, were unwilling to emphasize the role Judaism played in their exile because doing so would have denied the cosmopolitan project that had characterized the German-Jewish intelligentsia since the late-19th century and further contributed to their alienation. They wanted to participate in American intellectual life. This similarity in beliefs enabled the New School to function smoothly throughout the 1930s. There was little disagreement between Johnson and faculty members regarding the goals of the New School or how it should present itself to the outside world. These intellectual congruencies engendered the University in Exile's acceptance by American academics.

The faculty's American acceptance was reflected in the very positive reviews their essay collections received in scholarly journals. For example, Merle Fainsod called the New School's 1937 collection Political and Economic Democracy "suggestive," "stimulating," "rewarding," and, in parts, "brilliant." Fainsod also referred to the Graduate Faculty only as a "distinguished company of European scholars [103]." The 1939 collection War in Our Time received similarly positive reviews [104]. In the latter case, Nathan Leites referred to the volume's "high level of analysis [105]". None of these reviews mentioned the faculty's Jewish demographics. Although there was some trepidation about the non-empirical focus of some of the essays, in no way was the New School "tainted" as a Jewish institution. These reviews indicate that Johnson and the faculty members successfully disassociated the University in Exile and the German-Jewish scholars that largely comprised it from Judaism. 
By 1939, however, the degraded sociopolitical space the Jews occupied in National Socialist Germany had become too obvious to ignore. In 1935, the Nazis passed the Nuremberg Laws, which forbade marriage and sexual intercourse between Jews and Germans; made it illegal for Jews to employ German women under the age of 45 as domestic workers; and stripped Jews of German citizenship. In 1938, the Nazis forced Jewish men to adopt the middle name Israel and Jewish women to take the middle name Sarah and forbade Jews from attending German schools. These laws, coupled with the November 1938 Kristallnacht pogrom, clearly signified not only that the Nazis hated the Jews, but that that they had made Jew hatred an organizing principle of German society. It was too much for even the Jewish members of the Graduate Faculty, who remained committed to a cosmopolitan intellectual identity, to ignore.

For these reasons, in 1939 the first essay in Social Research dedicated to examining anti-Semitism, Erich Kahler's "Forms and Features of Anti-Judaism," appeared. Unlike his colleagues, Kahler, a Czechoslovakian Jew, highlighted the specifically anti-Jewish aspects of National Socialism. Broadly, the essay argued that anti-Semitism was a universal feature of history that could be found in all societies in different, yet recurring, forms [106]. In Kahler's opinion, the modern period of anti-Semitism was unique in that for the first time in history, anti-Judaism was not predicated on religious hatred, but was rather undergirded by patently false "scientific" racial theories. Unlike other faculty members, Kahler placed racial hatred at the center of the National Socialist triumph. He declared that the rise of the Nazis had demonstrated the utter failure of cosmopolitan Jewish attempts at assimilation. Christians had never accepted the Jews, and "[w]hen the time came," the Nazis made easy "use of popular [anti-Semitic] tendencies which had always lain ready beneath the surface" of Christian society [107]. By arguing this, Kahler implicitly rejected the entire cosmopolitan project of German and German-speaking Central European Jewry. There was no such thing as a Republic of Letters for the Jews to join. In the eyes of their enemies, they would always be first and foremost Jews. The Jewish intellectuals had been naïve to believe that their oppression could ever end.

Kahler emphasized that the Nazi attack on the Jews was not only an attack on Judaism, but also an attack on the cosmopolitan project of liberal democracy itself. He stressed that because "their spiritual law [was] never compatible with an unlimited claim to human power," the Jews had always "stood for democracy, for social equality and for peace [108]". The fact that the Jews lived in all countries also made them a potent symbol of cosmopolitan internationalism. For these reasons, Nazi attacks on the Jews were really attacks on the cosmopolitan project and the Nazi victory signaled this project's death [109].

Kahler's essay represented a strong blow against the German and Central European cosmopolitan ideal still embraced by the Jewish members of the Graduate Faculty. In painstaking detail, Kahler elucidated how from antiquity to the present Jew hatred was endemic to western society. Anti-Semitism crossed borders and cultures like no other ideology. He implied that it was foolhardy for his colleagues to think differently. Their cosmopolitan project, while admirable, had ended in defeat. Indeed, in the next years Social Research displayed a new sensitivity to Jewish issues. Between 1940 and 1945, the term "Jews" appeared in 45 articles and book reviews; "Jewish" in 40; variations on "anti-Semitism" in 17; "Jew" in 16; "Judaism" in 10; and variations on "anti-Semitic" in 4. 
The death of the European cosmopolitan project led to the emergence of a new focus on Jewish particularism. However, one must recognize that it was American progressive cosmopolitanism that helped save the generation of scholars who found a home at the New School; it was this cosmopolitanism that allowed the University in Exile's faculty members to examine their Jewish particularism. Although the cosmopolitan project failed in Central Europe, it partially succeeded in America.

\section{Conclusions}

In Intellectuals in Exile, Claus-Dieter Krohn convincingly demonstrates that the success of the University in Exile relied extensively upon receiving the necessary funding to support exiled German scholars. In emphasizing the financial structures that undergirded the New School's becoming the largest institutional home for intellectual exiles, however, Krohn largely ignores how ideological similarities contributed to the Graduate Faculty's flourishing. This paper illuminates how the cosmopolitan and interest-based congruencies between left wing American progressives and German- and Central European-Jewish intellectuals helped engender the University in Exile's achievements by allowing the institution to function well and impelling its acceptance by American academics. In demonstrating this, it also explains why in the 1930s Johnson and other faculty members devoted so little attention to Jewish issues.

There still remains much work to be done on the University in Exile's faculty members' relationship to Judaism. Questions that remain to be answered include: To what degree was the cultural-intellectual life of the faculty members "Jewish," that is to say, informed by Jewish cultural traditions? Were Johnson and faculty members speaking in a coded language when referring to the New School's "German" professoriate? How did de-emphasizing the faculty members' Judaism affect how Jewish donors like Halle viewed the Graduate Faculty? Did faculty members discuss their Judaism in publications outside of Social Research? If so, how? What, if any, were the New School scholars' opinions regarding Zionism? How did the faculty members relate to the New York intellectuals, many of whom were Jewish? These and other questions open up fruitful areas of future research.

\section{Acknowledgements}

The author would like to thank Malachi Hacohen, Julie Mell, Jody Bessner, Vanessa Freije, Abby Goldman, Katie Rosenblatt, David Weinfeld, and the anonymous reviewers of Religions for their helpful comments and suggestions.

\section{References and Notes}

1. From 1935 onward, the Graduate Faculty received over 5000 requests a year for positions. The New School also became a place where academics from other universities could ferry exiles they did not want or could not take. The faculty members themselves were committed to helping fellow and possibly future exiles. For example, Graduate Faculty members donated $3 \%$ of their salaries to aiding exiles, particularly young scholars whom the aid committees designed to help persecuted intellectuals often ignored. Robert Jackall, "Book Review: Peter 
M. Rutkoff and William B. Scott, New School: A History of The New School for Social Research," Contemporary Sociology Vol. 16, No. 3 (May 1987): 277 and Claus-Dieter Krohn, Intellectuals in Exile: Refugee Scholars and the New School for Social Research, trans. Rita Kimber and Robert Kimber (Amherst: University of Massachusetts Press, 1993), $16,76-78$.

2. The entire list of faculty who found a home at the New School in the 1930s and 1940s may be found here: "The University in Exile," accessed December 31, 2011, $<$ http://www.newschool.edu/nssr/subpage.aspx?id=28792>. Krohn also produces a list. Krohn, Intellectuals in Exile, 205-210.

3. Besides the obvious influence of a luminary like Strauss, the New School was a center of some major intellectual traditions. Due to Wertheimer, the New School was the first center of Gestalt psychology in America; Alfred Schütz helped introduce phenomenology to American philosophy and sociology; Arnold Brecht and Schütz helped develop the comparative study of governments; and the work of New School economists has been recently rediscovered and evaluated. For more on the New School's influence, the major account remains Krohn, Intellectuals in Exile. See also D. Brett King, Michael Wertheimer, Heidi Keller, and Kevin Crochetiére, "The Legacy of Max Wertheimer and Gestalt Psychology," Social Research 61, no. 4 (Winter 1994): 907-935; Elisabeth Allgoewer, "Emil Lederer: Business Cycles, Crises, and Growth," Journal of the History of Economic Thought 25, no. 3 (September 2003): 327-348; George Psathas, "Alfred Shutz's Influence on American Sociologists and Sociology," Human Studies 27, no. 1 (2004): 1-35; Harald Hagemann, "Dismissal, Expulsion, and Emigration of German-speaking Economists after 1933," Journal of the History of Economic Thought 27, no. 4 (December 2005): 405-420; Gary Mongiovi, "Emigré Economists and American Neoclassical Economics, 1933-1945," Journal of the History of Economic Thought 27, no. 4 (December 2005): 427-437; Gerhard Loewenberg, "The Influence of European Émigré Scholars on Comparative Politics, 1925-1965," American Political Science Review 100, no. 4 (November 2006): 597-604; George Steinmetz, "Ideas in Exile: Refugees from Nazi Germany and the Failure to Transplant Historical Sociology into the United States," International Journal of Politics, Culture, and Society 23, no. 1 (March 2010): 1-27; and Harald Hagermann, "European Émigrés and the 'Americanization' of Economics," The European Journal of the History of Economic Thought 18, no. 5 (2011): 643-671.

4. Other works on the University in Exile include Monika Plessner, "Die deutsche 'University in Exile' in New York und ihr amerikanischer Gründer," Frankfurter Hefte 19 (March 1964): 181-186; Benita Luckmann, “Eine deutsche Universität im Exil: Die 'Graduate Faculty' der New School for Social Research," in Soziologie in Deutschland und Österreich, 1918-1945: Materialien zur Entwicklung, Emigration, und Wirkungsgeschichte, ed. M. Rainer Lepsius (Opalden: Westdeutscher Verlag, 1981), 427-441; Benita Luckmann, "Exil oder Emigration: Aspekte der Amerikanisierung an der 'New School for Social Research' in New York," Leben im Exil: Probleme der Integration deutscher Flüchtlinge im Ausland, 1933-1945, ed. Wolfgang Frühwald and Wolfgang Schieder (Hamburg: Hoffman und Campe, 1981), 227234; Peter M. Rutkoff and William B. Scott, New School: A History of the New School for Social Research (New York: The Free Press, 1986); Stanford M. Lyman, “A Haven for 
Homeless Intellects: The New School and Its Exile Faculties," International Journal of Politics, Culture, and Society 7, no. 3 (Spring 1994): 493-512; Wilfred M. McClay, "Historical Research on the Refugee Intellectuals: Problems and Prospects," International Journal of Politics, Culture, and Society 7, no. 3 (Spring 1994): 513-524; and Claus-Dieter Krohn, "Differenz oder Distanz? Hybriditätsdiskurse deutscher refugee scholars im New York der 1930er Jahre," in Exil, Entwurzelung, Identität, ed. Claus-Dieter Krohn, Erwin Rothermund, and Lutz Winckler (Munich: Edition Text + Kritik, 2009), 20-39. The intellectual migration has also attracted an enormous amount of scholarly attention. The major general works on the subject include: Laura Fermi, Illustrious Immigrants: The Intellectual Migration from Europe, 1930-1941 (Chicago: University of Chicago Press, 1972); Lewis Coser, Refugee Scholars in America: Their Impact and Their Experiences (New Haven: Yale University Press, 1984); Ilja Srubar, ed., Exil, Wissenchaft, Identität: Die Emigration deutscher Sozialwissenschaftler, 1933-1945 (Berlin: Suhrkamp, 1988); Ernst Stiefel, Deutsche Juristen im amerikanischen Exil, 1933-1950 (Tübingen: Mohr, 1991); Sven Papcke, Deutsche Soziologie im Exil: Gegenwartsdiagnose und Epochenkritik, 1933-1945 (Frankfurt: Campus Verlag, 1993); Alfons Söllner, Deutsche Politikwissenschaftler in der Emigration: Ihre Akkulturation und Wirkungsgeschichte, samt einer Bibliographie (Opladen: Westdeutscher Verlag, 1996); Mitchell G. Ash and Alfons Söllner, eds. Forced Migration and Scientific Change: Émigré German-Speaking Scientists and Scholars after 1933 (Cambridge: Cambridge University Press, 2002); Jean-Michel Palmier, Weimar in Exile: The Antifascist Emigration to Europe and America (New York: Verso Press, 2006); David Kettler and Gerhard Lauer, eds. Exile, Science, and Bildung: The Contested Legacies of German Émigré Intellectuals (New York: Palgrave Macmillan, 2005); Axel Fair-Schulz and Mario Kessler, eds. German Scholars in Exile: New Studies in Intellectual History (Lanham, MD: Lexington Books, 2011); and David Kettler, The Liquidation of Exile: Studies in the Intellectual Emigration of the 1930s (New York: Anthem Press, 2011)

5. The émigrés' occasionally used the terms "cosmopolitan" and "cosmopolitanism," which are also widely used in the secondary literature. For these reasons, I use the terms. Also, the division of progressives into "right-leaning" and "left-leaning" is taken from Gary Gerstle, "The Protean Character of American Liberalism," American Historical Review 99, no. 4 (October 1994): 1051.

6. Daniel Rodgers examined in great detail the connections between American and European ideas in the progressive era. See Daniel Rodgers, Atlantic Crossings: Social Politics in a Progressive Age (Cambridge: Harvard University Press, 2000).

7. Professors fired included James McKeen Cattell, Henry Wadsworth Longfellow Dana, and Leon Fraser.

8. This did not mean that New School scholars would never work for Butler or at Columbia. For example, in the 1930s Johnson worked on Butler's Commission on Economic Reconstruction at Columbia. 
9. The educational philosophies of Dewey and Veblen, who viewed the primary goals of education as being the creation of "critical and inquisitive minds" dedicated to solving society's ills through research and a commitment to "democratic cosmopolitanism," were particularly influential on the New School's founders. Rutkoff and Scott, New School, 12-18 and Jackall, "Book Review," 276.

10. Seligman had studied in Germany under Karl Knies and Gustav Schmoller. Perhaps he helped stir Johnson's interest in German academia.

11. Croly offered Johnson the position because he had read and admired his essay "The Soul of Capitalism," written for the April-June 1914 edition of The Unpopular Review. Dorothy Ross briefly discusses Johnson's work from this period in her well-known The Origins of American Social Science. In this discussion, however, Ross paints Johnson as a "Roosevelt progressive" and "antisocialist," ignoring his close connections to Dewey and other leftleaning progressives as well as his recruitment of a number of prominent German socialists. Dorothy Ross, The Origins of American Social Science (Cambridge: Cambridge University Press, 1992), 408.

12. Krohn, Intellectuals in Exile, 61.

13. Johnson edited the encyclopedia with his former mentor Seligman. Both the Rockefeller and Carnegie Foundations contributed $\$ 1.25$ million to the project, which the Social Science Research Council oversaw. Alvin Johnson, "Report to the Trustees of the Graduate Faculty of Political and Social Science in the New School for Social Research, February 1935, by Alvin Johnson, Chairman," New School for Social Research Archives, New School for Social Research, New York, New York (hereafter referred to as the NSSRA), Box Graduate Faculty Administration Records, Folders 27-60, Folder 38: 3. For more on the encyclopedia, see Rutkoff and Scott, New School, chapter 4. In the end, more German social scientists produced articles for the Encyclopedia than academics from any other country.

14. Alvin Johnson, "Report to the Trustees of the Graduate Faculty of Political and Social Science in the New School for Social Research, February 1935, by Alvin Johnson, Chairman," NSSRA, Box Graduate Faculty Administration Records, Folders 27-60, Folder 38: 2.

15. Alvin Johnson to Agnes deLima, April 13, 1933, Alvin Johnson Papers at Yale. Quoted in Rutkoff and Scott, New School, 274. Also see "Faculty of Exiles is Projected Here," New York Times, May 13, 1933, 7.

16. Lederer and Johnson also hoped that Karl Mannheim, the famed founder of the sociology of knowledge and Lederer's former colleague from the University of Heidelberg, would join the New School faculty. Mannheim declined, instead accepting a position as a lecturer at the London School of Economics. This remained a sour point between Lederer and Mannheim for the rest of their lives (Lederer died in May 1939, Mannheim in January 1947).

17. Hans Speier, "Emil Lederer, Life and Work," Hans Speier Papers, German and Jewish Intellectual Émigré Collection, M.E. Grenander Department of Special Collections and Archives, University Libraries, University at Albany, State University of New York (hereafter referred to as the Speier Papers), Box 7, Folder 2: 27. 
18. Alvin Johnson Papers at the University of Nebraska-Lincoln, Archives and Special Collections, Lincoln, Nebraska (hereafter referred to as the Johnson Papers at Nebraska), Box 47, Folder Graduate Faculty-University in Exile and Rutkoff and Scott (1986), 94.

19. This did not mean that the University in Exile was, in its first years, on sound financial footing. According to Speier, "almost every month, and certainly at the end of every semester, one did not know whether the [University in Exile] would continue or not." "Gesprächsweise Mitteilungen zu einer intellektuellen Autobiographie," Speier Papers, Box 2, Folder 31: 129; Johnson Papers at Nebraska, Box 47, Folder Graduate Faculty-University in Exile; and Alvin Johnson, "Report to the Trustees of the Graduate Faculty of Political and Social Science in the New School for Social Research, February 1935, by Alvin Johnson, Chairman," NSSRA, Box Graduate Faculty Administration Records, Folders 27-60, Folder 38: 10. Halle was part owner of the Gulf Oil Company and associated with the Rockefeller Foundation. For more on the Rockefeller Foundation and other philanthropic organizations and anti-Semitism, see Marjorie Lamberti, "The Reception of Refugee Scholars from Nazi Germany in America: Philanthropy and Social Change in Higher Education," Jewish Social Studies 12, no. 3 (Spring-Summer 2006): 157-192. Interestingly, Lederer and Marschak had, in April and May 1933, asked the foundation to support the immigration of several scholars. Between 1933 and 1945, the Rockefeller Foundation spent \$1.4 million helping displaced scholars. For more on the Rockefeller Foundation, see Krohn, Intellectuals in Exile, 29-38. The philanthropist Doris Duke eventually aided Johnson in his project, contributing \$250,000 to the New School. Additional important exile aid committees included the British Academic Assistance Council; the Zurich based Notgemeinschaft deutscher Wissenchaftler im Ausland; and the United States Emergency Committee in Aid of Displaced Foreign Scholars. There were a number of specifically Jewish aid agencies, including the Joint Distribution Committee, the Hicem, and the Jewish Agency for Palestine, which helped intellectual exiles. Aid committees sometimes paid half of an exiles scholars' salary. All told, the Emergency Committee gave $\$ 800,000$ to support 335 scholars; the Rockefeller Foundation gave \$1.4 million dollars to aid 303 scholars (which represented half of all U.S. money given to aid exiles; roughly half of this aid, approximately $\$ 540,000$, went to the New School); the Oberlaender Trust gave $\$ 317,000$ for 300 scholars; the Carnegie Foundation gave \$110,000; the Lucius D. Littauer fund donated $\$ 100,000$; the New York Foundation offered \$23,000; and the Rosenwald family, into which Max Ascoli married, donated \$100,000, all to exile causes. Most foundations assisted only scholars who were above 30, so as not to affect young American academics' job prospects (Oberlaender did not abide by this). Krohn, Intellectuals in Exile, 28, 72.

20. Alvin Johnson, "Report to the Trustees of the Graduate Faculty of Political and Social Science in the New School for Social Research, February 1935, by Alvin Johnson, Chairman," NSSRA, Box Graduate Faculty Administration Records, Folders 27-60, Folder 38: 5 and "Graduate Faculty of Political and Social Science ('The University in Exile'), 1933-1934," in Graduate Faculty of the New School Catalogues, Fall 1933-Summer 1937, NSSRA. In its first year, the Advisory Committee for the University in Exile included Charles C. Burlingham (a lawyer); Wilbur L. Cross (governor of Connecticut); Dewey (then emeritus professor of philosophy at Columbia); Felix Frankfurter (professor of law at Harvard); Ernest 
Gruening (director of the Division of Territories and Island Possessions for the U.S. Department of the Interior); Oliver Wendell Holmes (former U.S. Supreme Court Justice); Robert M. Hutchins (president of the University of Chicago); Robert M. MacIver (professor of political science and sociology at Columbia); William A. Neilson (president of Smith College); George A. Plimpton (a publisher); Seligman (then professor emeritus of political economy at Columbia); and Herbert Bayard Swope (a journalist).

21. The New School was not permanently chartered until January 17, 1941. Until then, all masters and doctoral exams needed to be taken at New York University. "Absolute Charter of the New School for Social Research," Johnson Papers at Nebraska, Box 47, Folder Graduate Faculty-University in Exile.

22. Palmier, Weimar in Exile, 468. Krohn has described the American government's attitude toward refugees as apathetic. It is estimated that 7500 "academic professionals, doctors, lawyers ... as well as students" lost their jobs. If one includes artists, writers, and others who made their living off of cultural pursuits as well as intellectuals, approximately 12,000 individuals lost their jobs. In April 1933, 16\% of university faculty were dismissed. By 1938, $39 \%$ of all university faculty were fired. In the social sciences, $47 \%$ of all faculty were lost. Approximately $60 \%$ of dismissed faculty emigrated, with the United States becoming the most popular home for exiles. Krohn, Intellectuals in Exile, 11-15, 25.

23. "University in Exile," Johnson Papers at Nebraska, Box 47, Folder Graduate FacultyUniversity in Exile and Alvin Johnson, "Report to the Trustees of the Graduate Faculty of Political and Social Science in the New School for Social Research, February 1935, by Alvin Johnson, Chairman," NSSRA, Box Graduate Faculty Administration Records, Folders 27-60, Folder 38: 8. Other individuals whom Johnson hoped to bring over included Mannheim, Ascoli, Brecht, Rudolf Littauer, and Werner Hegemann. All except Mannheim would join the New School. In 1934, Johnson added several members to the faculty, including Hans Staudinger, Albert Salomon, Alfred Kähler, Fritz Lehmann, Carl Mayer, and Hans Simons.

24. Johnson took pains to explain that "[n]o member of the Graduate Faculty is a Marxist as the term is understood in America." "University in Exile," Johnson Papers at Nebraska, Box 47, Folder Graduate Faculty-University in Exile.

25. Arthur J. Vidich. "Book Review: Peter M. Rutkoff and William B. Scott, New School: A History of The New School for Social Research," Contemporary Sociology 16, no. 3 (1987): 275.

26. As Johnson said, "the German social scientist stands nearer to the political and administrative life of the country [than American academics], participating in expert commissions and in national and city governmental bodies." Alvin Johnson, "Report to the Trustees of the Graduate Faculty of Political and Social Science in the New School for Social Research, February 1935, by Alvin Johnson, Chairman," NSSRA, Box Graduate Faculty Administration Records, Folders 27-60, Folder 38: 3. 
27. Alvin Johnson, "Report to the Trustees of the Graduate Faculty of Political and Social Science in the New School for Social Research, February 1935, by Alvin Johnson, Chairman," NSSRA, Box Graduate Faculty Administration Records, Folders 27-60, Folder 38: 3. For details on the University in Exile's founding and funding, see Krohn, Intellectuals in Exile, chapter five.

28. Krohn, Intellectuals in Exile, 71.

29. Five of the founders were also economists.

30. In The Jewish Origins of Cultural Pluralism, Daniel Greene traces this idea through Horace Kallen and the Menorah Association at Harvard. See Daniel Greene, The Jewish Origins of Cultural Pluralism: The Menorah Association and American Diversity (Bloomington, ID: Indiana University Press, 2011).

31. Other prominent members of this organization were Dewey, Kallen, and Albert Einstein.

32. Aid organizations also recognized that anti-Semitism was a significant barrier to the émigrés finding jobs in America. Even academics sympathetic to the exiles' plight were wary of recruiting too many Jews. For example, when attempting to create a temporary committee to help European colleagues, Joseph Schumpeter declared that he wanted this committee to aid "as few Jews as possible." There were also political difficulties involved in aiding exiles, and aid organizations regularly received complaints that the New School scholars were communists dedicated to undermining America. Krohn, Intellectuals in Exile, 22-24, 35; Alvin Johnson to Clara Mayer, May 17, 1945. Cited in Krohn, Intellectuals in Exile, 22 and Joseph A. Schumpeter to W.C. Mitchell, April 22, 1933. Cited in Krohn, Intellectuals in Exile, 23.

33. Fritz Ringer. The Decline of the German Mandarins: The German Academic Community, 1890-1933.Cambridge: Harvard University Press, 1969, vol. 6.

34. Fritz Ringer. Max Weber: An Intellectual Biography (Chicago: University of Chicago Press, 2004), 9.

35. Recent scholarship has argued that one must see this embrace of a secular-intellectual culture as representing not a rejection of Judaism, but rather its transformation. That is to say, although Jews did reject elements of their Jewish heritage, they formed a new identity in distinctly Jewish spaces and in accordance with Jewish cultural-intellectual traditions. See, for example, Malachi Haim Hacohen, Karl Popper: The Formative Years, 1902-1945: Politics and Philosophy in Interwar Vienna (Cambridge: Cambridge University Press, 2000), chapter 1 and chapter 7 and Till van Rahden, Jews and Other Germans: Civil Society, Religious Diversity, and Urban Politics in Breslau, 1860-1925, trans. Marcus Brainard (Madison, WI: University of Wisconsin Press, 2008).

36. It is the unfortunate fact that the Graduate Faculty meeting minutes from the years 1933 to 1944 are presently lost. According to Sonia Salas, Associate Director of Administration at the New School for Social Research, when the Graduate Faculty relocated from $655^{\text {th }}$ Avenue in 2007 the faculty's archival material was sent offsite without an inventory. The person in charge of moving the material has since left the New School, and presently New School administrators are unable to pinpoint the material's location. Hopefully, these files will one day be found. 
37. "Graduate Faculty of Political and Social Science ('The University in Exile'), 1933-1934," in Graduate Faculty of the New School Catalogues, Fall 1933-Summer 1937, NSSRA.

38. See reference 37.

39. See reference 37.

40. Alvin Johnson, "Foreword," Social Research 1, no. 1 (February 1934), 1.

41. See reference 37 .

42. Alvin Johnson, "Report to the Trustees of the Graduate Faculty of Political and Social Science in the New School for Social Research, February 1935, by Alvin Johnson, Chairman," NSSRA, Box Graduate Faculty Administration Records, Folders 27-60, Folder 38: 1.

43. See reference 37.

44. Johnson, "Foreword," 2.

45. Alvin Johnson, "Report to the Trustees of the Graduate Faculty of Political and Social Science in the New School for Social Research, February 1935, by Alvin Johnson, Chairman," NSSRA, Box Graduate Faculty Administration Records, Folders 27-60, Folder 38: 1.

46. Alvin Johnson, "Report to the Trustees of the Graduate Faculty of Political and Social Science in the New School for Social Research, February 1935, by Alvin Johnson, Chairman," NSSRA, Box Graduate Faculty Administration Records, Folders 27-60, Folder 38: 2.

47. Johnson, "Report to the Trustees of the Graduate Faculty of Political and Social Science in the New School for Social Research, February 1935, by Alvin Johnson, Chairman," NSSRA, Box Graduate Faculty Administration Records, Folders 27-60, Folder 38: 8.

48. See reference 47.

49. Daniel Tanner, Crusade For Democracy (Albany: State University of New York Press, 1991), 17.

50. John Dewey, The Later Works of John Dewey, volume 17, 1925-1953 (Carbondale, IL: Southern Illinois University Press, 2008), 147-148, 597-598.

51. Alvin Johnson, "Eclipse of the Great Man," American Journal of Economics and Sociology 20, no. 4 (July 1961): 424.

52. There were a variety of responses to immigrants from various world regions. Dewey, for example, believed (Western and Central) European immigrants could contribute more to the American nation than non-European immigrants. This discussion centers on progressive responses to European immigrants. See Thomas D. Fallace, Dewey and the Dilemma of Race: An Intellectual History, 1895-1922 (New York: Teachers College Press, 2010), 127.

53. John Dewey, Reconstruction in Philosophy (New York: Henry Holt Press, 1920), 202-205. See also Robert B. Westbrook, John Dewey and American Democracy (Ithaca: Cornell University Press, 1993), 212-215 and Fallace, Dilemma of Race, 101, 124.

54. Rivka Shpak-Lisak, Pluralism and Progressives: Hull House and the New Immigrants, 1890 1919 (Chicago: University of Chicago Press, 1989), 141-142 and Gerstle, "Protean Character," 1051-1052, 1055.

55. He repeatedly stressed that America, as an exceptional nation, needed to incorporate - but move beyond - its old and new European roots. Westbrook, American Democracy, 214 and Fallace, Dilemma of Race, 121. 
56. Noah Pickus, True Faith and Allegiance: Immigration and American Civic Nationalism (Princeton: Princeton University Press, 2007), 7 and Douglas Charles Rossinow, Visions of Progress: The Left-Liberal Tradition in America (Philadelphia: University of Pennsylvania Press, 2008), 41. During the war, Kallen termed this "cultural pluralism." Sidney Ratner, "Horace M. Kallen and Cultural Pluralism," Modern Judaism 4, no. 2 (1984): 185-200 and William Toll, "Horace M. Kallen: Pluralism and American Jewish Identity," American Jewish History 85, no. 1 (March 1997): 57-74. Rossinow stresses that among left-leaning progressives, there was "no consensus on questions of race and ethnicity." Thus, one should not ignore that amongst these progressives, there were differences in thought. Kallen, for instance, argued that America should become a nation of nations, that is to say, ethnic groups should fully retain their identity, using English as a common, public language. He did not believe they should assimilate into a so-called "melting pot" (a well-known progressive term from the period) that would see European immigrants abandon their cultural heritages and embrace American (i.e., Anglo-Saxon) culture. Dewey, however, believed that America should assimilate European contributions in the service of creating a new, American identity (although he too rejected an embrace of Anglo-Saxondom). This is seen in a letter Dewey wrote Kallen in 1915, responding to Kallen's 1915 essay "Democracy versus the Melting Pot." Dewey argued in favor of immigrants "assimilat[ing] to one another — not to Anglosaxondom[.]" John Dewey to Horace Kallen, March 31, 1915, Horace M. Kallen Papers, Box 7, Folder 13, American Jewish Archives, Cincinnati, OH. This rejected the "melting pot metaphor" of complete assimilation which Dewey "never did care for[.]" Thanks to David Weinfeld for sending me a copy of this letter. The citation for Kallen's piece is Horace M. Kallen, "Democracy versus the Melting-Pot, Parts I and II," The Nation, February 18 and 25, 1915. Addams' (and William I. Thomas') beliefs more closely echoed Dewey's than Kallen's. Shpak-Lisak (1989), 25-29. For Kallen's views, see Horace M. Kallen, Culture and Democracy in the United States: Studies in the Group Psychology of the American Peoples (New York: Boni \& Liveright, 1924). For more on Dewey and Addams, see Eric P. Kaufmann, The Rise and Fall of Anglo-America (Cambridge: Harvard University Press, 2004), 98-100. There is a significant debate about Dewey's opinions toward immigrants. See Walter Feinberg, "Progressive Education and Social Planning," Teachers College Record 73, no. 4 (May 1972): 484-505; Clarence J. Karier, "Liberalism and the Quest for Orderly Change," History of Education Quarterly 12, no. 1 (Spring 1972): 57-80; J. Christopher Eisele, "John Dewey and the Immigrants," History of Education Quarterly 15, no. 1 (Spring 1975): 67-85; Charles L. Zerby, "John Dewey and the Polish Question: A Response to Revisionist Historians," 15, no. 1 History of Education Quarterly (Spring 1975): 17-30; and Ronald K. Goodenow, "Racial and Ethnic Tolerance in John Dewey's Educational and Social Thought: The Depression Years," Educational Theory 27 (Winter 1977): 48-64. As Westbrook has noted, these debates center on the so-called Polish question, which refers to Dewey's wartime analyses of Polish immigrants' politics. Westbrook, American Democracy, 212. A full-length work that presents Dewey as more conservative than traditionally supposed has recently been published. See Fallace, Dilemma of Race. For more on Dewey, see Eisele, "Immigrants" and Pickus, True Faith, 71-75. Also see Jonathan Hanse, The Lost Promise of 
Patriotism: Debating American Identity, 1890-1920 (Chicago: University of Chicago Press, 2003).

57. Gerstle argues that the left-leaning progressives shifted from a cultural to an economic focus in the interwar years because they adopted the perspective that cultural questions were fundamentally irrational and unable to be measured. By contrast, they believed that economic issues, being quantifiable, could be measured and thus changed. This latter belief was undergirded by the new sciences of psychology and psychiatry, which emphasized that ordinary people's behaviors were subject to irrational emotions. To Dewey and other progressives, cultural politics no longer appeared a useful means to achieve progressive aims. After Hitler's rise, however, left-leaning progressives returned to cultural questions. In particular, the 1940s saw a boon of left-leaning progressive (now termed liberal) literature discussing long-ignored issues like civil rights, Zionism, and immigration reform. This shift was fostered not only by Nazism, but also by liberals' analysis of the Soviet Union. Whereas in the 1920s, they viewed collectivist Soviet projects as rational, by the 1940s - in the wake of Stalin's purges, the starvation of the kulaks, and other Soviet crimes - they considered these projects economic manifestations of (irrational) totalitarianism. Now, culture appeared just as rational as the irrational economy. Gerstle, "Protean Character," 1057-1059, 1065, 1070-1071. See also David A. Hollinger, "Ethnic Diversity, Cosmopolitanism and the Emergence of the American Liberal Intelligentsia," American Quarterly 27, no. 2 (May 1975): $133-151$.

58. See, for example: Norman Hapgood, “Schools, Colleges, and Jews,' Harper's Weekly 62, January 22, 1916, 78; Norman Hapgood, 'Harvard 'Talk' about Jews,' Literary Digest 73, June 24, 1922, 28; E.S.M., “As for the Jews of Harvard ...” Life 80 (2070), July 6, 1922, 15; Victor S. Yarros, Robert M. Lovett, Fay H. Babbe, M. R. M., Joseph Girdansky, Charles Sheres, Donald A. Roberts, and W.L. Whittlesey, "Anti-Semitism and the Colleges," The Nation 115, no. 2975, 45-46; “"What Was Your Father's Name?”" The Nation 115, no. 2987, 323; "Colleges Deny Bias Against Any Sect: Columbia, Brown, Harvard, and Dartmouth Say Jews Are Not Discriminated Against," The New York Times, April 30, 1926, 11; "Denies Yeshiva Is Protest: G.A. Rogers Says Jewish College Will Not Bar Outsiders," The New York Times, June 3, 1926, 22; "Dr. Wise Criticizes Greek Fraternities: Urges Jewish Students Not to Deny Their Race-Decries College Quota System," The New York Times, April 4, 1927, 23; "Jewish University Is Planned Here: First College of Kind Will be Non-Sectarian, Its Organizers Decide," The New York Times, May 16, 1929, 6; "Sifts Anti-Jewish Bias in Trade and Schools: American Jewish Congress Is Weighing Group Action to Combat Discrimination," The New York Times, May 22, 1930, 14; "Bias in Colleges Denied: Dr. Rypins Finds Medical Schools Do Not Bar Jews," The New York Times, December 17, 1934, 39. These systems were of course responses to the fact that Jews were making inroads into American universities and beginning a process of "de-Christianization" of the university system. See David A. Hollinger, Science, Jews, and Secular Culture: Studies in MidTwentieth Century American Intellectual History (Princeton: Princeton University Press, 1998), chapter 2 . 
59. The term "genteel anti-Semitism" seems to have been derived from the 1947 Gregory Peck-starring drama Gentleman's Agreement. In this film, Peck played a journalist who pretended to be a Jew to expose the anti-Semitism of the protestant community of Darien, Connecticut. The film won the Academy Award for Best Picture, Best Supporting Actress (Celeste Holm), and Best Director (Elia Kazan). It was nominated for five other Oscars, including Best Actor, Best Actress, Best Supporting Actress, Film Editing, and Writing for a Screenplay. Leonard Dinnerstein, Antisemitism in America (New York: Oxford University Press, 1995), 83-84 and Robert A. Rosenbaum, Waking to Danger: Americans and Nazi Germany, 1933-1941 (Santa Barbara: Praeger, 2010), 40-42.

60. In the late-nineteenth century, the Protestant elite coalesced around the idea that educational training needed to reproduce an aristocratic class composed of men who retained a "manly, Christian character." Jews were naturally excluded from this process. Jerome Karabel, The Chosen: The Hidden History of Admission and Exclusion at Harvard, Yale, and Princeton (Boston: Houghton Mifflin, 2005), 29, 132.

61. Michael Greenberg and Seymour Zenchelsky, "Private Bias and Public Responsibility: Anti-Semitism at Rutgers in the 1920s and 1930s," History of Education Quarterly 33, no. 3 (Autumn 1993): 295-296.

62. For a discussion of these issues, see Oliver B. Pollak, "Antisemitism, the Harvard Plan, and the Roots of Reverse Discrimination," Jewish Social Studies 45, no. 2 (Spring 1983): 113-122; Harold S. Wechsler, "The Rationale for Restriction: Ethnicity and College Admission in America, 1910-1980," American Quarterly 36, no. 5 (Winter 1984): 646, 650-651; and Karabel, The Chosen, 133-134. Wechsler argues that the restriction on Jewish immigration at Columbia indicated the shift from elite secondary schools to elite colleges as the gatekeepers of American aristocracy.

63. Marcia G. Synott, "The Admission and Assimilation of Minority Students at Harvard, Yale, and Princeton, 1900-1970," History of Education Quarterly 19, no. 3 (Autumn 1979): 285-304; Marcia G. Synott, The Half-Open Door: Discrimination and Admissions at Harvard, Yale, and Princeton, 1900-1970 (Westport, CT: Greenwood Press, 1979); Pollak (1983); Wachsler (1984), 650-652; Tamar Buchsbaum, "A Note on Antisemitism in Admissions at Dartmouth," Jewish Social Studies 49, no. 1 (Winter 1987): 79-80; Greenberg and Zenchelsky (1993), 297; Dan Oren, Joining the Club: A History of Jews and Yale (New Haven: Yale University Press, 2000); Karabel (2005); and Zev Eleff, “"The Envy of the World and the Pride of the Jews:' Debating the American Jewish University in the Twenties," Modern Judaism 31, no. 2 (May 2011): 230. For example, at the May 1918 meeting of the members of the Association of New England Deans, there were fears about the rise of Jewish students at universities. Synott, “Admission and Assimilation,” 288-289.

64. Peter Novick, That Noble Dream: The 'Objectivity Question' and the American Historical Profession (Cambridge: Cambridge University Press, 1988), 172-173 and Hollinger (1998), 25.

65. John Higham, Send These to Me: Jews and Other Immigrants in Urban America (New York: Atheneum Press, 1975), 138-173.

66. Higham, Send These, 166. 
67. From 1946 to 1947, Johnson, NYSCADE, the American Jewish Committee (AJC), Brooklyn Democratic Assemblyman Bernard Austin, and Republican State Senator Walter J. Mahoney introduced the Austin-Mahoney Bill to ban quotas (the only other academic to support the Austin-Mahoney bill was president Harold Taylor of Sarah Lawrence College). The Archdiocese of New York opposed the bill by arguing that it gave the state power to make educational decisions, which violated the individual freedom of parents. To protest the Archdiocese's opposition, NYSCADE organized rallies in New York City's garment district to collect signatures. In the first week of March 1947, NYSCADE, the AJC, and a group of Jewish war veterans staged sit-ins at Albany's capitol building to demand the AustinMahoney bill's passage. The bill was nevertheless defeated. However, NYSCADE and the AJC redrafted the bill in such a way that religious schools were exempted from its provisions. This change enabled the bill's passing in October 1947. Pamela Rice, “A Legislative Attack on Educational Discrimination," The Journal of Negro Education 23, no. 1 (Winter 1954): 99; Martha Biondi, To Stand and Fight: The Struggle for Civil Rights in Postwar New York City (Cambridge: Harvard University Press, 2006), 107; and Tod Ottman, "Forging SUNY in New York's Political Cauldron," in SUNY at Sixty: The Promise of the State University of New York, eds. John B. Clark, W. Bruce Leslie, and Kenneth P. O'Brien (Albany, NY: State University of New York Press, Albany, 2010), 22-25.

68. The foundation constantly worried that it recruited too many Jews. Indeed, the Rockefeller Foundation was considering funding the University of Frankfurt but believed that too many Jews worked there. Krohn, Intellectuals in Exile, 22-24, 35.

69. Throughout the early-1930s faculty members were accused of being, variably, communists or Nazi-sympathizers. The FBI even set up an investigation whereby agents infiltrated the New School by acting as students. Unsurprisingly, no charges were ever filed against faculty members. Krohn, Intellectuals in Exile, 21-24, 72, 160.

70. Alvin Johnson, "Report to the Trustees of the Graduate Faculty of Political and Social Science in the New School for Social Research, February 1935, by Alvin Johnson, Chairman," NSSRA, Box Graduate Faculty Administration Records, Folders 27-60, Folder 38: 12.

71. Alvin Johnson, "Report of the Dean of the Graduate Faculty of Political and Social Science in the New School for Social Research, September 1939," Box Graduate Faculty Administration Records Folders 27-60, Folder 38 Graduate Faculty Reports 1935-1951: 3.

72. Of the American subscribers, there were 18 public libraries; 99 university, college, and school libraries; 170 teachers, professors, and academics; and 236 businesspeople and miscellaneous subscribers. Of the foreign subscribers, there were 4 public libraries; 24 university, college, and school libraries; 34 teachers, professors, and academics; and 52 businessmen and miscellaneous subscribers. "Report of the Dean of the Graduate Faculty of Political and Social Science in the New School for Social Research, September 1936," Box Graduate Faculty Administration Records Folders 27-60, Folder 38 Graduate Faculty Reports 1935-1951: 6.

73. This despite the fact that several progressives associated with the New School, including Kallen, Bourne, and Seligman, were sympathetic with the Zionist cause.

74. Albert Salomon, “Max Weber's Sociology,” Social Research 2, no. 1 (February 1935): 63. 
75. Arthur Feiler, "Discussion III," Social Research 4, no. 3 (September 1937): 407.

76. Frieda Wunderlich, "Education in Nazi Germany," Social Research 4, no. 3 (September 1937): 348.

77. Wunderlich, "Education," 350-351.

78. Wunderlich, "Education," 355 and Frieda Wunderlich, "Book Review: Edward Y. Hartshorne, Jr., The German Universities and National Socialism," Social Research 6, no. 3 (September 1939): 441.

79. Emil Lederer, "The Search for Truth," Social Research 4, no. 3 (September 1937): 279.

80. Lederer, "Search," 280.

81. There is also the possibility that Lederer and other faculty members did not want to impel discussions of American racial issues. At the time, American communists placed racial concerns at the top of their agenda. Mentioning race, therefore, may have associated the New School with communism, something that faculty members wanted to avoid.

82. In addition to this explanation, New School scholars pointed to a variety of factors that contributed to Hitler's victory. These included Weimar politicians' ignorance of the centralized nature of their authority (Lederer); the mass panic of the Depression, which opened a space for interest groups, notably East Prussian landowners, to support revolutionary ends (Feiler); the state's inability to reduce unemployment (Colm and Wunderlich); urbanization (Brandt); the ability of lawmakers to change the law too often (Max Ascoli); an ill-considered constitution (Brecht); the medieval German intellectual legacy (G.A. Borgese); the state's dominance of society and subsequent rise of a bureaucratic aristocracy (Salomon); the Nazis' organized militancy (Ascoli); and the political and organizational skills of the Nazis (Hans Simons).

83. Emil Lederer, "Comment on Keynes, II," Social Research 3, no. 4 (November 1936): 487.

84. Emil Lederer. "On Revolutions," Social Research 3, no. 1 (February 1936): 9-11, 16-17.

85. Eduard Heimann. "Socialism and Democracy," Social Research 1, no. 3 (May 1934): n.308 and Eduard Heimann, "I," Social Research 4, no. 3 (September 1937): 398.

86. Adolf Löwe. "The Task of Democratic Education: Pre-Hitler Germany and England," Social Research 4, no. 3 (September 1937): 383-385.

87. Frieda Wunderlich. "New Aspects of Unemployment in Germany," Social Research 1, no. 1 (February 1934): 109 and Gerhard Colm, "VI," Social Research 4, no. 3 (September 1937): 411-412.

88. Emil Lederer. "Freedom and Science," Social Research 1, no. 2 (May 1934): 222-223, $227-$ 228.

89. Lederer, "Search," 278-281.

90. Albert Salomon. "Tocqueville, Moralist and Sociologist," Social Research 2, no. 4 (November 1935): 407.

91. Albert Salomon. “The Place of Alfred Weber's Kultursoziologie in Social Thought," Social Research 3, no. 4 (November 1936): 498-500.

92. Salomon noted that this was what Greek intellectuals did in the past vis-à-vis the Roman world. Without Greek intellectuals, he maintained, Cicero's De re publica would have been impossible. Albert Salomon, “II,” Social Research 4, no. 3 (September 1937): 332-334. 
93. The two were, of course, related; in a democracy, anti-Semitism would theoretically not be as salient as it was in a fascist state. This became a central argument of Jewish groups in the 1940s and 1950s. During this period, major American Jewish organizations, including the AJC, the American Jewish Congress, and the Anti-Defamation League, argued that combating all forms of discrimination would help mitigate anti-Semitism. See Stuart Svonkin, Jews against Prejudice (New York: Columbia University Press, 1999).

94. Gerhard Colm. "Economics Today," Social Research 4, no. 2 (May 1937): 194-197, 199202.

95. Wunderlich. "Education," 360 and Löwe, "Task," 388-391.

96. This is the influential thesis advocated in George L. Mosse's German Jews beyond Judaism. According to Mosse, the "classical concept of Bildung largely determined the postemancipatory Jewish identity." George L. Mosse, German Jews beyond Judaism (Bloomington, ID: Indiana University Press, 1997), 7. Mosse had implicitly advocated this thesis in earlier work, including George L. Mosse, Germans and Jews: The Right, the Left, and the Search for a 'Third Force' in Pre-Nazi Germany (London: Orbach and Chambers, 1970). Although some scholars have questioned aspects of this thesis, "the greater validity" of the notion that for many German-Jews Bildung and the universalist intellectual ideal became a "new Jewish tradition" has been generally accepted. For critiques of aspects of Mosse's thesis, see Paul Mendes-Flohr, "Book Review: George L. Mosse, German Jews Beyond Judaism," Studies in Contemporary Jewry 5 (1989), 377-379; Steven E. Aschheim, "German Jews beyond Bildung and Liberalism: The Radical Jewish Revival in the Weimar Republic," in Culture and Catastrophe: German and Jewish Confrontations with National Socialism and Other Crises (New York: New York University Press, 1997), 31-44; and Shulamit Volkov, "The Ambivalence of Bildung: Jews and Other Germans," in The GermanJewish Dialogue Reconsidered: A Symposium in Honor of George L. Mosse, ed. Klaus L. Berghahn (New York: Peter Lang, 1996), 81-98 (these citations were taken from Aschheim). Works that make use of this thesis include George L. Mosse, "Das deutsch-jüdische Bildungsbürgertum im 19. Jahrhundert," in Bildungsbürgertum im 19. Jahrhundert, ed. Werner Conze und Jürgen Kocka, (Stuttgart, Klett-Cotta, 1990), 168-180; David Sorkin, The Transformation of German Jewry, 1780-1840 (Oxford: Oxford University Press, 1991); Paul Mendes-Flohr, German Jews: A Dual Identity (New Haven: Yale University Press, 1999); and Simone Lässig, Jüdische Wege ins Bürgertum: Kulturelles Kapital und sozialer Aufstieg im 19. Jahrhundert (Göttingen: Vandenhoeck \& Ruprecht, 2004).

97. Recently, Simone Lässig has argued that German authorities impelled Jews' acceptance of Bildung. See Lässig, Jüdische Weg.

98. This was a major point of Mosse, German Jews. Quote from Steven E. Aschheim, "George Mosse at 80: A Critical Laudatio," Journal of Contemporary History 34, no. 2 (April 1999): 310 .

99. Jeffrey Peck, Mitchell Ash, and Christiane Lemke, "Natives, Strangers, and Foreigners: Constituting Germans by Constructing Others," in After Unity: Reconfiguring German Identities, ed. Konrad Jarausch (New York: Berghahn Books, 1997), 66 and Leon Poliakov, The History of Anti-Semitism, volume 4: Suicidal Europe, 1870-1933 (Philadelphia: 
University of Pennsylvania Press, 2003), 143-144. Jewish cosmopolitanism had, of course, come under significant attack from nationalist German scholars. For example, in the third volume of his Deutsche Geschichte im 19. Jahrhundert, Heinrich von Treitschke portrayed Jewish cosmopolitanism as a mask for Jewish hatred of Christianity. Peter Pulzer, Jews and the German State: The Political History of a Minority, 1848-1933 (Detroit: Wayne State University Press, 2002), 21. This criticism remained salient amongst academics in interwar Europe as well. For instance, in the late-teens and early 1920s, Max Hildebert Boehm railed against international, cosmopolitan Jewry. See Poliakov, Suicidal Europe, 143-145.

100. The image of the international, cosmopolitan Jew famously recurred throughout Nazi propaganda.

101. Malachi Haim Hacohen, "Dilemmas of Cosmopolitanism: Karl Popper, Jewish Identity, and 'Central European Culture,"” Journal of Modern History 71, no. 1 (March 1999): 105-106.

102. As Malachi Hacohen has argued, Jews, as the "losers of ethnopolitics," were forced to adopt such beliefs. Hacohen, "Dilemmas," 107.

103. Merle Fainsod, "Book Review: Political and Economic Democracy. Edited by Max Ascoli and Fritz Lehmann," American Political Science Review 31, no. 4 (August 1937): 729-731.

104. For positive reviews and citations, see Ray F. Harvey, "Book Review: War in Our Time. Edited by Hans Speier and Alfred Kähler," Public Opinion Quarterly 3, no. 3 (July 1939); Harold J. Tobin, "Book Review: War in Our Time. Edited by Hans Speier and Alfred Kähler," American Political Science Review 33, no.4 (August 1939); Robert Gale Woolbert, "Recent Books on International Relations," Foreign Affairs 17, no. 4 (July 1939); Boris Erich Nelson, "Book Review: War in Our Time. Edited by Hans Speier and Alfred Kähler," Annals of the American Academy of Political and Social Science 207 (January 1940); Quincy Wright, "Rights and Duties under International Law: As Affected by the United States Neutrality Act and the Resolutions of Panama," American Journal of International Law 34, no. 2 (April 1940); Quincy Wright, "International Law and Commercial Relations," Proceedings of the American Society of International Law at Its Annual Meeting 35 (April 24-26, 1941); and William O. Shanahan, "The Literature on War: Part II," The Review of Politics 4, no. 3 (July 1942). An outlier is W.G. Weaver, "Book Review. War in Our Time. Edited by Hans Speier and Alfred Kähler," American Sociological Review 4, no. 5 (October 1939).

105. Nathan C. Leites, "Book Review: War in Our Time. Edited by Hans Speier and Alfred Kähler," American Journal of Sociology 46, no. 2 (September 1940).

106. Erich Kahler, "Forms and Features of Anti-Judaism," Social Research 6, no. 4 (November 1939): 455.

107. Kahler, "Forms and Features," 479.

108. Kahler, "Forms and Features," 480.

109. Kahler, "Forms and Features," 482. In addition to Kahler, in 1939 Feiler published a book review where he acknowledged Jews' centrality to the National Socialist imagination. He declared that the Nazis represented an "enormous danger" to the Jews, rightly predicting that if Eastern European governments followed the racist National Socialist lead then the future of the entire Jewish people was at stake. Feiler also disagreed with the assumption of Sir John 
Hope Simpson, the author of the report he reviewed, that the Jewish problem was primarily an economic one that land reforms, industrialization, and market expansion could solve. Instead, Feiler attributed Jew hatred not to any economic base, but to "the non-economic, super-economic, irrational causes of Europe's self-destruction and decay." By 1939, then, members of the Graduate Faculty argued that the Jews played a special historical role in the National Socialist imagination. Arthur Feiler, "Book Review: Sir John Hope Simpson, Refugees, a Preliminary Report of a Survey," Social Research 6, no. 1 (February 1939): 117. 
Reprinted from Religions. Cite as: Bormuth, M. Meaning in History-A Comparison Between the Works of Karl Löwith and Erich Auerbach. Religions 2012, 3, 151-162.

Article

\title{
Meaning in History-A Comparison Between the Works of Karl Löwith and Erich Auerbach
}

\section{Matthias Bormuth}

International Center for Ethics in Sciences, University of Tübingen, Tübingen, Baden-Württemberg 72074, Germany; E-Mail: matthias.bormuth@uni-tuebingen.de

Received: 5 January 2012; in revised form: 28 February 2012 / Accepted: 7 March 2012 /

Published: 23 March 2012

\begin{abstract}
Karl Löwith (1897-1973) and Erich Auerbach (1892-1957) were assimilated German Jewish scholars who came to America during and after World War II. In the early 1940s both émigrés wrotetheir masterpieces From Hegel to Nietzsche and Mimesis in Japan and Turkey. In these books, the philosopher as well as the philologist, provide a certain philosophy of history forced by the historical crisis of Europe. The differences in their viewpoints can clearly be seen in their decisive judgments on Goethe and the French Revolution. The comparison first looks at the question what impact the reality of being expelled from the German University of Marburg had on the development of their thoughts. The expanding war and the persecution of the European Jews is taken into account as well. The second focus is directed on the experience both made at the American East Coast and how this might have influenced their later writings namely Meaning in History and Philology of World-Literature. And at last the question is raised which significance the Jewish-Christian background had for Löwith and Auerbach especially for their attitude towards the religious sphere.
\end{abstract}

Keywords: Auerbach; Löwith; exile; philosophy of history; Mimesis; Hegel; Nietzsche; Goethe

\section{Different Philosophies of History in Exile: From Hegel to Nietzsche and Mimesis}

Karl Löwith (1897-1975) and Erich Auerbach (1992-1957) were assimilated German-Jewish scholars who emigrated to the United States during the 1940s. Their files in the records of the Emergency Committee in Aid of Displaced Foreign Scholars show that the philosopher and the philologist were highly esteemed in the American academy. Löwith had written two impressive books on Jacob Burckhardt [1] and Nietzsche [2] and Auerbach was widely acknowledged as the 
author of Dante-Poet of the Secular World [3]. This paper will compare their different philosophies of history by focusing mainly on later works written during exile.

Löwith spent several years in Rome before he had a call for a professorship at the University of Sendai in late 1936. From Japan he reached the American East Coast just before Pearl Harbor. He taught mostly at a small Theological Seminary in Hartford and for a short term at the New School in New York. Auerbach survived the Holocaust in Istanbul, directly on the border between Europe and Asia, holding the privileged position as a professor of Romance Philology. The masterly quality of Mimesis: The Representation of Reality in Western Literature published shortly after the war in Switzerland paved his way to Yale [4]. The book was first conceived in 1942 shortly after Löwith had finished his study From Hegel to Nietzsche. The Revolutionary Thought in 19th Century [5] in Japan.

Both books are comparable in their leitmotifs. They provide the reader with decisive perspectives on progress and meaning in history. Their authors can be seen as typical representatives of liberal "Bildungsbürgertum" without real interest in politics until Hitler came to power. From Löwith we know that he held Thomas Mann's Reflections of an Unpolitical Man [6] in high esteem even during the Weimar years. And it is no wonder that he was fascinated in those years by Heidegger's contempt for the public world of the "they" [7]. Although Auerbach had sympathies with left-wing liberal thinking since the Weimar years, his own thoughts turned away from the public sphere as can be seen from his enthusiasm for Montaigne's retreat from the public. The Essais appeared to him as a new bible for cosmopolitan intellectuals aspiring to lead a more private life, concentrating on the communication with books and writing [8]. The little university town of Marburg offered both the chance of living in such an ivory tower.

After Hitler came to power, things became different. In the beginning, the fact that Auerbach and Löwith had served as soldiers in the First World War preserved them from the bitter fate of being expelled from academic paradise. The Nuremberg Laws made an end of this in 1935. The philosopher had wisely taken the opportunity offered by a grant of the Rockefeller Foundation to move to Italy, while the philologist - more privileged as a full professor-tried as long as he could to stay in Marburg. In the portrait of Stendhal given later in Mimesis, Auerbach's own experience of late disenchantment is mirrored: "From his sketch of his life it should appear that he first reached the point of accounting for himself [...] when he was seeking a haven in his 'storm-tossed boat', and discovered that, for his boat, there was no fit and safe haven [9]."

The decisive impact the political events had on their lives left its traces in their works. Löwith reflected his growing awareness of the historical world in a letter written while preparing for the great journey to Japan. According to this retrospect his first book The Individual in the Role of Fellow Man confined itself to the understanding of the inner world based on the idea of existential dialogue [10]. At the end of the Weimar-period his comparative study Max Weber and Karl Marx took a step further by focusing on "modern man as a private person in bourgeois society" [11]. However, it was only after 1933 that the historical world and its political changes became a serious question for Löwith. He tried to develop a philosophical answer writing about life and work of Nietzsche and Jacob Burckhardt in separate books. Burckhardt's stoic ethics were for him the most sympathetic reaction to revolutionary times, as his later work From Hegel to Nietzsche confessed with a self-critical tendency: "[...] a resignation without profit; for renunciation is easy when it 
renounces most [12]." The review on Burckhardt's famous Reflections on History written in the early American exile spoke of the historian as a "contemporary" who already saw a hundred years ago what would come to full knowledge only in the twentieth century: "All his amazing prophecies of military totalitarianism are not a mere guess but an exact deduction from his diagnosis of European history since the French Revolution. Hence it is possible for the first time to understand Burckhardt's vision and comprehension in their full depth and significance and to appreciate what he called his 'malism', i.e., a full look at the worst [13]."

The answer Auerbach was looking for in the tumults of history was more hopeful. Provoked by the question of a German assistant, he wrote in October 1938 how irritated he was by "all the evil that's happening": "From my biography, my profession, and my writing it is clear why these heavy claims on my time persistently pursue me and why each moment of my life strengthens them. I know well what the most general rules and direction of the expected renewal must be. I know well enough how to reject all distorted, false and half measures and ideas. Only it is not concrete, not yet. The consequence: I am a teacher who does not concretely know what he should teach [14]." Writing Mimesis he made up his mind about possible progress in history and focused on the French Revolution without any hesitation as the positive turning point of human emancipation [15].

This attitude was historically rooted in the nineteenth century when many European Jews - and not only the liberal ones - expressed their deep gratitude to the French Revolution because of its impact on their liberation. An example can be seen in Heinrich Graetz and his Popular History of the Jews where one finds a whole chapter "The French Revolution and the Emancipation of the Jews" with the opening sentence: „The French Revolution was a judgment sent to expiate the sins of a thousand years in one day [16]." For Löwith, whose family had gained a status of upper bourgeois wealth and security early on, this thankful attitude towards the French Revolution never seemed to hold any attraction. On the contrary: It was for him the beginning of the end as will be seen later.

Common to both German Jews was the Hegelian framework of their philosophies of history. Although Löwith had been writing against any idea of progress since his early study Burckhardt's Attitude towards Hegel's Philosophy of History [17], he kept Hegel's perspective on a meaningful progress which had first been pronounced in Germany by Kant in his Idea for a Universal History with a Cosmopolitan Purpose (1784) [18]. Auerbach was also fascinated by this idea tracing it back to Giambattista Vico's idea of "Divine Providence”. Along with Vico, Auerbach believed that the human standpoint as a provisional one was not able to reveal the deeper truth of the historical process, only changing aspects could be seen [19].

But Auerbach was at least convinced that the revolutionary perspective provided man with a progressive margin of hope. Therefore one finds in Mimesis a remark on Karl Marx which states him to be the historically most important eye opener for the "presently visible germs of the concrete future" [20]. From Hegel to Nietzsche argues just in the opposite direction, denouncing any value that might emerge from revolutionary activities. In 1939 there is not much left of Löwith's early interest in Marx' criticism of economic injustice. It is no wonder that Löwith read Tocqueville against the original intention of Democracy in America as someone who wass judging the American Revolution negatively as the beginning of a "democratic despotism" [21]. 


\section{Controversial Views on Goethe and his Attitude Towards Reality}

We do not know whether Auerbach was familiar with Tocqueville and his Democracy in America, but Mimesis mirrors indirectly the famous insight that the democratic progress is worth a personal tribute: "[Goethe] foresaw a shallowing of intellectual life; he saw nothing to make up for such a loss [22]." Auerbach drew a sketch of the German classical figure as a conservative who knew well that the French Revolution meant a turning point in the development of modern emancipation. Twice he quoted the famous words Goethe spoke after the defeat of the old European forces at Valmy in 1792: "Today a new stage in history has begun and you can say that you were witness to its birth." Auerbach's first comment in a lecture of 1941 stressed the deep ambivalence which emerged out of the awareness of the objective importance on the one side and the subjective inclination against the "revolutionary movement" on the other: "The statement shows his apprehension. [...] At the same time, he was not in favor of the uprising he felt sure would be victorious. Until the end of his life, he shrank from any movement which resembled an uprising of the people [23]."

In Mimesis the criticism is developed further and more polemically. The reader is confronted with Goethe's confession of belonging to the aristocratic world of Weimar and of being alienated from his roots as a "Bürger" of Frankfurt [24]. The book describes Goethe's fear of social emancipation and explains it through his affinity for stable and secure conditions as necessary means for his self-cultivation. The reader has to face an embarrassing quotation of Goethe which confirms the repressive politics of restoration as long as the realm of science is not affected: "State and church may be able to show cause why they should declare themselves dominant; insofar they are dealing with the recalcitrant masses, [...] but in the sciences the most absolute freedom is necessary [25]."

According to Auerbach this deeply conservative and self-absorbed attitude is responsible for the confinement of the horizons of Goethe's autobiographical writings which were not reflecting society in its actual dynamics as "the germ of developments in process and in the future [26]." Their beginnings are traced back by Mimesis to the French Revolution: "For Europe there began that process of temporal concentration, both of historical events themselves and of everyone's knowledge of them, which has since made tremendous progress and which not only permits us to prophecy a unification of human life throughout the world but has in a certain sense already achieved it. Such a development abrogates or renders powerless the entire social structure of orders and categories previously held valid [27]."

In From Hegel to Nietzsche things are turned upside down. Goethe is highly praised for his literary engagement against "democratic leveling and industrialization" and Löwith with great affirmation quotes from a late letter: "I see a time coming when God will no longer have pleasure in it; he will once more have to destroy everything to make room for a renewed creation [28]." The "chasm of the great French Revolution" is seen as the "beginning of a whole 'Age of Revolutions', in which the masses were to win from the upper classes an independent political power [29]." Löwith welcomed the criticism with which Goethe faced the democratic claims of the literary youth and their enthusiasm for the revolutionary emancipation: "There are many excellent young people, but the idiots all want to begin at the beginning, independently, ... without help, [...] I look 
upon this course of events since 1789 [30]." He saw Goethe as a bastion against the false ideas which were leading the authors of "Young Germany" [31].

Ludwig Börne and Heinrich Heine are mentioned by Löwith as two of the leading figures of this movement. Both have in common that they decided to be baptized in order to make their way in German society. They knew too well that the time of restoration had withdrawn all the rights the French Revolution and the later Code Napoleon had brought for the Jewish people in Germany. Börne stressed this personal experience of repression as stimulating for the development of his deep sense of liberty: "Yes, since I was born as a slave, I love freedom more than you [32]." And Heinrich Heine pointed out in his very polemical essay on Börne that his criticism on Goethe as an adversary of emancipation was mainly influenced by his origin from the Frankfurter ghetto called "Judengasse" [33].

This may be taken as a hint that Auerbach who called Goethe ironically a "burgher's son in that class-conscious social order" might have been influenced by this motive also [34]. However, one finds in Mimesis not one word on Goethe's negative attitude towards Jewish emancipation [35]. The leitmotif of this history of Western literature is human emancipation as such driven into reality by the French Revolution. Only indirectly one can find in Mimesis a trace linking Auerbach's criticism on Goethe to Jewish history and a Jewish perspective.

We cannot follow this question further at this point and have to sum up: Goethe is seen by Auerbach as the exemplary defender of the old world of separated strata, a world which is opposing the development of human emancipation. The accusation is: According to this perspective Goethe did not care for the dynamic process of social change, and all his attention to external reality was limited by the question whether it would provide optimal conditions for his inner development. On the other hand, Auerbach was aware that the dynamic perspective he preferred was not easy to keep on the track of self-cultivation: "He who would account to himself for his real life and his place in human society is obliged to do so upon a far wider practical foundation and in a far larger context than before, and to be continually conscious that the social base upon which he lives is not constant for a moment but is perpetually changing through convulsions of the most various kinds [36]."

Exactly this instability of the modern world was the reason why Löwith was attracted to the conservative attitude of Goethe. In a world of permanent crisis provoked by various ideas of possible progress, he saw the representative of Weimar classics as one of the few who had pointed out at an early stage the dangers of the disastrous dynamics of the ideas of 1789 . Therefore, Löwith claimed in the tradition of Goethe that a society should reserve privileged and stable positions for those who were willing to become themselves.

\section{Viewpoints in America: Meaning in History and Philology and 'Weltliteratur'}

During their American years both scholars partly changed their opinions about the possiblity of progress in history and its impact on their personal lives. Some hints of this will become obvious through a comparison of their decisive texts written around 1950.

One can sense in reading Meaning in History. Theological Implications of the Philosophy of History that Löwith must have been in close contact with Protestant thoughts for a long while. His teaching in Hartford provided him with detailed knowledge of the dialectics of eschatological belief. Evidently Löwith's picture was also influenced by Max Weber's classical study The 
Protestant Ethics and the 'Spirit' of Capitalism. However, he was not interested in deepening Weber's sociological analysis forty years later in new circumstances. Rather he wanted to show the general difficulties faced by any belief in earthly progress, which was the secularized version of the Protestant belief. Positively stated, he was fascinated by the times of early Christianity where ethics were not developed at all since one hoped to be rescued soon from the idle ways of the world. For Löwith, it was important that this unworldly ethos of the first believers was in its structure similar to the ancient ethos of the stoics: "The human result, though not the motivation, of skepticism and faith in regard to the outcome of history is the same: a definite resignation, the worldly brother of devotion, in the face of the incalculability and unpredictability of historical issues [37]."

No question, Löwith was skeptical about all zeal for progress and meaning in earthly life. He traced back its beginning to the later history of the church when Augustine tried to connect systematically the eschatological hope for the "City of God" with the need to do the best for the "City of Man." All modern — scientific and political-ideas of progress were somehow a secularized offspring of Christian ethics. Especially the Age of Enlightenment, although it demonstrated an anticlerical attitude, was unconsciously bound to this perspective. Löwith was therefore no friend of any theory or practice of human progress; for he took the French Revolution as an example of its contradictions and cruelties.

Löwith's conservative attitude also left him skeptical of American democracy with its claims of equal rights and social justice. It is no wonder that he looked for a possibility to return to Old Europe as a professor for German. In 1952 he took the opportunity offered by his former colleague and friend Hans-Georg Gadamer in Heidelberg. Jürgen Habermas who spent his early years as an academic there described Löwith's attitude as a form of "stoic retreat from historical consciousness" [38]. And Dieter Henrich who once visited Löwith in the Swiss mountains drew a portrait of him as a "Sceptico Sereno" exclusively contemplating the eternal blue of nature [39].

Auerbach who remained in America until his sudden death in 1957 avoided all political tendencies in his writings. His essay Epilogemena to Mimesis was surely written in awareness of the McCarthy Era, as it defended the book as "far remote" from a "socialist tendency [40]." And in most of his later writings the former interest in social justice was then confined to a solely historical perspective without turning from Augustine's religious ideas to the modern prospect of emancipation and its revolutionary powers.

However, in his late writings there is one great exception. It is the essay Philology and Weltliteratur which Edward Said greatly admired and translated in 1969. Written in honor of a Swiss scholar who worked extensively on Goethe's idea of world-literature [41], Auerbach took the opportunity of returning to his dear enemy. But this time his criticism of Goethe and his privileged position was rather restrained. One finds him writing with an ironic tone: "[Goethe] gladly avoided thoughts about what later history has made inevitable. He occasionally acknowledged the depressing tendencies of our world, yet no one could then suspect how radically, how unexpectedly an unpleasant potential could be realized [42]."

This particular shift was part of a greater change in Auerbach's view on the historical process. While in Mimesis he had judged the standardization mostly as a temporary "crisis of adjustment" ["Anpassungskrise"], he later seemed to have lost his hope for a better future. The conclusion in Philology and Weltliteratur reads almost like the one Löwith had given more than a decade earlier 
in From Hegel to Nietzsche: "The process of leveling proceeds with a greater rapidity than ever before. Standardization, in short, dominates everything. All human activity is being concentrated either into European-American or into Russian-Bolshevist patterns [43]." Since the year Auerbach spent at Princeton's Institute for Advanced Studies in 1948 which provided him with contacts with great humanist scholars like Erwin Panofsky, in Yalehe later became more and more part of the privileged class of distinguished scholars without political interests.

This academic career and the public interest which some chapters of Mimesis had gained in Partisan Review were formative for Auerbach's new view on Goethe. He expressed skepticism about whether private circles of cultivated men could still have the radiating power Goethe had in the classical period: "Certain distinguished individuals, small groups of highly cultivated men always have enjoyed [...] an organized cultural exchange: they will continue to do so. Yes this sort of activity has little effect on culture or on the reconciliation of peoples: it cannot withstand the storm of opposed vested interests [44]." Therefore he claimed a different way of embedding the "conception of Weltliteratur" in modern times when science had become the only "myth". Only a synthetic form of cultural history could preserve the perspective of "Weltiteratur" and selforientation; however, only if written by scholars whose talent was rooted both in arts and science: "In this manner, the full range of the spiritual movements of the last thousand years will not atrophy within [the cultures]." Auerbach drew a hopeful prospect: "And only this much can be said, that for an age of transition such as ours the effect could be very significant. It may well be that this effect might also help to make us accept our fate with more equanimity [45]."

On first view, it is astonishing that Auerbach does not mention Mimesis as an example for a synthetic way of writing cultural history. From the first chapter on Homer and the Bible drawing the famous polarization between literary perspectives of fore- and background to the great finale on the contradictions of modern individualism seen in the works of Proust, Joyce and Woolf, Mimesis is a synthetic and secular history of human "self-expression" written — as the late essay says — "as if according to plan [46]." However, Auerbach decided to illustrate his argumentation by a rather ambiguous example writing about his rival Ernst Robert Curtius and his masterwork European Literature and the Latin Middle Ages [47]: "In its best parts this book is not a mere agglomeration of many items, but a radiation outwards from a few items [48]."

One thing Mimesis had in common with Curtius' book was the strong focus on the ChristianCatholic thinking from Augustine to the Middle Ages, although both were fashioning outlooks on modern times. In regard to Auerbach, this is illustrated by the legendary story told by him personally that a monastic library in Istanbul became decisive for the book since it provided him with a complete edition of the Church Fathers. In his last book Literary Language and its Public in Late Latin Antiquity and in the Middle Ages this perspective gained an exclusive importance [49]. The Jewish tradition which stood in the beginning of Mimesis had vanished totally. Instead, Auerbach proclaimed Paul to be the key-figure who replaced the Biblical thought of the Jewish claim on God, with the idea of a world-religion. Augustine then provided this dimension with philosophical arguments and a suggestive prose during the decline of the Roman Empire.

No wonder that Philology and Weltiteratur closed with a prospect which reminds one of the romantics who also looked back to the Middle Ages as a time of a inspiring faith and wholeness of thought. Auerbach claimed in this sense the renaissance of the spirit of this past: "We must return, 
in admittedly altered circumstances, to the knowledge that prenational medieval culture already possessed: the knowledge that the spirit [Geist] is not national." His interpretation of this "spirit" recalled two conditions as necessary for cultivating the supranational dimension: "paupertas" and "terra aliena." In other words: Poverty and alienation from the world were attitudes of the early Church Fathers, the Desert Fathers, and the medieval monastic reformers who made it vivid again during the Middle Ages. All of those believers took the world as something provisional while their love belonged to the eternal home. Auerbach quoted Hugh of St. Victor, a medieval monk in the tradition of Augustine and Plato. His praise for the higher world is illustrated by a climax devided in three steps: "Delicatus ille est adhuc cui patria dulcis est, fortis autem cui omne solum patria est, perfectus vero cui mundus totus exilium est..." In other words: "The patriotic attitude is fine, but the cosmopolitan one more worthwhile; and perfection lies in the ethos of the man for whom the whole world seems to be a place of exile". Auerbach's reading is secular and underlines the importance of the quote for a modern man without a religious belief who has become disenchanted with faith in earthly progress and meaning: "Hugo intended these lines for one whose aim is to free himself from a love of the world. But it is a good way also for one who wishes to earn a proper love for the world [50]."

One can sum up: After his years in Istanbul, Auerbach withdrew more and more from the social hope that had inspired Mimesis. Instead his last essay ended with the ironic turn that the leveling power of standardization may fulfill the dream of equal rights on the lowest possible level. He only kept the idea that books like Mimesis written between art and science could give guidance for the spiritual self-orientation for those who were still individually driven by the questions of the Western tradition. In their search for meaning, the Christian attitude of the Middle Ages could be helpful in reducing the expectation of worldly progress.

Without doubt by taking this position the late Auerbach moved closer towards Löwith. The only meaning history still had, was to demonstrate how right those were who saw the world as a place of exile. All one could do was to develop an ethos of "equanimity" facing history as a provisional realm without believing in a higher world of redemption.

\section{Epilogue}

Since this journal issue is organized in the framework of "Jewish Studies," it is useful to close with short remarks about the role Jewish thought played for the scholars. Without doubt: Erich Auerbach wrote his works - except for the first chapter of Mimesis - mostly from the perspective of the Catholic and partly Protestant traditions. The Confidential Information Auerbach gave to the American Rescue Committee in fall of 1935 underlined his deep inclination to the Christian world: "I belong to the religious community of Jewish belief, but I am indebted by my works to Christiantheological circles, mostly of Catholic provenience [51]." In a private letter of 1941 recently published one finds an astonishingly harsh criticism of the Jewish religion as a dead body of dogmatic thoughts [52]. Only in the form of the secularized idea of socialism was Auerbach able to keep the piety towards the Jewish traces of this movement. But he focused strongly on the Christian ways of secularization. And in the Epilegomena to Mimesis he even spoke about cutting off the provocative Jewish beginnings of his book where he had been stressing the anthropological deepness and earnestness of the biblical story of Abraham against the shallow and easy narrative 
Greek epos on Odysseus: "I considered for a moment letting the Homer chapter fall entirely by the wayside. For my purposes it would have sufficed to begin with the time around the birth of Christ [53]". In this respect his last methodological essay, only published after Auerbach's death, totally neglects the importance his famous book had given to the Jewish heritage for the enrollment of Western thought and literature: "In Mimesis [...] I was able, however inadequately, to disclose something of the influence of Christianity on the development of literary expression, and even to throw light on an aspect of the development of European culture since antiquity [54]."

What did Löwith think of Jewish tradition? He was born into a socially accepted family of assimilated Jews, being baptized in a Protestant church in Munich. Later he married the daughter of the director of a Protestant Gymnasium in Berlin. The Christian world was also decisive for his later intellectual orientation; especially since his days as a student of Heidegger when he was taking part in the circle of Protestant theologians in Marburg. But already around 1920 he recognized his own Jewish roots as a social reality since a close friend of his youth cut off all ties with him after having become a disciple of a still widely unknown anti-Semite called Adolf Hitler. After 1933 Löwith quoted Franz Rosenzweig who can be seen as a Hegelian philosopher with a Jewish belief to point out "that the liberal German-Jewish standpoint on which nearly all of German Jewry had a place for close to a hundred years' had become so isolated today [55]." But this experience did not change his affinity to the "Lebenswelt" of cultural Protestantism in which he had been raised. Writing in 1942 on Martin Heidegger and Franz Rosenzweig he took the opportunity of describing himself as someone who was "only a Christian in the way one is German or French" and not "a believing Jew or a pious gentile" [56].

Nevertheless as a secular philosopher raised up in the tradition of German Protestant culture, in the years of emigration and the tyranny of Hitler Löwith took a great interest in Biblical writings which were concerned with the sufferings of man. And therefore it is no wonder that Löwith closed the epilogue of his autobiographical sketch of 1939 with a classic quote from the Old Testament. The words of Job could and can be read in the stoic perspective of insightful resignation: "Man born of woman is short-lived and full of disquiet. He blossoms like a flower and then withers; he slips away like a shadow and does not stay. (Job 14: 1-2, New English Bible) [57]."

\section{References and Notes}

1. K. Löwith. Jacob Burckhardt. Der Mensch inmitten der Geschichte. Luzern: Vita Nova Verlag: 1936.

2. K. Löwith. Nietzsches Philosophie der ewigen Wiederkunft des Gleichen. Berlin: Verlag Die Runde, 1956. English edition: Nietzsche's Philosophy of the Eternal Recurrence of the Same. University of California Press; USA 1997.

3. E. Auerbach. Dante-Poet of the Secular World. New York: New York Review Books, 2007. The German edition was published in 1929 by de Gruyter in Berlin, the English translation for the first time in 1961.

4. E. Auerbach. Mimesis. The Representation of Reality in Western Literature. Princeton: Princeton University Press, 2003. The German edition was published in 1946, the English edition for the first time in 1953. 
5. K. Löwith. From Hegel to Nietzsche. The Revolution in the Nineteenth-Century Thought. New York: Columbia University Press, 1991. The German edition was published in 1941 in Switzerland; the translation into English took until 1961.

6. The Betrachtungen eines Unpolitischen were first published in 1918 at the end of WW I.

7. M. Heidegger. Being and Time. New York: State University of New York, 2010. The book was first published in German in 1927.

8. M. Bormuth. 'Mimesis' und 'Der Christliche Gentleman'. Erich Auerbach schreibt Karl Löwith. Warmbronn: Ulrich Keicher, 2006, 24-27.

9. M. Bormuth. Mimesis, 460f.

10. K. Löwith. Das Individuum in der Rolle des Mitmenschen. München: Drei Masken Verlag, 1928.

11. K. Löwith. Sämtliche Schriften. Stuttgart: Metzler Verlag, 1994, Vol. 5, 324-407. The article was published first in 1932 in the Archiv für Sozialwissenschaft.

12. K. Löwith. From Hegel to Nietzsche. The Revolution in the Nineteenth-Century Thought. New York: Columbia University Press 1991, XVII.

13. Löwith wrote a review on the English translation of Burckhardt's famous lecture "Weltgeschichtliche Betrachtungen" which was edited by James Hastings Nichols and published in 1943 with the title Force and Freedom. Reflections on History: Cf. K. Löwith, Sämtliche Schriften. Stuttgart: Metzler Verlag, 1984, Vol. 7, 372-374, 373.

14. E. Auerbach. Scholarship in Times of Extremes: Letters of Erich Auerbach (1933-1946), on the Fiftieth Anniversary of his Death. Introduction and Translation by Martin Elsky, Martin Vialon and Robert Stein. PMLA 122 (2007), 142-162.

15. For the history of the term in regard to the French Revolution, see: Reinhard Rürup, "Jewish Emancipation and the Vision of Civil Society in Germany," Yearbook of the Leo Baeck Institute 51 (2006), 43-50.

16. H. Graetz. Popular History of the Jews. New York: Hebrew Publishing Company, 1919, $373,387$.

17. K. Löwith. Sämtliche Schriften. Stuttgart: Metzler Verlag, 1984, Vol. 7, 9-38. The German title of his lecture held in 1928 was: "Burckhardts Stellung zu Hegels Geschichtsphilosophie".

18. Kant claims precociously: "Es ist hier keine Auskunft für den Philosophen, als daß, da er bei Menschen und ihrem Spiele im großen gar keine vernünftige eigene Absicht voraussetzen kann, er versuche, ob er nicht eine Naturabsicht in diesem widersinnigen Gange menschlicher Dinge entdecken könne; aus welcher, von Geschöpfen, die ohne eigenen Plan verfahren, dennoch eine Geschichte nach einem bestimmten Plane der Natur möglich sei. "Cf. I. Kant, Werke in sechs Bänden. Darmstadt: Wissenschaftliche Buchgesellschaft, 1956, Vol. 4, 31-50, 34.

19. E. Auerbach. Literary Language and its Publicum in Late Latin Antiquity and in the Middle Ages. New York: Pantheon Books, 1965, 16: "One aspect or another of the Platonic verum is actualized in every stage of history; no historical period embodies the whole of it. It is fully contained only in the plan of Providence or in the total course of history; [...]."

20. M. Bormuth. Mimesis, 445. 
21. K. Löwith. From Hegel to Nietzsche. The Revolution in the Nineteenth-Century Thought. New York: Columbia University Press, 1991, 253. Löwith used the German translation of an anthology of Tocqueville's writings and letters which concentrated on Democracy in America and was edited by Albert Salomon, also a German émigré and later professor at the New School. Cf. A. Tocqueville, Autorität und Freiheit. Zürich: Rascher, CH, 1935.

22. M. Bormuth. Mimesis, 451.

23. E. Auerbach. Literature and War. An Istanbul-Lecture 1941/42. In East West Mimesis: Auerbach in Turkey. K. Konuk. Stanford: Stanford University Press, 2010, 194-204, 200f.

24. M Bormuth. Mimesis, 450.

25. M. Bormuth. Mimesis, 448. Auerbach quotes from Wilhelm Meisters Wanderjahre, book 3, chapter 14.

26. M. Bormuth. Mimesis, 451.

27. M. Bormuth. Mimesis, 459.

28. K. Löwith. From Hegel to Nietzsche, 27. Löwith quotes from Goethe's letter to Eckermann, September 231828.

29. K. Löwith. From Hegel to Nietzsche, 26.

30. K. Löwith. From Hegel to Nietzsche, 231. Löwith quotes from Goethe's letter to Zelter, January 21792.

31. K. Löwith. From Hegel to Nietzsche, 402.

32. P. Arnsberg. Die Geschichte der Frankfurter Juden seit der Französischen Revolution. Der Gang der Ereignisse, Eduard Roether Verlag, Darmstadt, 1983, Vol. 1, 136.

33. H. Heine. "Ludwig Börne. Eine Streitschrift" Sämtliche Schriften. München: Hanser Verlag, 1975, Vol. 4, 7-143, 17-23.

34. M. Bormuth. Mimesis, 450.

35. This topic has been discussed by: Berghahn Klaus L., and Hermand J., Eds. Goethe in German-Jewish Culture. Rochester: Camden House, 2001.

36. M. Bormuth. Mimesis, 459.

37. K. Löwith. Meaning in History. The Theological Implications of the Philosophy of History. Chicago: University of Chicago Press, 1949, 199.

38. J. Habermas. "Karl Löwith: Stoic Retreat from Historical Consiousness" PhilosophicalPolitical Profiles. Cambridge: MIT Press, 1983, 79-98.

39. D. Henrich. "Sceptico Sereno" In Natur und Geschichte. Edited by H. Braun. Karl Löwith zum 70. Stuttgart: Geburtstag, Kohlhammer, 1967.

40. E. Auerbach. ”Epilogemena to Mimesis. “Mimesis (1953): 559-574, 570.

41. F. Strich, Goethe und die Weltliteratur (Francke, Bern, 1946).

42. E. Auerbach. "Philology and Weltliteratur." Centennial Review 13 (1969): 3.

43. E. Auerbach. "Philology and Weltiteratur", $2 \mathrm{f}$.

44. E. Auerbach. "Philology and Weltliteratur", 6.

45. E. Auerbach. "Philology and Weltliteratur", 7.

46. E. Auerbach. "Philology and Weltliteratur", 5.

47. The translation of the German edition of 1948 was published in 1953: E. R. Curtius. European Literature and the Latin Middle Ages. New York: Pantheon Books, 1953. 
48. E. Auerbach. "Philology and Weltiteratur", 13.

49. E. Auerbach. Literary Language and its Public in Late Latin Antiquity and in the Middle Ages. New York: Pantheon Books, 1965. The German edition was published shortly after Auerbach's death in 1958.

50. E. Auerbach. "Philology and Weltiteratur", 17.

51. File "Auerbach, Erich" In "Emergency Committee in Aid of Displaced Foreign Scholars", Box 38, Folder 55, Manuscript and Archives Division, New York Public Library.

52. Auerbach wrote in December 1941 in a letter to his German friend Alexander Rüstow who also taught at Istanbul University. I give just a short quote out of a longer passage cited by Martin Vialon: "Die Juden sind seit ihrem ersten Exil dauernd unvermeidbare Minorität - [...] überall potentieller Gegenstand des Hasses und der Verfolgung. [...] Ihr eigenes geistiges Leben, das eigentlich Jüdische im Geistigen ist längs erstart und wirkt gespenstisch." Cf. M. Vialon, Jahrbuch der Deutschen Akademie für Sprache und Dichtung 58, (2011): 1-40, 38.

53. E. Auerbach. "Epilogemena to Mimesis." Mimesis (1953): 559-574, 560.

54. E. Auerbach. Literary Language and its Publicum in Late Latin Antiquity and in the Middle Ages, 20.

55. K. Löwith. My Life in Germany before and after 1933. A Report. Athlone Press, London, 1994, $138 \mathrm{f}$.

56. K. Löwith. M. Heidegger, and F. Rosenzweig. "Ein Nachtrag zu Sein und Zeit." In Sämtliche Schriften. Stuttgart: Metzler Verlag, 1984, Vol. 8, 72-101.

57. K. Löwith. "My Life in Germany." 147. 
Reprinted from Religions. Cite as: Hacohen, M.H. Typology and the Holocaust: Erich Auerbach and Judeo-Christian Europe. Religions 2012, 3, 600-645.

Article

\title{
Typology and the Holocaust: Erich Auerbach and Judeo-Christian Europe
}

\author{
Malachi Haim Hacohen
}

History Department, Duke University, Box 90719, Durham, NC 27708, USA;

E-Mail: mhacohen@duke.edu

Received: 25 May 2012; in revised form: 7 July 2012 / Accepted: 11 July 2012 /

Published: 17 July 2012

\begin{abstract}
In response to Nazi exclusion of the Jews from German society on racial grounds, Erich Auerbach (1892-1957), a secular Jewish intellectual inspired by cultural Protestantism and Catholicism, formed a vision of a cosmopolitan Judeo-Christian civilization that reintegrated the Jews as biblical founders and cultural mediators. But the integration expunged any mark of traditional Jewishness. Focusing on Christian figurative thinking (typology), Auerbach viewed the binding of Isaac through the crucifixion, and contemporary Jews as civilization's (unwilling and undeserving) martyrs. In the aftermath of the Holocaust, his cosmopolitanism reached a crisis, reflected in his postwar vision of Western decline. The progressive mandarin who had begun his intellectual life elevating Dante's care for everyday life and sympathizing with French realist social critique ended endorsing Hugh of St. Victor's alienation from reality and Pascal's acquiescence in totalitarian rule.
\end{abstract}

Keywords: Auerbach; émigrés; cosmopolitanism; Judeo-Christian; typology; Holocaust; figura; Akedah; Mimesis; everydayness

\section{Introduction}

Among the Jewish émigrés who sought sanctuary in World War II on the outskirts of the old continent, in Istanbul University, was literary historian and philologist Erich Auerbach (1892-1957), author of the monumental Mimesis: The Representation of Reality in Western Literature (1946) [1,2]. In 1947 he immigrated to the U.S. and sent Mimesis to an admired German author, Thomas Mann, who was commuting between his U.S. war refuge in Palisades Heights and his postwar European one in Ascona, Switzerland. Mimesis' "central theme, European realism, has the greatest attraction for me," responded Mann in 1949. "Your approach, treating [realism] historically and tracking the 
everlasting artistic disposition for it through the centuries carries a pedagogical message" [3]. Neither of them spoke openly about the Holocaust. Ironically, Mann resurrected biblical myth to respond to Nazi racial one, whereas Auerbach saw Mann's realism, and biblical insistence on truth as opposed to classical myth, as the only proper response. But both questioned the German humanist focus on the classical and the claim to ownership over it, and both resurrected the Hebrew Bible to challenge the hegemony of the classical heritage in German culture. In ways often underappreciated, secular German and Jewish intellectuals responded to National Socialism by reaffirming a Judeo-Christian Western tradition [4,5].

\section{Vico and Dante: A Jewish Cultural Protestant in Weimar Germany}

Born to an affluent and German acculturated Berlin Jewish family, Auerbach grew up in a predominantly Jewish neighborhood in Charlottenburg, and attended the French gymnasium (französisches Gymnasium), first established by Huguenot exiles and now carrying on French cultural traditions. Auerbach was by no means an accomplished student, but republican France became his second Heimat and his future pursuit of romance languages owed much to this early French exposure. Son of a jurist, he pursued law, earning a doctoral degree from Heidelberg in 1913. In Heidelberg, he apparently made the acquaintance of several members of the Max Weber circle, including Georg Lukàcs, Walter Benjamin, and Karl Jaspers [6,7]. French sympathies made no dent in his German patriotism: He served on the western front in WWI, was wounded and decorated. The loss of friends was traumatic but, like the Holocaust later, he consigned it to silence. Auerbach's literary concerns alone alluded to the pain, loss and injustice of a cruel and unpredictable world.

Returning to civil life, Auerbach sought a change of profession. In 1921, he earned a second doctorate in Romance philology with a dissertation on French and Italian early Renaissance novellas. The rise of the novella, he suggested, reflected the historical transition from the medieval to the Renaissance world, the rise of Renaissance man, conscious of his individuality, seeing himself in the midst of earthly life (irdischen Dasein) [8]. His early publications, dedicated to Dante, launched into arguments he would pursue throughout life. Dante's characters in The Divine Comedy, though they inhabited Hell, Purgatory and Paradise, forever retained their earthly nature. Auerbach celebrated Dante as a German poet, an Italian who joined, as Shakespeare did, a German-European pantheon [9-11]. Dante spoke to Germany's spiritual crisis because he conveyed confidence in the viability of a Christian community and a providentially guided universe, where rewards and punishments were justly meted, and the protagonists' character was their destiny. This confidence, Auerbach recognized, was now woefully lost. He was groping for a literary sensibility appropriate to a secularized Christian culture, for a dignified attention to the social world, to everydayness (täglichen Dasein).

"A Prussian of the Mosaic faith," Auerbach described himself in the dissertation's bio [12]. In 1923, he married Marie Mankiewitz, daughter to an affluent Jewish family (the largest private shareholder of Deutsche Bank) [13]. He gave his son, born later that year, the distinctly Christian name Clemens, and did not have him circumcised (until a doctor recommended the procedure for medical reasons fourteen years later) [14]. There was nothing traditionally Jewish in Auerbach's education or culture. He accepted the liberal Protestant view, articulated by theologian and 
historian Adolf von Harnack, that postbiblical Judaism no longer retained its intellectual vitality and became obsolete, a particularist religion in a universal Christian world. Yet the liberal Protestant call to Jews to convert and become part of the German nation never seemed to tempt him, and he remained a member of the Jewish community. Unlike Franz Werfel, he did not think of the Jews, in an Augustinian fashion, as witnesses to Christian truth. A cultural Christian of Jewish origins, he could not believe in Jesus as Christ, and accepted his Jewish fate with composure [15].

Cultural Protestantism shaped Auerbach's view of contemporary life. He thought that secularization and historicism created a cultural crisis that left the world disenchanted, devoid of firm cultural norms. A student of philosopher and theologian Ernst Troeltsch (1865-1923) - he attended Troeltsch's seminar and belonged to his circle in the Weimar Republic's early years-Auerbach searched for the secular equivalent of Christian religious ideals [16,17]. Harnack and Weber, too, inspired his historical mode of inquiry but all three, Harnack, Troeltsch and Weber, left him without answers. Like them, he was willing to see modern cultural values as vouched in the nation, but they lacked his social sensitivity. He viewed the Christian concern for the poor as exemplary of attentiveness to daily life, and upheld St. Francis as the embodiment of authenticity [18]. His fascination with the sacred and his affinity for the downtrodden were reminiscent of Expressionist artists and writers. Weber made light of such sensibilities, but they became the overriding theme of Auerbach's lifelong work [19].

Troeltsch represented liberal historical theology pushed to its limits. His history denuded Christianity of supernaturalist claims, the Incarnation included. Jesus became a world historical figure, embodying humanity's aspirations, founder of a Christian culture that evolved into Europe's legacy. Troeltsch's comparative study of world religions progressively disrupted his sense of Christian and European superiority. The cultural relativism historicism occasioned was palpable and painful to him, a Protestant theologian, and he looked back longingly to medieval Europe as an integral civilization free of doubt. Yet, even in the aftermath of WWI, Troeltsch was still hoping, against hope, that history would reveal a transcendental pattern [20,21].

Troeltsch's Jesus, a world historical figure, became a point of departure for Auerbach's life-long work. Like Troeltsch, Auerbach secretly believed that history displayed divine intentions and searched his entire life for patterns rendering its meaning. Like him, he longed for past communities where God and man cohabited peacefully. National Socialism constituted a caesura because it became impossible for Auerbach to reconcile "all the evil that is happening" with "God and the eternal world" [22]. He never ceased searching for meaning in history but, in the postHolocaust years, hope would be gone.

Much as Troeltsch and Auerbach craved meaningful patterns, they rebuffed the Hegelian confidence in a universal history, and refused a unifying narrative integrating the plurality of cultures. In Oswald Spengler's The Decline of the West, Troeltsch saw a monistic history, hostile to liberal culture [23]. Seeking counter models, Troeltsch encouraged Auerbach to study the Italian philosopher of history, Giambattista Vico (1668-1744), who was not well known in Germany at the time. To Vico, culture was a human creation, and history a succession of epochs, represented in a plurality of nations, each an aspect of the divine. His "world of nations" consisted of civil societies at divergent stages of development spread around the globe, following a pattern, leading from aristocratic polities, imagining gods and heroes governing, to rational organization in 
monarchies and republics. Troeltsch and Auerbach found in Vico a history accentuating cultural pluralism, divinely inspired but human made. Vico became the site for the interplay of tensions between universalism and pluralism, divine and human, which Auerbach never wished to resolve or think to their end, allowing them to coexist and motivate his work.

As Auerbach became, in 1923, a librarian at the Prussian National Library, he had the leisure to translate Vico's Scienza Nuova and engage his views on language, culture and history [24,25]. "Vico's conception of philology and of the 'world of nations'," he said in the postwar years (when he thought the world of nations was approaching its end), "complemented and molded, in my thinking and in my work, the ideas deriving from German historicism" [26]. Auerbach's distaste for Cartesian rationalism and French classicism, his consciousness of the multiple perspectives available into a historical period, his historical philology and contextual approach to literature, and his interpretive reenactment of historical agents, all reflected an adaptation of German historicism via Vico. He rejected only Vico's cyclical historical determinism, which was too reminiscent of Spengler. In "Vico und Herder" (1932), he suggested that Vico parted with Christian transcendentalism by having providence work its way immanently through history, a move toward secularization [27]. Yet, Vico did not question the individual's relationship to God, and, like Vico, Auerbach was content to live with the tension between an immanent history and a transcendently oriented individual. He declined to move toward an emphatically secular historicism.

Vico made it easier for Auerbach to escape, if only barely, the traps of Heidegger and the "Conservative Revolution." Auerbach admired Stefan George-his Dante book was, at points, reminiscent of the hero-worshipping biographies of the George Circle - and he thought Heidegger a profound thinker. "An awful fellow," he said after WWII, "I am glad I did not fall into his hands when I was young." "But," he added, "he had substance" [28,29]. In the Weimar years, young academic Germany turned against formal and idealist philosophy in search of authenticity. The poet embodied authenticity, whether in the aristocratic heroic fashion of the George Circle or in Heideggerian overcoming of the "everydayness of existence" (Alltäglichkeit des Daseins). One sought to explore the "life-world" as it revealed itself, uncorrupted by the traditional philosophical pursuit of objectivity [30,31]. "Everydayness" became a central motif for Auerbach but with a "progressive" twist, one affirming the grandeur of the daily struggles of the downtrodden [32]. He made literary concern for the everyday tragic the acid test of modern literature, and he judged the success of literary realism by its grasp of concrete social life. He found the seventeenth-century French classical tragedian, Racine, empty because his characters did not emerge from daily life, and he lauded Proust for having captured the earthly world [33,34]. Auerbach "democratized" George's search for the hero via the "everyday tragic" and rechanneled Heideggerian "everydayness" via Vico, rendering it more sociocultural, less existential.

If Vico made a democratic redirection of “everydayness" possible, Auerbach's politics remained unclear, until National Socialism forced him to clarify it. Marxist literary critic Walter Benjamin (1892-1940) and philosopher Ernst Bloch (1885-1977) were his houseguests in the early 1920s, but his cultural politics was not leftist. His student, literary historian Werner Krauss (1900-1975), remembered him as a liberal nationalist. "You know me sufficiently ... to realize that I can understand the motives of your political views," he wrote historian Erich Rothacker when the latter joined the National Socialist Party [35]. "It would pain me much, ... if you wanted to deny me the 
right to be a German." Until the Nazi triumph, however, the temptations of George's "secret Germany" (which included intellectuals of Jewish origin) and of Heidegger's call for the authentic were great. Only when the political order collapsed, and Auerbach faced exclusion as a Jew, did he affirm, elliptically, via Christianity, the socially progressive bent of "everydayness" - and his own inclusion.

In 1929 Auerbach published Dante: Poet of the Secular World [36,37]. His book portrayed Dante as a transformative realist poet, who broke with allegory and brought out human character-concrete and historical. In The Divine Comedy, disembodied spirits in Hell emerge as tragic personalities, as if still alive, Cato, a pagan and a suicide, guards Purgatory's gates (and not a Christian saint, as the secular empire was the fount of justice). To Auerbach, Dante captured and transformed classical and Christian literary genres, and created new possibilities for literary realism [38].

Plato was notoriously suspicious of mimetic reality, poetic or artistic, and Aristotle, considering tragedy the noblest genre, "states very clearly that [it] must not represent [reality] as it comes to us, in its apparent disorder and disunity [but as] a correction of actual events, a happening superior to actual happening" [39]. Classical tragedy depicts "the hero's final struggle with his destiny, [and it] so divides and consumes him that nothing remains of his personality but his age, race, class and the most general traits of his temperament" [40]. But with Christ and the crucifixion-that "problematic and desperate injustice of an earthly happening"- "the drama of earthly life took on a painful, immoderate, and utterly unclassical intensity" [41]. Gospel narratives, focusing on Jesus' life and leading to the Passion, captured this historical drama. Christianity opened up new mimetic possibilities, enabling new forms of literary representation.

To be sure, Christianity relegitimized the earthly world only within the framework of eschatology and otherworldly justice. Neoplatonic efforts to allegorize biblical narratives repeatedly tested Christianity's earthly character. But realism persevered, and Dante repossessed, reshaped and pushed it further. Envisioning a "happy end" to his otherworldly tour, and using the "vulgar" vernacular, Dante, misunderstanding Aristotelian criteria, felt compelled to call his masterpiece a comedy. Truly, The Divine Comedy endowed the earthly world with a tragic vision of humanity that would not vanish even when secularization did away with Christian eschatology.

Dante served as Auerbach's habilitation under philologist, medievalist and Romanist, Leo Spitzer (1887-1960). With Spitzer's endorsement, and the support of Germany's most eminent medievalist, Karl Vossler, Auerbach was appointed, in 1929, to the Marburg chair in romance languages, vacated by Spitzer (who had moved to Cologne). Auerbach arrived in Marburg the year after Heidegger had left. Philosophers Hans-Georg Gadamer and Karl Löwith and theologian Rudolf Bultmann were on the faculty - the last two were close colleagues - and Marburg was thought to have a fairly liberal mandarin culture. The Auerbachs would remember their Marburg years as a golden age - the time when Erich was a full professor (ordinarius) surrounded by gifted students and colleagues, and they lived in a congenial German milieu.

These were also the turbulent years of the Nazis' rise to power. The Marburg student associations were, as elsewhere, the Nazi avant-garde. Auerbach did his best to distance himself from politics and, in 1932, enjoyed a summer vacation with a convertible in Italy. Historian Matthias Bormuth observes that Auerbach's 1932 "The Writer Montaigne" drew the contrast between Christian martyrdom and Montaigne's inner solitude (Einsamkeit), and diverged from 
Mimesis by sympathizing with Montaigne's withdrawal from public life to his home $[42,43]$. Feeling vulnerable as an intellectual of Jewish origin seemed to have only reinforced Auerbach's mandarin proclivity to opt for inner freedom when politics was becoming oppressive. Personal martyrdom was never an option for him but, in 1932, the ideal itself, which would become a subject for contemplation and admiration with WWII, still seemed remote, intangible.

Other German humanists, in contrast, took an open political stance. They established an important context for understanding Auerbach's work and politics. Leading romance philologist, Ernst Robert Curtius (1886-1956), published in 1932 a call for reconstituting a new Christian humanism against National Socialism and communism [44]. Curtius was both a literary critic and a medievalist, a Protestant fascinated with medieval Catholicism. He introduced T. S. Elliot to Germany, and familiarized the Germans with English, French and Italian literature. He regarded himself a German cosmopolitan and a European: "My conviction is cosmopolitan (not internationalist)," he said, to distance himself from socialist internationalism, "European on the basis of impartial ... national (not nationalist) feelings" [45].

As a leading conservative proponent of German-French reconciliation, and a member of international Catholic networks, as the Europäischen Kulturbund, Curtius inveighed against nationalism and secularism, and called for an intellectual elite to lead a cultural revival grounded in a shared European Christian culture. "Limiting the French message to Enlightenment and Revolution overlooks that France has long been the most Christianized European nation [and] ignores the best ... in the French spirit [and] tradition" [46]. He attacked sociologist Karl Mannheim and secular Jews for their historicism, relativism and skepticism, and for their refusal to adopt Christianity, humanism and Deutschtum [47,48]. The Jew became signifier for hated modernity but this was not simple antisemitism. Curtius' model for cultural renovation was none other than Hugo von Hofmannsthal, the icon of European Catholic cosmopolitanism.

Auerbach and Curtius shared much. Both represented a younger generation of romance philologists who expanded into literary criticism, ranging from classical to medieval to modern. Both were German humanists drawn to Dante, French literature and high modernism-Joyce and Proust. Both were German cosmopolitans, committed to a Christian European culture and adverse to the German nationalist denunciation of France as a Negernation. Both were rooted in "Europe of nations," now threatened by ethnonationalism. But Auerbach did not share Curtius' deep hostility to modernity and could not but sense that drawing Christian culture's boundaries threatened Jews like him. His response to Nazism was more demure and oblique than Curtius' but also more progressive. If Curtius turned to Catholic France, to contemporary poets Paul Claudel and Charles Péguy, Auerbach turned to republican France and nineteenth-century French social realism. He folded German romanticism into French realism, and declared the French the most authentic realists, European culture's peak achievement. Like other humanists, he sought to build a European culture on French-German affinities, a bulwark against Nazism, but his culture was more democratic and liberal.

Auerbach's 1929 inaugural lecture at Marburg on Dante and the Romantics recouped his past work for his new interest in modern realism: He recounted the discovery of Dante by Hegel, Schelling and Vico and argued that it reinforced the realistic bent of Romanticism [49]. As he was teaching French literature in Marburg, he noticed that the French realists followed a pattern he had 
observed in Dante, a pattern he now called Stilmischung, the "mixing," or merging of styles through the everyday tragic. Realism ended the classical Stiltrennung (separation of styles) by breaking the decorum rules designating the appropriateness of style (and genre) to subject, separating noble tragedy from lowly comedy. In his 1933 "Romanticism and Realism," Auerbach claimed Stendhal and Balzac, the great French realists, as inheritors of the Romantic tradition of Innerlichkeit (inwardness). Everydayness emerged as central for the Romantics and realists alike, and both rejected French classicism and formalism, with their elitist presumptions. Tragic realism reflected egalitarianism in the aftermath of the French Revolution. The French may have led the trend, but they built on German Romanticism [50].

If The Divine Comedy represented a perfect fusion of styles, French classicism, a child of French absolutism, was its opposite, a combination of laicism and hierarchy. Auerbach's 1933 essay on the emergence of the seventeenth-century French literary public reflected his hostility toward classicism [51]. The essay dovetailed with contemporary scholarly interest in court culture and the French bourgeoisie, such as expressed in the works of Bernard Groethuysen and Norbert Elias [52,53]. Throughout the seventeenth century, a powerless aristocracy and an alienated bourgeoisie competed for cultural leadership, the former acquiring empty manners, the latter counter-posing salon to court, and claiming that honnêteté (integrity) could be had by all (but the common people). But, to Auerbach, the emergent urban public and aristocratic court alike were superficial. Absolutism had a stifling effect on public life and culture.

In contrast, nineteenth-century social realism was the secular equivalent of Christian universalism. In "On the Serious Imitation of the Everyday" (1937), Auerbach presented Flaubert's Madame Bovary as an ultimate expression of "existential realism" that probed the depth of being-in-the-world. The imitation of everydayness transcended the classical separation between tragic and comic, between Racine and Molière, and, for the first time, applied a sophisticated psychology to daily life [54]. Rousseau was a central figure in the development of the new literary sensibilities, which reflected the democratization of French society in the aftermath of 1789 and 1848.

In constructing French absolutism, court and classical tragedy as a counter-model to historical Christianity, democracy, and mixed literary genres, was Auerbach thinking of 1930s Germany? He was too sensitive a historian not to recognize the gap separating racist populism and ethnonationalism from aristocratic hierarchy and royal authoritarianism. Yet, in the aftermath of 1933, he developed deep suspicion of abstract norms and heroic ideals, of myth and legend, and of hierarchies, and the suspicion converged with his contempt towards "the dreadful inauthenticity of 'blood and soil' propaganda" and Nazi racial hierarchy that made exclusion of the Jews from European culture possible [55]. Against classicism and racism alike he posed Christian authenticity: historical truth (contrasted with myth), daily life, egalitarianism, the dignity of the oppressed. Racism was inauthentic. There were nations, they could be ethnic, and they had each a unique cultural character. But German Jews, however different racially, were German because they shared in a German European culture inheriting the Judeo-Christian legacy.

\section{3. "Figura" and Exile: Christian Typology and Jewish Emancipation}

This culture had now to go into exile. As a decorated front soldier, Auerbach escaped the first wave of academic dismissals of Jews in the spring of 1933. He attempted, to the very end, to keep a 
low profile and ride the storm, and advised others to do the same. He told the Romanische Forschungen editor, Fritz Schalk, who was under attack by Nazi students at Rostock, to hold his nerves, not to provoke the students, and he added: "Something of what the youth want is right. We should take the wind out of their sail by accomplishing it better and in a different fashion" [56]. What Auerbach found acceptable in Nazi demands is unclear, but Leo Spitzer, who had lost his Cologne position in April 1933 and went to Istanbul University, thought that Auerbach betrayed the tribal "feeling of solidarity in times of sudden misery" [57]. Auerbach postponed as long as he could the mandatory pledge of allegiance to Hitler, but, on September 19, 1934, he took the oath to retain his job. Increasingly aware of the untenability of his position, he shifted his teaching duties to his assistant, Werner Krauss. On leave in Italy in September 1935, he grasped immediately the implications of the Nuremberg Laws, and began looking for a position abroad.

His suspension came quickly in mid-October. Marburg was determined not to begin the new academic year with Jews on the teaching faculty. Auerbach inquired with the Warburg Institute in London but they could offer no help. Preferring Europe to the U.S.-Palestine was never considered-Auerbach competed with another German Jewish cosmopolite, Victor Klemperer (1880-1960), for a professorship in "Western European philology" at Istanbul University. Klemperer was, like him, a decorated war veteran and a romance philologist who had just been dismissed from his Dresden position. With a letter from Italian philosopher Benedetto Croce (who had collaborated with Auerbach on the Vico translation), and with support from the previous chair holder, once again Spitzer (who was now going to the U.S.), Auerbach prevailed. He requested, and received, a leave from Marburg and permission to take residence abroad. He went to Switzerland to brush up on his French and, in September 1936, showed up for his new job in Istanbul, the family following him in November. The assimilated Klemperer, married to a non-Jew, survived the Holocaust in Germany by a thread. His Diary, published half a century later, Ich will Zeugnis ablegen bis zum letzten (I will bear witness to the last), would rivet Europeans [58]. He, a cosmopolitan German European was the true German, not the Nazis, he said. "How did you manage to survive in Germany?" wondered Auerbach in a postwar letter to Klemperer [59].

Auerbach was one of about 130 German exiles to whom Turkey provided refuge from Nazism. Istanbul Üniversitesi was a traditional Islamic school reorganized, in 1933, as a university, as part of Mostafa Kemal Atatürk's Westernization and secularization effort. The education ministry dismissed many teachers, and looked for Europeans to head newly established departments. For obvious reasons, Nazi Germany provided the largest pool of applicants. At one time or another in the 1930s, Istanbul University had on its staff such future luminaries as economists Fritz Neumark, Wilhelm Röpke and Alexander Rüstow, mathematician Richard von Mises and philosopher Hans Reichenbach (the last two connected with the Vienna Circle network), and philologists Leo Spitzer and Auerbach [60]. Most were of Jewish origin but they brought with them non-Jewish German assistants, and, together, they constituted a German exile community on the Bosporus. They turned German humanistic education into a model for Turkish higher learning. Almost all left eventually, some before the war, for the U.S. and Switzerland, others returned to Germany after the war. In the interim, they shaped a generation of Turkish scholars, and participated in Europeanizing the Turkish university $[61,62]$. 
Auerbach felt ambivalent about Turkey's Westernization. As department head, he was responsible for the curriculum of European language instruction, wrote a French textbook, and helped set up a library catalogue. He needed to lay the ground for all fundamentals of university education and negotiate constantly with a recalcitrant bureaucracy [63]. He was not an administrator by nature, and, unlike Spitzer and some of his friends, he attempted no Turkish immersion. As a German Jewish professor teaching French to Turks, he felt alienated. He despised Turkish nationalism and thought the nation-building project destructive: an assault on multiple old cultures, an invented barbarous language, and a fictitious secular identity [64,65]. The refugees, he was aware, took over positions of Islamic scholars deposed, like them, by secular nationalists and were resented by large Turkish constituencies. Vico's world of nations was running amuck. Auerbach held copycat modernization and nationalization from above responsible.

Istanbul was a war haven but it was exile, and "the bread of exile," Auerbach quoted Dante, "tastes salty" [66]. Like other German émigrés, he lived in the picturesque suburb of Bebek, riding the tram to the university in the Beyazit district. He admired the city's cultural legacy, especially the old architecture (and despised modernized quarters), and he enjoyed the colorful scenery and gastronomy. He sent his son Clemens to an international school. The low cost of living made a decent, if modest, life possible, even as his resources were dwindling during the war. But he felt uprooted. He never applied for Turkish citizenship. Once his German travel documents expired in 1941, he had no clear legal status. The German government was watchful over Germans living in Turkey, regarding them as potential cultural ambassadors for the Third Reich. Nazis infiltrated émigré clubs and took them over. In 1943, Istanbul University established, over émigré objections, a German department under a Nazi. Upon arrival in Istanbul, Auerbach had signed that he would not engage in political activity (so as to protect Turkish neutrality). A 1939 German report bemoaned that Istanbul University had been judaized (verjudet) and the director of European languages was a non-Aryan, a former Marburg professor who could not be trusted. The report urged the expatriation of all non-Aryan émigrés. Auerbach was not completely safe $[67,68]$.

Exile came as a shock. Auerbach found himself excluded from the German European culture in which his scholarship was grounded and of which he was an exponent. German journals were close to him, and, in romance philology, there was really no non-German equivalent. His path-breaking essays during his Turkish sojourn - two of them in French and English, languages in which he had never written-were published in Finnish, Italian and U.S. journals and in new Turkish series. A Swiss publisher brought out Mimesis in 1946. Istanbul University had no academic library. Angelo Roncalli, future Pope John XXIII and, at the time, the Papal Delegate in Greece and Turkey, opened to him the library at the Dominican monastery in San Pietro di Galata, which had the complete Patrologia Latina [69]. But the sparse and occasionally incorrect scholarly references in his essays made his isolation evident. He was homesick before his first year in Istanbul was over. The family took its summer 1937 vacation in Germany. While in Berlin, Clemens was summoned by the Gestapo to check on his residence, yet Marie still dared to return the summer after to finish family business. On the way back to Istanbul, the Auerbachs travelled via Salzburg, Trieste and Athens, clinging to the German European culture they inhabited, refusing to accept their exile [70].

Yet, experiencing humiliation and exclusion, observing the collapse of the European order from the margins of the continent, and witnessing Turkey's modernization, Auerbach acquired a 
measure of distance from European culture and a more global perspective on it. He sensed that he was witnessing Europe's dissolution, and the experience was painful and sobering. Already in the fall of 1935, upon reading, in the Neue Zürcher Zeitung, a section of Benjamin's reminiscences of his Berlin childhood around 1900, Auerbach spoke of "memories of a home that vanished so long ago!" [71]. His renewed correspondence with Benjamin disclosed nostalgia, mourning and redemptive hope for European culture, all mixed. He retained just enough providentialism —or was it after all Hegelian historicism? - to assume a moral pattern to history, from which one could derive instruction for action. The triumph of National Socialism and the end of Jewish emancipation upset this pattern, and he was at a loss, searching for sources of spiritual renewal for European civilization.

The challenge is not to grasp and digest all the evil that's happening - that's not too difficult — but much more to find a point of departure for those historical forces that can be set against it. To seek for them in myself, to track them down in the world, completely absorbs me. The old forces of resistance - churches, democracies, education, economic laws - are useful and effective only if they are renewed and activated through a new force not yet visible to me [72].

Where was he to turn in exile, searching for this new force? Traditional Jews could turn to Jacob, their wandering ancestor, and seek comfort and instruction in his travails. As secular a Jewish intellectual as sociologist Norbert Elias composed, in 1940 in a British detention camp, "The Ballad of Poor Jacob" that retold the wandering Jew story as a parable for the universal refugee: "And once again he walked without money a little further into the wide world" [73]. Exile, as experience and motif, still tied Auerbach to his Jewish heritage: In Mimesis, he noted in passing that "Jacob really [was] a refugee." He apparently lectured to the Istanbul Jewish community on educational issues (something he was unlikely to do in Germany) [74]. But Jewish sources and traditions were a closed book to him. One wonders what Auerbach could say to the Jewish community.

Instead, Auerbach turned to Augustine and Dante, whom he considered the great spiritual and literary innovators of the West. The topoi of his exile essays were the Passion, sermo humilis and figura: The Passion's shaping of Western emotions, Augustine's refashioning of sermo humilis - Scriptures' lowly style when speaking of the sublime - and Dante's deployment of figura, typology, as a bridge between the historical and the transcendent [75-78]. All provided models for Christian engagement in the world. All were grounded in the Incarnation and the Passion - in Christ human and divine. Werfel believed as a Catholic in the cross and remained Jewish as an act of solidarity with his people. Auerbach was just enough secular not to believe in the miracle of the cross, and remain Jewish by default, but more than enough cultural Christian to uphold the event and the biblical narrative recounting it as world transformative-conveying symbols and ideals that nourished Western civilization. He sought the guidance of Augustine and Dante as to how to translate theses ideals into Western renovation.

Augustine, Auerbach thought, lived like him the dissolution of a civilization - that of the Western Roman Empire. He remolded Latin to make culture accessible to the common people, "fill[ing] this language with new content and giv[ing] it a special style ... sermo humilis" [79]. The transformation of rhetoric, accompanied by Augustine's new psychology and ethics, shaped the Western understanding of the individual and the literary possibilities for expressing it. Still, 
Augustine was of limited use to Auerbach. His view of history as an inconsequential interim between Christ's first and Second Coming, of earthly life as a sojourn, a pilgrimage, and an exile from the Lord, and of the Roman Empire as a pact of criminals ran contrary to Auerbach's earthly Christian world and to his experience of exile [80]. Augustine would never recognize Auerbach's "everyday tragic."

Dante presented a stark contrast to Augustine. The Florentine exile's views on Christian and civic life, like Auerbach's own, left no place for permanent homelessness. Auerbach's October 1938 letter to medievalist Karl Vossler suggested that he began viewing his own exile via Dante's protagonist in The Divine Comedy $[81,82]$. He found in Dante two models for engaging the world: the first, exemplified in "Figura," drew on the Christian legacy to transform literary style and culture, the second, exemplified in Mimesis, shaped a cosmopolitan literary public to become its spokesperson. Dante showed how the predicament of exile and the crisis of European culture could be overcome through cultural innovation. Standing at the apex of medieval culture and presaging the Renaissance, he sustained Auerbach's hope, prior to WWII, of cultural restoration.

Whence, Auerbach wondered, The Divine Comedy's transformative power? How did Dante manage, historically, to break with both Christian allegory and the classical decorum and create the everyday tragic? Dante's and medieval literature's recovery of a patristic mode of biblical exegesis, figura, or typology, which entailed an omnitemporal conception of history that superseded cyclical and linear ones, was Auerbach's answer.

Figural interpretation establishes a connection between two events or persons, the first of which signifies not only itself but also the second, while the second encompasses and fulfills the first. The two poles ... are separate in time, but both, being real events or figures, are within time, within the stream of historical life [83]. Moses and Christ ... are related as figure and fulfillment [but] Moses is no less historically real because he is a ... figura of Christ, and Christ, the fulfillment, is no abstract idea but also a historical reality [84].

Dante could so skillfully make historical figures express transcendental meaning because medieval literature capitalized on a millennium old typological understanding of history and text, paving the way for The Divine Comedy.

Auerbach had not known figura's universe well prior to his exile. He was neither a classicist nor a patristic scholar by training but a romance philologist, a Dante and Vico scholar who moved to work on French literature. His study of Dante required that he reconstruct historically the mimetic problem and its Christian transformation but he had no detailed knowledge of classical and patristic sources beyond the education of a humanistic scholar. In exile, he studied patristic literature intensively and felt moved. He found in it consolation and encouragement, and the experience would shape Mimesis. In the postwar years, he would still be enraptured by the survival of Christian culture through the early middle ages but the focus would no longer be patristic. Figura constituted the intellectual and emotional world of Aurbach's Turkish exile.

Figura signaled also Auerbach's turn to Catholicism. In 1921 he had declared himself a Prussian Jew (rather than simply a German Jew), intimating his preference for Protestant culture. But with the Nazi triumph, cultural Protestantism, wholly invested in the nation state, appeared bankrupt, and its protagonists were commonly rushing to reconcile with the new regime. 
Auerbach's method continued to reflect his Protestant training, but his vision, from the mid-1930s on, showed significant marks of the Catholic understanding of modernity and secularization, and he expressed admiration for medieval Christendom [85]. Already in his 1933 essay on the seventeenth-century French public, Auerbach offered a rudimentary theory of secularization, inspired by Catholic philosopher Étienne Gilson (1884-1978). The emergent public, designed to distance the bourgeoisie from "everyday life," was the moral agent behind classical tragedy's revival. Like Descartes' epistemological subject, the public reflected de-Christianization, a disavowal of the divine in the mundane. National Socialism's anti-Christian turn mimicked early modern absolutism.

"I belong to the Jewish community," said Auerbach in 1935, "but my work has been engaged for many years with Christian theology, especially of Catholic circles (Guardini, Gilson)" [86]. Romano Guardini (1885-1968) was a leading German Catholic scholar and an anti-Nazi public intellectual. Auerbach's protagonists for the next decade would resemble Guardini's: Augustine, Dante, and Pascal. Luther was nowhere to be seen. Typology was primarily a Catholic affair, first of Gilson, and then of Jesuit theologian, Henri de Lubac (1896-1991), who assailed antisemitism as anti-Christian and would inspire Vatican II $[87,88]$. For a cultural Christian and a German Jew, it was not unreasonable to sense, in the 1930s, that Catholic culture offered greater space for Christian Jews than Protestant one. Moving between cultural Protestantism and Catholicism, Auerbach made typology a Jewish project.

"Figura" provides a history of typology as a literary and artistic form, from the Roman poets to patristic literature to Dante. Auerbach began "Figura" with the Hellenization of Roman education in the first century BCE and the transmission of Greek literary and philosophical concepts, such as schẽma, into Roman culture. He moved from republican era poets Lucretius and Cicero to imperial era poets Virgil, Catullus and Ovid, and from them to architecture, jurisprudence and, above all, to Quintilian's rhetoric. The poets were fascinated by "the play between model and copy, the changing form, the deceptive likeness of dream figures" [89], the architects contemplated models to emulate, and Quintilian designated by figura multiple literary tropes, product of the metaphoric imagination that enriched rhetoric. Figura remained primarily literary, of interest to limited intellectual circles.

The advent of Christ, the crucifixion, and Christian sacraments changed radically figura's meaning and significance ${ }^{[} 90$ ]. Jesus' disciples naturally looked to the Hebrew Bible for prophecies figuring his advent. The Greek typos, used in early accounts to designate prefiguration of events and persons connected with Christ, devolved into the Latin figura, now combining biblical "prophecy" with classical "representation." "Figure" turned into "prefigure" (of the New Testament by the Old), the literary notion became historical, designating real events and persons [91]. For Paul, on his mission to the Gentiles, the Hebrew Bible turned "from a book of the law and history of Israel into one of a unique great promise and a prehistory of Christ. ... What the Old Testament thereby lost in the efficacy of its law and in the autonomy of its national history, it gained in concrete dramatic actuality" [92]. "[T] the newly converted peoples, [it gave] a basic conception of world history," "its integral teleological view ..., the providential order ... captur[ing] the[ir] imagination and innermost feeling ... with its living historicity" [93]. Figura became constitutive 
of the Christian conception of reality and history. It represented "a fresh beginning and rebirth of creative powers" [94].

Christian typology combined historical depth with popular reach. The future was concealed yet embodied in persons, who were not historically contingent but signified universal and eternal meaning; God himself was incarnated in figures and sacraments. Allegorical, ethical and spiritual interpretations, rendering biblical persons and events symbolic, provided an alternative to typology. From Jewish philosopher Philo to Church Father Origen and the Alexandrian School to medieval times, allegory coexisted with figura. But allegorization, insisted Auerbach, remained an elite project, whereas Christian typology, phenomenal and historical, expanded the reach of figural thinking to the socially downtrodden, bringing together high and low. Beginning its triumphant march in patristic literature in the third century with Tertullian, typology became hegemonic with Augustine in the fourth century. Both Tertullian and Augustine were staunch realists, who rejected allegorical spiritualism. "When you hear an exposition of the mystery of Scriptures telling of things that took place," admonished Augustine, "believe what is read to have actually taken place ... lest ... you seek to build in the air" $[95,96]$.

Medieval allegory was doctrinally one of the fourfold sense of Scriptures but figura predominated, insisted Auerbach [97]. Separating typology from allegory, Auerbach rebutted the common view of The Divine Comedy as allegorical. Virgil, who guided Dante through Hell, and Beatrice who welcomed him in Paradise were figures, not allegories, real historical persons, not theological principles. An embodiment of poetic eloquence and worldly virtues-liberty, wisdom, justice and piety-Virgil, the fullness of earthly perfection, had the capacity to guide Dante to the threshold of insight into the divine. Beatrice, sent by divine grace to guide Dante (and humanity) to salvation, incarnated revelation, but her relationship to Dante could not fully be explained by dogmatic considerations. She was also his beloved Florentine, and their lives did intersect. Every mythical or historical figure in the Comedy had a meaning connected with what Dante knew about their life. Virgil was not "virtue" or "reason," rather, the literal meaning figured the theological, and the theological confirmed and fulfilled it, both meanings having a place in a providential history [98].

"Figura" ended on a rather minor note that seemed to diminish the brunt of Auerbach's tour de force. To his earlier call to revisit allegory and figura in medieval literature, Auerbach now joined the observation that figura's history showed how a word could develop into a world historical situation. Paul's mission to the Gentiles endowed the classical concept with structures that would shape the late antique and medieval intellectual worlds [99]. Viewing Paul's move from national to world religion (Judaism to Christianity) as the crucial turning point in history was in line with the common Christian view, but it did not elucidate figura's implications for Europe. How did Christian realism shape modern culture? Auerbach hinted that medieval literature already contained the origin of secular realism but he shunned any suggestion as to how secularization had taken place. His caution reflected his genuine bewilderment about the origins of the European crisis - he sensed that secularization prepared the way but he just did not know how.

All the same, "Figura" did have a political agenda, if not as open as the academic one. Academically, Auerbach intervened in medieval studies, urging scholars to distinguish between allegory and typology, between the diversity of literary metaphors and figura. Typology was, he insisted, the quintessential Christian mode, and Christian realism was mainstream. But his professional 
intervention was politically loaded. He discovered figura just as the exclusionary power of race made him painfully conscious of his Jewishness. "Figura" stuck a position in German debates on the "Jewish" character of the Old Testament. Auerbach sought to renegotiate Jewish membership in German European culture, i.e., Jewish emancipation, by highlighting the Jewish origins of European culture.

Thinkers ranging from liberal Protestant to Nazi dissociated the New Testament from the Old. The liberals aimed to rescue a Christian mission — universal or national—from "Jewish particularism," the racists, most radically the German Christians, to establish Aryan Christianity. In his 1933 Advent Sermon, Munich Cardinal Faulhaber tepidly defended the Old Testament as holy, if inferior, to the New [100]. Reformed theologian Karl Barth (1886-1968), a leader of the anti-Nazi Confessing Church, affirmed, in contrast, the unity of revelation: The Old Testament pointed forward to Christ, the New Testament backward. But for him, too, the Old Testament had no value as a book about Ancient Israel: "For us the Old Testament is valid only in relation to the New. If the Church has declared itself to be the lawful successor to the Synagogue, this means that the Old Testament is witness to Christ before Christ but not without Christ" [101,102].

Against this chorus, Auerbach underlined the historical continuity between the Old and New Testament by using typology. He reargued the case for the Old Testament against the like of Harnack who wished to de-canonize it. "It was not until very late," he said acerbically, "that Europeans began to regard the Old Testament as Jewish History and Jewish Law" [103]. He uncovered a patristic and medieval interpretive mode that superseded the progressive conception of history. Still, precisely because he wished to sustain Jewish integration, and, in 1938, still held hope for Germany, he never took the Barthian turn of Jewish rebels of his cohort, who radically separated reason and revelation, challenged their parents' optimistic historical theology, and affirmed authentic Jewish identity. He would not commit himself to the Catholic critique of Enlightenment and the nation state, either. Barth, the Catholics and Auerbach agreed that the Old and New Testament were of a piece, but Barth's anti-nationalist, anti-historical, unearthly Christianity left Jews forever as the Other, and the Catholics were profoundly antimodern. Liberal histories brought Jews and Christians so close to each other that Auerbach would not give them up for Barth's Christocentric history or forgo modernity. He would rather work through history than through theology, negotiate with Harnack rather than with Barth, argue with prejudice rather than concede incommensurable truth and otherness, heal rather than reject modern life.

"Figura" was a desperate attempt to salvage emancipation and German Jewish cosmopolitanism through a shared Judeo-Christian tradition. It allowed only for a diminished space for Jews, and, indeed, it is not clear that they could any longer be recognized as Jews. In the debate between Judaism and Christianity, Auerbach accepted the Christian argument-Christianity superseded Judaism. A December 1941 letter to an Istanbul colleague, Alexander Rüstow, made his view about Judaism's obsolescence clear: Jewish life had long been reified, and Jews were leading a ghostly existence [104].

The uncanny feeling Judaism evokes, the sense that it is laden with a curse, grew, and became concrete, through the role the Jews played in the rise of Christianity. Christianity originated with the Jews but they rejected it, so that the mission reverted to the Gentiles, forming a contrast between 
Jewish Law (now but a shadow and a ghost) and the fulfillment of Christian Grace (which disempowered the Law) [105].

The Jews had had no authentic spiritual life since the time of the Prophets but they still presented the spectacle of a people living apart in exile, attached to their ancestry. Through the ages, they survived as a minority, subject to hatred and persecution, while other nations, with viable political life, vanished. The Enlightenment constituted a break, removing the taboo against the Jews - forever. Modern antisemitism was a byproduct of nationalist struggles, an opportunistic endeavor to use atavistic relics to reinforce exclusion, historically hopeless and meaningless. The Jews were part of European culture, and antisemitism had no object, purpose or prospect. It was "a side issue." In time, it would disappear [106]. The Jews may meanwhile suffer but they should be thankful for the role of martyrs for humanity - a role they did not deserve - that fell in their lot.

This extraordinary statement, made at a time when, unbeknownst to Auerbach, Soviet Jews were already being shot in the tens of thousands, and Hitler was completing the plans for destroying all of European Jewry, provides precious insight into Auerbach's worldview. It reflects crude Christian supersessionism, incredible optimism about Jewish emancipation, a profound misreading of antisemitism, and an avowal of the Christian martyr role for the Jews. Auerbach's ignorance of Jewish typology was grounded in the conviction that postbiblical Jewish life was not part of European history. The Jews became part of Europe only when the Enlightenment made their integration possible - and no longer as Jews: "Anything significant that came out of the Jews was absorbed by the host nations" [107]. Jewish history-if such existed-was not part of European history.

Jewish ethnic survival was for Auerbach a source of puzzlement-of wonder (and perhaps hidden pride) mixed with apprehension about their "uncanny" existence. Like philosopher Karl Popper, Auerbach had no doubt that it was high time for Jewish life to end-for the Jews to become part of Christian Europe. Popper imagined the culture integrating the Jews as avowedly secular, its relationship to Christianity tenuous; for Auerbach, it clearly bore the marks of secularized Christianity. The National Socialist attack on the Jews was only significant for its denial of humanity, and the Jews acquired their universal role as Christian martyrs. Christian martyrology became paradigmatic of the Jewish experience, and Auerbach, captivated, devoted to it increasing attention during and after WWII. The murdered Jews were integrated into European civilization - as (undeserving) Christian martyrs.

"Figura" was emblematic of European history integrating the Jews as Christians. Auerbach's turn to Catholicism facilitated a transformation of cultural Protestant narratives but he retained them, however altered, because he did not wish to give up on modernity or emancipation. He modified Harnack by skipping over Marcion (who rejected the Hebrew Bible), highlighting Tertullian and Augustine, and ending with Dante rather than with Luther or modern Protestantism. Dante became a start-point of modernity, of secularization that would de-eschatologize Christian history but absorb Dante's vision of humanity, leaving a universal history to be shared by Christians, Jews and all. This universal history, however, still bore its Christian marks - it did not permit Jews to remain Jews. A Christian humanist who remained Jewish, Auerbach constructed a narrative of Western civilization that appealed to the highly acculturated German-Jewish 
intelligentsia — and today's Europeans. "Figura" has become his most famous essay, and virtually canonical.

\section{Mimesis and the Holocaust: The Jewish Origins of European Civilization}

European restoration, German Jewish cosmopolitanism and emancipation all depended on the survival of Vico's world of nations. With the collapse of Europe in World War II, Auerbach lost hope for them. Mimesis, written (according to Auerbach) between May 1942 and April 1945, at the height of the war and the Holocaust, reflected a change of orientation. As a refugee without national identity on the outskirts of a devastated continent, Auerbach no longer wrote as a German European. His previous audience was gone, at least for the war (and he suspected forever), and he did not know who his prospective audience might be, or what shape postwar Europe might take, indeed, if it, and he, would survive at all. He had to refashion his authorial identity and imagine a new audience. "The Jewish refugee in Istanbul," says Carl Landauer, "very much the outsider, reestablished himself as an insider" by reconfiguring both the European audience and himself as members of the Western tradition [108].

Deploying a style suggested by high modernist novels, Auerbach began writing as a cosmopolitan spokesperson for a "European classico-Christian literary culture" [109,110]. He appeared as a panEuropean, at once a Christian humanist and a modernist, drawing the boundaries and charting the legacy of Europe for a cosmopolitan audience. In exile from Florence, Dante proclaimed "the world is my fatherland," and the Swiss historian, Jacob Burckhardt, echoed him: "My country is the whole world" [111,112]. Auerbach joined this lineage of aspiring cosmopolitans, imagining "a European world in which he was at home" [113].

Mimesis charted the history of Western literary styles and their representation of reality in nineteen (and, in later editions, twenty) exquisitely crafted essays on the classics of Western literature. Auerbach began with the Odyssey and the Hebrew Bible, continued with the classical Roman poet Petronius and the New Testament, moved on to the fourth-century historian Marcellinus Ammianus and Augustine, and captured the transition from the late antique to the medieval with Gregory of Tours' History of the Franks. He skipped half a millennium to the medieval epic of Roland, the romance of Yvain and "Adam and Eve" Christmas plays, paid homage to Dante in the unforgettable "Farinata and Calvacante," and showed Boccaccio and the fifteenth-century chivalrous chronicler, Antoine de la Salle, negotiating the Renaissance and the waning middle ages. The sixteenth-century giants, Rabelais, Montaigne and Shakespeare (and, in later editions, Cervantes) gave a measure of secularization, Molière and his critics displayed seventeenth-century French classicism, an Abbé Prévost 1731 sentimental novel paired with Voltaire's Candide and Saint Simon's Memoirs of Louis XIV's court marked an emergent Enlightenment, and Schiller and Goethe drew the German enlightenment's limits and their import for German realism. Mimesis concluded with three essays on modern realism, beginning, respectively, with Stendhal, the brothers Goncourt, and Wolfe, but comparing their works with other exemplars of French, English, German and Russian realism.

The format for Mimesis' essays was uniform: Auerbach opened with long quotation from the work, which provided the focus for his analysis. He tracked the uniqueness of the literary style and placed it in its life-world, accentuating comparable or competing literary modes. The book had no 
footnotes. The limits of the Istanbul library, Auerbach suggested, made writing a book covering three millennia possible but also dictated his textual focus and his daring construction of context. Mimesis had no introduction or conclusion to provide an overarching argument or context. Only a brief epilogue lent Mimesis a measure of coherence, offering an historical outline of the doctrine of styles. Critics complained that Auerbach's realism was impossible to pin down, as the meaning of reality kept shifting from epistemological (empirical and sensational) to sociological (class structure) to psychological (emotional state). Mimesis remained elusive.

As if to increase Mimesis' mystery, Auerbach made very few allusions, mostly oblique, to his own world - to National Socialism, exile and the war. Mimesis' opacity, joined by its aesthetic appeal and daunting reach and erudition, gave rise to a lively debate on Auerbach's narrative of Western civilization. Commentators have viewed Mimesis alternatively as literary Christology, Jewish philology, secular criticism, minority literature and literary modernism [114-118]. This much is clear: Postwar U.S. and European critics alike have found Auerbach enthralling, and his fame has been on the increase. Auerbach told a story postwar Europeans loved to hear. Mimesis did end up shaping the new cosmopolitan audience Auerbach imagined and became a charter for a new Europe.

Mimesis' focus remained, however, on the current European crisis. Auerbach offered clues to its origins by putting forward an ironic vision of secularization and a rudimentary theory of the failure of German literary culture. His leitmotif was the emergence of modern literary realism in the secularization of Christian realism [119]. Like Weber's story of capitalist rationality, Auerbach's secularization narrative was ironic [120]. Christian realism legitimated the earthly world, and the earthly world, in turn, diminished the divine. Dante never intended to dispel the enchanted life his Comedy depicted, but "Dante's work made man Christian-figural being a reality, and destroyed it in the very process of realizing it" [121]. Auerbach could not fully explain the secularization process but the vanishing of typology and the rise of historicism gave measure of it. He located several literary sites, notably among sixteenth-century authors, to show secularization happening. For Montaigne, "life on earth is no longer the figure of the life beyond. ... To live here is his purpose and his art" [122]. Modernity confronted an eclipse of the divine, loss of providential history, and an irreparable breach between the earthly and transcendental.

Auerbach found all secular substitutes to Christian realism falling short, unable to make up for transcendental loss. Neither historical progress nor aesthetic perfection or self-cultivation (Bildung) could make up for the dissolution of the bond between human and divine. But the French realists' social criticism and their grasp of the everyday tragic reflected a dignified literary sensibility, one appropriate to a secular culture undergoing democratization. Stendhal's narration in The Red and the Black of his protagonist's progressive disillusion with the Parisian elite gave realism its most authentic expression. Both the Flaubert generation's turn to aestheticism, to art for art's sake, and the realists' indifference, especially Zola's, to the transcendental were inadequate responses to bourgeois materialism, but they could not diminish the grandeur of their cultural and social critiques. The French realists gave a glimpse of lost Christian realism. The Christian humanist found in secular democratic realism the closest approximation to the original.

Humanism itself, however, came under scrutiny and revision. This emerged most clearly in Auerbach's critique of Goethe. Goethe confronted Germany's political fragmentation and conservative 
social order with equanimity. Historicism opened possibilities for literary realism by highlighting process and change but Germans could not look beyond their regional cultures. When the French Revolution raised the prospect of a democratic national culture, Goethe recoiled, reaffirmed his preference for the nobility and posed Bildung and the integrated personality as ideals. But a national culture required social engagement, not self-cultivation. Germany developed no realist literary tradition. When unification came from above, Germany found itself without a culture adequate to modernity's challenges. Thomas Mann was, in fin-de-siècle years, the first serious German realist, and, shortly after, World War I threw European realism into turmoil, from which it emerged with a fragmentary modernist style, unable to sustain a national culture. Nazism encountered no cultural barrier on its way to power. German humanism was implicated in the German catastrophe.

Goethe was the George Circle's hero, their model for fashioning the "self as character." Auerbach's critique of German culture represented a reevaluation of the circle, philological humanism and his own past [123]. Human perfectibility and aesthetic integrity were incompatible with a secular democratic age. They reflected refusals to pay heed to social deprivation and to come to terms with transcendental loss-harmonious personality was forever gone with the divine. Self-cultivation displayed over-appreciation of classicism and the aesthetic and a failure at Christian humility. To make philological humanism more socially responsive, "Figura" and Mimesis underlined the limits of classicism, and Mimesis parted with scholarly style and emulated high modernism. Just as French realism responded to democracy, Auerbach's modernism responded to European turmoil and globalization. He held German culture responsible for democracy's failure but the challenge was global. The European nation state was approaching its end. Philological humanism had now to address a cosmopolitan public.

French authors predominated in Mimesis, reflecting Auerbach's move from German to European cosmopolitanism. Not one German work provided the title or focus for any of Mimesis' chapters. "Romance literatures are more representative of Europe than ... the German," insisted Auerbach [124]. German humanists, like Curtius, shared his French and modernist sympathies, not to mention his Christian appreciation, but he parted with the national tradition in ways they never did. He was unique in his democratic vision of Christianity, in aligning realism and democracy, in rooting them in Christian realism, and in criticizing Bildung, humanism's fountain. His critique presaged postwar liberal theories of a German Sonderweg, a unique German path, divergent from Western liberal democracy. Postwar liberals, too, traced the roots of the German catastrophe in cultural authoritarianism and elitism and focused on German intellectuals' political irresponsibility. But Auerbach did not think he was exploring a Sonderweg. No national culture, he said, reached the height of French realism. The German failure had the most serious consequences but the crisis was European, indeed global, and it went to the heart of secular modernity.

Mimesis could offer no solution to the European crisis. Rechristianizing the secular world was no more possible than escaping Weber's iron cage of capitalism. Works such as Lukàcs' Theory of the Novel, emerging from Weber's Heidelberg circle and pre-WWI mandarin sociology, understood modern literary genres to be reflective of the breakdown of a holistic premodern world, the dissolution of Gemeinschaft (community) [125,126]. Mimesis updated them with consciousness of the end of Europe. Lukàcs and Auerbach upheld realism for its social consciousness, admired 
Mann, and censured German Kultur for the Nazi disaster [127]. But Lukàcs strove to break out of the iron cage through communism; Auerbach, a mild liberal, remained entrapped. To Auerbach, secularization, not capitalism, was the root of modernity's travails. Concern for the poor was at the heart of Christianity, but atheistic socialism could not undo transcendental loss, only reinforce it. Auerbach was permeated with Weber's tragic vision, reinforced by a Catholic sensibility of modern loss. His disposition toward European culture was a combination of nostalgia and criticism, detachment and engagement, depression and exhilaration.

One wonders how Auerbach could maintain this interplay of proximity and distance facing the Holocaust. But the murder of the European Jews is not mentioned even once in Mimesis and appears not to figure in Auerbach's European crisis. Postbiblical Jews vanish from Auerbach's narrative of Western literature. He made a special effort to ignore them: In discussing Shylock as a (non-) tragic figure, he overlooked his Jewishness. Contemporary readers find his silence so baffling that they strive to find clues to the Holocaust in Mimesis [128,129]. Is Auerbach's discussion of the binding of Isaac, the Akedah - a Jewish martyrology topos emerging repeatedly in Holocaust discourse - not a gesture toward the Holocaust [130]? Is the vindication of the Hebrew Bible against classical epic, of bound Isaac against Odysseus, destroyer of Troy, not a claim to Jewish spiritual superiority—and survival—over German might?

How one would wish! Mimesis did respond to the Jews' exclusion from European culture by showing the Jews as founders of this culture and challenging German affinity for the classical. Indeed, in no other Auerbach work is there such concern for the Hebrew Bible, such insistence on calling biblical authors (of the Gospels, too) "Jewish," and using the appellation Judeo-Christian for the emergent Western tradition. But neither the binding of Isaac nor the plea for the Old Testament was a Holocaust referent. Auerbach was ignorant of the Akedah typology [131]. He chose the binding of Isaac with an eye to the real world-making event, the "scandal of the cross" [132]. However much he defended the dignity and independence of the Old Testament, and sought to remain neutral on the Christian interpretation of the Akedah as prefiguration of the crucifixion, he absorbed the binding of Isaac into a Christian narrative of Western literature. Christian supersessionism reigned triumphant.

Moreover, Auerbach thought of WWII as a European and German catastrophe, not a Jewish one. He was writing Mimesis as representative of "European classico-Christian culture," not as a Jew. He had every apprehension that, were he to appear as one, he would not be recognized as an authentic representative. Biblical Jews were part of Western history, indeed, its founders. Postbiblical Jews became members only insofar as they were part of Christian civilization. Mimesis' panEuropean space, and cosmopolitan audience, had no room for Jews, qua Jews.

Auerbach's strategy for Jewish integration via Christian culture remained the same even as his projected audience expanded from the nation to the cosmopolis. This was less than evident because Auerbach did not pursue openly Mimesis' agenda. Even his thrust against classical hegemony and promotion of the Judeo-Christian heritage remained camouflaged. The contents, or essay titles, would suggest a classical transmission line from Homer's Odyssey to Petronius' poetry to Ammianus' history. Not until medieval Christian drama did Auerbach place a religious text at the center of an essay, and this was the single essay in Mimesis where he did so. There was no biblical transmission line. The major works Auerbach used to control the classical- the Hebrew Bible, the 
New Testament, Augustine's Confessions - appeared as comparisons in essays dedicated to classical works. Christian typology, figura, did its work behind the scene. Not surprisingly, critics push Auerbach just a bit further-beyond what his intentions or intellectual resources would allow_-by suggesting that he camouflaged a Jewish agenda under Christian rubrics. On the Jewish Question, however, Auerbach remained consistent from "Figura" to Mimesis: The Jews were to be integrated as cultural Christians.

The Old Testament became in Mimesis the central conduit for Jewish membership in the West. In the magnificent "Odysseus' Scar," Mimesis' opening chapter, Auerbach contrasted the two models of realism informing Western literature: Greek epic and the Hebrew Bible. The Homeric poem's elevated style, its rich and intricate description of worldly scenes, uniformly, completely and unmistakably explained, contrasted with the Bible's sparing use of language, its rough narrative accentuating aspects of characters and scenes, leaving much unexpressed, in the background, calling for interpretation. Biblical protagonists had inner psychological intensity and a grappling multilayered consciousness, while Homer's heroes never changed, and their emotions were laid bare in the foreground. Claiming absolute truth, biblical narrative constructed a universal history, however disjointed, to impart ethical and pedagogical messages, and events found their meaning in temporal connections. For Homeric legend, historical time, and truth, were inconsequential, and horizontal connections - a tightly and beautifully woven web - provided the meaning. The Homeric epic displayed everyday realism but "everyday" was confined to the idyllic home, in contrast with biblical struggles, which, pregnant with transcendental significance, took place in the domestic and public sphere alike. The epic reflected a static "feudal" society, and its heroes were aristocrats, the Old Testament reflected a nomadic society, its protagonists were often humble in origin, the entire social ladder was immersed in everyday life. "In the Old Testament stories, the sublime, tragic, and problematic take shape precisely in the ... everyday" [133]. The Hebrew Bible was the fountainhead of Western realism.

The fragmentary character of biblical narrative reflected the difficulty of complete representation of any historical situation. Classical Greece discovered historical complexity and psychological intricacy and, with them, the mimetic problem-Homer's horizontal connections could no longer be easily, let alone fully, established. The classical response, from Aristotle to Horace, was the doctrine of styles, separating among high (epic), middle (didactic; historical), and low (pastoral) style. Everyday life, appropriate as popular comic subject, was proscribed from noble tragedy. Judeo-Christian writings, argued Auerbach, presaged modern realism by overcoming the separation. In the Gospel of Mark, Peter's denial of Jesus showed a lowly human undergoing psychological and emotional turmoil, "trembling for his miserable life," and acquiring through the "despair and remorse following his desperate failure" consciousness of sin, revealing to him, and us, "the significance of Christ's coming and Passion" [134]. That a fisherman would emerge as a tragic hero through an all too human failure, and that this failure would embody sublime universal meaning, was unthinkable to classical literature.

A scene like Peter's denial fits into no antique genre. It is too serious for comedy, too contemporary and everyday for tragedy, politically too insignificant for history. ... It portrays something which neither the poets nor the historians of antiquity ever set out to portray: the birth of a spiritual movement in the depths of the common people, from within the everyday occurrences of 
contemporary life, which thus assumes an importance it could never have assumed in antique literature [135].

Christ's dual character as Son of God and of a carpenter, his "humiliation and elevation" on the cross, broke through class barriers and literary styles, joining the humble and the sublime. The Passion forced confrontation with reality, made aristocratic distance and disdain impossible, and reshaped Western emotional life. It created a new universal message.

$[\mathrm{M}]$ issionary work to the Gentiles characteristically began with a member of the Jewish diaspora, the Apostle Paul [who] adapted the message to ... a far wider audience, detach[ing it] from special preconceptions of the Jewish world $\ldots$ by a method rooted in Jewish tradition but now applied with incomparable greater boldness, the method of revisional interpretation [136].

Interpreting the Old Testament figuratively, the new method, typology, detached meaning from sensory perception, and deepened the antagonism between sensory appearance and meaning, emergent in the Hebrew Bible and permeating Christian reality. The great challenge, and attraction, of Christian realism consisted in this tension-in finding the transcendental represented in the mundane, in projecting an earthly world infused with transcendental meaning. Jewish Christians introduced typology as they launched universalism. Restoring early Christianity to its Jewish context, Auerbach made (pre-rabbinic) Jews shapers of Western destiny [137].

Christians still lacked a literary language. Throughout late antiquity, the Church Fathers progressively took over classical rhetoric, even as they remained suspicious and ambivalent toward it. By Augustine's time, they could speak eloquently to the educated. Yet, witnessing the waning of classical culture, Augustine, a master of rhetoric himself, recognized the need to shape a Christian style. More than anyone before, he sensed that the Passion "engendered a new elevated style," "a new kind of sublimity," "which was ready to absorb ... the ugly, the undignified, and the physically based." The result was "a new sermo humilis, a low style [that] encroaches on the sublime and the eternal," of which Augustine gave splendid examples in his writings [138]. But sermo humilis still had no capacity to represent concrete historical events. Typology had annihilated classical history, and Augustine's concern was to bring the Roman Empire's trajectory, not everyday life, in conformity with Christian universal history. For Christian realism to emerge, concluded Auerbach in a historicist fashion, time and "the sensuality of new peoples" were necessary [139].

Auerbach found the apex of Christian realism in the high Middle Ages - in twelfth century liturgical dramas about the Fall, thirteenth century popular religious poetry about Mary at the cross, the letters of St. Bernard and St. Francis and, of course, in Dante. They managed to bring the Incarnation and the Passion, the convergence of humility and sublimity, to bear on the common people's daily life in ways never accomplished before. St. Francis drew the imitatio Christi out of rhetoric and into his own life and became an inimitable model. Auerbach credited him — "a great poet, an instinctive master of the art of acting out his own being"-with "awakening the dramatic powers ... of the Italian language" $[140,141]$. St. Francis prepared the way to Christian realism's greatest work, The Divine Comedy. Mastering the typological art of transcendental significance in earthly events, Dante fulfilled the potential Augustine created with sermo humilis, and, in the very act, began its destruction. The height of Christian realism was also the beginning of secularization. 
Mimesis' Christ - the Christ of sermo humilis - was the one nailed to the cross, not the triumphantly rising Christ, certainly not the judge at the end of days. He was Christ who walked among and cared for the downtrodden, was himself an outcast, and bespoke the equality and dignity of humankind. He was the Christ of Auerbach's exile and the Holocaust. A poor humiliated outcast in Istanbul, Auerbach found solace in the convergence of sublimity and humility, in sermo humilis, aptly translated as "subaltern" style [142,143]. That Auerbach saw his own condition in literary depictions of Christ is likely, that he saw the fate of his persecuted and murdered brethren in Europe in the cross is possible. Christ was Jesus of Nazareth, a Galilean Jew, son of a Jewish carpenter, but, equally crucial, he was also the Christian God.

It would be no use pretending that the ways of Christianity and Judaism never parted, and Auerbach was pursuing a Jewish agenda. In response to the Holocaust, traditional Jews turned to the Akeda and Jewish martyrology and, in anger, evoked the memory of the ancient perpetrator of genocide, Amalek [144]. Auerbach turned to Jesus on the cross, Mary at the cross, Augustine's sermo humilis, and, in the postwar years, also to Christian martyrology. Christian realism may have had its origin in the Hebrew Bible, but the world in which Auerbach found it fulfilled, that of St. Bernard, St. Francis and Dante, was as closed to Jews as any have been. That the cosmopolitan European public Mimesis envisioned would be more open to Jews was a desperate Auerbach wager (for once, a successful one). Auerbach's "stylistic analysis [was] so Christ-centred that it seem[ed] on the verge of ... a Christological literary history" [145]. The Judeo-Christian project for Jewish integration was tenuous at best.

\section{A German Jewish Cosmopolitan in Despair: Globalization, Postwar Germany and the U.S.}

"May my study reach its readers - both my friends of past years who have survived and all others for whom it is intended," concluded Auerbach Mimesis, "and may it contribute to bringing together again those who clearly kept their love for our Western history" [146,147]. His call for a

survivors' meeting to learn what may be salvaged of Europe was sad and uncertain, but not hopeless: The cosmopolitan literary public Mimesis envisioned might yet be constituted. He still had no sense of the magnitude of the destruction. His feelings about his own future were similar: uncertain but not hopeless. He did not wish to remain in Turkey, where the enthusiasm for humanist educational reform was waning, was considering a return to Germany and, having sent his son Clemens to Harvard for graduate education in the fall of 1945, he was contemplating a move to the U.S. Mimesis' success, his 1947 immigration to the U.S., his 1950 appointment at Yale, and his growing reputation on both sides of the Atlantic represented great personal accomplishment. But his postwar reflections on the European future became increasingly gloomy. In the bipolar Cold War world, the progressive German mandarin thought his Europe was gone. The Jews were gone, the emancipation project to which he had still clung in 1941, proved a phantasm, that "side issue," as he had called antisemitism, rendering it irrelevant. He would no longer entertain any projects for a Judeo-Christian civilization. His studies now focused on early medieval Europe, trying to decipher how late antique culture survived through the dark ages, once the Western Roman Empire had been gone. His cosmopolitanism was not a happy one.

Auerbach still felt German and European. In the immediate postwar years, he was trying to reestablish connections with friends left behind and to explore the possibility of a Marburg 
reappointment. Just as he feared, more than a few of his friends did not survive. Students of draft age sent to the Russian front usually did not come back [148]. For the survivors-German colleagues undergoing postwar hardship-Auerbach cared deeply. He sold furniture and books to send Clemens to Harvard, but he still went out of his way to mail Care packages to Germany, especially to his former (non-Jewish) assistant, Werner Krauss, who was in poor health after prolonged incarceration [149,150]. Emotionally and intellectually, he remained vested in Germany and, in many ways, would remain so all his life. Untenable as his situation in Turkey was, he still felt he needed to explain to German colleagues why a German European would send his son to study in the U.S. and explore emigrating there [151-153]. Until 1947, his preference was a return to Marburg. Had the call from Marburg arrived, Auerbach would have probably accepted it.

War and exile did transform, however, the German European Auerbach. They impressed upon him that he was not, and could never hope to be a German insider. Krauss, now a communist professor in Marburg, and later in Leipzig, did everything he could to attract him back, repeatedly broaching a Berlin appointment with the Soviet Zone's education administration. In the summer of 1946, he assured Auerbach that nothing more than good will toward socialism would be required of him. Longing for Berlin but apprehensive about its geopolitics and the ideological burden, Auerbach hesitated. "I am very liberal ... Here [in exile] I could free myself like nowhere else of any commitment; precisely my position as someone who is nowhere an insider, fundamentally and inassimilablly a foreigner, is what one wishes and expects of me; where you want me back, one expects 'basic favourable disposition"" [154]. His alienation, his sense of himself as a permanent outsider, incapable of commitment, was new. He would not have spoken of himself as a foreigner in Germany prior to the war, and even Mimesis underlined social commitment. His newly discovered marginality reinforced his move away from the nation and towards an ephemeral European cosmopolis.

Family and scholarship joined alienation to challenge the nation's call to return. His son was in the U.S., and a flood of reports about the hardship of life in Germany reached Turkey. In Istanbul, he was getting poorer, unable to afford support for Clemens at Harvard, feeling ever more dejected about the bureaucracy and with no career prospect. Germany had to address some of these needs, for him to return. Krauss urged upon him the importance of his repatriation for building up a new Germany: "Reintegration in the Heimat [is] an inner need that one cannot resist with impunity. ... Germany is only bearable and worth affirming as a project, not in its present state" [155]. In vain: Early in 1947, Auerbach got three offers from German universities-Greifswald, Halle and Münster, the first two in the Soviet Zone, Münster in ruins. It was evident that working conditions would be inadequate, and he declined. He admired Krauss' dedication, but, Krauss' communism aside, he could not share his commitment to Germany.

Auerbach was still waiting for Marburg - the hub of university life in the U.S. Zone, with a glorious tradition and old colleagues on the faculty, site of his fondest memories of Germany. One wonders whether he did not also think of a Marburg invitation as restitution, an apology to rectify the injustice done to him. In April 1947, he received from Marburg's reform-oriented Philosophy Dean, former Vienna Circle associate Kurt Reidemeister, a letter suggesting that if Krauss left for Leipzig, and the ministry approved a full professorship, a position would open up for him. Auerbach gave rare expression to his frustration, saying he was tired of building his career as a 
house of cards that repeatedly collapsed [156]. He now opted for the U.S., but he assured Krauss, only as a breathing spell: "I want to be back in Germany." Krauss called on him again, from Leipzig, in the summer of 1949, offering him to try Humboldt University in Berlin for a year. " We must have you among us," he pleaded [157]. Auerbach, his reputation in the U.S. growing, accepted shortly after a position in Yale's French Department. The two would never see each other again.

Disappointed, perhaps even bitter, as Auerbach was at having to bid farewell to Europe, he did not project his bitterness towards Germany. He acknowledged no Jewish dimension to the tragedy that befell Europe, and, if he now recognized his own liminality in German culture, he never thought of it as ethnic in origin - his liberalism, he suggested, was implicated, or his own character. Mimesis" "survivors" note- "my surviving friends of past years"- was not a veiled allusion to the Jews: The friends after whose fate Auerbach inquired were for the most part non-Jews. He was critical of people counseling the émigrés, "especially Jews," not to return to Germany, of "prominent and otherwise quite sensible people who try to exercise a kind of moral pressure" [158]. He assured Bultmann that he neither held the Germans collectively responsible for the tragedy nor thought it right to single them out for blame [159]. Like other Europeans, Germans fell victim to the contradictions of modernity. Like the Jews, they were survivors, too.

Both Bultmann and Krauss served on Marburg's "planning committee," and both warned Auerbach of creeping renazification [160]. Frustrated with university reform's failure, Krauss left for Leipzig [161,162]. Auerbach, in contrast, was skeptical about university reform and defensive about charges of nazification in the German academy [163]. He showed sympathy for German efforts to return to normalcy: "Bourgeois orderliness is ... a human need," he told former student, Martin Hellweg. "After three decades of such horrible experiments ... the Germans can be nothing other than terribly tired and in need of rest" " 164 . The closest he came to implicating Germans in the Holocaust was in his letter to Klemperer, i.e., in internal Jewish assimilationist discourse: "It is strange for someone in my situation to find out increasingly that the Germans, except perhaps the Jews, are really the most efficient and, insofar as work is concerned, the most reliable people (Volk)," but, he added, "this in itself is quite insufficient. ..." [165]. Just as obliquely, he advised Germans to begin thinking globally again, but in a new fashion, with greater awareness of cultural difference and global needs [166]. What his innermost thoughts about the murder of the Jews were, we may never know. Like many of his generation, he said not a word about the Holocaust.

Auerbach's 1946 essay, "The Triumph of Evil in Pascal," provides, however, further hints about his view of culpability in the Holocaust. The Christian confronting evil political power was at the center. For Pascal (1623-1662), might was evil but it made right. Earthly laws were arbitrary but obedience to them was divinely sanctioned as punishment for corrupt human nature. Evil laws were just, and "one must obey unquestioningly ... without devotion, or rather from devotion to God" [167]. The Passion provided the model for suffering injustice, and liberation from it was only in the beyond. Resistance was only permitted as expression of God's will, and a good measure of its legitimacy was its hopelessness. Striving for victory was impermissible, as those seeking to suppress the resistance were also doing God's will.

Combining Augustinianism and raison d'êtat, Pascal's wretched earthly world was a far cry from Dante, and his hateful endorsement of murderous absolutism was a long way from realist 
social criticism. Yet, Auerbach found his ethical theory cogent and moving, and, ironically, a starting point for secular political criticism. Members of Auerbach's October 1949 Princeton seminar on Pascal sensed that they were hearing the quiet protest of a German Jewish émigré against totalitarianism. "Auerbach," said one, "had faced with his flesh and blood the reality of evil force; the extremity of Pascal's thought answered, for him, an extremity of experience. Pascal, too, had lived in a totalitarian state" [168]. True enough, but they were also hearing a vindication of good Germans (and Jews) who obeyed Hitler. Those, who offered hopeless resistance, were admirable but one could not incriminate even perpetrators who "obeyed unquestioningly, without regard for any possible benefit, but also without devotion." By the mid-1950s, Auerbach expressed his wish that Germans, and Europeans in general, rid themselves of the guilt complex, which obstructed their intellectual recovery [169].

Auerbach was never a decisive person, let alone a risk taker. He had to be forced to go to the U.S., without a promised job, in his mid-fifties, and start a fourth career. Departing from Istanbul in July 1947, the Auerbachs left behind "furniture and porcelain, ... the residues of our bourgeois past," material vestiges of Germany and Europe [170]. Emotionally and spiritually, however, they never left Europe. Auerbach held the typical German mandarin's prejudices against "America" and never rid himself of them. Western literature remained for him European literature, abendländische in the interwar sense, not westliche in the postwar trans-Atlantic sense. Mimesis made no mention of American authors. When Auerbach contemplated a new global literary public, the making of early medieval Europe provided the model, and contemporary Europe the focus [171]. He wrote in German to the end of his life, saw his major audience and interlocutors as European, repeatedly visited Europe, and, in response to German job offers, periodically reconsidered a return to the Heimat. Marie Auerbach never spoke English fluently and harked back to the blissful Marburg years [172]. The U.S. would never become the Auerbachs' cultural home.

The Auerbachs landed on the East Coast in September, "falling into [Erich's former colleague Leo] Spitzer's arms for the third time" [173]. Auerbach approached former Istanbul colleagues and German émigrés at Harvard, Johns Hopkins, and Princeton, in a desperate search for a job [174]. The U.S. was kind to him. At the Modern Language Association convention in December, he got a job for the spring of 1948 at Penn State College. The urbane German mandarin went for eighteen months to a state university, predominantly an engineering and natural science school, in the heart of rural America.

Writing German colleagues, Auerbach shared his impressions of rural America: from the standpoint of human relations-delightful, intellectually_below criticism [175,176]. The U.S. must be, he said, the world's happiest and easiest country to live in. Americans were sympathetic and ready to help, their optimism, naïveté, and trust in the future "strike a European who has experienced the last thirty years" as incredible. Daily interaction was relaxed, warm, and free of hierarchy, inhibition or complexity. But he found the intellectual level at Penn State unacceptably low, and he was pleased to have around a German émigré philologist with whom he could "speak European" [177]. He was aware that intellectual life was different at elite universities, but he projected from his state university to American culture. Moving to Yale in 1950 would not change his view. He had at Yale a superior library, and colleagues and graduate students the like of whom he had not known since Marburg. He appreciated them but he was still dismayed by the informal 
relations between undergraduates and professors and reflected unfavorably on academic sports culture. America embodied rampant modernization, the standardization and leveling process threatening European and global culture with dreary uniformity.

Auerbach's U.S. reflections reinforced his apprehensions about proposed university reforms in Germany. He was critical of American involvement and warned his friends that the U.S. academy could provide no model for Germany. The German system was, on the whole, "incomparably better," and U.S. style democratization would lower the intellectual level. He acknowledged that, "after all that happened," German universities may require change, but it should be grounded in German conceptions [178]. Mimesis probed the limits of Bildung and humanist ideals and offered an egalitarian Christian vision as an alternative. Now that humanist education faced a serious democratic challenge, Auerbach recoiled. Contemporary critics view the anxiety he expressed about the loss of diversity (Mannigfaltigkeit) in "Philology and Weltliteratur" (1952) as an appeal for cultural pluralism, or, in contemporary parlance, multiculturalism [179]. They are not wrong, but Auerbach's pluralism was a product of German mandarin discourse and reflected ambivalence about modernity and democracy, cultural pessimism (Kulturpessimismus), and anti-Americanism [180].

Auerbach remained a captive of the Bildung discourse he criticized, and this raises questions about his progressivism and cosmopolitanism. His intellectual profile defies a sharp outline. As a young man in Weimar - a George admirer and a German patriot - he was fairly conservative, but he also kept the company of Marxists, like Benjamin and Bloch. He deployed historicist categories as national spirit but they were attenuated by contextual analysis - historical, even sociological. His disposition towards the nation was ambivalent: He liked it in its premodern phase, thought well enough of nineteenth-century democratic nationalism, but regarded ethnic and populist nationalism as destructive of the nation. He trusted German state officials and adhered to bureaucratic procedure ad absurdum (submitting, in early 1941 from Istanbul, a request to extend his permission to reside abroad), but his ideal state was always part of a cosmopolitan Europe of nations.

The colleagues Auerbach kept were, for the most part, the more liberal mandarins, like Bultmann and Vossler. Among the humanists, his response to Nazism was distinct for affirming a democratic vision of Christianity. He welcomed "the inner history of the last thousand years [as] the history of mankind achieving self-expression" but he also thought it ended in stultifying uniformity and leveling. A product of Protestant academic culture, his affinities were with Catholic cosmopolitanism. The epitome of upper-bourgeois Jewish urbanity, he was an advocate of Christian sermo humilis, critical of Castiglione and Montaigne for cultivating a courtly style. His class prejudice came out most in contempt for American culture and fellow Jews (and, in both cases, prejudice reflected also his resentment of their accomplishments). "Son of a Viennese Jew and an opera singer," he said of Spitzer, a colleague to whom he owed his life, "he is full of activity and tactlessness, and has very lively ideas but not even a shadow of culture and true critical spirit" [181,182]. So much for Christian clemency for Jews lacking proper composure, and yet clemency and humility remained Auerbach's cherished ideals.

Auerbach's students suggest how unconventional a mandarin he was. He was surrounded by dissenters (partly, no doubt, because he was Jewish). Hollweg and Krauss were Marxist socialists and were let off by the Nazis. Other students could not make a career in Nazi or postwar Germany. Krauss joined the Rote Kapelle (Red Orchestra) resistance group in Berlin, was arrested in 
November 1942, sentenced to death in January 1943, and saved only through the intervention of the Marburg faculty, which had his sentence commuted to a prison term by declaring him psychologically deranged. In the postwar years, both Helwegg and Krauss were involved in programs for the democratic re-education of Germans. Krauss helped lay the foundations of East Germany's academic culture by developing Marxist literary studies and drafting Bloch and Klemperer. Auerbach helped Krauss get the Bloch appointment through but refused to join, repeatedly making his liberal stance explicit [183]. He admired Krauss for acting on his convictions but also feared what awaited him in the Soviet Zone.

Auerbach's anticommunism never translated into Cold War politics. He was equally apprehensive about capitalist and communist modernization and resentful of what he regarded as a bipolar world squashing European diversity. More conservative intellectuals were content to use U.S. military power against communism while inveighing against the Americanization of European culture but Auerbach declined political engagement in the postwar years just as he had done in interwar Germany. If he did not advocate resistance to Nazism, he would not second anti-Soviet mobilization. Against totalitarianism, he consistently turned to Christian martyrology, first to Christ himself, then, in the postwar years, to St. Perpetua, whose triumphal vision was to Auerbach a source of consolation and unbound admiration [184]. Auerbach was by no means a conventional cultural critic but it was to disabuse intellectuals like him of their antiamerican prejudices and coax them towards a warmer acceptance of modernity and an unwavering commitment to Western liberal democracy, that the Cold War liberals established The Congress for Cultural Freedom [185]. Postwar trans-Atlantic liberalism represented hopeful cosmopolitanism, not Auerbach's pessimistic Christian humanism.

"European civilization is approaching the term of its existence," wrote Auerbach in his last, posthumously published book. "[A]lready it is beginning to be engulfed in another, more comprehensive unity" [186]. He was unable to describe the emergent "unity" but he was not looking forward to it. Already in the 1930s, he found behind fascism and nationalism-German, Italian and Turkish - "a ruse of providence, designed to lead us along a bloody and tortuous path to an International of triviality and a culture of Esperanto" [187,188]. Technologies of modernization and nationalization undermined European pluralism. The European nation, and its state, Germany in particular, could not be saved. One had now to turn from nation to humanity, and think globally. But how was global culture possible when uniformity and leveling made humanistic education ever more problematic? Goethe's cosmopolitanism, the search for Weltliteratur, did not turn out as expected. Globalization served as an opening not to Weltliteratur, but to morbid uniformity and a "European crisis."

What could the humanist philologist do to address the European crisis? Unable to outline a new cosmopolitanism, Auerbach sought instead "to form a lucid and coherent picture of [European] civilization" and its legacy. He looked backward to the making of Europe to learn how the decline of the West (Abendland) may be not averted but weathered. Ironically, he was perusing the history he was living - in reverse, looking at the dissolution of imperial Rome and Europe's formation, while living Europe's' dissolution and the reformation of a universal culture. Still, the cultural transmission from late antiquity to the middle ages was to yield the essence of the European legacy.

Empire was never Auerbach's ideal: He loved the late Roman Empire about as much as 
Augustine had. He described imperial Roman culture as living on borrowed time. Having undermined the ancient city-states' civic cultures, the Empire was incapable of cultural innovation, and became lifeless, its aristocratic literary public progressively diminishing. Empire meant stagnation. In contrast, Auerbach loved the plurality of medieval Europe, the authenticity, however primitive, of the new peoples' cultures, and the interplay between national life and " $a$ European society," between "vulgar" culture and "a European ... Hochsprache (language of high culture)" [189]. The medieval moment metamorphosized later, it seems, in the Viconian world of nations, extending into the nineteenth-century, in Europe prior to the triumph of ethnonationalism. These were the high points of European culture, moments long gone, which Auerbach was trying to recapture as the European essence.

The flowering of European culture, Auerbach decided, was dependent on Christian reworking of the classical heritage. As the literary public, always a narrow elite, was progressively diminishing in late antiquity, Christianity became, against its will, the custodian of classical culture. Through sermo humilis, Christianity made the sublime "accessible to all, descending to all men in loving-kindness ... at one with the entire Christian congregation" [190]. Here was a model of cultural transmission appropriate for a democratic global age-Christianity helping shape a new universal culture.

What unites [European nations] is their common root in antiquity and Christianity. For this combination contains the dialectical force which - even if Europe, like Rome before it, should now lose its power and even cease to exist as such — has prefigured the forms of a common social and cultural life on our planet [191].

Christianity tied together the divergent metamorphoses of Auerbach's cosmopolitanism, from the Weimar Dante, a German European cosmopolitan, to Mimesis' wartime pan-European modernist public, to the hopeless globalism of postwar years. But the variety of Auerbach's cosmopolitanism was also grounded in the German nation. He was unable to imagine, as Austrian intellectuals did, a vital imperial culture. Hofmannsthal, Popper, Joseph Roth, Friedrich Torberg and Werfel had each to negotiate between imperial and national identities, and their cosmopolitanism reflected negotiation's results. Auerbach's cosmopolitan public remained ephemeral, and the new global culture an intangible nightmare, because he could never see beyond the Europe of nations. Once the German nation was gone, he faced the void.

The Europe of nations first emancipated the Jews, then, at its moment of collapse, murdered them. As if acknowledging the fait accompli, Auerbach's classical-Christian literary public had, in his last book, no place for the Jews. They vanished from Europe, losing even the role they had had in Mimesis, as makers of European civilization. Their disappearance reshaped Auerbach's cosmopolitanism. The German cosmopolitan who had begun his way hopefully with Dante and Christian engagement in the earthly world, and went into exile with Dante, bemoaning having to eat foreign bread and imagining a cosmopolitan literary public, ended up in despair with Pascal's hatred of the world and Hugh of St. Victor's espousal of permanent exile as the ground of cosmopolitanism. "The man who finds his homeland (patria; Heimat) sweet is still a tender beginner; he to whom every soil is as his homeland is already strong; but he is perfect to whom the 
entire world is a foreign land (exsilium)" [192,193]. Auerbach finally brought his cosmopolitanism in conformity with Jewish exile -through Christian sources and with no hope for the future.

\section{German Jewish Cosmopolitanism Triumphant: Auerbach in Contemporary Europe}

The despair and alienation characterizing Auerbach's postwar writings contrasted remarkably with their spectacular success. In the spring of 1949, just as Auerbach found out that his heart condition would make it impossible for him to continue at Penn State (he lost his university health insurance), he received an invitation to the Institute of Advanced Studies at Princeton for 1949-1950. Princeton literary critic and Dante scholar, Francis Fergusson, who had met Auerbach in Vermont late in 1947, urged the Institute Director, Robert Oppenheimer, to invite the still unknown visitor, so as to facilitate the launching of a (soon to become famous) literary seminar. The émigrés' network, above all Princeton's art historian, Erwin Panofsky, joined in lending their support. Fergusson and most U.S. critics read no German, so Auerbach's reputation was initially based on émigré reports and personal encounters. But not for long: As different Mimesis essays began showing up in 1950 in U.S. literary journals, the enchantment was immediate. The sophisticated, beautifully crafted essays were a pleasure to read. Scholarly encounters with the quietly erudite Auerbach left the impression of a rare exemplar of old world urbanity. "All around you hear nothing but Mimesis," complained a jealous Curtius, visiting Princeton in 1949 [194].

In the spring of 1950, Auerbach received a "very good offer" from Yale. Yale would become the final station in his tumultuous life: "The good traveler arrived at his destination and rested" $[195,196]$. He and Marie received U.S. citizenship, a security they had not known since the Nuremberg Laws [197]. A Marburg chair offer arrived, all too late, in March 1953, to find the Auerbachs staying in the U.S., not altogether happily but with pride that they no longer depended on the Heimat that had cast them out. In 1956, Auerbach became the first Sterling Professor of Romance Languages at Yale. The fall after, he died, just short of his sixty-fifth birthday.

Already in the last years of his life, Auerbach was becoming a mythical figure in the U.S., the model of the émigré scholar, survivor of a superior culture, who was propelling the American academy to new heights. Henri Peyre, a leading French Studies scholar and the chair of Auerbach's department at Yale, testified to the emerging legend: "Jew by birth (Israélite de naissance), agnostic by formation and cast of mind, painter of Greco-Roman culture and reader of the Church Fathers and Dante, [Auerbach] seemed to us to embody the precious qualities of the European humanist of the time of Lessing, Herder and Goethe" [198]. Mimesis appealed to wide and diverse audiences. Selected essays were first published in the New Critics' literary magazines. Auerbach's German historical philology challenged the New Critics' formalism, yet his agile stylistic analysis appealed to them. Reviews of Mimesis were admiring: "hailed as 'the most important and brilliant ... literary history that had been published in the last fifty years'," wrote René Wellek [199-201]. Wellek himself remained critical, and Auerbach's reviews of American works on Dante were a rejoinder and created an exemplary dialogue between divergent interpretive traditions. Mimesis also contributed to the emergent comparative literature field, and was popular among medievalists. No consensus has ever emerged on its arguments but there was no denial of Auerbach's achievement [202-204]. 
New York intellectuals, Alfred Kazin and Delmore Schwartz, wrote the first two blurbs appearing on the cover of Mimesis' paperback edition [205-207]. This was no coincidence. The post-Marxist Jewish intelligentsia sought integration into the Western literary tradition via high modernism. Mimesis provided a blueprint. Historian David Hollinger has shown how a secular cosmopolitan worldview, emphasizing scientific universalism, served the Jewish entry into the U.S. academy in the postwar years [208]. The Congress for Cultural Freedom, representing a collaboration of European remigrés and New York intellectuals, made this worldview central to an emergent liberal trans-Atlantic culture. The secular Jews usually left it to their non-Jewish colleagues to think through the possibilities of Christian cosmopolitanism for a religiously tolerant Europe. But in Auerbach they found a Christianity-inspired Jew who provided an unmatched narrative for Jewish integration into a secularized Christian West. To be sure, Auerbach left no room for ethnic Jewish consciousness, but the majority of U.S. Jewish intellectuals sought no such in the postwar years. They taught college students with relish the grand narrative of Western civilization, from Homer and the Bible via the medieval Christian West to the scientific revolution and the Enlightenment to twentieth-century modernism. Auerbach provided the ultimate vindication for the postwar Jewish secular liberal cosmopolitan worldview.

Mimesis had appeared in German in the fall of 1946, seven years earlier than the U.S. edition. European responses came a bit slower and were more muted. Germans were more familiar with Mimesis' distinctive blend of historical philology, stylistic analysis and modernism, which had been introduced by the interwar generation of humanist philologists. Europe also had no equivalent to the U.S. progressive Jewish intelligentsia to turn Auerbach's abendländische narrative into a liberal westliche one, no comparable secular Cold War liberalism. Still, numerous positive reviews established Auerbach securely as a leading German philologist. The polemics with Curtius over the history of Stiltrennung, which elicited Auerbach's reaffirmation of Mimesis'-and his ownGerman identity, highlighted Auerbach's prominence [209,210]. The 1953 Marburg chair offer reflected Auerbach's new status.

By the late 1960s, however, the Western civilization narrative of the Cold War years came under siege. The U.S. Jewish intelligentsia was exploring its ethnoreligious identity, the 68ers on both sides of the Atlantic challenged the Western narrative on grounds of class, gender and race and highlighted its imperialist implications, and the German 68ers, in particular, attacked the interwar philological humanists as anticommunists and fascists. Auerbach never drew as much fire as Curtius, but the critique spilled over to him, too [211]. The liberal grand narrative had not quite emerged from under the 68ers' attack when the poststructuralists demolished whatever remained of it. Mimesis seemed to have lost its luster, and Auerbach was in danger of becoming obsolete.

Just at this moment, help came from the least expected quarter-from Edward Said and postcolonial studies. Said was not known for forgiveness toward Eurocenteric Western narratives but Auerbach was an exception. From early on in his career, when he and Maire Said translated "Philology and Weltliteratur" (1969) to his 1983 essay collection, The World, the Text, and the Critic to one of his last essays - an introduction to a new edition of Mimesis - Said was engaged with Auerbach [212,213]. Their parallel use of Vico as an Ansatzpunkt (starting-point) for their work may have first triggered Said's interest but his emotional attachment to Auerbach was due most to a feeling of shared liminality as cosmopolitan intellectuals in exile. Both Said and 
Auerbach shared secularized Christian inspiration and humanist training, and yet, living on the East-West boundary, were liminal to the traditions forming them. Said captured better than anyone Auerbach's peculiar position as “a non-Christian explaining Christianity's achievement [and] in so doing, travel[ing] from his roots still further" [214].

To be sure, as representatives of their respective "minority cultures," Auerbach and Said displayed opposite attitudes [215]. Auerbach assumed distance toward his Jewishness and sought nothing more than integration in the Western mainstream. When Martin Buber requested, in 1956, that Auerbach write an introduction to the Hebrew edition of Mimesis, Auerbach declined, mentioning that he had refused a similar Italian request and was unfamiliar with Israel [216]. He made it clear he had no special relationship to Modern Hebrew culture. In contrast, Said imaginatively espoused Palestine and the Arab world, and sought to vindicate them against the West. But Said recognized that he, too, "travelled further from his roots," and, precisely because Auerbach's Jewishness was non-threatening, exile's affinities could count the most. Said was kind to Auerbach. Where I see Auerbach lamenting, as a German mandarin, modernization and Bildung's decline, Said saw him protesting nationalist uniformity, presaging the rise of other civilizations, and rescuing sense and meaning from fragments of modernity, from exile, by reconstructing an alternative European history from the margins [217]. Auerbach became a postcolonial prophet.

The last two decades have witnessed explosion of global interest in Auerbach. The search for useable concepts of global culture and transnational European history found in the Jewish German émigré, skirting the cultural and geographic boundaries of three continents, a unique cosmopolitan potential. East-German scholars may have led the way with publication, in the late 1980s, of Auerbach's correspondence with Benjamin and Krauss [218,219]. Since then, Auerbach's centenary, the fiftieth anniversary of his death, and Mimesis' fiftieth anniversary have been celebrated with major conferences and publications. Auerbach's sparse archives and surviving correspondence have been painstakingly collected and studied in detail ${ }^{[} 220^{]}$. Literary and historical studies of every aspect of his biography, work, and global reception have continuously appeared, and the stream is growing. In Great Books courses, "Odysseus' Scar" and "Farinata and Calvacante" are read in conjunction with Homer and Dante. No German Jewish émigré, other than Arendt and Benjamin, has attracted similar attention in recent decades. Auerbach has become a European and global intellectual par-excellence.

\section{Conclusions}

It is not difficult to see Auerbach's attraction for contemporary Europeans. Mimesis constructed a cosmopolitan literary public and a pan-European space, inclusive of Jews, and, due to its Istanbul production site-“a non-European, albeit Europeanizing space"-gesturing toward the East and Muslim inclusion [221]. The cosmopolitan culture (weltliche Kultur) into which Auerbach, the exile, performing as a modernist writer versed in Europe's traditions, wished to be integrated is the world Europeans would like to see themselves creating today [222]. Mimesis seems to allude to the Holocaust, but recollects cherished literary moments, highlights Europe's Christian past but seems to open it up universally. Auerbach projects Europe as it could have been, if only National Socialism had not triumphed: cosmopolitan and multicultural, accepting of Jews and Muslims (on 
condition they became secular Christians). The German Jewish émigré wrote a cultural history Europeans love, offering an overcoming of Europe's past (Vergangenheitbewältigung), in which all wish to take part.

Auerbach made no demands as a Jew. He negotiated his way into European culture via Dante. He confronted Europe and the Holocaust with Christian martyrology — with Christ on the cross, St. Perpetua, St. Augustine, St. Bernard and Pascal — not with the Akeda, Amalek or Jacob. The dark past of Jewish-Christian relations was not part of his history. His humanism articulated a society living on Christian heritage, open to non-believers who were willing, like him, to become part of the heritage. Burckhardt had created the figure of Dante as a cosmopolitan exile, and Auerbach inhabited it. The German Jewish émigré became the great mediator of European culture, the best of Europeans, a culturally Christian Jew, and the better for it.

The traditional Jewish historian cannot but feel irate about Auerbach becoming for contemporaries the paradigmatic European Jew. His life and work show Jewish assimilation at the limits of its success. His friends and associates were mostly non-Jewish, tied by genuine solidarity, friendship and love, and a shared German European culture. Most of them opposed the Nazis, and some risked their lives resisting. They do give a measure of what Germany could have been like if the disastrous turn nationalism had taken in the 1880s had not culminated with National Socialism. But they also show the limits of the Jewish life assimilation permitted, and suggest that we resist both the cultural history Auerbach offers and histories of the European Jewish intelligentsia that make him the paradigmatic German Jewish intellectual.

To be sure, the Jewish European histories foregrounding Auerbach, and the definition of Europeanness they form, are amongst the most benevolent that Jews have been offered in over two millennia. Jewish life will continue, perhaps even thrive, in Auerbach's Europe, even if traditional Jews are relegated to the margins. But contemporary Europe, where progressive Germans ease even Gershom Scholem's way back into German culture, and where appreciation of Jewish ethnicity and acceptance of Jewish difference are not uncommon, can do better. There must be other ways of writing Jewish European history.

An alternative Jewish European history cannot return to nationalist narrative. Auerbach belongs in it: a Jewish intellectual working European, specifically Christian, materials, to express universal ideals, responding to his situation as a German acculturated Jew, and, at the same time, as a secular Christian and German intellectual. Primo Levi recounts the elevation he experienced in Auschwitz when reciting the Ulysses Canto from Dante's Inferno - "you were made men, to follow after knowledge and excellence"-while walking to a paltry lunch [223]. Lodz (Litzmannstadt) Ghetto diaries describe the elevation experienced at the Jewish Orchestra's performance of German composers - the Jews seen in photos wearing the yellow star armbands [224]. Spitzer, who rebuked Auerbach for lack of ethnic solidarity, confessed in his April 1933 letter to Löwith: "I have recently heard the Passion of St. Matthew, its meaning is very timely when describing the loneliness of the persecuted" [225]. No one can deny the authenticity of these experiences or suggest that Dante, Beethoven and Bach - and even St. Matthew and the Passion-did not become part of Jewish European culture. But they cannot stand alone as signifiers for the European Jew and European Jewish culture. Their Europeanness entailed a loss of traditional Jewish culture, which must remain part of European history. 
Visiting his Habilitationsvater in Cologne shortly after he had been appointed in Marburg, Auerbach wrote in Spitzer's guestbook: "Our subject is ... that Rome whence Christ is Roman," echoing Purgatorio XXXII: 102: "Quella Roma onde Cristo e romano" [226,227]. The Jewish historian, aware of Christian Rome's significance in Jewish history, can barely restrain himself from responding to Auerbach with Christian Rome's own wrathful cry at the Muslim reconquest of Jerusalem from the Crusaders: "Deus venerunt gentes" (Psalm 79:1) — "O God, the nations have invaded your inheritance." Instead, and more productively, the historian may confront Auerbach and Spitzer with an alternative Jewish European history, one focusing on the Jewish struggle against Rome, and highlighting the Europeanness of traditional Jewish culture.

\section{Acknowledgments}

This is a chapter in my book, now near completion, Jacob \& Esau Between Nation and Empire: A Jewish European History. I benefitted from criticism at the Triangle Intellectual History Seminar (Duke-UNC-NCSU-Wake-Forest) and the Johns Hopkins History Seminar, as well as from comments by Adi Gordon (Cincinnati) and three anonymous Religions reviewers. My debts to Auerbach scholars, particularly Matthias Bormuth and Martin Vialon, are indicated in the notes.

\section{References and Notes}

1. Erich Auerbach. Mimesis: Dargestelte Wirklichkeit in der abendländischen Literatur. Bern: A. Franke, 1946. 2nd ed. 1959.

2. Erich Auerbach. Mimesis: The Representation of Reality in Western Literature, translated by Willard R. Trask. Princeton, NJ: Princeton University Press, 1953. References to Mimesis henceforth are jointly to the English and second German edition.

3. 23 September 1949: "Ihre Art, es historisch abzuhandeln und diese immer verbleibende künstlerische Haltung durch die Jahrhunderte zu verfolgen, hat etwas durchaus pädagogisches." Photo and reprint: Süddeutsche Zeitung (27-28 May 2006): 16, with a discussion by Martin Vialon, "Passion und Prophetie. Eine Entdeckung: Thomas Manns Dankesbrief an Erich Auerbach für das Buch 'Mimesis'."

4. American Jews and Protestants, who wished to repel late 1930s antisemitic populism and urged U.S. anti-Nazi intervention in Europe, were the first to use "Judeo-Christian" to describe a shared Western legacy. (Mark Silk. "Notes on the Judeo-Christian Tradition in America." The American Quarterly 36:1 [1984]: 65-85.) The term became common in Europe only in the postwar years. It appears neither in the Nazi attacks on humanism's shared Jewish-Christian origins nor in interwar religious and secular affirmations of Europe's Jewish-Christian origins. Auerbach may have been among the first to use it.

5. In Mimesis, "Judaeo-Christian" (jüdisch-christlich) expands from early Jewish-Christian culture (Mimesis. pp. 72, 320 [English]; pp. 73-74, 305 [German]) to a European Western mode of representing reality (pp. 119, 201 [English]; pp. 116, 192 [German]). (Thanks to Avihu Zakai of the Hebrew University for the English references.) 
6. Martin Vialon. "The Scars of Exile: Paralipomena concerning the Relationship between History, Literature and Politics - Demonstrated in the Examples of Erich Auerbach, Traugott Fuchs and Their Circle in Istanbul." Yeditepe'de felsefe 2 (2003): 198.

7. The Heidelberg information is based on a letter from Marie Auerbach to Traugott Fuchs, 11 April 1973. Martin Vialon. Erich Auerbachs Briefe an Martin Hellweg (1939-1950): Edition und historisch-philologischer Kommentar. Tübingen: Francke, 1997, pp. 82-83, n. 7. It is not altogether clear when Jaspers and Auerbach met and, if and when Jaspers read Auerbach's work. But in 1929, Jaspers and Friedrich Gundolf (1880-1931), a leading member of the Stefan George Circle, unsuccessfully pushed to appoint Auerbach in Heidelberg.

8. "The novella is situated in the midst of time and place; it is a piece of history... It must be realistic in as much as it takes for granted empirical reality ... [Its] Ethos must be not metaphysical but grounded in the laws of social community": Erich Auerbach, Zur Technik der Frührenaissancenovelle in Italien und Frankreich. Heidelberg: C. Winter, 1921, 1.

9. Erich Auerbach. "Zur Dante-Feier." Neue Rundschau 23 (1921): 1005-6. This short article commemorated the six-hundredth anniversary of Dante's death.

10. Erich Auerbach. "Stefan Georges Danteübertragung." Cultura Italiana e Tedesca 2:1 (1924): 17-20 was a laudation for George's rendering of (parts of) The Divine Comedy.

11. Both notes 9 and 10 are reprinted in: Erich Auerbach: Geschichte und Aktualität eines europäischen Philologen, edited by Martin Treml, and Karlheinz Barck. Berlin: Kulturverlag Kadmos, 2007, 407-13.

12. "Ich bin Prüßn, jüdischer Konfession": Karlheinz Barck. "Erich Auerbach in Berlin. Spurensicherung und ein Porträt.” In Erich Auerbach, edited by Treml and Barck, 197 (photo of original bio holograph).

13. Earl Jeffrey Richards. "Erich Auerbach's Mimesis as a Meditation on the Shoah." German politics and Society 19:59 (Summer 2001): 64.

14. Clemens Auerbach. "Summer 1937." In Erich Auerbach, edited by Treml and Barck, 497. Yet, somehow, Clemens must have retained, or acquired, a dim awareness of things Jewish. He noted that his parents arrived in the U.S. "on September 23, 1947, which happened to be Erev Yom Kippur!” Martin Vialon, Erich Auerbachs Briefe, p. 95, n. 1.

15. A referee argued that as "Auerbach self-identified as a Jew from start to finish," my reading of him as a cultural Christian "goes against [his] own declarations." But Auerbach acknowledged his Jewishness as a matter of fact rather than a commitment. He occasionally qualified his Jewishness by German and Christian affinities (p. 12 n. 86 below), and cared and spoke about the latter a great deal more. To Auerbach, descent marked German Jews from non-Jews but he offered no insight as to what the community of fate might mean to him. The closest he got was the startling statement (p. 14 n. 105 below) on the "uncanny existence" of postbilical Jews in the aftermath of their rejection of Christianity. His terms were Christian and theological. He also eliminated postbilical Jews from his narratives. To "Judaize" Auerbach, scholars override extensive textual and historical resistance and invent terms of Jewish affinity unavailable to him.

16. Ernst Troeltsch. The Social Teaching of the Christian Churches, translated by Olive Wyon. Chicago: University of Chicago Press, 1976, 2 vols. 
17. Matthias Bormuth. "Menschenkunde zwischen Meistern-Auerbach und Löwith." In Erich Auerbach, edited by Treml and Barck, pp. 85-87 tracks Harnack's influence on Auerbach, especially on his view of Augustine.

18. "Über das Persönliche in der Wirkung des hl. Franz von Assisi." In Gesammelte Aufsätze. 1927, pp. 33-42.

19. Max Weber. "Science as a Vocation." In The Vocation Lectures, edited by David S. Owen, and Tracy B. Strong, translated by Rodney Livingstone. Indianapolis, IN: Hackett, 2004, pp. 29-30.

20. Ernst Troeltsch. Der Historismus und seine Probleme [1922], edited by Friedrich Wilhelm Graf, and Matthias Schlossberger. Berlin: Walter de Gruyter, 2008, 2 vols. esp. the editor's account of Troeltsch's seminar and the Auerbach-Troeltsch relationship on I: 26-30, 46, 283-284.

21. Historismus und seine Überwindung [1924] (trans. as: Christian Thought, Its History and Application [1923]), German and English, edited by Gangolf Hübinger, and Andreas Terwey. Berlin: Walter de Gruyter, 2006.

22. "Scholarship in Times of Extremes: Letters of Erich Auerbach (1933-46), on the Fiftieth Anniversary of His Death.” introd. \& trans. by Martin Elsky, Martin Vialon, and Robert Stein. Proceedings of the Modern Language Association (henceforth PMLA). Auerbach to Traugott Fuchs, 22 October 1938, 122:3 (2007): 752, 755, respectively.

23. Der Untergang des Abendlandes: Umrisse einer Morphologie der Weltgeschichte [19181923]. 2 vols. Munich: C. H. Beck'sche Verlagsbuchhandlung, 1927.

24. Die neue Wissenschaft über die gemeinschaftliche Natur der Völker [Principi di una scienza nuova, 3rd ed., 1744], translated by Erich Auerbach. Munich: Allgemeine Verlagsanstalt, 1924.

25. Erich Auerbach. New Science: Principles of the New Science Concerning the Common Nature of Nations, translated by David Marsh. London: Penguin, 1999. In his editor's introduction (p. 39), Auerbach acknowledged Troeltsch's inspiration.

26. "Introduction: Intentions and Method." In Literary Language and Its Public in Late Latin Antiquity and in the Middle Ages (1958), translated by Ralph Manheim. Princeton, NJ: Princeton University Press, 1993, p. 7.

27. Erich Auerbach. "Vico und Herder." Deutsche Vierteljahrsschrift für Literaturwissenschaft und Geistesgeschichte 10:4 (1932): 671-686.

28. Erich Auerbach. "Heidegger ist ein furchtbarer Kerl, aber er hat wenigstens Substanz": Auerbach to Martin Hellweg, 16 May 1947. In Martin Vialon. Erich Auerbachs Briefe. p. 84, n. 8.

29. "Was für ein grossartiger Mann! Aber ich bin doch froh, dass ich ihm nicht in die Hände gefallen bin, als ich jung war": Auerbach to Karl Löwith, 26 May 1953, quoted in Matthias Bormuth, "Menschenkunde zwischen Meistern-Auerbach und Löwith." In Erich Auerbach, edited by Treml and Barck, p. 85, n. 12 .

30. Hans-Ulrich Gumbrecht. "Everyday-World and Life-World as Philosophical Concepts: A Genealogical Approach.” New Literary History 24:4 (1993), esp. 753-56. 
31. Gumbrecht's “Pathos of Earthly Progress': Erich Auerbach's Everydays." In Literary History and the Challenge of Philology: The Legacy of Erich Auerbach, edited by Seth Lerer. Stanford, CA: Stanford University Press, 1996, pp. 13-35, is also helpful in understanding Auerbach in the 1920s.

32. Auerbach may have well found the alltäglich (everyday) in German translations and literary criticism of Horace's doctrine of styles in Ars Poetica, which designated everyday language as appropriate for comedy or satire but not for tragedy. A German translation for high schools (Program des Karl-Gymnasium in Stuttgart zum Schlusse des Schuljahrs 1887-88) http://books.google.com/books?id=zSzgAAAAMAAJ\&pg=PA11\&lpg=PA11\&dq=alltaglich $\mathrm{e}+$ ars + poetica + horace $\&$ source $=$ bl\&ots=ePQABrIRLF\&sig=Pwp3xYRh7W9fPNEgBrmDR3 OLf0c\&hl=en\&ei=gee6TLPLDYKglAf_vKGZAg\&sa=X\&oi=book_result\&ct=result\&resnu $\mathrm{m}=6 \& \mathrm{ved}=0 \mathrm{CCcQ6AEwBQ} \# \mathrm{v}=$ onepage $\& \mathrm{q} \& \mathrm{f}=$ false $\quad($ accessed $\quad$ on 17 October 2010) translates line 90 of Ars Poetica, "indignatur item privates ac prope socco," as "ebensowenig als je die gemeinalltägliche Sprache," and line 235, "non ego inornata et dominantia nomina solum," as "immer nur schmockloss schlichte, alltägliche Worte zu wählen." But the "everyday" became significant for Auerbach because of Alltäglichkeit's resonance in Weimar discourse.

33. "Racine und die Leidenschaften." 1926.

34. And "Marcel Proust: Der Roman von der verlorenen Zeit." 1927. In Gesammelte Aufsätze zur romanischen Philologie, edited by Fritz Schalk. Bern: Francke, 1967, pp. 196-203, 296-300, respectively.

35. 29 January 1933, PMLA 122:3 (2007): 745.

36. Dante als Poet der irdischen Welt. Berlin: Walter de Gruyter, 1929; trans. Ralph Manheim. New York: New York Review of Books, 2007. Auerbach advisedly used the term irdisch, meaning earthly, or worldly, and not secular. Ironically, Dante's earthliness was the fountain of secularization, but neither Dante's nor, arguably, Auerbach's worldliness was secular. The English title, rendering irdisch as "secular," could be misleading.

37. Edward Said noted it: "[T] he crucial word irdischen, or 'earthly,' was only partially rendered by the considerably less concrete "secular"': "Erich Auerbach, Critic of the Earthly World." Boundary 2, 31:2 (2004): 13.

38. The term "realism" is scarcely used in Dante. In the introduction, Auerbach notes the term's vagueness, and moves on to speak of the mimetic problem. But rudiments of "everyday tragic realism" are already in Dante.

39. Auerbach, Dante (English edition), p. 8.

40. Ibid, p. 90.

41. Ibid, pp. 13-14.

42. Erich Auerbach. "Der Schriftsteller Montaigne.” In Gesammelte Aufsätze zur romanischen Philologie. 1932, pp. 184-195

43. Matthias Bormuth. "Menschenkunde zwischen Meistern-Auerbach und Löwith." In Erich Auerbach, pp. 99-101.

44. Deutscher Geist in Gefahr. Stuttgart: Deutsche verlags-anstalt, 1932.

45. Curtius to André Gide 12 July 1921: “einer kosmopolitischen (nicht internationalistischen) europäischen Gesinnung auf dem Fundament eines unbefangenen und unverzerrten 
nationalen (nicht nationalistischen) Gefühls." Quoted in Guido Müller. Europäische Gesellschaftsbeziehungen nach dem Ersten Weltkrie: Das Deutsch-Französische Studienkomitee und der Europäische Kulturbund. Munich: R. Oldenbourg, 2005, p. 68, n. 121.

46. "Die geistige Bewegung in Deutschland und der französische Geist." Westdeutsche Wochenschrift. 31 October 1919, as quoted in Guido Müller. Europäische Gesellschaftsbeziehungen. 102.

47. Ernst Robert Curtius. Deutscher Geist in Gefahr. 85. Curtius spoke of secular Jews as abgefallene Juden, literally, "apostates," or better, "heterodox Jews."

48. For Curtius in Weimar, see: Hans Manfred Bock, Kulturelle Wegbereiter politischer Konfliktlösung. Tübingen: Gunter Narr Verlag, 2005, p. 61ff.

49. Erich Auerbach. "Die Entdeckung Dantes in der Romantik." In Gesammelte Aufsätze zur romanischen Philologie. 1930, pp. 176-183.

50. "Romantik und Realismus." In: Erich Auerbach, edited by Treml and Barck. 1930, pp. 426-438.

51. Das französische Publikum des 17. Jahrhunderts, Münchener romanistische Arbeiten, III. München: Hueber, 1933; "La Cour et la Ville" (1951). In Scenes from the Drama of European Literature, translated by Ralph Manheim, Minneapolis: University of Minnesota, 1984, pp. 133-179.

52. Bernard Groethuysen. Origines de l'esprit bourgeois en France: 1, L' Eglise et la bourgeoisie (1927). Paris: Gallimard, 1977.

53. Norbert Elias. Die höfische Gesellschaft: Untersuchungen zur Soziologie des Königtums und der höfischen Aristokratie (1933). Neuwied: Luchterhand, 1969. Groethuysen and Elias' fame arrived even later than Auerbach's.

54. “Über die ernste Nachahmung des Alltäglichen" (1937). In Erich Auerbach, edited by Treml and Barck. pp. 437-465.

55. Auerbach to Benjamin. 3 January 1937. In Karlheinz Barck, and Anthony Reynolds. "Walter Benjamin and Erich Auerbach: Fragments of a Correspondence." Diacritic 22:3/4 (1992): 81-83.

56. "Etwas von dem, was dieser Junge will, ist richtig. Man muss ihm den Wind aus den Segeln nehmen, indem man es besser und anderes macht": 19 May 1936. In "Erich Auerbach: Briefe an Paul Binswanger und Fritz Schalk." Romanistiches Jahrbuch 59 (2009): 178. Auerbach wrote from Geneva and was already bound for Istanbul.

57. Spitzer to Karl Löwith, 21 April 1933. Karl Löwith papers, Deutsches Literaturarchiv, Marbach, as quoted in: Matthias Bormuth. "Menschenkunde zwischen Meistern-Auerbach und Löwith.” p. 98.

58. Berlin: Aufbau-Verlag, 1995, 2 vols.

59. Martin Vialon. "Wie haben Sie es geschafft, in Deutschland zu überleben? Zum fünfzigsten Todestag des großen Romanisten erstmals publiziert: Erich Auerbachs Brief an Victor Klemperer vom 7. Mai 1949.” Süddeutsche Zeitung (13 October 2007): 16. 
60. Surgeon Rudolf Nissen headed the Bosporus medical school; sculptor Rudolf Belling taught at the Academy of Fine Arts; urban planner Ernst Reuter, mayor of postwar Berlin, taught in Ankara, where classicist Georg Rohde established a classical library, and German musicians contributed to the state opera and conservatory. See: Azade Sehan. "German Academic Exiles in Istanbul: Translation as the Bildung of the Other." In Nation, Language, and the Ethics of Translation. edited by Sandra Bermann, and Michael Wood. Princeton, NJ: Princeton University Press, 2005, pp. 274-288.

61. Kader Konuk. "Jewish-German Philologists in Turkish Exile: Leo Spitzer and Erich Auerbach." In Exile and Otherness: New Approaches to the Experience of the Nazi Refugees, edited by Alexander Stephan. Bern: Peter Lang, 2005, pp. 31-47.

62. Emily Apter. "Global Translatio: The 'Invention' of Comparative Literature, Istanbul, 1933." Critical Inquiry 29:2 (2003): 269-270 suggests that Spitzer, Auerbach and the journal Romanoloji Semineri Dergisi (Journal of the Romance Studies Seminar) were instrumental in developing the comparative literature discipline.

63. Auerbach to Karl Vossler, 8 June 1938, 10 October 1938, 28 April 1939. In Martin Vialon. Und wirst erfahren wie das Brot der Fremde so salzig schmeckt: Erich Auerbachs Briefe an Karl Vossler, 1926-1938. Warmbronn: Keicher, 2007, pp. 22-27.

64. Auerbach to Johannes Oeschger, 27 May 1938. In Süddeutsche Zeitung (14 October 2008): 16, with a discussion by Martin Vialon. "Wie das Brot der Fremde so salzig schmeckt: Hellsichtiges über die Widersprüche der Türkei: Erich Auerbachs Istanbuler Humanismusbrief."

65. Auerbach to Walter Benjamin, 3 January 1937. In "Scholarship in Times of Extremes." PMLA 122:3 (2007): 750-51.

66. Auerbach to Karl Vossler, 10 October 1938. In Martin Vialon. Erich Auerbachs Briefe an Karl Vossler. p. 25.

67. Kader Konuk. East West Mimesis: Auerbach in Turkey. Stanford, CA: Stanford University Press, 2010, pp. 102-132.

68. Auerbach knew he was not safe: "That we would be exiled from here, if one had the power to do so, is certain; and, then again, we lack no enemies here either." "Dass 'man' uns von hier vertreiben wird, wenn man die Macht dazu hat, steht fest, und dann werden auch hier die Feinde nicht fehlen.” Auerbach to Johannes Oeschger, 27 May 1938, 16.

69. Auerbach. "Epilegomena zu Mimesis." In Erich Auerbach. edited by Treml and Barck, 1954, p. 473 , n. 12 .

70. Clemens Auerbach. "Summer 1937." In Erich Auerbach, edited by Treml and Barck. pp. 495-500.

71. Auerbach to Benjamin, 23 September 1935, 6 October 1935, PMLA 122:3 (2007): 747-752, 759-760; Walter Benjamin. Berlin Childhood Around 1900, translated by Howard Eiland. Cambridge, MA: Belknap Press of Harvard University Press, 2006.

72. Auerbach to Traugott Fuchs (Spitzer's assistant who became a close friend in Istanbul), 22 October 1938, PMLA 122:3 (2007): 752-55 (German and English).

73. "Und dann zog er wieder ohne Geld ein Stueck weiter in die weite Welt": "Die Ballade von armen Jakob.” In his: Los der Menschen. Frankfurt am Main: Suhrkamp, 1987, pp. 87-98. 
74. Mimesis. p. 18 (English). Jacob is one of several biblical figures Auerbach uses to argue that biblical characters are intended as real and not mere symbols. Martin Vialon, "Wie das Brot der Fremde so salzig schmeckt," quotes a 2007 report of the former head of the Rome Jewish community, Giacomo Saban, who had known the Auerbachs in Istanbul as a young student. Vialon ventures that exile may have been a motif of Auerbach's talks.

75. "Figura." Archivum Romanicum 22 (1938): 436-489.

76. Erich Auerbach. "Figura." In Neue Dantestudien, rev. ed. Istanbul: I. Horoz basimevi, 1944, pp. 11-71, translated Ralph Manheim (1959), In Erich Auerbach. Scenes from the Drama of European Literature. pp. 11-76.

77. "Sacrae scripturae sermo humilis." In Neue Dantestudien. 1941, pp. 1-10; rev. and expanded edition: "Sermo humilis." In Erich Auerbach, Literary Language and its Public. pp. 25-67.

78. “Passio' as Passion." PMLA 56 (1941): 1179-1196. Auerbach uses "figura" rather than typology, but the latter term has been universally used for the figurative thinking he outlined. He later acknowledged the identity of the two: "Epilegomena zu Mimesis." p. 474.

79. Auerbach. Literary Language and Its Public. 335. More on sermo humilis later, when discussing Mimesis and the postwar years.

80. Locus classicus: Augustine, De civitate Dei: The City of God Against the Pagans. (English and Latin), 7 vols. Cambridge, MA: Harvard University Press, 1957-1972, I:15, V:17, XIX:18.

81. Auerbach to Karl Vossler, 10 October 1938. In Martin Vialon. Erich Auerbachs Briefe an Karl Vossler. p. 25: "Si sa di sale la pane altrui; und mich ängsten die Gedanken an weitere fremde Treppen (how salty the bread of others is; and thoughts of more foreign steps make me anxious)."

82. Auerbach quoted to Vossler Paradiso XVII: 58-60: "You shall leave everything you love most ... You are to know the bitter taste of others' bread, how salty it is, and how arduous and bitter the walk is, climbing and descending another's stairs."

83. Auerbach. "Figura." 468 (I use the original 1938 German edition unless otherwise noted), p. 53 (English), Manheim's translation.

84. Auerbach. "Figura." 454 (German), p. 34 (English).

85. Das französische Publikum des 17. Jahrhunderts, pp. 45-53. Auerbach cut this section from the postwar German and English editions of "La Cour et la Ville."

86. Emergency Committee in Aid of Displaced Foreign Scholars, Box 38, Folder 55, Manuscripts and Archives Division, New York Public Library. (Henceforth, Emergency Committee, NYPL. My thanks to Matthias Bormuth for the document.) Auerbach was responding to a questionnaire, querying, whether the Academic Assistance Council might approach religious communities on his behalf.

87. The German academic authority on typology in medieval poetry was Julius Schwietering: "Typologisches in mittelalterlicher Dichtung." In Vom Werden des deutschen Geistes, edited by Paul Merker, and Wolfgang Stammler. Berlin: De Gruyter, 1925, pp. 40-55.

88. Auerbach does not cite Schwietering and, instead, engages Gilson ("Figura." 60-61, 235-36, n. 41 [English] and 474-75, n. 37 [German]). Notwithstanding the poor library in Istanbul, this is puzzling. 
89. Auerbach. "Figura." 444 (German), p. 21 (English).

90. The Last Supper, said Auerbach, was "the purest picture of the concretely present, the veiled and tentative, the eternal and supratemporal elements contained in the figures": "Figura." 474 (German), p. 60 (English). Manheim's translation.

91. Auerbach. "Figura." 461-62 (German), pp. 44-45 (English).

92. Auerbach. "Figura." 466 (German), p. 51 (English).

93. Auerbach. "Figura." 468, 470-71 (German), pp. 53, 56 (English), respectively.

94. Auerbach. "Figura." 471 (German), p. 56 (English).

95. Auerbach. "Figura." 458 (German), p. 39 (English). Dante spoke of The Divine Comedy as "allegorical" but he meant "typological": "Dante's Letter to Can Grande." Translated by Nancy Howe. In Essays on Dante, edited by Mark Musa. Bloomington, IN: Indiana University Press, 1964, pp. 32-47.

96. James Markham. "Epistle to Can Grande: Text and Translation." http://www.english.udel.edu/dean/cangrand.html.

97. Auerbach. "Figura." 478 (German), p. 63 (English).

98. Auerbach. "Figura." 477-489 (German), pp. 64-76 (English).

99. Auerbach. "Figura." 489 (German), p. 76 (English).

100. Michael von Faulhaber. Germany: Advent Sermons Preached in St. Michael's, Munich, in 1933. Unknown: Burns, Oates \& Washbourne, 1td, 1934, ibid.

101. Karl Barth. Homiletics, translated by Geoffrey W. Bromiley, and Donald E. Daniels. Louisville, KY: Westminster/J. Knox Press, 1991, p. 80 (Bonn seminar lectures, 1932-33).

102. Idem. Church Dogmatics I. 2 (1938). London: T\&T Clark International, 2004, pp. 70-101.

103. Auerbach. "Figura." 468 (German), p. 53 (English).

104. 12 December 1941, Nachlass Alexander Rüstow. Bundesarchiv Koblenz, quoted in Martin Vialon. "Helle und Trost für eine 'neue Menschlichkeit'-Erich Auerbachs türkisches Exilbriefwerk." Deutsche Akademie für Sprache und Dichtung. Jahrbuch 2010. Göttingen: Wallstein Verlag, 2011, pp. 38-40. I am grateful to Vialon for a pre-published version of his essay.

105. Ibid., p. 38: "Ihr eigenes geistiges Leben, das eigentlich Jüdische im Geistigen ist längst erstarrt und wirkt gespenstisch. [...] Das Gefühl des Unheimlichen, Fluchbeladenen wurde gesteigert und konkretisiert durch die Rolle, die sie bei der Entstehung des Christentums gespielt haben. Das Christentum ging von ihnen aus, aber sie haben es verworfen, so dass die Mission sich an die Heiden wandte und der Gegensatz zwischen dem jüdischen Gesetz (das nur noch Schatten und Gespenst sei) und christlicher Gnadenerfüllung (die das Gesetz entkräftete), konstruierte."

106. Ibid., .p. 40: "Der Antisemitismus seit etwa 1820 ist nichts mehr als eine Ausnützung solcher Atavismen im Dienste ganz anderer Ziele, er ist nur noch ein Anhängsel von sozialen und nationalistischen Kämpfen. Im Rahmen der uns erwartenden Probleme wird der Antisemitismus gegenstandslos werden, davon bin ich fest überzeugt, er ist nur noch ein Randproblem, das nie gehört werden, aber verschwinden wird.” 
107. Ibid., p. 38: "Alles was seither Bedeutendes von ihnen ausging, ist an die Kulturen der Wirtsvölker angerankt": This would suggest that Jews did actually make postbiblical contributions to European culture but Auerbach insists that, when a contribution was made, it would no longer be defined as Jewish but as European.

108. Landauer. “Mimesis' and Erich Auerbach's Self-Mythologizing." German Studies Review 11:1 (1988): 88. Landauer emphasizes the intersubjectivity of Auerbach's Western tradition. This evokes a comparison with Popper. It would appear that, for Auerbach, the intersubjectivity of the Western classics relied on the community of readers' shared background, on the similarity of ideals and sentiments among benefactors of the classicChristian tradition. For Popper, the intersubjectivity of philosophy, science and democracy required only an open critical public, an exchange of arguments. All the same, the wartime appeal of both Jewish exiles, reared on a liberal Protestant view of the West, to intersubjectivity is thought provoking.

109. Auerbach. Mimesis. pp. 547-48: In Joyce, Proust and Wolfe, "there is greater confidence in syntheses gained through full exploitation of everyday occurrence than in chronologically well-ordered total treatment. ... [T] his technique of modern writers [compares] with that of certain modern philologists who hold that the interpretation of a few passages from Hamlet, Phèdre, or Faust can be made to yield more ... decisive information about Shakespeare, Racine, or Goethe and their times than would systematic [biographies]. The present book may be cited as an illustration."

110. The expression "European classico-Christian literary culture" belongs to J. B. Trapp, quoted in Carl Landauer, “"Mimesis” and Erich Auerbach's Self-Mythologizing.” 95, n. 24.

111. Dante, De Vulgari Eloquentia, I, vi, lines 11-12, edited by Warman Welliver. Ravenna: Longo, 1981, (Latin and English), pp. 52-3.

112. Jacob Burckhardt. Die Kultur der Renaissance in Italien, 2nd ed. Leipzig: Seemann, 1869, p. 108. Burckhardt transformed the tormented Florentine patriot into an avowed cosmopolitan. Dante wrote: "nos autem, cui mundus est patria," translated as "I, however, to whom the world is fatherland." Burckhardt rendered it: "meine Heimath ist die Welt überhaupt!"

113. Carl Landauer. “Mimesis' and Erich Auerbach's Self-Mythologizing.” 88.

114. Helmut Kuhn. "Literaturgeschichte als Geschichtsphilosophie." Philosophische Rundschau 11 (1963): 222-248.

115. James Porter. "Erich Auerbach and the Judaizing of Philology." Critical Inquiry 35:1 (2008): $115-147$.

116. Edward Said. "Erich Auerbach, Critic of the Earthly World." Boundary 2, 31:2 (2004): $11-34$.

117. Amir Mufti. "Auerbach in Istanbul: Edward Said, Secular Criticism, and the Question of Minority Culture." Critical Inquiry, 25:1 (1998): 95-125.

118. Carl Landauer. “'Mimesis' and Erich Auerbach's Self-Mythologizing.” German Studies Review 11:1 (1988): 83-96. 
119. Matthias Bormuth is helpful here: Mimesis und der christliche Gentleman. Erich Auerbach schreibt an Karl Löwith. Warmbronn: Verlag Ulrich Keicher, 2006. Bormuth kindly provided me with an English translation (to be published shortly) of this hard to obtain book.

120. But his sense of the irreparable modern loss of the divine was profound: A Catholic sensibility of modernity's inadequacy complemented the ironic Protestant vision.

121. Auerbac. Mimesis. p. 202 (English).

122. Auerbach. Mimesis. p. 310 (English).

123. Esp. Mimesis, p. 550, speaking obliquely of sects "crystallizing around poets, philosophers, and scholars."

124. Auerbach. "Epilegomena zu Mimesis.” p. 476.

125. Georg Lukàcs. Die Theorie des Romans: ein geschichts-philosophischer Versuch über die Formen der grossen Epik [1916]. Neuwied am Rhein: Luchterhand, 1963.

126. Shai Ginsburg of Duke University has tracked in Mimesis strong traces of Lukàcs' 1930s Essays on Realism, ed. and intro. by Rodney Livingstone, trans. by David Fernbach [Cambridge, MA: MIT Press, 1981]. He insists that these essays, and not the early Theory of the Novel, shaped Auerbach's intellectual horizons in Mimesis.

127. Georg Lukàcs. Die Zerstörung der Vernunft: der Weg des Irrationalismus von Schelling zu Hitler. Berlin: Aufbau-Verlag, 1954.

128. Earl Jeffrey Richards. "Erich Auerbach's Mimesis as a Meditation on the Shoah." 62-91, and, more subtly, James Porter. "Auerbach and the Judaizing of Philology." esp. 119.

129. Both begin with Auerbach's statement on the rise of National Socialism as a history unsuitable for legend: Auerbach, Mimesis. pp. 19-20 (English), pp. 22-23 (German).

130. Isaac was bound (ne-ekad, נעקד) to be offered as "olah," or a "burnt offering," the Hebrew term for sacrifice, rendered in Greek as "holokau(s)ton." The term Holocaust does not become common, however, until the late 1950s.

131. Shalom Spiegel. The Last Trial: On the Legends and Lore of the Command to Abraham to Offer Isaac as a Sacrifice: The Akedah, trans. (from the Hebrew) with an introduction by Judah Goldin. New York: Pantheon Books, 1967.

132. James Porter. "Auerbach and the Judaizing of Philology." 122-23, suggests that the German Christians' use of the binding of Isaac to demonstrate the Old Testament's perversity also made the Akedah Auerbach's topic of choice for his first essay.

133. Auerbach. Mimesis. p. 22 (English), p. 25 (German).

134. Auerbach. Mimesis. p. 42 (English).

135. Ibid. pp. 45, 42-43, respectively.

136. Ibid. p. 48.

137. Contemporary scholarship would prefer "the Jesus movement" to "early Christianity" and "Jewish followers of Jesus" to "Jewish Christians." Christianity was not a religion separate from Judaism prior to the second century, if then.

138. Auerbach. Mimesis. pp. 72, 154, 72 (English), respectively.

139. Auerbach. Mimesis. p. 76 (English).

140. Auerbach. Mimesis. p. 173 (English). 
141. The laudation of St. Francis, reminiscent of the George Circle, was all the more remarkable for Auerbach's acknowledgement that his style was poor. But St. Francis vividly conveyed emotional reality, and this counted for Auerbach more than aesthetics. This was evident also in Auerbach's sympathetic treatment of Gregory of Tours, and in his elevating St. Perpetua into a model of sublime humility in the postwar years: "Sermo humilis." In Literary Language and its Public. pp. 60-65.

142. Auerbach. "Sermo humilis." 39.

143. "Subaltern" is also used in the German original: Romanische Forschungen 64:3/4 (1952): 316.

144. Shalom Spiegel. The Last Trial; Gershon Greenberg. "Introduction: Ultra-Orthodox Responses during and following the War." In Wrestling with God: Jewish Theological Responses During and After the Holocaust, edited by Steven T. Katz with Shlomo Biderman and Gershon Greenberg. Oxford: Oxford University Press, 2007, pp. 11-26. The Jewish homiletic tradition that Isaac was actually sacrificed and burnt to ashes, but rose from the dead, and his ashes protect the Jewish people as zekhut (merit, זכות) against transgression and persecution makes Auerbach's turn to Christ especially poignant.

145. Helmut Kuhn. "Literaturgeschichte als Geschichtsphilosophie." Philosophische Rundschau 11 (1963): 248: Auerbach's "keineswegs christlich gedachte Stilanalyse ist doch so christozentrisch entworfen, daß sie im Begriffe zu sein scheint, sich in eine christologische Literaturgeschichte zu verwandeln."

146. Auerbach. Mimesis. p. 518 (German); Mimesis (English), p. 557: "Möge meine Untersuchung ihre Leser erreichen; sowohl meine überlebenden Freunde von einst wie auch alle anderen, für die sie bestimmt ist; und dazu beitragen, diejenigen wieder zusammenzuführen, die die Liebe zu unserer abendländischen Geschichte ohne Trübung bewahrt haben." I modified Trask's translation.

147. James Porter. "Auerbach and the Judaizing of Philology." 118-19 called my attention to the translation difficulties.

148. Auerbach to Martin Hellweg, 22 June 1946. In Marin Vialon, Erich Auerbachs Briefe an Martin Hellweg. pp. 69-76.

149. Auerbach to Werner Krauss, 30 January 1946, 22 June 1946, 27 October 1946 and Krauss to Auerbach, 26 March 1946. In Karlheinz Barck. "Eine unveröffentliche Korrespondenz: Erich Auerbach/Werner Krauss.” Beiträge zur Romanischen Philologie 26:2 (1987): 310-16, 319-320.

150. Auerbach to Martin Hellweg. 22 June 1946, 69.

151. Auerbach to Werner Krauss. 22 June 1946, 27 August 1946, 27 October 1946, 18 December 1946, 22 February 1947, 314-17, 319, 323.

152. Krauss to Auerbach. 15 March 1947, 326.

153. Auerbach to Martin Hellweg. 22 June 1946, 69; Auerbach to Klemens von Klemperer. 7 May 1949, Süddeutsche Zeitung (13 October 2007): 16. 
154. Auerbach to Krauss, 27 August 1946, 317: "Ich konnte mich hier wie nirgends von sonst jeder Bindung freihalten; gerade meine Haltung als nirgends Hingehöriger, grundsätzlich und unassimilierbar Fremder ist das, was man von mir wünscht und erwartet, aber wo Sie mich inhaben wollen, erwartet man eine "Grundbereitschaft."'

155. Krauss to Auerbach, 29 September 1946, 318: "Ich möchte mir nämlich vorstellen, daß diese kurze Reintegration in die Heimat selbst für den letzteren Fall ein inneres Bedürfnis ist, dem man nicht ganz ungestraft widersteht. Meine letzten Erfahrungen zusammenfassend, kann ich wohl sagen, daß Deutschland überhaupt, auch für uns, nur als Project erträglich und bejahenswert ist, keinesfalls aber als ein Zustand."

156. Auerbach to Krauss. 16 April 1947, In Karlheinz Barck. "Eine unveröffentliche Korrespondenz: Erich Auerbach/Werner Krauss.” Beiträge zur Romanischen Philologie 27:1 (1988): 161-63.

157. Krauss to Auerbach. 25 October 1949, 183.

158. Auerbach to Krauss. 22 June 1946, Beiträge zur Romanischen Philologie 26:2 (1987): 312: "Besonders über die Rückkehr- und Wirkungsmöglichkeiten sind Thre Worte sehr verschieden von dem, was man sonst hört; ganz allgemein wird davon gewarnt, zumal bei Juden, ja es fehlt nicht an prominenten und sonst ganz vernünftigen Leuten, die in dieser Richtung eine Art moralischen Drucks ausueben versuchen."

159. Martin Vialon. "Erich Auerbach und Rudolf Bultmann: Probleme abendländischer Geschichtsdeutung." In Marburger Hermeneutik zwischen Tradition und Krise, edited by Matthias Bormuth, and Ulrich von Bülow. Göttingen: Wallstein Verlag, 2008, esp. pp. 178-79.

160. Bultmann to Auerbach. 18 June 1948, in: Marin Vialon. "Erich Auerbach und Rudolf Bultmann.” p. 184.

161. Krauss to Auerbach. 23 July 1947, Beiträge zur Romanischen Philologie 27:1 (1988): 166-8.

162. For the failure of postwar German university reform, with a focus on Marburg, see: Craig K. Pepin. "The Holy Grail of Pure Wissenschaft: University Ideal and University Reform in Post World War II Germany.” Ph.D. dissertation. Duke University, 2001.

163. Auerbach to Martin Hellweg. Easter Sunday 1948, 25 December 1948, in: Martin Vialon. Erich Auerbachs Briefe. pp. 102, 116.

164. "Bürgerlichkeit ist ... ein menschliches Bedürfnis. ... Nach drei Jahrzehnten so ungeheuerlicher Experimente ... können die Deutschen nichts anders sein als schrecklich müde": 22 June 1946, p. 69.

165. 7 May 1949, Süddeutsche Zeitung (13 October 2007): 16: "Es ist komisch in meiner Lage immer mehr festzustellen, dass die Deutschen, ausser vielleicht die Juden, wirklich das tuchtigste und in der Arbeit zuverlässigste Volk sind. Aber das allein tut es nicht ..." He would never dare write a non-Jewish German or a traditional Jew this way.

166. Auerbach to Martin Hellweg, 20 June 1950: "Die Deutschen sollten ... wieder anfangen, weltpolitisch zu denken, aber auf eine andere Weise als früher-nicht rein aus deutschen Vorstellungen und in engsten deutschen Interesse." 
167. “The Political Theory of Pascal." In Scenes from the Drama of European Literature. p. 129, a slightly expanded version of the translation of the German original, published in The Hudson Review 4:1 (1951): 79.

168. Robert Fitzgerald. Enlarging the Change: The Princeton Seminars in Literary Criticism, 1949-1951. Boston: Northeastern University Press, 1985, p. 15.

169. Henri Peyre. "Erich Auerbach (1892-1957)/Romanist." In Marburger Gelehrte, edited by Ingeborg Schnack. Marburg: N. G. Elwert Verlag, 1977, pp. 10-11: "son rêve eût été ... de contribuer à la reconstruction des universités comme Marburg, Heidelberg, Bonn, dont il attendait beaucoup, une fois l'Allemagne et le reste de l'Europe occidentale avec elle, liberés de leur complexe de culpabilité. (His dream would have been ... to contribute to the reconstruction of universities like Marburg, Heidelberg, or Bonn, of which he expected much, once Germany and the rest of Western Europe freed themselves from their guilt complex)."

170. Another emigration, another loss, and another new start - "a somewhat late start," Auerbach told Krauss self-mockingly, "but better late than never (Ein etwas später Aufbruch - aber mieux vaut tard que jamais).” Beiträge zur Romanischen Philologie. 27:1 (1988): 9 July $1947,166$.

171. Carl Landauer. “"Mimesis' and Erich Auerbach’s Self-Mythologizing.” 95, n. 24.

172. Stephen G. Nichols. "Philology on Auerbach's Drama of (Literary) History." In Literary History and the Challenge of Philology. edited by Seth Lerer. pp. 63-65.

173. Auerbach to Krauss. 1 October 1947, as quoted in Martin Vialon. "Die Stimme Dantes und ihre Resonanz.” In Martin Treml and Karlheinz Barck. Erich Auerbach. p. 46, n. 1.

174. In 1940, when Auerbach was concerned about the approaching expiry of his German permission to reside in Turkey, his U.S. friends searched for a U.S. position for him and collected money to support a potential first year salary: letter of the Association of Immigrant Scholars (Notgemeinschaft) to the Committee in Aid of Displaced Foreign Scholars, 30 December 1940, Emergency Committee, 38:5, NYPL.

175. Auerbach to Krauss. 3 March 1948, In Vialon. "Die Stimme Dantes.” p. 47: "menschliches sehr gut, sachliches indiskutabel."

176. See also Auerbach's letters to Martin Hellweg, 5 October 1947, Easter Sunday 1948, pp. 94, 102-103 and Klemperer, 7 May 1949.

177. Auerbach to Karl Vossler. 5 June 1948. In Martin Vialon. Erich Auerbachs Briefe an Karl Vossler. p. 29.

178. Auerbach to Martin Hollweg. 25 December 1948, 20 June 1950, pp. 116, 136.

179. Maire and Edward Said, trans. The Centennial Review 13:1 (1969): 1-17.

180. Fritz Ringer. The Decline of the German Mandarins: The German Academic Community, 1890-1933. Cambridge, MA: Harvard University Press, 1969.

181. Auerbach to Paul Binswanger. 3 March 1930, Romanistisches Jahrbuch 59 (2009): 164.

182. Auerbach knew this was unfair: Letter to Karl Vossler. 10 October 1938. In Erich Auerbachs Briefe, edited by Martin Vialon. pp. 25-26: "He is my friend, he has done for me more than anyone, he is a generous man, full of life, and a major scholar. All the same, everything he says, does and writes irritates me." 
183. Krauss to Auerbach. 25 November 1947, 8 January 1950, Beiträge zur Romanischen Philologie 27:1 (1988): 170, 184.

184. Auerbach. "Sermo humilis" (English), pp. 60-65.

185. Malachi Hacohen. 'From Forvm to Neues Forvm: The 'Congress for Cultural Freedom,' the 68ers and the Émigrés." In Das Jahr 1968-Ereignis, Symbol, Chiffre, edited by Oliver Rathkolb and Friedrich Stadler. Göttingen: V \& R Unipress, Vienna University Press, 2010, pp. 239-274.

186. "Introduction: Intention and Method." In Literary Language and Its Public in Late Antiquity and in the Middle Ages. p. 6.

187. Auerbach to Benjamin. 3 January 1937, PMLA 122:3 (2007): 750-51.

188. See also his letter to Benjamin. 12 December 1936, 749, on Turkish ur-nationalism, and to Johannes Oeschger, 27 May 1938, Süddeutsche Zeitung (14 October 2008): 16 on nationalization and modernization as "barbarization" (Barbarisierung).

189. “The Western Public and Its Language.” In Literary Language and Its Public. p. 338.

190. Ibid. p. 65.

191. Ibid. p. 338.

192. Auerbach. "Philology and Weltiteratur." 17.

193. Auerbach quotes Hugh of St. Victor, Didascalicon III: 19: The Didascalicon of Hugh of St. Victor, translated by Jerome Taylor. New York: Columbia University Press, 1961, p. 101.

194. "Man kann ja gar nichts anderes mehr hören als Mimesis": Konrad Bieber to Carl Landauer, 2 February 1986, reporting on Curtius in Princeton in 1949, quoted in: "Mimesis and Erich Auerbach's Self-Mythologizing." 83.

195. Dante. The Banquet (Il Convivio), IV: xii, par. 19, translated by Katherine Hillard. London: Kegan Paul, 1889, p. 290.

196. Dante. Opere. Florence: Bemporad \& Figlio, 1921, pp. 273-74.

197. Stephen Nichols. "Philology on Auerbach’s Drama of (Literary) History." 65.

198. "Erich Auerbach (1892-1957)/Romanist." 10.

199. Wellek. “Auerbach's Special Realism.” Kenyon Review 16 (1954): 299.

200. For a list of early reviews of Mimesis, see: Herbert Lindenberger. "On the Reception of Mimesis." In Literary History and the Challenge of Philology. pp. 212-13.

201. For a bibliography of Auerbach's reviews, and text of his reviews of Fergusson's and Charles Singleton's works on Dante, see: Gesammelte Aufsätze. pp. 368-69, 317-19, 313-14, respectively.

202. For the U.S. reception of Mimesis, see also: Carl Landauer. "Auerbach's Performance and the American Academy." In Literary History and the challenge of Philology. pp. 179-194 and note 201.

203. William Calin. The Twentieth-Century Humanist Critics: From Spitzer to Frye. Toronto: University of Toronto Press, 2007, pp. 43-56.

204. Among Auerbach's students at Yale were future leading literary critics, Geoffrey Hartmann and Frederic Jameson. Mimesis also inspired the linguistic turn in intellectual history, as represented by Hayden White, Metahistory. Baltimore: Johns Hopkins University Press, 1973, esp. pp. 2-3, n. 4. 
205. Princeton, 1968.

206. The blurbs represented selections from their laudatory essay and review in The American Scholar 34:3 (1965): 474-498 (quotation on 484).

207. And The New York Times Book Review (29 November 1953): 40, respectively.

208. David Hollinger. Science, Jews, and Secular Culture: Studies in Mid-twentieth-century American Intellectual History. Princeton, NJ: Princeton University Press, 1996.

209. Ernst Robert Curtius. "Die Lehre von den drei Stilen in Altertum und Mittelalter (zu Auerbachs Mimesis)." Romanische Forschungen 64 (1952): 57-70.

210. Erich Auerbach. "Epilegomena zu Mimesis." Romanische Forschungen 65 (1954): 1-18. Reprint: Erich Auerbach, edited by Treml and Barck, pp. 466-479.

211. Michael Nehrlich. "Romanistik und Anti-Kommunismus." Das Argument 4:3/4 (1972): 276-313.

212. The Centennial Review 13:1 (1969): 1-17; Cambridge, MA: Harvard University Press, 1983.

213. And Boundary 2, 31:2 (2004), 11-34, respectively.

214. "Erich Auerbach." Boundary 2, 31:2 (2004): 20.

215. Amir Mufti. "Auerbach in Istanbul: Edward Said, Secular Criticism, and the Question of Minority Culture." Critical Inquiry. 25:1 (1998): 95-125.

216. Buber to Auerbach. 31 December 1956; Auerbach to Buber, 12 January 1957, In Erich uerbach, edited by Treml and Barck. pp. 488-89.

217. "Erich Auerbach." Boundary 2, 31:2 (2004): 33.

218. Karlheinz Barck. "5 Briefe Erich Auerbachs an Walter Benjamin in Paris," Zeitschrift für Germanistik 6 (1988): 688-94.

219. Idem. "Eine unveröffentliche Korrespondenz: Erich Auerbach/Werner Krauss." Beiträge zur Romanischen Philologie 26:2, 27:1 (1987-88): 301-326, 161-186.

220. Auerbach's papers are in the Deutsches Literaturarchiv in Marbach. Much of his correspondence has been published — my notes pay homage to the publications — and Martin Vialon has been preparing a comprehensive scholarly edition.

221. "The book owed its existence to the very fact of Oriental, non-Occidental exile and homelessness", Edward Said, The World, the Text, and the Critic, pp. 7-8.

222. Carl Landauer. “"Mimesis' and Erich Auerbach's Self-Mythologizing.” 89.

223. Survival in Auschwitz (New York: Touchstone, 1996), pp. 112-115, quoting Inferno XXVI: 116-17: "fatti non foste a viver come bruti, ma per seguir virtute e canoscenza."

224. Alan Adelson, producer. Lódź Ghetto (videorecording), directed by Kathryn Taverna and Alan Adelson. Westport, CT: Jewish Heritage Project, 1992.

225. Leo Spitzer to Karl Löwith. 21 April 1933, as quoted in "Menschenkunde zwischen Meistern-Auerbach und Löwith.” In Erich Auerbach. p. 98.

226. As quoted in Hans Ulrich Gumbrecht. "Pathos of the Earthly Progress." pp. 25, 253 n. 46.

227. Auerbach used the phrase again in "Figura." 482, n. 43 (German), p. 236, n. 47 (English) to denote the convergence of earthly and heavenly Rome in Dante. 
Reprinted from Religions. Cite as: Zakai, A.; Weinstein, D. Erich Auerbach and His "Figura": An Apology for the Old Testament in an Age of Aryan Philology. Religions 2012, 3, 320-338.

Article

\title{
Erich Auerbach and His "Figura": An Apology for the Old Testament in an Age of Aryan Philology
}

\section{Avihu Zakai ${ }^{1}$ and David Weinstein ${ }^{2, *}$}

1 The Hebrew University of Jerusalem, Jerusalem 91905, Israel; E-Mail: avihuzakai@gmail.com

2 Wake Forest University, Political Science Department, Tribble Hall, Winston-Salem NC 27109, USA

* Author to whom correspondence should be addressed; E-Mail: weinstd@wfu.edu;

Tel.: +336-758-5133; Fax: +336-758-6104.

Received: 16 January 2012; in revised form: 27 March 2012 / Accepted: 6 April 2012 /

Published: 13 April 2012

\begin{abstract}
Auerbach's goal in writing "Figura" and Mimesis was the rejection of Aryan philology and Nazi barbarism, based on racism, chauvinism and the mythologies of Blood, Volk and Soil, which eliminated the Old Testament from the Christian canon and hence from European culture and civilization. Following the Nazi Revolution of 1933 and the triumph of Aryan philology, Auerbach began writing "Figura," published in 1938, where he provided an apology for the Old Testament's validity and credibility, striving to prove that the Jewish Bible was inseparable from the New Testament contrary to the claims of Aryan philology and Nazi historiography. Auerbach's "Figura" should be considered not merely as a philological study but also, and more importantly, as a crucial stage in his response to the crisis of German philology with Mimesis, in turn, seen as his affirmation, against Aryan philology's Nazi racist and völkish views, of the humanist, Judeo-Christian foundation of European civilization.
\end{abstract}

Keywords: philology; Figura; allegory; Arian philology; Nazi historiography

\section{Introduction}

We must emphasize with all decisiveness that Christianity did not grow out of Judaism but developed in opposition to Judaism. 
Moses and Christ [are] related as figure and fulfillment.

Erich Auerbach, "Figura," 1938

Away with the Old Testament! A Christianity which still clings to the Old Testament is a Jewish Religion, irreconcilable with the spirit of the German people.

Demand by the German Christians in the rally at Berlin Sportpalast, 13 November 1933

[Figural interpretation] wished to preserve the full historicity of the Scriptures along with the deeper meaning.

Erich Auerbach, "Figura," 1938

Did Christianity arise out of Judaism being thus its continuation and completion, or does it stand in opposition to Judaism? To this question we respond: Christian faith is the unbridgeable religious contradiction to Judaism.

“The Godesberg Declaration” of the Evangelical Lutheran Church, April 4, 1939

[Auerbach's figural interpretation] asserted both the historical reality of the Old and the

New Testaments and also their providential connectedness.

Lowry Nelson, Jr. “Erich Auerbach: Memoir of a Scholar,” Yale Review 69 (1979-80)

In the "Introduction" to his Literary Language \& Its Public in Late Latin Antiquity and in the Middle Ages, 1958, Erich Auerbach (1892-1957) described the close, inextricable connection in his thought between philology and ideology, thus illuminating his unique approach in the field of "philology and literary expression," and showing how intrinsically connected his philological enterprise was to "the inward and outward crises of Europe" of his times [1]. Auerbach claimed that in comparison to other prominent philologists of his time, such as Karl Vossler (1872-1949), Ernst Robert Curtius (1886-1956) and Leo Spitzer (1887-1960), the source of his work was unique: "My work" he wrote "shows a much clearer awareness of the European crisis [2]."

It is our thesis in what will follow that Auerbach's philological, historical and philosophical enterprise in "Figura" (1938) and Mimesis: The Representation of Reality on Western Literature (1946) was directed against a very specific and well-defined crisis in Germany and Europe of his time. Auerbach referred in the above words not only to the general political and social crises of his time in Germany [3], but also, and most importantly, to a specific crisis in his own discipline, namely the crisis of philology, the development of Aryan philology and its eventual triumph in the Third Reich following the Nazi Revolution of 1933. Aryan philology was based on racism, antiSemitism, narrow nationalism and sheer chauvinism. It strove to eliminate the Old Testament from the Christian canon, and, hence, from the very fabric of European culture and civilization [4]. Our goal here is to show and analyze the extent to which Aryan philology influenced Auerbach's thought and motives in the writing of "Figura." 


\section{Arian Philology}

Based on the legends and mythologies of "Blood, Volk and Soil"-Blut und Boden, the major slogan of Nazi racial ideology which focused ethnicity based on blood, folk and homeland, Heimat-Aryan philology was a unique German racist, chauvinist and anti-humanistic philology, which strove to fashion new Aryan origins of the German people, to shape a new Germanic or Nordic Christianity, to reject and eliminate the Old Testament from the Christian canon, and thus to construct new origins, aims and goals, for the history of the German people in particular and of Western civilization in general. Much of Auerbach's works, but most specifically "Figura" and Mimesis, were directed against the racist, chauvinist and anti-Semitic premises of Aryan philology [5].

During the Weimar Republic, "Philology had become a metaphor for numbing, drudgery, authoritarian discipline [6]." In contrast, Auerbach's philology is humanistic, or a philological humanism in other words, meaning a philology which is not based on racism, nationalism, chauvinism and Aryanism. He was a humanist philologist who stressed the humanist dimensions of Western culture and literature in contrast to Aryan, racist, philology. Against the German myths of Blood, Volk, Soil and Aryanism, he strove to prove the origins of European humanist civilization. Auerbach's narrative therefore is the narrative of Western civilization, not of specific race or ethnic group of people. Having advocated philological humanism in place of Aryan, racist philology, Auerbach rather promoted the Judeo-Christian humanist tradition of Western civilization. His was then the struggle of humanist philologist, of "historicist humanism" [7], against Aryan philology's de-canonization of the Old Testament and Nazi barbarism. Auerbach believed in historicism, or that mode of mode of thinking that assigns a central and basic significance to a specific context, such as historical period, geographical place and local culture. As such it stood in contrast to individualist theories of knowledge such as empiricism and rationalism, which neglect the role of history and traditions.

Aryan philology in Germany was inextricably linked to ideology and history as it tended to uphold Nazi racist and völkish ideology. That the elimination of the Old Testament from the fabric of German life and culture became central in Nazi ideology can be clearly seen in the thought of the influential Nazi intellectual Alfred Rosenberg (1893-1946), who was one of the main advocates of key Nazi ideological creeds such as racial theory, persecution of the Jews, Lebensraum ("habitat" or literally "living space"), and more. For Rosenberg, "the eternal Aryan values were contrasted to Judaeo-Christian depravity." Hence, he declared: "The Old Testament as a book of religious instruction must be abolished once and for all. With it will end the unsuccessful attempts of the last one-and-a-half millennia to make us all spiritual Jews." (Emphasis added). Regarding Jesus himself, Rosenberg claimed that as "for Jesus' ancestry is concerned, there is not the slightest reason to believe" that "Jesus was of Jewish ancestry [8]."

The struggle in Germany against the Jewish Bible, and against Jewish influence in general, reached its height after the Nazi Revolution of 1933, which signaled also the triumph of Aryan philology in Germany. A clear example of the influence of omnipresence Anti-Semitism fueled by combined forces of Aryan philology and Nazi historiography can be clearly seen in the mass rally organized along Nazi party style by the German Christians_-Deutsche Christen - on 13 November 
1933 at the Berlin Sportpalast. The German Christians movement, officially organized in 1931 as the Nazi Wing of the Evangelical Church, initially emerged during the 1920s "as an effort to synthesize Christianity with a rabid German Nationalism [9]." It was established "to ensure the racial survival and de-judaizing the Christian faith and had been represented in sundry Church parliaments [10]." In the 1933 Berlin Sportpalast rally, before a packed hall of 20.000 supporters, banners proclaiming the unity of National Socialism and Christianity were interspersed with the omnipresent swastikas. A series of speakers addressed the crowd's pro-Nazi sentiments with ideas such as the removal of all pastors unsympathetic with National Socialism, the expulsion of members of Jewish descent, etc. Not the least among these demands was "the removal of the Old Testament from the Bible," or from the Christian canon, and the adoption of a more "heroic" and "positive" interpretation of Jesus, who in pro-Aryan fashion should be portrayed as battling mightily against corrupt Jewish influences [11].

According to Nazi Pastor Dr. Reinhold Krause, who preached at the Berlin rally, German Protestantism needed a "second Reformation." Hence he submitted three reforms, among them the "Elimination of the Old Testament and of "palpably misrepresenting or superstitious passages in the New Testament' [12]." (Emphasis added). Krause demanded the elimination of the Old Testament because of its Jewish "commercial morality" and "unedifying stories of "cattle-dealers and pimps," as well as the rejection of the theology of "Rabbi Paul [13]." Needless to say, that "meeting enthusiastically adopted a resolution supporting Dr. Krause's reforms [14]." Indeed, many "Deutsche Christen theologians who were loyal to Nazi ideology rejected the OT [Old Testament], precisely because they thought of it as a Jewish book [15]." For example, Ludwig Müller (1883-1945), the leader of the German Christians and Reich's Bishop (1933) of the German Evangelical Church, declared in 1934: "We must emphasize with all decisiveness that Christianity did not grow out of Judaism but developed in opposition to Judaism [16].” (Emphasis in original).

In this broad historical, racial, Anti-Semitic and Aryan philological, context, Auerbach's "Figura" can be described as an apology for the Old Testament in an age of the crisis of German philology and the triumph of Aryan Philology following the Nazi revolution of 1933. Auerbach argued therefore that figuralism or typology "originated in early Christian efforts to show that Jesus Christ was indeed the Messiah and had fulfilled Jewish prophecies, by retrospectively explaining the Hebrew Bible as the 'Old' of the 'New Testament' [17]." By seeing that figural interpretation "asserted both the historical reality of the Old and the New Testaments and also their providential connectedness" [18], the credibility and validity of the Old Testament was thus fully asserted and its authority fully assured against the premises of Aryan philology. Likewise, Mimesis, which Auerbach began writing in 1942, the most decisive year in World War II in which the Battle of Stalingrad, the Battle of Midway in the Pacific Ocean, and El Alamein in North Africa all took place, is an apology for Western Judeo-Christian humanist tradition in an age of peril, barbarism and tyranny. That is, it is an apology not in terms of regret, remorse, or sorrow but rather as a strong defense or justification. "Figura" and Mimesis are indeed an apologetic endeavor of a humanist apologist. Like Augustine and Pascal, to name only a few famous Christian apologists, Auerbach too wrote an apology — an apology for Western humanist civilization in a time of the gravest existential threat it faced. Apology is typically written by someone who claims to know the truth and strives to show it in its full colors in a world which denounced it; hence it is written in 
dark times of peril and danger threatening this truth. This applied as well to Auerbach, because, as René Wellek has written, what Auerbach produced "was oriented toward truth" [19] or, to use Auerbach's own words, toward "an absolute claim to historical truth [20]."

Auerbach's seminal essay "Figura" [21] appeared in 1938, though its inception took place in Germany before Auerbach went into exile [22]. And after taking refuge in Istanbul in 1936, "Auerbach finished drafting the essay on figura from notes gathered before he had left Germany and from research undertaken in Turkey [23]." If this contention is right, and there is no reason to believe otherwise, then Auerbach began working on his famous essay after the Nazi Revolution of 1933, which also signaled the triumph of Aryan philology. Thus, although "Figura" is minted in the thick veins of medieval exegesis, it is our thesis that in this essay Auerbach enlisted philology in the service of humanist ideology, or in his struggle against the premises of Aryan philology. More specifically, he used philology in order to show that figural and not allegorical interpretation guided Western Christianity until the Age of Enlightenment, hence confirming the close and intrinsic connection between the Old and the New Testaments, in contrast to the racist, Anti-Semitic premises of Aryan philology.

Auerbach argued that the word figura, originated "in pagan antiquity," and was then developed by "the Church Fathers" into a system of singular figural interpretation of reality, which "was of the greatest historical importance," ([21], pp. 27-8) thus establishing close, intrinsic and inseparable ties between the Old and the New Testament, Judaism and Christianity. "Figura" thus signifies a unique mode of historical causation, "figural causation" [24], which is radically different from ancient, classic teleological notions of causality. Further, seeing that figura denotes an important Patristic mode of biblical exegesis, Aryan philology's aim to eliminate the Hebrew Bible from the Christian canon, and as a consequence to construct new origins and hence goals for the German people, clearly had no warrant and validity whatsoever. Indeed, Auerbach brought into the foreground in 1930s a thesis about figura, which was known only to modern medievalists and philologists [25], but the reason for that is more than clear: he fully understood that this thesis was vitally relevant to his own historical, political, ideological and philological context in his struggle against the premises of Aryan philology. His was then a grand mission of great proportions in "Figura:" to provide the meaning of figura and its humanist ramifications for the course of European civilization as it was used after the fashion of Saint Paul, Augustine, Aquinas and Dante. In the hands of Auerbach, then, figura, which was born "in the nexus of Judaism and Christianity," embodies "one of the conditions of the literary project of the West [26]." Philology, in other words, became in Auerbach's hands an ideological tool and figural interpretation was transformed into a formidable weapon against Aryan philology. Humanist ideology, thus became an essential part of philology, and philology became inseparable from ideology.

\section{3. "Figura" and "Allegory"}

In "Figura," Auerbach strongly insisted on a firm and rigid demarcation between "figura" and "allegory," or the Index figurarum and the Index de allegoriis [27], thus drawing a clear-cut contrast between "allegory, in which figure is feigned to illustrate a given proposition, and figura, in which both terms, the figure and the figured, are deemed real [28]." Basically, Auerbach explains, figure "differs from allegory in that allegory involves an abstract sign that leads beyond 
itself rather than to another real historical being" as in the case of figure [29]. Figura thus implies realism, and vice versa. Later on in Mimesis, Auerbach explained that one of the main differences between allegory and figura is that allegory moves "horizontally" on earth, or in the historical realm, while figura "vertically," thus connecting Heaven and earth or the sacred and the secular. Allegory is "horizontal," because it deals with the realm of "the temporal and causal," while figura is vertical since "both occurrences are vertically linked to Divine Providence [30]." Hence, as we will see later, figura and the figural view of reality denote eschatology and apocalypse.

Although acknowledging "the fact that allegoria is prominent in medieval exegesis," Auerbach nonetheless insisted "that figura is the dominant mode and that it replaces allegory as a category for the Christian interpretation of the Bible and the physical universe [31]." The figural view of reality is thus radically different from the allegorical one. In the broad historical and religious confines of the rise of Christianity, according to Auerbach, the "spiritualist-ethical-allegorical" interpretation had "little influence on the freshly converted people" to Christianity ([21], p. 55). One of the main sources for the different power and role Auerbach assigned to figura and allegoria lay in their different origins: "the figural method in Europe goes back to Christian influences, while the allegorical method derives from ancient pagan sources, and also that the one is applied primarily to Christian, the other to ancient materials" ([21], p. 63. Emphasis added). European literary culture's representation of reality thus, in accordance with Auerbach's newly acquired "anticlassical bias" [32], did not originate with the pagan classic Greeks, which the Nazis adored and worshiped, but rather with the Judeo-Christian heritage. This contention will later serve as the core of the first chapter in Mimesis.

Evidently, Auerbach considered "figura" as an example of "Ansatzpunkt, a major semantic point of departure providing insight into very large literary or cultural movements - in the case the separation between classical and Christian forms and attitudes." This important concept in Auerbach's philological philosophy leads us directly to the crucial issue of Auerbach's main aim in his famous essay, or in the words of Jesse M. Gellrich: "If the opposition of figure and allegory is such a point of departure, then what is the larger problem to which it provides access?" Auerbach's concern, argues Gellrich, is clearly "predominantly with the Christian departure from classical use of figura in rhetoric and oratory, but he also discusses the distinction from allegory, which he represents as Greek literary form and an Eastern influence fundamentally incompatible with the historical interests of Western exegesis." In sum, writes Gellrich, according to Auerbach "Tertullian and Augustine are to be separated from Origen and Philo of Alexandria, insofar as the Greek writers compose an allegorization that devalues the relevance of the historical record by rendering the entire Old Testament as a mere shadow show of moral concepts and future happenings [33]." (Emphasis added.) In contrast, according to Augustine, "what is the Old Testament but the New Testament veiled; and what is the New Testament but the Old Testament unveiled [34]." The Old Testament thus prophetically prefigures the New Testament, and the later could be read as a figural realization or interpretation of the Hebrew Bible. More specifically, in the context of the history of salvation and redemption, Figura denotes eschatology and apocalypse; hence it constituted a crucial dimension of sacred, providential history. In "Figura," therefore, Auerbach set out a transcendentalist scheme. In sum, by claiming the predominance of figura in Christian thought, Auerbach opposed "the spiritualist-ethical-allegorical method." ([21], p. 55). 
This is the crux of the matter - figura signifies essentially an intrinsic, inextricable relationship between the Old and the New Testaments. Historically and theologically, there were two well-defined schools in early Christianity regarding the right interpretation of the Hebrew Bible. The Alexandrian allegorical school, which was influenced by the thought of the Hellenistic Jewish world in Alexandria in which Philo and others viewed the Bible in Platonic terms as essentially an allegory, which was later Christianized by Origen Adamantius of Alexandria in the third century, and the figural school of Tertullian and Augustine. Yet, while allegorization "devalues the relevance of the historical record" of the Hebrew Bible and hence its value as the history and the laws of the Jewish people, figura, in contrast, through the figural, typological interpretation of history, which is the essence of figura according to Auerbach, rather keeps and preserves it:

Figural interpretation establishes a connection between two events or persons, the first of which signifies not only itself but also the second, while the second encompasses or fulfills the first. The two poles of the figure are separate in time, but both, being real events or figures, are within time, within the stream of historical life ([21], p. 53).

Figural interpretation thus connects two events or persons in historical time; the first, the type, signifies itself and the second, while the second, the antitype, fulfils the first, or the type. In other words,

figura is something real and historical which announces something else that is also real andhistorical.

The relationship between the two is similarity ([21], p. 29).

Later on in Mimesis, Auerbach elaborated this point, claiming that the "figural interpretation of history" implies "that every occurrence, in all its everyday reality, is simultaneously a part in a world-historical context through which each part is related to every other, and thus is likewise to be regarded as being of all times or above all time [35]."

These contentions, it should be stressed, are not merely philological semantic ones, but rather, ideological ontological in their nature, since, in the hands of Auerbach, they established the intrinsic, inextricable connections between the Old and the New Testament. The Christian interpreters thus viewed 'the relationship between the earlier and latter events as 'genetic' and 'causal,' as willed by God and therefore 'providential' [36]." As Auerbach constantly strove to show, "Moses and Christ" are "related as figure and fulfillment" ([21], p. 34). In the same vein, Adam, Moses, Joshua, and David in the Old Testament are all prefigurations of Christ in his earthly mission. Likewise, Eve is a figure of Ecclesiae and Passover is a figure Christ - the wine a figure of his blood and the bread of his body ([21], pp. 27-9, 31-2). Thus Bishop Eucherius of Lyon wrote in the fifth century: "The intention of the Old Testament is to point to the New by figures and prophecies; that of the New to kindle the minds of men to the glory of eternal beatitude" ([21], p. 44). Later on in Mimesis Auerbach elaborated on this theme, claiming the Old Testament's "episodes are interpreted as figures or phenomenal prophecies" [37], arguing that God is a "supratemporal figural conception;" hence in the Mystère d'Adam of the latter part of the twelfth century He "is called figura" and "figura salvatoris" [38].

Ultimately, according to Auerbach, the aim of figural interpretation "was to show that the persons and events of the Old Testament were prefigurations of the New Testament and its history of salvation" ([21], p. 30). Figural, typological historical interpretation was based on vertical structure, or a providential design, while traditional classical chronological historical interpretations 
were based on horizontal succession. Seeing that figural interpretation "asserted both the historical reality of the Old and the New Testaments and also their providential connectedness" [39], the credibility and validity of the Old Testament is thus fully asserted and its authority fully assured against the premises of Aryan philology. In other words, "typological system of exegesis, expounded philologically in 'Figura,' actually contains a philosophy of history [40]." Humanist philology thus denotes historicism, or humanist history in Auerbach's mind and vice versa. Evidently, one can find here the main reason why Auerbach emphasized repeatedly the dominance and predominance of figure in the life and thought of the early church and medieval history up through the eighteenth century [41]. Thus he argued:

The difference between Tertullian's more historical and realistic interpretation and Origen's ethical, allegorical approach reflects a current conflict ... one party strove to transform the events of the New and still more of the Old Testament into purely spiritual happenings, to 'spirit away' their historical character- the other wished to preserved the full historicity of the Scriptures along with the deeper meaning. In the West the latter tendency was victorious ([21], p. 36. Emphasis added).

The triumph of figura in Patristic literature began with Tertullian in the third century and it reached its hegemonic culmination in the fourth century with Augustine. Both alike strove to reconcile the Old with the New Testament, claiming both parts of the Bible are the work of God. Figura thus became the foundation of the Christian conception of reality and, hence, of history. More specifically, figuralism or typology "originated in early Christian efforts to show that Jesus Christ was indeed the Messiah and had fulfilled Jewish prophecies, by retrospectively explaining the Hebrew Bible as the 'Old' of the 'New Testament' [42]." For example, "Joshua of the Old Testament serves as a figure for Jesus, and Jesus represents a fulfillment or completion of Joshua [43]." In sum, both parts of the Bible are essentially the work of God, an important contention Auerbach pressed against the premises of Aryan philology.

Historically, "figural interpretation was of great practical use for the [Christian] mission of the fourth and the following centuries," including of course, Auerbach noted with sheer irony, the conversion of the various German barbaric tribes ([21], p. 43). Furthermore, being a unique "interpretation of history" (([21], p. 57), figural interpretation determined for many centuries the Christian sense of time and vision of history, "or to put it more completely, the figural view of history was widespread and deeply influential up to the Middle Ages and beyond" ([21], p. 60). From the "fourth century on, the usage of the word figura and the method of interpretation connected with it are fully developed in nearly all the Latin Church writers," and since then, continues Auerbach, "in most European countries figural interpretation was active up to the eighteenth century," or the Age of Enlightenment ([21], pp. 34, 61). This was, in sum, Auerbach's response to Aryan philology's elimination of the Old Testament from the marrow of the Christian canon and the origins of Western civilization. More specifically, figural interpretation of reality "asserted that Jewish laws, customs, derivations, and philosophies were intrinsic-and inseparable - part of Western culture [44]."

Evidently, for Auerbach, figural realism, or the figural view of reality, is based on the overall figural interpretation of history. In this unique figural view: 
history, with all its concrete force, remains forever a figure, cloaked and needful of interpretation. In this light the history of no epoch ever has the practical self-sufficiency which, from the standpoint both of primitive man and of modern science, resides in the accomplished fact; all history, rather remains open and questionable, points to something still concealed, and the tentativeness of events in the figural interpretation is fundamentally different from the tentativeness of events in the modern view of historical development. In the modern view, a provisional event is treated as a step in an unbroken horizontal process; in the figural system the interpretation is always sought from above; events are considered not in their unbroken relationship to one another, but torn apart, individually, each in relation to something other that is promised and not yet present.

Whereas in the modern view, the event is always self-sufficient and secure, while the interpretation is fundamentally incomplete, in the figural interpretation the fact is subordinated to an interpretation which is fully secured to begin with: the event is enacted according to an ideal model which is a prototype situated in the future and thus far only promised. ([21], pp. 58-9. Emphasis added)

We quote this passage at length because Auerbach will later make "needful of interpretation" central to his distinction between the Homeric and the Hebrew biblical style in the first chapter of Mimesis. In this book, the figural interpretation of history reached its apotheosis in Dante and after him it declined. Dante thus signified a climax of the figural interpretation in the Middle Ages. Later on, the French realist novels of the nineteenth century constituted yet another apotheosis in the representation of reality, but this time without the figural interpretation of history.

It should be noted, however, that the distinction Auerbach made between allegoria and figura in his philological enterprise has no factual, historical basis at all. In fact, according to Gellrich, rather "allegory eventually became the conventional category in medieval exegesis for describing the prefiguring characteristics of the Old Testament that Auerbach reserves for figura [45]." Likewise, Brian Stock argues that Auerbach's "obvious weakness lay in the field of allegory," namely his contention that figura and not allegory became the dominant mode in Western culture [46]. In view of these critical contentions, we may suggest that Auerbach's idiosyncratic distinction is rather an ideological and not solely philological one.

Auerbach's goal was to show that although figura originated "in pagan antiquity" it was uniquely developed by "the Church Fathers" into a system of singular, figural historical interpretation, which "was of the greatest historical importance." ([21], pp. 27-8) In its unique Judaeo-Christian usage and conception, Auerbach explained in Mimesis, figura is an Ansatzpunkt, thus introducing "an entirely new and alien element into the antique conception of history [47]." But as some have convincingly argued, "typology is another name for figura and scholars have long been aware that the rudiments of typology are discernable in the Aeneid," or in pagan, classical culture. For example, "Aeneas prefigures the emperor Augustus; when he is with Cleopatra he prefigures Mark Anthony; Dido prefigures Cleopatra. Note that all this is figura, not allegoria, according to Auerbach's distinction of terms [48]."

Yet, if the above is right about the use of figura in the pagan, classical world, this is not quite so regarding Auerbach's apocalyptic and eschatological notion of figura. For him, figura essentially denotes an important apocalyptic and eschatological dimension in sacred, providential history, thus 
unquestionably establishing an inextricable link between the Old and the New Testament. And there is no apocalyptic or eschatological dimension when we say that Aeneas prefigures the emperor Augustus, but it is rather clearly the case with regarding "Moses and Christ," since they are "related as figure and fulfillment," ([21], p. 34) and Christ's First and Second Coming are the most decisive apocalyptic and eschatological events in the sacred history of salvation and redemption. Accordingly, Auerbach argued that figura introduced a crucial point of semantic departure, an Ansatzpunkt, from the classical to the early Christian world or "an entirely new and alien element into the antique conception of history [49]."

\section{Meaning and Significance of Auerbach's "Figura"}

Our goal here of course is not to refute the credibility and validity of Auerbach's thesis about figura, but ultimately to understand it. Why, then, did Auerbach insist on using this wrong and unwarranted distinction between figura and allegoria? The answer is clear: he strove to combat Aryan philology's rejection and exclusion of the Hebrew Bible. "Figura" then is "concerned predominantly with the Christian departure from classical use of figura in rhetoric and allegory." The details of this distinction and its validity should no detain us here, but suffice it to say that for Auerbach, figura is a clear and important instance of "Ansatzpunkt," a crucial point of departure which reveals the separation between forms and attitudes in the classical and Christian worlds [50]. The predominance of figura in Christian thought, according to Auerbach, served him well in his attempt to counter the decanonization of the Old Testament and hence its exclusion from the history of Western civilization. For, as Auerbach claimed, figura signified the relationship between two equally real persons, events, circumstances, etc. Now, if indeed he could prove that figural interpretation became predominant mainly in early Christianity, and not earlier in the pagan, classical world in which allegory was the dominant mode, then he could establish that a unique and indeed inseparable relationship existed from the very beginning between the Jewish and the Christian Bible. Philology, then, was essential to the ideological struggles and controversies in Nazi Germany. This is one of the main thrusts behind Auerbach's "Figura."

In contrast to figura, then, which preserved the historicity of the Old Testament, allegory endangered the validity and credibility of the Jewish Bible. Auerbach therefore associated "the historicity of recorded events with the figuring stories about the Hebrew Bible." Thus, although the "Hebraic narratives have historicity," they are "in danger of evaporating into mere 'signs' by the allegorizing intention of Hellenic form of thought." For in contrast to figura, Auerbach argued, allegory "disregarded" the "concrete, historical reality of the people and events in Old and New Testament narrative" (Emphasis added). As Gellrich has observed,

the preference for figura and the disapproval of allegory are recto and verso of a single attitude, an inclination to conserve the specific contribution of the Hebrews to the New Testament and to the contour of history that exfoliated from it in the Western Middle Ages [51].

Assuming that Gellrich is correct in his interpretation, we would like pose another question: why did Auerbach prefer the figural interpretation of reality over the allegorical one? And against whom was he trying "to conserve the specific contribution of the Hebrews to the New Testament"? Our answer is that he was trying to establish to the utmost the inseparable and inextricable 
relationship between the Old and the New Testament in contrast to Aryan philology. Auerbach explained that in the past, figural interpretation "had grown out of a definite historical situation, the Christian break with Judaism and the Christian mission among the Gentiles" ([21], p. 56). Yet now, in Nazi Germany during the 1930s, and in a clear twist of historical irony, Aryan philology was leading rather to an unprecedented total break with Judaism, this time by severing the ties not only with national history of the Jews but also with the figural interpretation of history, which is the heart of Christian sense of time and vision of history. Plainly, the price of severing ties with the Old Testament would be indeed very high and fatal in terms of the very essence of the Christian faith, namely Christianity would lose "its conception of providential history" ([21], 52), the basis of which was found essentially in figural interpretation. This was one of the gravest ramifications of Aryan philology.

The Church Fathers, explains Auerbach, tended indeed to "often justify the figural interpretation on the basis of certain passages in early Christian writings, mostly from the Pauline Epistles" ([21], p. 49). These passages sought "to strip the Old Testament of its normative character and show that it is merely a shadow of things to come" ([21], p. 50). In other words, the Old Testament in Paul's figural interpretation ceased to be "a book of the law and history of Israel and became from beginning to end a promise and prefiguration of Christ." Yet, as Auerbach emphasized, what the Old Testament lost "as a book of national history, it gained in concrete dramatic actuality" ([21], p. 51). Or more specifically, as Auerbach wrote later in Mimesis,

The Old Testament was played down as a popular history and as the code of the Jewish people and assumed the appearance of a series of 'figures,' that is of prophetic announcements and anticipation of the coming of Jesus and the concomitant events [52].

Thus, a major semantic turning-point, Ansatzpunkt, took place with the rise of the figural interpretation of history: "The total content of the sacred writings was placed in an exegetic context which often removed the thing told very far from its sensory based," or its immediate concrete historical context [53]. Subsequently, for Auerbach, "figural interpretation introduced by Paul when seeking to convert the Gentiles" acquires the "most fundamental consequences in the story that Mimesis tells [54]." Or as Auerbach wrote in Mimesis: "Paul and the Church Fathers reinterpreted the entire Jewish tradition as a succession of future prognosticating the appearance of Christ, and assigned the Roman Empire its proper place in the divine plan of salvation." For "millennia" this figural interpretation of history "undergoes an incessant and active development with the life of man in Europe [55]."

In contrast to figural interpretation, allegorical interpretation sought rather "to exclude the Old Testament altogether," which meant among other things that "Christianity would necessarily have lost its conception of a providential history, its intrinsic concreteness, and with these no doubt some of its immense persuasive power" ([21], p. 52. Emphasis added). For it is through the figural interpretation of sacred, providential history, based on figura and fulfillment, promise and its realization, from the Old to the New Testament, that Christianity acquired its power and validity hence establishing an inextricable connection between the Hebrew and the Christian Bible. "In the struggle against those who despised the Old Testament and tried to despoil it of its meaning, the figural method again proved its worth" ([21], p. 52. Emphasis added). This historical lesson 
applied not only to early Christianity but to Nazi Germany as well. Thus, although the above words referred to the struggle between the "Judaeo-Christians" and Paul's figural interpretation in early Christianity, Auerbach must have had in mind as well the proponents of Aryan philology in his own time. In other words, his acute awareness of the problem of eliminating the Old Testament in early Christianity may well arisen because of attempts to eliminate the Old Testament in his own time in Nazi Germany.

If Aryan philology strove to eliminate the Old Testament, then ironically, as Auerbach was quick to point out, it was rather the figural interpretation which "changed the Old Testament from a book of the people of Israel into a series of figures of Christ, and the Redemption." And it was rather in this form and in this context, "from which the Jewish history and national character had vanished," that "the Celtic and Germanic peoples, for example, could accept the Old Testament; it was a part of a universal religion of salvation" and necessarily "a universal vision of history" ([21], p. 52. Emphasis added). Readers of "Figura" can clearly see here an historical irony; while Germanic barbaric tribes received the Hebrew Bible in the long process of their Christianization from the fourth to the eighth century, modern German Nazi barbarians excluded and rejected it. Further, it was indeed not until "after the Reformation that Europeans began to regard the Old Testament as a Jewish history and Jewish law" ([21], p. 53). But first, the Old Testament

came to the newly converted people as figura rerum [substantive figure] or phenomenal prophecy, as a prefiguration of Christ, so giving them a basic conception of history, which derived its compelling force from its inseparable bond with faith, and which for almost thousand years remained the only accepted view of history. Consequently, the attitude embodied in the figural interpretation became one of the essential elements of the Christian picture of reality, history, and the concrete world in general" ([21], p. 53. Emphasis added).

One can clearly see in the above quote how humanist philology and ideology closely intertwined in Auerbach's mind. Not only were racist and Anti-Semitic Aryan philology and völkish historiography unwarranted, but it was the Old Testament which provided a sense of time and a vision of history, along with faith, to the Germanic tribes. Admittedly, only in exile and definitely not in Nazi Germany, could Auerbach write these words. Ironically, then, exile has its advantages and blessings too, or its "pleasures" and its "positive things [56]." An additional example to this sad irony can be seen in Auerbach's words that "it is quite possible that" Mimesis "owes its existence" to "the lack of a rich and specialized library. If it had been possible for me to acquaint myself with all the work that has been done on so many subjects, it might never have reached the point of writing [57]." Likewise, being in exile and out of the reach of Nazi authorities in Istanbul, Auerbach could now write in plain words about the German tribes and the transformation of the German Reformation without fear and trembling. "Virtue made of necessity has seldom been better exemplified than by Auerbach in his expulsion from his homeland [58]."

All this is crucially important, of course, not only to a discussion of "Figura" as an example of a philological Ansatzpunkt in general, but also to the Ansatzpunkt in Auerbach's philological enterprise in particular, namely his struggle against Aryan philology. "Turning a point of momentous cultural change upon a pivot of syntax (along with its meaning of course) was an art he fashioned for himself." This is more than clear in "Figura" in which he revealed "the great insight 
of his life," namely, figural interpretation, or the view "that all interpretation of Christian literature, as well as exact exegesis, depended on an assumed and traditional Christian doctrine that the New Testament is elaborately and fully an historical and typological fulfillment of the Old [59]." In other words, "Figura" decisively influenced the content and form of Mimesis: "the style of the Hebrew narrative has a definite place in Auerbach's historicism and he linked it to figura in his subsequent work, principally the study of Western realism in Mimesis." Hence in the first chapter in Mimesis, Auerbach set forth his famous claim "for the historicity in the Hebraic style by contrasting Old Testament narrative with the Hellenic style of the Homeric poems [60]."

We would like however to offer a different interpretation about this important link between "Figura" and Mimesis as well as the use of the style of the Hebrew narrative in the later work. Mimesis, Auerbach's mission in exile, was written as a grand tour of the Western humanist tradition in order to combat Nazism and Aryan philology. The question in his mind therefore was not only of "historicism" or "figural interpretation," which were very important issues in Auerbach's philological philosophy, but also his struggle against Nazi barbarism. Hence Auerbach used his findings in "Figura," about the style of the Hebrew narrative and the figural interpretation of history in Mimesis as well. We may say therefore that the essay "Figura" is a figura of Mimesis, or conversely, that Mimesis is the fulfillment and realization of "Figura."

That "Figura" was an important Ansatzpunkt in Auerbach's overall philological studies can be clearly seen also with regard to his first book on Dante. Auerbach informs us in "Figura," that Dante's Comedy is "based on figural conception." Yet, when writing his book on Dante in the late 1920s, continues Auerbach, "I lacked a solid historical grounding for this view." However, after developing, following the Nazi revolution of 1933, the historical meaning and philological significance of figura with its unique form and content in Western culture, he argues "I have now found the historical grounding; it is precisely the figural interpretation of reality" which "was the dominant view in the European Middle Ages" ([21], pp. 71-72). Later on, in Mimesis, Auerbach followed this point, claiming that the figural interpretation of reality "for millennia" underwent "an incessant and active development with the life of man in Europe [61]." Accordingly, "the earthly event is a prophecy or figura of a part of a whole divine reality that will enact in the future" ([21], pp. 71-72). "Figura" was thus clear evidence not only of a philological Ansatzpunkt but also of a historical and ideological transformation in Auerbach's thinking.

Evidence for this assertion can be clearly seen in the radically different views of Auerbach with regard of Beatrice in his first book on Dante and in his "Figura," in which Beatrice became a great, revelatory, prophetic figura according to the apocalyptic and eschatological dimensions inherent in this concept. In the book on Dante, Auerbach argued that Beatrice "is an allegorical figure" [62], but later in "Figura," Beatrice was radically transformed into "revelation incarnate," a figura who "finds the only possible salvation" for Dante ([21], pp. 72-73). Hence, "she is figura or idolo Christi" ([21], p. 75). Further, "Beatrice is not fiction. There really was a little girl in red dress whom Dante met, at the age of 9, in the house of Portinari. This Beatrice (and unlike the seducing idols of courtly love) figured the beauty and the goodness of God [63]." "Figura" thus constituted an important philological, historical and ideological, Ansatzpunkt in the development of Auerbach's philological philosophical thought.

Auerbach concluded "Figura" with an important statement: 
Our purpose was to show how on the basis of its semantic development a word may grow into a historical situation and give rise to structures that will be effective for many centuries. The historical situation that drove St. Paul to preach among the gentiles developed figural interpretation and prepared it for the influence it was to exert in late antiquity and the Middle Ages ([21], p. 76. Emphasis added).

We should read these words, especially the singular role attached here to St. Paul, in the gloomy, anti-Semitic context of Nazi Germany. "Figura" was published in 1938, and a year later, in May 1939, the "Institute for the Study and Eradication of the Jewish Influence on German Church Life" was established. At the opening ceremony of the Institute, its scientific director Walter Grundmann declared that the "elimination of Jewish influence on German life is the urgent and fundamental question of the present German religious situation [64]." The Institute was, of course, only the culmination of a long process in Germany, especially after the Nazi Revolution of 1933, in which Aryan philology gained the upper hand.

How a "word" grew "into a historical situation" was fundamental to Auerbach's unique philological way of interpretation. The word is the source of realism because "on the basis of its semantic development a word may grow into a historical situation and give rise to structures that will be effective for many centuries" ([21], p. 76). This approach stood at the foundation of his singular philosophy of realism that appeared later in Mimesis. Indeed, this central point-from "a word ... into historical situation" - can be equally applied not only to the concept of "Figura," which grew from a word into an important magisterial literary, historical interpretation, but also to Mimesis, which too was developed from a word into a majestic history of Western humanist literature.

\section{Conclusions}

When Auerbach concluded "Figura" and eventually saw its publication in 1938, he must have felt great relief. Against the racist premises of Aryan philology he was able finally to prove the centrality, as well as the validity and credibility, of the Old Testament to the history of Christianity in particular and to Western civilization in general. But this achievement was marred by the gathering clouds and the growing rattle of the drums of war over his beloved Europe. Soon World War II broke out and "Figura," too narrow in its form and content in being only a response to the German crisis of philology, was no longer deemed suitable in his eyes to meeting the challenge of this tremendous historical moment with its severe ramifications for the fate of Western culture and civilization. Accordingly, by 1942, the most crucial year in World War II, Auerbach found his unique voice, his grand singular mission to save the humanist face of Europe. In "Figura," he dealt with an important crisis, the crisis of German philology and its epitome in Aryan philology, clearly a narrow problem in view of the magnanimity and horrors of World War II. Now in 1942, the year of the battles of Stalingrad, Midway and El Alamein, he was more than convinced that "Figura" was no longer an adequate response in view of the evil threatening the humanist soul of Western civilization. No wonder, then, that at the nadir of the war, in 1942, Auerbach had a revelation, an epiphany in Istanbul, which led him to write Mimesis. In this broad historical and philological context, we can say again, in Auerbach's terms, that the essay "Figura" is a figura of Mimesis, or conversely, that Mimesis is the fulfillment and realization of "Figura." 
Auerbach's philological philosophical system is based on an analysis of a major, decisive philological turning-point in history, or "semantic development," as Auerbach stated in "Figura" ([21], p. 76). This essay is indeed a clear example of that unique philological way of inquiry. Its ideological and philological origins lay essentially in the reaction to Aryan philology, which signified a radical major important turning-point in literary history, namely from humanist to racial, Aryan philology. Hence, Auerbach enlisted all his philological powers to refute it. Mimesis, on the other hand, is based not on one "semantic development" only but rather on a series of major, decisive philological turning-points in Western literary history. The tremendous existential risk posed to Western humanist civilization with World War II demanded from him nothing less than a major study which encompassed the whole history of the West. "Figura" was directed against a crisis within German philology, while Mimesis was directed against the crisis of Western culture and civilization as a whole. Thus, it is radically different from "Figura," being a long survey of European humanist literary civilization spanning three millennia and eight languages from, as Auerbach significantly stated, "Genesis all the way to Virginia Woolf" [65]. These are revealing words, which clearly defined not only the content and form of Mimesis, but most importantly its ideological, philological agenda, or Auerbach's struggle against Nazi barbarism and un-humanism.

\section{References and Notes}

1. Erich Auerbach. "Introduction: Purpose and Method." In Literary History \& Its Public in Late Latin Antiquity and in the Middle Ages. Princeton: Princeton Univ. Press, 1965 [1958], p. 6.

2. Ibid., p. 6. For Auerbach's life and thought, see: Karlheinz Barck, and Martin Treml (Hrsg.). Erich Auerbach: Geschichte und Aktualität eines europäischen Philologen. Kulturverlag Kadmos. Berlin: Kadmos 2007, and Frank-Rutger Hausmann. "Vom Strudel der Ereignisse verschlungen." Deutsche Romanistik im 'Dritten Reich' (2008).

3. There were many crises in Germany during the first half of the twentieth century; the crisis of ideology, of politics, of theology, of historicism, of culture and of philology-with which we are dealing here-and more. For studies dealing with these various crises, see George L. Mosse. The Crisis of German Ideology: Intellectual Origins of the Third Reich. New York: Grosset \& Dunlap, 1964; Fritz Stern. The Politics of Cultural Despair: A Study in the Rise of the Germanic Ideology. Berkeley and Los Angeles: Univ. of California Press, 1961.

4. It should be noted that the German humanistic and philological crisis of the early twentieth century was inextricably connected to the crisis of historicism. According to Michael Holquist, "the crisis of historicism was in effect a crisis in belief. The long three stage descent from A. belief in an absolute god, through, B. a succeeding belief in the absolute of reason, to C. the 19th century loss of faith in any absolute after the Romantic appropriation of Kantian epistemology led to a re-formulation of subjectivity." Holquist in a personal letter to the authors, July 29, 2011. See also Holquist. "The Place of Philology in an age of world literature." Neohelicon. Forthcoming. See also David Weinstein, and Avihu Zakai. Exile and Interpretation: Reinventing European Intellectual History in the Age of Tyranny. Forthcoming. This study contextualizes ideologically and politically Hans Baron, Erich Auerbach, Leo Strauss and Karl Popper's scholarship. 
5. According to William Calin, Auerbach's struggle was not only against Aryanphilology. Since Johann Gottfried von Herder, "the German intellectuals have had a wish-fulfillment passion for everything Greek, with the culmination in Heidegger's notion that there are only two truly philosophical languages: Greek and German. Hitler took the trouble to have his picture taken next to (or in front of) the Acropolis. As I see it, this German model was directed not only against the Jewish Old Testament; it also pushed aside the Latin/Roman and, consequently, repudiated the French and Italian traditions." This may also help to explain "why Auerbach centered on French and, to a lesser extent, Italian." Calin in a letter to the authors, 11 July 2011.

6. Suzanne L. Marchand. German Orientalisn in the Age of Empire: Religion, Race, and Scholarship. New York: Cambridge Univ. Press, 2009, p. 316.

7. Erich Auerbach. "Philology and Weltliteratur." The Centennial Review 13, Winter 1969, 4.

8. Alfred Rosenberg as quoted by Peter M. Head. "The Nazi Quest for an Arian Jesus." Journal for the Study of the Historical Jesus 2 (2004): 69.

9. Susannah Heschel. "Natzifying the Christian theology: Walter Grundmann and the Institute for the Study and Eradication of Jewish Influence on German Church Life." Church History 63 (December 1994): 588. On the German Christian movement, see Doris L. Bergen. Twisted Cross: The German Christian Movement in the Third Reich. Chapel Hill: Univ. of North Carolina Press, 1996; Jack Forstman. Christian Faith in Dark Times: Theological Conflicts in the Shadow of Hitler. Louisville: Westminster, 1992; and Richard Steigmann-Gall's important critical re-evaluation of Nazi ideology in The Holy Reich: Nazi Conception of Christianity, 1919-1945. New York: Cambridge Univ. Press, 2003.

10. Waldmar Gurian. Hitler and the Christians. New York: Sheed \& Ward, 1936, p. 68.

11. Victoria Barnett. For the Soul of the People: Protestant Protest against Hitler. New York: Oxford Univ. Press, 1992, pp. 34-35.

12. “GERMANY: New Heathenism.” Time, 27 November 1933. http://www.time.com/time/ magazine/article/0,9171,746354,00.html.

13. Mordecai Paldiel. Churches and the Holocaust: Unholy Teaching, Good Samaritans, and Reconciliation. Jersey City: Ktav, 2006, p. 33.

14. See note\# 12.

15. Pamela Eisenbaum. "The Christian Canon and the Problem of Antisemitism." In A Shadow of Glory: Reading the New Testament after the Holocaust, edited by Tod Linafelt. New York: Routledge, 2002, 11. See also E. C. Helmreich. The German Churches under Hitler. Detroit: Wayne State Univ. Press, 1979.

16. Bergen. Twisted Cross, 21. For an important analysis of three distinguished, scholarly, and influential theologians who greeted the rise of Hitler with great enthusiasm and support, see Robert P. Ericksen. Theologians Under Hitler: Gerhard Kittel, Paul Althaus and Emanuel Hirsch. New Haven: Yale Univ. Press, 1985.

17. Vassilis Lambropoulos. The Rise of Eurocentrism: Anatomy of Interpretation. Princeton: Princeton Univ. Press, 1993, p. 11.

18. Lowry Nelson, Jr. "Erich Auerbach: Memoir of a Scholar.” Yale Review 69 (1979-80): 316. 
19. René Wellek. "Erich Auerbach (1892-1957). Comparative Literature 10 (1958): 94. See also, Wellek. "Review: Auerbach's Special Realism." Kenyon Review 16, Spring 1954, 299-307.

20. Auerbach. Mimesis: The Representation of Reality on Western Literature, translated by Willard R. Trask. Princeton: Princeton Univ. Press, [1953] 2003, p. 14.

21. Erich Auerbach. "Figura." 1938, In Auerbach, Scenes from the Drama of European Literature. Gloucester, Mass.: Peter Smith, 1973. All references in the text to "Figura" are to this edition.

22. Jesse M. Gellrich. "Figura, Allegory, and the Question of History." In Literary History and the Challenge of Philology: The Legacy of Erich Auerbach, edited by Seth Lerer. Stanford: Stanford Univ. Press, 1996, 111. According to Martin Elsky in a personal letter to the authors, July 1, 2011, "Gellrich is right about Auerbach starting 'Figura' in Marburg just before leaving for Istanbul. I believe the evidence appears in Auerbach's letter to Karl Vossler, 15 September 1935. Auerbach is considering Spitzer's proposal that he replace him in Istanbul when Spitzer leaves for Hopkins, though he's still hoping for a possibilities in Europe. Towards the end of the letter he remarks: 'Concerning my own work on realism, that will have to wait a while, there may still be more to get out of it.' This is usually interpreted as a reference to his start on 'Figura,' begun that is on the eve of his move to Istanbul, where it was completed. He comments on the importance of the essay in a letter from Istanbul to his student in Marburg, Martin Hellweg, 22 May 1939. Both letters appeared in a translation in "Scholarship in the Age of Extremes," PMLA 2007, 742ff. In the above mentioned letter to Vossler, Auerbach wrote that "my work of realism" will "have to wait a while; there may still be more to get out of it." See Auerbach. "Letter to Dr. Karl Vossler." 15 September 1935, In "Scholarship in the Age of Extremes." 747.

23. Gellrich. "Figura, Allegory, and the Question of History." 111.

24. Hayden White. "Auerbach's Literary History: Figural Causation and Modernist Historicism." In Literary History and the Challenge of Philology: The Legacy of Erich Auerbach, edited by Seth Lerer. Stanford: Stanford Univ. Press, 1996, p. 125. Note that Auerbach rather rejected the notion of "figural causation," claiming in Mimesis that "figural interpretation" is "established between two events which are linked neither temporally nor causally-a connection which is impossible to establish by reason in the horizontal dimension." See Mimesis, p. 73.

25. Louis G. Kelley. "Auerbach, Erich." In Encyclopedia of Contemporary Literary Theory: Approaches, Scholars, Terms, edited by I. R. Makaryk. Toronto: Univ. of Toronto Press, 1993, p. 235: "In an absolute sense there is little new in what Auerbach writes about figura: any theologian who knows his Aquinas or medieval mystics will still find no surprises in Auerbach's exposition, except that Auerbach's wholesale application of the idea to literature, and to Dante in particular, would take him aback."

26. Galili Shahar. “Auerbach's Scars: Judaism and the Question of Literature.” Jewish Quarterly Review 101, Fall 2011, 611.

27. Erich Auerbach. "Epilegomena to Mimesis." 1953, In Mimesis, p. 568. Hegel greatly influenced Auerbach's formation of the notion of figura. See Frank R. Ankermist. "Why Realism? Auerbach on the Representation of Reality." Poetic Today 20, Spring 1999, 62, n. 18 . 
28. A. D. Nuttall. “Auerbach's Mimesis.” Essays in criticism 54 (2004): 68.

29. Carl Landauer. “Mimesis' and Erich Auerbach's Self-Mythologizing.” German Studies Review 11, February 1988, 90.

30. See ref. 20, p. 74.

31. Gellrich. "Figura, Allegory, and the Question of History." 108.

32. Claus Uhlig. “Auerbach's 'Hidden'? Theory of History." In Literary History and the Challenge of Philology: The Legacy of Erich Auerbach, edited by Seth Lerer. Stanford: Stanford Univ. Press, 1996, 47.

33. Gellrich. "Figura, Allegory, and the Question of History." 107-9. For Auerbach's concept of Ansatzpunkt, see Said, Beginnings: Intention and Method. New York: Basic Books, 1975.

34. The quote from Augustine appeared in a letter to the authors from Professor Jesse M. Gellrich, July 5, 2011.

35. See ref. 20, p. 156.

36. White. “Auerbach's Literary History.” p. 128.

37. See ref. 20, p. 73.

38. Ibid., pp. 156-7.

39. Lowry Nelson, Jr. "Erich Auerbach: Memoir of a Scholar." Yale Review 69 (1979-80): 316.

40. Uhlig. "Auerbach's 'Hidden'? Theory of History," 47.

41. For Auerbach, the Enlightenment of the eighteenth century, with its de-sacralization and disenchantment of the world, put an end to traditional figural interpretation. For the Enlightenment's struggle against the Christian re-enchantment of the world, see Avihu Zakai. Jonathan Edwards's Philosophy of History: The Re-Enchantment of the World in the Age of Enlightenment. Princeton: Princeton Univ. Press, 2003; and Jonathan Edwards's Philosophy of Nature: The Re-Enchantment of the World in the Age of Scientific Reasoning. London: T\&T Clark, 2010.

42. Vassilis Lambropoulos. The Rise of Eurocentrism: Anatomy of Interpretation. Princeton: Princeton Univ. Press, 1993, p. 11.

43. Landauer. "'Mimesis' and Erich Auerbach's Self-Mythologizing.” 90.

44. Geoffrey Green. Literary Criticism and the Structure of History: Erich Auerbach and Leo Spitzer. Lincoln: University of Nebraska Press, 1982, p. 35.

45. See note \# 22, pp. 108-9.

46. Brian Stock. "Literary Realism in the Later Ancient period." In Literary History and the Challenge of Philology: The Legacy of Erich Auerbach, edited by Seth Lerer. Stanford: Stanford Univ. Press, 1996, p. 144.

47. See note \#20, p. 73.

48. See ref. 28, p. 71.

49. See ref. 20, p. 73.

50. Gellrich.“Figura, Allegory, and the Question of History.” pp. 107-9.

51. Ibid., p. 110.

52. See ref. 20, p. 48.

53. Ibid., p. 48. 
54. Michael Holquist. "The Last European: Erich Auerbach as Precursor in the History of Cultural Criticism." Modern Language Quarterly 54 (1993): 380.

55. See ref. 20, p. 16.

56. Edward W. Said. "Introduction: Secular Criticism." In Said, The Word, The Text, and the Critic. Cambridge, Mass.: Harvard Univ. Press, 1983, p. 8. See also Said. "Reflections on Exile." 1984, in Said, Reflections on Exile and Other Essays. Cambridge, Mass.: Harvard Univ. Press, 2000, p. 186.

57. Auerbach. "Epilogue," In Mimesis, p. 557.

58. Nelson. "Erich Auerbach." p. 319.

59. Ibid., pp. 314-5.

60. Gellrich. "Figura, Allegory, and the Question of History." 110. An excellent analysis of Auerbach's first chapter of Mimesis, "Odysseus Scare," can be found James I. Porter. "Erich Auerbach and the Judaising of Philology." Critical Inquiry 35, Autumn 2008, 115-47.

61. See ref. 20, p. 16.

62. Auerbach. Dante: Poet of the Secular World. Chicago: University of Chicago Press, 1961 [1929], p. 60.

63. See ref. 28, p. 69.

64. Ibid., p. 69.

65. Auerbach. "Appendix: 'Epilegomena to Mimesis.'” p. 563. 
Reprinted from Religions. Cite as: Gordon, A.; Greenberg, U. The City of Man, European Émigrés, and the Genesis of Postwar Conservative Thought. Religions 2012, 3, 681-698.

Article

\title{
The City of Man, European Émigrés, and the Genesis of Postwar Conservative Thought
}

\author{
Adi Gordon ${ }^{1, *}$ and Udi Greenberg ${ }^{2}$ \\ 1 Amherst College, Amherst, MA 01002, USA \\ 2 Department of History, Dartmouth College, Hanover, NH 03755, USA; \\ E-Mail: udi.greenberg@dartmouth.edu \\ * Author to whom correspondence should be addressed; E-Mail: adi.gordon@uc.edu.
}

Received: 5 June 2012; in revised form: 14 July 2012 / Accepted: 16 July 2012 /

Published: 6 August 2012

\begin{abstract}
This article explores the forgotten manifesto The City of Man: A Declaration on World Democracy, which was composed in 1940 by a group of prominent American and European anti-isolationist intellectuals, including Thomas Mann, Reinhold Niebuhr, and Hermann Broch. Written in response to the victories of Nazi Germany, the manifesto declared that the United States had a new global responsibility not only to lead the war against fascism and Marxism, but also to establish a global order of peace and democracy under U.S. hegemony. Moreover, the authors of the manifesto claimed that such an order would have to be based on the rejuvenation of conservative values; in their view, the collapse of Western democracies under the weight of totalitarian aggression was the consequence of inner moral and intellectual degeneration. The City of Man therefore called on the United States to lead the spiritual transformation of democracy into a modern political religion, which would bring about the intellectual and political unity of humanity under one state and one creed. This article analyzes the manifesto as a rare window into the difficulty intellectuals faced as they tried to conceptualize the totalitarian challenge prior to the United States' entry into the war. Moreover, it claims that The City of Man expressed the emergence of postwar conservatism and Cold War ideology, as well as the unique role played by European émigrés in this process.
\end{abstract}

Keywords: Americanism; European émigrés; anti-isolationism; totalitarianism; world federalism; conservatism; democratization; Judeo-Christian; Pax Americana; Cold War ideology 


\section{Introduction}

The heroic evacuation of Dunkirk, marking the imminent fall of France and with it the rest of Europe, began on Sunday, May 26, 1940. On that bleak weekend, in a gray and rainy Atlantic City, a group of anti-isolationist intellectuals gathered to compose a manifesto geared to guide the United States' path now that Europe's fate had been sealed. "The entire Old World," they wrote, "where our forefathers lie and whence all life and light came to us, sinks in a catastrophe unequaled in the record of man" [1]. The members of the group were alarmed that Americans had failed to grasp the full significance of Europe's demise, the true nature of the totalitarian threat, and the new responsibility that the war in Europe bestowed upon the United States. They believed that the country was mired in internal conflict and degenerate defeatism, which prevented it from realizing its duty to enter the war. The mood at the meeting was decidedly gloomy [2,3].

The declaration that ultimately emerged from this meeting, however, was as optimistic as it was ambitious. The authors assumed that the United States' entry into the war was both imminent and inevitable, for "[w]ar, declared or undeclared, actual or virtual, has chosen us" [4]. Moreover, the declaration went beyond other voices that supported U.S. intervention in the European war, adopting a radical proposal calling upon the United States to prepare for its inevitable goal of constructing a new post-war order. The United States, the writers claimed, had no choice but boldly to assume global leadership and create a universal state. Through its new found hegemony, it would establish a global order of peace, democracy, and prosperity. Part of the declaration, in fact, included a detailed program for the construction of this state's institutions. Yet the element that the writers considered most important was the drafting of a spiritual program, designed to guide the United States in this new global order. According to the authors, it was only by accepting the spiritual legacy of the collapsing Europe, "whence all life and light came," and, more specifically, by bringing about a religious revival, that the United States could hope to succeed in its mission. Invoking Augustine's The City of God, they called their manifesto The City of Man: A Declaration on World Democracy, and they themselves embraced the name "The Committee on Europe" or the "Committee of Fifteen." In the authors' minds, the manifesto was to serve as a practical blueprint for policymakers, and the Committee as their advisors.

If the manifesto's radical proposal was unique, the composition of the "Committee" was exceptional. The individuals who gathered in Atlantic City included both prominent intellectuals of the European migration and North American thinkers, a rare example of such cooperation in the period's intellectual landscape. Indeed, it was this diverse background that formed the basis for their ambitious goal of fusing "European" and "American" visions to produce a roadmap for a new global order. The driving force behind the Declaration's genesis was Giuseppe Antonio Borgese, the Italian literary critic and journalist. Under his energetic stewardship, the Committee was joined by Thomas Mann, the uncrowned leader of the German intellectuals in exile (and Borgese's fatherin-law); the Austrian author Hermann Broch; the renowned scholar of nationalism Hans Kohn, who had only recently abandoned his Zionist and pacifist convictions and left Palestine for the United States in 1934; and the Hungarian ex-politician Oscar Jaszi, who since 1925 had worked as a scholar in the United States. From the United States, participants included the Christian theologian Reinhold Niebuhr; the Harvard political scientist William Yandell Elliott, at the time one of 
President Roosevelt's close advisors; the scholar of urban life Lewis Mumford; and several other journalists and scholars, such as Herbert Agar, Frank Aydelotte, and Dorothy Canfield Fisher.

The attitude adopted by the European émigrés in the group, who were both the initiators of the project and the more active members of the Committee, was peculiar. While most of them had only recently arrived in the United States, often with scant knowledge of their host society, they did not shy away from writing about America's destiny and values for Americans and as Americans. Rather than establishing their authority as "men of the world," as European cultural insiders, they preferred not to be identified as European exiles. Hans Kohn, who was born in Habsburg-era Prague, went so far as to state at this forum that "American political traditions and doctrines had been undermined by the large-scale migration since the [eighteen] eighties from the politically most backward parts of Europe" [5,6]. This, of course, was a problematic case for a central European to make, especially as he purported to explain to Americans what their "American political traditions and doctrines" actually were. Indeed, unlike many renowned members of the German emigration, the European members of the Committee did not make disdainful statements about the reactionary elements in American life [7]. Hence, aware that their core group consisted of "prominent European personalities who have left their native countries and have carried across the ocean their knowledge and their ardor," the Committee strove to create in their group "a majority of American thinkers and scientists" [8].

While The City of Man has been all but forgotten by scholars, the story of its composition represents a crucial moment both in the history of European migration and in the evolution of Cold War thought. By analyzing the text's interpretation of contemporary world politics, its social-political proposals, its religious convictions, and finally its relationship to Augustine's The City of God, this short essay sheds light on two moments of intellectual transition. First, while scholarship on Central-European immigration in the United States has often focused on liberal and Left-leaning circles, the "Committee of Europe" tells the story of a deeply conservative tendency among certain exiles [9-15]. In fact, while some of the manifesto's authors, most notably Hans Kohn and Reinhold Niebuhr, were self-proclaimed liberals, The City of Man represented a conservative moment in their writing [16-18]. The text is replete with classic conservative statements: about the role of the family and private property as the pillars of civilization; the foundational role of Christianity in the establishment of legitimate political order; opposition to large-scale economic planning; and the corruption of traditional values in the era of mass consumption and industrialization [19]. Indeed, while most European conservative thought had been absorbed by 1940 by the authoritarian regimes that emerged in Europe, the manifesto was a rare attempt to reconstitute a conservative, pro-democratic, and firmly anti-Nazi position by redefining both the totalitarian crisis and the role of the United States in the world [20,21]. Studying the themes and evolution of the text thus sheds light on the process of adaptation on the part of conservative thinkers to the new conditions of emigration in the face of rapidly changing international conditions [22-27].

Second, and equally important, the manifesto reflects the transition from the international visions of the 1920s to the hard-headed ideology of the Cold War. On the one hand, The City of Man presents the seeds of Cold War thought; in it, the writers define the United States through its destined role as the vanquisher of totalitarianism and protector of world democracy. Like many 
early Cold War texts, it envisions that the United States' heroic fight against Fascism — which in 1940 was still in the realm of the authors' fantasy — would continue into the future and defeat other forms of totalitarianism, in particular Communism. Yet the manifesto's agenda was also marked by visions of peace, religion, and democracy that had evolved in earlier contexts and in other, European cultures. It reflected conservative and strong utopian impulses that had been formed years before the beginning of the war in Europe. The manifesto was therefore a unique attempt to adjust earlier convictions to new realities. This process, with its tensions and contradictions, generated a variety of programmatic ideas, some of which would be forgotten, while others would continue to resonate beyond the moment of 1938-1940.

\section{Defining the Enemy: Communism, Nazism, and the "Obsessive Myth of the Modern Mind in its Decay"}

While the European authors in the group that gathered in Atlantic City had been observing European politics with alarm for years, it was only in 1939 that they decided to call on the United States to intervene and reform the old continent. Shocked by the Munich Agreement of November 1938, in which the British and French Empires agreed to Hitler's demands and acquiesced in the dismembering of Czechoslovakia, Borgese began to contemplate a proposal for an alternative Western diplomacy. In May 1939 he composed the group's first memorandum, which outlined potential topics of discussion. After months of deliberations, Thomas Mann, Reinhold Niebuhr, and Lewis Mumford joined him in March 1940 in inviting the other members to participate in the official drafting of The City of Man.

The first mission that the group set itself in its manifesto was to define Europe's new regimes, and to explain why their growing power posed a threat not only to Europe, but also to the United States. Yet even though many of the Europeans in the group were refugees from right-wing regimes-Borgese from Fascist Italy, Jaszi from militarist Hungary, Mann from Nazi Germanyone of the main drivers of their declaration was anti-Communism. To the members of the group Communism was a destructive force, a deadly ideology second only to Nazism, which could not co-exist with democracy. In fact, the group's first memorandum constituted not only a protest against the "appeasement" of Nazism in Munich, but also a warning against potential rapprochement between Western powers and the Soviet Union [28]. The memorandum stated that one of the major threats posed to democracy by fascism was that it might force Western countries into a dangerous anti-fascist alliance with the Soviet Union. "If the Western powers," Borgese warned, "perhaps fortified by a more or less ambiguous alliance with Russia, will resist the forthcoming challenges of Nazism and Fascism, a conflagration may ensue with consequences as huge in immediate loss of wealth and human lives as in the probable aftermath of chaotic revolutions" [29]. To these émigrés Communism posed a threat as grave as fascist domination. In this first memorandum, the Committee identified one of the areas on which it hoped to advise statesmen as "the deadlock of economic class warfare" [30].

While the Molotov-Ribbentrop Pact in August 1939 had rendered the authors' fears of a Western alliance with the Soviet Union irrelevant, it spurred them to combat Marxism with greater urgency. The diplomatic earthquake in Europe, in fact, merely intensified their anti-Soviet rhetoric and fear of Soviet expansion. The letter of invitation to the gathering in Atlantic City, for example, 
began by lamenting not only the fall of Poland, but also the fall of Finland to Soviet troops. It discussed "the conversion of Bolshevism... with Nazism... to aggressive expansion" and stressed that the foundations of Europe were plagued not only by "racial rancor," but also by "class-hatred" [31]. Weary of Soviet might, members of the Committee conflated all Marxist thought with Communism, asserting that the former inevitably led to the latter. Capitalist societies, they warned, had to address the revolutionary impulses so widespread among the working class, or else they would disintegrate from within [32].

Most of the manifesto's thrust, however, concerned the threat of Nazism. As much as it was a guide for a future world order, The City of Man was an attempt on the part of conservative European émigrés to provide a definition and analysis of the Nazi present. According to the manifesto, Nazism was the most radical form of nihilism. It was an explosion of brute force, a rejection of all moral codes and of civilization itself. "The barbarians of the early Middle Ages were eager to learn in the school of Christ and Rome," the authors warned. "But nothing is holy to their successors of our day, and the lawlessness of power is their only law" [33]. In the eyes of the Committee, Christians failed to recognize that Nazism was in essence an assault on their own beliefs, and that the two could not co-exist. They vehemently condemned Germany's Christians for supporting Hitler and "celebrating through seven days the triumphs of an Antichrist" [34].

According to The City of Man, Bolshevism and Nazism were twin manifestations of the same process: the response of uprooted masses to modernization, the temptations of modern technology, and weakening traditional ties. In the authors' eyes, the disintegration of such ties and the materialism of urban life left individuals stripped of their dignity and individuality. Under the pressures of modern economic competition, they became members of mass organizations, obedient participants in formless movements. In this analysis, the Communists and Nazis equally directed the masses' blind anger against civilization. In the manifesto's apocalyptic language, "the festering masses... generated volcanic forces, which shatter and rend when seeming accident gives them vent." In these conditions,

The despair of the masses needs only ruthless leadership to become the revolt of the masses. The leadership was provided in the Old World. The emptiness of man's heart was filled with the pride of the conquering hordes or with the slumber of the enslaved herd, and today['s] mass-man, rootless man, has been summoned to the destruction of civilization by which he had been betrayed [35].

To the frustrated masses who felt the meaning draining out of their life, the ruling classes promised a coming age of plenty, with rising standards of living. "Poverty and insecurity remained, but our mechanical prowess, with its millions of gadgets, was the answer to the ancient needs of man" [36]. In such a world, "[t]he sword will again be mightier than the pen, and in carnivals of destruction brute force and wild frenzy will alternate with the lethargy of a declining civilization" [37]. To the authors of the manifesto, Nazism was not merely a form of intense nationalism or imperialism. Rather, like Communism, it contained at its core a nihilist orgy of violence, bereft of values or meaning.

Borgese, Mann, Niebuhr, and the rest of the Committee furthermore agreed that the ideological structures of Marxism and Nazism were such that each could easily lead to the other. Indeed, Nazism inhered "the anarchy $[\ldots]$ of a degenerate socialism [...] which substituted for the idea of 
Justice the scheme of mass-regimentation, with its equality of servitude and its universality of deprivations" [38]. The Committee believed that Germans' acceptance and support of Nazi rule was "the outcome of bleak decades of training in the impotence of class-struggle and class-grudge." This was because both relied on "the fading of all faith and hope except the crude dogma of materialism and the desire for rising standards of living and steadier security." In essence, both the radical Left and radical Right were united in their worship of material comfort, and in utopian visions of prosperity. Pointing to what they saw as ideological similarities between Nazism and Communism, the drafters of the manifesto added that "Stalin, working through from the other end, inevitably reaches Hitler, in the middle of the same darkness" [39].

Moreover, The City of Man claimed that at a deeper level both ideologies were the most radical manifestations of the modern desire for revolution. According to the manifesto, the glorification of revolution was a malaise of modernity, the product of the modern impulse to abandon all traditional bonds and customs. By seeking to produce the classless society or the master race, the Communists and the Nazis ultimately joined hands in completing the process of modernization. "Revolution," the authors lamented, was:

an obsessive myth of the modern mind in its decay... the counterpart of war. It is war itself, with fire and steel, with fraud and terror; nor is there any comforting choice between perpetual revolution as projected by extreme Communism into the infinity of Evil and eternal war as hallowed by Fascism and Nazism in their black masses [40].

In the authors' eyes, Fascism and Communism merged into a single, perverse system, possessing the same spiritual source and, ultimately, developing the same political nature.

By conflating the enemy regimes of Nazism and Communism, the authors of the manifesto were among the first thinkers to discuss the new "theory of totalitarianism." Indeed, they used the "totalitarian" neologism extensively throughout the text. This line of thought, which asserted that both political theories were in fact mere variations on a single, dark manifestation of modernity, would famously emerge as one of the most important terminologies of the Cold War in the West. In 1940, however, such statements were still relatively new in the United States. While political theorists had begun to develop this theory in the 1930s, the works by figures such as Hannah Arendt, Friedrich Hayek and Carl J. Friedrich that would elaborate it most influentially would appear only several years hence [41-45]. The City of Man, therefore, marked one of the first attempts to chart for American audiences the treacherous terrain of global enemies. The manifesto portrayed Europe's revolutionary regimes as destroyers of civilization, and the impending clash with them as inevitable.

\section{3. "The Anarchy of laissez-faire Liberalism": Conservative Thought, Liberalism, and Democracy}

The City of Man's fierce attack of Marxism and Nazism, however, did not mean that its authors embraced the liberal democracies of their time. Quite the contrary, the manifesto included an almost equally aggressive attack on modern liberalism, blaming it for the disasters that had befallen Europe and the world. The charge at the heart of the declaration was that liberal Western democracies were, in fact, neither truly liberal, nor genuinely democratic. If democracy were 
to survive the aggression of totalitarianism, it had to be reimagined and redefined in a conservative key.

According to the manifesto's drafters, it was ultimately liberalism that was the source of contemporary catastrophes. In its glorification of individuality and economic prosperity, liberalism had given birth to the material emptiness of the modern age. The manifesto maintained that " $[\mathrm{t}] \mathrm{he}$ brute force and wild frenzy" of Nazism are "the mongrel product of rugged individualism as carried to utmost efficiency in the anarchy of laissez-faire liberalism, in the exploitation of the masses by competitive capitalism, and of a degenerate Socialism" [46]. It was liberalism, rather than authoritarianism or imperialism that had generated the social and spiritual conditions that eventually led to democracy's demise. Comparing the Nazis to figures of American history, the Declaration maintained that:

The Führer and war-lords of our times, the conquering beasts of prey, emerged from the same ferments which had bred, at earlier stages of social decay... the robber baron of industry, the ruthless money-maker and the political boss exploiting his municipal satrapy—or, at all stages of history, the individual felon rising against and above the community..." [47]

From the Committee's perspective, liberalism's preoccupation with individual liberty and economic prosperity had led to human hubris. Rather than robust cooperation with fellow citizens, it had shattered traditional ties and taught nothing but selfishness. It was the liberal era that "had flung open the gates of the prisons" in which "today's tyrants... had been criminal offenders" [48]. Both socially and intellectually, liberalism was the condition for totalitarianism's nihilist revolution.

This decisively conservative view of liberalism - as the nihilist destroyer of tradition - meant that totalitarianism was not a distant threat posed by foreign countries. Rather, the conditions for its emergence were present in the fabric of every liberal country, including the United States. To the authors, the history of the "robber baron" indicated that even their host country could fall prey to the nihilist revolt. Indeed, they believed that French and British appeasement and U.S. isolationism presented the clearest indication of their inner spiritual collapse:

In the decline of Western civilization the collective purpose of democracy, with its commandments of discipline and loyalty, had given way to a corrupted liberalism, with its claim of unrestricted liberty for each one to think and act as he pleased. The all-embracing benignity of this perversion reserved some applause for the rugged individualist who proved strong and free enough to kill the freedom of his countrymen; and the principle of noninterference in the domestic policies and in the mutual quarrels of other nations covered under a banner of superstitious liberalism the contraband of approval and help to whatever foreign country had freely chosen to forfeit its own freedom or had freely managed to kill the freedom of its neighbor [49].

It was because of "corrupted" liberalism's similarity to totalitarianism that "[t]he arm of totalitarianism is long enough to reach into the anchorite's desert... No refuge would be spared" [50]. The City of Man, therefore, was an extreme attack not only on Europe's new regimes, but also on the principles of disintegrated liberalism. Resting on openly conservative convictions, the manifesto claimed that any break with the past was bound to degenerate into revolution.

According to the writers of The City of Man, therefore, the rebirth and triumph of Western society could only be achieved through a return to the traditional values of the past. The 
individual's life, they wrote, is "humble in the knowledge of its limits, under the all-human dogma of fallibility. It has meaning only by participation in the unlimited past... and no one man... or generation can embody the heritage and promise of Man" [51]. According to the manifesto, this meaningful past could survive only through traditional voluntary associations, which together constituted the "democratic brotherhood of sacrifice." These included the "primary groups of family, educational association, neighborhood, and church," all of which had to be "restored in new forms with new life" [52]. According to this communitarian vision of society, it was "[t]he pillars of family and property" that were to be regarded as "unshakable and holy" [53]. The survival of civilization thus depended on the rejection of individualism and materialism, and on the revival of communal bonds. Only by such a return to the past could totalitarianism be defeated.

In these assertions, The City of Man echoed the era's most famous conservative attack on Nazism, namely Hermann Rauschning's The Revolution of Nihilism: Warning to the West, which was published in German in 1938 and a year later in English. A former Nazi who abandoned the party and went into exile, first in Britain and later in the United States, Rauschning famously depicted Nazism as a movement of nihilists. Like the authors of the manifesto, he maintained that Nazism was a modern mass phenomenon, a revolt of the masses, which sought to destroy traditional values such as religion and community; and like the Committee, he compared the German regime to its arch-enemy, the Soviet Union [54,55].

Yet The City of Man also radically broke with the Europe's contemporary conservative thought by enthusiastically and unequivocally embracing democracy. Going beyond Rauschning's support of monarchism, its authors declared democracy to be the only legitimate political system, and the only manifestation of traditional values. In their eyes, the totalitarian potential at the heart of liberalism had one clear consequence: "the concepts of a vital democracy," they boldly claimed, "must be dissociated from the notion of a disintegrated liberalism, which is a precursor of tyranny and a prey to it" [56]. Democracy must therefore find a new spiritual foundation.

According to the Declaration, the precondition for such a rejuvenated democracy was dramatic economic and social reform that could reverse the destructive effects of modernization. Yet even though the group included one of the Roosevelt Administration's closest advisors, William Yandell Elliot, its vision for a new economic order was based not on modern schemes of the welfare state, but on a return to the economic theories of the nineteenth century. The authors invoked the works of the late nineteenth century theoretician Henry George, to whom they referred as "an American prophet," in particular his 1879 Progress and Poverty [57]. According to George, the solution to the ills of modern society was the transformation of the land into public property, and the abolition of all taxes and regulations. He envisioned the disappearance of private ownership of land, and that all wealth generated from nature's resources was to be equally distributed among men and women. At the same time, the state was to withdraw from all economic regulation of labor and capital, and would only protect the sacredness of private capital. In George's view, this model would bring prosperity and justice to all [58-60].

In establishing its blueprint on such socio-economic ideas, the City of Man sought to offer a conservative reversal of all modern politics and a redefinition of democracy's intellectual core. Rather than observing it as the realization of individual wills, "the conflicting concourse of uncontrolled individual impulses... a dispersive atomism," the manifesto's authors envisioned 
democracy as "a harmony subordinated to plan... a purposive organism" [61]. They believed that welfare should be administered through voluntary charity, organized by local communities, and not by the bureaucratic agencies of the state. Ultimately, they concurred with Henry George's claim, "[p]olitical economy and social science cannot teach any lessons that are not embraced in the simple truths that were taught to poor fishermen and Jewish peasants by One who 1800 years ago was crucified" [62].

The City of Man's conservative attack on liberalism as the foundation of totalitarianism on the one hand, and its enthusiastic embrace of democracy on the other render it an important milestone in the transformation of European conservative thought. The manifesto was one of the first attempts to redefine democracy as the only system that could resist the corrupting force of modernization and nihilism. Such a view of democracy, not as the agent of modernization or a system at best to be passively tolerated, but as the defender of traditional structures and bonds, was rare among European conservatives; and it was only with the advent of the Cold War that these notions would reach the mainstream of the European Right [63-65]. Yet this view's enthusiastic democratic conviction rendered its conservatism invisible to many readers. Even the few scholars who commented on the manifesto regarded its support of democracy as a sign of liberalism, overlooking its openly conservative language [66]. Paradoxically, it was their conservative convictions that led the manifesto's authors to offer a dramatically new vision for the future.

\section{Christianity and Judaism in the New Spiritual Order}

According to the "Committee of Europe," the key to the emergence of a new and conservative democratic order, that would defeat totalitarianism and transcend liberalism, lay in a religious revival. Democracy, they hyperbolically claimed, "is the plentitude of heart-service to a highest religion embodying the essence of all higher religions. Democracy is nothing more and nothing less than humanism in theocracy and rational theocracy in universal humanism" [67]. According to the manifesto's writers, the power and appeal of fascism lay in its spiritual energy; it was a secular religion, which demanded fanatical devotion. In this interpretation, the defeat of France and the weakness of the West were the result of spiritual faintness, of the skepticism and faithlessness of the secular age. Democracy, therefore, could survive only if it too, like its adversaries, became a religion. "A constitutional reform of democracy," they decisively argued, "cannot be founded but on the spirit of a new religion" [68]. This democratic religion, they claimed, was universal in its essence, and worshiped the dignity of man and the rule of law. It could accommodate worshipers of different backgrounds and beliefs. It was, indeed, by virtue of its universal nature that it could achieve eternal peace and unite the people of the world under a single, global state.

Despite such lofty statements about the universal nature of the democratic religion, however, and its compatibility with a variety of religions, the manifesto could not conceal the central role that Christianity played in the eyes of its authors. In a highly orientalist fashion, they claimed that democracy was inherently tied to monotheism, and that the nations of the world would have to follow in the footsteps of the United States on the slow march to progress. The "cults of exotic origins," they wrote, failed to reach "the universality of the religion of the Spirit, to which all men are witnesses... none of them willfully and consciously conflicted with the basic tenets on which the world-religion of the Spirit is founded." 
The Asiatic doctrines, to be sure, withered in a saintly inertia which made them unable - from Buddhism and earlier down to the present day - to participate decisively in struggle and progress... Tolstoyism itself, a cross of West and East, and Gandhism itself, a cross of East and West, have been unable to offset altogether the debilitating influence of Asia's passive worship and of the commandment of non-resistance to evil [69].

In the opinion of these American and European authors, the religions that lay beyond the borders of the United States harbored no potential for spiritual revival.

It was therefore only Christianity, they claimed, that would allow democracy to achieve its global triumph. Only Christianity could serve as the basis for a self-assured culture that would overcome the fascist threat and establish global peace. "This universal religion," the authors claimed, "harbored in the best minds of our age," was the "common prayer of democracy militant which must be the hymn of democracy triumphant... Its substance matured out of whatever rose highest in man's speculations and hopes" [70]. In sharp contrast to their comments on "Eastern" cultures, however, the authors were confident that Christianity would readily be embraced by the people of the world. According to their tortured logic, the vast majority of the world's population already believed in its principles, even if it was not wholly aware of it. "Most of us," the manifesto quoted President Roosevelt, "believe in the spirit of the New Testament. The statement is true even for great numbers of people who are not, or never were, under the direct influence of the Scriptures. It is true even for most of those who reject all kinds of transcendent belief and cling, or think they cling, to rational knowledge and scientific experiment alone" [71]. Ultimately, the creation of a democratic society and a Christian society were identical projects in the minds of the manifesto's authors.

The Christian impulse of the manifesto revealed itself in its ambivalent and uneasy attitude toward Judaism and Jews. Including former Jewish nationalists such as Hans Kohn, and the Jewish converts to Christianity Hermann Broch and Oscar Jászi, the Committee regarded the place of the Jewish minority as central to its imagined postwar order. In the authors' mind, the centrality of anti-Semitism in Nazi ideology positioned the Jews as the litmus test for the spiritual health of a community. "The Jew among us," they wrote, "survivor of persecutions, warns us by his very presence that anti-Semitism is the entering wedge of racism, the dusk of hatred which preceeds the totalitarian night." Like the failure of U.S. society to abolish its own racial discrimination, they wrote, the persecution of the Jews "helps us by reminding us that our slow progress is a mere token of the justice we pledged - until all races rise to equality in maturity" [72].

The City of Man therefore preceded the wartime rhetoric that would emerge in the United States in the following years, underscoring a natural bond between the Christian and Jewish communities $[73,74]$. In the same manner in which American intellectuals would soon declare that the United States was a "Judeo-Christian" culture, so did the manifesto place Judaism on an equal footing with Christianity as the twin elements of the future "common faith" of universal religion [75]. "The prophetic spirit and heroic universalism of the Hebraic traditions," they asserted, "have been and are incessantly expressed in unorthodox and even secular forms of Jewish life. They have brought and bring a contribution of inestimable value to the spirit of democracy" [76].

These statements, however, could not hide the aversion that the writers felt toward most Jews. In their eyes, Judaism represented passivity, in sharp contrast to the active and creative nature of the 
Christian faith. Indeed, the "Hebraic traditions" were valuable only as long as they followed the principles of Christian universalism and denounced any sense of Jewish uniqueness. "[M]ost of the Synagogue," they warned, "tempted to this course no doubt by the stern problem of survival which faces the Jewish people in a hostile world, was overcome by sterility... and by the racial stubbornness which severed the orthodox Jew from Jesus, highest of Jewish prophets" [77]. The authors doubted whether Jews could overcome their race and nature and join the necessary spiritual revival. According to The City of Man, democracy, like Christianity, was based on certain elements of ancient Judaism, which had endured only in the furthest margins of the contemporary Jewish world. Ultimately, the authors believed, Jewish rejection of the universal teaching of Christ reflected Judaism's undemocratic core.

The participation of Jewish authors in the writing of such statements, composed in the darkest years of Nazi persecutions, is perplexing. While no record remains to document their thoughts, one might speculate that their embrace of Christianity in the manifesto was informed by strategic considerations. The pronounced anti-Semitism among some in the isolationist camp in the United States, such as Father Charles Coughlin, who vocally warned that international Jewry was plotting to drag the country into war against its own interests, might have encourage the marginalization of Nazi anti-Semitism as ancillary to its alleged attack on Christianity. Indeed, Jewish émigrés such as Kohn might have believed that framing the manifesto in an openly Christian spirit would be the most effective way to persuade their U.S. readership to embrace their anti-isolationist agenda.

Beyond any potential strategic choices, the manifesto's ambivalence toward the place of the Jews in the anti-totalitarian struggle reveals the uneasy and not always inclusive origins of "JudeoChristianity." Like many Christian thinkers, Catholic and Protestant alike, who abhorred Nazi racism in the 1930s and 1940s, the authors of The City of Man regarded Nazi attacks on the Jews first and foremost as a manifestation of the Third Reich's anti-Christianity [78]. To them, constructing ties between Judaism and Christianity was not intended to reveal deep spiritual connections between the two religions. Rather, its purpose was to expose the Nazi obsession with Jews as a marginal factor that afforded a glimpse of its true essence, namely its totalitarian mission directed against the Christian churches. Indeed, the Committee members found no difficulty in reconciling their attacks on Nazi anti-Semitism with embracing biological terminology to accuse Jews of "racial stubbornness." In The City of Man, the religion of democracy remained Christian in essence, and it was only those who embraced the essential Christian creed who could be admitted to the future world democracy.

\section{Universal Peace in the Universal State}

The City of Man's political, economic, and religious values culminated in its most utopian and concrete recommendation: the realization of Immanuel Kant's vision of "perpetual peace" through the establishment of universal harmony under a single global state. Prefacing what would, for a brief moment, become a popular idea in the United States at the close of WWII, the writers of the manifesto laid the blame for the failure of earlier attempts at international cooperation at the door of the principle of national sovereignty $[79,80]$. As long as humans were divided in separate nation-states, they would inevitably experience a clash of interests and dominance. "Peace," they wrote, 
could not be the outcome of subtle bargaining in the clearing houses of secret diplomacy backed by standing armies. It cannot rest upon coalitions and ententes, or upon half-hearted security pacts; it cannot be achieved through structures like the League of Nations, which presumed to dispense justice without exercising power, or through one-sided and lame leaderships like that of England's and France's rulers...[81]

The mere existence of nation states, the manifesto declared, was a sign of modern degeneration, the awful disaster of human life. It was the source of nihilism and a belief in the supremacy of brute force.

Universal peace, according to the manifesto, could only be founded "on the unity of man under one law and one government... the Universal State, and State of States [82]." Only such a state deserved the title "The City of Man," the true manifestation of peace and justice. The unity of man was the only response to the threat of totalitarianism. "[A]11 that survives of mankind must breathe in one breath and fight in one fight, since the whole earth has become one living-space or dyingspace for all nations of men [83]." In the authors' minds, this universal state was to be modeled on a multilayered structure, on a combination of local and central power. Like the United States, it would have an elected President, but its different states were to enjoy substantial autonomy. "[T]he pluralistic system of the American Commonwealth," they wrote, "although prevented so far from reaching a complete expression... had shown... that the combination of local autonomy with unitary authority is feasible on a continental scale, and therefore ultimately on a world wide scale [84]."

According to The City of Man, this utopian vision had an obvious and clear leader-the United States. In a narrative that was soon to become one of the core elements of Cold War ideology, the authors proclaimed that it was the United States' natural and inevitable destiny to lead the world into a future of order and peace, eliminating the totalitarian threat along the way. "Nothing could be more shocking to America's humility and pride," the manifesto stated "than the necessity to take leadership among the nations." This leadership, however, was far removed from arrogance and imperialism, and would constitute a form of service to the entire globe. Leadership, they wrote, "implies some sort of imperium. But there is a difference between imperialism and imperium."

Chosen by the objective circumstances of history for a privilege which is a service, for a right which is a duty. This is, indeed, the substance of a chosen people: power in the frame of service. [...] "Rome did not spread upon the world; the world spread upon the Romans." This was the destiny of other nations and cultures, in ancient and in modern ages as well. This - to the largest extent of worldleadership for world-communion in the comradeship of man - is the destiny of America, as manifest as it was unwanted, since the English speaking nations were "left to fight alone," and all the world must sink unless we take the helm. [...] There are in the family of nations children who must grow up, sick who must be cured, maniacs who must be confined, criminals who must be apprehended, before maturity and redemption become the common lot [85].

With this statement, the City of Man reached its climax. Engaged in the fight for its own spiritual survival against totalitarianism, the United States was revealed also as the power responsible for the freedom of the entire world. It was the heir to all of civilization, its citizens the new "chosen people" of the Christian faith. And most importantly, it was to be a leading polity and 
a determined force. As the authors concluded, "The healing of the world requires a firm hand... American leadership is world-trusteeship; the Pax Americana a preamble to the Pax Humana [86]." With such statements, the manifesto reflected the final transformation in the thought of former pacifists such as Hans Kohn and Reinhold Niebuhr, who, in the face of Nazi aggression, abandoned their earlier convictions and embraced the use of force as part of America's responsibility.

The City of Man thus adapted older messianic visions of the United States to the new conditions of total war. Reproducing old visions of the United States as a unique guarantor of civilization and Christianity, the manifesto went further by portraying its global mission against totalitarianism as an integral part of its identity. The U.S. declaration of independence, the manifesto claimed, was "an Old Testament of Americanism," and its new global leadership was to be the "New Testament of Americanism," the realization and fulfillment of its spiritual essence [87]. Indeed, so the authors believed, the United States could not survive as an enlightening model or as merely one among many forms of life. Rather, its very existence depended on global dominance and the universal teaching of Christianity. While this fusion of religion and diplomacy would become common among U.S. intellectuals and political leaders within a few years, in 1940 it still lay in the future [88].

The City of Man, therefore, presented both a nebulous pre-figuration of Cold War ideology and at the same time developed ideas and themes that were dramatically alien to it. It defined the United States through its opposition to totalitarianism, but also considered its ultimate objective to be the abolition of all sovereignty, including its own; it called for religious pluralism, but defined the spiritual power of the U.S. as dependent on Christianity alone; and it presented a vision that was unminstakingly utopian, yet claimed it to be the only concrete and pragmatic program for the defeat of totalitarianism. These tensions rendered the City of Man a heterogeneous and incoherent document, and within a few months, with the United States' entry to the war, it was forgotten altogether.

\section{Conclusion: The City of God and the City of Man}

The City of Man never directly mentions St. Augustine or his De Civitate Dei (City of God), yet it parallels Augustine's text in more profound ways than the mere allusion in its title. Whereas Augustine reflects on the fall of Rome, the 1940 manifesto reflects on the fall of Europe. Augustine's work set out to prove that it was not Christianity that had brought about Rome's demise, while The City of Man sought to prove that it was not democracy that had led to Europe's collapse. Both pointed to Christianity as offering the solution to the political catastrophes of their era.

The City of Man, however, inverted the original meaning of the term "City of Man." In Augustine's book, "The City of Men" (in plural) is the earthly city, a domain of vice and sin, the city which is "ruled by its lust of rule," the new Babylon [89]. It is contrasted to "The City of God," "the eternal city," "Jerusalem." According to Augustine's theology of history, all human history comprises the struggle between these diametrically opposed cities. "Cain [...] belonged to the city of men; after him was born Abel, who belonged to the city of God." [90] "[T] Augustine explained, "were made by two loves: the earthly city by the love of self, unto the contempt of God, and the heavenly city by the love of God unto the contempt of self" [91]. In stark 
contrast, in the 1940 manifesto, "the city of man" stands for concrete political action in the world, a military mission against fascism, racism, and revolution, and the establishment of new global institutions. Unlike Augustine, the Committee of Europe envisioned a concrete formula for a new political order, a global yet worldly state.

By positioning the United States at the center of this anti-totalitarian and Christian mission, The City of Man reveals the birth of Cold War ideology from the crisis of appeasement. The alleged necessity of a Pax Americana, the identification of the United States with the legacy of Western civilization, the advocacy of a muscular American democratizing mission in the world, all articulate key elements of Cold War ideology. Given the course of U.S. history in the decades that followed, this part of the manifesto strikingly anticipates the intellectual terms of the $g$ lobal conflict.

Much of the manifesto, however, would sound alien and incomprehensible to readers of the Cold War era. The City of Man's sincere advocacy of a world federation, its nineteenth-century concepts of social and economic reform, and especially its understanding of Nazism would not become part of the global conflict's intellectual mainstream. Indeed, these ideas did not stand the test of time, and to the current day reader they often seem insufficiently mature and even inadequately thought out.

This mixed legacy is a product of the years in which the Committee operated. It came into being in late 1938; published its first memorandum in spring 1939; and convened and drafted its declaration in spring 1940. The original drive, in the wake of the Munich agreement, focused on the larger, historical significance of appeasement as a tragic embodiment of the worsening crisis of liberal Western democracies. The writers' attack was not a critique along Realpolitik lines, but a fundamental accusation: now that liberal Western democracies themselves appeared to have abandoned their commitment to the tenets of democracy and to the core values of Western civilization, no-one could or would combat the fascist tide in Europe. More importantly, however, the City of Man's conference in Atlantic City took place in May 1940, more than a year prior to Operation Barbarossa, and a year and a half before the United States' entry to WWII. These two events of the second half of 1941 not only changed the course of WWII, but dramatically shaped the manner in which European and American thinkers comprehended Nazism in the ensuing Cold War decades.

Seventy years after its composition, the manifesto has become "unreadable." Much of it was an attempt to respond to questions that were existential in 1940, yet have since lost their urgency. Most of all, the manifesto revealed its authors' deep anxiety that, with the rise of fascism, Nazism, and Communism in Europe, it was both democracy and conservative values and traditions that had been discredited beyond repair. Even though it committed itself to optimistic and messianic visions of the future, The City of Man was written from the abyss of despair, and on the assumption that Europe was irretrievably lost. Yet it was this anxiety that led the authors to invest their hopes in the United States, and to define it as the only shield against totalitarianism. It was this anxiety that added to earlier highly idealist visions of the United States a new messianic mission to heal the world of its modern illnesses. Thus did the numerous European émigrés on the "Committee of Fifteen," before many in their host country, capture the dawn of the new "American Century." 


\section{Acknowledgments}

The authors wish to thank Avner Greenberg, Sven-Erik Rose, Nitzan Lebovic, and the anonymous reviewers for truly thoughtful and valuable comments.

\section{References and Notes}

1. Herbert Agar, Frank Aydelotte, and Giuseppe Antonio Borgese, et al. The City of Man: A Declaration on World Democracy. New York: Viking Press, 1940, 11-12.

2. This description of the meeting is based on the memoirs of Lewis Mumford and the diary of Thomas Mann: Lewis Mumford, My Work and Days: A Personal Chronicle. New York: Harcourt, 1979, 391-394.

3. Thomas Mann. Tagebücher 1940-1943. München: S. Fischer, 1977-1995, 81-83.

4. Agar et al. The City of Man. 14.

5. Mumford. My Works and Days. 392.

6. This argument resembles that which Allen Bloom would famously make some 50 years later in his The Closing of the American Mind. New York: Simon and Schuster, 1987.

7. Some of the often-mentioned cases are Bertolt Brecht and the Frankfurt School. Ehrhard Bahr has recently both addressed their anti-Americanism, and challenged (or at least qualified) it. See: Ehrhard Bahr. Weimar on the Pacific: German Exile Culture in Los Angeles and the Crisis of Modernism. Berkeley: University of California Press, 2007, 83-93.

8. Agar, et al. The City of Man. 101, 103.

9. The scholarship on liberal and left-leaning émigrés is extensive. See, for example, Bahr. Weimar on the Pacific. Berkeley: University of California Press, 2008, and notes 10-15 below.

10. Uta Gerhardt. Denken der Demokratie: die Soziologie im atlantischen Transfer nach 1945. Stuttgart: Steiner, 2007.

11. David Kettler, and Gerhard Lauer, eds. Exile, Science, and Bildung: The Contested Legacies of German Émigré Intellectuals. New York: Palgrave Macmillan, 2005.

12. Edward Timms, and Jon Hughes, eds. Intellectual Migration and Cultural Transformation: Refugees from National Socialism in the English-Speaking World. Vienna and New York: Springer, 2003.

13. Lewis A. Coser. Refugee Scholars in America: Their Impact and their Experiences. New Haven: Yale University Press, 1986.

14. Martin Jay. Permanent Exiles: Essays on the Intellectual Migration from Germany to America. New York: Columbia University Press, 1986.

15. On the emerging scholarship on conservative thought among émigrés, see: Noah B. Strote. "Emigration and the Foundation of West Germany, 1933-1963." PhD Dissertation, University of California-Berkeley, 2011.

16. On Niebuhr and liberalism, see, Eyal J. Naveh. Reinhold Niebuhr and Non-Utopian Liberalism: Beyond Illusion and Despair. Brighton: Sussex Acad. Press, 2002.

17. On Kohn and Liberalism, see Ken Wolf. "Hans Kohn's Liberal Nationalism: The Historian As Prophet." Journal of the History of Ideas 37 (1976): 651-672. 
18. Some members of the Committee, such as Borgese, have long been regarded by scholars as conservatives; see for example David Ward, Piero Gobetti's New World: Antifascism, Liberalism, Writing. Toronto: Toronto University Press, 2010, 139.

19. It is notoriously difficult to arrive at a strict and uncontroversial definition of "conservatism"; for the purpose of this essay, we have relied on the definition provided by Jerry Muller, which defines conservatism through a set of basic assumptions: the defense of existing institutions, customs, and habits; belief in the inherent imperfectability of human nature; resistance to dramatic social change; the utility of religion; and skepticism toward humanitarianism. See his "What is Conservative Social and Political Thought?" In Conservatism: An Anthology of Social and Political Thought from David Hume to the Present. Princeton: Princeton University Press, 1997, 3-31.

20. For a classic work on the cooperation (and consequent disillusionment) of conservative thinkers with fascism and Nazism, see Jerry Muller. The Other God that Failed: Hans Freyer and the Deradicalization of German Conservatism. Princeton: Princeton University Press, 1987.

21. For a preliminary discussion of conservative tendencies among the émigrés from Nazi Germany, see Jean-Michel Palmier. Weimar in Exile: The Antifascist Emigration in Europe and America. London: Verso, 2006, 568-570.

22. Scholarship has begun to pay increasing attention to the conservative elements in the European emigration. See, for example, Malachi H. Hacohen. Karl Popper, the Formative Years, 1902-1945: Politics and Philosophy in Interwar Vienna. Cambridge, UK: Cambridge University Press, 2000, and notes 23-27 below.

23. Eugene R. Sheppard. Leo Strauss and the Politics of Exile: The Making of a Political Philosopher. Waltham, Mass: Brandeis University Press, 2006.

24. Noah Strote. Emigration and the Foundations of West Germany. PhD Thesis, University of California, 2011.

25. James Chappel. Slaying the Leviathan: Catholicism and the Rebirth of European Conservatism. PhD. Dissertation, Columbia University, 2012.

26. Adi Gordon. "The Ideological Convert and the Mythology of Coherence: The Contradictory Hans Kohn and his Multiple Metamorphoses." Leo Baeck Institute Year Book LV (2010), 273-293.

27. Udi Greenberg. "The Limits of Dictatorship and the Origins of Democracy: the Political Theory of Carl J. Friedrich from Weimar to the Cold War." In The Weimar Moment: Liberalism, Political Theology, and Law, edited by Kaplan, Leonard V., and Rudy Koshar. Lanham, Md: Lexington Books, 2012, 443-464.

28. Agar, et al. The City of Man, 97.

29. Ibid., 97-98.

30. Ibid., 104.

31. Ibid., 109-110.

32. Ibid., 112.

33. Ibid., 12.

34. Ibid., 81 . 
35. Ibid., 18.

36. Ibid., 17.

37. Ibid., 51.

38. Ibid.

39. Ibid.

40. Ibid., 67.

41. The first works on Totalitarianism appeared in the mid-1930s in Europe, but the term and the theories began to take hold in the United States only in the mid-1940s. On the evolution of the theory of Totalitarianism, see James Chappel. "The Catholic Origins of Totalitarianism Theory in Interwar Europe.” Modern Intellectual History 8:3 (November 2011): 561-590, and notes $42-45$ below.

42. Anson Rabinbach. "Moment of Totalitarianism." History and Theory 45 (2006): 72-100.

43. Wolfgang Wippermann. Totalitarianismustheorien: die Entwicklung der Diskussion von den Anfängen bis heute. Darmstadt: Primus, 1997.

44. Abbott Gleason. Totalitarianism: The Inner History of the Cold War. New York: Oxford University Press, 1995.

45. William David Jones. The Lost Debate: German Socialist Intellectuals and Totalitarianism. Urbana: University of Illinois Press, 1999.

46. Agar, et al. The City of Man, 51.

47. Ibid.

48. Ibid., 52.

49. Ibid., 30-31.

50. Ibid., 12.

51. Ibid., 48.

52. Ibid. Emphasis added.

53. Ibid., 80.

54. See Hermann Rauschning. The Revolution of Nihilism: Warning to the West. NewYork, Alliance Book Corporation, 1939.

55. Following the United States' entry into the war, Rauschning too adopted, in his way, the democratic slogan: Hermann Rauschning. The Redemption of Democracy, the Coming Atlantic Empire. New York: Alliance Book Corporation, 1941.

56. Agar, et al. The City of Man, 31 .

57. Ibid., 52.

58. See Henry George. Progress and Poverty: an Inquiry into the Cause of Industrial Depressions, and of Increase of Want with Increase of Wealth. New York, D. Appleton and co., 1880.

59. It is likely that the authors relied on a shorter version of George's text, which was published in 1929 with an introduction by John Dewey. Significant Paragraphs from Henry George's Progress and Poverty. New York: Robert Schalkenbach Foundation, 1929.

60. After WWII, several European conservative thinkers cited George's ideas as having inspired the notion of a Christian economic order. See Chappel, Slaying the Leviathan, 340.

61. Agar, et al. The City of Man, 33. 
62. Ibid., 48-49.

63. On Christian Democracy, see, for example, Wolfram Kaiser. Christian Democracy and the Origins of the European Union. New York: Cambridge University Press, 2007, and notes 6465.

64. Michael Gehler, ed. Christian Democracy in Europe since 1945. New York: Routledge, 2004.

65. Noel D. Carry. The Path to Christian Democracy. Cambridge, Mass.: Harvard University Press, 1996.

66. See, for example, Paul Michael Lützeler. "Kitsch and Art: Broch's Essay 'Das Böse im Wertsystem der Kunst'." In Hermann Broch, Visionary in Exile. Rochester: Camden House, 2003, 67-88.

67. Agar, et al. The City of Man, 33.

68. Ibid., 80.

69. Ibid., 39.

70. Ibid., 36.

71. Ibid., 35 .

72. Ibid., 69.

73. On this development see Mark Silk. "Notes on the Judeo-Christian Tradition in America." American Quarterly 36, no. 1 (Spring 1984): 65-85, and note 74 below.

74. Deborah Dash Moore. GI Jews: How World War II Changed a Generation. Cambridge, Mass.: Harvard University Press, 2004.

75. Ibid., 38 .

76. Ibid., 39-40.

77. 77 Ibid., 40, emphasis added.

78. On the emergence of anti-racist yet still anti-Jewish Catholic thought, see John Connelly. From Enemy to Brother: The Revolution in Catholic Teaching on the Jews 1933-1965. Cambridge, Mass.: Harvard University Press, 2012. Connelly attributes the beginning of the transformation in the Catholic Church from anti-Semitism to tolerance and cooperation to the works of converts (mostly from Judaism, but also from Protestantism) who fled Nazi Germany and later Europe during WWII.

79. On the movement for world government, which enjoyed considerable popularity between 1942 and 1947 in the U.S., see Lawrence S. Wittner. One World or None. Stanford: Stanford University Press, 1993, 44-45, and note 80 below.

80. Joseph Preston Baratta. "The International History of the World Federalist Movement." Peace and Change 14, no. 4 (1989): 372-403.

81. Ibid., 23.

82. Ibid., 23-24.

83. Ibid., 61.

84. Ibid., 25.

85. Ibid., 61.

86. Ibid.

87. Ibid., 58-59. 
88. On the role of Christian thought and messianism in particular in Cold War U.S. thought and culture, see Jason W. Stevens. God Fearing and Free: A Spiritual History of America's Cold War. Cambridge, Mass.: Harvard University Press, 2010.

89. Augustine. The City of God, translated by Marcus Dods. New York: Random House Modern Library, 1950, Book 1, chapter 1.

90. Ibid., Book 15, chapter 1.

91. Ibid., Book 14, chapter 28. 
Reprinted from Religions. Cite as: Mell, J. Twentieth-Century Jewish Émigrés and Medieval European Economic History. Religions 2012, 3, 556-587.

Article

\title{
Twentieth-Century Jewish Émigrés and Medieval European Economic History
}

\section{Julie Mell}

Department of History, North Carolina State University, Campus Box 8108, Raleigh, NC 27695, USA; E-Mail: jlmell@ncsu.edu; Tel.: +1-919-382-9202; Fax: +1-919-382-9269

Received: 31 May 2012; in revised form: 13 June 2012 / Accepted: 14 June 2012 /

Published: 27 June 2012

\begin{abstract}
This essay discusses the intellectual contributions of five Jewish émigrés to the study of European economic history. In the midst of the war years, these intellectuals reconceptualized premodern European economic history and established the predominant postwar paradigms. The émigrés form three distinct groups defined by Jewish identity and by professional identity. The first two (Guido Kisch and Toni Oelsner) identified as Jews and worked as Jewish historians. The second two (Michal Postan and Robert Lopez) identified as Jews, but worked as European historians. The last (Karl Polanyi) was Jewish only by origin, identified as a Christian socialist, and worked first as an economic journalist, then in worker's education and late in life as a professor of economics. All five dealt with the origin of European capitalism, but in different veins: Kisch celebrated and Oelsner contested a hegemonic academic discourse that linked the birth of capitalism to Jews. Postan and Lopez contested the flip-side of this discourse, the presumption that medieval Europe was pre-capitalist par excellence. In doing so, they helped construct the current paradigm of a high medieval commercial revolution. Polanyi contested historical narratives that described the Free Market as the natural growth of economic life. This essay explores the grounding of these paradigms in the shared crucible of war and exile as Jewish émigrés. This shared context helps illuminate the significance of their intellectual contributions by uncovering the webs of meaning in which their work was suspended.
\end{abstract}

Keywords: European economic history; Jewish émigrés; Guido Kisch; Robert Lopez; Toni Oelsner; Michael Postan; Karl Polanyi; medieval economic history 


\section{Introduction}

In the war years of 1943-44, when the destruction of European Jewry was spiraling to a dreadful conclusion, two émigré historians from central Europe took up their pens to write about an old essay on the economic function of medieval Jewry- "Die Stellung der Juden im Mittelalter, betrachtet vom Standpunkt der allgemeinen Handelspolitik" (The Status of the Jews in the Middle Ages Considered from the Standpoint of Commercial Policy) [1,2]. The essay was written by one of the founders of the German Historical School of Political Economy, Wilhelm Roscher. It argued that the Jews had functioned in the Middle Ages as a commercial carrier and "tutor" to the "younger nations." When these "Germanic nations" matured and engaged in commerce, they rebelled against their tutors, and imposed anti-Semitic strictures out of commercial jealousy. For Roscher, medieval Jewry provided a case study, illustrating universal laws on the relationship between minorities and niche economic activities. But for the émigré historians, Guido Kisch and Toni Oelsner, Roscher's essay was a means of combating the anti-Semitism destroying the Jewish people. Both Kisch and Oelsner responded to the common stereotypes linking Jews, Judaism and capitalism via Roscher, albeit in different keys [3-5].

Kisch and Oelsner were not the only Jewish émigrés to write about the origins of capitalism and the economic history of medieval Europe in the midst of the war years. This article considers five émigrés of Jewish origin: Guido Kisch, Toni Oelsner, Michael Postan, Robert Lopez, and Karl Polanyi. All addressed contemporary debates and the contemporary European crisis through economic history. These five have been chosen because they addressed European economic development from the perspective of medieval European history. Other twentieth-century Jewish émigrés wrote on economic topics; some were even medievalists [6]. But these five are representative of three key trajectories - one dealing with the question of the "economic function of the Jews," one reconstructing the commercial expansion and contraction of medieval Europe, and one economy as an instituted process. These topics form centric rings around a nuclear core of issues associated with capitalism, commercial development, money, credit, and economic exchange. Associated with these issues, though only sometimes directly addressed by these intellectuals, was a discourse that linked capitalism, credit, and, money with Jews and Judaism. The new paradigms created by these scholars would profoundly shape postwar intellectual trajectories both inside and outside of Jewish studies.

These intellectuals are not usually discussed together, for their professional fields ranged across a wide spectrum. Their Jewish identities and their academic success varied widely as well. Kisch and Oelsner defined themselves as Jewish historians and self-identified as Jews. But Kisch was a professor both before and after emigration, while Oelsner was a university student in Germany and the US who never received a permanent academic position after completing her MA. Postan and Lopez defined themselves as European historians and held important chairs at Cambridge and Yale, respectively. Although they did not hide their Jewish identity, it was de-emphasized in the elite academic institutions of Cambridge and Yale, and goes almost unnoticed in the obituaries, festschrifts, and encyclopedia articles written about them [7,8]. Polanyi was born to an assimilated Jewish Hungarian family, baptized Protestant as a child along with his siblings, and associated in adulthood with a Christian socialist movement. Emigrating from Hungary to Vienna after serving 
in WWI, he worked as an economic journalist in Vienna, as a lecturer in England for the Worker's Educational Association and, late in life, received academic positions in the US as a professor of economics. His intellectual work was widely influential among anthropologists, sociologists, and historians, but not among economists.

This article suggests that these intellectuals are connected and their works are shaped by the common experience of being "Jewish émigrés" in the mid-twentieth century. Understanding this experience illuminates the deeper intellectual connections between their groundbreaking work on economic history. By associating the intellectual contributions of Oelsner with Postan and Lopez, and Postan and Lopez with Polanyi, our understanding of the significance and latent implications of their new paradigms for European economic history is enriched.

All five of these intellectuals participated in a common twentieth-century European intellectual endeavor, the analysis and theorization of capitalism. All were working out of a common history of European economic thought, informed particularly by the German Historical School and the 'founding fathers' of sociology (Tönnies, Simmel, Sombart and Weber). They shared with other European and American scholars who were not Jewish émigrés a common European intellectual culture. This Jewish integration into European intellectual life was an important facet of twentiethcentury Jewish experience, one which led some of these figures to de-emphasize their Jewishness or to abandon it altogether. Why emphasize here then their experience as Jewish émigrés?

These intellectuals emigrated as Jews, and the experience of emigration decisively shaped them. Whether they wished or not, Nazi racial policy imposed the identity "Jewish" on them. Fascism, totalitarianism and anti-Semitism cut across their life-paths in diverse ways. Those fleeing the dark shadow of the Holocaust experienced the trauma of Europe's collapse on a profoundly personal level, and their intellectual works explored it on an impersonal, historical level. Their intellectual trajectories, on the one hand, were shaped by the academic cultures of Great Britain and the United States into which they integrated. Their Jewishness on the other hand, served as a touchstone for intellectual projects that have shaped trans-national European culture far beyond the boundaries of any particular, local "Jewish" affiliation. This they shared with other Jewish émigrés such as Erich Auerbach, Hans Kohn, and Konrad Wolf [9-12]. By drawing out the red thread that binds these émigrés together, it becomes evident that their intellectual works dealing with medieval economic history respond in some measure to the modern Jewish Question, because of the persistent discourse linking Jews, Judaism, and capitalism [13].

\section{Guido Kisch, Toni Oelsner, and "The Economic Function of the Jews"}

Guido Kisch and Toni Oelsner were as unlike in their conclusions about Roscher's essay as they were in their professional success. Guido Kisch celebrated Roscher's essay as an argument for Jewish inclusion in the German nation; Toni Oelsner derided it as a root of anti-Semitic stereotypes. Guido Kisch was a Czech-Jewish historian dismissed from the University of Halle in 1933. Between 1933 and 1935, he held a position at the Jüdisch-Theologisches Seminary in Breslau before emigrating to the US where he received a position at Hebrew Union College and founded the journal Historia Judaica which brought out its first issue in 1938 [14]. Six years later, Kisch commemorated Roscher in the journal, writing a commentary "The Jews' Function in the Mediaeval Evolution of Economic Life in Commemoration of the Anniversary of a Celebrated 
Scholar and his Theory," [15] which he paired with an English translation of Roscher's article prepared by Solomon Grayzel [16].

Roscher was drawing on a deep European discourse about Jews and economics $[17,18]$. But writing in the mid-1870s, when the stock market crash of 1873 was linked with rising anti-Semitism, Roscher was arguing in a philosemitic and liberal vein for Jewish emancipation. In analyzing why Jews were tolerated in the early Middle Ages and persecuted in the high and late Middle Ages, Roscher constructed an economic law on the basis of 'organic folk theory' and grounded it in the Historical School's theory of evolutionary economic stages through which all cultures passed: natural economy — barter economy_money economy_credit economy [19-22]. Organic folk theory held that a nation, a people (Volk), underwent an organic growth from youth to maturity to old age. The Jews were a more "commercialized people" than the Germanic tribes of early medieval Europe, and thus as merchants sustained European trade during the dark ages and "tutored" the younger nations in trade and commerce. When "Europeans" matured, they pushed their competitors, the Jews, out of commerce and into moneylending. The persecution of Jews in the high and late Middle Ages was a perfect example, Roscher argued, of a cross-cultural "economic law" in which younger nations lashed out at their elders because of trade jealousy. The historical "fact" that Jews had performed a vital "economic function" in Europe's economic development toward a modern market economy was a call for the full integration of German Jewry into the emerging German nation. But it was equally an intellectual argument illustrating a "universal law" of a middleman minority, which applied in different cultures and periods. Kisch celebrated Roscher's philosemitic assessment of Jewish commercialism as an antidote to Nazi anti-Semitism, and he subtly changed it. The translation and the commentary dropped the comparative dimension. Roscher's "universal historical law" became contingent and unique Jewish history. For Kisch, the Jewish story was only a Jewish story. And Jewish difference was the calling card for Jewish inclusion in the modern European nation-state.

Toni Oelsner, in contrast to Kisch, was an underprivileged young woman who was pulled from high school to support her family. Her belated studies at the University of Frankfurt were interrupted when the Nazis came to power. After emigration to the US via England, she completed a BA and MA at the New School for Social Research and worked at part-time academic jobs in New York. She never attained a secure academic position, but she published several path-breaking articles [23-25]. The first of these was "Wilhelm Roscher's Theory of the Economic and Social Position of the Jews in the Middle Ages: A Critical Examination" [26-28]. Although published only in the late 1950s, the article was researched and written in 1943-44 under a Rosenwald Fellowship of the Emergency Committee in Aid of Displaced Foreign Scholars [29]. Oelsner formulated a sharp critique of Roscher's essay as an antidote to Nazi anti-Semitism. She argued that the "special 'economic' function of the Jews" was mere folk-psychology, which when "deprived of [its] philo-Semitic and liberal guise could be turned into models for and instruments of the destructive Nazi "Jewish science"' [30]. Oelsner saw only the fine line that connected the "economic function of the Jew" to Nazi anti-Semitic propaganda.

Like Kisch, she reduced Roscher's universal "law" on middlemen minorities to contingent and unique Jewish history. The fact that two Jewish historians fixed on Roscher's economic function of the Jews as their "war-effort" marks how profoundly important the discourse on Jewish economics 
was. Both scholars were fighting an old battle even as their world collapsed around them, and they rode the tidal wave of the Holocaust into exile. Emancipation, integration, and even assimilation had failed. Anti-Semitism had triumphed, and both fought against it through Roscher's essay.

However, unlike Kisch, Oelsner discarded Jewish economic difference in toto. By breaking with the notion of Jewish economic difference, she rejected too the cultural framework that granted meaning to the "Jewish economic function" in both its anti-Semitic and philosemitic dress. With this rejection of Jewish economic difference, Oelsner foreshadowed the trajectory that scholarship would move only decades after the dust of the war years had settled. This trajectory has been reworking Jewish history as European history, as a complex history of shared culture, institutions, politics, and economics that could play out in very different ways for Jewish Europeans and Christian Europeans. Oelsner's own move in this direction can be seen in her last and (unpublished) essay on Jewish agriculture in the upper Rhineland (southwest Germany of today) during the High Middle Ages [31]. Kisch and Oelsner represent the Janus-face of the discourse on Jewish economics. Both were fighting anti-Semitism. However, the discourse of difference was the best argument for Jews' full inclusion in Europe. Moreover, the discourse of difference was the mechanism preventing that integration.

\section{Michael Postan, Robert Lopez, and Medieval Capitalism}

Where Kisch and Oelsner focused on Roscher's essay as a representative moment in the nineteenth-century discourses on Jews and economics, Michael Postan and Robert Lopez focused instead on the arguments of an intellectual heir to Roscher, Werner Sombart. Postan and Lopez were central figures in a generation of scholars that challenged the characterization of medieval economy as pre-capitalist, and they were formative in developing a new paradigm that charted an economic expansion during the high Middle Ages and a contraction in the late Middle Ages. But before turning our full attention to them, the intellectual arguments of Sombart against whom they wrote must be considered.

Sombart and his intellectual rival Max Weber took up the German Historical School's historicization of economy at the turn of the twentieth century and reworked it to address Karl Marx's paradigm of capitalism [32-36]. They resolved the economic stages of the Historical School into two poles - premodern and modern - and revalued the Historical School's liberal progressivism as a dark modernism, an iron cage to match the cruel barbarity of capitalism [37,38]. Both Sombart and Weber integrated Roscher's "economic function of the Jews" into their studies of capitalism, but Weber more subtly than Sombart. Sombart glorified medieval Christendom as an idyllic era of pre-capitalism in which craftsmen and peasants were intimately tied to the products of their labor. Judaism embodied the profit motive and Jews, the agents of capitalism [39]. Jews and Judaism became essential components of Sombart's narrative of the rise of capitalism, because they solved a conceptual problem. The problem was this: If modern capitalism is the antithesis of medieval anti-capitalism (and both are inherently European), then how does one explain the transformation from one to the other? For Sombart, Jews and Judaism (understood as a foreign element circulating in the European terrain and embodying capitalism) worked well as the essential causal agent moving Europe from pre-capitalism to capitalism. Max Weber would prefer the Protestant ethic, though even he saw this ethic as grounded in the ancient Hebrew prophets [40]. But both Sombart 
and Weber explained Europe's radical (and in their view unique) transformation towards capitalism through an agent of change external to medieval Europe - the Jews for one, the (Jewishly inflected) Protestants for the other.

Sombart's characterizations of medieval anti-capitalism and its obverse the Jewish spirit of capitalism were explosive. German-speaking, Jewish scholars from Central Europe criticized Sombart's portrayal of Jews as the originators of capitalism [41-43]. The last interlocutor would be Toni Oelsner, who published a critique of Roscher, Sombart, and Weber four years after her original essay on Roscher appeared [44]. However, the more historiographically significant debate was led by European scholars whose formative intellectual years and academic careers were spent in Italy, England, France, and the US [45]. These scholars contested Sombart's characterization of medieval Europe as pre-capitalist, while ignoring his work on Jews and Judaism. The debate began in the early twentieth century, picked up speed in the interwar period, and crystallized in a new paradigm in the 1940s. The response to Sombart and the Historical School reflected the growth of medieval economic history as a field in its own right [46]. The scholarship that generated the new paradigm stretched over several decades and reflects the life-work of several generations of historians, among them, the Jewish Marc Bloch who unsuccessfully tried to emigrate and was executed as part of the French resistance [47], non-Jews like Norman Gras who emigrated from Canada to the US to establish business history at Harvard and Raymond de Roover who emigrated from Belgium to study with Gras, Usher and the economist Nef. But probably the two most prominent scholars in the construction of the new paradigm of a medieval "Commercial Revolution" or "economic expansion" were the Jewish émigrés, Michael Postan and Robert Lopez.

Michael Postan would become one of the most distinguished and influential economic historians of the twentieth century, following checkered university studies that took him from Eastern Europe to the London School of Economics [48,49]. Born to a Jewish family in Tighina, Bessarabia [50], he enrolled briefly in the University of St. Petersburg in 1915 to study natural sciences and sociology. Soon after, he moved to the University of Odessa to study law and economics, before enlisting in the army in 1917. After demobilization in 1918, he resumed his studies at the University of Kiev. But at the end of 1919, he found himself "out of sympathy with events following the 1917 revolution, [and] he left Russia in circumstances of some risk to himself" [51,52]. Postan it seems had been a radical socialist, though later in life was no longer a Marxist [53]. He is reported to have been involved in the Jewish Autonomy Movement in the Ukraine and to have written a "Treatise on the Political Organization of Autonomous Minorities" (1919) [54]. He may have served as a member of the Secretariat [55]. Postan supported himself as a journalist while attempting to continue his studies in Vienna and Cernowitz unsuccessfully. In 1920 he landed in England, (he had had some English schooling in Bessarabia), and between 1921 and 1926 completed a first degree and an MA at the London School of Economics. There his interests were shaped in the direction of economic history by faculty such as R.H. Tawney and Eileen Power. Power recognized his talent and cultivated his career, awarding him a research assistantship in 1926 and arranging lectureships at the LSE, University College, London, and Cambridge. She sought a readership at Oxford for him unsuccessfully [56] and had her eye on the chair in economic history at Cambridge for him years in advance [57,58]. 
Postan quickly evolved from Power's research assistant to her intellectual collaborator. Their intellectual companionship, like the more famed one of Bloch and Febrve, produced rich fruit. In 1937, it was cemented by marriage, despite the astonishment of friends and acquaintances at the differences in professional position, age (Power was his elder by 11 years), and "physical characteristics." These "physical characteristics" were also described as Postan's "Russianness" and his "foreignness" $[59,60]$. It is unclear to what extent Postan's ethnicity was perceived as "Jewish." None of the obituaries or encyclopedia articles mention his Jewishness [61]. But Postan himself did not abandon his Jewish identity in Great Britain. Between 1927 and 1932, he was associated with the "Council of the Jewish Health Organisation of Great Britain" and was listed in the "Who's Who" entries of the Jewish Year Book in 1927-32 and again in 1945-6 [62]. In 1938, Postan was appointed to the chair that Power had eyed for him, the chair of Economic History at Cambridge [63]. He would hold this chair until his retirement in the mid-1960s. With Power's untimely death in 1940, Postan carried on the intellectual projects she had begun and that he had collaborated on, in particular the Economic History Review and the Cambridge Economic History of Europe. The closeness of their collaboration can hardly be over estimated. Both Power's letters from the early to mid-30s and Postan's letters attest to the strength of it [64]. After Power's death, Postan noted that "they had collaborated in a way few people realised. Each wrote independently, but by the time one or the other sat down to write, 'the other was so familiar with what was going to be written that he (or she) could easily have done the writing'. 'This was possible not only because we collected our evidence together, mostly working on the same mss. (We began doing that in 1925), and always discussed it, but because we were evolving towards the same views at the same time' [65]."

Over the course of his career, Postan shifted away from his and Power's focus in the 1930s on medieval credit and trade to long-term economic trends driven by demographic changes. Postan would develop a model of high medieval economic expansion and late medieval contraction. His early work contested Sombart's pre-capitalist golden age. His later work overturned the German Historical School's theory of progressive uni-linear economic stages centered on trade, money, and markets. (Lopez would move in a similar direction.) In two early articles, Postan attacked the "notion of an undeveloped state of credit in the Middle Ages" generated by the theories of the Historical School. He investigated the use of "Credit in Medieval Trade" (1928) in one and the "dealings in credit" through "Private Financial Instruments" (1930) in the other [66-68]. Through both articles he showed "how the economists, and through them also the historians, have underestimated the volume of medieval credit and consequently misunderstood its nature" [69]. In 1933, he co-edited with Eileen Power Studies in English Trade in the Fifteenth Century. The volume explored the fifteenth century as "the great transformation from mediaeval England, isolated and intensely local, to the England of the Tudor and Stuart age, with its worldwide connections and imperial designs. It was during the same period," Power and Postan claimed, "that most of the forms of international trade characteristic of the Middle Ages were replaced by new methods of commercial organization and regulation ... [which] marked movement towards capitalist methods and principles" [70]. In the same year, Postan published a major bibliographic review that assembled the evidence for a European-wide "medieval capitalism" [71]. All these works developed the hard empirical case for a nascent capitalism in medieval England and Europe 
contra Sombart, and the Historical School of Political Economy represented by Hildebrand and Bücher.

Postan was by no means the sole or principal representative of this trajectory. Postan's article on medieval capitalism assembles a wide array of scholarship. Its arguments were preceded by two interwar articles published in the American Journal of Economic and Business History that critiqued Sombart, Weber, Tawney, Brentano and presented the new commercial activity of the high Middle Ages [72,73]. Moreover, the roots of the challenge to Sombart go back to Henri Pirenne's Les pèriodes de l'histoire sociale du capitalisme in which Pirenne proposed a thesis of commercial expansion in the high Middle Ages and stagnation in the later Middle Ages [74]. Pirenne was an important mentor for Eileen Power and for the French historian Marc Bloch who in turn influenced Power. All three likewise shaped Postan. In the same year that Postan published "Medieval Capitalism," Marc Bloch published his seminal article "Natural economy or money economy: a pseudo-dilemma" [75,76]. Bloch challenged the Historical School's categories of "natural economy" and "money economy" as "lazy solutions whose apparent simplicity" would be "exploded by searching enquiry" [77].

In 1934, the plans for the first volumes of the Cambridge Economic History of Europe were laid by Eileen Power and Sir John Clapham. Both Marc Bloch and Michael Postan would offer substantial help in the planning of the project. The first volume was to be devoted to medieval agrarian life, the second to medieval "urban, industrial, and commercial" problems, and the third to medieval economic policy and theory [78]. The extent of Postan's collaboration in the planning of the volumes and the execution of the first volume was probably unknown even to Clapham himself [79]. The Cambridge Economic History of Europe would be the most important and lasting scholarly contribution to emerge from the interwar and immediate postwar years. Postan would become co-editor when Power died suddenly from a heart attack in 1940 as the first volume went to press, and Postan would become principal editor on Clapham's demise in 1946. When Volume Two appeared, it made normative the concept of a commercially vibrant medieval Europe, putting to rest once and for all the notion of a precapitalist medieval Europe espoused by the Historical School and Sombart. The key contributions to Volume Two were Postan's and Lopez' paired chapters on trade [80]. Together with Raymond de Roover's contribution in Volume Three on "The Organization of Trade," these two chapters provided the best overview to the field of medieval economic history for many years [81].

The series was intentionally European in scope and built on the collaboration of European and American scholars. But during and after the war, it would become an émigré project to a large extent. The first volume on "Agrarian Life" had begun when international collaboration was still possible, but by the end many submissions were delayed or cancelled because of the war [82]. Richard Koebner, a Jewish Professor in Breslau was forced to emigrate. He took up a position at the Hebrew University in Jerusalem. His important chapter on "Settlement and Colonization of Europe" leading off the volume was delayed, because he faced difficulties "mastering the art of lecturing in Hebrew" [83]. The Italian scholar who was to write the Italian section was unable to deliver his manuscript at all [84]. The Dane who replaced the Italian scholar died, and the Fin who replaced the Dane, wrote "'from somewhere in Finland' in November 1939 that he hoped to get back to economic history but that 'it was a small thing compared with the independence of his 
country'." The Spanish contributor was a refugee without his notes and therefore unable to complete his contribution. Of the Polish Professor Rutkowski, Clapham wrote "all that we know with certainty is that he cannot be at his University of Poznán" [85]. Professor Ganshof was serving in the reserve army of Belgium. Marc Bloch was mistakenly believed by Clapham to have safely emigrated to America [86,87].

Progress on the second volume "Trade and Industry in the Middle Ages" faced similar difficulties. Power was no long alive to write the general essay on trade in the Mediterranean South as had been planned, nor Bloch to help find and guide contributors on the continent. Two other contributors had died, the rest were cut off from contact with the editors when Britain entered the war. The British contributors were compelled to take up war duties. Postan himself served in the Ministry of Economic Warfare [88]. Consequently, when the project was taken up again at the end of the war, the entire list of contributors had to be reconsidered and new invitations issued. In particular, collaboration with scholars from Eastern Europe became very difficult. For both intellectual and logistical reasons, Postan significantly revised Power's original plans for Volumes Two and Three. Volume Two was narrowed to focus solely on trade and industry, making the discussion of commercial expansion even more prominent. Development of towns, economic policy of municipal governments, and the history and policy of gilds, urban finance and related topics would appear in Volume Three alongside the issues of economic policy and economy theory [89]. The upshot was that the authors of the two general chapters on trade and industry in Southern and Northern Europe had to cover fields even larger. Postan solicited Robert Lopez to write "The Trade of Medieval Europe: the South," and he himself wrote "The Trade of Medieval Europe: the North."

By the time Lopez' chapter appeared in print, he was ensconced in a comfortable academic position at Yale [90]. But his professional path during the war years was anything but certain. Born in 1910 to an Italian Jewish family, Lopez was already an accomplished medieval historian with three published books by 1938. He had received his doctorate in 1932 at the University of Milan, and held positions at several Italian universities from 1933 to 1938, including a chair of history in his native Genoa [91]. When he fled fascist Italy, he passed through England. There in 1939, Lopez was entertained by the foremost Jewish historian in Britain Cecil Roth [92]. Lopez left for the United States to complete an American Ph.D. An American colleague, Robert Reynolds had advised Lopez that an American Ph.D. was necessary to secure academic employment in the US, and Reynolds helped Lopez gain admittance to the University of Wisconsin where Reynolds was on the faculty. In 1942 Lopez was awarded a doctorate [93]. From 1942 to 1943, he worked as a scriptwriter in the Italian office of the Voice of America in New York City [94]. He lectured at Brooklyn College from 1943-45, and at Columbia from 1945-46, while also serving as a foreign news editor for CBS. In 1946, Lopez was appointed to the chair in History at Yale University, where he would become a Sterling Professor of History before his retirement in 1981 [95-98]. It is worth noting that Lopez was one of the first Jews to be appointed at Yale College. According to Lopez himself, when he was brought to Yale,

he was told that he was coming in a time of crisis; he was to replace three professors who had either retired or died. A Sephardic Jewish refugee . . . Lopez informed the appointments committee of his 
religious background. Knowing something of Yale's past, he did not want to enter under false pretenses [99].

More than Postan, Lopez was grounded academically in his native academic culture before emigration. His early works fit easily into what Croce called the economic-legal school of Italian historians [100]. But like, Postan he was shaped intellectually by the experience of emigration. In Italy, he wrote local histories out of the archives of his native Genoa [101]. In the US, his best-known books were broad histories of Europe and European economic development [102-105]. Also, like Postan, he acquired a chair at an elite institution and came to shape a whole generation of scholars. But more than Postan, he maintained an overt Jewish identity even in the less than philosemitic air of Yale [106-108]. Lopez was "certainly proud of being Jewish and would never have hidden his cultural identity," a former graduate student commented [109]. Lopez married a Belgian émigré, Claude Kirschen from an assimilated Jewish family, and their children maintain a Jewish identity [110]. At the end of his career, he developed close ties to the Israeli academy including invitations to the Hebrew University, to the Institute for Advanced Study, and requests to decide on the tenure cases of Israeli medievalists [111].

Lopez' chapter on trade in southern Europe for the Cambridge Economic History of Europe was a celebrated essay that sketched out the narrative he would later develop in The Commercial Revolution of the High Middle Ages. Lopez masterfully described the "lights and shadows in western trade" during the early Middle Ages, the rise of Italy and the Muslims. He dismissed theories of natural economy or barter economy, documented the continued presence of money and trade and teased out fluctuations in local versus long-distance trade. The heart of the chapter, however, was devoted to what he called the "Commercial Revolution," a concept he borrowed from a close friend and fellow European émigré, Raymond de Roover [112-114]. Lopez described the significance of the "Commercial Revolution" in bold terms:

The startling surge of economic life in Europe in the "high" Middle Ages is probably the greatest turning point in the history of our civilisation. . . It was instrumental in bringing about all the momentous changes which ushered in our contemporary civilisation much before the end of the MA and was, in turn, influenced by all these changes. It caused the old feudal system to crumble and the old religion to weaken; it gave liberty to the serfs... and ... created a new aristocracy of wealth. . . . Italy was to the medieval economic process what England was to the modern [115].

Lopez leaves no room for doubt that he identified the Commercial Revolution with capitalism. "The golden age of medieval trade ... knew many of the characteristics which we regard as typical of capitalism:" accumulation of capital, growing use of credit, improvement of business methods to compete, expansion of markets, separation of management from ownership and labor, state interest, desire for profits [116].

The original context within which de Roover used the concept is instructive. In 1941 just as the first volume of the Cambridge Economic History was seeing the light of day, N.S.B. Gras and his Belgian student, Raymond de Roover delivered papers at the American Historical Association and the Business Historical Society. Gras, a Canadian who held the first chair in history at the Harvard Business School from 1927, discussed "Capitalism-Concepts and History." He argued that the essential element of capitalism was business administration; for it was business administration that 
managed the fundamental factors of labor, land, and capital [117,118]. Petty capitalism which flourished in ancient and medieval towns was transformed into mercantile capitalism, the second of five stages, by the sedentary merchant who replaced the traveling merchant. With new management techniques, new credit instruments, new forms of insurance, and above all new partnerships, the sedentary merchant controlled increasing levels of trade from the counting house. Gras essentially adopted the Historical School's method of historical stages to capitalism and located a form of it in the Middle Ages.

de Roover, commenting on Gras' argument, gave a weighted spin to this shift from traveling to sedentary merchant and from petty to mercantile capitalism by defining it as a "Commercial Revolution of the thirteenth century" which cut the Middle Ages in two. de Roover took care to specify precisely what he meant by a Commercial Revolution. It is worth quoting him, for this forms the basis of the first and most precise use of the concept "Commercial Revolution"-a usage still current today [119].

By a commercial revolution I understand a complete or drastic change in the methods of doing business or in the organization of business enterprise just as an industrial revolution means a complete change in the methods of production, for example, the introduction of power-driven machinery. The commercial revolution marks the beginning of mercantile or commercial capitalism, while the industrial revolution marks the end of it [120].

Lopez would deepen and broaden the concept, moderate the uni-linear developmental scheme with a late medieval contraction, but he would never veer from the trade and market-centered definition [121]. de Roover would maintain the narrative that he adopted from Gras when he published his chapter on the "Organization of Trade" for the third volume of the Cambridge Economic History of Europe (1963), but interestingly de Roover dropped the concept of Commercial Revolution [122].

Lopez would develop the main ideas of his own chapter more fully in the monograph he published at the height of his career The Commercial Revolution of the High Middle Ages (1971). The monograph elevated de Roover's concept of "commercial revolution" to a historiographic paradigm that continues to shape the field [123]. Essentially, Gras, de Roover, and Lopez refuted Sombart by demonstrating that a Sombartian capitalism happened earlier, in the high Middle Ages. But Lopez also integrated Roscher's notion of the economic function of the Jews into his narrative of European economic development [124]. The chapter on "The Take-Off of the Commercial Revolution" includes a short section on "The Jews" who are described as the only link in the early medieval period to the commerce outside of Europe. The early medieval Jews were supplanted by "The Italians," and the chapter turns to the heart of Lopez' narrative of commercial development centered on "Coins and Credit," "Contracts," and "Transportation" [125].

Postan's complementary chapter in the Cambridge Economic History, "Trade in Medieval Europe: The North," likewise described a commercial expansion during the high Middle Ages and a contraction in the late Middle Ages. He did not however use the terminology of "Commercial Revolution" nor did he center his historical narrative on the techniques of business administration that Lopez and de Roover favored. Rather he emphasized the trade in basic foodstuffs and raw materials for industry (wool, timber, pitch, metals) over against a conventional image of medieval 
trade in luxury goods only, on the one hand, and against a sharp separation of agriculture and commerce, on the other. Postan, like Lopez, clearly dismissed the theories of Sombart and the Historical School. "An unbiased student of medieval agriculture," he says, "cannot avoid the conclusion that social existence in medieval villages would have been impossible without some market and some trade.

This conclusion is in the nature of things hypothetical, but it is sufficiently obvious to shift the onus of proof from those who assume some trade at all historical times to those who wish to deny its existence at any period of the historical, as distinct from the pre-historical, past. In this sense medieval trade never "arose"; but it undoubtedly expanded and contracted [126].

Postan disposed of the old uni-linear account of economic history as commercial development that steadily rises. In place of a narrative describing a commercial rise from the Dark Ages when trade virtually disappeared to the sixteenth century when it flourished abundantly, Postan put in place a narrative of cyclical expansions and contractions. These rhythms were generated not by trade but in the rural countryside by demographic change.

One can sense in this 1952 chapter, Postan's own intellectual shift. At the start of his career he focused on medieval trade and finance, evident in his seminal articles on "Credit in Medieval Trade" (1928) and "Medieval Capitalism" (1933) and his collaborative work with Power Studies in English Trade in the Fifteenth Century (1933) [127-129]. By his mid-career, his interests had shifted to agrarian life, with particular attention to agriculture, serfdom, and labor services. By the end of his career he had developed a "population-centered interpretation of medieval economic history as an alternative to the trade-centred interpretation. . . . Postan demonstrated that the pre-industrial economy of Europe was marked by a succession of long cycles of demographically driven expansions and contractions, following a basically Malthusian dynamic" [130].

It has been suggested that the initial version of this theory is in Postan's 1950 address to the International Congress of Historical Sciences [131]. But one can see an earlier move away from a money, market and trade-centered interpretation in his seminal 1944 article on "The Rise of a Money Economy" $[132,133]$. This takes us back to the midst of the war years, when Postan was working for the Ministry of Economic Warfare and the 2nd volume of the Cambridge Economic History was on hold. In this article, Postan pointedly demonstrated that the historian's recourse to the notion of a "rise of a money economy" was a stopgap explanation for any number of historical problems in any number of historical periods. (Rather like the Jewish moneylender, we might note.) If "rise of the money economy" refers to the birth or first use of money, it belongs to a period preceding the Neolithic or even pre-historic Bronze Age. If rise of the money economy is used to mean the general expansion of money payments, then it means something not much different from the rise of an exchange economy and the decline of a natural economy; and this, Postan argued, can be empirically tested. Yet, this very notion of natural economy Postan rightly noted has been under attack and come to mean little more than a tendency towards self-sufficiency, which oscillates back and forth in different historical periods. (Bloch's 1933 essay on natural economy or money economy was one of those attacks.) "Used in this sense," Postan concluded, "the formula of the rise of money economy points to a real social process, easy to identify and dangerous to miss," but of little revolutionary significance. It is moreover a historical phenomenon 
"of composite origin and reflecting an infinite variety of causes, social, economic and political." Even in the sense of increased money payments "the formula is sometimes wrapped up in a great deal of theory and mysticism, or else hitched to irrelevant facts. The most irrelevant of facts ... is the so-called increase of money" [134]. "In some writings," Postan continues, "and especially in some German writings, the rise of money economy figures as a permanent tendency of historical development as an ever-unfolding manifestation of the progressive destinies of humanity." But Postan concludes, "in reality it is none of these things. It is certainly not uninterrupted, and in that sense not progressive" [135]. At no point but the present has there been sustained growth, and contemporary phenomena cannot be regarded as eternal. One cannot but note the chronological concurrence of Postan's essay with that of Oelsner and the monograph of Karl Polanyi, to be discussed shortly, and their common critiques of the Historical School, and reflect on the way that Postan's essay too, though less overtly, was a "war-time effort" in more than a chronological sense.

During the 1940s and 1950s, Lopez too wrote a series of articles that critiqued interpretations of luxury goods and gold currency by the great innovators in medieval economic history, Henri Pirenne and Marc Bloch. These essays can be seen as a tentative move by Lopez from a money, market, and trade-centered approach to a political and cultural explanation of economic change. In "Mohammed and Charlemagne: A Revision" (1943), Lopez challenged Pirenne's "catastrophic thesis" that the Arab conquests caused a "sudden collapse in international trade"-which, in turn, produced sweeping social and economic internal revolutions [136]. Lopez demonstrated that the disappearance of four luxury goods in the west originated in political and cultural changes in the Byzantine and Arab world. In this respect he foreshadowed the recent conclusions of Michael McCormick that Pirenne was right for the wrong reasons [137]. In "Back to Gold, 1252" (published in Postan's journal The Economic History Review), Lopez modified explanations that tie the disappearance and reappearance of gold currency in the medieval west simply to contraction and expansion of trade. Lopez offered convincing political interpretations for the cessation of gold currency in the west: The Carolingians did not wish to 'tick off' the Byzantines by claiming too many imperial symbols. Lopez offered a nuanced and complex interpretation of Genoese and Florentine issuance of gold coinage in 1252. The Genoese and Florentines capitalized on a combination of favorable circumstances: "the ratio between the price of gold and that of silver fell to its lowest medieval level, a major business cycle reached the peak of prosperity, and opportunities for investment of Genoese gold coins in certain foreign countries took a most auspicious turn" [138].

In "An Aristocracy of Money in the Early Middle Ages" published in 1953, Lopez examined moneyers as an urban-patriciate of the early Middle Ages made prominent by the possession and handling of money. He argued that moneyers in the early Middle Ages were at their peak of power when they were the sole holders of coined metal. "They were an 'aristocracy of money' not when money was most useful, but when it was most rare" [139]. The argument clearly challenges presumptions of a non-money economy in the early Middle Ages and moves in the same direction as Bloch and Postan, while still maintaining that a decisive change took place in the High Middle Ages. Despite these moves towards a sophisticated political interpretation of economic change, Lopez' masterpiece The Commercial Revolution of the High Middle Ages, written at the pinnacle of his career, holds to a trade-centered interpretation. 
Lopez and Postan both refuted a Sombartian vision of a precapitalist Middle Ages and the Historical School's theory of economic stages by locating the dawn of modernity in a high medieval economic and demographic expansion. Lopez and Postan stand as foremost representatives of a whole cadre of medieval scholars who rediscovered the rich commercial life of medieval Europe. Their paired chapters in the Cambridge Economic History of Europe stand as twin pillars in a collaborative construction of a new paradigm. The Cambridge Economic History together with their later works were central in crafting a new scholarly consensus concerning the basic rhythms of medieval economic history. They charted a high medieval take-off followed by a late medieval contraction, and they argued that that take-off, despite the contraction, laid the groundwork for sustained growth in the long sixteenth century.

Whether one prefers Lopez' trade-centered formulation “Commercial Revolution” or Postan's demographically driven "expansion and contraction," it is clear that both refuted the empirical basis for a "pre-capitalist Middle Ages." They were not alone; a number of scholars had contributed to this new paradigm and even more were taking it up and weaving it into mainstream history [140-160]. But Postan and Lopez were leaders. Their formulations crystallized this new historical trajectory and articulated the new paradigms that would be adopted in the historical literature. What they passed over in silence is that the new paradigm lends support to Oelsner's critique of the Jewish narrative: The logical implication of a refutation of Sombart is a refutation of the commonplace narrative of the "Jewish moneylender." By jettisoning a medieval economy envisioned as a barter or natural economy, one no longer needs "outsider Jews" operating as cultural carriers of commercial life until Europeans matured and developed money, markets, and trade. Their economic history helped open medieval history beyond a narrow focus on church history and the history of monasticism and Christian theology that predominated together with traditional political history. But Postan showed no interest in Jewish topics, and Lopez wove Roscher's old paradigm neatly into his Commercial Revolution with the synthetic art of a journalist [161]. The explanation for this fact lies in their Jewish identity.

Both Postan and Lopez, like Marc Bloch, adopted an assimilationist mode characteristic of their generation. They did not reject their Jewish identity, but by quietly deemphasizing it, integrated themselves more easily into academic circles [162]. Bloch's better-documented struggle with his Jewish identity can provide both a parallel and a point of contrast for Postan's and Lopez' identity as European scholars and Jews. At the outbreak of the war, Bloch had enrolled for service in the French army [163]. When France was occupied, he sought refuge in Vichy France and attempted to emigrate to the US. Although Bloch was invited to the US in October 1940 on a Rockefeller fellowship at the New School [164], he remained in France after failing to receive visas for all dependent family members. Following his sons' lead, he joined the French Resistance. Even then, Bloch continued to offer advice on the Cambridge Economic History via clandestine letters to Postan until a few months before he was captured [165]. He died a hero's death, when a group of 28 prisoners were executed in a field in the spring of 1944 a few months before the liberation [166,167]. During the war, Bloch wrote his own "Spiritual Testament" to replace the "Hebrew prayers, whose cadences . . . accompanied so many of my ancestors and my father himself to their last rest." He refused the Kaddish, because he valued above all a "'total sincerity in expression and spirit,' and it would be dishonest to have recourse to the rites of a religion in which he did not believe. . . 'Face 
to face with death,' he affirmed that he was born a Jew. 'Above all,' however he felt himself 'very simply French" [168]. Bloch's seemingly simple passionate attachment to a national French identity was however clearly a reaction to the racial laws of Vichy France and a rejection of the imposition of a racial definition that led to the exclusion of Jews [169]. In this respect there is a sharp contrast between the trapped nationalist, Bloch, and the successful émigrés.

Postan and Lopez had integrated well in their new homelands and acquired a new layer of national identity. Jewishness was both the cause of their double nationalities and the bridge between them. This double identity can be seen in the closing lines of a letter which Lopez helped drafted for the conductor Arturo Toscanini during the war: "For I love Italy, and with equal devotion I love you sons of this great American Republic which, together with the United Nations, will soon put an end to despotic wars, and bring into the renovate world a bright and more breathable atmosphere of freedom and peace" [170]. The letter was both published as an open letter to the American people in Life magazine and sent in an abbreviated form privately to the President. It was part of Lopez' war effort. Like Toscanini, Lopez was both an Italian patriot and an American patriot. The Jewish identity that led to his emigration was a bridge between his old country and his new.

Postan differed from Lopez in ultimately rejecting a theoretical basis in a trade-centered economic history and in more quietly disengaging from Jewish history. In this respect, Postan's work aligns with the last émigré of Jewish origin to be considered here, Karl Polanyi.

\section{Karl Polanyi and the Great Transformation}

In the depth of the war years, a refugee from Central Europe Karl Polanyi (1886-1964) penned his classic The Great Transformation in the safe harbors of Great Britain and the United States [171]. Like Kisch and Oelsner this was his war effort. But whereas they responded to the current destruction of European Jewry, Polanyi analyzed the causes behind the collapse of European civilization as a whole. Polanyi's work, when placed in the context of other émigré works can be read, I propose, as another response to the Jewish Question. For it reworks the whole concept of economy to displace the centrality of the profit motive (linked by Sombart to Jews and Judaism) and the self-regulating market system. Polanyi as a socialist and assimilated Jewish thinker adds another dimension to the Jewish responses to economic history described here.

Polanyi was born in 1886 in Vienna. His father's family came from Ungvar, then Northern Hungary, and "were part of the rising urban bourgeoisie and the movement for the national assimilation of Hungarian Jewry." Mihaly Pollacek, Karl's father, moved his family to Budapest in the late 1880 s where his success as a railway contractor made them economically part of the upper-middle class. But according to his granddaughter, "Mihaly Pollacek regarded the Hungarian 'gentry' with horror and contempt, as he did the wealthy Jewish 'gentroid' bourgeoisie of Budapest. He maintained social contact with neither. Personally, he remained Jewish and a Pollacek; but Magyarized the names of his children to Polanyi and changed their religion to Protestant (Calvinist) [172-174]." Karl studied law at the university, and after brief involvement with a socialist student organization, joined the Galilei Circle a progressive community of "free thinkers" devoted to consciousness raising through teaching and learning. Several miserable years as a lawyer in his uncle's firm were followed by service in the Austro-Hungarian army in Galicia from 
1915 to 1917 . Disabled by illness and hospitalization in 1917, Polanyi slowly emerged from what had been a ten-year crisis with a new passionate focus on the social sciences and the question of freedom [175]. When the Szabadgondolat of which he was an editor was closed by the Communist regime in 1919, he left for Vienna. There he would meet other Hungarian emigrants who fled the White Terror of 1920, including his wife Ilona Duczynska, a socialist revolutionary and political activist [176]. This was the first of Polanyi's exiles. In Vienna, he worked as an economic journalist for the Österreichische Volkswirkschaft and took part in the intellectual life of interwar Vienna. Though not a central figure, he was recognized for his participation in the Calculation Debates where he advanced a non-orthodox socialist position. He advocated de-centralized planning against Mises' arguments that planning is impossible on the one hand and Neurath's vision of centralized planning on the other. In 1933, as Hitler's success strengthened the Austrian fascists, Polanyi emigrated to England. But his wife and child remained behind. With the collapse of Austrian democracy and the success of the Heimwehr fascism, his daughter Kari was sent to him in England. Ilona joined them only two years later having stayed in Austria to participate in the illegal Schutzbund [177]. In England, Polanyi was associated with Christian socialist circles and socialist scholars R.H. Tawney and G.D.H. Cole. Through these connections he was employed as a lecturer in adult education for the Workers' Educational Association (W.E.A.) and the Extra Mural Delegacies of the Universities of Oxford and London, and arranged a lecture tour in the U.S. [178]. Moving in these circles, he is likely to have crossed paths with Eileen Power and Michael Postan. Power ran a seminar on economic history with Tawney, and she too For Power was associated with the Worker's Educational Association. During this period, Polanyi deepened his knowledge of Industrial Revolution particularly with reference to England [179]. These studies would bear fruit in The Great Transformation [1944], an interpretive study of the nineteenth century in which Polanyi attempted to explain the rise of Fascism and collapse of European society.

His analysis focused on the capitalist ideology of a self-regulating market, which he considered utopian, and it issued in a formative critique of contemporary economic theory as market driven.

Our thesis is that the idea of a self-adjusting market implied a stark utopia. Such an institution could not exist for any length of time without annihilating the human and natural substance of society; it would have physically destroyed man and transformed his surroundings into a wilderness. Inevitably, society took measures to protect itself, but whatever measures it took impaired the self-regulation of the market, disorganized industrial life, and thus endangered society in yet another way [180].

An autonomous market system severs the symbiotic connection between society and economy, inverting their natural order. The aim of the economy is no longer the satisfaction of society's material needs, but ever increasing profit. The profit motive drives economic activity, regardless of the human and environmental costs. This inversion shows itself in the commoditization of factors such as labor, land, and money, which are commodities only in fiction.

Polanyi built his argument for the regulation of modern economy by demonstrating how economies across time and space have been embedded in social institutions. Drawing on the ethnographic literature describing primitive economies, Polanyi constructed three ideal types of "economic exchange"-reciprocity, redistribution, or exchange. (This last was the historic origin of the self-regulating market system, but, he emphasized, it need not have developed in this direction.) 
Only an economy embedded in its social institutions is properly directed to sustaining human life, as opposed to accumulating capital. The ideal of a self-regulating market system, Polanyi concluded, is historically unprecedented, an aberration in human history, one which is destroying European society.

By arguing that a self-adjusting market system is a false utopia and historically unprecedented, Polanyi attacked the root principles of classical political economy and neo-classical economicsthat an autonomous market system is the pinnacle and teleological end of economic development. In this system of thought, the market system becomes identical with "economy" and serves as a theoretical model for all cultures in any historical period. Polanyi in contrast pointed out the historical contingency of and the utopian elements in classical and neo-classical economics. He argued that the following principles are valid only for a study of modern market systems, and then only in part: (1) the basic economic unit is an autonomous agent, (2) with an innate propensity to "truck, barter and trade," (3) which propensity naturally gives rise to markets, (4) which markets naturally give rise to a self-regulating market system [181]. In no primitive society, Polanyi argued, does the orthodox economic story bear out: individuals do not show a propensity to barter, nor does barter give rise to local markets and a division of labor, necessitating regional and long-distance trade. Polanyi specifically articulates his critique as a response to Adam Smith. This is not surprising given the English context within which he was reading and lecturing during the war. What is not viscerally evident is that the Smithian propensity to "truck, barter, and trade" had been linked in German economic literature specifically to Jews and Judaism [182]. This German context unveils another layer in Polanyi's thought, suggesting that his work can be read as a profound response to the Sombartian reduction of Jews and Judaism to the spirit of capitalism.

Following the enthusiastic reception of The Great Transformation, Polanyi received a visiting professorship in 1947 at Columbia University where he directed a project supported by the Council for Research in the Social Sciences at Columbia on the origins of economic institutions. After his retirement in 1953, he and the anthropologist Conrad Arensberg directed an Interdisciplinary Project funded by the Ford Foundation on the economic aspects of institutional growth, as well as a faculty seminar at Columbia on the same topic. This series of research projects reached fruition in the path-breaking collection of essays Trade and Market in the Early Empires: Economies in History and Theory, edited jointly by Polanyi, Arensberg, and the sociologist, Harry Pearson, in consultation with the Assyriologist A.L. Oppenheim from the Oriental Institute at Chicago. The aim of the volume as a whole was the exploration of the relation between social institutions and economic patterns, in both market and non-market economies. The underlying impetus for the volume was the sociological understanding of economy or what Polanyi referred to as the "place of economy in society."

The collection drove a single argument home, due in large measure to Polanyi's guiding vision: the economic process must be rethought more broadly than the market complex in order to understand pre-industrial and primitive economies. "The authors see in the market bias an intellectual obstacle to that broadening of our vision in matters economic which they advocate" [183]. Just as Polanyi argued in The Great Transformation, the authors here hold that

Adam Smith's discovery of the market as the pivot of the economy was more than a practical insight...His concept of the market as a spur to competition gave the decisive impetus for that view of 
society that was to arise from such an economy: a concept that was eventually regarded as an universal tool in the atomistically conceived history and theory of man. The market, then, shaped both the organization of our actual material existence and the perspectives from which we were allegedly enabled to grasp all forms of social organization [184].

Polanyi and his fellow editors protested against the neoclassical definition of the "economic" as economizing action in a situation of scarcity, and its claim to historically universal applicability.

Such an approach must induce a more or less tacit acceptance of the heuristic principle according to which, where trade is in evidence, markets should be assumed, and where money is in evidence trade, and therefore markets, should be assumed. Naturally, this leads to seeing markets where there are none and ignoring trade and money where they are present, because markets happen to be absent. The cumulative effect must be to create a stereotype of the economies of less familiar times and places, something in the way of an artificial landscape with only little or no resemblance to the original [185].

Polanyi argued that the economic has a substantive meaning, not just a formal (neo-classical) meaning. The substantive meaning refers to the satisfaction of material wants through humankind's interchanges with nature and fellow human beings. "Only the substantive meaning of 'economic'," Polanyi argues, "is capable of yielding the concepts that are required by the social sciences for an investigation of all the empirical economies of the past and present" [186]. That is, focusing on rational economizing limits the scope of investigation, ruling out economic activities that do not conform to the modern market system. The anthropologist, sociologist and historian is faced, Polanyi argues, with a great variety of institutions other than markets, in which humankind's livelihood is embedded. Thus an analytical method devised for a special form of the economy, which was dependent upon the presence of specific market elements is useless. Only the substantive definition opens economic thought up to non-market systems [187].

Trade and Markets in Early Empires set off a revolution in the newly emerging sub-field of economic anthropology and had a similar if less far reaching effect in ancient history. During the sixties and seventies, economic anthropology was divided between "formalists" subscribing to the use of contemporary economic theory for primitive economies and "substantivists," following Polanyi's model, joined somewhat later by a third approach, that of the New Left Marxists, which posed a focus on production as a counterpoint to Polanyi's on circulation. Polanyi's model had some muted influence in medieval history as well, particularly through Georges Duby's Early Growth of the European Economy, which drew on Polanyi as well as the sociologist Marcel Mauss, following a seminar of the Annales School [188-190]. While Polanyi's influence in economic anthropology has waned, his contributions have been absorbed into the make-up of the field and synthesized with other approaches. With the foundation of a Karl Polanyi Institute in Montreal and a series of conferences connected with the Institute from the mid-1980s on, Polanyi's ideas received renewed attention from a diverse group of thinkers concerned with globalization, third world development, freedom within state regulation, ethics in economy. With the weakening and collapse of the Soviet controlled Communism of central and Eastern Europe, western Marxism all but gave its last gasp. Polanyi offered in the West a broad, innovative thinker championing a non-Marxist socialism, with an ethical economics based in Christian thought [191]. 
Polanyi was a Christian socialist, but he was also Jewish. As a socialist thinker, he was part of a large group of assimilated Jewish intellectuals and political activists who have been invisible in the literature on modern Jewish history their socialist identity took precedence over their Jewish identity. As an assimilated Jew, Polanyi was Jewish in a social sense, through the networks of familial and social ties within which his life was embedded. Finally as a central European émigré, Polanyi had the racial category that denied his own self-identification as a Christian socialist thrust upon him. His intellectual trajectory was shaped by the experience of emigration as a "Jew." Without the exposure to the traditions of political economy and history in England, perhaps too without the personal trauma of exile, the Great Transformation would never have been written. Without the fellowships and scholarly connections in the US, the collaborative work at Columbia would not have produced the same forceful, intellectual model influencing anthropologists, sociologists and premodern historians in the postwar period. Though he neither saw himself as "Jewish" nor linked his work to Jewish history, his work challenged the very construction of "economy" around a "profit motive" that was linked with Jews and Judaism.

\section{Conclusions}

These five intellectuals represent a range of émigré experiences and Jewish identities. Postan and Polanyi were émigrés in the aftermath of the Russian Revolution and the political upheavals in Eastern Europe. Both cycled through Vienna and London, and both had intimate knowledge of socialism with roots in central and eastern European Jewish politics. Postan had settled in England, entered the university system, and built a career, ultimately securing a comfortable chair at Cambridge. Postan, Polanyi, and Lopez would all work as journalists before establishing (or re-establishing) themselves in academia. Polanyi was a journalist for a decade in Vienna, but would become an émigré once again along with Kisch, Lopez, and Oelsner as a consequence of Nazi racial policy. Kisch and Lopez emigrated to the US as already established scholars, though Lopez enrolled in and completed an American Ph.D. program for the sake of employment. Oelsner coming late to the university and denied entrance in the 1930s, would gain both a BA and an MA in America. In this she was similar to Postan, but unlike Postan, Oelsner never achieved a secure academic position. Polanyi, a committed socialist, worked forty years as a teacher in the worker's educational movement and would become a visiting professor in the US, first through a wartime fellowship at Bennington College, then through his wartime writings at Columbia University.

But despite differences in identity and personal experience, these émigrés are united by the fact that each one responded to the contemporary European crisis in intellectual projects on the economic history of premodern Europe. The "lived historical experience" of the war years brought new urgency and crystallized the construction of new paradigms that have profoundly shaped intellectual work in the later twentieth century [192]. For Kisch, Oelsner, and Polanyi, this intellectual intervention was their war effort. Their intellectual projects directly grew out of the collapse of European Jewish life on the one side (Kisch/ elsner) and the collapse of European democracy on the other (Polanyi), and their personal experience of both.

Postan's and Lopez' works were not so evidently a "war effort." Their intellectual trajectories had already been set in place in the interwar years, but there are complex ties between their work, their émigré experience, and the war. For both, their war effort was the more traditional one of 
serving in war offices where their native languages made them highly useful. Postan became the head of the Russian section of the Ministry of Economic Warfare and contributed to the official civil history of the war [193,194]. Lopez worked in the Italian section of the Office of War Information as a scriptwriter. Both of them met their future wives as co-workers in the war offices. Lopez quipped that his successful courtship of Claudia Kirschen "was his supreme wartime accomplishment" [195]. Four years after Power's death, Postan married Lady Cynthia Keppel, the daughter of the Ninth Earl of Albemarle [196]. An unintended consequence of these marriages was the greater ease of accepting these "foreign" and Jewish émigrés into the social circles of the academic elite and thereby the solidification of their intellectual influence [197]. Postan and Lopez would each educate a whole generation of medieval historians in Great Britain and the United States. In a similar way, the disruption the war caused to the Cambridge Economic History of Europe threw Postan and Lopez to the forefront in the composition of that key second volume. Perhaps their interest in commercialization in the medieval period was deepened by the political experiences that led to emigration. But for Postan and Lopez, the crisis of the war itself did not radically shape their intellectual projects. Rather it was the nature of their émigré experience that did. As émigrés, both Postan's and Lopez' intellectual trajectories were shaped by their encounters in a new academic setting (as was Oelsner's). Postan was brought into economic history by his teachers at the London School of Economics. Lopez, already an accomplished economic historian when he arrived in the States, was broadened by his American experience. His formerly narrow, local studies gave way to exceptional broad and synthetic works (in part no doubt due to that essential American element of distance from the archives) [198].

Neither Postan nor Lopez wrote Jewish history nor engaged with Jewish historical issues (aside from Lopez' modest incorporation of “the economic function of the Jews"). But a latent connection exists due to the prominence of political discourses laced with stereotypes linking Jews and capitalism in first half of the twentieth century. Neither Postan nor Lopez intended their work to refute Roscher's theory of an "economic function of the Jew" (and to suggest such would be to diminish the broad-ranging historical palette with which they dealt). But they proposed a model of expansion and decline before the sixteenth century that fits hand-in-glove Oelsner's critique (even if Lopez like Kisch accepted Roscher's model). Postan in particular developed a historical narrative that realized Polanyi's theoretical critique of a linear, teleological progression of economy grounded in a Smithian economic man with an "innate propensity to truck, barter and trade" or what we might also call the "Jewish moneylender." Two of these émigrés were fiercely Jewish and devoted their intellectual life to questions of Jewish history (Kisch and Oelsner), two personally identified as Jews but had little involvement in scholarship on Jewish Studies (Postan and Lopez) $[199,200]$, one was a Christian socialist of Jewish origins (Polanyi). But the pressure of Nazi racial categories and the war produced similar effects - emigration and intellectual projects that rethought European economic history with particular emphasis on the premodern. The intellectual trajectories charted here contributed major new paradigms that profoundly shaped intellectual work in the post-war years and continue to shape our thinking today. 


\section{References and Notes}

1. W. Roscher. "Die Stellung der Juden im Mittelalter, betrachtet vom Standpunkt der allgemeinen Handelspolitik." In Zeitschrift für die gesammte Staatswissenschaft, edited by K. Bücher. Tübinger: Verlag der H. Lauppschen Buchhandlung, 1875. The essay was first published in Italian in the Giornale degli Economisti, 1875.

2. It was republished in Roscher's collected essays Ansichten der Volkswirthschaft aus dem geschichtlichen Standpunkte; Leipzig: C.F. Winter, 1878, Volume 2, pp. 321-354.

3. Kisch published a celebratory assessment of Roscher's essay together with a truncated part of the original German essay translated by Solomon Grayzel. G. Kisch. "The Jews' Function in the Mediaeval Evolution of Economic Life in Commemoration of the Anniversary of a Celebrated Scholar and his Theory." Historia Judaica 6 (1944): 1-12.

4. W. Roscher. "The Status of the Jews in the Middle Ages Considered from the Standpoint of Commercial Policy." Historia Judaica 6 (1944): 13-26.

5. Toni Oelsner published a sharp critique. T. Oelsner. "Wilhelm Roscher's Theory of the Economic and Social Position of the Jews in the Middle Ages: A Critical Examination." YIVO 12 (1958-9): 176-95.

6. In particular, one must mention Richard Koebner and Jacob Katz, both of whom emigrated to Palestine. The first was an important medievalist and comes into the story told here as a contributor to the Cambridge Economic History edited by Postan. Katz had tremendous influence on the field of Jewish studies. Other figures for instance would include Simon Kuznets. See: S. Lo, and E. G. Weyl, eds. Jewish Economies. New Brunswick: Transaction Publishers, 2011.

7. The one exception for Lopez is the encyclopedia article by Felice Lifshitz: F. Lifshitz. "Lopez, Robert." In Encyclopedia of Historians and Historical Writing. London: Fitzroy Dearborn, 1999, Volume 1, pp. 732-23.

8. The one exception for Postan is Maxine Berg's biography of his first wife Eileen Power: M. Berg. A Woman in History: Eileen Power 1889-1940. Cambridge: Cambridge University Press, 1996.

9. A. Gordon. "The Need for the 'West': Hans Kohn and the North Atlantic Community." Journal of Contemporary History 46 (2011): 33-57.

10. See the articles in this journal issue: M. Bormuth. "Meaning and Progress in History-A Comparison between Karl Löwith and Erich Auerbach.” Religions 3 (2012): 151-162.

11. M. Hacohen. "Typology and the Holocaust: Erich Auerbach and Judeo-Christian Europe." Religions 3 (2012): forthcoming.

12. O. Ashkenazi. "Home-Coming as a National Founding Myth: Jewish Identity and German Landscapes in Konrad Wolf's I was Nineteen.” Religions 3 (2012): 130-50. 
13. This essay proceeds by reconstructing the modern twentieth-century historical context for the writing of medieval history and granting this context a formidable influence in the invention of new paradigms for understanding medieval history. Recovering the context for the intellectual discoveries in no way diminishes their truth-claims. Rather it only suggests that the path to this truth lies through the smoke and ashes of WWII. Medieval history is a creative enterprise that nests like a Russian doll inside layers of modern experience.

14. For Kisch's biography, see: s.v. "Kisch, Guido," and s.v. "Kisch, Bruno." In International Biographical Dictionary of Central European Émigrés, 1933-1945. Munich: Mynchen Saur, 1980, Part Two; Volume Two, pp. 621-623.

15. G. Kisch. "The Jew's Function." In The Jews' Function in the Mediaeval Evolution of Economic Life, in Commemoration of the Anniversary of a Celebrated Scholar and his Theory. New York: Historia Judaica, 1944.

16. W. Roscher. "The Status of the Jews in the Middle Ages." In The Jews' Function in the Mediaeval Evolution of Economic Life, in Commemoration of the Anniversary of a Celebrated Scholar and his Theory. New York: Historia Judaica, 1944.

17. Two excellent recent monographs have charted this intellectual and cultural terrain: J. Karp. The Politics of Jewish Commerce: Economic Thought and Emancipation in Europe, 16381848. Cambridge: Cambridge University Press, 2008.

18. D. Penslar. Shylock's Children: Economics and Jewish Identity in Modern Europe. Berkeley: University of California Press, 2001.

19. The simplest and sharpest model is that of B. Hildebrand. "Natural-, Geld- und Kreditwirtschaft." Jahrbuch Nationalökonomie 2 (1864): 1-24. Hildebrand organizes evolutionary classification around the methods of exchange, defining three main stages: "the prehistorical and early medieval stage of natural economy when goods were exchanged against other goods; the later medieval stage of the "cash" (money) economy, when goods were bought for ready money; and the modern stage of credit economy when commercial exchange was based on credit."

20. For discussion and citation, see: M. M. Postan. "Credit in Medieval Trade." In Medieval Trade and Finance. Cambridge: Cambridge University Press, 1973, 2.

21. Karl Bücher was more knowledgeable about the Middle Ages than other economic theorists of the Historical School and careful not to simplify the stages of economic development to the radical extent that Hildebrand had. But still in his version, credit in its various permutations from occasional to consumptive to commercial still formed the backbone of the evolutionary ladder. K. Bücher. Industrial Evolution. New York: Burt Franklin, 1901.

22. Bücher's nuanced model came to form "one of the axiomatic assumptions of historical research." (Postan, ibid.) See also: D. Lindenfeld. Practical Imagination: the German Sciences of State in the Nineteenth Century. Chicago: University of Chicago Press, 1997.

23. For Oelsner's biography, see: s.v. “Oelsner, Toni.” In International Biographical Dictionary of Central European Émigrés. London: Munchen, 1983, Part Two; Volume Two, 872.

24. See also her interview: “'Bloch hielt einen Vortrag über Träume vom besseren Leben.' Gespräch mit Toni Oelsner." In Die Zerstörung einer Zukunft: Gespräche mit emigrierten Sozialwissenschaftlern, edited by M. Greffrath. Hamburg: Rowohlt, 1979, 223-47. 
25. It is further elaborated in: "Dreams of a Better Life: Interview with Toni Oelsner." In Germans and Jews since the Holocaust: The Changing Situation in West Germany, edited by A. Rabinbach, and J. Zipes. New York: Holmes and Meier, 1986, 98-119. It should be said that Oelsner's inclusion in the foregoing sources on émigrés denotes fair recognition of her scholarship, despite the fact that she never held a permanent academic post.

26. T. Oelsner. Wilhelm Roscher's Theory of the Economic and Social Position of the Jews in the Middle Ages. Oelsner's article has remained a starting point for anyone reconsidering this historical narrative.

27. See for example: L. Little. "The Function of the Jews in the Commercial Revolution." In Povertà e Ricchezza nella Spiritualità dei secoli XI e XII. Todi: Accademia Tudertina, 1969, 271-87.

28. M. Toch. "Jews and Commerce: Modern Fancies and Medieval Realities." In Peasants and Jews in Medieval Germany. Aldershot: Ashgate, 2003, XV.

29. It was also supported through a subsequent grant by Siegmund Baruch to YIVO. For the history of her research grants, see her note in the aforementioned article, p.176.

30. T. Oelsner. Wilhem Roscher's Theory. pp. 176-7.

31. T. Oelsner. "The Economic and Social Condition of the Jews of Southwestern Germany in the 13th and 14th Centuries." In Toni Oelsner Collection. Archives of the Leo Baeck Institute.

32. W. Sombart. The Quintessence of Capitalism. London: T. Fischer Unwin, 1915, and Jews and Modern Capitalism. London: T. F. Unwin, 1913.

33. M. Weber. The Protestant Ethic and the Spirit of Capitalism. New York: Scribner, 1958.

34. On the relationship of Sombart and Weber to the Historical School, see: Lindenfeld, D. Practical Imagination. p. 296.

35. See also A. Mitzman. The Iron Cage: an Historical Interpretation of Max Weber. New York: Knopf, 1970, and Sociology and Estrangement: Three Sociologists of Imperial Germany. New York: Knopf, 1973.

36. Toni Oelsner first mapped out the connections between Roscher, Sombart and Weber in: T. Oelsner. "The Place of the Jews in Economic History as Viewed by German Scholars: A Critical-Comparative Analysis.” Leo Baeck Institute Yearbook 7 (1962): 183-212.

37. My rendering of Sombart's and Weber's construction of the Middle Ages and its relationship to their thinking on Jews and Judaism is indebted to two essays, neither of which however, puts these together in precisely this way: J. Baldwin. "The Medieval Theories of the Just Price: Romanists, Canonists, and Theologians in the Twelfth and Thirteenth Centuries." In Pre-Capitalist Economic Thought: Three Modern Interpretations. New York: Arno Press, 1972.

38. P. Mendes-Flohr. "Werner Sombart's The Jews and Modern Capitalism: An Analysis of its Ideological Premises." Leo Baeck Institute Year Book 21 (1976): 87-107.

39. W. Sombart. Jews and Modern Capitalism. Glencoe, Ill: Free Press, 1951.

40. M. Weber. Protestant Ethic and Ancient Judaism. New York: Free Press, 1952.

41. E. Täubler. "Zur Handelsbedeutung der Juden in Deutschland vor Beginn des Städtewesens." In Beiträge zur Geschichte der Deutschen Juden. Leipzig: G. Fock, 1916. 
42. J. Guttman. "Die wirtschaftliche und soziale Bedeutung der Juden im Mittelalter." Monatsschrift Geschichte und Wissenschaft des Judentums 51:15 (1907): 257-90.

43. On the Jewish response to Sombart including the fistfights after his public lectures, see: D. Penslar. Shylock's Children. pp. 165-171.

44. T. Oelsner. "The Place of the Jews in Economic History as viewed by German Scholars: A Critical Comparative Analysis.” Leo Baeck Institute Yearbook 7 (1962): 183-212.

45. A number of important historians who do not come into this account directly, but ought to be mentioned are: the Italians Gino Luzzato and Armando Sapori, the French scholars Yves Renouard and André-E. Sayous, and the American scholars Abbott Usher, Frederic Lane, Frank Knight, and Florence Edler.

46. A good description of the growth of the field is given by R. Goldthwaite. "Raymond de Roover on Late Medieval and Early Modern Economic History." In Business, Banking, and Economic Thought in Late Medieval and Early Modern Europe: Selected Studies of Raymond de Roover, edited by J. Kirshner. Chicago: University of Chicago Press, 1974, 3-14.

47. See the references below.

48. R. Brenner. s.v. "Postan, Michael Moissey (1899-1981)." In New Palgrave Dictionary of Economics. New York: Palgrave MacMillan, 2008, 2nd ed. Volume 6, p. 539.

49. E. Miller. "Michael Moissey Postan: 1899-1981." Proceedings of the British Academy 69 (1983): 543-545.

50. Bessarabia was formerly the eastern part of the Principality of Moldavia ceded to Imperial Russia in the aftermath of the Russo-Turkish war.

51. Obituary: Professor Sir Michael Moissey Postan, 1899-1981. Economic History Review 35 (1982): iv-vi.

52. See also: E. Miller. "Michael Moissey Postan: 1899-1981.” Economic History Review 35:1 (1982): 544.

53. M. Berg. Woman in History: Eileen Power (1889-1940). Cambridge: Cambridge University Press, 1996, 163.

54. E. Miller. "Michael Moissey Postan: 1899-1981.” Economic History Review 35:1 (1982): 544. My sincere thanks to Dr. Aladár Madarász for searching Russian and Ukrainian libraries for possible publications by Postan in these years.

55. M. Berg. A Woman in History, Eileen Power, 1889-1940. New York: Cambridge University Press, 187. note 50 .

56. Power was bitter about the lack of enthusiasm for Postan at Oxford, writing scathingly afterwards to Postan and Webster about the remoteness of the Oxford mind: "It is not that they are unaware of the outer world, but by some odd optical elusion they are aware of it as a part of Oxford...They are slightly warmer about the British Empire, but that, of course, is because it was invented by Lionel Curtis. It is marvellous to be able to live like flies in amber (or are they more like prawns in aspic?), but God alone knows why you want to do it." Power to Postan, 26 February 1932, Power-Postan Papers cited in Berg, M. A Woman in History, 191. 
57. Power wrote quite frankly to Postan in the early 1930s: "Clapham's chair will be vacant in about 7 years time. You can't get a chair in London or Oxford, because you are blocked by myself \& Clark; but I have for some time had my eye on Cambridge for you. It is a snag that you are not a Cambridge man; but as far as I can see there aren't going to be any Cambridge men available, for Clapham has failed to train up any successor of the right calibre." She goes on to say "I shall never say this to anyone but you, because it would be most unsafe, but I have had it for some time in my mind. It depends entirely on how big a reputation you can amass in the next 7 years, \& on how we manage Clapham." Power to Postan, 29 January n.d., Power-Postan Papers cited in: Berg, M. Woman in History, 192.

58. She was delighted and relieved when he did receive the chair in 1938, remarking to her friend Helen Cam. "I never thought the Committee would have the sense." Power and Postan were married by this time. Power to Cam, 6 February 1938, Cam Papers, cited in: Berg, M. Woman in History, 197.

59. Power's friend Nadine Marshall recalled that "She was very British, and he very Russian." Power's housekeeper remarked "I don't like to think of Miss Eileen being walked over at her age, but these foreigners are rather good at it." M. Berg, Woman in History, 194. Berg herself uses the term "physical characteristics."

60. The memorial to Postan published in the Proceedings of the British Academy makes mention both of his "Russian origin" and his "distinctive appearance." In Proceedings of the British Academy 69, London: Oxford University Press, 1983, 543, 545.

61. The sole exception is the biographer of Eileen Power, as noted above, despite his Hebrew middle name Moissey.

62. The Jewish Year Book. London: Greenberg and Co., 1927-32 and 1944-5.

63. Some accounts suggest that Power selflessly gave up her own chance of securing the position for Postan. But her reasons were much more complicated and the position was by no means securely Postan's if she stepped out of the way. See her letter to Cam, 6 January 1938, Helen Cam Papers, Girton College archives, cited in Berg, M. Woman in History, 196-97.

64. See Berg's discussion and the passages she cites in: M. Berg. Woman in History. 192-99.

65. M. Berg. Woman in History. 197 citing Postan to Webster, 10 October 1940, Webster Papers.

66. M. M. Postan. "Credit in Medieval Trade.” Economic History Review 1 (1928): 234-61.

67. M. M. Postan. "Private Financial Instruments." Vierteljahrschrift für Sozial- und Wirtschaftsgeschichte 23 (1930): 26-75.

68. Both articles were reprinted in the collection of Postan's essays: M. M. Postan. Medieval Trade and Finance. Cambridge: Cambridge University Press, 1973, 1-27, 28-64.

69. M. M. Postan. "Credit in Medieval Trade." 27.

70. E. Power, and M. M. Postan, eds., Studies in English Trade in the Fifteenth Century. London: G. Routledge and Sons, 1933, xvii.

71. M. M. Postan. "Medieval Capitalism.” Economic History Review 4 (1933): 212-27.

72. F. Knight. "Historical and Theoretical Issues in the Problem of Modern Capitalism." Journal of Economic and Business History 1 (1928): 119-136.

73. J. Strieder. "Origin and Evolution of Early European Capitalism." Journal of Economic and Business History 2 (1929): 1-19. 
74. The essay was published simultaneously as a French monograph and an English article: H. Pirenne. Les pèriodes de l'histoire sociale du capitalism. Brussels: Librairie du Peuple, 1914; and "The Stages in the Social History of Capitalism." American Historical Review 19 (1914): 496-515. This essay reads as an early draft of all his later theories - those on the collapse of European economy in the Carolingian period, the origins of towns, and most important of all for our concern, his narrative of high medieval economic history, published posthumously as Economic and Social History of the Middle Ages. London: Routledge \& Kegan Paul, 1936.

75. It is published in the original French in the 2 volumes of Bloch's collected essays: M. Bloch. "Économie-nature or économie-argent." In Mélanges Historiques. Paris: Imprimerie Nationale, 1966, Volume 2, 868-77.

76. It was extracted and translated in the English collection of Bloch's essays: M. Bloch. Land and Work in Medieval Europe: Selected Papers by Marc Bloch. Berkeley: University of California Press, 1967, 230-43.

77. M. Bloch. "Natural Economy or Money Economy." 231.

78. M. M. Postan, and E. E. Rich. "Preface." In Cambridge Economic History of Europe. Cambridge: Cambridge University Press, 1952, Volume 2, vi.

79. Power writes to Postan some years before their marriage: "I do, I confess, feel rather worried about you. You would be a much better editor than I, and you are continually having to give me advice \& help in work for which I get the credit. I don't really know quite what to do about it. I can't help asking for the best advice I can get over things, \& I have an extremely high opinion of you ... I could plan this without consulting you at all, but it would be so silly. It is just the unfortunate fact that I am 12 years older that puts me in Chairs and on the editorial page of these things" (Power to Postan, 9 January n.d. cited in M. Berg. Woman in History. 192. This is the same letter in which Power shares her hopes for the chair at Cambridge going to Postan when Clapham retires.)

80. Cambridge Economic History of Europe, 1st ed. 1952, Volume 2, 119-354.

81. Lopez himself cites these three chapters as such in the bibliography to his own Commercial Revolution of the High Middle Ages. Englewood Cliffs, NJ: Prentice Hall, 1971.

82. J. H. Clapham. "preface" in Cambridge Economic History of Europe. Cambridge: Cambridge University Press, 1941, Volume 1, v-viii.

83. Former students from the Hebrew University still tell amusing stories of Koebner reading his Hebrew lectures transcribed in Roman characters without a sense of their meaning.

84. We are not told who this was or whether he was of Jewish origins.

85. This would seem to be Jan Rutkowski, the accomplished economic historian of Poland rather than Konrad Rutkowski, the medieval historian turned Gestapo officer explored in Borislav Pekic's novel How to Quiet a Vampire: A Sotie. Evanston, Ill: Northwestern Univ. Press, 2005.

86. J. H. Clapham. "Preface." In Cambridge Economic History of Europe. Cambridge: Cambridge University Press, 1941, Volume 1, viii.

87. M. M. Postan, and E. E. Rich. "Preface." In Cambridge Economic History of Europe. Cambridge: Cambridge University Press, 1952, Volume 2, v. 
88. M.W.F. and P.M. “Obituary: Professor Sir Michael Moissey Postan, 1899-1981.” Economic History Review 35 (1982): v.

89. Ibid., vi.

90. Lopez' correspondence with the de Roovers in 1945-46 suggests that Lopez was writing the chapter before beginning the position at Yale: Robert Sabatino Lopez Papers, Yale University, MS. 1459, Box 3, Folder 60.

91. Document no. 16: Coordinator of Information, "Application and personal history statement," s.d., ma maggio-giugno 1942. In Roberto Lopez: l'impegno politico e civile (1938-1945), edited by Varsori, A. Florence: Universita degli studi di Firenze, 1990, 137-141.

92. Roth to Lopez, 22 September 1939, Robert Sabatino Lopez Papers, Yale University Library, MS. 1459, Box 9, Folder 203. Roth attempted to forge some useful connections for Lopez in America and remained in contact with him, if distantly, over the years.

93. Ibid.

94. Ibid. See the discussion of Lopez' anti-fascist position and many documents from this period in Varsori's book.

95. For Lopez' biography, see, in addition to the aforementioned volume by A. Varsori. Roberto Lopez: A. Lewis, J. Pelikan, and D. Herlihy. "Robert Sabatino Lopez.” Speculum 63 (1988): 763-765.

96. F. Lifshitz, s.V.. "Lopez, Robert S." In Encyclopedia of Historians and Historical Writing. London: Fitzroy Dearborn, 1999, Volume 1, 732-33.

97. Most recently P. Freedman. "Robert S. Lopez (1910-1985)." In Rewriting the Middle Ages in the Twentieth Century. Turnhout: Belgium: Brepols, 2005.

98. A bibliography of Lopez' publications until 1976 is included in the festschrift for Lopez: H. Miskimin, D. Herlihy, and A. Udovitch, Eds., The Medieval City. New Haven: Yale University Press, 1977, 329-34.

99. D. Oren. Joining the Club: A History of Jews and Yale. New Haven: Yale University Press, 2000, 280.

100. R. Goldthwaite. "Raymond de Roover on Economic History." Business, Banking, and Economic Thought in Late Medieval and Early Modern Europe: Selected Studies of Raymond de Roover. Ed. Julius Kirshner. Chicago: University of Chicago Press, 1974: 4.

101. He published one local Genoese history while in the US: La Prima crisi della banca in Genova, secolo XIII (Milan, 1956).

102. In order of chronology and importance, one must mention first the source collection edited with Irving Raymond: R. Lopez, and I. Raymond, eds. Medieval Trade in the Mediterranean World. New York: Columbia University Press, 1955.

103. R. Lopez. The Tenth Century: How Dark the Dark Ages? New York: Rinehart, 1959.

104. R. Lopez. La Naissance de l'Europe. Paris: A. Colin, 1962. translated into 5 European languages.

105. R. Lopez. The Commercial Revolution of the High Middle Ages. Englewood Cliffs, NJ: Prentice-Hall, 1971, translated into 2 languages.

106. On Yale's and other elite American universities growing antipathy to Jews and secret quotas on Jewish students in 1920s and 1930s, see: J. Karabel. The Chosen: The Hidden History of Admission and Exclusion at Harvard, Yale, and Princeton. Boston: Houghton Mifflin, 2005. 
107. Dan A. Oren. Joining the Club: A History of Jews and Yale. New Haven: Yale University Press, 1985.

108. O. Pollak. "Antisemitism, the Harvard Plan, and the Roots of Reverse Discrimination." Jewish Social Studies 45 (1983): 113-22.

109. John Munro, personal correspondence with author, 6 March 2012. Lopez' proud Jewish identity also comes out in his published writings. See the discussion below of The Commercial Revolution of the High Middle Ages. But Lopez would not have expressed his Jewish identity in terms of religion: "Roberto's anti-clericalism, as part of his anti-Fascism, explains in my view, his reluctance to express any feelings or views about his Jewish identity in terms of religion: in other words, he was anti-religious in general." (John Munro, personal correspondence with author, March 11, 2012.)

110. Ibid.

111. He was invited to the Hebrew University for a semester in 1979, when this fell through because of his wife's illness, again in 1981. Thereafter he became integrated into the Israeli academy evidenced by multiple invitations to lecture, an invitation to the Institute for Advanced Studies, the translation of one of his articles into Hebrew (he had little Hebrew), requests to write on the tenure cases of Israeli medievalists Shulamith Shahar and Kenneth Stow, the invitation to participate in a conference in Italy on Italian-Jewish history which was organized as part of Israel's diplomatic negotiations with the Italian government. (Robert Sabatino Lopez Papers, Yale University, MS. 1459, Box 14, Folder 287.)

112. Raymond de Roover was not however a Jewish émigré. For de Roover's and Lopez' friendship, see their correspondence: Robert Sabatino Lopez Papers, Yale University Library, MS 1459, Box 3, Folder, 60. This file includes an extensive correspondence with Florence Elder de Roover, an economic historian in her own right. Both of the de Roovers sent Lopez extensive comments on his essay for the $\mathrm{CEH}$ and commendations after it was published.

113. See in particular: de Roovers to Lopez, 24 October 1946 and 15 May 1951. Robert Sabatino Lopez Papers, MS. 1459, Box 3, Folder 60. On Raymond de Roover as economic historian, see: Goldthwaite, R. Raymond de Roover on Late Medieval and Early Modern Economic History.

114. Kirshner, J. "Raymond de Roover on Scholastic Economic Thought." In Business, Banking, and Economic Thought in Late Medieval and Early Modern Europe: Selected Studies of Raymond de Roover. Chicago: University of Chicago Press, 1974, 3-36.

115. M. M. Postan. Cambridge Economic History. Cambridge: Cambridge University Press, 1966. Volume 2, 289-90.

116. Ibid., $320 \mathrm{f}$.

117. N.S.B Gras. "Capitalism-Concepts and History." Bulletin of the Business and Historical Society 16 (1942): 21-34.

118. Gras had earlier emphasized business administration as the key to capitalism in: N.S.B. Gras, Business and Capitalism. New York: F. S. Crofts \& Co., 1939.

119. For a contemporary usage that follows de Roover closely, see: N.J.G Pounds. An Economic History of Medieval Europe. New York: Longman, 1994, 407-8.

120. R. de Roover. "The Commercial Revolution of the Thirteenth Century." In Enterprise and Secular Change. Homewood, Ill: R. D. Irwin, 1953, 80. 
121. The obituary of Lopez in Speculum agrees wholly with this view: Robert Sabatino Lopez. Speculum. 764.

122. De Roover does not highlight the terminology of "Commercial Revolution" in his chapter of the Cambridge Economic History. Nevertheless this chapter is regarded as "the best statement" of "de Roover's general orientation as an economic historian," because, according to Goldthwaite, it elaborates "his concept of the commercial revolution of the fourteenth and fifteenth centuries." (R. Goldthwaite. "Raymond de Roover." p. 13.)

123. It is worthy of note in the context of the concerns of this paper that Lopez touches at times on Jews in commerce and seems to retain the formulations of Roscher, even as his own work should have made him most skeptical.

124. Lopez. Commercial Revolution. 60-62.

125. Ibid, 63-84. My thanks to the students of History 498 spring 2012 at the North Carolina State University who emphasized in our discussions Lopez' close identification of Jews and Italians.

126. M. M. Postan. Cambridge Economic History, 1st ed. Cambridge: Cambridge University Press, 1966. Volume 2, 156-57.

127. M. M. Postan. “Credit in Medieval Trade.” London: E. Arnold, 1955.

128. M. M. Postan. "Medieval Capitalism.” In The Economic History Review 4:2 (1933): 212-27.

129. E. Power, and M. M. Postan, Eds. Studies in English Trade in the Fifteenth Century. London: G. Routledge \& Sons, 1933.

130. R. Brenner. "Postan, Michael Moïssey." In New Palgrave Dictionary of Economics, 2nd ed. 2008, Volume 6, 540.

131. Ibid. Postan's report is published as: M. M. Postan. "Rapport de M.M. Postan.” IXe Congrès International des Sciences Historiques I Rapports. Paris: A. Colin, 1950, 225-41.

132. M. M. Postan. "The Rise of a Money Economy." The Economic History Review 14:2 (1944): $28-40$.

133. See also: E. Miller. "Postan." 547-48.

134. See ref. 131, p. 33.

135. Ibid. p. 35.

136. R. Lopez. "Mohammed and Charlemagne: A Revision." Speculum 18 (1943): 14-38.

137. M. McCormick. Origins of the European Economy: Communications and Commerce, AD 300-900. Cambridge: Cambridge University Press, 2001, 798.

138. R. Lopez. "Back to Gold, 1252." Economic History Review 9 (1956): 219-240, citation from 240 .

139. R. Lopez. “An Aristocracy of Money in the Early Middle Ages.” Speculum 28 (1953): 1-43, citation from 43.

140. One can see the narrative of economic expansion and contraction defined in the Cambridge Economic History of Europe beginning to be reflected in the textbook histories of medieval Europe, first as single chapters appended to the more traditional narratives of political and intellectual history written in the 1950s and 1960s: R.H.C. Davis. A History of Medieval Europe: From Constantine to Saint Louis. London: Longmans, 1957. 
141. D. Frankforter. The Medieval Millennium: An Introduction. Upper Saddle River, NJ: Prentice-Hall, 1999.

142. A. Haverkamp. Aufbruch und Gestaltung. Deutschland, 1056-1273. Munich: C. H. Beck, 1984.

143. W. Hollister. Medieval Europe: A Short History. New York: Knopf, 1982.

144. M. Keen. A History of Medieval Europe. New York: F. A. Praeger, 1968.

145. With the increasing prominence of social and economic history by the 1970s, it receives a more fundamental role in general textbooks such as: J. Mundy. Europe in the High Middle Ages, 1150-1309. London: Longman, 1973.

146. The revision of Hollister's textbook: J. M. Bennett. Medieval Europe: A Short History. Boston: McGraw Hill, 2006.

147. This is also the case in the recent narrative constructed along the lines of Braudel's and Wallerstein's “world economy”: F. Crouzet. A History of the European Economy, 1000-2000. Charlottesville: University Press of Virginia, 2001.

148. What is more important - by the 1970s the narrative of economic expansion and contraction began to receive whole textbooks unto itself: R-H. Bautier. The Economic Development of Medieval Europe. New York: Harcourt Brace Jovanovich, 1971.

149. C. Cipolla. Before the Industrial Revolution: European Society and Economy 1000-1700. London: Routledge, 1976.

150. C. Cipolla, ed. The Fontana Economic History of Europe. London: Collins/Fontana, 1972.

151. Guy Fourquin. Histoire économique de l'occident medieval. Paris: A Colin, 1979.

152. G. Hodgett. A Social and Economic History of Medieval Europe. London: Metheun, 1972.

153. N. Pounds. An Economic History of Medieval Europe. London: Longman, 1994.

154. Most recently: J. Favier. Gold and Spices: The Rise of Commerce in the Middle Ages. New York: Holmes and Meier, 1998.

155. P. Spufford. Power and Profit: The Merchant in Medieval Europe. London: Thames \& Hudson, 2003.

156. Monographs within national historiographies also show this tendency, with Luzzatto's on Italy unsurprisingly the earliest: G. Luzzatto. An Economic History of Italy from the Fall of the Roman Empire to the Beginning of the Sixteenth Century. New York: Barnes \& Noble, 1961.

157. E. Miller, and J. Hatcher. Medieval England: Rural Society and Economic Change. London: Longman, 1978.

158. E. Miller, and J. Hatcher. Medieval England: Towns, Commerce and Crafts, 1086-1348. London: Longman, 1995.

159. One should also mention Postan's own survey: M. M. Postan. The Medieval Economy and Society: An Economic History of Britain 1100-1500. Berkeley: University of California Press, 1972.

160. See also the extensive citation of national historiography in: D. Herlihy. "The Economy of Traditional Europe." Journal of Economic History 31 (1971): 153-64. 
161. One can speculate that Roscher's narrative on the Jews afforded Lopez a way of synthesizing pride in both his Jewish and Italian identities, in as much as the two become nearly equivalent players in the story of the commercial revolution that has shaped medieval studies in North America. See, his chapter on "The Jews" and its relationship to the following sections: R. Lopez. Commercial Revolution. 60-63.

162. One article in this issue explores this issue in regard to the New School and the Jewish intellectuals in exile brought to the safety of the US during the war: D. Bessner. "'Rather More than One-Third Had No Jewish Blood': American Progressivism and German-Jewish Cosmopolitanism at the New School for Social Research, 1933-1939." Religions 3 (2012): 99-129. See also the references in note 72 above.

163. H.S. Hughes. Between Commitment and Disillusion. Middletown, CT: Wesleyan University Press, 1987, 48.

164. From September 1940 to December 1941, the energetic President of the New School for Social Research rescued 50 prominent European scholars through similar fellowships. Bloch never made it to the US, because he was unwilling to leave his elderly mother and a grown daughter and son behind. (Fink, C. Marc Bloch: A Life in History. New York: Cambridge University Press, 1989, 248-49.)

165. M. M. Postan, and E. E. Rich. "Preface." In Cambridge Economic History of Europe. Cambridge: Cambridge University Press, 1952, Volume 2, v.

166. It is commonly told that Bloch died with the cry of "Vive la France!" on his lips. The source would seem to be the testimony of a survivor of one of the 28 victims of the massacre.

167. See: C. Fink. Marc Bloch. 321, note 89 referring to the Perrin testimony. Also see H.S. Hughes. Between Commitment and Disillusion. 49 on Bloch's death.

168. H.S. Hughes. Between Commitment and Disillusion. 51.

169. See particularly ch. 10 "Vichy" of Fink, C. Marc Bloch. Bloch in his opposition to the Union des Israélites de France argued that the arbitrary construct "the Jewish people" prepared the way for ghetto or expulsion (pp. 275-76). In response he insisted: "We are French. . . We cannot conceive another destiny than a French one. (274)" My thanks to Carole Fink for putting me in touch with some of Robert Lopez' former graduate students.

170. A. Varsori. Roberto Lopez: l'impegno politco e civile (1938-1945). Firenze: Nicola Zanichelli, 1938: 234.

171. K. Polanyi. The Great Transformation: The Political and Economic Origins of Our Time. Boston: Beacon Press, 2001.

172. K. Polanyi-Levitt, and M. Mendell. "Karl Polanyi: His Life and Times." Studies in Political Economy 22 (1987): 7-39, see especially 15.

173. On Karl Polanyi, see also: S.C. Humphreys. "History, Economics, and Anthropology: The Work of Karl Polanyi." History and Theory 8 (1969): 165-212.

174. J.R. Stanfield. The Economic Thought of Karl Polanyi: Lives and Livelihood. New York: St. Martin's Press, 1986, esp. ch.1.

175. Ibid., 20-1.

176. Ibid., p. 15.

177. Ibid., p. 26. 
178. Ibid., p. 29.

179. Ibid.

180. K. Polanyi. Great Transformation. 3-4.

181. See especially: K. Polanyi, C. Arensberg, and H. Pearson. "The Place of Economics in Societies." In Trade and Market in the Early Empires. New York: Cambridge University Press, 1957, 239-42.

182. The single most prominent and influential example of this linkage must be Karl Marx's "On the Jewish Question": K. Marx. The Marx-Engels Reader. New York: Norton, 1978, 26-52.

183. K. Polanyi, C. Arensberg, and H. Pearson. "Concluding Note." In Trade and Market, Glencoe, Ill: Free Press, 1957, 373.

184. Ibid., pp. 373-74.

185. K. Polanyi. "The Economy as Instituted Process." The Sociology of Economic Life Eds. Mark Granovetter and Richard Swedberg. Boulder, CO: Westview Press, 1957, 257.

186. Ibid., p. 244.

187. Ibid., p. 245.

188. G. Duby. Early Growth of the European Economy. Ithaca: Cornell University Press, 1974. The French version was published one year earlier by Gallimard. The substance of the seminar was published as: "Pour une histoire anthropologique: la notion de réciprocité," Annales 29 (1974):1309-80.

189. The Annales issue was translated and republished with additional case studies as: "Symposium: Economic Anthropology and History: The Work of Karl Polanyi." Research in Economic Anthropology 4 (1981): ix-285.

190. Polanyi was also being discussed in the early seventies in the French journal La Pensée: Y. Garlan. "La place de l'économie dans les sociétés anciennes." La Pensée 171 (1973): $118-127$.

191. For Polanyi's biography, see the references above.

192. In part they have been so influential because interest in economic history has waned in both Jewish studies following the Holocaust and in European history following the heyday of quantitative methods in the 1980s. On the turn from economic topics in Jewish studies, see the excellent introduction by Gideon Reuveni in the edited volume on new approaches to Jewish economic history: G. Reuveni. "Prolegomena to an 'Economic Turn' in Jewish History." The Economy in Jewish History: New Perspectives on the Relationship of Ethnicity and Economic Life. Oxford: Berghahn Books, 2010: 2011.

193. Miller. "Michael Moissey Postan." 548-49.

194. The volumes he published were British War Production (1952) and in collaboration with Denys Hay and J.D. Scott, The Design and Development of Weapons (1964).

195. Pelikan Lewis, and Herlihy. "Robert Sabatino Lopez." 764.

196. E. Michael Miller. "Moissey Postan." 548.

197. Power's letters quoted above reveal her acute sensibility of Postan's outsider status when seeking a post for Postan at Oxford and Cambridge. Their own marriage met with some surprise and disapproval. Postan's marriage to a daughter of an Earl both indicates his greater integration as a Cambridge professor, and must have facilitated that integration even further. 
A commentator I heard at a recent conference panel devoted to Lopez' legacy quipped that Lopez was successful at Yale in part because he married the "right sort of woman" (Medieval Academy 2010, New Haven). What this meant is not quite clear as Claude Kirschen, though she may not have considered herself Jewish, was from an assimilated Jewish Belgian family and had to flee during WWII. (John Munro, personal correspondence with author, 6 March 2012).

198. F. Lifshitz, s.v. "Lopez, Robert S." 732.

199. Lopez however seems to have read medieval Jewish history. See his letter concerning arrangements for teaching at Hebrew University: Lopez to Shahar, 5 November 1979, Robert Sabatino Lopez Papers, Yale University, MS. 1459, Box 14, Folder 187.

200. See too his collected articles in the Robert S. Lopez collection at the Arizona State University, http://www.acmrs.org/academic-programs/online-resources/lopez-collection (accessed on 12 June 2012). 
Reprinted from Religions. Cite as: Kettler, D.; Meja, V. Karl Mannheim's Jewish Question. Religions 2012, 3, 228-250.

Article

\title{
Karl Mannheim's Jewish Question
}

\section{David Kettler $^{1, *}$ and Volker Meja ${ }^{2}$}

1 Bard College, Annandale, New York 12504, USA

2 Memorial University of Newfoundland, St. John's NL, Canada A1C 5S7;

E-Mail:vmeja@mun.ca

* Author to whom correspondence should be addressed; E-Mail: kettler@bard.edu; Tel.: $+845-876-5293$.

Received: 5 January 2012; in revised form: 26 March 2012 / Accepted: 6 April 2012 /

Published: 11 April 2012

\begin{abstract}
In this paper, we explore Karl Mannheim's puzzling failure (or refusal) to address himself in any way to questions arising out of the position of Jews in Germany, either before or after the advent of Nazi rule - and this, notwithstanding the fact, first, that his own ethnic identification as a Jew was never in question and that he shared vivid experiences of anti-Semitism, and consequent exile from both Hungary and Germany, and, second, that his entire sociological method rested upon using one's own most problematic social location — as woman, say, or youth, or intellectual — as the starting point for a reflexive investigation. It was precisely Mannheim's convictions about the integral bond between thought grounded in reflexivity and a mission to engage in a transformative work of Bildung that made it effectively impossible for him to formulate his inquiries in terms of his way of being Jewish. It is through his explorations of the rise and fall of the intellectual as socio-cultural formation that Mannheim investigates his relations to his Jewish origins and confronts the disaster of 1933. The key to our puzzle is to be found in the theory of assimilation put forward in the dissertation of his student, Jacob Katz.
\end{abstract}

Keywords: Karl Mannheim; Jacob Katz; Jewishness; sociology; intellectuals; cultivation; assimilation; Germany

\section{Introduction}

From one point of view, there can be no question that the sociologist, Karl Mannheim, belongs in a collection of studies dedicated to "European Jewish Émigrés and the Shaping of Postwar 
Culture." He certainly belonged to the cohort of exiles compelled to flee National Socialist Germany when he was ousted from his professorship as a Jew and effectively rendered unemployable; and his two best-known books, Ideology and Utopia and Man and Society in an Age of Reconstruction - particularly the latter - were extensively discussed in both academic and wider public settings during the ten or more postwar years, notwithstanding his untimely death in 1947. He was asked to broadcast to Germany in the BBC's re-education program, much to the chagrin of Carl Schmitt and others [1], and he had been chosen as first Head of the European UNESCO office when he became ill [2].

Yet Mannheim, as we understand him, does not fit easily into the company of the other figures examined under the present heading at the mini-conference held at Duke University on April 3, 2011 because the contributions of the others were presented as somehow grounded in their Jewish identities, especially under the conditions of the war and post-war period, while Mannheim clearly kept his distance from his Jewish antecedents in his intellectual life. He thought and spoke as intellectual and as sociologist - the articulation of the intellectual's role he considered appropriate to the age-but not in any case as a Jew. His principal interlocutors during many of his exile years, in fact, were expressly Christian thinkers to whom he spoke in his capacity as a thinker without religious identity. The idea that his intellectual contributions might be accounted Jewish by virtue of his imputed ethnicity, which he never denied, would have disturbed him. Even if we were to argue that he was nevertheless a member of the Jewish community of fate (Schicksalsgemeinschaft), we would find at least one occasion on which he expressly denied precisely this and, more generally, we would be compelled to overrule the self-understanding of a thinker who built his entire thought on the primacy of reflexive clarity [3].

There is a more disturbing alternative offered by a subtle thinker who sharpens the problem precisely because he offers such a fertile proposal to explain Mannheim's position, up to a critical point. In a recent study, Ulrich Oevermann has written:

One of the important and inherently paradoxical historical consequences of the precarious minority status of Jew since the time of antiquity - and increasingly with the Christianization of the Occident-was that the dialectical mainspring driving towards a universal rationalization, which was inclined towards secularization, became ever more tightly wound in the course of the struggle for survival and adaptation, which was itself marked by a tension between "chosenness" and the universal ethic in whose name the "chosenness" was grounded. And under the conditions of entry into modernity, this led to a thoroughgoing cosmopolitan and universalistic intellectuality among European Jews. For the Jews socialized to this intellectuality, a Judaism understood primarily either as ethnic or as religious identity became increasingly obsolete. The consequence of the Nuremburg Racial Laws was that this universal-historical line of development was radically and brutally cut off. The industrially executed mass destruction of European Jews that was the sequel of these laws meant perforce that all surviving Jews and their descendants would henceforth have to define themselves in their collective social identities as victims of this persecution. Anything else would amount to a selfdestructive denial of reality [4].

The last two sentences pose a challenge not only to Mannheim but also to numerous "surviving Jews" who defined themselves rather as comrades in one or another Socialist formation, as 
scientists, as continuators or innovators in cultural work, whether cosmopolitan or variously bounded. Paradoxically, Oevermann's formulation would also call into question the realism of Zionists during the years before the Eichmann trial, when the separation from the "passive" victims was a pervasive motif. There is much ingenuity in Oevermann's subtle version of what is sometimes called "psychological Judaism," or "Jewish consciousness"-both terms offering poor connotative equivalents to the culturally laden German concepts of "Psychologie" and "Bewusstsein"- which offers a depth-structural hypothesis for a development that is subject to more sociological attention in the article below; but the proposition that the inner dynamic of Jewishness led Jews as such to became cosmopolitan intellectuals is no more proof against a myriad of counter-examples than the contention that failure to define themselves later as above all Jewish survivors is against their nature, to speak with Aristotle. Neither the writ of the Nuremberg Laws nor the murderous decree of the camps ran in the diverse and versatile mentalities of the individuals who share a designation as Jews.

A Jewish refugee who eventually played an important part in the German postwar academic culture can serve as authority for questioning the availability of a deep Jewish consciousness - as distinct from the shared but variously interpreted experiences of a generation - to which intellectual and cultural achievements can be referred. The testimony of Ernst Fraenkel is especially poignant because his considered judgment differed so markedly from his initial reaction, which approximated to Oevermann's generalization, at least in relation to the German setting in which he had earlier functioned as political intellectual. Immediately after the war, in a letter to a Socialist comrade who had remained in Germany, he wrote:

In the relationship between Germans and Jews, now that 5,000,000 Jews have been murdered, I feel solidarity with the Jews - and only with them. I do not believe that it can be expected of any Jew that he will ever in future live in Germany [...]. I was in Germany long enough to know that a considerable proportion of the German population endorsed Hitler's measures against the Jews. After this campaign has led to massacre, it is not permissible for me as a Jew ever again to make the cause of this people my own. That may sound bitter. I feel very bitter on this question. I believe that this wound can never be healed [5].

Yet in 1954, after a number of years in which he did indeed live in Germany and define himself first as representative of American political thinking and then as associate of German antiCommunists of the reformist left, including especially the recipient of his earlier letter, Fraenkel wrote an article on "The Jewish Question" in a volume produced jointly with a Wehrmacht veteran and dedicated to German political education in which he cast doubt on notions of a common Jewish ethnic identity or consciousness. He wrote:

The sociological character of the Jewish minority can hardly be established with any scientific certainty, since the Jewish communities scattered throughout the world differ so greatly in cultural and social characteristics and since neither Jews nor non-Jews are agreed as to who should be designated as a Jew.

Fraenkel was charged at the time by a well-known Jewish advocate, Hugo Marx, with having failed to recognize Jews as an "authentic ethnic minority "with its own collective "essence and attitude"; and he did not deny the charge. His point in reply was simply to emphasize the priority of 
the political task to which he had set himself and-at least implicitly - the terms of the alliances he had entered to advance these objectives [6].

Our aim in this preface is not to deny by any means that the distinctive historical experiences of figures like Ernst Fraenkel or Karl Mannheim are conditioned by their designation as Jews or their needs to cope with the consequences of that designation. But we challenge the claim that there is an essentially Jewish way of undergoing these experiences or a Jewish way of acting in consequence [7].

We, the authors of this study, exemplify the complexity of the situation. Like Lillian Furst, to whom this collection is dedicated, one of us, David Kettler, is a member of the "second wave" of Jewish émigrés from Germany. He was born in Leipzig in 1930, the second son of young parents who were East European Jews, and he escaped to the United States with his immediate family in March of 1940. The prime mentor of his graduate studies was Franz L. Neumann, an exile scholar and intellectual, who taught at Columbia University. The other, Volker Meja, was born in Berlin two months after Kettler's flight. His father, an engineer,_was a Wehrmacht soldier during the last two war years, and Meja's remaining family spent the last eighteen months of the war with his paternal grandparents in Silesia, and as a small child experienced the flight westward ahead of the Russian troops. Meja came to the United States on a Fulbright stipend after undergraduate study in Frankfurt with Max Horkheimer and Theodor W. Adorno and earned a doctorate at Brandeis University under Kurt H. Wolff, an émigré who had been a student of Karl Mannheim. He has had most of his academic career in Canada, while remaining a citizen of the German Federal Republic. The two of us have been collaborators in the study of Karl Mannheim and some other topics for almost forty years. We have differed often, but we have never experienced a division as between a Jewish and non-Jewish sensibility, except possibly for one afternoon in 1988, when we made two stops on a drive from Frankfurt a. M. to Cracow. First, we visited the village where Volker spent almost two years to escape the bombing of Berlin. And then, towards evening, we visited Auschwitz. On those occasions, we were both deeply affected but not in the same ways. Yet the paper we jointly delivered in Cracow bore no signs of these radically different experiences and memories. Neither author thought or wrote as a victim. We were preoccupied, rather, with the decline of trade unions in the West and worried about its consequences for the welfare state.

The original of the study presented below was written in Kettler's birthplace, Leipzig, during our joint fellowship at the Simon Dubnow Institute for Jewish History and Culture. We think that it is germane to the present occasion and are grateful for permission to contribute a revised version to the present collection [8].

\section{A Puzzle and a Paradox}

In this paper, we explore the puzzling failure (or refusal) on the part of the sociologist, Karl Mannheim, to address himself in any way to questions arising out of the position of Jews in Germany, either before or after the advent of Nazi rule - and this, notwithstanding the fact, first, that his own ethnic identification as a Jew was never in question and that he shared vivid experiences of anti-Semitism, and consequent exile from both Hungary and Germany, and, second, that his entire sociological method rested upon using one's own most problematic social location-as woman, say, or youth, or intellectual — as the starting point for a reflexive investigation. A number of 
circumstances - including his choices of residence in notably Jewish middle-class neighborhoods in both Frankfurt and London, his seeming comfort with his identification as a Jewish person among colleagues and students, his abstention from any actions of disavowal, and his life-long close relations with his unquestionably self-identified Jewish parents, who outlived him in Hungary - make it implausible to ascribe this seeming contradiction to some blanket denial of or disassociation from his own Jewish background. The key to our puzzle, we believe, is to be found in a place defined by an unsurprising relation for as dedicated a teacher as Karl Mannheim: in the work of one of his students, Jacob Katz.

Instead of a puzzle, we now offer you the paradox that, far from avoiding reflection grounded on his position and experiences as a Jew, it was precisely Mannheim's convictions about the integral bond between thought grounded in reflexivity and a mission to engage in a transformative work of Bildung that made it effectively impossible for him to formulate his inquiries in terms of his way of being Jewish. It is through his explorations of the rise and fall of the intellectual as socio-cultural formation that Mannheim investigates his relations to his Jewish origins and confronts the disaster of 1933. The crux is to be found in the theory of assimilation put forward in the dissertation that Jacob Katz planned with Karl Mannheim, according to Katz's testimony, but that he could not complete before Mannheim's expulsion from the university.

Jacob Katz was a Hungarian Jew from the village of Magyargencs. Strictly orthodox and a supporter of the religious Zionist organization, Mizrachi, he began his stay in Frankfurt, while preparing for university admission, in one of the city's yeshivas, which also provided him with sanctuary during his university studies. In addition to Karl Mannheim, the teachers he recalls in his memoirs include Paul Tillich and Theodor W. Adorno, Max Wertheimer, Max Horkheimer (whose course he fled because the teacher "lacked any inspiration") and a number of history and literature teachers. He was able to earn his doctorate in 1934 after the ouster of most Jewish faculty deprived him of his adviser, because of the professional and "fair" attitude of the historian, Georg Künzel, to whom Mannheim had sent him after his ouster, and who also promoted Margarethe Freudenthal, another Jewish "orphan" of Mannheim. In the case of Katz, good will combined with luck to secure him a second reader. Künzel coopted a Jewish Orientalist, G. Weil, who normally would have no qualifications in this field, and whose dismissal, delayed because of his military service, took effect on the day after the viva voce. With a stop-over in London to improve his English, during which time he attended some classes taught by Mannheim at the London School of Economics, Katz arrived in Palestine in 1936, in keeping with plans he had already made in 1930. He taught in the Sociology Department of Hebrew University, headed by Martin Buber, and he was one of the most prominent Israeli historians of the modern diaspora, operating throughout within the framework of a sociological approach, not uncontroversial among his peers [9].

In our paper, we shall touch on the following points: First, we summarize the main theses of Katz's pioneering work: "The Origins of Jewish Assimilation in Germany and its Ideology [10]." Second, we offer reasons for considering Katz's analysis as an extension and application of Mannheim's own thought, including an examination of their reciprocal interest in precisely this study, drawing on our familiarity with Mannheim's practice derived from earlier studies of other doctoral projects fostered by Mannheim and mentored by him. These are reasons, in short, for thinking that Mannheim's conduct in this matter was the expression of a deliberate strategy. 
Inevitably, such reasons cannot move this claim beyond the level of speculation. Yet our juxtaposition of Katz and Mannheim does not depend on this speculation, since Katz may be understood, in any case, to provide an explanation for the conduct common to Mannheim and other Jewish intellectuals of a certain kind. Third, then, in the light of Katz's theses, we review some key elements of Mannheim's work after 1933, notably his theory of the disintegration of the cultural elite structure as decisive for a diagnosis of the German catastrophe, to show this work as meeting Katz's functionalist criteria for assimilationist Jewish thought. In conclusion, we suggest a surprising parallel between the assimilationist project that we impute to Mannheim and the vastly more successful undertaking of American Jewish intellectuals between 1910 and the 1940s to help "reconstitute American intellectual life and ... to construct, in the process, the particular, liberal vision of American culture that became a common possession of the American intelligentsia during the middle decades of the twentieth century [11]."

Our aim is not Ideologiekritik, a dismissive exposé of Karl Mannheim's thought, but an examination in the spirit of Mannheim's own sociology of knowledge, intended to open a neglected dimension of Mannheim's thought to negotiations from the standpoint of a new set of concerns, specifically, his problematic relationship to Jewish questions. Among premises not now on the table for discussion is our assumption that assimilated Jews are not inherently condemned to greater incoherence of thought or intensity of personal or political crisis than Jews of any other kind - not to speak of every variety of non-Jew. We reject what has been called in a different context the "jargon of authenticity," just as we do not mean to commit ourselves to the contention that individuals who are somehow cut loose from their home-whether by choice, circumstance, or exile-are uniquely situated to understand the human condition, a thesis that Mannheim himself advocated-and that was put into question by another of his prized students, at least as it applies to political émigrés [12]. Implicitly, then, we are also probing — through a case study — the complex reciprocal interplay between generative teachers and creative students.

\section{Assimilation and Bildung}

Briefly stated, it was the central contention of Jacob Katz's dissertation that the status of assimilated Jew depended historically upon the emergence of a new social location where Jews could be active on terms that did not merely hive off the discourse and practices constitutive of Jewish communal life, which could also be said of instructional sites where Jews acquired useful knowledge and scientific instruction, but whose constitutive ground rules rendered the distinction between Jew and non-Jew immaterial [13]. In principle, if not in practice, this required the Christians as well as the Jews to suspend their preoccupations with their religious starting points. Only under those conditions could Jews enter into collaborative relations with centers of nonJewish thought and culture, not merely for the sake of science, but also, as Katz himself put it, applying a distinction of critical importance for German discourse of the Weimar era and a subject given special attention in the working group under Mannheim's guidance to which Katz belonged, for the sake of Bildung [14]. Such a social location, Katz shows, came into being with the formation of what he calls the modern Bildungselite at the end of the eighteenth century; and the relevant terms of discourse, turning above all on the concept of equality, can be comprehended, he contends, as Enlightenment thought, or Liberalism [15]. 
Citing Georg Simmel, moreover, Katz is not satisfied with speaking of the social location of the Bildungselite in abstract terms, but he also calls attention to concrete social associations and meeting grounds, from the academies of the mid-century to the salons of the following generation, where sociability came to count almost as much as actual mental performance (Geist and Bildung) in the shared cultivated idiom. The constitutive ideology of assimilationism, accordingly, is to be understood not in terms of this or that substantive deviation from some core of Jewish doctrine, given the contested boundaries of these inherently non-dogmatic teachings, but in terms of its functionality for incorporating the assimilationist Jew in this more inclusive context, as a mode of social advancement under newly hospitable social conditions of elite formation, which the assimilationist Jews themselves, once admitted, did much to shape, so that it is only a slight exaggeration to go beyond Katz and to speak of a mutual assimilation.

\section{Jacob Katz and Karl Mannheim}

The similarities between Jacob Katz's analysis of Jewish assimilation and Mannheim's sociology are noted not only by Katz's grateful acknowledgment of the teacher who gave him his handhold in the alien world of secular social sciences but also by numerous commentators on Katz. Benjamin Ze'ev Kedar stands out among the latter because he specifies several important points of contact [16]. First, he notes that Katz "took up Mannheim's ideas about the socially unattached intelligentsia." In that connection, then, Kedar also point to a broader conception of a "neutralized social form," which figures importantly in Katz's subsequent work, if also in a skeptically amended version. Finally, Kedar cites a passage in a work by Katz of 1955, where Katz expressly refers to Mannnheim's essay on Generations in constructing his own concept of "precursors." These thematic continuities are doubtless important, but the structural parallels are more profound.

These similarities are further elaborated here, if only in brief, both because they offer some new insights into Katz's early thought and because we want to hold open the ultimately unprovable possibility that Mannheim saw his educational transactions with Katz as part of his own work of self-clarification, as we have elsewhere shown to have been the case, with high probability, in his dealings with his student, Nina Rubinstein, whom he painstakingly supported in her work on their shared status as political émigrés [17]. In investigating the points of contact between Katz and Mannheim, it is not enough to compare Katz's writings with Mannheim's published texts. Katz never cites Mannheim in his 1935 dissertation, and this was not because Katz had been somehow forced to comply with new anti-Semitic norms in bibliographic practice, since Katz generously credits the writings of Hans Weil, another Jew, who had been a fellow member of the Mannheim seminar, although he received his doctorate at Göttingen. Weil's dissertation on the history of Bildung, suitably revised in consultations with Mannheim, was selected to follow Mannheim's own Ideologie und Utopie in the series that Mannheim edited. In his memoirs, then, Katz speaks of Weil as emerging "from the school of Karl Mannheim." For Katz, as for Weil, the crucial contribution made by Mannheim came through classes and conversations between the two men.

This point is important enough to warrant documentation through a rather lengthy quotation from Katz's autobiography: 
In 1930, the year that I enrolled in the university, Karl Mannheim was appointed in place of the sociologist Franz Oppenheimer.... [W] ithin a year the young Mannheim, subsequently renowned as one of the founders of the sociology of knowledge, made a name for himself among the students as an interesting and stimulating lecturer... At the very first class I knew beyond doubt that here was the person from whom I had most to learn... I enrolled in the course and asked to join his seminar, and to use a rather grandiloquent phrase, thereafter my hand never left his - that is, until Mannheim was banished from Frankfurt with the rise of the Nazi party. Mannheim exhibited a personal interest in the life of his advanced students. The two of us shared a common Hungarian-Jewish background although we came from opposite ends of the spectrum.... Mannheim's knowledge of Judaism was scanty, but he was much interested in its problems, especially in the role played by Judaism in the emergence of modern society. One of the most interesting seminars that Mannheim conducted, together with a number of other teachers, concerned the rise of liberalism. The seminar students were divided into groups, each one charged with exploring the historical sources to determine the role played by a specific sector of society in the development of liberalism. One of the groups dealt with the Jewish factor; and when I joined the class, I found their work already in progress under the direction of one of the more senior students. When this student left the university, I took his place - and thus was born the idea for my dissertation on the assimilation of German Jewry [18].

More precisely, the group that Jacob Katz joined was actually an interdisciplinary "Working Group on Social History and History of Ideas: Early Liberalism in Germany," which ran for two years beginning in the academic year 1931/2 and was instructed as well by the economist, Adolf Löwe, the political scientist, Ludwig Bergsträsser, and the historian, Ulrich Noack-with Paul Tillich also occasionally present. Student participants included Norbert Elias, Hannah Arendt and her husband, Günther Stern (later known as Günther Anders), Hans Gerth, and Hans Weil, a number of whom based important subsequent work on their experiences in and contributions to the working group [19].

The definition and scope of Bildung was a major field of contention during the Weimar years, and Weil's book played an important part in the later stages, providing key arguments, for example to the right-wing sociologist Hans Freyer, as well as to Mannheim, notably on the obsolescence of a Bildung grounded in aristocratic experience [20]. The contest about Bildung was carried into exile by the predominately Jewish refugee intellectuals, and Mannheim's own post-1933 diagnosis of cultural crisis - as well as his therapeutic scheme-belong to this discourse. As for the Liberalism workshop in Frankfurt, Hans Gerth's dissertation on early Liberalism, completed in 1933 but approved only in 1935, is another prime document of the seminar. Expressly designed to parallel Mannheim's earlier study of conservatism, it refers to the Jewish contribution to the confluence of social factors constituting Liberalism only in conjunction with merchant bankers, notably Rothschild [21]. As in Mannheim's earlier book, the emergent stratum of intellectuals, who do the primary ideological work, is traced to Protestant clerical households. Katz's work can be read as a supplement, as its thesis was doubtless received in the workshop. Other sociological studies traceable to this remarkably fecund seminar are Margarethe Freudenthal's study of the changing status of women in the household, which begins with a remarkable account of the Goethe family, as well as Norbert Elias' social ecological study of the courtly society [22]. 
Katz's account of the birth of his dissertation may be supplemented by a speculation informed by study of detailed records available in two other cases, comprising a remarkable archive in the case of Nina Rubinstein. Mannheim's expressions of "interest" in the "life" of Jacob Katz, as well as his interest in problems of Judaism, as reported by Katz, would have been integral to their discussions of ideas for the dissertation. It was a cardinal principle of Mannheim that individual study had to begin as an exercise in self-clarification, focusing precisely on an aspect that is experienced as problematic, primarily because of a clash between institutionalized social expectations, articulated in prevalent ideologies, and the concrete social experience of the individual. Mannheim would have been fascinated by Katz's profound immersion in the practices and supportive community of orthodoxy, and he would have learned or surmised that Katz, as he reports in his memoirs, experienced some strain between that essential part of his life and the world of the university student, and especially his encounters with assimilated Jews. A secondary principle in the design of students' projects was the selection of a topic possessing structural similarities to their own "life" problems, but simultaneously remote in time or place. In the case of Rubinstein, perplexed by her life within the Menshevik emigration in Berlin, the project ended up dealing with French émigrés of 1789. Katz's study similarly focuses on the eighteenth century.

Out of consideration for his student, Mannheim would have refrained from urging Katz to make any tensions involving orthodoxy itself the starting point for his sociological studies, since he frequently used the example of a transmutation of religious identification from practice to problem as a moment of distantiation that marked the end of religious authenticity. For example, in his 1930 lecture course on the "Introduction to Sociology," which Katz, it should be noted, almost certainly did not attend, Mannheim said: "Tolerance is the first stage in the distantiation of phenomena. The state of being addressed by religion and morality is replaced by an altogether different attitude towards these objects, by a distantiation, through which a change in function comes into being. The following must be added: anyone who comes from a bounded world-view will be horrified by the situation of distantiation from the last things, treating them as variable. They will find it an act alien to life, exterminating everything [23]."

Mannheim was not always so considerate when dealing with individuals other than students, as witness a furious letter from Michael Polanyi after a meeting between the two old acquaintances, in which Polanyi berates him because, in his view, Mannheim has seen fit to cross-question him on the sources and origins of his [Christian] religious convictions, as if they were some sort of pathological symptom [24]. The difference between the "interest" shown on the two occasions, however, is to be explained not only by the difference between mentoring a student and speaking with a peer, but also by the changes over the years between the two occasions in Mannheim's own relation to religious questions other than the sociological.

Katz gives a compelling if somber account of Mannheim's condition in the first phase of his second exile. He writes:

Upon arriving in London, I naturally lost no time in visiting Mannheim with a copy of my printed dissertation, in which he too had had a part, in hand. I began attending his lectures and one of his seminars [at the London School of Economics], but these were a faint echo of those given in Frankfurt. There were few students, the teacher still struggled with the language, and the intellectual curiosity that had once united teacher and student was totally absent. Mannheim's seminars for 
advanced students were attended mostly by Americans, and they too displayed little of the alertness of Mannheim's previous students. When asked to deliver a lecture on my dissertation topic, I had to overcome not only the language barrier but also the lack of audience interest in so remote a subject. Little wonder, therefore, that I had no real sense of satisfaction after completing my talk.

Mannheim did not hide his distress, but neither did he complain.... I could gauge Mannheim's view of his situation by a question that he tossed out without warning: 'How long do you think it would take me to master Hebrew should I decide to learn it?' Not that the spirit of Zionism had suddenly descended upon him, but the oppressiveness of his situation led him to consider possible alternatives, among them the Hebrew University in Jerusalem. This was nothing more than a momentary flash, an idea that faded just as rapidly as it had come."

Katz may have underestimated Mannheim's actual interest in Jerusalem. Their discussion must have taken place while Mannheim was in fact in the process of weighing — and rejecting - an offer to join the new "University in Exile" in New York, so that Mannheim in fact did not lack another alternative. Then too there is the as yet unexplained circumstance that Mannheim's library was sent to the Hebrew University after his death. It is of course possible that this was simply a decision of his widow [25].

Mannheim's encounter with Katz coincides with his most intense personal questioning about his own religiosity. Because of its character as testimony, we quote an extended excerpt from a transcript of Mannheim's intervention in a discussion held in the home of the theologian, Paul Tillich. The context is Christian, of course, but we should note Mannheim's ambiguous reference to his genetic inheritance, as well as his rejection of the "spiritualized" deity of the intellectuals. There are evident parallels, moreover, to discussions in the circle around Martin Buber, with whom Mannheim participated in Heidelberg seminars, and whose 'I-thou' vocabulary plays a part in Mannheim's 1930 lectures at Frankfurt:

One ought to talk about God, and I do not want to evade this. I believe that the question of God must be posed here in a quite extreme form. Scheler has said, and I must go along with this: if there is a God and if he is supposed to matter to me, then, in view of the modes of experience, it can only be a personal God. Because the highest form in which I can be addressed is not spirit, machine, natural law, or anything altogether sublime, but the primal experience of personality. It must be possible for me to speak with him, he must be able to address me. That is the feeling I have unconditionally, perhaps from childhood, as a matter of genetic inheritance (Erbgut), on the basis of the modes of encounter that one has as a human being. Either a God or none - and if so, then a personal God. I must be able to beg his pardon, to pray to him; he must have this personal quality.

I cannot accept the intermediate stages that are placed between man and God, stages that are already installed by Protestantism. The development to the point of the Hegelian World Spirit arose out of this spirit of retreat. Spiritualization arose for the sake of the intellectuals, who found the simple personal conception hard to defend and who were able to arrange God for themselves only in this pantheistic form. This spiritualized God is of no use to me. On the one hand, it is the historical merit of Protestantism to have carried this process into effect, but on the other hand, it is a renunciation of much unconditional evidence and generative force. 
If I return to the primal question of either a personal God or none, I cannot come to any conclusion but that I do not know. One thing I do know. A personal God has never addressed me. I have indeed had experiences that you would call religious. But to experience these as if I had encountered a personal God could only be done by a man from the middle ages. I can provide a phenomenological description of what I call self-encounter, but only as a being thrown back (Zurückgeworfensein) on my own loneliness, the innermost source that springs up within myself and that is ecstatic, - and yet not so that a strange voice speaks into me, as a medieval mystic would say. Because I want to be just so exact (and modern man is like that) and because I have experienced it in this way, I cannot say that a personal God has spoken, and I remain silent about it. I have not had him directly, but that is not all right (in Ordnung). And things are not all right with the world, there is something wrong with the ever greater analytical breakdown, something is lost. I also cannot see how my understanding could reach the point where it could say that there is nothing behind it all [26].

Drawing once more on the transcript of Mannheim's inaugural lecture course at Frankfurt, which Katz did not attend, we note the following: "Do not think about problems that do not become acute! If certain problems do not become acute in your life, do not believe that you would not be a cultivated person without these problems. When this problematic reaches you, however, you must know what it means and what possibilities the situation opens up. Perhaps one person can then even help another [27]."

To engage Jacob Katz in a study of assimilation may well have appeared as a brilliant opportunity for Mannheim to gain help with his own deep uncertainties while gently initiating a student into a process, on the other hand, which Mannheim must also have expected to result in his own distantiation from his present commitments. Whether he saw the latter as risk or opportunity is hard to say, but his sense of sociological mission was inseparable from his conviction that there was something else. The contradiction would have appeared inescapable. Yet we do not want to build too much on this speculative excursus, whose claims are not essential to our main thesis. That is, whether Katz's theory of assimilation provides a key to our understanding of Mannheim's intellectual management of his Jewish question, which is our present concern, does not depend on the extent to which it also documents a process of intimate collaboration between the two men, where the student helps the professor to probe more deeply into his own existential uncertainties.

Yet the primary relationship between the two, especially from Katz's point of view, was that between teacher and student in a simpler sense, and the teacher, Karl Mannheim, during the Frankfurt years appeared above all in the guise of empirical-historical sociologist, with philosophical conundrums very much on the periphery, and quite possibly invisible to someone who came to university with Katz's sharp distinction between the sites of his scientific training and the sites of his cultivation - and with a supportive local network of orthodox Jewish associations to sustain the difference [28].

We turn, then, to some similarities between Katz's structure of analysis and the teachings of the "scientific Mannheim" of the Frankfurt classroom. Mannheim's lecture courses in Frankfurt followed a sequence of historical periods, each used as the occasion for highlighting a distinct complex of institutional concepts largely derived from Max Weber's systematizations. The Summer 1931 course that covered the time period from antiquity to feudalism, for example, developed the concepts of family, tribe, and patrimonial rule; the Summer 1932 course on the high 
middle ages and early modern period brought out themes of upward mobility, classes, women and the educated strata. There was also a course focused on the developments of urban, bourgeois society and the concomitant rise of state formations. The point of the sequence is epitomized in the catalogue title of the first one, "The Social Forms of the Present and their History [29]."

Mannheim's design embodied what may be called a "historical approach" with an unembarrassed presentist agenda. There is a complex relationship between Mannheim's pedagogical and theoretical strategies, especially in the uses of history. From the latter point of view, there was a strong phenomenological element in Mannheim's approach, incorporating historical elements into an apprehension of "the social forms of the present [30]."

In applying our understanding of Katz's theory of the rise of assimilation and its ideology to Mannheim's management of his situation as assimilated Jew in a world that undermined the structural supports of trans-religious liberal space, we implicitly treat Katz's approach as more nearly phenomenological than historical. To justify this reading, we draw especially on Mannheim's practice of recommending historical distantiation to his students as a resource for a kind of phenomenological Wesensschau, as a methodological aid to confronting their own most problematic experiences.

Whether this was in fact the case for Katz in his days as Mannheim's student cannot be stated with certainty, especially because Katz's later use of the research reported in his dissertation treats the epoch of the rise of assimilation merely as a phase in a process that generated a sequence of differently designed social constitutions, notably in his Out of the Ghetto [31]. It is of course open to us to contend that Katz's early insight has no less power than his subsequent periodization-and that in fact his later conceptions in fact represent comparatively minor adaptations of the basic design. On the other hand, the design itself may have been affected by the ambiguous requirements of a thesis defended after the establishment of Nazi rule in the universities. In the end, the theory we derive from Katz and apply to Mannheim can be validated by the authority of Katz with only somewhat more assurance than we can treat Katz as expounder of Mannheim's self-understanding. Yet in both respects, we obviously think that the probabilities are worth the gamble.

The main conceptual elements in Katz's study of assimilation are the emergence of the Bildungselite in the 18th Century, the correlation between a new social formation of "intellectuals" within this setting and Enlightenment or liberal thought, the importance of concrete settings of conversation and sociability, the shift of perspective from one generational unit to the other, the motif of social advancement, and, overall, the identification of sociological analysis with the identification of "functional" relations rather than substantive ones. The themes are applied as analytical tools in historical sociology, rather than being theoretically developed, as they are in Mannheim's published writings. Their treatment here corresponds to the approach in Mannheim's lecture courses, as well as in Katz's most frequently cited source, Hans Weil's study of Bildung, which was developed, like Katz's own work, in Mannheim's Working Group on Early Liberalism [32].

In both Mannheim's publications and his classes, as in a large manuscript study of intellectuals left unfinished at his death, Jews who have left the community of the faithful always figure in Mannheim's recitations of the miscellaneous social elements who are collected in the emergent Bildungsschicht between the mid-eighteenth and early twentieth centuries. Yet he never separately addresses Katz's distinctive questions about the processes that led to their departure from the 
Jewish community and to their acceptance within the programmatically "spiritual" (geistig) social groupings of non-Jews. To Mannheim, the dissolution of all primary religious communities and "primitive" modes of understanding the world appear simply as the single most important but nevertheless self-evident aspect of the processes of modernization. "Secularization" appeared irreversible, at least as far as the old religious institutions were concerned. Katz's starting point within the ranks of the orthodox problematizes that self-evidence and opens questions about Jewish assimilation that are analogous to the questions opened about the self-evidence of other aspects of liberalism by the revival of conservative thought, which Mannheim had entered into for purposes of his seminal study of Conservatism, five or six years before his meeting with Katz [33].

\section{Another Jewish Reception of Mannheim's Principal Work}

To clarify the special character of Katz's intellectual negotiations with Mannheim, it is worthwhile to contrast it with the only other distinctly Jewish contemporaneous reception of Mannheim we have been able to find, a quite long review of Mannheim's Ideologie und Utopie by Rabbi Ignaz Maybaum in the Zionist periodical, Jüdische Rundschau [34]. Because of the importance of communicative transactions with his surroundings in the very constitution of Mannheim's Bildungs-oriented project, notably in relation to students and colleagues, but also with publics more broadly defined, we researched the Jewish Umfeld of Mannheim's work, focusing on a search for direct (or indirect) receptions of his work within the contested terrain of contemporaneous Jewish discourse. There is no evidence, however, of anything resembling Mannheim's intense interactions with two Christian groupings, the Paul Tillich Circle in Frankfurt and the Moot in England (where he always participated, it should be noted, as unquestionably non-Christian). Nor have we found any evidence that Mannheim was challenged by Jewish publicists, who one might suppose to have been disturbed that he made no effort at all to carry on the scholarly and personal involvement in Jewish affairs that marked the career of his immediate predecessor in the Chair of Sociology at Frankfurt, Franz Oppenheimer.

The Zionist publicist, Maybaum, is in fact highly favorable in his assessment of the book, although he is markedly selective in the segments he recombines in his account of its argument. First, however, he dismisses Mannheim's concept of “total ideology" as an embodiment of what he considers to be Mannheim's mistaken claims that all social knowledge is perspectival in structure and that consequently a "science of politics" must somehow mediate the ideological conflicts to generate a "synthesis" in the form of a shared realism, a corresponding moderation of conflict, and its transmutation into a negotiation of contrasting interests. Instead, Maybaum emphasizes the contrast between ideologies and utopias that Mannheim develops in portions of the three essays unsystematically joined in the book, notably in the essay on utopia that is located at the end, without in fact serving as the conclusion of a cumulative argument, as Mannheim himself notes. The unified plot that Maybaum imposes on Ideologie und Utopie, then, involves the difference between intellectuals trapped in backward-looking ideologies by ignorance, the psychology of interests, or manipulative design, and intellectuals possessing the energy and insight to define the world by utopias, which have the capacity to validate themselves in practice by energizing action to implement their visions. Maybaum's sole criticism of the Mannheim he extracts and praises is that his review of utopias fails to recognize Messianism, where Maybaum would situate the 
intellectuals of Zionism. We add two small points, to close this excursus. First, it should be noted that Mannheim's "amplification" of his utopia concept in his 1930 course eliminated the ambiguity on which Maybaum's reading rests: "utopia" now appears simply as a preliminary stage in the process of distantiation from unproblematic, "primitive" interpretations of experience. Second, on the other hand, it should be said that the positive assessment of the "mission" of intellectuals that Maybaum did share with Mannheim and that doubtless first attracted him to Ideologie und Utopie did not give way when most Zionist discourse after 1933 concentrated single-mindedly on "salvation through physical work and the accompanying disdain for pursuits requiring brain instead of brawn." He warned "dejectedly" against the Zionist abandonment of Bildung, according to a historian of the Jewish publicistic in Nazi Germany [35].

The important point arising out of the brief comparison between Maybaum's and Katz's relationships to the work of Karl Mannheim is that while Maybaum read Mannheim for political theses grounded in sociological interpretation, Katz dealt with Mannheim, above all, as teacher, very much in the sense of value-free social science. We have called attention to a surplus dimension, where Mannheim intended sociological studies also to provide orientation through selfclarification, but it seems clear that this dimension mattered much more to Mannheim than to Katz, whose orientation was not problematical. There was a certain asymmetry in their shared enthusiasm for Katz's project.

\section{The Cultured Elite in Mannheim's Diagnosis of National Socialism}

Katz's analysis offers us a vital new dimension for grasping Mannheim's understanding of and response to the Nazi regime,- - specifically, it leads us to find Mannheim's self-awareness of his position as assimilated Jew and his despair at the fate of this group embedded in the primary manifest level of his diagnosis of the structural pathology, not limited to Germany, and in his proposed therapeutic response. The destruction of the Bildungselite is the more inclusive frame of reference, as the destruction of the labor movement was for Socialist emigrants.

In 1933, even before he arrived in London, his ultimate place of exile, Karl Mannheim approached the Paris office of the Rockefeller Foundation with a project proposal. He requested the extraordinary sum of $\$ 50,000$ (five times as much as the Foundation awarded Alfred Weber for ten volumes of detailed economic research) to bring together a team of exiled social scientists and his best Frankfurt students in order to study "The Sociological Causes of the Cultural Crisis in the Era of Mass-Democracies and Autarchies." For the interdisciplinary senior staff, Mannheim proposed the psychologist Theodor Reik, the social historian Alfred von Martin, the political scientist Sigmund Neumann, and the legal sociologist, Franz L. Neumann. Mannheim also asked for five "young social scientists," as well as two "observers" in Germany and Russia. Another source adds Ernest K. Bramstead, Norbert Elias, W. Falk, Hans Gerth, Svend Riemer, and Albert Salomon-all but one former Mannheim students--presumably to fill the junior roles [36].

"The urgent occasion for study," he writes to the Rockefeller Foundation, is the conjunction between an "era of the most highly perfected technical rationalization and planning" and socialpolitical forces that will, if unchecked, "lead to the dissolution of all forms of culture and a universal reversion to barbarism." His "sociological investigation into the social conditions for the growth and existence of 'culture" "is designed to uncover "the clue to the remedial measures 
needed" to direct the un-avertable shift to the planning of culture not "according to the preconceived patterns of the various political groups" but according to knowledge capable of halting the abandonment of the "common Christian-humanitarian basis of Western society." The central analytical figures are the distinctions between unplanned and planned sectors of society and the correlate conceptions of elite and mass; and Mannheim's leading idea, as in his subsequent published writings, is that developments in the unplanned sector have led to destructive changes in the function of liberal non-intervention, undermining the structured reproduction of cultural elites and their publics in favor of a vicious symbiosis of leaders and masses. What emerges perhaps more clearly here than in some of Mannheim's later writings is that his distinctive contribution to the widespread confident advocacy of planning was intended to be the planned reconstitution of an intellectual elite dedicated to high culture, albeit democratic in recruitment. The research aims to integrate historical, comparative, and empirical studies of social mechanisms of elite (de)formation, with the sociologist functioning as coordinator of an interdisciplinary team.

Notwithstanding Mannheim's historically and instrumentally apt qualification of the foundational culture as both humanitarian (sic) and Christian, the sociological focus on the disintegration and eventual restoration of what Katz had called the Bildungselite indicates to us that we have found the locus of Mannheim's treatment of what we want to circumscribe as his Jewish problem, the problem of the assimilated Jews whose social status and activity are constituted by their place in that socially transcendent location, namely their identification with the freischwebende Intelligenz which forms the most dynamic and innovative element in the more broadly defined cultivated segment of society. In a treatise written in 1924 as he was preparing to move from philosophy to sociology, Mannheim offers a theoretical account of the formation of the Bildungskultur and the range of possibilities that it opens to such socially unattached social existences as impoverished gentry and the Jewish element for comparatively liberal choice in the political or cultural tendencies they make their own [37]. The "crisis of culture," we maintain, was signaled for Mannheim not least by the anti-Semitic assaults against assimilated Jews, notably their exclusion from the cultural sphere that had been Mannheim's own home in Germany.

The pain of this exclusion can be gauged from a somewhat dramatic statement he made at the time of his first arrival there, as exile from Hungary:

At this time-and perhaps it will some day be different - I am interested above all in the lives of those to whom I belong. We, the multitude spread all over the world, are the only international rootless scatterings without ground under our feet, we who write and read books and who are one-sidedly interested, in writing and reading, in the spirit alone. .... Cultivation, true humanism, forms men into a new kind of stratum, cutting across the economic and other sociological classifications. Cultivation also shapes the most spontaneous forms of life and transports man into an isolated world incomprehensible to others. While the cultures of China and India created an externally visible caste for these people, our isolation is sometimes hidden from view, since the stratum does not possess such an unambiguous mark of recognition.

When I think about the general and mistaken beliefs that are a consequence of not having such a mark, it always amazes me how much closer I am to those who participate in this cultivated humanism and how much closer they are to me than they or I are to those who share their nationality 
but are an altogether different kind of people. I respect their efforts (and time may eventually grant meaning to their strivings), but I simultaneously scorn the lies of those who, under national or racial catchphrases or the slogan of class struggle, want to fulfill the romantic dream that they are at one with the race or class that they programmatically represent [38].

\section{Mannheim and the "Jewish Sect."}

If this is indeed the solution to the riddle of Mannheim's seeming total indifference to the situation of Jews in Germany notwithstanding his non-denial of his own identity and the methodological grounding of his thought on the moment of self-reflection, it yields a result that is unsatisfactory in a number of basic respects. First, it is an awareness devoid of any solidarity with Jews who have nothing to do with the Bildungselite, perhaps even orthodox Jews like Katz, not to speak of the numberless poor of the East. Second, there is no acknowledgment of the enormous violence against Jews, which is shocking even if we recognize that Mannheim died before the implications of the mass murders condensed into concepts of Shoah and Holocaust.

Before addressing these profound limitations, however, it is necessary to address the paradox in our thesis, which is that we impute a central concern with a vital Jewish theme to a thinker who did not himself refer to the supposed Jewish dimension of either the emergence (except in passing) or the terminal crisis of the cultural elite, which encompassed the intellectuals with whom he identified himself. Jacob Katz's exposition of the assimilationist ideology offers an explanation of the paradox, especially through his recognition of the "functional" or what might also be identified as the rhetorical dimension of this pattern of thought. If Mannheim was convinced that the effectiveness and perhaps the existence of the assimilated Jew depended on the vitality of a socialcultural space where the difference between Jew and Christian did not count, then he could reasonably conclude that it would be impossible to contribute to its reconstitution by speaking as a Jew, at least in a historical setting in which all the talk of inter-religious unity had become transparently empty, as was true at the latest since the First World War.

It should perhaps be emphasized once more that we consider the class of assimilated Jews of interest to Katz and of relevance in understanding Mannheim to be a bounded social formation rather than a moment in a continuous movement towards denial of Jewish origins or ethnic ties. Karl Mannheim is an altogether different case than the noted philosopher, Karl Popper, who rejected all links to a Jewish legacy in any sense [39]. Mannheim was always, as Nina Rubinstein recalled in old age, "a guter Jud," in the eyes of his students. We have explored the methodological problems associated with such bounded formations, constituted and reconstituted by processes of negotiation elsewhere, notably in the context of exile studies [40].

Mannheim's main design in Weimar Germany was to make the academic discipline of sociology a place open to intellectuals in his sense, which clearly included the assimilated Jews of his generation. Sociology, moreover, was to play a critical role in repairing threatening breaches in the civil fabric of society, notably by contributing to the political education needed to undergird the republican constitution. In brief, it was the new Bildung [41]. Mannheim's distinctive conception of sociology as the framework for a new Bildungselite and as an agency for the reconstitution of both civil society and an organon for a saving political knowledge is put in a curious light by the ironic label of a "Jewish sect" attached to sociology by his predecessor at Frankfurt, Franz Oppenheimer. 
A positivist in his conception of the discipline and a dedicated Zionist in his politics, Oppenheimer frequently wrote in Jewish publications on the sociology of anti-Semitism and similar themes [42]. Like many Zionist writers of the time, Oppenheimer agreed with anti-Semites about the hatefulness of many Jewish characteristics, but insisted that these had to be explained by the oppression and restrictions under which they were forced to live in the diaspora. In any case, he had a far different conception of both the discipline and Jewishness, and he did not respond to the state of the question as we recognize it with the help of Katz.

Like Mannheim, the literary critic and philosophical writer, Erich Kahler, similarly placed problems of German Bildung at the center of his diagnosis of and therapeutic response to the "cultural crisis," but he had no reservations about speaking as a Jew of a kind. In a book that infuriated the Nazis when they came to power and led to Kahler's exile in 1933, Israel unter den Völkern, he gave the mission of saving German culture to Jewish men of culture. This is not the place to relate this curious twist to our thesis about assimilation, but it would not be hard to show Kahler's strategy to be a variant on the general project of reconstituting a neutralized cultural site [43].

Mannheim's closest approach to an express identification with Jews in a published work gains this character only by the context in which it appeared. Writing in Hungarian in 1924, Mannheim claimed for himself a place in the principled political emigration from Horthy's authoritarian regime, asserting an elite function for that segment among those that fled. What is interesting from the present point of view is that the editor of the émigré publication, Samu Fényes, claimed that it was "das Judentum" that had first crystallized the concept of "humanity," which is the hallmark of the "most perfect patriot" who serves as model for the publication, Diogenes [44]. It is interesting both that Fényes should have considered Mannheim a kindred spirit and that Mannheim should have published there, at a time when he was simultaneously having to validate himself at Heidelberg, against hostile anti-Semitic official attitudes, as an unpolitical German scholar.

Mannheim's opponents in German academic life included figures like the noted literary scholar, Robert Curtius, who were not the most rabid anti-Semites, but who expressly criticized the openness to Jews that Mannheim's sociological project entailed. They saw a link between his version of sociology and his Jewish identity. His main competitor within the profession in Germany, Leopold von Wiese, a sociologist celebrated by many American sociologists at the time, wrote an obituary for Mannheim after his death in 1946 in which he remembered a conflict between them about the meaning of freedom. He concluded that Mannheim's idea of freedom culminated in rule of the "clever" and that it would be alien to someone "whose parents did not come from the ghetto [45]." Speaking for sociology in Mannheim's sense amounted to speaking as a Jew, at least in the mind of his non-Jewish contemporaries.

The rhetorical context was even more difficult in England, at least on Mannheim's reading, since his conception of the Bildungselite required that it had to validate itself by its responsiveness to crisis, by its dynamic leadership, conditions that were not in his view met by the "smug" British publics that did in fact, we might note, offer a secure and influential home-or at least institutionalized routes of access - for English Jews of different degrees of assimilation, from whose influential centers Mannheim himself had, in any case, evidently suffered some rebuffs. After several failed efforts in social science circles, Mannheim found what he considered to be a 
promising setting in an expressly Christian group and among conservative cultural critics like T.S. Eliot, who spoke in terms of a Christian culture, while patronizing non-Christians like Mannheim himself and his close friend, Adolph Lowe. He could keep his distance from their religious convictions by emphasizing his status as both emigrant and sociologist, but he could not hope to address the relations between the cultural order they promoted and the fate of assimilated Jews, let alone the persecution and destruction of Jews in general, except as a symptom of the "crisis."

It is our argument in brief that Mannheim's silence on Jewish questions is to be explained by the priority he assigned to what he saw as a "crisis of liberalism" to be countered by a Bildung in the guise of a sociologically informed "political education," and that this complex project, combined in what he took to be the mission of sociology both before and after his expulsion from Germany, also comprehended what he took to be his own Jewish question. We would contend, moreover, that understanding this as an assimilationist ideology, in Katz's terms, does not in itself deny Mannheim's thinking important cognitive worth, as we have tried to show in numerous publications. On the subtle relations between ideological perspectives and social knowledge, we side with Mannheim's claim that there may be interdependence as well as mutual contradiction, depending on the structure of the ideology and the historical context to which it is applied. And in this, we side as well, of course, with Jacob Katz, who never questioned that in Mannheim he had found "the person from whom I had most to learn."

\section{Mannheim's Silence}

Yet once the discussion turns to evaluation, we are confronted with the "limitations" noted above, which may be deemed ethical or cognitive, but in any case belong to the moral philosophy of knowledge. Whatever the theoretical perspective, how is it possible to address the largest questions of social explanation and diagnosis without some express attention to a whole population hunted to misery and death? Even Max Weber's conception of value-free social science always provided expressly that the selection of questions to be addressed by science may be subjected to ethical judgment. Solidarity is not an irrelevant demand. Yet the most familiar habitus of that term suggests a far more prominent parallel case, the reluctance of socialist analysts of all varieties not expressly identified as Jewish to jeopardize their capacity to speak for and to the working class movement by focusing on the fate of Jews, except insofar as they could be subsumed under an analysis of the proletarian situation. A friendly rival of Mannheim in the Weimar years on questions of both sociology and Bildung, Albert Salomon, broke with exile socialists on these grounds; while Mannheim's sometime student, Franz L. Neumann, on the other hand, remonstrated with Max Horkheimer when the Institute of Social Research decided, for a number of reasons, to invest great intellectual efforts in the study of ant-Semitism, maintaining that he had himself written a whole book on National Socialism without more than incidental mention of anti-Semitism and that the proposed new focus risked an abandonment of their socialist theory.

Some recent scholarship suggests that Neumann's fears were not altogether unjustified, but also that the problem of accounting for the new emphasis in the work of Horkheimer and Adorno is too complex to incorporate in the present study. We would suggest, however, that the considerations we develop in the case of Mannheim also have a bearing on the work of his rather scornful intellectual opponents, operating in a very different context. The subsumption of the horrors in 
German Europe under the rather bland heading of anti-Semitism, as it had been the domestic target of American Jewish investigation and mobilization for years, and as it still framed the inquiries pursued by the Institute for Social Research, raises a number of similar questions about the virtual neglect of key happenings affecting the great mass of European Jews. At present, we are only calling attention to Neumann's objections, stated, at least implicitly, in terms of solidarity with the working class movement. Horkheimer and Adorno did not so much oppose it; they lost interest [46].

In both the socialist and liberal cases (as we may label Mannheim's project), the scientific work was meant simultaneously to perform a rhetorical function, to produce and reproduce the cultural structures they consider decisive - a working-class movement in the one case and a Bildungselite in the other. In both cases, the functional designs precluded a response to other considerations. The parallel does not resolve the problem, but it puts it in a larger more complex problem context, which cannot be explored here.

We come finally to the question that cannot be avoided by anyone living today, Mannheim's manifest failure to take notice of the mass destruction of European Jews. By 1943, when he published Diagnosis of our Time, much was already known. The photographs of old Jews scrubbing streets in Vienna in 1938 or the detailed reports of November 9, 1938 in Germany should have sent sufficient signals even in 1940, when he published Man and Society in an Age of Reconstruction. When we confront this extraordinary omission, however, we must recognize that Mannheim simply never confronted physical violence at any level of his studies. It was a blind spot, perhaps related to his profoundly constructive project of a humane but regulated society, based on strategic controls and compromise. Violence, amazingly, was not interesting. In that sense, notwithstanding what may be called the constitutional-political character of his whole approach, he was a profoundly unpolitical thinker, the very antithesis of another old critic of his, Hannah Arendt [47]. It may be argued that to confront Mannheim in the 1940s with the question of the Holocaust is anachronistic not in the sense that the news about the mass murders of Jews was not known, but in the sense that at the time of his death, as has been shown through detail studies of historians by Nicolas Berg and through a sociological overview by Jeffrey C. Alexander a year earlier, the events were almost universally construed as "atrocities" and "war crimes," like other atrocities and war crimes of the regime, not as an integral event of unique character and ontological evil [48]. Yet that possible historical qualification does not affect Mannheim's larger blindness to violence against Jews, not to speak of the question why it was Arendt not Mannheim who saw the graver possibilities. So our criticism of Mannheim's one-sidedness stands.

\section{The Jewish Question in American Social Science}

That the interconnection between the effort to renew a socio-cultural space where assimilation is possible and the avoidance of Jewish questions in the work of Karl Mannheim and other Jewish intellectuals of his Weimar generation can be elucidated with the help of Jacob Katz's conception of a functional assimilationist ideology invites consideration of other situations that may also be clarified by this approach. An interesting parallel phenomenon is the role of Jewish intellectuals in the de-Christianizing of American academic culture with the help of a celebratory ideology of science. It is the merit of David A. Hollinger's work that he highlights, first, the extent to which the 
idea of a Christian culture continued to dominate American university life well into the twentieth century, second, the idea of a conjunction between science and democracy as prime vehicle of the largely successful attack on the hegemony of this conception, and, third, the vital role played by Jewish intellectuals in promoting this ideology of science, even where the element of myth-making is fairly patent, as in the elevation of Justice Holmes to an iconic role [49]. An elective affinity between the Weimar and American projects, notwithstanding the shattering difference between the tragic defeat of the one and the triumph of the other, is suggested by Hollinger's selection of Robert K. Merton, a sociologist who revealed his Jewish antecedents fairly late in his career, as a paradigmatic figure of the American project, since Merton was also the most influential American interpreter of Mannheim during the 1930s and 1940s. In that interpretation, however, Merton shifted the reading of Mannheim from the focus on sociology as a form of the intellectual's world to a concern with sociology as science. We are arguably confronted with simply a different mode of the functional ideology of assimilation.

Introducing the question of an American comparison, frees the consideration of the German case from the claustrophobia of the endless debate about the supposed German-Jewish symbiosis. If Katz's theory of assimilation is freed from the notion of irreversible stadial development, which displaced what we provisionally called a "phenomenological" reading of his theses, it will appear that the need to produce and reproduce the "neutralized" social space essential to assimilation is a recurrent one, and that there is no cumulative or "progressive" development of Jewish intellectuals' awareness from assimilation to national consciousness - nor a necessary decline to self-hatred and self-denial. Without unusual philosophic gestures, then, it may prove that Katz's findings about assimilation in the eighteenth century are revealing not only about his teacher, Karl Mannheim, but also about Jewish intellectuals in various Western settings.

\section{References and Notes}

1. Carl Schmitt. Ex captivitate salus. Erfahrungen der Zeit 1945/47. Cologne: Greven, 1950, 22-23.

2. Reinhard Mueller. "Nach einer furchtbaren Frustration. Ein Brief von Julia ueber ihren Ehemann Karl Mannheim". Archiv für die Geschichte der Soziologie in Oesterreich Newsletter 16, December 1997, 14-16.

3. David Kettler and Volker Meja. Karl Mannheim and the Crisis of Liberalism. New Brunswick and London: Transaction, 1995, 262.

4. Ulrich Oevermann. "Soziale Konstellation des Exils am Ende des Weltkriegs und die Pragmatik der „First Letter“. Eine Struktur- und Sequenzanalyse.” In Nach dem Krieg! - Nach dem Exil? Erste Briefe/First Letters, edited by Detlef Garz, and David Kettler. Munich: Text + Kritik, 2012.

5. Ernst Fraenkel. "Brief vom 23 März 1946 an Familie Suhr." In Ernst Fraenkel Gesammelte Schriften, III. Neuaufbau der Demokratie in Deutschland und Amerika, edited by Gerhard Göhler with Dirk Rüdiger Schumann. Baden-Baden: Nomos, 1999, 383, 389-95.

6. Ernst Fraenkel. “Judenfrage.” In Ernst Fraenkel Gesammelte Schriften,II. Nationalsozialismus und Widerstand, edited by Alexander von Brünneck. Baden-Baden: Nomos, 1999, 583-94.

7. Shlomo Sand. The Invention of the Jewish People. London: Verso, 2008. 
8. David Kettler and Volker Meja. "Karl Mannheim's Jewish Question. History, Sociology, and the Epistemics of Reflexivity”. In Simon Dubnow Institute Yearbook 3 (2004): 325-47.

9. Jacob Katz. With My Own Eyes. Hanover, NH: Brandeis University Press, 1995; Benjamin Ze'ev Kedar, "Soziologische Geschichtsschreibung: Jacob Katz als Schüler Karl Mannheims." Jüdischer Almanach 1998/5758 des Leo Baeck Instituts. Frankfurt am Main: Jüdischer Verlag 1997, 79-86.

10. Jacob Katz. Die Entstehung der Judenassimilation in Deutschland und deren Ideologie. In Jacob Katz, Imagination and Assimilation. Studies in Modern Jewish History. Farnborough: Westmount, 1972.

11. David A. Hollinger. "The 'Tough-Minded' Justice Holmes". In Science, Jews, and Secular Culture. Princeton: Princeton University Press, 1996, 42-59, 51.

12. Nina Rubinstein. Die französische Emigration nach 1789. Ein Beitrag zur Soziologie der politischen Emigration, Dirk Raith, ed. Graz-Wien: Nausner \& Nausner, 2001. See David Kettler. "Self-Knowledge and Sociology: Nina Rubinstein's Studies in Exile." In The Liquidation of Exile. Studies in the Intellectual Emigration of the 1930s, edited by David Kettler. London: Ashgate Press, 2011, 25-34.

13. J. Katz. Die Entstehung.

14. David Kettler and Gerhard Lauer. "The 'Other Germany' and the Question of Bildung". In Exile. Science, and Bildung: The Contested Legacies of the German Intellectual Emigrants, David Kettler and Gerhard Lauer, eds. New York: Palgrave-Macmillan 2005; Colin Loader, and David Kettler. Karl Mannheim's Sociology as Political Education. New Brunswick: Transaction Publishers, 2002.

15. David Kettler, Colin Loader and Volker Meja. "Hans Gerth and Hans Weil: the Genealogy of the liberal Bildungselite," Chapter 6 of Karl Mannheim and the Legacy of Max Weber. Retrieving a Research Programme. Aldershot, England: Ashgate, 2008.

16. Kedar. "Geschichtsschreibung".

17. David Kettler and Volker Meja. "Their own 'peculiar way': Karl Mannheim and the Rise of Women.” International Sociology 8, March 1993, 5-55.

18. J. Katz. Eyes, 78-79.

19. Ulrich Herrmanns. "Vorwort" in Hans H. Gerth, Bürgerliche Intelligenz um 1800. [1935], Ulrich Herrmann, ed. Göttingen: Vandenhoeck \& Ruprecht, 1976, 9. Kettler, Loader, Meja, "Hans Gerth."

20. Loader and Kettler. Education.

21. Gerth. Intelligenz, 27.

22. Margarethe Freudenthal. Gestaltwandel der städtischen, bürgerlichen und proletarischen Hauswirtschaft. Frankfurt: Ullstein, 1986; Norbert Elias. Court Society. Oxford: Basil Blackwell, 1983.

23. Karl Mannheim. “An Introduction to Sociology." In Sociology as Political Education, edited and translated by David Kettler and Colin Loader. New Brunswick: Transaction Publishers 2001, 15.

24. Kettler and Meja. Crisis, 256-57.

25. J. Katz. Eyes, 104-5. 
26. Karl Mannheim. “On Religious Experience and Rationalization”. In Mannheim, Political Education, 137-138.

27. Mannheim, Introduction, 22.

28. David Kettler, Colin Loader and Volker Meja. Karl Mannheim and the Legacy of MaxWeber. Retrieving a Research Programme. Aldershot, England: Ashgate, 2008.

29. Karl Mannheim Archives at Keele University. Cp. Hermanns, "Vorwort", 9.

30. Reinhard Laube. Karl Mannheim und die Krise des Historismus. Göttingen: Vandenhoeck \& Ruprecht, 2004.

31. Jacob Katz. Out of the ghetto: the social background of Jewish emancipation, 1770-1870. Cambridge MA: Harvard University Press, 1973.

32. Gerth. Intelligenz, $81 \mathrm{n} 11$.

33. Karl Mannheim. Conservatism, edited by David Kettler, Volker Meja and Nico Stehr. London: Routledge and Kegan Paul, 1986, 2001.

34. Ignaz Maybaum. "Ideologie und Utopie". In Juedische Rundschau, Nr. 101/102, 24.XII. 1929. p. 693.

35. Jacob Boas. "German Jewry's Search for Renewal in the Hitler Era as Reflected in the Major Jewish Newspapers (1933-1938)." The Journal of Modern History 53, No. 1, On Demand Supplement, March 1981, D1001-D1024: D1014. Cp. Hermann Zabel, Andreas Disselnkötter, and Sandra Wellinghoff, eds. Stimmen aus Jerusalem. Zur deutschen Sprache und Literatur in Palästina/Israel (Deutsch-Israelische Bibliothek Vol. 2) Berlin: LIT Verlag 2006, 28f.

36. Rockefeller Foundation Archives. RF/RG1.1/401S/73/969; Henk Woldring, Karl Mannheim. The Development of His Thought. New York: St. Martin's Press, 1986, 40.

37. Karl Mannheim. Structures of Thinking, edited by David Kettler, Volker Meja, and Nico Stehr. London: Routledge and Kegan Paul, 1982, 267.

38. Karl Mannheim. "Heidelberg Letters". In Political Education, 79-97, 82-83.

39. Malachi Haim Hacohen. "Dilemmas of Cosmopolitanism: Karl Popper, Jewish Identity, and 'Central European Culture"'. The Journal of Modern History 71, March 1999, 105-49.

40. Kettler, and Meja. Crisis. Cp. David Kettler. Social Regimes, Rule of Law and Democratic Change. Berlin: Galda and Wilch, 2002, as well as Kettler and Lauer. Exile and Kettler, Liquidation.

41. Loader and Kettler. Education.

42. Franz Oppenheimer. "Der Anti-Semitismus im Lichte der Soziologie". In Der Morgen. Monatschrift der deutschen Juden. Berlin, 1925, 184-91.

43. Erich von Kahler. Israel unter den Völkern. Zürich: Humanitas, 1936; Gerhard Lauer. Die verspätete Revolution. Erich von Kahler. Wissenschaftsgeschichte zwischen konservativer Revolution und Exil. Berlin \& New York: De Gruyter, 1995.

44. Reinhard Laube. Karl Mannheim und die Krise des Historismus. Göttingen: Vandenhoeck \& Ruprecht, 2004, 514-515.

45. Leopold von Wiese. "Karl Mannheim.” Kölner Zeitschrift für Soziologie und Sozialforschung. 1947. 
46. Jack Jacobs. "Horkheimer, Adorno, and the Significance of Anti-Semitism: The Exile Years." Kettler and Lauer, Exile, 157-168; Thomas Wheatland. "Not-Such-Odd-Couples: Paul Lazarsfeld and the Horkheimer Circle on Morningside Heights." Kettler and Lauer. Exile. 169-184; David Kettler. "Negotiating Exile: Franz L. Neumann as Political Scientist.” In Der Eigensinn des Materials. Erkundungen sozialer Wirklichkeit, edited by Caroline Arni et al. Frankfurt a. M./Basel: Stroemfeld, 2007, 205-224.

47. Peter Baeh. "Of Politics and Social Science: 'Totalitarianism' in the Dialogue of David Riesman and Hannah Arendt." Edited by David Kettler and Thomas Wheatland. Contested Legacies: Political Theory and the Hitler Era, Special Issue of the European Journal of Political Science, 5:2, June, 2004.

48. Nicolas Berg. Der Holocaust und die westdeutschen Historiker. Erforschung und Erinnerung. Göttingen: Wallstein, 2003; Jeffrey C. Alexander, "On the Social Construction of Moral Universals. The 'Holocaust' from War Crime to Trauma Drama." European Journal of Social Theory 5 (2002): 5-85.

49. David A. Hollinger. Science. 
Reprinted from Religions. Cite as: Dubnov, A.M. What is Jewish (If Anything) about Isaiah Berlin's Philosophy? Religions 2012, 3, 289-319.

Article

\title{
What is Jewish (If Anything) about Isaiah Berlin's Philosophy?
}

\author{
Arie M. Dubnov
}

School of History and the Department of General History at the University of Haifa, Israel

Received: 23 March 2012; in revised form: 28 March 2012 / Accepted: 31 March 2012 /

Published: 13 April 2012

\begin{abstract}
This paper has two central aims: First, to reappraise Isaiah Berlin's political thought in a historically contextualized way, and in particular: to pay attention to a central conceptual tensions which animates it between, on the one hand, his famous definition of liberalism as resting on a negative concept of liberty and, on the other, his defense of cultural nationalism in general and Zionism in particular. Second, to see what do we gain and what do we lose by dubbing his philosophy Jewish. The discussion will proceed as follows: after describing the conceptual tension (Section 1), I will examine Berlin's discussion of nationalism and explain why comparisons between him and Hans Kohn as well as communitarian interpretations of him are incomplete and have limited merit. I will continue with a brief discussion of Berlin's Jewishness and Zionism (Section 3) and explain why I define this position "Diaspora Zionism". The two concluding sections will discuss Berlin's place within a larger Cold War liberal discourse (Section 5) and why I find it problematic to see his political writings as part of a Jewish political tradition (Section 6).
\end{abstract}

Keywords: Berlin, Isaiah (1909-1997); Kohn, Hans (1891-1971); Namier, Lewis B. (1880-1960); Shklar, Judith N. (1928-1992); nationalism; communitarianism; Cold War liberalism; Jewish political tradition

\section{Introduction}

"No man is an Iland, intire of it selfe; every man is a peece of the Continent, a part of the maine." So, at least, asserted the seventeenth-century English metaphysical poet John Donne in one of his most famous meditations, giving birth to a metaphor numerous subsequent authors and commentators have not tired of citing. At least one inhabitant of the British isle, Sir Isaiah Berlin (1909-1997), must have agreed full heartedly with Donne: "I am a social being in a deeper sense 
than that of interaction with others," Berlin wrote in his seminal essay "Two Concepts of Liberty" (1958). "I am not disembodied reason. Nor am I Robinson Crusoe, alone upon his island." What I, the island, really am, Berlin asserted, has much to do with my relation to the continent or other islands in the archipelago:

For am I not what I am, to some degree, in virtue of what others think and feel me to be? When I ask myself what I am, and answer: an Englishman, a Chinese, a merchant, a man of no importance, a millionaire, a convict - I find upon analysis that to possess these attributes entails being recognized as belonging to a particular group or class by other persons in my society, and that this recognition is part of the meaning of most of the terms that denote some of my most personal and permanent characteristics. [...] It is not only that my material life depends upon interaction with other men, or that I am what I am as a result of social forces, but that some, perhaps all, of my ideas about myself, in particular my sense of my own moral and social identity, are intelligible only in terms of the social network in which I am (the metaphor must not be pressed too far) an element [1].

Being "me" and being with others need not become polarized. What I am is intimately tied to the larger collective I see myself as part of. Moreover, Berlin added: the lack of thereof, the feeling of islandish insulation and isolation, the sense I lack proper recognition from others is what prompts me to complain of lack of freedom. Put otherwise, as much as we are free agents, the very way we ascribe meaning to our identity and our sense of freedom depends on our interaction with others, not on what eighteenth century moralists called "moral sentiments" and capacity to be empathic towards others, but on a more prosaic fact: that we must have an audience and interlocutors, for without it vita contemplativa becomes an asylum, and without an audience and a reference group, without this daily interactive experience with others, we would never be able to transcend our alienating individualistic isolation.

"Two Concepts of Liberty," originally delivered as Berlin's inaugural lecture as Chichele professor in social and political theory at Oxford University, enjoyed a remarkably rapid process of canonization. Not long after its publication it came to be considered a landmark text in liberal thought, generating ever since a mass industry of commentary and interpretation, and, one might add, an interesting mixture of praise and condemnation. Criticizing excessive individualism, needless to say, was not the kernel of Berlin's essay. Its two main tasks were to come up with a more precise definition of the term liberty and, secondly, to do so by formulating a conceptual dichotomy separating a positive (and potentially totalitarian) understanding of freedom from a negative (liberal and humane) understanding of the same concept. On the face of it, Berlin's task was to apply the tools of analytic philosophy on a key concept in political thought, notorious for embracing the utmost heterogeneity of meanings. In a way, one may argue, the essay emerged from Berlin's deep "philosophical" concern about improper usage of language. And indeed, much of Berlin's effort becomes easier to understand when we take into consideration the fact he began his academic career as an analytic philosopher of language. Like many others (including Quentin Skinner and other members of the Cambridge School of intellectual history who criticized Berlin for being a sloppy in his methods as historian of ideas), Berlin admired the work of John L. Austin, who posed the same question-How to Do Things With Words? - in the title of his most influential 
work, showing that "performative utterances" are, in fact, types of acts and that they operate, in a sense, in the world [2].

Yet, to elucidate the meaning of such heavily charged words as liberty, cannot be seen a politically "neutral" act, for the analysis reveals itself as a critique of ideologies. To understand, like Karl Manhheim did in Ideology and Utopia, that "the same word, or the same concept in most cases, means very different things when used by differently situated person," is one thing [3]. To show that one party holds the truthful definition of the word, while the other party abuses and distorts it, is already something else. And what Berlin sought to do was exactly this: to differentiate what he considered to be the "correct"-i.e., liberal - understanding of the word liberty from the way it was, in his opinion, misunderstood, misused and eventually abused by Nazi and Soviet regimes. This, he made it clear, was not divorced from the realities of his day. Showing what we do with the word liberty allowed him to address the charged ideological landscape of his own time and place. Unsurprisingly, it automatically made "Two Concepts" also into a statement of Cold War Liberalism. Leo Strauss, for instance, recognized it instantaneously. "Berlin's comprehensive formula," he wrote, "is very helpful for a political purpose-for the purpose of an anti-communist manifesto designed to rally all anti-communists [4]." More dismissive, Ernst Gellner had an even harsher verdict: Berlin, he was reported saying, was nothing but "The C.I.A's J. S. Mill [5]."

And indeed, in retrospect it is a hard not to see "Two Concepts" as an essay heavily shaped by ideological concerns of the day. But if so, why was it important for Berlin to criticize excessive individualism in this context? Negative liberty, he argued in the same essay, requires certain "frontiers," separating the private sphere from the public one, and assumes the existence of demarcation that secures a secluded space "within which men should be inviolable." Why at the very same time did he want to dissociate freedom from that isolated, "island" mentality in which the wants, needs and freedoms of the individual are placed ahead of a sense of social belonging? This question has grave implications about our understanding of Berlin's political philosophy in particular and liberal thought in general. Given the fact individualism, that "symbolic catchword of immense ideological significance," as Steven Lukes called it [6], was so often seen as the organizing principle of Liberalism, it is quite surprising to find one of the foundational texts of twentieth century liberal thought containing such a fierce rebuff of that feature of modernity. Berlin's critique of individual-centered Liberalism demands us to put the conventional reading of Berlin under scrutiny. All too often he is identified as belonging to a group of Cold War refugee liberals who were highly skeptical of any form of collectivism, considered it highly susceptible to authoritarian abuses, and who, as a general rule, preferred to think of society as the outcome of individual projects. If that is indeed the case, why was he insisting that we must go beyond individualism, that liberal political theory should acknowledge humans' need for association, fraternity, and communal solidarity? And why at the time when nationalism was seen by virtually all leading Cold War liberals as a menace and as the mirror opposite of Liberalism was he defending the politics of recognition and an idea of nationality that seemed as mirror opposite of all that a true enlightened liberal should cherish? Was Berlin simply impossibly inconsistent? Or should we, alternatively, come up with a more nuanced and rich re-appreciation of Cold War Liberalism in general, and the role of Jewish intellectuals in it in particular? 
These seemingly abstract, theoretical questions were inherently tied with Berlin's personal life story and particular secular and quintessentially national sense of Jewishness. In his later writings and interviews Berlin talked about his Jewishness more freely, revealing an even more surprising reliance on ethno-national language and metaphors. "When I go to Israel I feel free, I do not feel that I am in a foreign country," he told Ramin Jahanbegloo. "In Israel I don't particularly feel a Jew, but in England I do. I am neither proud nor ashamed of being good Jew. I am as I am, good or bad. Some people have dark hair, others have blonde hair, some people are Jews as some people are Welsh. For me being a Jew is like having two hands, two feet, to be what one is. Israel is a country where I have a natural affinity with the inhabitants [7]." How could it be, asks historian Pierre Birnbaum, that Berlin found such "naturalist, essentialist conception of Judaism, Herder-like to an extreme that almost seems to fall into the category of biological" what is Liberalism [8]? Birnbaum was not reading between the lines. Karl Popper was equally bewildered after Berlin wrote to him in February 1966 that he "want[s] to claim Herder as pioneer of anti-behaviorist antifideist naturalist value/fact distinction [9]." Berlin did exactly this in his essays on Vico and Herder and Popper could not understand why his Oxford colleague would take that dark road which takes him away from the universalistic vision of a rational Open Society he considered the presiding spirit of Liberalism. Berlin made his references to Herder, to be sure, not only quite explicit, and drew a clear line connecting Jewish nationalism with the father of volksgeist:

I think that it is true to say that there are certain basic needs, for example-for food, shelter, security and, if we accept Herder, for belonging to a group of one's own-which anyone qualifying for the description of human being must be held to possess. These are only the most basic properties; one might be able to add the need for a certain minimum of liberty, for the opportunity to pursue happiness or the realization of one's potentialities for self-expression, for creation (however elementary), for love, for worship (as religious thinkers have maintained), for communication, and for some means of conceiving and describing themselves, perhaps in highly symbolic and mythological forms, their own relationship to the environment—natural and human — in which they live [10].

If that is the case, was Berlin indeed a herald of Liberalism and of the free choice of individuals or an ethno-nationalist apologist in disguise? To be sure, anyone trying to reconcile Berlin's negative-freedom-based Liberalism with his identitarian claim and writings in defense of nationalism is bound to face some grave conceptual tensions. A number of interpreters and political philosophers identified this tension, but only a few tackled it head-on [11]. Their writings on Berlin allowed them to address more general normative questions such as whether one can reconcile liberal freedoms with the value of national belonging and national self-determination, and whether pluralism and cultural nationalism are compatible or mutually exclusive and more. Some even hinted, directly or indirectly, that understanding what liberal nationalism is has clear implications for anyone searching for an imaginative but not utopian normative horizon that may help the state of Israel confront its internal challenges. Predictably, because in a majority of cases these interpretations were dominated by normative considerations they encouraged readers to think about Berlin's thought in a rather decontextualized way.

I have no intentions of going down that alley. The interpretive role of the intellectual historian, I believe, is neither to address today's quandaries nor to rescue lost authorial consistency from a 
thinker whose ideas seem puzzlingly erratic. We need to identify the nodal points of friction and cracks that make Berlin's philosophy less consistent yet also more complex than previously assumed, and our main effort should not be directed at attempting to solve them. What we need is to explain historically how these tensions came into being and how Berlin's texts were, in fact, responses to these predicaments and dilemmas. To reiterate: precisely because the aim of this essay is to reassess conceptual tensions and understand them against their historical background, I find it vital to emphasize what this essay shall not do: It will not try unearthing a well-hidden key idea that, if only brought to light, would make Berlin's philosophy seem surprisingly systematic and consistent all of a sudden, and it will not use Berlin as a jumping point to raise a general normative and political debate about the merits and possibility of liberal nationalism in general or liberal Zionism in particular. What this essay calls for is, first, an understanding of Berlin in his own terms and, second, a more historically-grounded understanding of the inner tensions which characterize his of writings.

A long answer to the questions raised above requires us to examine Berlin's intellectual biography and to see the way in which these conceptual tensions emerged and developed over time. This was done by me elsewhere and will be not repeated here [12]. To examine chronologically the intricate relationship between "life" and "thought," however, is not the only way in which one can address these questions. A shorter, concise answer to some of the above questions can be offered if we put the theoretical tensions and cracks at the center of our discussion. I will do so by introducing and elucidating one of the conceptual tensions (but not necessarily the only) I find central to Berlin's thought: the relationship between his conceptions of freedom and Jewish nationality, culminating in what I call Diaspora Zionism. It should be clarified that Diaspora Zionism, is not a term used by Berlin himself but a concept I coined in order to interpret his position. It is, in other words, a hermeneutic device as well as a descriptive category I employ when contextualizing Berlin's thought. And, as any term "imported" into and "imposed" on Berlin, it calls for scrutiny.

Our discussion will proceed as follows: we shall examine some of Berlin's views on nationality/ism and explain why comparisons between him and Hans Kohn as well as communitarian interpretations of him are incomplete and have limited merit (Section 2). We shall continue with a brief discussion of Berlin's Jewishness and Zionism (Section 3) and explore the links which tie his conception of freedom to his Diaspora Zionism (Section 4). The two concluding sections will discuss Berlin's place within a larger Cold War liberal discourse that was described as "negative Liberalism" or "Liberalism of Fear" (Section 5) and why I find it problematic to see his political writings as part of a Jewish political tradition (Section 6).

Together, these will allow me to also to address a more general question which the title of this paper alludes to, namely what is Jewish (if anything) about this kind of political philosophy? Here again, we can offer a long and short answer. The short answer would be: nothing. It would be wrong and misleading to label Berlin's philosophy "Jewish" or "Hebraic," and it would be quite difficult to place in what recent authors describe as a "Jewish political tradition." In the concluding Section I will give the reasons why. At the very same time, I argue, we cannot ignore Berlin's Jewishness. It was for him a major (although not the only) generator of predicaments that, eventually, were addressed through text and theory. 


\section{Nationality/Nationalism: Good, Bad or Ugly?}

One of the most striking features of the way in which Western Europe re-invented itself after the two catastrophic total wars is the way in which it shed a legacy of strong statism and replaced blood-thirsty nationalistic chauvinism with more-or-less pacifist politics of conscious animated by a spirit of collaboration, striving towards a peaceful, federalist unification. West Germany was the epitome of that transformation. As Konard Adenauer declared in 1952: "The people must be given a new ideology. It can only be a European one [13]." A superficial, bird's-eye-view of that remarkable transformation is bound to raise the question which historian James Sheehan asked in his recent book-where have all the soldiers gone [14]? Away with the chauvinistic rhetoric of national glory, and goodbye to the military parades, welcome nonviolent commercial competitiveness and guilt-ridden moralität.

Yet, as much as the rhetoric changed, practices and foundational ideas remained active. Next to and inseparable from the rise of a European "civilian state," Sheehan reminds us, there was also a not less remarkable decolonization process during which, between 1940 and 1980, more than eighty of the European power's overseas possessions - inhabited by about $40 \%$ of the world's population - became independent states [15]. Nor was the Wilsonian principle of self-determination abandoned. The presumption that there is an ineluctable link between peoples and nations remained, and still is, the governing principle of international politics. What could be a better illustration of this if not the formula "We the Peoples of the United Nations..." with which the preamble of the UN Charter (1945) opens [16]? Wouldn't it be more accurate to suggest, then, that exactly because this was the fundamental mode of political argumentation accompanying the demise of Western colonialism, describing emancipation through a national prism and language was, in fact, never off the agenda? In the postwar world nationalism, thus, encapsulates a paradox. It signifies all that was pathological, zealous, abnormal about the European mind and led Europe to its abyss. At the same time, this was still the only genuine way in which political movements, seeking to gain support and international legitimation, could present their demands.

Berlin recognized this paradox. "There is no need to emphasize the obvious fact that the great majority of the sovereign states represented at the Assembly of the United Nations today are actuated in a good deal of their behavior by strong nationalist passions, even more than their predecessors of the League of Nations," he wrote in 1978 in "Nationalism: Past Neglect and Present Power," his most famous essay on the subject [17]. Nationalism was, he argued, probably the strongest animating force in modern European history: what started with German and Italian strives for self-rule turned quickly into the dominant trend of European politics and by 1919-into a universal principle. It was a fantastic illustration of the power of ideas, he believed, the way in which an apparently abstract theory of sovereignty shaped maps, stirred wars, and changed the very way in which people think of themselves. Yet, this was hardly an essay of an apologist seeking the rehabilitate nationalism. Nationalism, Berlin stated, was "the elevation of the interests of the unity and self-determination of the nation to the status of the supreme value before which all other considerations must, if need be, yield." What stirred nationalist movements was a "pathological inflammation of wounded national consciousness," a sense of superiority and xenophobic hatred of others - whether these were internal minorities or neighboring nations [18]. On other occasions he 
reiterated this denunciation: "Nationalism is an inflamed condition of national consciousness which can be, and on occasion has been, tolerant and peaceful," he declared in 1991 [19]. What nationalism "simply means," he explained to Ramin Jahanbegloo, is "that we say to ourselves that nobody is as good as we are, that we have a right to do certain things solely because we are Germans or Frenchmen [20]." This was not an idea Berlin developed at an old age or one which appears only in his strictly historical essays. "[N]ationalist, communist, authoritarian, and totalitarian creeds of our day," he wrote in "Two Concepts", are "[s]ocialized forms" of "the positive doctrine of liberation [21]." The ideology of nationalism rested on a far-fetched theory, which, like many other autocratic regimes, molested the idea of liberation, taking it way beyond any ethically justifiable standard.

Nonetheless, this "positive," intense "pathological inflammation," Berlin insisted, should not be equated with the natural sense of collective fate and solidarity, from normal patriotism, and even from that modest sense of pride one derives from a sense of difference which distinguishes his social group from that of others. Nationalism, the bigoted and relatively recent ideology of severe and fanatical particularism, should be distinguished, in other words, from the everlasting need of humans to belong to collectives:

The need to belong to an easily identifiable group had been regarded, at any rate since Aristotle, as a natural requirement on the part of human beings: families, clans, tribes, estates, social orders, classes, religious organizations, political parties, and finally nations and states, were historical forms of the fulfillment of this basic human need.[...] Common ancestry, common language, customs, traditions, memories, continuous occupancy of the same territory for a long period of time, were held to constitute a society [by all major European thinkers]. This kind of homogeneity emphasized the differences between one group and its neighbors, the existence of tribal, cultural or national solidarity, and with it, a sense of difference from, often accompanied by active dislike or contempt for, groups with different customs and different real or mythical origins; and so was accepted as both accounting for and justifying national statehood [22].

What makes the "need to belong" a central notion in Berlin's political philosophy is the fact it stands at the point of intersection at which his visions of Liberalism and nationalism meet, rendering both more complex than they appear at first glance. And not less important: the distinction between nationalism and need to belong provided the theoretical kernel for Berlin's diaspora Zionism. The following quote, taken from Berlin's 1975 lecture entitled "The Achievement of Zionism," exemplifies this:

Nationalism often means the pathological condition of national consciousness when, for some reason, it becomes diseased and aggressive towards others. But in the Jewish case, all I mean is awareness of oneself as a community possessing certain internal bonds which are neither superior nor inferior but simply different in some respects from similar bonds which unite other nations. It does not preclude holding a large area of ideals in common with everyone else. This is the normal national consciousness defined by philosophers like Herder [23].

Anyone familiar with Hans Kohn's East/West dichotomy, contrasting the "illiberal, ethnic Eastern" nationalism with the "liberal, civic Western" forms of nationalism, can probably recognize the faint echoes of the famous typology in Berlin's words. In his 1944 magnum opus, The Idea of 
Nationalism, Kohn promoted a binary view of nationalism, famously arguing that "[w]hile Western nationalism was, in its origin, connected with the concepts of individual liberty and rational cosmopolitanism current in the eighteenth century, the later nationalism in Central and Eastern Europe and in Asia, early tended towards a contrary development [24].” It is hard to underestimate the impact this typology had on the subfield of nationalism studies [25]. Nor is the similarity with Berlin entirely coincidental: after all, like the anti-totalitarian Kohn, Berlin was also part of this Olympic gathering of intellectuals who treated nationality and nationalism, to use a witty remark by Ernst Gellner, as table wine, “- i.e., good for you if taken in moderation, but harmful if used in excess [26]." Kohn's theories were informed, as Adi Gordon shows, by his own involvement with Zionism and personal life story, and, secondly, were conjoined with his apprehensive antitotalitarianism, culminating, eventually, in a rather unquestioning Americanophile type of Cold War Liberalism [27].

So maybe what explains the fact that Berlin provides us with so many different accounts of nationalism/nationality has to do with the fact he was thinking through a Kohnian prism about the problem of nationalism? David Miller, who sought to expound the apparent inconsistence of Berlin's accounts of nationalism, considered the comparison to Kohn a possible "quick-fix solution" to the problem. For can we not rescue Berlin from accusations of theoretical sloppiness by arguing that although he never acknowledged it explicitly in none of his writings, Berlin was "in practice working with a distinction between 'benign' and 'malign' forms of nationalism, a distinction that runs roughly parallel to the more familiar distinctions between 'Western' and 'Eastern' or 'civic' and 'ethnic' nationalism [28]'? Miller swiftly aborts this line of interpretation, and rightly so. For the Kohn-Berlin resemblance is, in fact, a rather superficial one. Kohn took his geographical distinction way too seriously, describing liberal nationalism as characteristic for the area west of the Rhine (the so-called "West" minus Germany), whereas ethno-nationalism ideology was typically found east of the same river. A proud yekke (German-Jew), Kohn tended to believe that the real source of the nationalist menace was the intellectual ground laid by mediocre members of eastern intelligentsia groups, coming from societies that were not fully modernized, and therefore ill-prepared and unsuited to receive and use properly the national ideas. Nowhere in Berlin's writing do we find such a rigid geo-political demarcation. As an expert on Russia, and as someone who grew up in the multiethnic Riga, where German high-bourgeoisie culture was mixed with Russian imperial one, he could not accept such a simplistic mirror dichotomy. For Berlin there was sure a problem in the way Fichte and his German Idealist comrades thought of the national spirit, but Herder - a villain in Kohn's eyes but one of Berlin's heroes — wasn't viewed by Berlin as a thinker of "the East," but as a prophetic anti-Kantian Lutheran who, while spending his most productive years in the Baltic area, in Berlin's hometown, came to understand the real value of diversity and pluralism. A book review, as well as few sporadic comments found in his letters, suggests that Berlin may have appreciated Kohn's rhetorical abilities, but did not think highly of him as a theoretician [29]. The Kohnian distinction of east-ethnic and west-civic nationalism, in sum, could not be seen as parallel to the Berlinian distinction separating nationalism from the need to belong.

Political scientists, and particularly those writing during the 1990s, at the height of the Liberalism versus communitarianism debate, thought to address the same conceptual tension using 
this conceptual prism. For wasn't Berlin, arguing that "who I am" cannot be defined in isolation from my class, ethnicity, religion or membership in tradition or community, doing the same thing communitarians were doing when arguing humans are social animals whose apparently "private" identity is "encumbered" by their social roles [30]? The best way to understand the peculiar way in which this Berlinian notion of "the need to belong" stands vis-à-vis his own notion of negative liberty is to think of it, as philosopher Axel Honneth put it, as an "unhealthy tension" between liberal and communitarian strands in Berlin's thought:

In a nutshell Berlin is simultaneously a wholehearted liberal and a wholehearted communitarian, without being aware of the instability to which this synthesis inevitably leads. [...] Whereas the idea of negative freedom represents the epistemological consequence of the critique of rational monism, the idea of freedom as cultural belonging represents something like the normative precondition under which cultural pluralism can exist in a justified way [31].

Honneth was not the only one to read Berlin's notion of the need to belong through a communitarian prism. Yael ("Yuli") Tamir, one of Berlin's last doctoral students, spoke of a "strange alliance" between Berlin the liberal and the Berlin who stressed the problematic nature of retaining one's identity within the liberal framework. Tamir, in fact, considered her Doktorvater a forerunner of the later discussions that "gather under the banner of the 'politics of identity' or 'the politics of recognition' [32]." In this sort of reading the great liberal becomes a critic of Rawlsian-inspired liberal individualism and social atomism, a strong believer that no man is an island and that liberals' Achilles' heel is their tendency to overlook the particular and the concrete in the name of the universal and the abstract. There is also a hermeneutic side, so-to-speak, to this notion of belonging. "When men complain of loneliness," Berlin argued in his autobiographical essay "The Three Strands in My Life,"

what they mean is that nobody understands what they are saying: to be understood is to share a common past, common feelings and language, common assumptions, the possibility of intimate communication - in short, to share common forms of life. This is an essential human need: to deny it is a dangerous fallacy. To be cut off from one's familiar environment is to be condemned to wither [33].

There is more than a grain of truth to these interpretations. The trouble with these communitarian readings of Berlin, nonetheless, is that they impose on him a vocabulary, theoretical framework, concepts and sensibilities that were not available to him at the time he was formulating his own ideas. "I fear that being about to reach the age of $80 \ldots$ I doubt if I shall ever turn into a communitarian," he told Beata Polanowska-Sygulska in 1989. "I don't think I am an isolated island, but I think that relationships in an archipelago are more human and morally and politically preferable to coral reefs with little organisms squeezed all together [34]." To understand these naturalistic metaphors, the recourse to Herderian notions of organic "natural" collectivity, and the selective embracement of volkish discourse, Berlin should be read, I believe, as a thinker standing astride a fault line that in itself developed historically during the 1930s and 40s, a fault line which separated Zionism from Liberalism. With one leg rooted in each political tradition, Berlin was motivated to philosophize politically precisely because the combination generated a dilemma; and 
when this dilemma, I argue, is contextualized historically, what is "Jewish" about Berlin's philosophy becomes much clearer.

\section{Jewish Normalization and Its Discontents}

It is hard to pinpoint, however, a specific moment or event that pushed Berlin closer to Zionism. He was brought up in a family of Zionist sympathizers (his first childhood memory was of the wedding of his aunt Evgenia to Yitzhak Sadeh, the future architect of the Palmach) [35], and Berlin always assumed there was an obvious connection between his East-European-Jewish background and his decision to support this form of nationalism [36]. The fact Berlin also had the Hassidic blueblood running through his veins, being a direct descended from the Schneerson dynasty whose sons led the Habad movement, also had some impact. Not because it pushed him towards religiosity of any sort — quite on the contrary — but because it implanted in him a strong feeling of close kinship which he admitted having only occasionally, in intimate circles. As Berlin's father's memoirs evidently demonstrate, at Berlin's household traditional, observant Jewry was not far away from the bourgeois house's doorstep, and being un-religious never meant eager assimilationism nor did it contradict preoccupation with ancestral roots and much pride in the family status [37]. There was, of course, a dissonance between the patina of grandeur that enshrouded the family in Riga's Jewish community and the way Jewishness turned into a signifier of otherness once the family moved to England and young Berlin, as many sons of émigré families, was placed at the forefront of acculturation pressures and expectations. Yet, what Berlin's early biography bestowed in his is a pre-theorized, instinctive sense that being a Jew had much to do with a feeling that one is part of a clan or an extended meshpuche (family). Not that Berlin was always bragging about his Jewishness. Bryan Magee, the great popularizer of philosophy in Britain, recalled Berlin's self-dismissive descriptions of his younger self as a "fat little Jew" or a "dark, ugly little Jew" which would seem utterly un-politically correct in today's more sensitive society [38]. Nevertheless, they hint at an important aspect: a conscious awareness of one's inerasable, non-ignorable Jewishness, which provided fertile ground for ethno-national conception of identity to propagate.

This biographical backdrop also made Berlin quite dissimilar from many prominent GermanJewish intellectuals who were brought up in highly assimilated families. Some of them, Martin Buber and Gershom Scholem being probably the most famous examples, had their Zionist awakenings during interwar years if not even earlier, as part of what historian Steven Aschheim described as a radical "post-Bildung" revolt against parental liberal ethos [39]. Others, like Hannah Arendt and, according to some accounts, also Sigmund Freud, argued that it was only the vicious anti-Semitism of the 1930s that forced them, quite brutally, to start thinking of themselves as part of a Jewish collective [40]. As Peter Gay, Freud's biographer and ardent defender of the vehemently anti-clerical circles of the French enlightenment put it once, "Only Hitler made me into a Jew and, it turned out, not a very good one [41]." Nothing of this kind can be said of Berlin. His Jewishness was not "situational," in the sense that it was, first and foremost, part of a peculiar and unavoidable situation in which he found himself, willingly or unwillingly. We have enough sources, including accounts from others in his surrounding, to establish with great certainty that from a very early stage of his life Berlin had an acute sense of his Jewish otherness, and that this 
conscious only accentuated by immigration and acculturation in Britain. Boldly put, he did not need a Hitler to become aware that Jewishness, including others' responses to it, shaped his life in significant ways, and to develop a sharpened, hyper-sensitivity to the relationship between Jewishnness and status - both the gradations of status within Anglo-Jewish community, and the standing of Jews in the larger societies in which they found themselves.

Most famously, Berlin also repeatedly emphasized the fact that he had been mesmerized by Chaim Weizmann, the charismatic President of the World Zionist Organization, who, like Berlin, was also acutely aware of his Otherness - not only as a Jew within Gentile society, but also as an Ostjude folks-mensch who felt himself better attuned to the heartbeats of the Jewish masses than the members of the "Grand Duke" families, who had traditionally governed Anglo-Jewry [42]. The chemist from Manchester was subsequently seen by Berlin as the great synthesizer, able to take the best in Eastern "authenticity" without falling into rigid traditionalism, and combine it with European culture and science, without assimilating. In later years Berlin would become a central memory agent, helping to promote Weizmann's legacy through lectures, publications, by promoting the activities of Yad Weizmann, the Weizmann Memorial Fund, which published Weizmann's papers, and more. Weizmann, Berlin wrote, was the first genuinely free Jew in the modern world. What is the working definition of freedom behind this assertion still requires our elucidation.

But Weizmann merely pushed Berlin more in a direction he was already moving towards. By the time the two met, sometime during the winter of 1938, Berlin had already been exposed to Zionist ideology and rhetoric, thanks mainly to the influence of his family as well as that of the Polish-born historian Ludwik vel Niemirowski (1888-1960), better known in England as Lewis B. Namier. Lewis Namier is important for purposes of our discussion because he was one of the key importers of the Zionist normalization discourse to the English-speaking world [43]. Namier's working definition of the concepts normality and normalization was taken from the Zionist lexicon and was described vividly in the introduction he wrote in October 1933 to the English translation of Arthur Ruppin's Die Soziologie der Juden (originally published two years earlier, in 1931) [44]. Normality, according to Namier, described a condition of "a nation rooted in its own soil...attachment to home and country [which] give a man the strength to fight [45]." Namier's definition was drawn directly from Ruppin, whose analysis rested upon several basic sociological-normative premises. Two of them were, in Ruppin's words, that "normally everyone belongs to the community with which he feels closest united in language, culture, customs, and habits," and secondly, that there is "a peculiar mentality which distinguishes [the Jews] from the other European nations [46]." The strong conviction that only attachment to their ancestral homeland would cure the Jews of their pathological and abnormal condition motivated Namier's political Zionism. What echoed behind Namier's and Ruppin's conclusions alike was, among other things, Ferdinand Tönnies' sociological typology that distinguished the "healthy" feelings of warm, intimate togetherness that characterize the organic communal Gemeinschaft existence from the cold, "rational" and subsequently alienated individuality of members of modern civil society, the Gesellschaft (1887) [47]. Following Ruppin's Zionist sociology and developing it, Namier stressed the abnormal quality of this condition to diagnose the condition of world Jewry as a whole. The following excerpt exemplifies this: 
Our position in the world in anomalous, difficult, often ambiguous... [W] e must now undergo a fundamental process of economic re-orientation, but we have neither the resources of a State nor the place wherein to effect it...[O]ur foremost endeavor should be directed towards fighting "Luftmensch" - this untranslatable term describes men without solid ground under their feet, without training or profession, without capital or regular employment, living in the air, and it would almost seem, on air...[48].

The radical component in Namier's Zionism was his firm belief that this diseased condition characterized the condition of all Jews in the Diaspora - that is, not only those living in Russia or Poland or under oppressive regimes that deprived their Jewish minority of enlightenment and emancipation. Thus, the accusation of a "Galuth mentality" enabled Namier to mock also the leadership of Anglo-Jewry for being weak, "assimilationist" and too eager to please the Gentiles. Writing in 1933, as thousands of Jewish-German refugees began to flee Germany, Namier did not need to explain what he meant when describing the failure of assimilation. For him, "the question which the Jews must now ask themselves"- that is, all Jews living in the Diaspora - "is whether they can and should assume responsibility for bringing Jewish children into the world of the Galuth, to face a fate which seems to become worse every year [49]." Exactly because German Jewry was the most conspicuous vanguard of modernization among the Jews, this Jewish community, more than any other, epitomized for him a deep structural and moral flaw.

Berlin embraced the normalization discourse, and would employ very similar ideas in the postwar years. The Cold War context should also be taken into consideration here, for much of his writings on the subject were highly critical of the Isaac Deutscher-inspired idea of the "non-Jewish Jew [50]," mocking Jewish communists who were eager to embrace the utopian idea of a classless cosmopolitan post-revolutionary world in which they would finally be unchained from their embarrassing ethno-national origins. His disgust at extreme assimilationism was far from being "politically correct," to use the colloquial American expression, and in his essays on Jewish and Zionist issues he would describe this social trans-cultural practice using terms such as self-alienation, self-denial, and even the highly problematic notion of Jewish self-hatred [51]. Berlin's Lucien Wolf Memorial Lecture of December 1957 on Moses Hess provides a good example of this [52]. Another example can be found in his 1968 essay on Disraeli and Marx in which, when criticizing assimilationist tendencies, he argued:

$[\mathrm{I}] \mathrm{t}$ is a well-known neurosis in an age of nationalism in which self-identification with a dominant group becomes supremely important, but for some individuals, abnormally difficult... The baptized Jewish intellectual, still regarded as racially a Jew by his fellows, could not hope to be politically effective so long as nationalism remained a problem for him. It had somehow to be eliminated as an issue... [This explains why] Marx identified himself with a social force, the great international class of the disinherited workers, in whose name he could thunder his anathemas [53].

The discourse of Jewish normality and abnormality went, therefore, hand in hand not only with Berlin's understanding of cultural nationalism and the need to belong, but also with his strong Cold War anticommunist beliefs. And if one reads carefully Berlin's discussion of what he defined as "The Search for Status"- the title of the sixth section in his magisterial "Two Concepts of Liberty" - one finds Berlin arguing that "[t]he lack of freedom about which men or groups 
complain amounts, as often as not, to the lack of proper recognition," once again defending -in liberal terms - the idea of belonging. What is significantly different about Berlin, when compared to Namier and other advocates of the Jewish normalization discourse, is that Berlin never accepted the notion of shlilat ha'galut, the negation of exile, and the historical teleology it entailed. And it was for that reason that his approach towards Zionism could be best labeled Diaspora Zionism.

\section{The Diaspora Zionist}

To thoroughly understand Berlin's Diaspora Zionism we must briefly consider the way in which Berlin perceived liberty as an opportunity concept. I borrow the term opportunity concept from Charles Taylor and Tom Baldwin [54]. Definition of freedom as an "opportunity concept," regards it as a condition in which one is hindered by the minimum possible constraints that may limit the range of choices available. "The more avenues man can enter, the broader those avenues, the more avenues that each opens into, the freer they are," argued Berlin. Although Negative Freedom and the "opportunity concept" are not identical, the emphasis placed on the absence of obstacles because it guarantees the free exercise of choice is crucial to our argument. In this sense, free choice and opportunity are one of the preconditions for achieving Berlin's cherished, correct and liberal negative liberty. "Political choice," Berlin wrote in later years, "[is a condition in which] there are as many doors open for me to walk through as can be opened-freedom from interference, Negative Freedom [55]."

Interestingly, the place in which we find the first use of freedom as an opportunity concept is Berlin's 1951 essay "Jewish Slavery and Emancipation," which, in fact, is a bold pro-Zionist manifesto. The essay, originally published at the Jewish Chronicle, was written as part of an open debate Berlin had with Arthur Koestler. Writing what would be the far reaching implications of the foundation of the State of Israel on world Jewry, Koestler offered a rigid "either-or" formulation, according to which from 1948 every Jew has to decide whether he wants to remain in Europe - in which case he must assimilate and shed his particularist, dissimilative features - or immigrate to Israel and become an active member in the new Jewish republic. Berlin was outraged. It is an idea, argued Berlin, which took Jews back to square one. Not only did it not help promote Zionism but quite the contrary: it eliminated the novel contribution it had made to world Jewry in general: the possibility of every individual to choose how and where to live. And it is in this context that we find Berlin using for the first time a conception of freedom as an opportunity concept:

The creation of the State of Israel has rendered the greatest service that any human institution can perform for individuals - has restored to Jews not merely their personal dignity and status as human beings, but what is vastly more important, their right to choose as individuals how they shall livethe basic freedom of choice, the right to live or perish, go to the good or to the bad in one's own way, without which life is a form of slavery, as it has been, indeed, for the Jewish community for almost two thousand years [56].

This formula did not contradict Berlin's anti-totalitarian convictions: while, he argued, the essential feature in totalitarianism was its "denial to human beings of the possibility of choice," Zionism had altered the life circumstances for all Jews, by creating a situation in which the Jew as 
an individual has several possible courses of actions that he may choose from, not a single path he must walk through.

The meaning of having more choice was that one enjoyed greater freedom. If there was a Zionist achievement, that was the heart of it.

By presenting such an argument Berlin had made a claim that is political as well as philosophical, one that neither extreme Zionists in the 1940s nor republican / neo-Roman theorists like Quentin Skinner and Phillip Petit today [57] would willingly accept. It is based on the idea that living in a state of social or political dependence does not automatically restrict our options and thereby limit our freedom. Berlin's understanding of Weizmann's Zionism was based on similar principles: the creation of a Jewish national home is a noble cause worth fighting for because it would enable every individual Jew to choose freely, for the first time in modern history, whether he wishes to continue living among non-Jews - as Berlin himself chose to do - or to live as a member of a Jewish community and take a part in Jewish communal life. Weizmann himself was displeased by the fact that Berlin decided not to become an Israeli, but the notion that the creation of a Jewish State was a necessity, and the hope that it would also guarantee the emancipation of non-Zionist Jews, was an idea that both Berlin and Weizmann held. Ironically, what made Zionism "kosher" is the fact that it was transforming the notorious "Jewish Question" from a collective and national problem into a personal and existential dilemma of the Jewish individual.

This formula is what I call Diaspora Zionism. I use the prefix diaspora to emphasize the dissimilarity between Berlin's Zionism and what we may "Palestino-centric Zionism," by which I refer to the view that does holds that sooner or later all Jews would and should make Aliyah (immigrate to Israel) and make themselves Israelis. What the Zionist thinkers called "the negation of Galut" is absent in Diaspora Zionism. There is no historical teleology or secular Messianic imperative that emerges from this Zionism, according to which a mass voluntary migration of all Jewish communities in the Diaspora should accompany the establishment of a Jewish State. Fulfillment of the Zionist dream, in other words, did not, in Berlin's view, contradict the continued existence of Jewish life outside the sovereign Jewish state. He never saw Diaspora communities as inferior types of Jewish existence, nor thought that they should disappear sooner or later. Nevertheless, unlike the Diaspora Nationalism of Simon Dubnow, or even the Bundist blend of Marxism and nationalism, Berlin's idea was compatible with traditional Zionism, accepted its basic axioms and was not its ideological competitor.

In a way, it was a post-1945 version of what is known in earlier Zionist history as Gegenwartsarbeit or "hoveh'avodat ha" (lit. "work of the present times"), neatly summarized in a slogan coined by the noted Polish-Zionist activist Yitzhak Grünbaum: Zionism opposes the Exile (galut), but does not oppose the existence Diaspora (golah). Furthermore, it is a manifest aim of the national movement not only to organize all Jewish masses in the East and Central Europe as a national minority and lead them, but also to strengthen Diaspora communities, promoting their "cultural, material, and political" wellbeing, which would eventually help them contribute to the creation of a sound national life in the land of Israel. It was an optimistic, early twentieth-century vision of liberal nationalism. It wished to promote minority rights and not only mass migration, to bring about a more liberalized, democratic type of collective life to the Jews. Famously, the Helsingfors Zionist conference of December 1906 accepted this idea and made it part of the official 
Zionist ideological platform [58]. Needless to say, the idea was not alien to the young Chaim Weizmann and the other members of the short-lived democratic faction, as to many East and Central European Zionist activists who believed that Jewish nationalism would go hand in hand with progressive politics and greater liberalization. Nevertheless, historical context once again should be mentioned. It should be noted that the condition of Jews in 1906 was quite different to that of the post-1945 and post-1948 world, and I doubt whether we can find a direct genealogical route - in the Foucaultian sense - connecting Berlin to the Gegenwartsarbeit advocates.

Interestingly, the formulation of freedom as an opportunity concept, which we find dominant feature in Berlin's Zionist writings, predates "Two Concepts." While it would not be until 1958 that he would use a term such as "negative freedom," the philosophic formula juxtaposing choice, liberty and nationality appears as soon as October 1951 [59]. Without this essential component one cannot appreciate fully what Berlin means by the term "negative freedom." The journey that famously ended with "Two Concepts," in short, begun because postwar Zionism, demanding Jews to choose between immigration and assimilation, created an impossible either-or situation to which Berlin felt compelled to reply. Read historically, not as canonical texts addressing eternal questions but as attempts to solve these dilemmas, we can thus reappraise Berlin's philosophy in a fresh, unconventional way.

\section{Cold War Liberalism: In Search of a Definition}

Was the acceptance of basic Zionist axioms compatible with the central tenets of Cold War Liberalism? And if so, can we characterize Berlin's political philosophy as Jewish? Both questions are immensely tricky to answer. The problem with the first question is that it assumes the existence of a single coherent, theoretical statement of anything called "Cold War Liberalism." What makes the second question no less challenging is that it raises an even more fundamental concern regarding the way we use the adjective "Jewish" to label certain theories, philosophical approaches, and intellectual orientations. The two last sections of this paper will address these two questions.

Recent years witness a revival of scholarly interest in Cold War Liberalism. But what were the exact contours of this strand of Liberalism and what were its distinctive features? We can offer a preliminary list: no doubt, anti-utopianism, coupled with an ambivalent and a highly pessimistic appreciation of modernity as a whole, were hallmarks of postwar intellectual discourse in the western side of the iron curtain. The need to come in terms with nihilistic practices of a new type and scale, with the gulag and the concentration and extermination camp, with political ideologies that proved horrifyingly effective in mobilizing, controlling, displacing and butchering masses, became themes looming large in the works of novelists, artists and political thinkers, and in particular in the work of those political thinkers that cultural and geographical displacement was part of their personal experience. Moreover, the proximity of influential political thinkers to policy makers and their active involvement in postwar planning, together with some successful attempts of the CIA to create institutions, journals and forums - the Congress for Cultural Freedom and Encounter magazine being two famous examples - that would help bring together an international caucus of intellectuals who were willing to collaborate under the anti-totalitarian banner, cannot allow us to ignore the existence of a transatlantic republic of letters, shaped by and reacting to the bipolar world order after 1945. 
Nevertheless, there is no apparent reason that we should accept without further inspection the common assumption that there was, to use a fashionable tag, such a thing as a "Cold War consensus [60]." Prominent liberal public intellectuals operating, roughly, between the 1950s and 1980s, were not products of a single intellectual assembly line, nor did they ever produce a programmatic manifesto which constituted a certain Cold War "liberal school" whose adherents were expected to accept and comply with. The Cold War was long enough, and stretched over such a vast areas of the globe, that it allowed members of several generations, coming from different backgrounds (not all necessarily suffering directly from the same political menace), to intermingle and exchange ideas. We should be alarmed if Cold War Liberalism would become a catchphrase that permits analytical discrepancy or, worst, promote the superficial view that all liberal-minded thinkers in the English-speaking world reacted to the horrors of the first half of the century in the exact same way. Scheming through secondary literature dealing with Anglo-American intellectuals from the period - not to mention high-journalism and public discourse which evokes the names of Cold War thinkers to address contemporary predicaments - today's brightest students, born after the breakup of the so-called Cold War consensus, remain baffled. They find it almost impossible to identify any significant theoretical divergence which sets apart the a staunch anti-communist socialist like George Orwell from a cosmopolitan like Karl Popper or to identify those features which make both different from a lurid conservative like Michael Oakeshott. Correspondingly, when moving to the other side of the Atlantic pond, Cold War Liberalism is used so loosely that it wipes out any difference between libertarians who found their inspiration in the Austrian School of Mises and Hayek from thinkers who were interwar "Leftists" — whether supporters of the New Deal or much more radical Marxists and Trotskyites - who may have changed their views by the 1950s but still considered themselves sympathizers of social-democratic progressive politics. Even if Cold War Liberalism is used pejoratively, to describe what Michael Kimmage aptly called "the conservative turn," a greater nuance is still required [61]. This is especially true of the Jewish members of this cohort: to a certain extent both Henry Kissinger's dogmatic "international realism," Lionel Trilling's fictional anti-communism, Leo Strauss's critique of modern relativism, and Norman B. Podhoretz neoconservatism were symptoms of that turn. But were they arguing the same thing? Certainly not. Even conservative thought comes in many varieties.

Furthermore, as much as anti-totalitarianism was a universalist ideological theme, it was not a exclusively liberal stance. Weren't the critiques of positivism and totalitarianism more effectively disseminated by the Frankfurt School and the admirers of postwar Critical Theory? Marcuse's fusion of Freud and Marx was not less anti-totalitarian than Berlin's utter rejection of anything Marxist, and when popularized, in somewhat vulgarly simplistic way, by the revolting students in 1968, it could bestow them with a sense they were fighting for greater liberty against an oppressive totalitarian machine. But there are even trickier gray areas, and those require us to be more accurate in defining what we mean by liberalism. For was Hannah Arendt a Cold War liberal in the same sense, let us say, as Karl Popper, Isaiah Berlin, Jacob Talmon or Raymond Aron were? Arendt produced what is undoubtedly one of the most eloquent statements of anti-totalitarianism as soon as 1951, and so many of her now-canonical philosophical writings from that stage onwards were informed by this anti-totalitarian sensibility. Yet, wouldn't it be more accurate to locate the solution she offered to this modern disease in her admiration and attempt at revival of ancient 
republicanism? It is not a coincidence that her neo-Aristotelian ideals of humanity as constituted by active civic life, her vision of direct participation in a pre-Hobbesian body-politic, provided some of the inspiration to J. G. A. Pocock, one of the pillars of the Cambridge School of intellectual history, as he himself admitted in a usually ignored footnote crediting Arendt in The Machiavellian Moment, his classic study of a cross-Atlantic republican tradition [62]. This theory, as I suggested earlier, is offered to us as a civic humanist alternative to Liberalism, thus a characterization of Arendt as liberal should, as a minimum, be considered questionable.

A comparison with Berlin clarifies these problematics: Berlin has run out of patience with Arendt's virtue politics very quickly, prior to the publication of Arendt's controversial Eichmann book. When asked to review an earlier book of hers Berlin simply refused: "I found it absolutely unreadable," Berlin wrote to philosopher Morton White, adding a list of qualifications proving that in fact he read the book quite thoroughly: "all the rot about Greeks not liking work and the Jews liking it and men being alienated first from God and the Renaissance and now from mother earth itself - the desire to go to the moon being a deep metaphysical anxiety for flight from one's roots and origins - that is in the first forty pages - I found absolutely awful [63]." Not less savage was her dismissal by him in a conversation with political thinker Bernard Crick. "There is nothing there to put simply. Fairy gold, Crick, fairy gold. Metaphysical free-association' [64]". This was not simply personal, ad hominem animus. Finding his inspiration in Benjamin Constant- "that cold, perceptive independent, civilised Swiss," as he described him once-Berlin found the nostalgic admiration of the "liberty of the ancients" alien to the entire edifice of liberal thought as he understood it [65]. When "Two Concepts of Liberty" was reprinted in 1969 and included in Four Essays on Liberty, Berlin credited Constant in the volume's introduction and what could be a more symbolic homage to Constant than the fact Berlin chose a quote from one of Constant essays as the motto for his introduction [66]. The reliance on Constant's famous distinction between modern and ancient conceptions of freedom allowed Berlin to make what he considered to be a principal antitotalitarian claim: that modern politics shall not be redeemed from the totalitarian threat by salvaging pre-modern notions of direct participatory democracy. There was no way back, and modern republican restorative attempts, whether the one offered by Rousseau or that of Arendt, run the risk of collapsing into authoritarianism, not to rescue us from it. It is no wonder, then, that in later years, when he was asked by Ted Honderich to write an entry on "liberty" for the Oxford Companion to Philosophy, he fused Constant's temporal dichotomy between ancient and modern liberties with his own conceptual division of liberty into positive and negative variants. Negative liberty, he argued on that occasion, is not a natural, universal concept since its theoretical foundations lie in the idea "that there is a province of life-private life," and this, he argued, is an essentially a modern idea [67]. In fact, Berlin's own bifurcation of the concept of liberty had such an enormous impact on historians of political thought that contemporary Constant scholars fight the tendency to accept Berlin's interpretation and see the two theories as almost identical. Interestingly, even a careful scholar like Quentin Skinner could not resist the urge of coupling the two, presenting both, in his 1997 Inaugural Lecture as Regius Professor as two spokesmen of the same ideal of individual liberty [68]. It is beyond the scope of this paper to discuss what is problematic about this rather decontextualized equation. What is important to mention is that all too often the label Cold War Liberalism flattens out these types of nuance differences. To highlight them is vital, not 
because doing so will provide our students with a sound example of close reading of political texts, but because awareness of these minor differences challenge the very way Cold War Liberalism is used as an analytic category. Boldly put, we need to come up with more exact definition of the term and to use intellectual history more rigorously, to check dilettantism.

One tentative solution, offered by Jan-Werner Müller of Princeton University, is to treat the label Cold War Liberalism not as a term denoting a specific philosophic credo but as signifying a "particular sensibility." This sensibility, Müller suggest, could be best described using the phrase "Liberalism of Fear," coined in 1989 by the Harvard political theorist Judith N. Shklar [69]. Müller was not the first to suggest that there are areas of overlap between Berlin's and Shklar's "negative" Liberalisms. Paying tribute to his colleague and friend, the moral philosopher Bernard Williams (1929-2003) also suggested shortly before his death that Shklar's apt phrase, which describes not a theory nor a system but "a certain style of liberalism," captures quite concisely the type of Liberalism Berlin and, in fact, he himself, held dear [70]. So what is exactly Liberalism of fear? Shklar cherished the idea that liberals should focus their energy first and foremost on preventing political misjudgment and abuse of power, culminating in cruel violence and terror. Like Lord Acton, who held that political power tends to be corrupting and could be too easily abused by men who have access to it, Shklar's basic assumption was pessimistic: "every page of political history," she wrote, "[justifies the assumption] that some agents of government will behave lawlessly and brutally in small or big ways most of the time unless they are prevent from doing so [71]". This Liberalism, in other words, is concerned primarily with avoiding the worst, rather than achieving the best. For Williams this quality made this Liberalism distinctively different from the Liberalism of Locke or J. S. Mill, not only because it was much more pessimistic than their natural rights oriented Liberalism, but it is a Liberalism that is shaped fundamentally by the horrors of the twentieth century. It is a Liberalism of those who remember the horror of modern warfare and say "never again," it is "a response to these undeniable actualities and therefore concentrates on damage control." And most importantly: this sensitivity, Müller suggests, is not idiosyncratic but identifiable in diverse thinkers such as Berlin, Popper, and Aron. If so, we might as well use it as a platform for comparison. At last we have the shared working assumptions and normative common denominator that allow us to speak with more precision about Cold War liberal thought and to draw demarcation lines to distinguish it from other theories that populated the idea market at the time.

Müller's suggestion to use Shklar's memorable phrase as an interpretive prism makes much sense: like the other protagonists discussed in this issue, Shklar's biography resembled that of other children of the turbulent century. Like Berlin, Shklar was also born in Riga to Jewish parents who fled the Soviet Union when she was thirteen. She hailed the Anglophone philosophers for replacing utopianism with skepticism as a method of thinking about political philosophy, and did not hide the fact the political theory she produced was tinted by her and her family's personal experiences of displacement and what might as well be described as traumatic rejection of statism and totalitarianism [72]. If so, as I suggested elsewhere, we may paraphrase Müller and describe Cold War Liberalism as resting on two kinds of fear: First is the fear from utopia, fear "of ambitious programs advanced by those who felt absolutely certain in their convictions and sure about their political prescriptions [73]"; and second is the fear from fear itself, that is the understanding that 
the intimidation and terror of citizens-i.e., the creation of a situation in which masses submit themselves to the yoke of political authority out of panic from the possibility of being sent to a gulag, a concentration camp, or any other Kafkaian penalty colony - is a extremely forceful and dangerous motivating force that should be morally condemned [74].

Yet, this is far from a definitive solution. This will be neither the time nor the place to reiterate all of Shklar's arguments and provide a systematic comparison between her and other Cold War liberals, but we can put our finger at some troubling concerns. Even when he put Shklar next to her Oxonian colleague we will find clear chronological and conceptual gaps that set them apart. They were, after all, representatives of two different generations, with Berlin being almost two decades older than Shklar. We must also not forget that unlike Berlin who was responding to Stalinism and the Thaw Generation, Shklar, quite ironically, introduced her memorable phrase exactly when the Cold War draw to its close. Maybe, given this context, it would be more instructive to comprehend Shklar as a thinker who wished to examine critically what is dead and what is alive in the liberal philosophy that she swallowed as a student during the 1950s [75]? There also problems with the assumption that "negative" "fear politics" are the real crux of Cold War liberal discourse. To assume that positive values, even if only latent ones, were entirely absent from Cold War Liberalism, would be a oversight. As Michael Walzer once pointed out a-propos Shklar: whether explicitly or implicitly, most liberals ultimately do defend numerous positive values and endorse specific norms or behaviors ("entrepreneurship" being one example) that are not universal but, in fact, depend on particular cultural customs and standards [76]. And as Katrina Forrester reminds us in a recent essay, overemphasis put on Shklar's notion of fear encouraged commentators, erroneously, to ignore the sophisticated, "positive" discussions of politics of hope her writings offer and to produce, through what she calls reductio ad Hitlerum, a cliché, superficial image of negative Liberalism [77]. Similarly, as we have seen, there is no way we can reduce Berlin's complex philosophy to a single notion of negative liberty. He may be aptly described as a liberal of fear, but this cannot help us in understanding what made his eagerness to rehabilitate Herder and defend nationality. A comparison between Berlin and Popper reveals even more problems with Müller's thesis. For while Popper, as Malachi Hacohen showed exceptionally well, was moving towards a new form of rigidly anti-nationalist cosmopolitanism, Berlin was unwilling to follow the same road. Popper admired the Enlightenment, and Berlin — fascinated by the Enlightenment's critics. Popper dismissed Zionism as a form of atavism and neo-tribalism, while Berlin was an admirer of Weizmann and Moses Hess, busy condemning assimilationists and defending the state of Israel. Were these components of Berlin thought informed by the "particular sensibility" put under the banners negative politics and Liberalism of fear? Doubly so. They were maybe distinctive, making him different, if not even eccentric, when compared to a large number of his contemporary colleagues. But these were fundamental and indispensable ideas, informing Berlin's pluralism and liberalism alike, without which any interpretation of his philosophy would remain incomplete. In sum, as much as the description of postwar Liberalism as based on fear may help us appreciate the similarity we find in the analysis of the destructive and potentially authoritarian symptoms of utopianism in the writings of Cold War liberals, it says very little about the difference we find in the "positive" proposals the same intellectuals put forward when asked to construct the postwar civil society or offer a normative horizon that would guide its heralds. 
We are back, then, to square one: critical appreciation of totalitarianism and fear from it may have united the Cold Warriors, but their dreams about a better future made them very different. If we want to avoid using slack narratives that make use of vague notions like "the spirit of the age," we must treat such models with extreme caution. Biography is important, but it would be simply wrong to assume that traumatic memories, post-Holocaust pessimism, or what Ira Katznelson referred to as "intellectual desolation," pushed all thinkers in the same direction [78]. Similarly, a recurring leitmotif we find in diverse thinkers is not necessarily indicative of the "positive" ideas they considered fundamental. The comparative dimension is immensely important, but not because it allows us to identify points of resemblance and to construct a unifying definition, but also because comparisons reveal dissimilarities and, in this case, show that Cold Warriors, in fact, differed significantly in their visions of the future. We need to come up with an explanatory framework that would also acknowledge the internal political divisions within the liberal and antitotalitarian camp. And this requires greater nuance and finer tuning than some of today's discussions allow.

We are still in search of a definition. Or, alternatively, we should do what a large number of historians of the Enlightenment did long time ago: understand that their subjects took part in a trans-national republic of letters and in that sense constituted, collectively, a cosmopolitan scholarly network; yet, at the same time, that there is no "core principle" or a single "idea of Enlightenment," but that the same scholarly network reveal variances and dissimilarities and actually breaks up, along national, philosophical, religious and political fault lines, into plural Enlightenments.

\section{A Jewish Tradition of Political Thought?}

Does Judaism or Jewishness constitute one the fault lines along which Cold War Liberalism breaks up? Can Berlin's political philosophy_ given its unique, distinctive features and its author's biography — be justifiably labeled a Jewish political tradition? I doubt it. Neither biography nor the highly knotty uses of the concept of "tradition" justifies such labeling.

Let us take it one step at a time. If biography matters so much, and given the centrality of Jewishness to Berlin's own sense of identity, why not describe his ideas as "Jewish"? The answer is quite obvious: because it would be an absurd reductionism of one's "thought" to one's "life." I doubt, for instance, if the musical proclamation of the American pop singer Janis Joplin in her famous ballad - "freedom's just another word for nothing left to lose"-would be significantly reappraised and understood differently were we to mention the fact that she was born in Texas to a Church-attending family. In that sense Joplin's vision of liberty is not different from Berlin's: the mere fact that he was a Jew from Riga and a direct descendant of the Zemah Zedek, the Third Lubavitcher Rebbe, cannot, in itself, explain why he reached the conclusion that liberty, properly understood, should be defined as an absence of constraints on the individual. Neither will it be accurate to see Berlin as a Jewish philosopher in Martin Buber or Emmanuel Levinas' sense, to take two well-known examples, were Jewish philosophers: his thought did not imbibe Talmudic ideas or dress in modern clothes concepts that we may define as essentially "Jewish." Even a thinnest decorum of Jewish proverbs, aphorisms, rabbinic maxims and wise sayings we sometimes find in the writings of secular Jewish authors is absent from Berlin's prose. Quite the contrary, Berlin acquired a taste for British wit, and for much of his intellectual career had no intentions to 
encrust his elegant prose with what his non-Jewish interlocutors might have dismissed as moeurs des savages. What is commonly called Yiddishkeit was not his ornament of authenticity.

This is not only a question of style, but also one of content. There is no strong philological evidence to suggest that Judaism offered Berlin a storage house of ideas from which he could borrow theories, concepts and vocabulary. To clarify: I do not wish to argue that there is no such thing as "Jewish political tradition." In an impressive multi-volume collaborative project Michael Walzer, Menachem Lorberbaum and others analyze with much detail and bring sources that, they argue, constitute a two-millennia old "Jewish political tradition [79]." What originated in the Bible and the Talmud, these authors show, continued with midrashic literature, legal responsa, and shaped also numerous modern treatises, pamphlets and philosophical essays that have been written by intellectuals who drew on this long tradition of Jewish literature. Equally ambitious is David Biale's recent attempt to describe a tradition of Jewish secular thought, including a 350-years-old political tradition, stretching, roughly, from Spinoza to David Ben-Gurion, his secular admirer. In this case a trans-generational dialogue emerged as religious notions - such as that of God's election of Israel-were recast into various modern, "non-revelationist" theories, whether in a pseudo-scientific form of race, or through modern notions of nation and state [80]. In all the above cases, when we use the term tradition we assume the existence of trans-historical intertextuality, and not the fact the authors who produced these texts were Jews. To identify this intertextual relationship means to show how one text built its meaning on or ideas, signs, symbols, idioms, narratives and meanings that were introduced in prior texts, or at least to at least that it alluded to them. Walzer, defining the boundaries of the Jewish political tradition, is quite explicit on this issue:

What makes this body of work a distinct and more or less unified tradition, and what marks its limits, is its intertextuality. A long series of writers have addressed political questions by referring themselves to the same authoritative texts and to the critical events on which these texts are focused: the exodus from Egypt, the Sinai revelation and covenant, the winning of the land, the establishment of the monarchy in the time of Saul and David, and then the conquests and revolts, the wars and civil wars, that brought destruction, loss, and exile. And the same writers, despite their radical dispersion and the absence of all modern means of communication, refer endlessly to one another, agree and disagree with each other's interpretations of both texts and events. Reference and cross-reference constitute the tradition [81].

Analogously, what justifies the use of the adjective "Jewish" to describe secular Jewish thought in the case of Biale's study is the fact we can show that early and late modern non-observant Jewish authors did not simply ignore pre-modern Jewish religious texts ideas, but in fact had a somewhat dialectic relationship with them, and they sought to use them even if only to bestow new meaning in them. Using metaphoric language, Biale describes these older notions "like genes that required the social and political environment of modernity before they could be expressed," and as "providers of the dominant mentalité - the language and particular flavor — of that secularism when modern forces caused it to emerge [82]." These biological metaphors are not problem-free. Yet, they are meant to illustrate a similar idea. What makes a certain textual tradition "Jewish" is not the biography — or biology — of the authors but the way they used ideas originating in Jewish religious literature to address modern social and political problems. For unless we provide clear and 
convincing signs of intertextuality that constitutes the conceptual frame we call "tradition" what we will be left with is a theory that rests too heavily on a priori concepts which bends our interpretation in the sense that it forces us to situate an individual text within a larger frame we construct in hindsight, mostly informed by opaque teleological assumptions [83].

This methodological detour brings us back to Berlin's case. For what is at the stake here is not the question how we define the paradoxical term "Jewish secular culture" but according to what criteria we draw the border between authors who were part of a Jewish tradition of philosophizing about politics and other authors who were Jews writing about politics but were not contributing to this endless process of "reference and cross-reference" and, to use Walzer's words, "opted out of the referential system." The Berlin case illustrates these problematic questions: taking his first steps as an independent scholar as a British analytical philosopher, Berlin always stressed his mistrust of anything which is "metaphysical" and "non-empirical," and on one occasion even defined himself as "tone deaf" when it came to theological language and religious modes of thinking [84]. Subsequently, his understanding of sovereignty, power and politics was essentially modernist, not "Hebraic." Therefore, the suggestion that he is part of a Jewish political tradition stands on very thin ice. We can always speak of "non-Jewish Jews" to include Freud, Marx, Rosa Luxemburg and Trotsky in this tradition, as Isaac Deutscher famously tried to do, or quote the saying attributed to Heine, according to which "since the Exodus, freedom has always spoken with a Hebrew accent [85]." But aren't we running the risk of producing de-contextual clichés rather than historical interpretations? Only through close reading of the texts, only through careful analysis that identifies such intertextual connections, can we speak intelligibly of an ongoing, continual discourse and a genealogy (in the Nietzschean sense) of certain political conceptions and theories. The alternative is an utterly a-historical, fictional construct which provides no convincing explanation why texts produced in different times and places should be connected and under a single rubric.

Examining Berlin's intellectual interlocutors we also find an interesting mix of Jews and non-Jews. But here again, we mustn't privilege Jewishness too quickly: in his political thought we find a splendid eclectic mixture of ideas absorbed from distinct thinkers, such as Benjamin Constant, the British idealist philosopher and historian Robin George Collingwood, the hawkish Zionist Namier, the Viennese anti-positivist philosopher Karl R. Popper and many others. Of the above only Popper and Namier qualify somehow - if one speaks in strict Halachic terms - as Jews, although both were born and raised in a quintessentially assimilated family that was remote from its ethno-religious roots. Namier may have pushed Berlin to think more seriously about sovereignty, community and soil, but this was not based on ideas either one of them found in Jewish texts as much as in sociological and political theoretical texts produced in Europe of the nineteenth and twentieth century. Popper was even more alienated from his Jewishness. He refused to identify himself as a Jew, alluded to no Jewish text in his writing and considered Zionism to be nothing but a petrified form of Jewish racialism that was both stupid and wrong [86]. Popper, for sure, is the last thinker to be included in the traditions Biale, Walzer and others wish to portray, and even the inclusion of Namier in it would require us to demonstrate startling conceptual flexibility which runs the risk of analytical overstretching. Not so much because of the biographies of the two, as due to the nature and content of their writings. 
Yet, there is an alternative way to provide an account of Berlin's Jewishness. This can be done not by labeling his philosophy Jewish, nor by squeezing him into the confined box the phrase Jewish (secular or religious) political tradition denotes. This can be done if Jewishness would be located in the realm of the context, not the text. Or, more precisely: by seeing Berlin's Jewishness as generator of questions and problems, not of answers and solutions. Robin George Collingwood wrote eloquently quite long ago about a historical logic of questions and answers reminding us that the meaning of a given proposition is always relative to the question it answers [87]. Later on, Hans Georg Gadamer, paying homage to Collingwood in his monumental Wahrheit und Methode (Truth and Method), suggested returning to a logic of question and answer which he found as a source of inspiration and a means to understanding an historical text [88]. Drawing freely on these hermeneutic approaches, we can offer a contextualized reading of political philosophy if the texts are read as answers to a question, dilemma or problem that emerged, in specific historical circumstances and due to unique conditions, outside the text. As I this essay showed, Berlin's opportunity concept crystallized and took shape out of the personal dilemmas, existential doubts and ideological queries he experienced in the 1940s, and especially those related to his Jewish identity and ambivalent love affair with Zionism. Some of the definitive distinctive characteristics that provide Berlin's liberal thought its unique flavor emerged from these personal predicaments, and it is from this specific historical context that his attempt to provide a philosophical defense of Jewish nationalism that would be compatible with the central tents of Cold War Liberalism emerged. Jewishness and Jewish nationalism yielded problems and created challenges we, as intellectual historians, can use to contextualize one's thought. In Berlin's case, these were questions that he could not disregard or flout. Consequently, a large number of his key texts reveal attempts to come to terms with these questions, with various degrees of success. Ironically or not, the answers to the Jewish questions were found in a peculiar mixture of Herder and Mill, not the rabbis. We may have not explained how to solve the tension between liberty and community, but we are now at least able to understand why Berlin believed so strongly that political philosophy cannot ignore the fact that, at the end of the day, no man is an island.

\section{Acknowledgments}

This paper was originally presented at the symposium "Jewish émigrés and the shaping of the postwar culture" in memory of Lilian Furst (1931-2009) on April 3, 2011. I would like to thank Prof. Malachi Hacohen, the organizer of the symposium, for his invitation, kind hospitality and valuable comments. Additional thanks are due to Daniel Bessner, Julie Mell, David Weinstein, Adi Gordon, Udi Greenberg, Ofer Ashkenazi, Rivka Weisberg and Henry Hardy.

\section{References and Notes}

1. Isaiah Berlin. "Two Concepts of Liberty." In Four Essays on Liberty. London: Oxford University Press, 1969, 126-65. Quote appears on p. 155. Berlin prepared the essay for his Inaugural Lecture as Chichele Professor, and it was delivered at Oxford, on 31 October 1958. 
2. J. L. (John Langshaw) Austin. "How to do things with words." In The William James lectures 1955. Cambridge: Harvard University Press, 1962. For criticisms of Berlin see Quentin Skinner, "A Third Concept of Liberty." Proceedings of the British Academy 117 (2001): 237-68. It was Perry Anderson, producing one of the most rabid attacks on Berlin, who first accused him for being a poor historian and compared his method to that of the Cambridge School of intellectual history. See Perry Anderson. "The Pluralism of Isaiah Berlin." In $A$ Zone of Engagement. London: Verso, 1992, 230-51.

3. Karl Mannheim. Ideology and utopia: An introduction to the sociology of knowledge. London: Routledge \& Kegan Paul, 1960. Quote appears on p. 245.

4. Leo Strauss. "Relativism." In The rebirth of classical political rationalism: An introduction to the thought of Leo Strauss: essays and lectures, edited by Thomas L. Pangle. Chicago: University of Chicago Press, 1989, 13-26. Quote appears on pp.15-16. The essay was originally published in 1961.

5. John A. Hall. Ernest Gellner: an intellectual biography. London; New York: Verso, 2010. Quote appears on page 84. Some criticisms were voiced sooner, even before "Two Concepts" was published in Ernest Gellner, "[Review of Isaiah Berlin's] Historical Inevitability," British Journal of Sociology 7:3 (1956): 268.

6. Steven Lukes. Individualism. Oxford,: Blackwell, 1973. Quote appears on p. 173.

7. Ramin Jahanbegloo. Conversations with Isaiah Berlin. New York: Scribner's: Maxwell Macmillan International, 1991. Quote on p. 87.

8. Pierre Birnbaum. Geography of hope: exile, the Enlightenment, Disassimilation, trans. Charlotte Mandell. Stanford, Calif.: Stanford University Press, 2008. Quote from p. 245.

9. Isaiah Berlin to Karl Popper, 2 February 1966, in Karl R. Popper Papers, Hoover Institution Archives, Stanford University, Box 276, fol. 10.

10. Beata Polanowska-Sygulska, and Isaiah Berlin. Unfinished Dialogue. Amherst: Prometheus, 2006. Quote appears on p. 41. Elsewhere I suggested we can regard this theory of universal human needs as part of what I call Berlin's philosophical anthropology. See Arie M. Dubnov. "Anti-cosmopolitan liberalism: Isaiah Berlin, Jacob Talmon and the dilemma of national identity." Nations and Nationalism 16:4 (2010).

11. See in particular (in order of appearance):Yael Tamir. Liberal nationalism, Studies in moral, political, and legal philosophy. Princeton, N.J.: Princeton University Press, 1993. John Gray. Isaiah Berlin. Princeton, NJ: Princeton University Press, 1996; reprint, retitled Berlin for the paperback editon, published in the Modern Masters series, London, 1995: Fontana. Avishai Margalit. "The Moral Psychology of Nationalism." In The morality of nationalism, edited by Robert McKim, and Jeff McMahan. New York: Oxford University Press, 1997; _—. "The Crooked Timber of Nationalism." In The Legacy of Isaiah Berlin, edited by Mark Lilla, et al. New York: New York Review Books, 2001. David Miller. "Crooked Timber or Bent Twig? Isaiah Berlin's Nationalism.” Political Studies 53(2005).

12. Arie Dubnov. Isaiah Berlin: The Journey of a Jewish Liberal. New York: Palgrave Macmillan, 2012.

13. Quoted in Tony Judt. Postwar: A History of Europe Since 1945. New York: Penguin Press, 2005, 275. 
14. James J. Sheehan. Where have all the soldiers gone?: The transformation of modern Europe. Boston: Houghton Mifflin, 2008.

15. Ibid, 167.

16. "Charter of the United Nations and Statute of the International Court of Justice,". New York: Office of Public Information, United Nations, 1968. Top of Form The Charter of the United Nations was signed on 26 June 1945, in San Francisco. Various amendments were adopted in 1965, 1968 and later also in 1971 and 1973. The preamble appeared in all versions.

17. Isaiah Berlin. "Nationalism: Past Neglect and Present Power." In Against the Current: Essays in the History of Ideas, edited by Henry Hardy. New York: Viking Press, 1980.Quote appears on p. 337. The essay was originally published in Italian: "El nacionalismo: descuido del pasado y poder actual," Diá logos 14 No 6 (November/December 1978), 10-17; original English version was published in Partisan Review 46 (1979), 337-58.

18. Ibid., 333-55, 338.

19. — . "The Bent Twig: On the Rise of Nationalism." In Against the Current: Essays in the History of Ideas. New York: Viking Press, 1980, 238-61. Quote appears on p. 245.

20. Jahanbegloo. Conversations with Isaiah Berlin, 102.

21. Berlin. "Two Concepts.", 144.

22. — "Nationalism: Past Neglect and Present Power.", 338.

23. _- "The Achievement of Zionism (lecture delivered at an academic symposium of the Institute of Jewish Affairs, 1 June 1975). ” In Isaiah Berlin Virtual Library, edited by Henry Hardy, transcribed by Henry Hardy. http://berlin.wolf.ox.ac.uk/lists/nachlass/achiezio.pdf 1975). Quote appears on p. 329.

24. Hans Kohn. The idea of nationalism: a study in its origins and background. New York: Macmillan Co, 1944. Quote appears on p. 329.

25. For discussion and criticism of Kohn's impact on nationalism studies see Taras Kuzio. "The myth of the civic state: a critical survey of Hans Kohn's framework for understanding nationalism." Ethnic and Racial Studies 25:1 (2002): 20-39. Hedva Ben-Israel. "The Study of Nationalism as an Historical Phenomenon." In Be-shem ha-umah: masot u-maamarim 'al leumiyut ve-Tsiyonut [Hebrew: In the name of the nation: essays on nationalism and Zionism]. Beer Sheva: Ben-Gurion University Press, 2004. Don H. Doyle, Susan-Mary Grant, and John Breuilly. "John Breuilly interview for H-Nationalism." ASEN (Association for the Study of Ethnicity and Nationalism), http://www.h-net.org/ national/Breuilly.html. Craig J. Calhoun. Nations matter: culture, history, and the cosmopolitan dream. London; New York: Routledge, 2007, chap. 6. Paul Lawrence. Nationalism: history and theory. Harlow, England; New York: Pearson Education, 2005. The Italian historian of fascism Renzo de Felice went as far as naming Kohn the originator of the concept of totalitarianism. Abbott Gleason, however, does not consider him a central figure in this discourse. See Renzo De Felice. Interpretations of fascism. Cambridge: Harvard University Press, 1977. pp. 21-22. Abbott Gleason. Totalitarianism: The Inner History of the Cold War. New York: Oxford University Press, 1995.

26. Ernest Gellner. "Review: Now I Know My ABC's [Review of The Encyclopedia of Nationalism by Louis L. Snyder]." Transition, no. 51 (1991): 232-34. Quote appears on p. 233. 
27. Adi Gordon. "The Need for West: Hans Kohn and the North Atlantic Community." Journal of Contemporary History 46:1 (2011), pp. 33-57. See in addition also Noam Pianko. Zionism and the roads not taken: Rawidowicz, Kaplan, Kohn. Bloomington: Indiana University Press, 2010. and Kohn's own autobiography Hans Kohn, Living in a World Revolution: My Encounters with History. New York: [Trident Press] 1964.

28. Miller. "Crooked Timber or Bent Twig? Isaiah Berlin's Nationalism." Quote appears on p. 102.

29. It seems that Berlin met Kohn for the first time in Spring 1949. Shortly after that meeting he wrote to Noel Annan that Kohn "is perhaps not entirely serious, but never mind about that. [...] I think you will find him a very talkable and intelligent man about what is going on in the American academico-cultural world and a splendid gossip." Two years later, in August 1951, Berlin published a favorable, although not enthusiastic, review of Kohn's book, The Twentieth Century (Berlin, “This Modern Age," Jewish Chronicle, August 10, 1951, p. 10) but without any explicit reference to Kohn's famous typology of nationalisms. Writing in 1971 about Kohn's death to John Wheeler-Bennett, Berlin was somewhat dismissive when concluding: "although he [Kohn] was not a very clever or distinguished man he was in his own way not uncosy, and at any rate he was always very obliging to me." I. Berlin to Noel Annan, May 20, 1949, in Sir Isaiah Berlin's Papers, Oxford: Bodleian Library, MS Berlin 241, fol. 1; I. Berlin to John Wheeler-Bennett, March 22, 1971, in ibid., MS Berlin 192, fol. 239.

30. For a general introduction to the communitarian-liberal debate see Stephen Mulhall, and Adam Swift. Liberals and communitarians, 2nd ed. Oxford: Blackwell, 1996. And Daniel Bell. "Communitarianism." In The Stanford Encyclopedia of Philosophy, edited by Edward N. Zalta (2003). An influential, collection of essays accompanied by an oft-quoted programmatic introduction, is Michael J. Sandel, ed. Liberalism and its critics, Readings in social and political theory. New York: New York University Press, 1984. Interestingly, Sandel opens his collection with Berlin's "Two Concepts" as illustration of a strictly individualist Liberalism which stands in contrast with communitarianism. It should be noted, as Daniel Bell rightly reminds us, that communitarianism actually began first and foremost the form of a critical reaction to John Rawls' 1971 book A Theory of Justice, not Berlin's Liberalism.

31. Axel Honneth. "Negative Freedom and cultural belonging: an unhealthy tension in the political philosophy of Isaiah Berlin.” Social Research 66:4 (1999): 1063-77. Quotes appear on pp.1063, 1068.

32. Yael Tamir. "A Strange Alliance: Isaiah Berlin and the Liberalism of the Fringes." Ethical Theory and Moral Practice 1:2 (1998): 279-89. Quote appears on p. 280. See also idem, - , Liberal nationalism.

33. Isaiah Berlin. "Epilogue: The Three Strands in My Life." In Personal Impressions, edited by Henry Hardy. London: Pimlico, 1998, 255-60.The essay is based on the speech Berlin composed upon receiving the Jerusalem Prize in 1980.

34. Berlin in a letter to Beata Polanowska-Sygulska, 20 May 1989, as quoted in PolanowskaSygulska and Berlin, Unfinished Dialogue, p. 101.

35. Michael Ignatieff. Isaiah Berlin: a life. London: Chatto \& Windus, 1998. For Berlin's recollections see Berlin, "Yitzhak Sadeh," 77-90. 
36. Although Berlin himself habitually used it to describe himself as "Russian-Jew" I purposely do not use the term. For further discussion see my Dubnov, Isaiah Berlin: The Journey of a Jewish Liberal, chaps. 1, 3.

37. Mendel Berlin. "Appendix: For the Benefit of My Son." In The book of Isaiah: personal impressions of Isaiah Berlin, edited by Henry Hardy. Woodbridge, UK: Boydell Press, 2009, 265-314. esp. 266-7. See also Evan Zimroth. "In Search of Isaiah Berlin", in ibid., 5-7. Berlin's mother was more observant, and a passionate Zionist. Berlin tended to describe his father as a much less domineering than his mother, gentle, perhaps somewhat ineffectual at home-but did impress upon his son an Anglophilia that encouraged acculturation.

38. Bryan Magee. "Isaiah As I Knew Him.” In The book of Isaiah: personal impressions of Isaiah Berlin, edited by Henry Hardy. Woodbridge, UK: Boydell Press, 2009, 40-54. On p. 50. Magee tries to take some of the sting out of these phrases but I find his attempt unconvincing.

39. Steven E. Aschheim. Culture and catastrophe: German and Jewish confrontations with National Socialism and other crises. New York: New York University Press, 1996. esp. pp. 31-44.

40. For Arendt see Elisabeth Young-Bruehl, Hannah Arendt : for love of the world, 2nd ed. New Haven [Conn.]; London: Yale University Press, 2004. And Richard J. Bernstein. Hannah Arendt and the Jewish question. Cambridge, UK: Polity Press, 1996. On Freud see in particular Peter Gay. Freud: A Life for Our Time. New York: Norton, 1988. And

Freud, Jews, and other Germans: masters and victims in modernist culture. New York: Oxford University Press, 1978. Not everyone accepts Peter Gay's account. Yerushalmi provided a strikingly different account of the way in which Freud thought of his Jewishness: Yosef Hayim Yerushalmi. Freud's Moses: Judaism terminable and interminable. New Haven: Yale University Press, 1991.

41. Peter Gay. "The German-Jewish Legacy-and I: Some Personal Reflections." American Jewish Archives 40 (1988): 203-10. Quote appears on page 203.

42. Jehuda Reinharz. Chaim Weizmann, 2 vols. Oxford: Oxford University Press, 1985-1993.The third volume of the biography, touching upon the years in which Berlin became part of Weizmann's close circle, is being written these days by Prof. Motti Golani, Haifa University.

43. For Berlin's recollections see Isaiah Berlin. "L. B. Namier: A Personal Impression." In Personal impressions. London: Hogarth Press, 1980, 63-82.On Namier's Zionism activities see Norman Rose, Lewis Namier and Zionism. Oxford: Clarendon Press, 1980. J. L. (Jacob Leib) Talmon. The unique and the universal; some historical reflections. New York: G. Braziller, 1966, 296-311, Arnold Joseph Toynbee. Acquaintances. London: Oxford U.P., 1967. pp. 62-85.

44. Lewis Bernstein Namier. "Introduction." In The Jews in the modern world, ed. Arthur Ruppin. London,: Macmillan and Co., 1934, xiii-xxxi. Ruppin's book was originally published in Germany (2 vols., 1930-31) and later in Hebrew, in Tel Aviv (3 vols., 1931-33). Namier's introduction to the English translation is dated 10 October 1933.

45. Ibid, xiv. To be sure, what I call hereafter "the Jewish normalization discourse" did not originate in Ruppin, nor was an interwar period invention. It informs much of the writings and speeches of Max Nordau (1849-1923) and other Central European Zionist activists and writers 
who absorbed the fin de siècle's literary and scientific imagination. Among Anglo-Jews, as I argued elsewhere, we find similar ideas disseminated by the so-called "Wanderers of Kilburn," predominantly by the anthropologist and historian Joseph Jacobs (1854-1916), and the playwright and novelist Israel Zangwill (1864-1926). See my "'True Art Makes for the Integration of The Race': Israel Zangwill and the Varieties of the Jewish Normalization Discourse in fin-de-siècle Britain," in Geoffrey Alderman (ed.), New Directions in AngloJewish History. Boston: Academic Studies Press, 2010, 101-134. Unfortunately, it is beyond the scope of the present essay to provide a full genealogy of this discourse.

46. Arthur Ruppin. The Jews in the modern world. London: Macmillan and Co., 1934. Quote appears on pp. 6 and 16 (emphasis mine). Characteristic of this "peculiar mentality" were, Ruppin argued, a "capacity for quick thinking and the gift of combination" (both to be understood as virtues for those engaged in commerce), but Jews were also "inferior in certain other abilities, such as power of observation, the art of commanding men, skill of administration, etc." (ibid., p. 17). It was essential for Ruppin to stress, though, that these were the results of long historical developments and should not be explained racially or deterministically. For the background to Ruppin's study see Sergio DellaPergola. "Arthur Ruppin Revisited: The Jews of Today, 1904-1994." In National variations in Jewish identity: implications for Jewish education, edited by Steven Martin Cohen and Gabriel Horenczyk. Albany, N.Y.: State University of New York Press, 1999, 62-80.

47. Ferdinand Tönnies. Community and association, translated by Charles P. Loomis. London: Routledge \& Paul, 1955. For further discussion of Ruppin in this context see Mitchell Bryan Hart. Social Science and the Politics of Modern Jewish Identity, Stanford studies in Jewish history and culture. Stanford, Calif.: Stanford University Press, 2000. Yfaat Weiss. "Central European Ethnonationalism and Zionist Binationalism." Jewish Social Studies 11, no. 1 (2004). Ya'akov Goren. Arthur Ruppin: His Life and Work [Hebrew] (Ramat Ef'al Yad Tabenkin, 2005). Amos Morris-Reich. "Arthur Ruppin's Concept of Race." Israel Studies 11, no. 3 (2006).

48. Namier. "Introduction." xvii, xxv, xxviii.

49. Ibid.

50. Isaac Deutscher. The Non-Jewish Jew and Other Essays, edited by Tamara Deutscher. London, New York [etc.]: Oxford U.P., 1968.

51. See Bernard Wasserstein. "The Jewish Wars: Arthur Koestler, Issac Deutscher, Isaiah Berlin [Hebrew]." Zmanim 104 (2008): 80-89. as well as my Arie Dubnov. "A Tale of Trees and Crooked Timbers: Jacob Talmon and Isaiah Berlin on the Question of Jewish Nationalism." History of European Ideas 34: 2 (2008).

52. Isaiah Berlin. The life and opinions of Moses Hess. Cambridge: Published for the Jewish Historical Society of England [by] W. Heffer, 1959. The essay was later reprinted in Berlin's Against the Current, pp. 213-51.

53. __ "Benjamin Disraeli, Karl Marx, and the Search for Identity."

54. Charles Taylor. "What's Wrong with Negative Liberty?" in The Idea of Freedom: Essays in Honour of Isaiah Berlin, edited by Alan Ryan. Oxford: Oxford University Press, 1979; Thomas Baldwin. "MacCallum and the Two Concepts of Freedom." Ratio 26, no. 2 (1984). 
55. Berlin in Polanowska-Sygulska and Berlin, Unfinished Dialogue, 87.

56. Isaiah Berlin. "Jewish Slavery and Emancipation." In The Power of Ideas, edited by Henry Hardy (London: Pimlico, 2001). (emphasis mine, AD).

57. Quentin Skinner. Liberty before liberalism (Cambridge: Cambridge University Press, 1998). "A Third Concept of Liberty." Philip Pettit, Republicanism: a theory of freedom and government. Oxford: Clarendon Press, 1997.

58. For Gegenwartsarbeit see Ezra Mendelsohn. "Zionist Success and Zionist Failure: The Case of East Central Europe between the Wars." In Essential papers on Zionism, edited by Jehuda Reinharz and Anita Shapira. New York: New York University Press, 1996. Hagit Lavsky, Before catastrophe: the distinctive path of German Zionism. Jerusalem: Magnes Press Leo Baeck Institute, 1996. It should be noted that there are cases in which Zionist historians tended to treat the notion of Gegenwartsarbeit almost as a ideological heresy, collapsing eventually to a form of Dubnowist autonomism. For and example see Joseph Gorny and Shlomo Netzer. "“Avodat Ha-hove hamurchevet' be-hashkafat olamam shel Yitzhak Gruenbaum ve-shel Moshe Sneh be-Polin bashanim 1918-1939 [The 'expanded Gegenwartsarbeit' in the thought of Yitzhak Gruenbaum and Moshe Sneh in Poland,1918-1939]." In Olam yashan adam Hadash [Hebrew: Old world - new people: Jewish communities in the age of modernization], edited by Eli Tsur. Sde Boker: Mekhon Ben-Gurion and the Ben-Gurion Universithy Press, 2005.

59. Berlin's Political Ideas in the Romantic Age, a book-long manuscript written during the early 1950s but published only posthumously, represents another important step on the road towards this conceptual crystallization. See Isaiah Berlin. Political Ideas in the Romantic Age: Their Rise and Influence on Modern Thought. Princeton University Press, 2006., and in particular Joshua Cherniss' brilliant introduction to this volume.

60. Eugene R. Wittkopf, and James M. McCormick. "The Cold War Consensus: Did It Exist?" Polity 22, no. 4 (1990); Thomas H. Schaub. American fiction in the Cold War. Madison, Wis.: University of Wisconsin Press, 1991. Frances Stonor Saunders. The Cultural Cold War: The CIA and the World of Arts and Letters. New York: New Press : Distributed by W.W. Norton \& Co., 2000; H. W. Brands. The strange death of American liberalism. New Haven [Conn.]: Yale University Press, 2001. Giles Scott-Smith. The politics of apolitical culture: the Congress for Cultural Freedom, the CIA and post-war American hegemony (London; New York: Routledge, 2002).

61. Michael Kimmage. The conservative turn: Lionel Trilling, Whittaker Chambers, and the lessons of anti-communism. Cambridge, Mass.: Harvard University Press, 2009.

62. J. G. A. Pocock. The Machiavellian moment: Florentine political thought and the Atlantic republican tradition. Princeton, N.J.: Princeton University Press, 1975, 516, 550. This intellectual influence is rarely discussed by scholars who study the Cambridge School, yet was acknowledged by Richard H. King and Dan Stone in the introduction their collection on Arendt: Richard H. King, and Dan Stone, eds., Hannah Arendt and the uses of history: imperialism, nation, race, and genocide. New York: Berghahn Books, 2007, 16, n. 13.

63. I. Berlin to Morton White, as quoted in Morton Gabriel White, A Philosopher's Story. University Park, Penn.: Pennsylvania State University Press, 1999, 237-38. 
64. As quoted in Bernard R. Crick. Crossing borders: political essays. London; New York: Continuum, 2001. Bernard R. Crick. Crossing Borders: Political Essays. London: Continuum, 2001, 171.

65. I. Berlin to Conor Cruise O'Brien, 10 April 1991, as quoted in Conor Cruise O'Brien. The Great Melody: A Thematic Biography and Commented Anthology of Edmund Burke. Chicago: University of Chicago Press, 1992, Appendix, 615.

66. Berlin. "Introduction.", ix-lxiii on xlvi-xlvii. The epigraph on p. ix was taken from Constant's essay "The spirit of conquest and usurpation and their relation to European civilization," which was one of the earliest texts in which constant developed the modern/ancient typology. For English translation see Benjamin Constant and Biancamaria Fontana, Political writings, Cambridge texts in the history of political thought. Cambridge [Cambridgeshire]; New York: Cambridge University Press, 1988. For discussion see Helena Rosenblatt, Liberal values : Benjamin Constant and the politics of religion. Cambridge: Cambridge University Press, 2008. K. Steven Vincent, Benjamin Constant and the birth of French liberalism. New York: Palgrave Macmillan, 2011. Besides the motto, Constant is mentioned in Berlin's 1969 introduction essay when reply to Gerald MacCallum's critique of "Two Concepts." See Gerald C. MacCallum, Jr.. "Negative and Positive Freedom." The Philosophical Review 76, no. 3 (1967).

67. Isaiah Berlin. "Liberty." In Liberty: incorporating four essays on liberty, edited by Henry Hardy. Oxford: Oxford University Press, 2002, pp. 283-286 on p. 283. The entry was originally written for Ted Honderich's Oxford Companion to Philosophy. Oxford: Oxford University Press, 1995. In addition to his letter to Conor Cruise O'Brien, Berlin openly admitted that he found his inspiration in Constant in a 1986 conversation recorded by Polanowska-Sygulska. Berlin's full statement was: “There are three thinkers, I think, who have had a definite effect on me. One was Benjamin Constant ... Ancient liberty means nobody is protected against anybody else. In other words, anybody in the public assembly can speak against anyone; that's a liberty all right. Anybody can be expelled by the vote of the assembly. Nobody can forbid me to talk. Nobody can be forbidden to look into my life. Modern liberty, which is what I call negative, is a fence within which I can do what I like. The idea of private life is absent in Greece." Polanowska-Sygulska and Berlin. Unfinished Dialogue pp. 131-32. (emphasis mine, AD) Note that in this case Berlin is arguing quite explicitly that what he had always referred to as negative liberty was nothing but a different name to what Constant labeled using the term modern liberty.

68. Skinner. Liberty before liberalism. 60 n. 3 and chap. 3, esp. 113-117 and 117 n. 28.

69. Jan-Werner Müller. "Fear and Freedom: On 'Cold War Liberalism'." European Journal of Political Theory 7:1 (2008).

70. Bernard Williams. "The Liberalism of Fear." In the Beginning Was the Deed: Realism and Moralism in Political Argument. Edited by Geoffrey Hawthorn. Princeton, N.J: Princeton University Press, 2005, 52-61. Quote appears on p. 54. See also the use of the phrase in the works of Pratap B. Mehta. "Pluralism after Liberalism? " Critical Review 11:4 (1997). Richard Flathman. "Fraternal but not always sisterly twins: negativity and positivity in liberal theory." 
Social Research 66, no. 4 (1999). Jacob T. Levy. The Multiculturalism of Fear. Oxford: Oxford University Press, 2000.

71. Judith N. Shklar. "The Liberalism of Fear." in Political Thought and Political Thinkers, edited by Judith N. Shklar and Stanley Hoffmann. Chicago: University of Chicago Press, 1998. Quote appears on p. 10.

72. See in particular Shklar's autobiographical sketch:___. "Appendix: A life of learning." In Liberalism without illusions: essays on liberal theory and the political vision of Judith $N$. Shklar. Chicago: University of Chicago Press, 1996.

73. Müller. "Fear and Freedom: On 'Cold War Liberalism'."

74. "Systematic fear" and "institutionalized cruelty" were the terms used by Shklar to describe this sort of fear. Shklar, "The Liberalism of Fear." p. 11.

75. Shklar submitted her PhD dissertation, written under Carl Friedrich, in 1955. It served as the basis for her first book, - After Utopia; the decline of political faith. Princeton: Princeton University Press, 1957.

76. Michael Walzer. "On negative politics." In Liberalism without illusions: essays on liberal theory and the political vision of Judith N. Shklar. Chicago: University of Chicago Press, 1996.

77. Katrina Forrester. "Hope and Memory in the Thought of Judith Shklar." Modern Intellectual History 8, no. 03 (2011); ibid.

78. Ira Katznelson. Desolation and enlightenment: political knowledge after total war, totalitarianism, and the Holocaust. New York: Columbia University Press, 2003.

79. Michael Walzer et al. The Jewish political tradition, vol. 1: Authority. New Haven; London: Yale University Press, 2000. Michael Walzer et al., The Jewish political tradition, vol. 2: Membership. New Haven, Conn.; London: Yale University Press,. 2006. Vols. 3 \& 4 -dealing with the notions "Community" and "Politics and History" respectively-are in still in production. See also Menachem Lorberbaum, Politics and the limits of law: secularizing the political in medieval Jewish thought. Stanford, Calif: Stanford Univ. Press, 2001. Daniel Judah Elazar, ed. Kinship \& consent: the Jewish political tradition and its contemporary uses, 2nd ed. New Brunswick, N.J.: Transaction Publishers, 1997.

80. David Biale. Not in the heavens: the tradition of Jewish secular thought. Princeton, N.J.: Princeton University Press, 2011.

81. Walzer et al.. The Jewish political tradition, 1: Authority. pp. xxi-xxii.

82. Biale, Not in the heavens, 6.

83. I am drawing here, loosely, on John G. Gunnell. Political theory: tradition and interpretation. Cambridge, Mass.: Winthrop Publishers, 1979.

84. Isaiah Berlin and Fred S. Worms. "From Abraham to Washington: Extracts from an Unpublished Correspondence," Jewish Quarterly 45:4 (1998/9). Quote appears on p. 33. Nevertheless, Berlin never considered himself an atheist either: "dry atheists seem to me blind and deaf to some forms of profound human experience." he told Ramin Jahanbegloo. See Jahanbegloo, Conversations with Isaiah Berlin, 110.

85. Deutscher. The Non-Jewish Jew. 
86. Malachi Haim Hacohen. Karl Popper, The Formative Years, 1902-1945: Politics and Philosophy in Interwar Vienna. Cambridge: Cambridge University Press, 2000. ——. " “The strange fact that the state of Israel exists': the cold war liberals between cosmopolitanism and nationalism." Jewish Social Studies 15:2 (2009).

87. R. G. (Robin George) Collingwood. The idea of history : with lectures 1926-1928. edited by W. J. van der Dussen. Oxford: Oxford University Press, 1994.

88. Hans Georg Gadamer. Truth and method. New York: Seabury Press, 1975, 333. 
Reprinted from Religions. Cite as: Ashkenazi, O. Homecoming as a National Founding Myth: Jewish Identity and German Landscapes in Konrad Wolf's I was Nineteen. Religions 2012, 3, $130-150$.

Article

\title{
Homecoming as a National Founding Myth: Jewish Identity and German Landscapes in Konrad Wolf's I was Nineteen
}

\section{Ofer Ashkenazi}

Department of History and the School of Arts at the Hebrew University, Richard Koebner Minerva

Center for German History, Israel

Received: 5 January 2012; in revised form: 13 March 2012 / Accepted: 14 March 2012 /

Published: 22 March 2012

\begin{abstract}
Konrad Wolf was one of the most enigmatic intellectuals of East Germany. The son of the Jewish Communist playwright Friedrich Wolf and the brother of Markus Wolf - the head of the GDR's Foreign Intelligence Agency-Konrad Wolf was exiled in Moscow during the Nazi era and returned to Germany as a Red Army soldier by the end of World War Two. This article examines Wolf's 1968 autobiographical film I was Nineteen (Ich war Neunzehn), which narrates the final days of World War II-and the initial formation of postwar reality - from the point of view of an exiled German volunteer in the Soviet Army. In analyzing Wolf's portrayals of the German landscape, I argue that he used the audio-visual clichés of Heimat-symbolism in order to undermine the sense of a homogenous and apolitical community commonly associated with this concept. Thrown out of their original contexts, his displaced Heimat images negotiate a sense of a heterogeneous community, which assumes multi-layered identities and highlights the shared ideology rather than the shared origins of the members of the national community. Reading Wolf from this perspective places him within a tradition of innovative Jewish intellectuals who turned Jewish sensibilities into a major part of modern German mainstream culture.
\end{abstract}

Keywords: Heimat; GDR; Konrad Wolf; Ich war Neunzehn

\section{Introduction}

At first glance, Konrad Wolf's 1968 film I was Nineteen (Ich war Neunzehn) is a story of a triumphant homecoming. The protagonist Gregor Hecker, a Communist German-Jew, returns from exile together with the marching Red Army on its way toward Berlin in the spring of 1945 
(Figure 1a). Serving as a translator, he seems to personify a bridge between German and Russian nationalities, a link between the invading Soviets and the local-political, psychological and natural-landscape. The film begins, accordingly, with an ostensibly serene reunion between the protagonist and his homeland, which he left behind when the Nazis took power. Together with him, viewers are offered a panoramic view of the scenery, a wide river flows peacefully in the fog, with solemn hill slopes emerging in the background and small rafts crossing leisurely (Figure 1b).

This scenic view blends different themes and emphases. It combines the historical realism of the Soviet military campaign, the universal, psychological drama of an émigré's return to his place of birth, and the conventional imagery of German Heimat culture. The utilization of such imagery indicates that Hecker is not merely marching into a defeated state, but is rather returning to his Heimat, namely, to the "authentic" national landscape, undistracted by the annihilating forces of modernization and war. At first glance, the Heimat paradigm appears to reconcile the tensions between the universal and individual-psychological aspects of the scene. The protagonist's homecoming fits well within the generic narrative of Heimat culture (in particular in the aftermath of World War II), in which, conventionally, the rediscovered landscape and way of life of the community reminds the protagonist that — notwithstanding the reasons for his departure and his experiences during his journeys - there is "no place like home" [1]. Shortly thereafter, however, I was Nineteen deviates from the familiar formula, as Gregor Hecker's voice shatters the idyllic image of the German landscape and places it within a reality of violence, alienation and despair: "the war is lost," he announces in German through the loudspeakers to the Wehrmacht soldiers on the other side of the river, "and you are in a hopeless position" (Figure 1c).

Figure 1. (a) Gregor Hecker, the protagonist of Konrad Wolf's I was Nineteen. (b). Opening sequence: the first encounter of the prodigal son with the homeland. (c). The Heimat as a sphere of violence and despair.

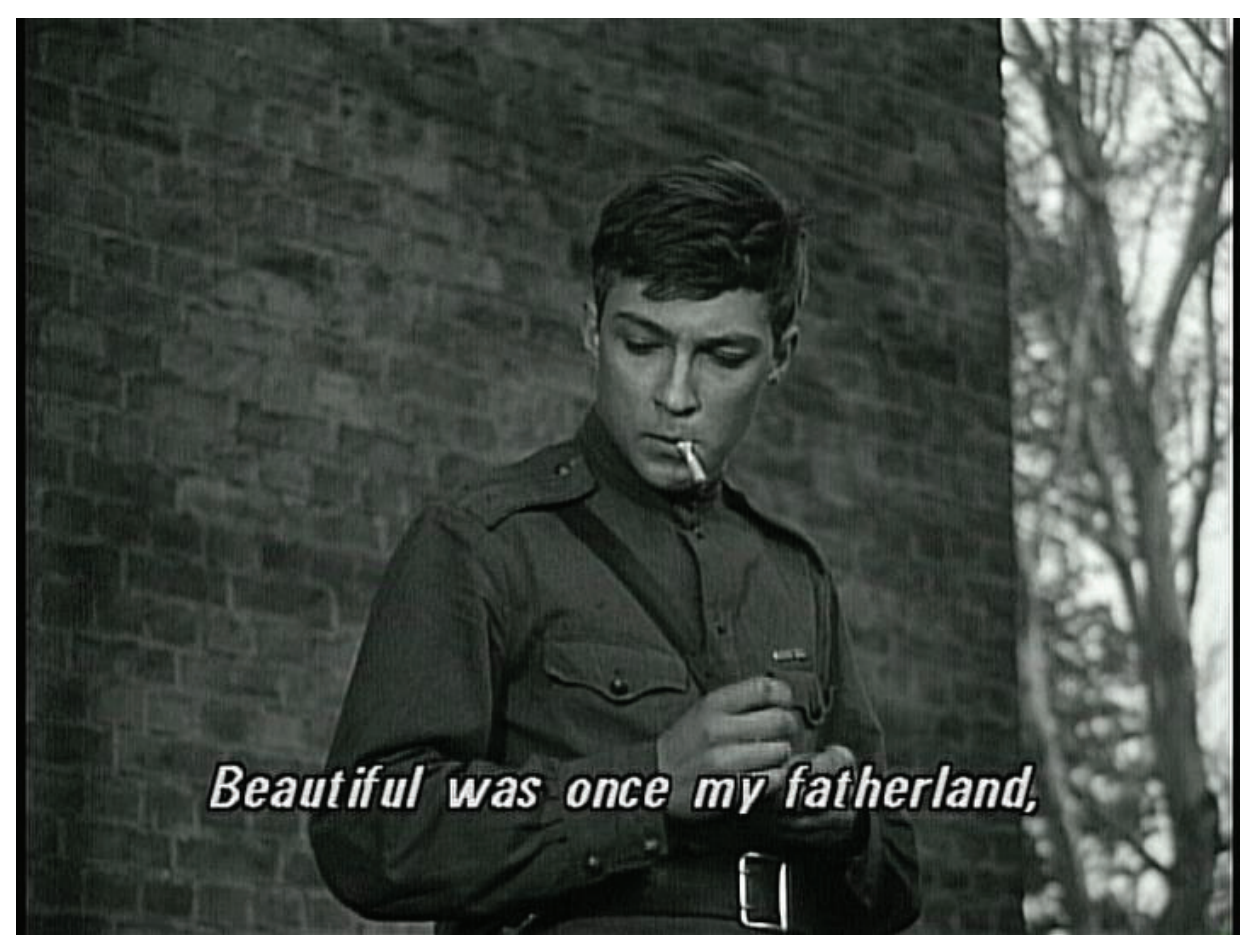


Figure 1. Cont.

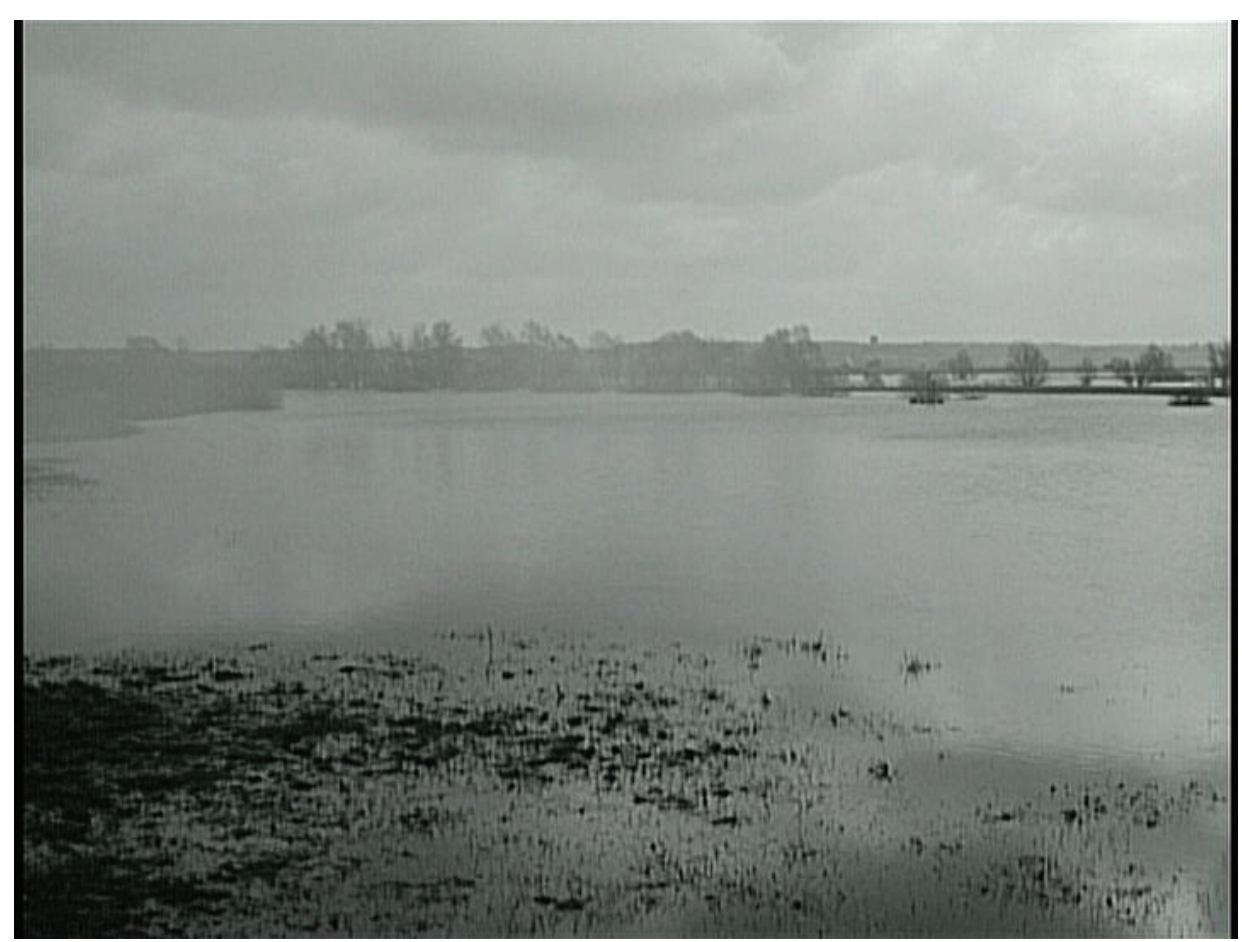

b

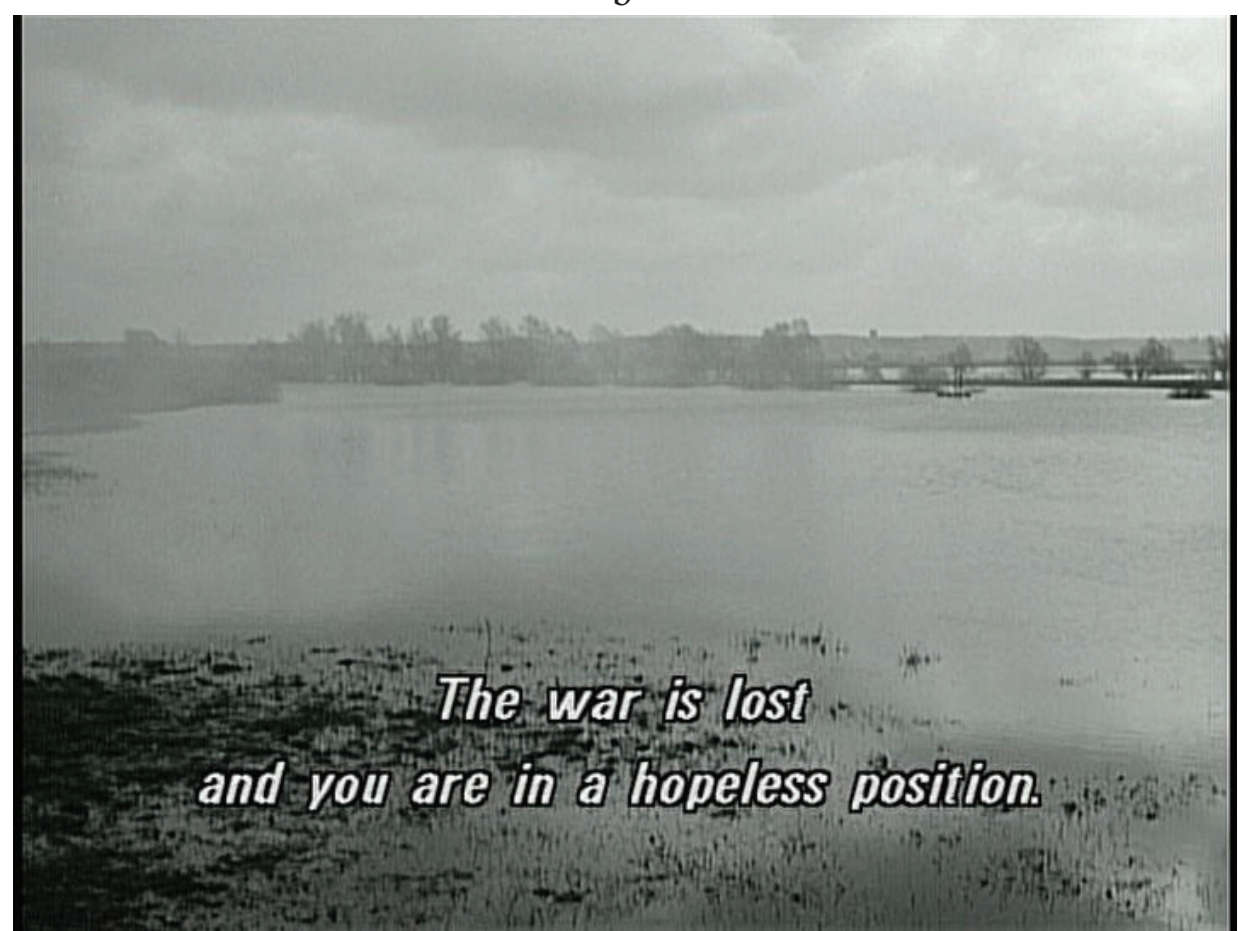

C

The incongruence of the peaceful scenery and the true nature of the scene-suggested by the repeated sentence emanating from the unseen loudspeakers-constitutes the former, generic Heimat imagery as a mere deception. This sense of deception is a cardinal element in the early films of Konrad Wolf (1925-1982), one of the most prominent East-German film-makers. It provides the framework within which Wolf formulated his cinematic reflections about the recent German past and the reconstitution of German nationalism after the National Socialist catastrophe. 
Based on a close reading of I was Nineteen, this article underscores the ways in which Wolf phrased his criticism of the formation of postwar German identity in the GDR through manipulation of Heimat symbolism. In undermining the generic imagery associated with the concept of Heimat (especially since 1933, when the perception of Heimat as a concept revolving "around the central themes of race, blood and German destiny" was standardized under Nazi rule [2]), Wolf sought to override the notion of collective identity it entailed: namely, that of a homogeneous community molded by its "authentic" attachment to the national landscape. Perceived in this manner, the concept of Heimat symbolized Wolf's incorrigible otherness as a German Jew. His portrayal of the final days of Nazi Germany, therefore, is formulated as a struggle against the attempt to view the local landscape as a metaphor for a German nationality that predetermines his otherness.

Since the late nineteenth century, and particularly in the aftermath of the World Wars, Heimat iconography offered a unique linkage between the regional landscapes and shared national characteristics, providing symbolism in which the familiar local landscape functioned as a metaphor for the abstract qualities of the nation [3-5]. Drawing on this tradition, Wolf described his works as an ongoing search for a Heimat, for a place in which he — through his protagonists — would feel "at home"; the place which would connect him with "his people" [6]. The discussion below suggests, however, that Wolf's quest for a genuine Heimat undermined the mythic powers of this imagery and portrayed it as a destructive illusion. Wolf's exploitation of the Heimat metaphor in search of a new German identity reveals a distinctive endeavor to face the challenge of the problematic German-Jewish "symbiosis" in post-Holocaust East-Germany. Blending irony and optimism, Wolf offered his viewers a vision of a community based on shared values and experiences rather than on inborn characteristics. His critique of the Heimat ideal, and his position as an "outsider within," was nonetheless rooted in the political paradigms of the Cold War. A sober supporter of German socialism, Wolf did not believe that the socialist credo alone would solve the 'Jewish problem'; he rather interpreted Socialism as a distinctive, critical viewpoint, according to which guidelines for a new path in German (and German-Jewish) history could be marked.

\section{German-Jewish Dialog in the East-German Heimat}

At the core of Heimat symbolism lie the contours and characteristics of the national community, its formation and its manifestations, and the changes in the political and social reality over time [7]. Postcards, poems, political addresses and films, have portrayed the environment of the Heimat and the relationships between the members of its community as the essential influence on the formation of individual identity within this sphere [8,9]. In his survey of pre-1918 Heimat iconography, Alon Confino, found that it served a dual objective: to indicate the (metaphorical) uniformity of "the local, regional, and national way of life," and to depict "the nation as a community within nature and in harmony with nature" [10]. It therefore incorporated "generic" landmarks, such as inconspicuous brooks, hills, and trees, alongside human-made objects, such as (unidentified) church towers. As recent scholarship has noted, contrary to a commonly held belief, Heimat imagery has never manifested a merely reactionary (and nationalist) longing for pre-modern harmony, but rather reflected an attempt to reconcile tensions that characterize times of fundamental social, cultural and political transformation [11-13]. This iconography, however, 
gained additional connotations in the aftermath of World War One and during the Nazi period. The notion of Heimat enabled the imagination of the nation as being detached from the war defeat, from the state's deep political crisis, and from the 'foreign' elements within modern German society. Within the then popular terminology of Ferdinand Tönnis' paradigms [14], Heimat enabled modern society in Germany to imagine itself as a German national community.

The history of the utilization of Heimat symbolism in German film begins in the early years of German cinema. Considered to be the only "genuine German genre," Heimatfilm contemplated the perennial conflicts of German society by combining a highly modernized technology of representation with iconic imagery of pre-modern, or ostensibly timeless, landscape [15-17]. Scholarly discussion of West-German Heimatfilm often refers to its immense popularity during the years of restoration under Adenauer's conservative regime, when the general mood was consistent with the genre's emphasis on nation-building and reconciliation of social tensions [18]. According to this interpretation, the panoramic images of a de-politicized landscape, detached from recent catastrophes, served a need both for escapism and nation-building in the years that followed the immense destruction and loss of the war.

Scholars have, until recently, tended to disregard the important role played by Heimat imagery, and Heimatfilm in particular, in the nation-building process and the establishment of national ideology in the GDR [19]. However, the current interest in the productions of DEFA (Deutsche Film Aktien-Gesellschaft, the East German national studios) — which underlines the role of genre films and transnational influences - facilitates a better informed discussion of the East German Heimatfilm of the 1950s and its socio-political roles [20]. It was, for instance, noted that films such as Martin Hellberg's Das verurteilte Dorf (The Condemned Village, 1952) and Der Ochse von Kulm (The Ox from Kulm, 1955) effectively mobilized Heimat imagery to serve the ideology of the SED. These films exploited the sentiments evoked by this imagery in modern German popular culture in order to reflect on the role of the GDR as the defender of "genuine" German attributes under threat from the capitalist superpower [21].

Heimatfilm's conventions are abundant in Konrad Wolf's films, in particular in the early years of his career. His debut as a film director, Einmal ist Keinmal (One Time is no Time, 1955), is a musical fairytale that incorporates various elements of the Heimatfilm genre. Utilizing scenery and soundtrack that echoed the traditional Heimat culture, Wolf's narrative - a love story involving a local girl and a visitor from West Germany-underlines the reconciliation of ideological tensions through the metaphor of harmonious integration of different musical traditions. When viewed alongside other contemporaneous East-German productions, however, it becomes apparent that several features of this film distance it from the political outlines of other Heimat-films made by DEFA: e.g., the ironic dialogues, the blend of realism and mystic components, and the airing of the distinctive point of view of a stranger, a visitor, throughout the film [22]. Wolf's fascination with Heimatfilm's conventional imagery is apparent in several later films, albeit in more implicit manner. Most notably, in films that portrayed the recent German history-such as Sterne (Stars, 1959) and Sonnensucher (Sun Seekers, 1958) - he recurrently displayed panoramic vista of Heimat-style landscape. With the transition to more concrete political circumstances, however, the lightheaded contemplations presented in the magical forest of One Time is no Time were replaced by a sense of urgency and gravity. This trend reaches its climax in Wolf's 1968 I was Nineteen. 
Here, reflecting on the Soviet occupation and on the East-Germans' ability to overcome the trauma of the war, Wolf presents Heimat imagery as an uncanny interference, unrelated to and yet underlining the horrors of the real world. Staged as a journey in a displaced Heimat, I was Nineteen underscores the dissociation between the imaginary Heimat and home. As I argue below, the film is a desperate attempt to restore the notion of a German community through the annihilation of the ideas and sentiments associated with Heimat. Eventually he calls for a new type of community that would encourage the assimilation of the social elements that could not participate in the Heimat ideal; a new German-Jewish symbiosis, that is.

In his widely cited and harsh criticism of the notion of "German-Jewish symbiosis," Gershom Scholem asserted that such a concept was dangerously misleading, since there had never been a genuine dialog between Germans and Jews in the pre-Nazi era. Jews, he maintained, could venture into the German national discourse - could be a part of, and influence, German identity - only as individuals who endeavored to efface the differences between them and their German 'hosts,' not "as Jews," [23,24]. Current scholars have criticized the "wrong and a-historical" notion of authentic and recognizably different Jewish and German cultural identities embedded in Scholem's terminology [25-27]. The emphasis has therefore shifted to the experiences and perceptions of the German-Jewish "symbiosis." Jack Zipes, for instance, depicted the German-Jewish intellectual experience in terms of a "failed" symbiosis, a phenomenon to which Jews aspired and depicted as a necessity, while at the same time acknowledging its impossibility and its 'destructive' potential [28]. Dan Diner's oft-cited reflection on the "negative" symbiosis locates it in post-World War II West Germany, where the presence of Jews generated a sense of "contradictory mutuality" that places Auschwitz as a major point of reference for both Jewish and German identities, and enabled the formation of post-Holocaust German nationalism (or the "reidentification of Germans with Germany") [29]. According to this argument, postwar West-German Jews have had an important role, qua Jews, in the German discourse of national identity, but did not, nor could they, participate in this discourse.

Scholars of the German Democratic Republic tend to portray the German-Jewish dialog in EastGermany in a way that recalls Scholem's depiction of the pre-1933 lack of symbiosis-i.e., integration into the discourse as individuals, not as Jews - rather than Diner's portrayal of the West-German pattern. Even though since the mid-1950s the GDR - like its Western counterparttolerated the activity of the Jewish community, funded it, and incorporated it into the post-Nazi national ethos, scholars commonly note that the Jews who rose to prominence in the cultural arena were not part of the Jewish community and have not identified themselves with its traditions and practices [30,31]. "Staunchly refus[ing] to consider themselves Jews," as one scholar remarked, these intellectuals and artists often regarded their Jewish ancestry as something related merely to religious conviction, and hence irrelevant to their German identity in the atheist-socialist GDR. Allegedly, like the Jews mentioned by Scholem, they became an important element of German national discourse only once they had marginalized their Jewish identity [33].

At first glance, Konrad Wolf seems to fit well within these parameters. The son of the famous Communist physician and playwright Friedrich Wolf, and the brother of Markus Wolf, the head of the GDR foreign intelligence (Hauptverwaltung Aufklärung), Wolf was undeniably one of the most prominent and influential film-makers of the GDR, who received local and international 
recognition as a representative of the emerging culture of his state. Similar to several other prominent artists and intellectuals of Jewish ancestry, Wolf was not a practicing Jew and his films hardly include any explicit identification with Judaism or with the Jewish people. A closer look at his films, however, reveals a more nuanced, multifaceted approach to the German-Jewish question, which deviates from a mere refusal to be identified as a Jew.

Wolf's life and works have underscored a variety of seemingly insoluble tensions caused by different perceptions of identity. Exiled in Moscow with his family since 1933, the youthful Wolf enthusiastically embraced Russian Communism, served in the Soviet military, and returned to Moscow after the war to complete his training as a film-maker. Here, he could hardly overlook the widespread anti-Semitic sentiments in the Moscow of the late Stalinist era [34]. Notably, Wolf's experiences as a conspicuous outsider during these years - both in Germany (as a Jew and as a soldier in the Red Army) and in Moscow (as a Jew and as a German) - did not drive him to the cultural margins of East-Germany [35,36]. His work, rather, incorporated his constant sense of alienation into the GDR's mainstream national culture. While Western critics associated him with the genius and the rebellious spirit of contemporaneous "New Wave" film-makers [37], the political leadership of the East-German state embraced him and appointed him head of the National Academy of Arts (a position he held from 1965 until his death in 1982). A member of the Central Committee of the governing Socialist Union Party (SED), Wolf declared that his entire filmography was facilitated by and dedicated to the ideas and values espoused by the party [38,39]. Nevertheless, despite the recognition accorded to his work by the state, his films were recurrently criticized by representatives of the SED and its suppoters for their "non-persuasive," or "superficial" ideological content [40]. In some cases, the 'vagueness' of his messages appeared to threaten the party's objectives; his film Sonnensucher (Sun Seekers, 1958) was banned for thirteen years before it was allowed to be screened. The ambivalence that caracterized his career, his immanent role as both insider and outsider to the socialist state, appears to correspond with his perception of German national identity and his place therein. Indeed, the grater part of his filmogrpahy focuses on rebellious individuals who seek to belong to the community without relinquishing their peculiarities; men and women who aspire to be insiders as outsiders (e.g., in Der geteilte Himmel, Divided Heaven, 1963; Solo Sunny, 1978; and Goya, 1971) [41].

\section{I was Nineteen: A Homeland without a Home}

To a large extent an autobiographical film, I was Nineteen narrates the final days of World War II from the point of view of Gregor Hecker, who-like Konrad Wolf_left Germany for the Soviet Union when he was eight, after the Nazis took power, and returned to his homeland as a nineteen year old soldier in the Red Army. Gregor's journey toward Berlin, into the German heart of darkness, occurs at a unique historical moment, namely, once the collapse of the National-Socialist State has become inevitable and before a new regime, a new national ideology, and a new notion of German identity have been established. Condensed to just a few hours that cover the end of World War II and the initial inkling of the Cold War, the events in the film also occur in a metaphorical realm, in which various perceptions of the German past and future are confronted. As he becomes re-acquainted with the German landscape, Gregor encounters a variety of German "types," such as a small town bourgeois couple; a member of the pre-1933 communist party; a wounded blind 
soldier; a still devoted SS officer, and an opportunist SS officer who exploits his privileges in order to survive the war; a contemplative intellectual; and an anxious, helpless family of farmers. These encounters repeatedly engender discussions about the "meaning" of Germany's recent history and about the 'essence' and the prospects of the national community. In the final scene Gregor joins forces with some deserting Wehrmacht soldiers against their common enemy, the still loyal SS units. At the end of this chain of events, which marks the end of the film, Konrad Wolf declaresthis time in his own voice- "I am German." Set in a lone farmhouse by a small stream, surrounded by trees, fields and hills, the depiction of this new alliance appears to suggest that Gregor has found - or rediscovered - his genuine community in "his" Heimat. The rediscovery of the German Heimat seems to match scholars' reading of I was Nineteen as a cornerstone of DEFA's antifascist film, which "allowed filmmakers to remap the affective landscape of antifascism, reassess its historical status, and reaffirm its meaning for the present" [42].

This impression, I argue, is wrong; I was Nineteen is a film about the deception and the danger embedded in the notion of Heimat, and represents an attempt to undermine its enduring hold on the national imagination. At the beginning of the film, after the crossing of the river mentioned above, Georg is back in his land of birth. The return of the protagonist to the German landscape is a narrative framework that resonates with that of the conventional Heimatfilm (including Wolf's One Time is no Time): an outsider arrives at the Heimat and eventually discovers that he belongs there; that he has come home. Yet, as in the unfolding of the opening scene, I was Nineteen sets up this framework in order to subvert its premise. Throughout the film Gregor seems to be devoid of Heimatgefühl, namely, of the emotional link to the place and the community to which one belongs; or, simply, of the feeling of "being at home" $[43,44]$. Wolf employs two main methods to confer this lack of Heimatgefühl. First, while set in "German" territory, the film consists primarily of movement and transitions of the scenery. Rather than being-in the landscape, Gregor relentlessly drives from one place to another together with his unit. One is shown no maps or given any strategic reasoning for the movement throughout the film. Depicted from Gregor's point of view, that of an uninformed ordinary soldier, his constant motion appears arbitrary, if not irrational. Like many of his fellow soldiers, Gregor is mostly confused about his whereabouts. His disorientation in the Heimat is compounded by the ostensibly arbitrary pauses in the journey. While the reason for some of these pauses is explained - e.g., the wish to prevent unnecessary bloodshed by convincing some German soldiers to surrender - most of the halts seem to occur at random (to the viewers and apparently to Gregor): e.g., in the home of a German intellectual; in the Sachsenhausen concentration camp; or in a riverside garden, where a man suspected of collaborating with the Nazis is captured and executed by another unit.

Gregor's inability to feel at home in the Heimat is underlined when he is appointed by his officer - again, in a seemingly arbitrary fashion - to the post of governor of a small German town. In this capacity he meets a young local woman, who craves his affection (and protection). The anticipated romantic union between the returning exile and representative of the young German generation appears at first to be a metaphor for a new potential union of different elements of postwar German society. Shortly thereafter, however - and as abruptly as he was appointed-Gregor is ordered to leave the town and moves on. His emphatic-yet-unconcerned approach toward the fate of the woman he leaves behind further accentuates his lack of emotional attachment to the land and 
its inhabitants. A similar indifference is exhibited during his encounter with an injured Wehrmacht soldier, when his vehicle momentarily comes to a halt on a small bridge. Gregor engages in conversation with the blinded soldier, speaking German in a way that emphasizes their belonging to the same nationality. Their camaraderie, nonetheless, is based on a lie. The blind German fails to notice - or pretends to be oblivious to the fact - that Gregor is part of the enemy's military (their dialog focuses on the question of where is Gregor "from," i.e., from which region in Germany). This false camaraderie is short-lived and Gregor soon moves on, unfeelingly leaving the man to die there.

I was Nineteen is thus a film about moving through the land, rather than about returning to and residing in the place where the protagonist "belongs." The abovementioned small town episode also serves to demonstrate the second method Wolf employs to undermine the expectations associated with the conventional tale of homecoming, namely, his apparent discomfort in actual German homes. When Gregor visits homes during the film, such as the apartment he confiscates for his office as local governor, he restlessly moves around in them, seldom sitting still. His behavior indoors oscillates between irritation and lack of confidence; even though he 'owns' the house, since his bedroom is also his office he is devoid of genuine privacy, a foundational element of the feeling of being at home. His inability to feel at home in Germany is underscored on a visit to the home of a "typical" German intellectual, who contemplates the origins of Nazism with the young Soviet officers in his library. Gregor refuses both to sit comfortably in the living room and to engage in conversation about German culture. His sense of unease with regard to the German home is manifested in his lack of interest in the particularities of the German cultural heritage. He cares little for the 'German psyche' (as revealed in the national culture) and has little patience for German music (contrary to other Red Army officers who are eager to listen to German music and to discuss its merit). Unlike his curious Russian fellows, his body language expresses agitation. He longs to be out of there.

Notably, Gregor's inability to feel at home is matched by his apparent inability to articulate the Jewish dimension of his identity. During his various encounters with Germans, he is repeatedly asked whether he is Jewish (some, like the conniving SS adjutant he meets in Spandau, ask directly; others, like the blind soldier, inquire indirectly about his family business in Köln). Gregor responds to these inquiries with a silent-at times almost embarrassed-gaze. Only once in the film does he reveal his emotions (or at least his confusion) regarding his ties with the Jewish people. This dramatic (and brief) display of emotion takes place at a rare moment in the film, when it abruptly deviates from Gregor's point of view and turns to a visit by Soviet generals in the nowdeserted Sachsenhausen concentration camp. The generals listen to an explanation of the camp's methods of extermination by a former operator of the local machinery. This powerful sequence cuts between the didactic exploration of the Nazi killing machine and the wet face of Gregor, who is taking a shower in an unspecified location. As he covers his eyes with a towel, Gregor's rage and helplessness appear to be a direct response to the murder of Jews (which is immediately contrasted by the somber and objectively detached faces of the generals in the camp). In the following shot, the generals ask the operator about the identity of the victims of the camp, to which the latter replies with the politically correct answer: "mostly Russians." When the camera cuts from this laconic statement to a close-up of Gregor's tormented face, it renders his inability to cope with this 
dismissal of the Jewish victims as "Russians," with the effacement of their difference. This tension defines Gregor's identity: he is not prepared to identify himself as (merely) Jewish, and cannot feel (merely) Russian or German. He can feel at home only in the space that lies in-between these fixed identities. Accordingly, this portrayal of the tensions inherent to his identity occurs at a rare moment in the film, in which Gregor-taking a shower-engages in an activity normally performed in private, at home. This is, however, a privacy of isolation. Gregor's silent defiance in the shower-room highlights his inability to express and communicate self-identity in private.

\section{4. "I am German": Heimat as a Sphere of Deception and Violence}

The aforementioned opening scene encapsulates Wolf's attitude toward the sentiments aroused by the concept of Heimat and its role in German national identity. The river, the hills, and the rafts on the foggy water convey the impression of a nostalgic postcard of generic German scenery and the human activity integrated peacefully within it. They appear to confirm the idea of a pre-modern German sphere that embodies national values and glory unaffected by the defeats of the fatherland. It soon becomes apparent, however, that this is the sphere of defeat. The sounds that accompany these images, the Red Army's announcement of the German defeat, in effect split the image of the national landscape: the visual elements display an imaginary harmony, anchored in a particular national tradition but devoid of any particularities of time and space; the soundtrack, by contrast, locates the occurrences in a specific historical moment, specific territory, and a specific political context. Notably, the reason for this audio-visual anomaly - the call to surrender - is announced by the protagonist, whose story recounts Konrad Wolf's own war-time experiences. Thus, the rupture in the Heimat image, and its alienating effect, is brought about by the particular presence of Konrad Wolf: it is he - a German-Jew and a devoted socialist - who cannot exist within the harmonious Heimat without ruining it. As an outsider, his mere presence in this imagined landscape tears it apart.

The disturbing presence of the (Jewish) outsider likewise underscores the nature of the fantasy embedded in the cultural encoding of the Heimat. It only exists as long as contemporary politics, violence and war, are overlooked. Notably, Wolf does not mourn the evaporation of the Heimat illusion, but is quick to demonstrate its potential menace. As the fog clears, it reveals the true nature of the leisurely floating "rafts": rather than a traditional means of transportation, they serve as improvised gallows for people suspected of undermining the national war endeavor (Figure 2a and b). The Heimat landscape, the imagined a-political, authentic sphere, conceals the violence inflicted on the individual by the "homogenous" community. This conviction, which appears in different contexts in some of Wolf's other films (most notably in Stars, Sterne, 1959), constitutes a fundamental principle in I was Nineteen; a key to its understanding as an attempt to rethink the rise and fall of East German nationality.

The presentation of the detached national landscape, untouched by modernity and war, as a realm of devastating deception is repeated throughout Gregor Hecker's homecoming journey. It reaches its climax toward the end of the film, in a scene in which the protagonist and other exhausted Red Army soldiers find respite on a small hill by the side of the road. With a panoramic view of the rolling fields, scenery apparently unscathed by recent horrors, the men momentarily forget their role as combat soldiers, play games, and engage in sincere conversation. This idyll is 
interrupted when other Red Army tanks approach the field. As the weary young men wave to their comrades, the arriving tanks open lethal fire (Figure 3). It is quickly revealed that these tanks serve SS units in disguise, who continue with the killing despite the imminent end of the war. As in the opening scene, the iconographic Heimat imagery forms the backdrop to cruel—and redundantviolence; the feeling of being in the Heimat, in a place removed from the worries of the present, facilitates deception and its violent outcomes.

Figure 2. (a) A gallows looms above the foggy German river in I was Nineteen. (b). A close look at reveals the reason for the brutal death: deviation from the shared beliefs and objectives of the national community.

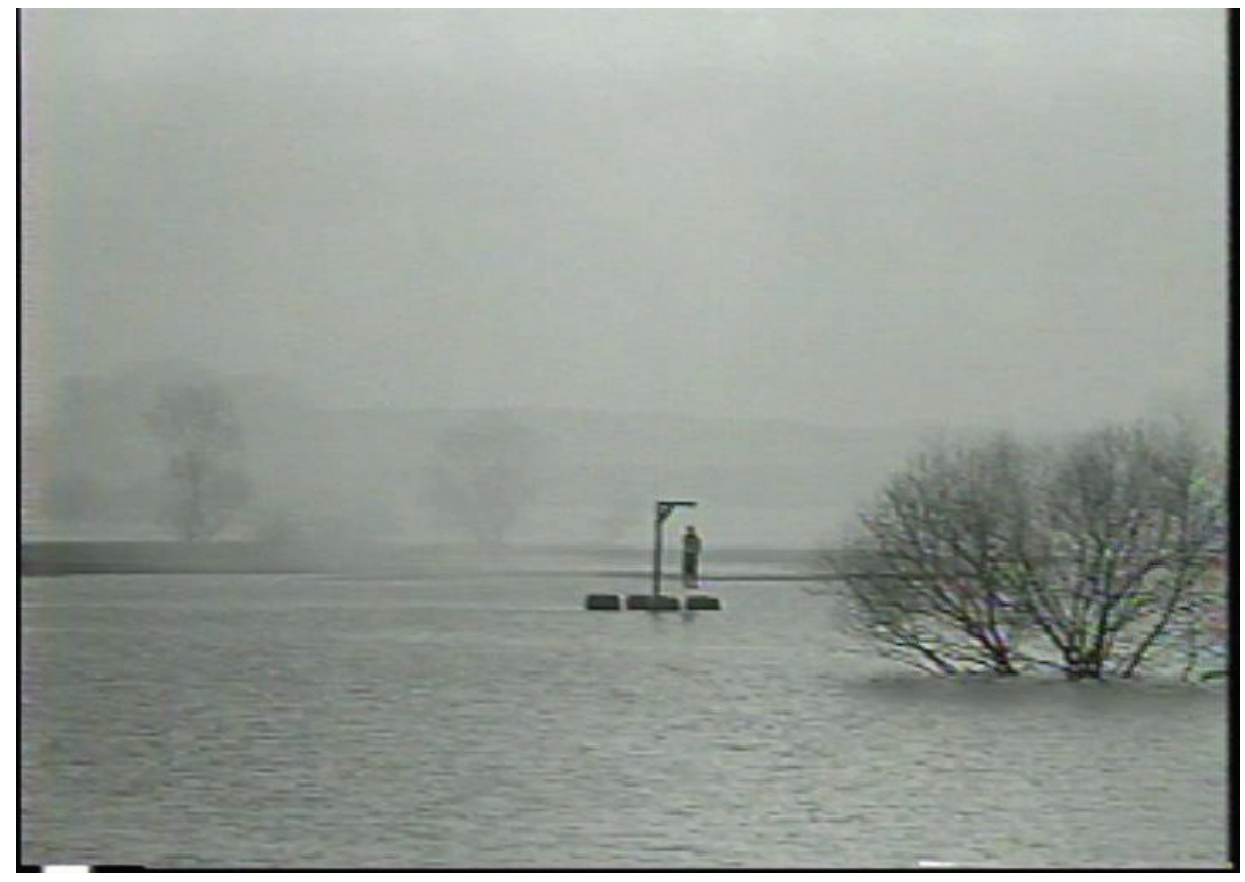

a

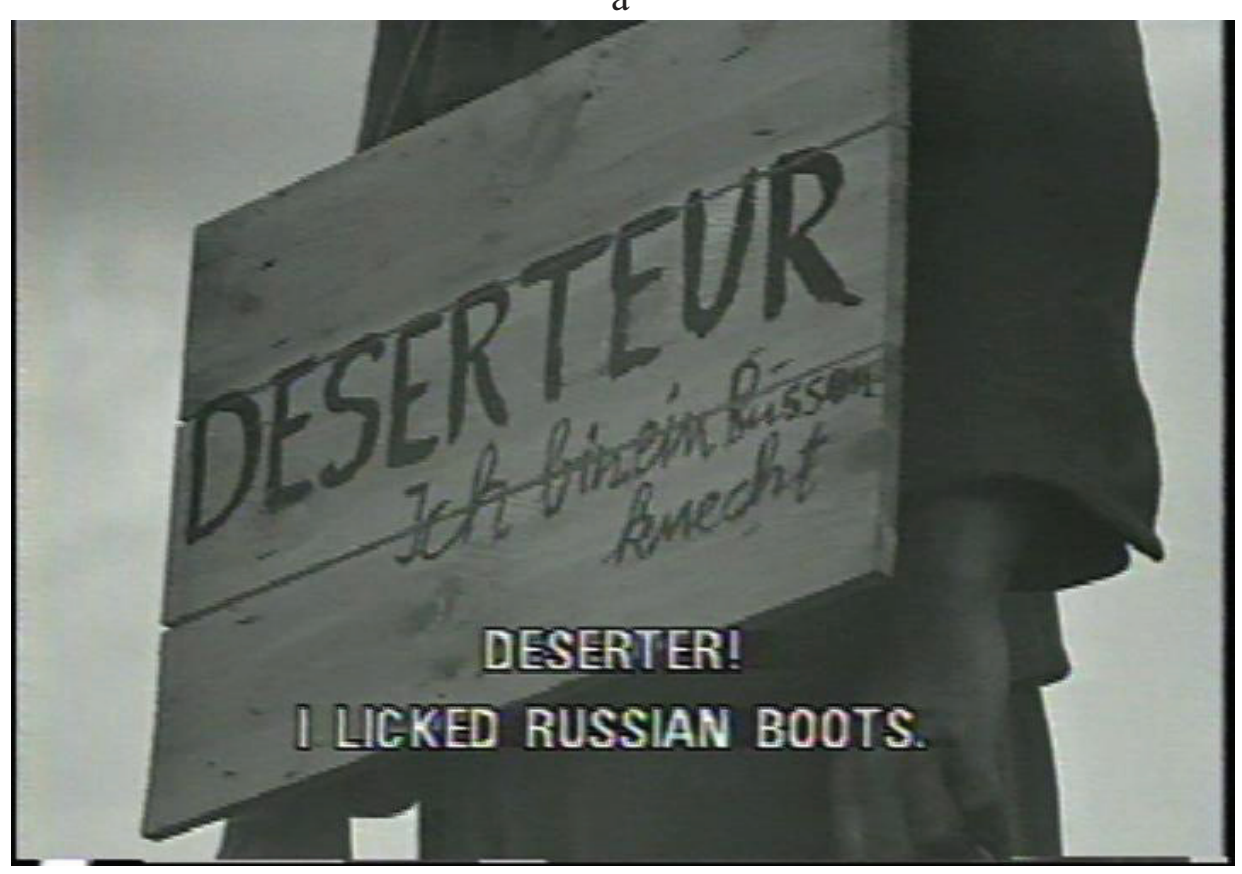


Figure 3. SS-militants in Red Army tanks shoot at the resting soldiers. The serene landscape as a place of deception and senseless death.

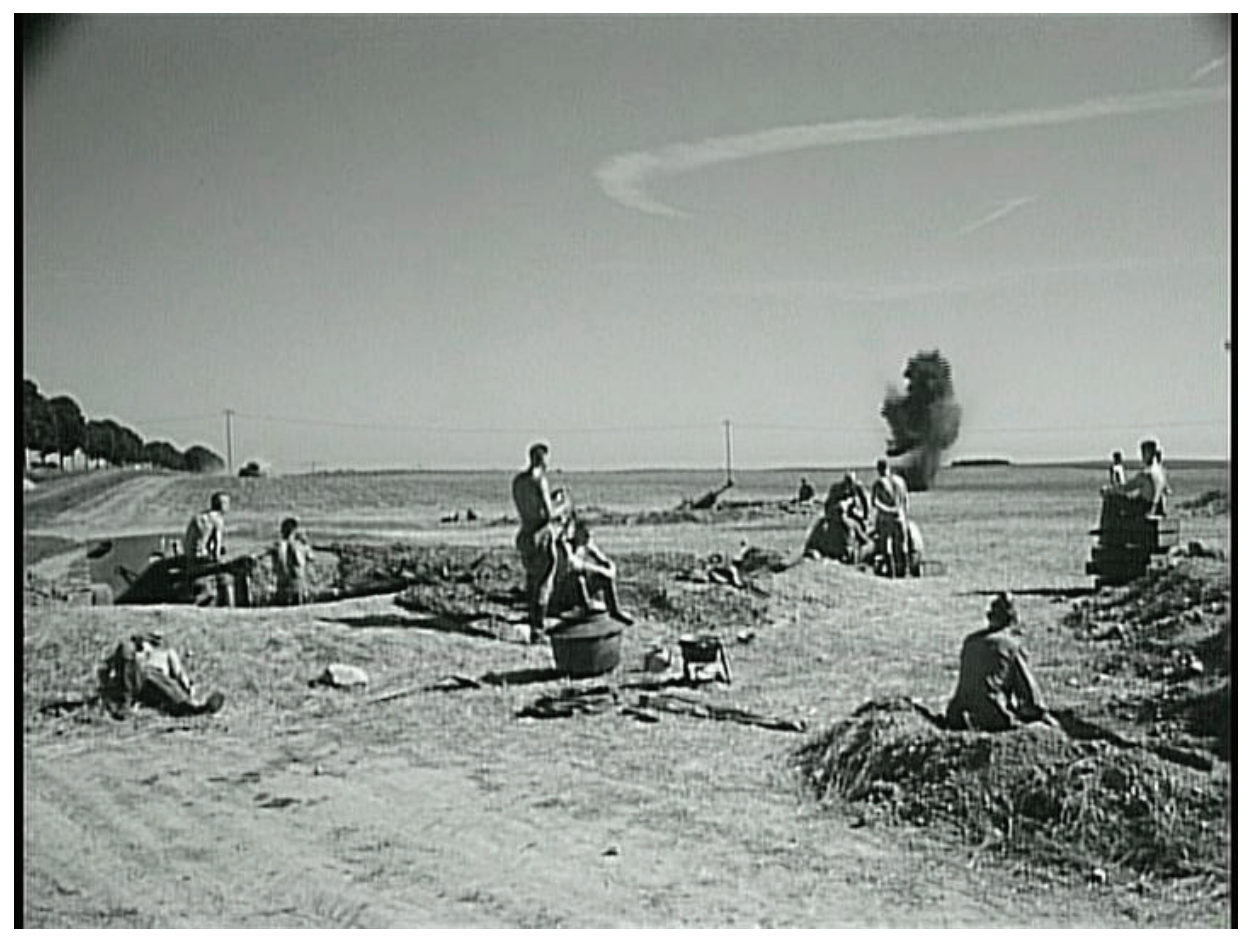

The ultimate rejection of the ideas and sentiments associated with the imagery of Heimat is delivered in the film's final scene. In the last moments of the war, Gregor stops his vehicle by a picturesque farmhouse and, together with his Russian commander and friend Sascha, convinces retreating German soldiers to lay down their weapons. In its composition, this scene mirrors the opening sequence. By contrast to the opening scene, however, this time the weary Wehrmacht men cross the narrow stream towards Gregor and throw down their guns as they accept that the war has come to an end. Strangely and reluctantly, Gregor senses an emotional bond with (or responsibility for) a young German soldier, and promises to deliver a letter from him to his family in Berlin. These emotions are expressed after the surrendering soldier reclaims his firearm. He now voluntarily fights alongside Gregor and Sascha against the remaining SS loyalists who drive along the other bank of the river and shoot at their capitulating compatriots. During the shooting, the little daughter of the farmers is caught in the line of fire, but is miraculously unharmed (thereby symbolizing, as in countless German films about the end of WWII, the future reconstruction of the nation by the young, innocent generation). Before this absurd incident is over, however, Gregor's close Russian friend Sascha is fatally hit by a stray bullet.

The shock of the meaningless death of his friend forms the backdrop against which the film presents a series of Heimat-style images. As in the opening scene, here too there is a conspicuous dissonance between the visual and audio elements of the image. And, once again, it is the voice of the protagonist, or of Konrad Wolf, that shatters the harmony of the imagined Heimat. As the Führer-loyalists drive away from the scene Gregor grabs the microphone-through which he previously declared the war to be over-and screams at the departing vehicles that his war has not ended, that he will continue "until you are dead [...] until there's no place left for you, nowhere on this planet; until you cannot shoot anymore, you criminals" (Figure 4). 
Figure 4. Gregor Hecker's voice interrupts the tranquil scenery and undermines the Heimatgefühl.
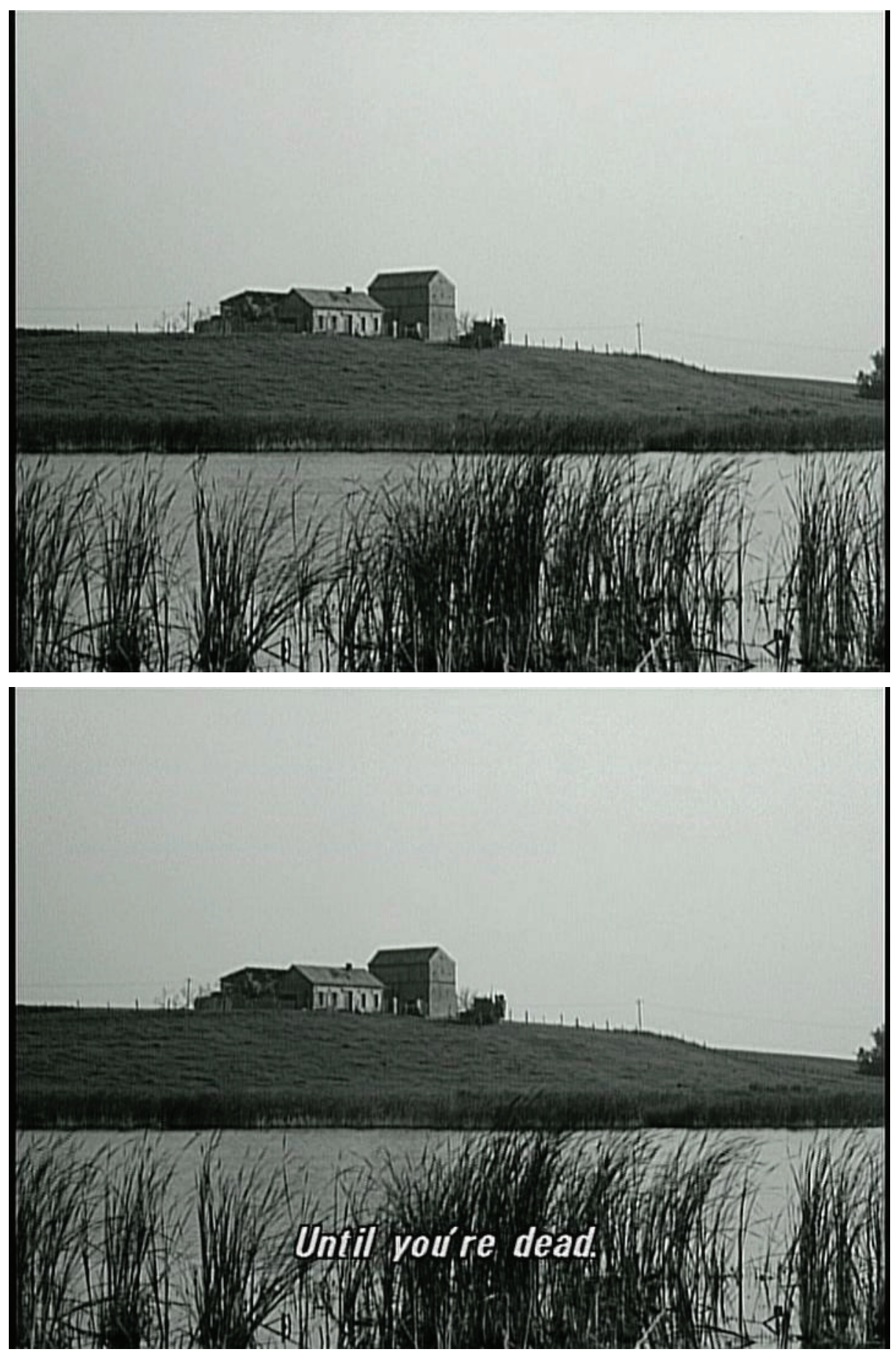

Furthermore, the most iconic Heimat image in this scene, and probably in the entire film, is displayed during the course of this desperate cry (Figure 5a). A wide-angle shot of the landscape includes the house and its barn (with cross-shaped windows, which allude to the Christian element of the landscape's dwellers), some undistinguished hills in the background, a small river and some trees, alongside manmade components, such as dirt roads, a wooden fence, and even telegraph lines. This serene combination of old and new, human creation and nature, local and "typically" national is the essential aspect of Heimat-imagination, and the main source of its allure. Displayed first during a pause in Gregor's monolog, this image seems almost detached from the violent 
conflict and the futile death that this place has witnessed. Wolf adds here a further layer to his disdain for the destructive deception of the concept of Heimat. This ideal image of harmony within the Heimat is shown here from a specific point of view: that of the SS-militants on the other bank of the river; this is the only perspective from which a homogenous community can be seen to prosper in its 'authentic' habitat (as becomes clear when Gregor's point of view is shown, Figure 5b).

Figure 5. (a) I was Nineteen, final scene: harmony of man and nature from the SS point of view. (b). Gregor's point of view during the same scene shows the shooting SSmilitants across the river.
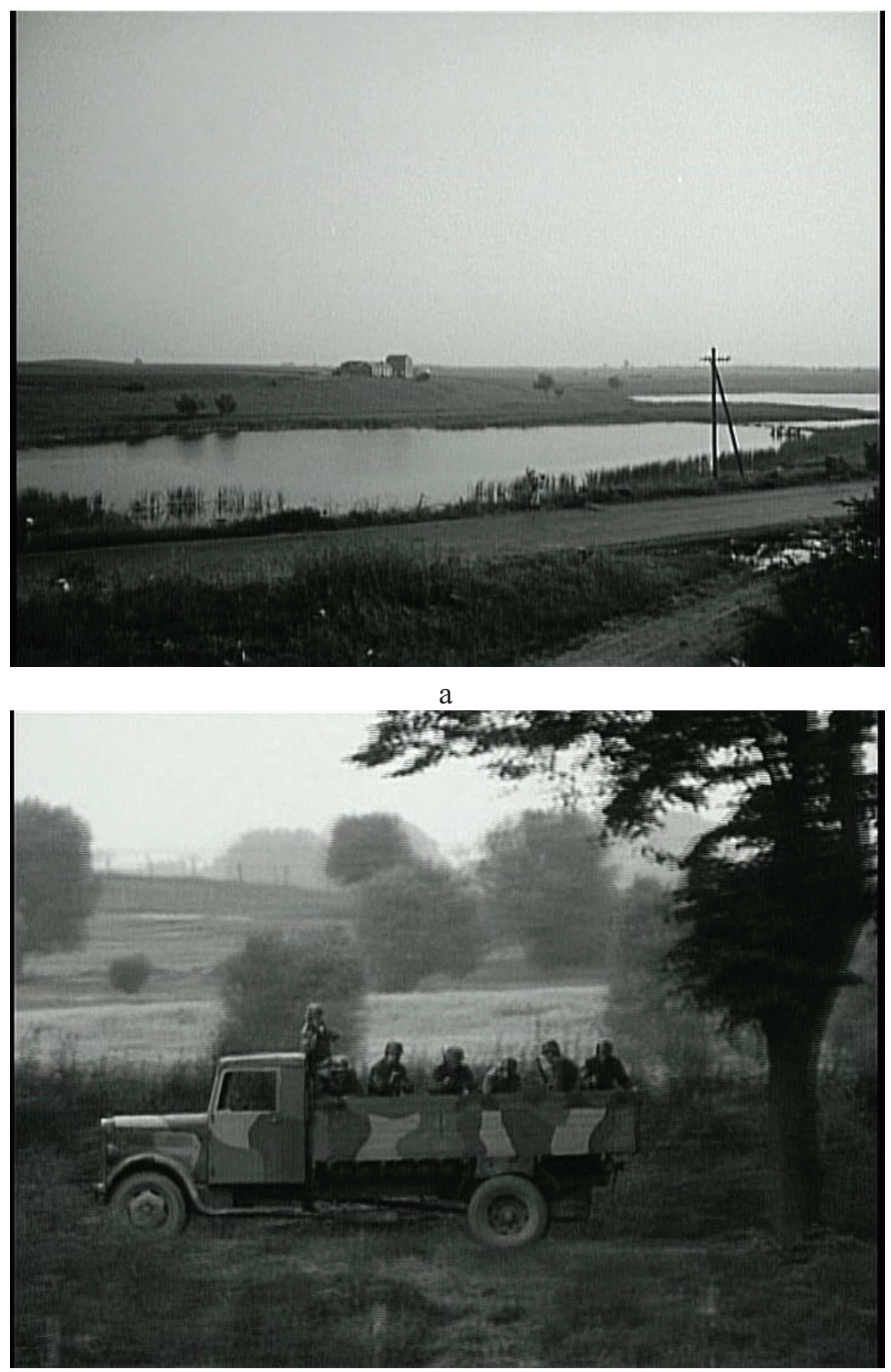
The concluding shot of the film is another Heimat-styled image, namely, a narrow dirt road in the midst of hilly fields. The human component of this image, however, does not signify a harmonious being-in the space, removed from modern conflicts, but rather portrays the exodus of Germans from the Heimat. A long line of defeated Wehrmacht soldiers is shown marching away from the camera, and away from the serene fields toward imprisonment and exile. In contrast to its conventional role in the German imagination, the Heimat here becomes the realm that manifests the results of politics in a most lurid manner. And this departure from the Heimat forms the backdrop to Wolf's concluding statement, "I am German." He can only be "German" when the Heimat as well as the ideals associated with it is deserted (Figure 6).

Figure 6. The defeated German soldiers marching away from the Heimat scenery.

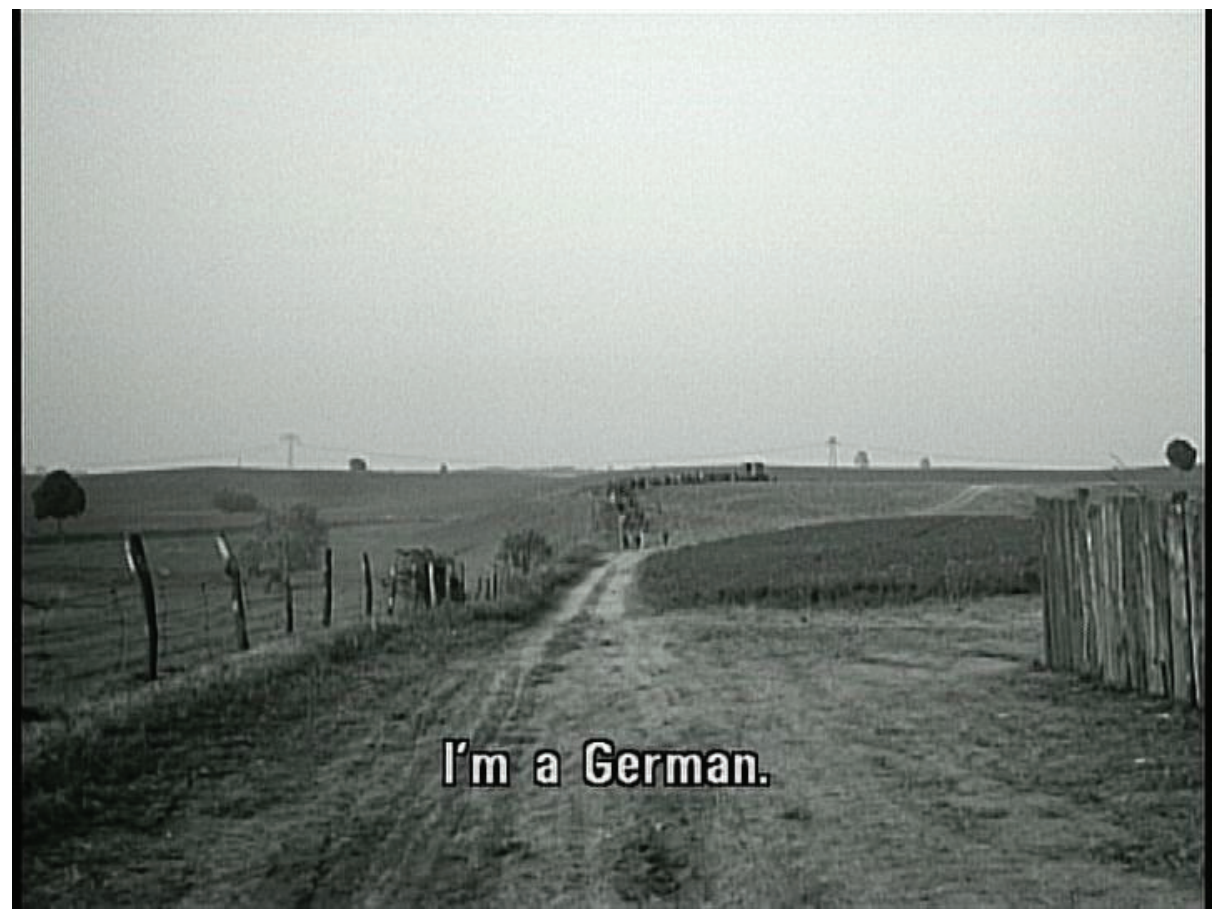

\section{5. "I am German"? The Failure to Produce an Alternative National Sphere}

To a large extent, therefore, I was Nineteen is a cinematic rejection of the premise of Heimati.e., of an authentic connection between the landscape and the homogenous community that dwells in it - and an exhibition of its destructive role in the formation of German national identity. Wolf goes further in this film, however, and endeavors to envisage an alternative public sphere, which could provide a new principle of collectivity to replace the Heimat's ethnic homogeneity.

The key scene of I was Nineteen introduces an alternative German national sphere. In this scene, the protagonist and a fellow Soviet officer enter the dungeons of the Spandau fortress on the outskirts of Berlin to discuss the terms of surrender with the German soldiers, SS officers, and civilians who have taken refuge there. Deep underground, the meeting place affords an ephemeral impression of detachment from the outside world and in particular from the "German" landscape. It is nonetheless infused with politics: the protagonist urges the Germans-representatives of party and military institutions - to make a decision contrary to their standing orders and possibly their worldviews, namely, to capitulate and secure the lives of the wounded, of the women and children, 
and of the officers themselves. The subterranean hall in which the meeting takes place thus becomes a unique sphere from which a new Germany could emerge at the end of the war. The evolution of this new Germany is, however, dependent on the outcome of the (political) debate among the survivors, and between them and the Red Army delegates (Figure 7a). No wonder, therefore, that the devoted Nazis attending this meeting not only decline the offer, but also cut short the discussion, arguing that this is no time to "discuss political matters" (Figure 7b).

Figure 7. a. Representatives of the different elements in GDR society discuss the condition for future cooperation. $\mathrm{b}$. below: The command of the SS officer, not to "discuss political matters," terminates the potential reconciliation.

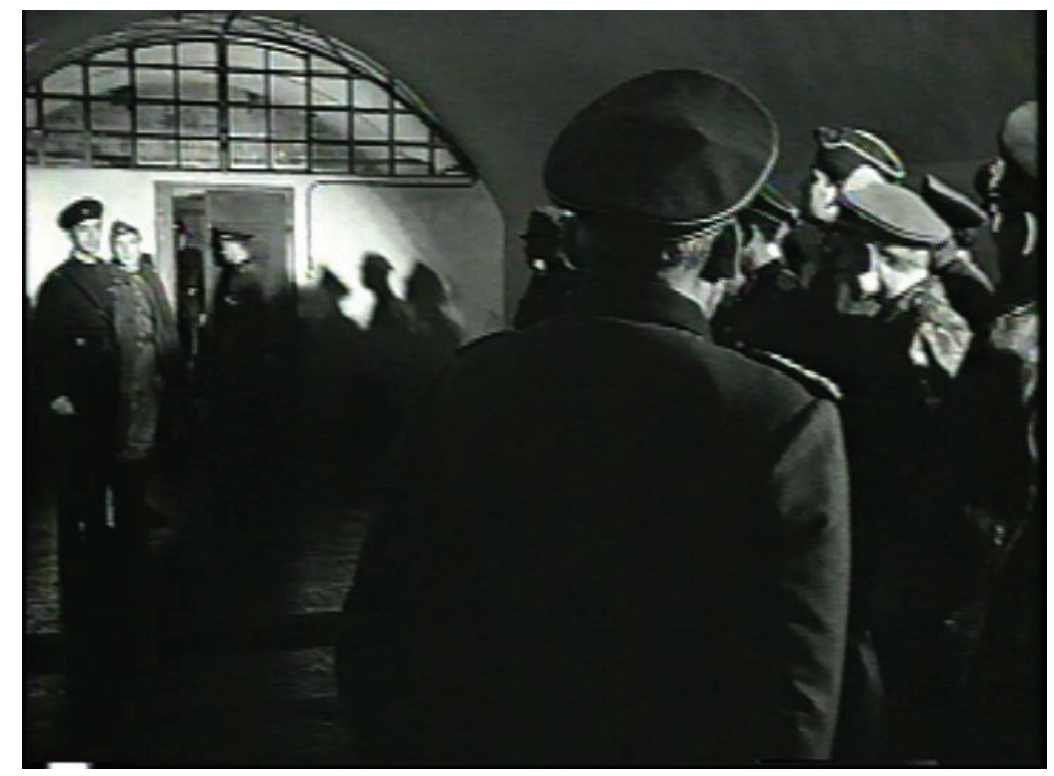

$\mathrm{a}$

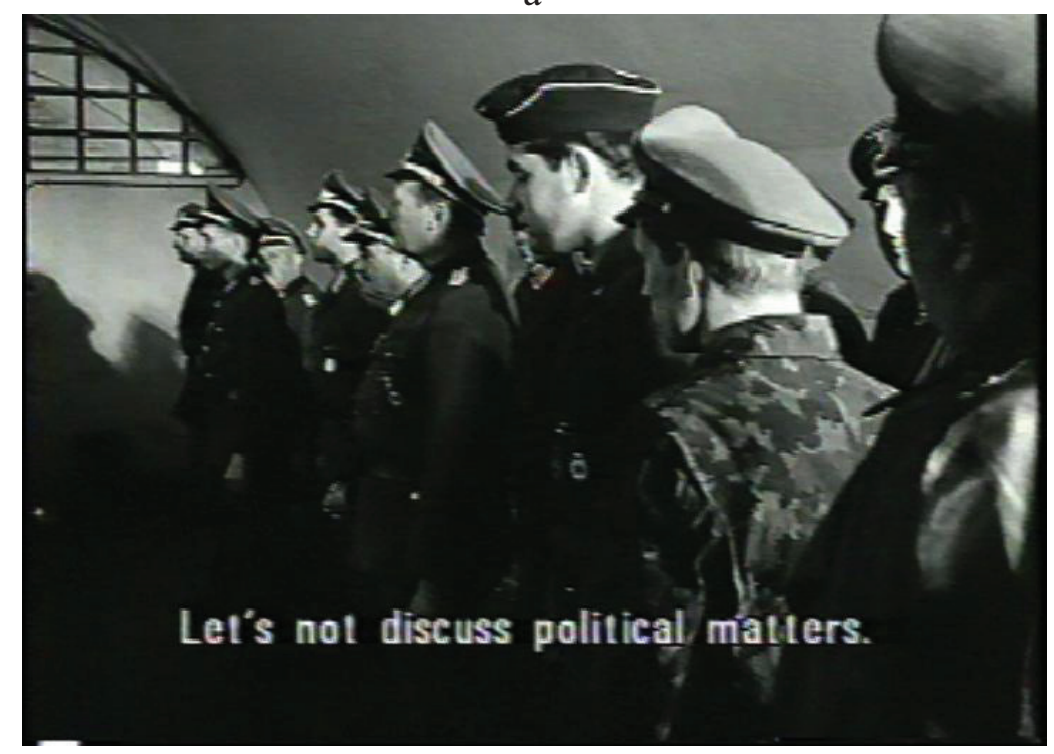

b

The people gathered in the cellar of the fortress embody the different strata of the future GDR's population and ideology: victims of Nazi aggression and (potentially reformed) servants of the Nazi war machine; German civilians who suffered the consequences of the Allied offensive, alongside a Jew returned from exile and a benevolent Soviet official. This scene in fact replicates a 
similar situation in Wolf's earlier film Sun Seeker, in which the East-German uranium miners gather in a tunnel to debate the rationale and the outcomes of their labor. The group of miners likewise includes several elements of the new GDR, from former Nazis and devoted communists to Holocaust survivors, intellectuals, and rebellious youth. Eventually, through the lengthy discussions of the merits of their work, these different elements merge to form a community united by shared ideals and morals (the Heimat thus becomes an ideal public sphere, in Habermasian terms, in which objectives and policies are openly discussed and decided [45]). Unlike the miners' ongoing debate, however, the encounter in the fortress portrayed in I was Nineteen ends without a political outcome that would bind the participants together despite (or because of) their differences. Symbolically, after the failure of the meeting the fortress is portrayed as a space that offers no hope for the future. In the following scene, a frantic young boy confesses to the savage killing of two Russian soldiers and wins a medal for bravery (implicitly, the SS officer who pins his own decorations on the boy exploits the occasion to rid himself of these incriminating insignia). Moreover, the SS officer who conspires to prevent capitulation sneaks away from the fortress to escape the consequences of his scheme. This ending of the scene does not merely subvert plain justice. It implies that any future society that evolves from the German catastrophe is likely to be founded by people like the escaped officer rather than by the obedient others, left in the fortress to die or to be expelled to POW camps in the Soviet Union. The final shot of this scene notably returns the viewers to the fantasy of a German landscape. As the SS-man escapes through the fortress's underground tunnels, Gregor watches him rowing away on the peaceful lake to vanish amid the trees and the fog.

\section{Conclusions}

I was Nineteen is Wolf's most elaborate attempt to envisage an alternative German identity, which would integrate 'foreign' elements through a shared vision and common objectives. The guiding principle of this film's imagery is to manipulate the cultural imagination associated with the notion of Heimat in the post-World War II German nationality. Heimat films played an important role in the nation building endeavor of the Cold War era in West and East Germany alike. The ideas associated with this imaginary sphere implied the existence of an authentic German identity, detached from the conflicts and catastrophes of the twentieth-century, which would facilitate the reconciliation of social tensions within a homogeneous community. An exiled Communist Jew, Konrad Wolf's identification with such a concept of community was always bound to be problematic. Yet Wolf was not a marginal or a subversive artist; he was a most prominent representative of GDR national culture, who fervently identified with what he interpreted as the objectives and ideology of the ruling socialist party.

Wolf's manipulation of Heimat symbolism provided a particular cultural context for his films, and transformed them from the realm of individual psychology to that of collective (German) identity. Through its ironic use of the audio-visual clichés of the Heimatfilm genre, I was Nineteen's imagery associates the horrors of German history with the longing for harmonious integration of old and new, and the nostalgic yearning to melt down different individuals into a ('natural') sense of homogenous collectivity. In a much cited essay on modern society, Georg Simmel characterized "the stranger" as an indispensible part of the modern environment that 
inevitably expresses "externality and contradictions" [46]; such characteristics were attributed often to the bourgeois urban Jew in pre-1933 Germany [47]. Wolf seems to be fascinated by this trope, but his "strangers" are elements in a post-bourgeois vision, of the kind (he believed to be) offered by the SED. Through the wry utilization of generic Heimat imagery Wolf envisioned an ideal socialist society, in which the acculturation of various "strangers" is the social norm.

More than any other German-Jewish film, I was Nineteen is a personal odyssey into the German community. It begins with Wolf's protagonist as an outsider who calls upon the Germans on the opposite bank of the river to surrender, and ends with Wolf's voiceover declaration, "I am German. I was Nineteen." This self-proclamation as German notwithstanding, at the end of this odyssey Wolf is not entirely at home. As throughout the film, he is now again in motion, driving away from the camera through the landscape, rather than residing in it. Thus, while Wolf openly regarded his Jewish origins as a matter-of-fact feature of his biography, and seemingly refused to enter the German cultural-intellectual discourse as a Jew, his contribution to this discourse explores the unique perspective of an inherent outsider who strives to be acknowledged as part of the collectivity despite, or perhaps because of, his otherness. Situated well within the tradition of German-Jewish film-making since the early 1920s [48], he therefore offers a distinctively "Jewish" sense of German nationalism, which encompasses (and is based upon) the idea of cultural and social symbiosis. In this regard, Konrad Wolf's perception of East German history is a unique demonstration of the way in which returning Jewish émigrés helped to shape German selfconsciousness during the formative years of the Cold War.

\section{References and Notes}

1. J. von Moltke. No Place like Home: Locations of Heimat in German Cinema. Berkeley: University of California Press, 2005, 6.

2. C. Applegate. A nation of provincials: the German idea of Heimat. Berkeley: University of California Press, 1990, 18, 77.

3. A. Confino. The nation as a local metaphor: Württemberg, Imperial Germany, and National Memory, 1871-1918. Chapel Hill: University of North Carolina Press, 1997.

4. T. Lekan. Imagining the Nation in Nature: Landscape Preservation and German Identity, 1885-1945. Cambridge: Cambridge University Press, 2004.

5. A. Bastian, Der Heimat-Begriff: eine begriffsgeschichtliche Untersuchung in verschiedenen Funktionsbereichen der deutschen Sprache. Tübingen: Niemeyer, 1995.

6. K. Wolf. Selbstaüsserungen. Sinn und Form 35:5 (1984): 897-900, here 900.

7. A. Kaes. From Hitler to Heimat: The Return of History as Film. Cambridge: Harvard University Press, 1992, 165-166.

8. A. Confino. The nation as a local metaphor: Württemberg, Imperial Germany, and National Memory, 1871-1918. Chapel Hill: University of North Carolina Press, 1997.

9. Waldenfels B. "Heimat in der Fremde." In Heimat: Analysen, Themen, Perspektiven. W. Cremer, A. Klein, Eds. Bonn: Bundeszenrale für Politische Bildung, 1990, 109-121.

10. A. Confino. "The Nation as a Local Metaphor", Heimat, "National Memory and the German Empire, 1871-1918" in History and Memory 5:1, Spring-Summer 1993, 42-85, here 58, 64.

11. C. Applegate. A Nation of Provincials, 1-19. 
12. J. A. Williams. Turning to Nature in Germany: Hiking, Nudism and Conservation, 1900-1940. Palo Alto: Stanford University Press, 2007, 219-257.

13. M. Umbach. German Cities and Bourgeois Modernism, 1890-1924. Oxford: Oxford University Press, 2009, 64-68.

14. T. Tönnis. Gemeinschaft und Gesellschaft: Grundbegriffe der reinen Soziologie. Darmstadt: Wissenschaftliche Buchgesellschaft, 1988[1887].

15. H. G. Pflaum. Film in der BRD. Berlin: Henschelverlag, 1990, 23.

16. T. Elsaesser. New German Cinema: A History. New Brunswick: Rutgers University Press, 1989, 141.

17. R. Rentschler. "Mountains and Modernity: Relocating the Bergfilm." New German Critique 51 (1990): 137-161.

18. H. Fehrenbach. Cinema in Democratizing Germany: Reconstructing National Identity after Hitler. Chapel Hill: University of North Carolina Press, 1995, 148ff.

19. A. Confino. Germany as a Culture of Remembrance: Promises and Limits of Writing History. Chapel Hill: University of North Carolina Press, 1996, 92-113.

20. J. von Moltke. No Place like Home; 170-202.

21. J. Palmowsky. "Building an East German Nation: The Construction of a Socialist Heimat, 1945-1961." Central European History 37:3 (2004): 365-399.

22. T. Lindenberger. "Home Sweet Home: Desperately Seeking Heimat in Early DEFA Films." Film History 18:1 (2006); 46-58, here 53ff.

23. G. Scholem. "Against the Myth of German-Jewish Dialogue." In On Jews and Judaism in Crisis: Selected Essays. W. J. Dannhauser, Ed., New York: Schocken Books, 1976, 61-64.

24. H. Arendt. "The Jew as Pariah: A Hidden Tradition." Jewish Social Studies 6:2 (1944): 99-122, here 99-100.

25. A. Funkenstein. "The Dialectic of Assimilation." Jewish Social Studies 1:2 Winter 1995, 1-14, here 10 .

26. S. E. Aschheim. "German History and German Jewry: Boundaries, Junctions and Interdependence.” Leo Baeck Institute Yearbook XLIII (1998): 315-23, here 320-321.

27. Samuel Moyn. "German Jewry and the Question of Identity." Leo Baeck Institute Yearbook XLI (1996): 292-308, here 295.

28. J. Zipes. "The Negative German Jewish Symbiosis." In Insiders and outsiders: Jewish and Gentile Culture in Germany and Austria. Dagmar C.G. Lorenz, Gabriele Weinberger, Eds. Detroit: Wayne State University Press, 1994, 144-154.

29. D. Diner. "Negative Symbiosis: Germans and Jews after Auschwitz." In Reworking the past: Hitler, the Holocaust, and the Historians Debate. P. Baldwin, Ed. Boston: Beacon Press, 1990, 251-61.

30. R. Ostow. "The Shaping of the Jewish Identity in the German Democratic Republic, 1949-1989." Critical Sociology 17:3, Fall 1990, 47-59, here 52-53.

31. K. Hartewig. Zurückgekehrt. Die Geschichte der jüdischen Kommunisten in der DDR. Köln: Böhlau Verlag, 2000, 286-293.

32. M. Richarz. "Jews in Today's Germanies." Leo Baeck Institute Yearbook XXX (1985): 126-30, 127. 
33. J. Herf. Divided Memory: The Nazi Past in the Two Germanys. Boston: Harvard University Press, 1997, 106-200.

34. G. Koch, and J. Gaines. "On the Disappearance of the Dead among the Living: The Holocaust and the Confusion of Identities in Konrad Wolf's Films." New German Critique 60. Autumn 1993, 60, 57-75, here 62.

35. K. Hartewig. "Die Loyalitätsfalle: Jüdische Kommunisten in der DDR.” In Zwischen Politik und Kultur. Juden in der DDR. Moshe Zuckermann, Ed. Göttingen: Wallstein Verlag, 2003, $48-62$.

36. M. Kessler. Die SED und die Juden-zwischen Repression und Toleranz. Berlin: Akademie Verlag, 1995, 119-120.

37. R. Guyonnet. "Etoile': Une Revendication bouleveresant de la vie Privée contre le siècle." L'Express. March 31960.

38. K. Wolf. "On the Possibility of Socialist Film Art: Reactions to Mama, I'm Alive (1977)." In German Essays on Film. R. W. McCormick, A. Guenther-Pal, Eds. New York: Continuum, 2004, 228-229.

39. Wolf's support for the Socialist enterprise is repeatedly manifested also in the 1985 published collection of his speeches, essays and interviews: D. Heinze and L. Hoffmann, Eds. Konrad Wolf im Dialog. Künste und Politik. Berlin: Dietz Verlag, 1985.

40. W. Teichmann. "Es geht um die Kultur des Gefühls." Fortsetzung der Diskussion über Einmal ist keinmal. Deutsche Filmkunst 5 (1995): 225-227.

41. M. Silberman. "Remembering History: The Film-maker Konrad Wolf." New German Critique 49, Winter 1990, 163-191.

42. S. Hake. "Political Affect: Antifascism and the Second World War in Frank Beyer and Konrad Wolf." In Screening War: Perspectives on German Suffering. P. Cook, M. Silberman, Eds. Rochester: Camden House, 2010, 102-122, here 102.

43. A. Bastian. Der Heimat-Begriff: eine begriffsgeschichtliche Untersuchung in verschiedenen Funktionsbereichen der deutschen Sprache (Niemeyer, 1995): 33, 42.

44. K. Schliephake and S. Orf. "Heimatbindung und -verständnis von Repräsentanten des öffentlichen Lebens.” Beiträge Region und Nachhaltigkeit 3 (2006): 89-102, here 97.

45. J. Habermas. The Structural Transformation of the Public Sphere. Translated by T. Burger. Boston: MIT Press, 1991.

46. G. Simmel. Sociology: inquiries into the construction of social forms. Volume 1; Brill, Leiden, 2009 [1908], 601-620

47. P. Mendes-Flohr. "The Berlin Jew as Cosmopolitan." In Berlin Metropolis: Jews and the New Culture, 1890-1918. E. D. Bilsky, Ed. Berkeley: University of California Press, 1999, 14-21, here 21-22.

48. Compare with O. Ashkenazi. Weimar Film and Modern Jewish Identity. New York: Palgrave-Macmillan, 2012, 1-15. 
Reprinted from Religions. Cite as: Lang, B. Haunted Encounters: Exile and Holocaust Literature in German and Austrian Post-war Culture. Nutrients 2012, 3, 424-440.

Article

\title{
Haunted Encounters: Exile and Holocaust Literature in German and Austrian Post-war Culture
}

\section{Birgit Lang}

School of Languages and Linguistics, The University of Melbourne, Parkville 3010 VIC, Australia; E-Mail: langb@unimelb.edu.au

Received: 2 May 2012; in revised form: 11 May 2012 / Accepted: 12 May 2012 /

Published: 14 May 2012

\begin{abstract}
In an essay titled 'The Exiled Tongue' (2002), Nobel Prize winner Imre Kertész develops a genealogy of Holocaust and émigré writing, in which the German language plays an important, albeit contradictory, role. While the German language signified intellectual independence and freedom of self-definition (against one's roots) for Kertész before the Holocaust, he notes (based on his engagement with fellow writer Jean Améry) that writing in German created severe difficulties in the post-war era. Using the examples of Hilde Spiel and Friedrich Torberg, this article explores this notion and asks how the loss of language experienced by Holocaust survivors impacted on these two Austrian-Jewish writers. The article argues that, while the works of Spiel and Torberg are haunted by the Shoah, the two writers do not write in the postAuschwitz language that Kertész delineates in his essays, but are instead shaped by the exile experience of both writers. At the same time though, Kertész' concept seems to be haunted by exile, as his reception of Jean Améry's works, which form the basis of his linguistic genealogies, shows an inability to integrate the experience of exile.
\end{abstract}

Keywords: Friedrich Torberg; Hilde Spiel; Jean Améry; Imre Kertész; exile literature; post-war era; Auschwitz; Holocaust literature

\section{Of Exile and Holocaust literature}

In a recent keynote address, the distinguished Holocaust historian Yehuda Bauer insisted on maintaining the historical contingency of the term Holocaust, and voiced his concern about comparing the exile experience to the Holocaust, arguing that he himself-although he had fled from National Socialism in Czechoslovakia with his parents-was not a Holocaust victim [1]. At the same time, parallels in the representation of exile and the Shoah do exist. The sense of 
insecurity created by the "Garden of Exile" in the Berlin Jewish Museum, designed by Daniel Libeskind, an American architect of Central European Jewish descent, for example, is intended to represent the exile experience of German Jews who fled after the rise of National Socialism [2]. In the "Garden of Exile", visitors stand on an uneven floor below the surface of the outside world, trapped in a labyrinth of skewed pillars, which make the surrounding buildings outside appear tilted. A comparable discombobulating experience is also created in the works of Nobel Prize winner Imre Kertész, when he develops his genealogy of Holocaust and émigré writing in two essays titled "The Exiled Tongue" and "The Freedom of Self-Definition" (2002) [3]. While for Kertész, the German language before the Holocaust signifies intellectual independence and freedom of self-definition (against one's roots), the trauma of the Holocaust resulted in the loss of language for the surviving writers. Kertész argues that survivors were confronted with severe difficulties in the subsequent post-war era-not only in Germany and Austria. They remained outsiders speaking a borrowed, post-Auschwitz language - even when writing in the national language of their home country [4]. In "The Exiled Tongue", Kertész uses this notion of a borrowed language to illustrate the distance of Holocaust writers from the respective societies they lived in, and develops a genealogy of Holocaust writers, including Paul Celan, Primo Levi, Tadeusz Borowski and Jean Améry. In "The Freedom of Self-Definition", Kertész furthermore situates his own writing in a wider tradition of Central European Jewish literature, including writers who did not write in the language of their national literature such as Franz Kafka. The home of such an émigré language, which closely resembles Gilles Deleuze's and Félix Guattari's concept of a minor language [5], Kertész argues, always remains fragile, and can only survive, if another big language, like contemporary German, is willing to embrace it—for a time. Kertész' model seems haunted, and shifts between times and places, the literary realm, historical narrative and (auto-) biographical experience - its logic as palpable as its contradictions. By leaving the reader with an elusive image of the émigré and post-Auschwitz tongue that is just outside his or her grasp, the texts embody the very condition/s they describe.

If this article engages in the ways in which exile and Holocaust literature are haunted by one another, it is not to question the historical difference between having escaped through exile and having survived in a concentration or death camp, but rather to investigate the ways in which exile and the Holocaust are represented by four acculturated and assimilated Jewish writers. The article will explore the selected works of two survivors, Kertész and Jean Améry, and two returned exiles, Hilde Spiel and Friedrich Torberg, and submits that in the post-war world, exile and Holocaust literature are haunted by one another, and that these narratives seem distinct and entangled at the same time.

According to Jacques Derrida, the concept of hauntology inherently embeds the realm of the past in that of the present as the ghosts of the past return to haunt us [6]. Such hauntings have been used both in trauma studies and in literary studies in an attempt to describe the lingering aftereffects of violence on its victims, which can be seen in the biographies of all the writers discussed in this article [7], and the textual instability that "makes[s] it impossible to assign meanings to things" [8] — best represented in Kertész' fluid concepts of post-Auschwitz and émigré language. Applying Kertész' concept of a post-Auschwitz language to the works of Torberg and Spiel exposes how their literary works were haunted by the Holocaust, but at the same time shaped 
by their own exile experience. Reading Kertész through his reception of Austrian exile and Holocaust survivor Jean Améry in turn reveals how Kertész reinterprets Améry’s position as both an exile and a survivor. The central site of haunting then remains the way in which the post-war representations of two distinct, but closely related historical experiences (exile, Holocaust), remain informed and haunted by one another.

A short introduction to the writers at the heart of this study: Kertész, born in 1929, who describes himself as a "chronicler of an anachronist condition, that of the assimilated Jew [9]", was deported to Auschwitz in 1944 from his native Budapest, still a youth, and later sent to Buchenwald and Zeitz; his father had previously been forced to join a compulsory labour squad and died during a death march. While his maternal grandparents were killed in the Holocaust as well, his paternal grandparents perished under the communist regime [10]. After the war, Kertész worked as a journalist, playwright and translator of German literature and philosophy in Hungary. Fatelessness, the first of his many novels, was published in 1975, and he eventually received the Nobel Prize for literature in 2002. The other writers in question differ from Kertész in nationality and generation, and show distinct biographical parallels with each other, having been born in Austria within half a decade (1908, 1911 and 1912) into assimilated and acculturated Jewish families. Jean Améry (1912-1978) was born in Vienna as Hans Maier, his father Paul fell in battle in WWI, and Améry moved to Bad Ischl with his mother, who opened a boarding house there to sustain the family. Améry's first literary publications stem from the late 1920s. In the 1930s he worked as a bookseller in Vienna, while starting his studies at the University of Vienna, attending the salons of Moritz Schlick and Karl Bühler, like Hilde Spiel a few years later [11]. Améry escaped to Belgium in late 1938 with his wife Regine Berger-Baumgarten. After the German invasion of the Netherlands and Belgium in May 1940, he was first interned in France, in the Camp de Saint-Cyprien and later at Gurs, from where he escaped to Brussels. He joined a small subgroup of the Belgian resistance, but was caught and subsequently tortured. Eventually identified as Jewish by the German authorities, he was deported to Germany in January 1944, first to Auschwitz, then to Buchenwald and Bergen-Belsen. After his liberation, and upon his return to Belgium, he learned that his wife had died of heart failure in 1944, while in hiding in Brussels; his mother had died in hospital in Vienna in 1939 [12]. After the war, Améry wrote mainly for Swiss newspapers, but remained in Belgium. His first major post-war work, At the Mind's Limits, was originally broadcast as a series of radio essays in Germany, and eventually published in 1966, and would become the foundation of a successful career as a public intellectual and writer in the German-speaking world [13]. Despite this, Améry never returned to live in Austria or Germany, and remained highly critical of anything that could be interpreted as a symbolic appropriation by either state [14]. Only for his last journey — he committed suicide — did he return to Salzburg.

In comparison to Kertész and Améry, Spiel and Torberg survived WWII relatively unscathed, since neither of them was interned during the war. Spiel (1911-1990) came from a relatively privileged background and had been a pupil at the renowned Schwarzwald reform school. Her debut novel Katie auf der Brücke was published in 1933, the same year she joined the Social Democratic Party, which would be declared illegal just one year later. At university she studied philosophy and worked for the Research Centre for Economic Psychology during her studies. Spiel already left Vienna in 1936 because of the worsening political climate, having received her $\mathrm{PhD}$ 
and married the German writer Peter de Mendelsohn, who accompanied her to London, in the year of her exodus. She worked as a journalist for both English and - after the war-German newspapers, and published several fiction and non-fiction books on Austrian and Jewish history. Spiel commuted between Berlin, London and Sankt Wolfgang until 1963, before settling in Vienna permanently, where she continued to publish both critical and creative works, and would play an important role in fostering a young generation of Austrian writers [15], among them Thomas Bernhard and Ingeborg Bachmann [16].

Torberg's escape route was more long-winded than Spiel's, Prague, Zurich, Paris, Lisbon and finally New York and Hollywood. Torberg (1908-1979) had been born in Vienna and had grown up in an observant middle-class Jewish family [17]. In 1920, after his Bar Mitzvah, he left with his family for Prague only to return in 1927. With the success of his first novel Der Schüler Gerber absolviert (1930) he was widely accepted in the literary circles of Prague and Vienna [18]. After his return from American exile in 1951, Torberg became one of the founders of the anti-communist journal FORVM, and was chief editor from 1954 to 1965 . FORVM, which was financed by the CIA-supported Congress for Cultural Freedom, formed an important platform for intellectual debate in post-war Austria [19,20]. Torberg, however, was not only a Cold Warrior, but published several novels during and after WWII, which all engaged with Jewish life, and was also wellknown as the German translator of the works of Israeli writer Ephraim Kishon.

\section{A post-Auschwitz language? Friedrich Torberg and Hilde Spiel}

Although Torberg and Spiel were not Holocaust survivors, both lost close family members in the Holocaust: Torberg lost his mother and his oldest sister (his younger sister Ilse Daus escaped to Palestine) [21], while Spiel lost her maternal grandmother [22]. Spiel, furthermore, blames the strains of exile for having killed her father "more slowly and less brutally, but just as definitely as a German concentration camp" [23]. The return to their former homes was not easy for either of the writers. Spiel was the first to put her feet on Austrian soil: she did so as a journalist and "belated war correspondent" for the London New Statesman [24], reporting both on her return to Vienna and the state of the DP camps in Carinthia in 1946. In a letter to her husband in Berlin, she describes the raw emotions surfacing more intensely than she had predicted and the sense of security she obtains from socializing with the British soldiers in Vienna [25]. Even if Spiel was gradually able to feel at home in Austria again after her return, she would reflect on her decision to return in her writings for the rest of her life, highlighting the fact that despite her success she continued to feel alienated from the Austrian population in some respects, which mourned the lost war while she rejoiced that it had been won [26]. Torberg had a similar emotional response to his return in 1951. Even though he could not see himself living anywhere else than Vienna, he continued to be haunted by wartime loss, as encapsulated in the last line of his poem Return from 1951: "But wherever I go, the dark garments of the dead fly around me [27]".

Spiel and Torberg were more aware than other members of Austrian society of the impact and devastation of the Shoah on post-war Germany and Austria. They never felt entirely comfortable upon their return to Austria and would keep their foreign citizenships for the rest of their lives. But did they write in what Kertész calls a post-Auschwitz language? After all both writers were able to forge successful careers for themselves in post-war Austria, and engaged in fierce political debates, 
not always sparing one another: Spiel criticized Torberg's very outspoken anti-communist stance, while Torberg accused her of being a fellow traveler. These public debates highlight, on the one hand, the pressures returned émigrés were under, but, on the other hand, the public nature of this debate also shows their status as prominent members of post-war cultural life [28-31]. While they were aware that the course of their lives had been altered, they did not have to rebuild their lives based on their camp experiences; in other words they did not become a 'medium of Auschwitz' —as Kertész puts it [32] —in that their whole existence was defined by past events. However, as authors of fiction and autobiographical accounts, their work, at least in large parts, revolved around the impacts of the Shoah on German and Austrian cultural life.

In the case of Torberg, such an assessment stands somewhat in contrast to secondary literature which often highlights his involvement in Cold War post-war politics, and his ostensible complicity in (unwittingly) supporting the mantle of secrecy that defined Austria's (not) coming to terms with the past in the 1950s and 1960s. According to Scheichl, Torberg's anti-communist stance in FORVM was detrimental to such matters, since large parts of the Austrian resistance to National Socialism in Austria had been carried out by members of the communist party, who also remained vocal in the post-war era [33]. Like Marcel Atze, he praises Torberg's rare satirical attacks on the Austrian judicial system in the context of the trial against former SS officer Franz Murer, also known as the "Butcher from Vilnius", or his support of the Eichmann trial. However, both commentators agree that Torberg could have done and said more [34]. Only when it came to the Shoah, Scheichl further adds, did Torberg's emotions ever overrule his political stance [35]. This split, however, into a 'conservative' and an 'emotional' Torberg falls short of acknowledging that the writer was on the whole a very passionate person, and that his Cold War enthusiasm could also be seen as an emotional reaction against Soviet anti-Semitism [36].

As a writer of fiction, Torberg found himself in a complex situation. He could not see himself living anywhere else than in Vienna [37], though he could have remained in the United States if he had seen a life for himself there. According to his own appraisal, he had mastered the English language "with ease" [38], but he only had very limited literary success in the United States, which he blamed on the working conditions in the film industry. His awareness of the political situation in Austria while in exile becomes obvious in his novels. In Auch das war Wien, published only in 1984, but written in 1938 or 1939, he already described anti-Semitic riots after the annexation. Mein ist die Rache (1943) is set in a concentration camp and features rabbinical candidate Joseph Aschkenasy, who can only free himself from the camp, if he shoots the KZ-commander, but eventually comes to regret his deed. In Hier bin ich, mein Vater (1948) the central character, Otto Maier, is a Jew who worked as an informant for the Gestapo in order to save his father, and only in the end understands the futility of his efforts (for summaries of Torberg's further works see $[39,40]$ ).

After his return to Vienna, however, the author Torberg fell silent for nearly 20 years, which in secondary literature - relying on Torberg's own testimony - is usually explained through his involvement with FORVM and his active engagement in Austrian post-war cultural and intellectual life [41]. But maybe, there was not so much that Torberg felt inclined or was able to say? Kertész argues that in the case of Holocaust survivors it takes a very long time, before they are-if at all-able to express themselves, and can regain their personal and authentic voice [42]. A collection of stories titled Golems Wiederkehr (1968), which also reprinted his earlier story 
Mein ist die Rache, represents Torberg's first attempt at a literary response to the Shoah after his return. In the eponymous story, Torberg combines the Golem myth with the history of the National Socialist Central Jewish Museum in Prague. He retells the miraculous prevention of the planned National Socialist torching of the Prague Altneuschul, where the Golem presumably rests, in anecdotal form, and intimates that the fact the Altneuschul survived unscathed was uncanny. Such an anecdotal style, however, which was for Torberg the essence of Jewish storytelling, was hard to maintain in the face of the enormity of the Shoah, and Torberg turned to the Middle Ages for his novel Süßkind von Trimberg (1972), which gives a fictional account of the life of the first documented Jewish poet of the German language. The life of Trimberg, who is first celebrated and then expelled, is a clear allegory for German-Jewish symbiosis and its tragic destruction.

It is only in his most popular work, Die Tante Jolesch oder Der Untergang des Abendlandes in Anekdoten, first published 1975 [43], however, that Torberg's anecdotal style comes into its own. This "book of melancholy", as he terms it in the introduction [44], contains, like the follow-up volume Die Erben der Tante Jolesch [45], a series of anecdotes, through which Torberg aims to (re-)create a lost past. While denying the nostalgic character of his undertaking in his introduction, and thus preempting his critics, a strategy often used by Torberg [46], he mourns the decline of an era and of the Habsburg middle-class. In order to make this retrospective view convincing, and to make it possible for Torberg to function as a witness - after all he was only ten years old when the monarchy ended-, he needs to construct a specific temporality, which "extends" the Habsburg empire until the annexation of Austria, ignoring the political frictions and any debate of the role of Austro-fascism. His anecdotes introduce the reader to a series of eccentric figures, unfit for the societies of the post-war era, who are distinguished by their peculiar sense of humor, ripe with self-irony and characterized by an inverse logic, which for Torberg were key features of Jewish humor [47]. It is this sense of humor that all characters in Tante Jolesch share, no matter if they are Jewish or not, and in this sense all citizens of Torberg's visionary Habsburg Empire seem Jewish.

Rather than engaging in a political debate about justice or restitution, the book conveys a sense of loss, and names National Socialism as the ultimate reason of the demise of this "extended" Habsburg Empire. At the same time, Torberg does not represent the crimes committed during the Shoah, although its presence is not far from the anecdotal surface. In a fairly comical story, Torberg describes a quarrel between his favorite uncle Paul and another Uncle:

"Uncle Paul was a lieutenant with the Deutschmeister. Uncle Bertie, with full name Albert Grossmann and husband of my mother's older sister, was a major in the same regiment. And suddenly Uncle Bertie jumped up, slapped the table with his hand so that the dishes rattled, and screamed at Uncle Paul with a voice trembling with anger, moustache tips bristling: 'Herr Lieutnant, how dare you?' and yelled a lot more that I did not understand. All I saw from the children's table was that Uncle Paul stood up - red-faced - and remaining standing until Uncle Bertie sat down again. Conversations amongst adults, who discussed the incident for days, helped me work out for myself that Uncle Bertie had made Uncle Paul stand at attention. The whole thing seemed scary and funny to me at the same time. Should the, probably very lengthy, book What Jews are Capable Of ever be finished, this episode cannot be left out [48]". 
Much could be said in this context about the importance of the Habsburg military for unifying the empire, and the ways in which it both undermined and perpetuated ethnic rivalries; or about the glass ceiling Jews encountered within this institution. What remains unsaid by Torberg though, is the fact that his favorite uncle was killed in the Holocaust [49], and that this story was an act of remembrance, not of the useless death of his favorite uncle, but of his life. Only after the success of Tante Jolesch did Torberg talk about the fate of his family in public [50]. For his mainly non-Jewish readers, the quirky and memorable characters created a possibility to relate to a Jewish past in a post-Holocaust society, the people close to him would have understood the personal meaning this work had for Torberg.

How does Torberg fit into the model suggested by Kertész? Torberg's strict adherence to the anecdotal form does not represent the break with literary traditions that Kertész associates with a post-Auschwitz language. Additionally, Golems Wiederkehr and the Trimberg-novel attempted to create a historical continuum of European anti-Semitism starting in the Middle Ages and culminating in the Shoah. In the Golem story, the comparative nature of the anecdote undermines the notion of the Shoah as an absolute caesura, as the German-Jewish literary critic Marcel Reich-Ranicki also suggested in a review of the Trimberg novel [51], for Kertész a prerequisite for post-Auschwitz language. Additionally, Torberg felt not so much that he was writing in a guest language in the post-war period, but instead that he was the only representative left who spoke a language at the brink of extinction. This becomes obvious in a letter to Max Brod from 1955: "I am a German-Jewish writer that means a Jew writing in German, I have always known, that that is what I am, and, if anything, since then the knowledge has increased that I most likely will be the last (...)" [52]. At the same time there is a shift in Torberg's writing pre- and post-exile. The four novels before his expulsion did not engage with Jewish topics as such, but with school life, sport and love. It is during his American exile that Jewish issues are raised in Torberg's fiction, the turn to the anecdote in this context could be compared to the formalist turn in exile poetry-poets shying away from modernist literary experimentation and returning to sonnets and other more classical forms - and was born out of a communicative practice of commemoration. Torberg and his close circle of friends not only preserved nostalgic memories of a lost coffee house culture, but also commemorated friends killed in the Shoah-just as he would commemorate his uncle Paul in Tante Jolesch [53]. The depiction of the consequences of the Shoah consequently was based on a model developed in exile; an argument that could be extended to his anecdotal style in the post-war era.

The discussion of Jewish history and culture in the German-speaking world, and the pained swansong of Central European (Jewish) Culture also resonates in Spiel's work, even though she refused to identify as Jewish [54]. Jacqueline Vansant has pointed out, that the "story of Jewish assimilation allows Spiel to highlight the contributions of Austrians of Jewish heritage [55]". Spiel's work includes a biography of Fanny von Arnstein (1962), which discusses the complexities of German-Jewish emancipation. In her historical works, she depicts the Austrian character, and in Vienna's Golden Autumn (1866-1938) (1987) she specifically highlights the contribution of Austrian Jews to the development of Vienna's rich culture and, implicitly, its loss. Unlike Torberg, Spiel does not situate any of her stories in a concentration camp or deal with the Shoah directly, instead snippets of information are embedded in her exilic tales, and the Shoah influences the underlying context of her explorations. This is the case in Anna und Anna (1988), a film script that 
dramatizes the parallel lives of the main character Anna, a liberal to left-leaning middle-class young woman, who has one Jewish grandmother, like Spiel. After the annexation of Austria, two versions of the same life are given, with Anna I remaining in Austria and Anna II leaving Vienna for London. In this late, and maybe most conciliatory of Spiel's works, the plight of Viennese Jews is mentioned once as part of Anna I's story, when a group of dissident artists and intellectuals who oppose but do not actively resist the regime learn of a grossly anti-Semitic speech of the infamous Reichstatthalter of Vienna, Baldur von Schirach. In this speech, Schirach, who is renowned as a friend of the arts, claims to have made the biggest contribution to European culture by ensuring that the remaining Jews of Vienna would be deported [56]. When challenged by his subordinate Thomas Walter, an associate of the dissident group, who points out that the Viennese artists would never forgive him, Schirach denigrates them as naïve and not understanding the needs of politics. After Thomas' account to the group, Anna points out Schirach's cynical approach, but her comment is perceived as insolent by the other group members, and she is objurgated by her partner who finds her remark incautious considering Thomas works for Schirach, to which Anna replies that they all do - including herself [57]. While the deportation of Jews does not play a central role in the film script, this scene highlights how artists and intellectuals also become complicit with the regime, not least by perpetuating a culture of fear and social control even amongst themselves.

Anna und Anna was one of Spiel's last comments on her own ongoing crisis of homecoming, which permeated her writing in the post-war period after her return. With the exception of Anna und Anna, her texts engaging with this topic remained autobiographical and depicted a self-attested schizophrenia contemplating the impossibility of living in two countries at once, and at the same time questioning her choice, i.e., her return to Austria. Reich-Ranicki summarized this stance critically as "wanting to have her cake and eat it too" [58]. While her treatment of the topic of homecoming after her return sometimes has nostalgic moments and represents an idée fixe, her novel The Darkened Room (1961) published in English shortly before Spiel's return to Austria - the German version titled Lisas Zimmer was published after her return - seems the most innovative of her treatments of the topic. It is characterized by what Kertész would call an atonal voice, a narration that challenges the reader, asking questions and allowing for a new representation of the past.

The story is set in post-war New York, and narrates the demise of its main character, the ageing, but still attractive femme fatale Lisa, who despite being married to an American, mainly surrounds herself with German and Austrian exiles. Having lived a glamorous life full of sex and drugs, she is homesick for Vienna but in order to finance her drug addiction and to support friends and lovers, sells off piece after piece out of her trunk of valuable European collectables. Her tragic story, symbolizing the demise of Europe, is predominantly narrated through the eyes of Lele, a former Lithuanian DP, whose parents were killed during the war and who first worked as a maid for a National Socialist German family, then after the war for the family of a British officer, and then for the Langendorfs, a Viennese émigré psychoanalyst couple in New York. She then starts working for Lisa and her husband Jeff. Her engagement with her new employers starts on good terms, however, by the end - the novel is written from a retrospect perspective - she has adjusted so "well" into the family that she not only shares Lisa's past lovers, but also her husband.

For Dagmar Lorenz, who judges Lele's character quite harshly, the competitive relationship between the two women symbolizes the conflict between humanism and fascism, with fascist thought 
disseminating internationally in the post-war era [59]. However, Lisa's downfall, like that of the Europe she symbolizes, starts long before fascism, as becomes obvious when Lisa expresses her homesickness for the Vienna of her youth: "No one but us knew what it meant to grow up in the ashes of an empire [60]". For Lele, the introduction to this exilic Europe remains a quite ambivalent encounter [61]. Not only is she sexually harassed by a writer, the seething emotions that erupt when Lieutenant Kline, formerly Klein, reports on the situation in post-war Berlin, and his momentary sympathies for the communist regime that killed her parents, shock her deeply. If, at the beginning of the narration, she had stated in her depiction of the DP camps that the Jewish survivors had only wanted to go to Palestine, since for them Europe represented a graveyard [62], she now describes the exiles as "with few exceptions, figures from afar and from the past, symbols of death and the obsolete, lemures on a graveyard, but nonetheless impressive in a macabre kind of way [63]".

Spiel thus has her prejudiced and emotionally involved homodiegetic narrator voice a view of exile, which highlights both its enduring character and the futility of exile from a post-war perspective. After the end of the war, the exiles remain stranded, still caught up in a past, they are not willing to forget, but at the same time without the possibility of return, due to geographical distance and the passage of time. An escape seems impossible, and compromise remains the best alternative: Lisa's marriage to Jeff, the commodification of the past-symbol both for the American lust for historical objects and the involuntary role of the exiles as executors of their own estate- - the warped attempts of assimilation. Rather than committing suicide, Lele aims to escape by marrying an American and moving as far West as possible. However, the reader can assume that her attempt to forget her past will be futile, after all she still has the urge to tell the story, which remains unresolved, and is unable to genuinely reflect on her own behavior and experience [64].

Like in Anna und Anna, the Shoah is only discussed in passing: Lieutenant Kline's fiancée was murdered in the gas chambers, and Lele's observations of Holocaust survivors confirm her desire to escape from Europe. While the devastation of the Shoah forms the underlying frame work for all of Spiel's exilic tales, it seems that with Lisa's Zimmer — written shortly before her own returnshe was able to create a destabilizing narrative that was more complex than her later elaborations on the topic. Similarly to Torberg, the return to Austria left her speechless for a time, which might not only have been a result of the unwillingness of the Austrian public to engage with works dealing with the National Socialist past, but also with her own adaptation process [65]. Kertész' verdict that writing in the post-war era remained hard holds true then, and it seems for Torberg and Spiel the loss of language that Holocaust survivors experienced in the post-war world did to a degree apply to them upon their return. While neither writer wrote in what Kertész calls a post-Auschwitz language, their work was not only defined by the experience of exile but also haunted by the Shoah.

\section{Imre Kertész, Jean Améry, and the Ghosts of Exile}

If Torberg and Spiel were not able to write in a (metaphorical) post-Auschwitz language, the question arises, what would such a language look like? To investigate this issue more closely, it is necessary to scrutinize Kertész' own terminology in more detail. Kertész develops the term in a series of literary associations arguing that, after Auschwitz, the languages, i.e., societies, in which survivors lived, either did not come to terms with their past, and swept the memory of the Shoah 
under the carpet, or victimized survivors yet again [42]. He contrast this with an authentic language, that only few survivors were able to develop, a language, however, that eats its children as all of the writers cited by Kertész committed suicide, as he notes [32]. While writers-and Kertész states as much-love the actual language they write in [66], in a post-Auschwitz language this actual language, i.e., German or Hungarian, can only function as a medium, as a borrowed or guest language that might tolerate interlopers and grant them asylum for a time [67]. The terrible and privileged post-Auschwitz language, however, is only accessible to a select few, survivors. Considered in the context of Kertész' wider goal to develop a culture of the Holocaust, which is directed towards Wiedergutmachung, while being aware of its impossibility [68], the function of such a post-Auschwitz language is to commemorate a select group of writers and strengthen their voice.

This idealized and skewed view of a post-Auschwitz language is contrasted by Kertész with an émigré language that is portrayed as the home of Eastern and Central European Jewish literature. According to Kertész, the latter was never written in the language of the immediate national environment - this is somewhat contradicted by such obvious examples as Arthur Schnitzler and Sigmund Freud, but also Torberg and Spiel-and was written in a language that can never be considered a native tongue; in other words the outsider status is engrained in its very definition. With some allowances, such a language could form the home for all four writers discussed here. In developing the model for his post-Auschwitz and émigré language model, Kertész draws heavily on an admired speaker of the post-Auschwitz language, namely Jean Améry and his ground-breaking essay "Wieviel Heimat braucht der Mensch?", "How Much Home Does a Person Need?" in English. It is this intertextual connection, which will be central to understanding how exile haunts the Shoah in the post-war period [69].

In his essay, Améry makes a distinction between "normal" homesickness and the homesickness of refugees, and argues while migrants mourn the loss of their country, the Jewish exiles from National Socialism had additionally lost their sense of belonging to a people, which rejected them, as well as their language [70]. This loss of language has been addressed by many exile writers, including Anna Seghers [71] and Peter Weiss [72]. Améry's examination of the issues of Heimat, which is based on his own (exile) experience, contains an eerie description of the impacts of National Socialism on the language of his fellow émigrés and the peculiar nature of their homesickness. Some exiles, Améry points out, refused to engage with the new German language crafted in the National-Socialist state, arguing that they were the original keepers of the German language, but they, according to Améry, spoke a language that was growing old. In an attempt to bridge this gap, he and some other fellow exiles read the 'Brüsseler Zeitung,' the Belgian National Socialist organ. While this did not ruin his language, it also did not allow it to evolve: "For I was excluded from the fate of the German community and thus from its language." Not unlike Spiel, he argues: " Enemy bombers, fine, but for me these were the German bombers that were laying the cities of England in ruins, and not the flying fortresses of the Americans, which were attending to the same business in Germany [73]". This led to an irreversible self-alienation, although, argues Améry, this was not necessarily obvious at the time, but rather the notion grew gradually and was furthered by the fact that so much of National Socialist terminology remained part of the post-war German language [74]. 
Consequently, Améry's relationship to the German language was deeply ambivalent. He viewed it as a Feindheimat, since "words were laden with a given reality [70]", forming the basis for the concept of self-alienation that was crucial for his philosophical interrogations in the post-war world. When Améry speaks of a language, he means an actual language. Unlike Torberg, Améry never aimed to reinvent or even commemorate the language of yesterday, although he publically appreciated Ingeborg Bachmann's use of a German no longer spoken [75]. His conflictedness about his decision not to become a French writer after 1945-somewhat comparable to Spiel's inability to find an answer to the question of where to live-haunted him until the very end [76]. For Améry, the post-war solution to the self-alienation he experienced was inherently political: "The only therapy could have been history in practice. I mean the German revolution and with it the homeland's strongly expressed desire for our return. But the revolution did not take place, and our return was nothing but an embarrassment for our homeland, when finally the National Socialist power was crushed from without [77]".

What becomes apparent, is that for Améry the beginning of the existential crisis, which Auschwitz was to become for him, was the expulsion from Austria, and that the homelessness of exiles and survivors could have been addressed and eased on a political national level after the end of WWII. We can assume that Torberg and Spiel would have agreed with this verdict, although the specific visions such a solution might have entailed would have looked different for the three writers, considering the political tensions between Spiel and Torberg already mentioned.

With the knowledge of hindsight, Kertész however points out that the downfall of the political, caused an ongoing disillusionment, which left most survivors and exiles with a sense of profound loneliness. In the freer, i.e., non-totalitarian, post-war societies, the flood of disappointments resulting from the fact that the catharsis many surviving intellectuals and philosophers had built their hopes on, did not take place the way they imagined, drove some survivors into further despair [78]. In a comment on his own resilience, he argues that the very continuity of self-denial in his life, be it in the Hungarian "humanist" (i.e., with a focus on classics) high school that taught Jewish pupils separately, to the Shoah to the Stalinist regime in Hungary, had helped him to develop his individual language [79].

When it comes to language, Kertész shifts Améry's concept of self-alienation to that of self-denial, and refers to the language of survivors (or émigrés) rather than exiles. By making Améry the privileged speaker of an exclusive language, Kertész expresses his appreciation and furthers Améry's literary esteem. He reacts to Améry's political disillusionment, and gives him a home in the world of literature. But just as the Shoah haunts exile literature, exile also haunts Kertész model of post-Auschwitz. Even when Améry accepted Auschwitz as the defining moment of his literary life — he rarely mentioned his budding pre-war literary career [80]—, his notion of self-alienation was grounded in the exile experience. That he, Spiel and Torberg belonged to a community of sorts, despite their different experiences, was understood and becomes apparent in the exchange of letters between Spiel and Améry [81], in the latter's, fairly critical, review of Torberg's debut novel Der Schüler Gerber [82], and perhaps best in an incident he described to his life-long friend Ernst Mayer in a letter. In it Améry commented on a radio discussion he had participated in with Torberg and Hans Egon Holthusen, an influential German intellectual and former Nazi and SS officer. In the debate, Améry argued that there was no such thing as a rightist intellectual, and he expresses 
slight surprise that he was met on friendly terms by Torberg, who had seemed somewhat dazed:

"He obviously seemed displeased that he had to oppose an Auschwitzer [Auschwitz survivor] [83]". Even if the political distance between Améry and Torberg was substantial, in this context they called a truce based on a common understanding of the past.

For Améry the notion of a post-Auschwitz language would have undoubtedly had a political character, its implications used for contemporary politics. Nearly forty year after the publication of Améry's essay, the fall of the wall, and a lengthy process of coming to terms with the past in Germany and Austria, the situation presents itself differently to Kertész. While his post-Auschwitz language transcends linguistic boundaries, it cannot find a way in which to contain the German and Austrian exile experience. Kertész' concept of an émigré language is more likely to embed the exile experience, however, his implicit reference to Guattari and Deleuze and the insistence on the foreign language environment as prerequisite at this point excludes not only Schnitzler and Freud, but also Torberg and Spiel.

\section{Conclusions}

While the writers in this article were all affected by, and wrote about, the events of the Second World War, their depictions of exile and the Holocaust seem both specific to one experience and at the same time haunted by the other. The works by Spiel and Torberg reveal that at least in the case of these two writers the return to Austria coincided with a hesitation to embrace more radical modernist forms of narration and/or to engage with the Holocaust in a more probing way. Further studies would need to reveal, if this was solely an effect of living in a society that had not yet come to come to terms with its past, or if the personal wish for return left the writers conflicted between the need to reintegrate and the wish to speak up. That such hauntings are defined by the author's biography can be seen in all four cases, most poignantly maybe in Kertész', who remains bound by the Holocaust experience even three decades (and more) after the publication of Spiel's and Torberg's work discussed in this article. However, also his notion of the émigré language offers strong parallels to his own biography. As a translator of German works into Hungarian, and as a Hungarian writer living in Berlin, he functions as an exemplar of his own theory. This would explain why he does not explicitly extend the linguistic inclusiveness of his concept of a post-Auschwitz language to that of the émigré language, while at the same time appropriating Améry's notion of language crisis, which the latter developed from his specific positionality to allow a more integrated account of the exile and the Holocaust experience.

\section{References and Notes}

1. Yehuda Bauer. "The End of the Holocaust?" The conference Aftermath: Holocaust Survivors in Australia, Australian Centre for Jewish Civilisation, Melbourne, Australia, March 2010.

2. Cf. Vera Bendt. "Wahnsinnige Wissenschaft'. E.T.A. Hoffmann, Exil und das jüdische Museum in Berlin.” E.T.A. Hoffmann Jahrbuch 8 (2000): 106-39.

3. "The Exiled Tongue" has not been translated into English so far; the translation of the title is taken from the original Hungarian piece "A számüzött nyelv". The German version "Die exilierte Sprache", originally published in the Frankfurter Allgemeine Zeitung on 2 September 
2002, was reprinted in a collection of essays of the same name, published by Suhrkamp in German in 2003. The same collection also includes the essay "Von der Freiheit der Selbstbestimmung", which was published in the Literary Supplement of The Guardian under the title "The Language of Exile" (19.10.2002, 4-6). The latter was republished under the title: Imré Kertész. "The freedom of self-definition." In Witness Literature. Proceedings of the Nobel Centennial Symposium, edited by Horace Engdahl. Singapore: World Scientific Publishing, 2002, 33-44.

4. Imré Kertész. "Die exilierte Sprache." In Die exilierte Sprache. Essays und Reden. Suhrkamp: Frankfurt a.M., 2003, 212, 217.

5. Cf. Gilles Deleuze, and Félix Guattari. Kafka: Toward a Minor Literature. Minneapolis, London: University of Minneapolis Press, 1986.

6. Cf. Jacques Derrida. Specters of Marx: The State of Debt, the Work of Mourning \& the New International. New York, London: Routledge, 1994.

7. For example: Gabriele Schwab. Haunting Legacies: Violent Histories and Transgenerational Trauma. NewYork, Chichester: Columbia UP, 2010.

8. Christine Berthin. Gothic Hauntings. Melancholy Crypts and Textual Ghosts. London: Palgrave Macmillan, 2010, 3.

9. Kertész. "Die exilierte Sprache." 229.

10. Alvin H. Rosenfeld. The End of the Holocaust. Bloomington: Indiana UP, 2011, 231.

11. Hilde Spiel. Die hellen und die finsteren Zeiten: Erinnerungen 1911-1914. Munich: List, $1989,81$.

12. Friedrich Pfäfflin. Améry, unterwegs nach Oudenaarde. Marbach: Deutsche Schillergesellschaft, 1982, 19-32.

13. None of Améry's novels, and only a few of his non-fiction works, have been translated into English.

14. While Améry would, for example, travel to Austria for readings, he objected to his friends' attempts to get the Austrian state to recognize his work (Pfäfflin. Unterwegs nach Oudenaarde. 36).

15. Marcel Reich-Ranicki. Reden auf Hilde Spiel. Munich: List, 1991, 101.

16. Christa Gürtler. "Das Café Bazar in Salzburg und Hilde Spiel als Korrespondentin der Salzburger Festspiele.” In Hilde Spiel und der literarische Salon, edited by Ingrid Schramm, and Michael Hansel. Innsbruck, Vienna: Studienverlag, 2011, 143-153.

17. David Axmann. Friedrich Torberg: Die Biographie. Munich: Langen-Müller, 2008, 10.

18. Axmann. Friedrich Torberg. 62f.

19. Cf. Anne-Marie Corbin. "'Das FORVM ist mein Kind.' Friedrich Torberg als Herausgeber einer publizistischen Speerspitze des Kalten Krieges." In "Gefahren der Vielseitigkeit": Friedrich Torberg, 1908-1979, edited by Marcel Atze, and Marcus G Patka. Wien: Holzhausen, 2008, 201-221.

20. Cf. Malachi Hacohen. "The congress for cultural freedom, the 68ers and emigrés in Austria." In Das Jahr 1968, Ereignis, Symbol, Chiffre, edited by Oliver Rathkolb, and Friedrich Stadler. Göttingen: V \& R Unipress, 2010, 239-274.

21. Axmann. Friedrich Torberg. 148. 
22. Spiel. Die hellen und die finsteren Zeiten. 179.

23. Spiel. Die hellen und die finsteren Zeiten. 205.

24. Spiel. Die hellen und die finsteren Zeiten. 208, 222-223.

25. Spiel. Die hellen und die finsteren Zeiten. 231.

26. Spiel. Die hellen und die finsteren Zeiten. 224.

27. Friedrich Torberg. "Aber wo ich auch gehe, flattern die dunklen Gewänder der Toten um mich." In Wien oder der Unterschied: Ein Lesebuch. Munich: Langen-Müller, 1998, 85.

28. Axmann. Friedrich Torberg. 274-277.

29. Michael Hansel. ““...Ein Lackerl Geifer zu erzeugen’. Friedrich Torberg als Vermittler und Verhinderer von Literatur." In "Gefahren der Vielseitigkeit": Friedrich Torberg, 1908-1979, edited by Marcel Atze, and Marcus G Patka. Wien: Holzhausen, 2008, 126-130.

30. Spiel. Die hellen und die finsteren Zeiten. 129-131.

31. Sandra Wiesinger-Stock. Hilde Spiel: Ein Leben ohne Heimat? Vienna: Verlag für Gesellschaftskritik, 1996, 150-161.

32. Kertész. "Die exilierte Sprache." 212.

33. Sigurd Paul Scheichl. "Why and how Friedrich Torberg's FORVM did not confront the past." New German Critique 93 (2004): 99.

34. Marcel Atze. “'Einen, der Unfassbares verübt, kann man nicht fassen.' Friedrich Torberg und die justizielle Aufarbeitung nationalsozialistischer Vergangenheit." In "Gefahren der Vielseitigkeit": Friedrich Torberg, 1908-1979, edited by Marcel Atze, and Marcus G Patka. Wien: Holzhausen, 2008, 195-196.

35. Scheichl. "Why and how Friedrich Torberg's FORVM did not confront the past." 101.

36. In an article railing against the one-sided portrayal of Israel as a mere satellite state of American imperialism by the German left, published in the Hamburg Die Welt (16.9.1967), Torberg argued that the left was willing to side with the Nazis just to avoid upsetting the Soviet regime (Marcu G Patka. “'Ich möchte am liebsten in Jerusalem begraben sein'. Der Zionist Friedrich Torberg." In "Gefahren der Vielseitigkeit”: Friedrich Torberg, 1908-1979, edited by Marcel Atze, and Marcus G Patka. Wien: Holzhausen, 2008, 172-3). In this context, Torberg also explicitly referred to Elie Wiesel's The Jews of Silence. A Personal Report on Soviet Jewry (1966), which describes the plight of Soviet Jewry under communism. Torberg's deep admiration of the Nobel Prize winner Wiesel was based on this shared understanding.

37. The idealizing nature of his relationship to Vienna started well before 1938, as an essay from 1934 shows, in which Torberg argues-somewhat satirically, but then again not (he was a master of the oxymoron) - that the civil war-like fights in February in Austria, in which over a thousand members of the paramilitary organization of the Social Democratic Party were killed by the police, the military and the Christian-conservative Heimwehr, were an Austrian rather than a Viennese act, and that the essence of Vienna, its inner melody, would form the most powerful resistance against the powers that be (Torberg. Wien oder der Unterschied. 53-54). The reason for such a deep connection to the city lay-according to Torberg-not only in the fact that he was born in the city and spent his formative years there, but "maybe even more so through the years of absence rather than those of residency" ("[D]urch die Jahre des Fernseins vielleich noch mehr als durch die der Ansässigkeit." Torberg. Wien oder der Unterschied. 53). 
Indeed, Torberg's family had left Vienna in 1921, two-years after Torberg had started at the progressive humanistic high school in Wasagasse, and directly after his Bar Mitzwah, since his father's Prague based employer, for whom he had built up a new central office in Vienna, pulled out of Vienna and offered Alfred Kantor a position in Prague (Axmann. Friedrich Torberg. 29-30). Torberg was uprooted for the first time, and he did not take to it overly well. The change to a more authoritarian, not reform oriented and scientific, German high school represented a culture shock, and the fact that he arrived three weeks into the school term and lived with friends of the family until his family arrived several month later, fostered a profound longing for Vienna (Axmann. Friedrich Torberg. 33).

38. Axmann. Friedrich Torberg. 139.

39. Cf. Evelyn Adunka. "Der deutschen Sprache letzter "Jud vom Dienst". Friedrich Torberg und sein Judentum." In "Gefahren der Vielseitigkeit": Friedrich Torberg, 1908-1979, edited by Marcel Atze, and Marcus G Patka. Wien: Holzhausen, 2008, 143-162.

40. Cf. Marcel Atze. “'Was von einem ganzen Lebenswerk bleibt': Friedrich Torbergs Prosatexte zwischen Produktion und Rezeption." In "Gefahren der Vielseitigkeit": Friedrich Torberg, 1908-1979, edited by Marcel Atze, and Marcus G Patka, Wien: Holzhausen, 2008, 25-58.

41. Atze. "Lebenswerk." 51.

42. Kertész. "Die exilierte Sprache." 210.

43. Friedrich Torberg. Die Tante Jolesch; oder, der Untergang des Abendlandes in Anekdoten. Munich: Langen-Müller, 1975.

44. Friedrich Torberg. Maria Poglitsch Bauer, Sonat Birnecker Hart, Tante Jolesch: Or, the Decline of the West in Anecdotes. Riverside, California: Ariadne Press, 2008, 1.

45. Friedrich Torberg. Die Erben der Tante Jolesch. Munich: Langen-Müller, 1978.

46. Franz-Heinrich Hackel. Zur Sprachkunst Friedrich Torbergs. Parodie-Witz-Anekdote. Frankfurt a.M., Bern et al: Peter Lang, 1984, 123-124.

47. Torberg's fierce and well-documented attack on Salcia Landmann's collection titled Der jüdische Witz (1960) was based on the near-clinical style in which she presented the jokes. For an overview of the affair, see Hackel. Zur Sprachkunst Friedrich Torbergs, 88-91; Adunka. "Der deutschen Sprache letzter 'Jud vom Dienst'." 152-153.

48. Torberg, Bauer, Hart. Tante Jolesch. 186. In German: Torberg. Die Tante Jolesch. 293-294.

49. Axmann. Friedrich Torberg. 18.

50. Atze. "Unfassbares." 197.

51. Atze, M. "Lebenswerk." 52.

52. "Ich bin ein deutsch-jüdischer Schriftsteller, d.h. ein in deutscher Sprache schreibender Jude, ich habe von Anfang an gewußt, daß ich es bin, und dieses Wissen ist seither höchstens um die Wahrscheinlichkeit vermehrt worden, daß ich der letzte sein werde (...). Wenn ich überhaupt noch eine jüdische Funktion habe, dann ausschließlich die, mein öffentliches Wirken so zu gestalten, daß möglichst viele Nichtjuden den Tod des letzten deutsch- jüdischen Schriftstellers als Verlust empfinden; ob trauernd oder aufatmend ist mir gleichgültig, sie sollen nur merken, daß etwas zu Ende gegangen ist, wofür sie keinen Ersatz haben." Torberg. Wien oder der Unterschied. 252.

53. Atze. "Lebenswerk." 53. 
54. Wiesinger-Stock. Hilde Spiel. 51-52.

55. Jacqueline Vansant. Reclaiming Heimat: Trauma and mourning in memoirs by Jewish Austrian reémigrés. Detroit: Wayne State UP, 2001, 129.

56. Hilde Spiel. Anna \& Anna. Vienna: Kremayr \& Scheriau, 1989, 113.

57. Spiel. Anna \& Anna. 114.

58. Reich-Ranicki. Reden auf Hilde Spiel. 65-66.

59. Dagmar Lorenz. "Hilde Spiel: Lisas Zimmer Frau, Jüdin, Verfolgte." Modern Austrian Literature 25 (1992): 89.

60. "Niemand außer uns wußte, was es heißt, in den Trümmern eines Weltreichs aufzuwachsen." Translated by BL. Hilde Spiel. Lisas Zimmer. Frankfurt a.M., Berlin: Ullstein, 1996, 61.

61. Even then, Lisa's attempts to assimilate into a world, which was already shattered, were hindered by various intrigues; initially the aristocratic uncle of her fiancé seduced middle-class assimilated Jew in order to compromise her. However, her extravagant and destructive life style, the lies and the confusion around the drug addicted Lisa and her fallible narrator, which are furthered through characters like Mrs. Langendorf, who not only communicates to Lele that Lisa had not helped her parents to escape from National Socialism, but also leads Lisa believe that she is actually suffering from cancer, which furthers her demise, allow Spiel to present a complex perspective on the exile experience. Spiel. Lisas Zimmer. 74.

62. Spiel. Lisas Zimmer. 14.

63. Spiel. Lisas Zimmer. 65-66.

64. Spiel might herself have been worried about the reception of the novel. In a letter to fellow émigré and writer Hermann Kesten, she called her attempt at the novel bold (Ariane Thomalla. "Nachwort: Der Damaskusweg der Hilde Spiel." Spiel, Lisas Zimmer, 316), the fictional epilogue of the novel by Paul Bothe, a writer and character in the novel, suggests the same. On the last three pages, Spiel drives home to the reader what already has been said. She relativizes the story again by having Bothe emerge as the editor of Lele's novel. Not only does he suggest that he interfered with her manuscript - "where necessary"-, but he also distances himself from Lele's view of Lisa: While the victorious cause pleased the gods (that is Lele, the Americans, the powers that be), he argues, the conquered cause (Lisa, Europe), pleased Cato, i.e., himself (Spiel. Lisas Zimmer. 297).

65. Whether Spiel's ambivalence stance on her own Jewishness played a role here would need to be considered further. Reich Ranicki points to the fact that Spiel rejected being classified as Jewish and maintained a Catholic identity (Reich-Ranicki. Reden auf Hilde Spiel. 92-93). Other commentators have pointed to Spiel's conflictedness on the issue, as her biographer highlights, additionally adding that Spiel's individualism might play a role in this context (Wiesinger-Stock, S. Hilde Spiel: Ein Leben ohne Heimat? Verlag für Gesellschaftskritik: Vienna, 1996, 51-53).

66. Kertész. "Die exilierte Sprache." 217.

67. Kertész. "Die exilierte Sprache." 215.

68. Imré Kertész. "Der Holocaust als Kultur," in Die exilierte Sprache. Essays und Reden. Frankfurt a.M.: Suhrkamp, 2003, 88-89. 
69. The corresponding passages in Améry's "Wieviel Heimat braucht der Mensch?" and Kertész: "Die exilierte Sprache" are: on the notion of return Améry p. 87, Kertész p. 206; on self-alienation Améry p. 89 versus self-denial Kertész p. 209; on false belonging to country Améry p. 100 versus language Kertész p. 218; on language in Nazi German Améry pp. 103-104 versus totalitarian language Kertész p. 209-210.

70. Jean Améry. "How much home does a person need?" In At the Mind's Limits. Contemplations by a Survivor on Auschwitz and its Realities. Bloomington: Indiana UP, 1980, 51-52.

71. Anna Seghers. "Volk und Schriftsteller." In Über Kunstwerk und Wirklichkeit. I Die Tendenz in der reinen Kunst, edited by Sigrid Bock. Berlin: Akademie-Verlag, 1970, 191-197.

72. Burkhardt Lindner. "Protokoll, Memoria, Schattensprache. 'Die Ermittlung' von Peter Weiss ist kein Dokumentartheater." In Rechenschaften. Juristischer und literarischer Diskurs in der Auseinandersetzung mit den NS-Massenverbrechen, edited by Stephan Braese. Göttingen: Wallstein, 2004, 131-145.

73. Améry. "How much home does a person need?" 53.

74. Améry. "How much home does a person need?" 42.

75. Amery did so in his obituary of Bachmann in 1973; Bachmann's story Drei Wege zum See (1972) directly references Améry and his writings.

76. Jean Améry, and Gisela Lindemann. Weiterleben, aber wie? Essays 1968-1978. Stuttgart: Klett-Cotta, 1982, 9.

77. Améry. "How much home does a person need?" 50-51.

78. Kertész. "Die exilierte Sprache.” 213.

79. While Kertész' post-war resilience could also be a result of his relative youth upon his deportation, and the fact that he had not been a grown-up member of society and hence might not have experienced its collapse as profoundly as other survivors, his ability to live in the "extended temporality of Auschwitz" and to generalize from this experience seems astounding, but might point to a sense of displacement or at least the refusal to expose that very experience.

80. He had sent the manuscript of his posthumously published novel Die Schiffbrüchigen to Thomas Mann and Robert Musil, and parts of it had been published in Hermann Hakel's Jahrbuch 1935 (Pfäfflin. Améry, unterwegs nach Oudenaarde. 21).

81. Jean Améry. Ausgewählte Briefe: 1945-1978. Werke 8. Stuttgart: Klett-Cotta, 2007, 159.

82. Jean Améry. "Sie lernten nicht für das Leben. Schülertragödien von Emil Strauß, Hermann Hesse, Friedrich Torberg." In Aufsätze zur Literatur und zum Film. Werke 5. Stuttgart: Klett-Cotta, 2007, 276-291.

83. The exact context of this public discussion remains unclear, it possibly took place shortly before or after Holthusen's public comment on his National Socialist past titled 'Freiwillig zur SS', published in Merkur (20) 1966, to which Améry responded in an open letter the following year, in which he riposted Holthusen: "You joined the SS, voluntarily, I arrived elsewhere, utterly involuntarily" (Jan Süselbeck. "Anderswohin, ganz freiwillig." In literaturkritik.de 11 (2006)). Already in 1960, the Austrian poet Mascha Kaléko refused to accept the designated prestigious Fontane price, because Holthusen had been a member of the jury. 
Reprinted from Religions. Cite as: Furst, L.R.; Aliaga-Buchenau, A. Growing up in Wartime England-A Selection from "The Rachel Chronicles: A Kind of Memoir". Religions 2012, 3, 993-1024.

Article

\title{
Growing up in Wartime England-A Selection from "The Rachel Chronicles: A Kind of Memoir"
}

\section{Lilian R. Furst ${ }^{\dagger}$ and Anabel Aliaga-Buchenau *}

Department of Languages and Culture Studies, University of North Carolina at Charlotte, 9201 University City Blvd., Charlotte, NC 28223-0001, USA

$\dagger \quad$ Lilian R. Furst passed away on 11 September 2009.

* Author to whom correspondence should be addressed; E-Mail: aaliagab@uncc.edu; Tel.: +1-704-687-8765.

Received: 18 September 2012; in revised form: 17 October 2012 / Accepted: 18 October 2012 / Published: 29 October 2012

\begin{abstract}
The following contribution is an excerpt from the unpublished memoirs of Austrian Jewish émigrée, Lilian Renée Furst (1931-2009), a pioneer in the field of comparative literature. This journal issue grew out of an April 2011 conference in her memory, held at the National Humanities Center, on "Jewish emigres and the Shaping of Postwar Culture." The nexus between her innovative intellectual contributions and her experience as a Jewish émigré reflects one of the conference's central concerns: How, why, and in what fashion did the émigrés' dislocations shape innovative intellectual paths and cosmopolitan visions of Europe and European culture. Born in Austria and educated in England, Furst pursued an intellectual career in the United States, hoping it would allow her to break out of narrow national boundaries. The excerpt of her memoir here illuminates how her life's work as a pioneer in the field of comparative literary studies grew out of her experience with language as a German-speaking refugee in wartime England. Her memoir written in the third person about "Rachel" also reflects her dual identity as Jew and European. Part I by Dr. Anabel Aliaga-Buchenau, the literary executor of the memoir and a former graduate student of Furst, places "The Rachel Chronicles: A Kind of Memoir" in relation to Furst's other autobiographical writing. Part II includes Furst's own introduction to "The Rachel Chronicles," followed by her chapter on "Growing up in wartime England." (The whole of her unpublished memoir is available to researchers in the "Personal Papers of Lilian R. Furst," Girton College Archives, Cambridge University (http://janus.lib.cam.ac.uk/db/node.
\end{abstract}


xsp?id=EAD\%2FGBR\%2F0271\%2FGCPP\%20Furst)). Part III is a bibliography of Furst's writings.

Keywords: Lilian R. Furst; Jewish émigré; memoir; comparative literature; England in WWII

Figure 1. Lilian Renée Furst.

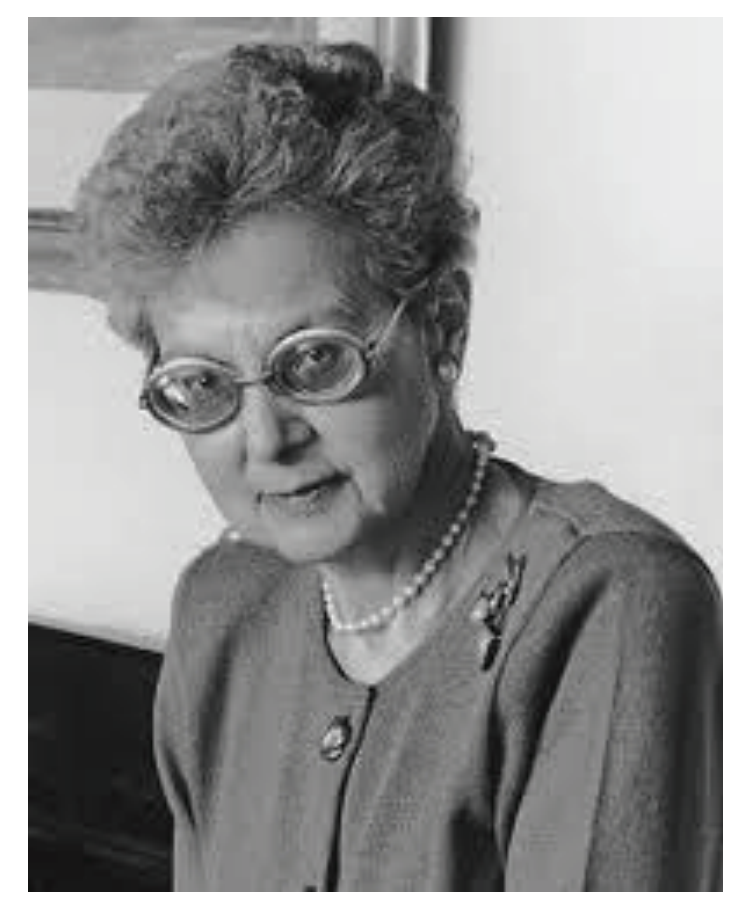

\section{1. "Remembering Lilian Furst" by Anabel Aliaga-Buchenau}

When she spoke she held the entire room in the palm of her hand. A small lady, in an elegant red suit, with gray hair in a bun, wrapped in a tartan travel blanket stood in front of an audience at the Annual Meeting of the Philological Association of the Carolinas. This is the image of Dr. Lilian Furst I want to remember (Figure 1). She was giving a talk entitled "Being a Woman Graduate Student in Cambridge in the 1950s," which is based on the chapter of her unpublished manuscript "The Rachel Chronicles: A Kind of Memoir." In the chapter, Furst's alter ego, Rachel, experiences graduate student life in Cambridge in the 1950s. She details the cold rooms, and the necessity of the travel blanket, which Furst brought to her keynote address about fifty years after its last usage in Cambridge. Lilian Furst was the kind of speaker who held everyone's attention, had her audience chuckling, and actually seeing and imagining her life at Cambridge. Her gift for words translated into excellent presentations, engaging classes, prize winning academic monographs and in the case of "The Rachel Chronicles" a very personal "kind of autobiography." As she explains in the introduction to the unpublished manuscript, Rachel is Lilian Furst's alter ego. "The Rachel Chronicles" was not the first autobiographical writing by Furst. She published Home is Somewhere Else: Autobiography in Two Voices in 1994. In this earlier autobiography, Lilian Furst tells her story from the child's perspective superimposed with the view of her father's observations. She had 
discovered her father's journal detailing their life in Vienna during the thirties and their escape to England from Nazi persecution. In alternating chapters, the reader experiences the events from the child's and the father's standpoint. The autobiography lends itself to teaching classes on the Holocaust, or rather on fates on the "margins of the Holocaust" as Furst called it. She wrote "The Rachel Chronicles" much later and in a sense this autobiographical sketch is more personal, detailing Furst's memories of the different phases of her life: the early years in Vienna, briefly the escape, the year in a boarding school in England as a fresh exile, the years in Manchester, graduate school in Cambridge, her first job in Belfast, her move to the United States to teach comparative literature at The University of Oregon in Eugene, her life teaching in Chapel Hill, her collection of friends and bears, her reunification with her furniture from her childhood in Vienna, and the deterioration of her eyesight. In this volume the chapter "Growing up in Wartime England" tells of the refugees' arrival in England and their attempt at creating a new life. Rachel's first concern is going back to school and when the war breaks out her father is detained as an "enemy alien." Through the London air raids the reader follows Rachel and her family as they move from Bournemouth to Bedford to Manchester, struggling to make ends meet. Finally, Rachel's father is able to practice his profession as a dentist. Throughout Rachel's life ran the red thread of her wish to go to school, to learn. "The Rachel Chronicles" detail facets of Lilian Furst's life not previously available to the public. It provides important insights into this extraordinary life and at the same time serves as social history. Where else would one learn that incoming students of Girton College in Cambridge were admonished to bring a travel blanket to withstand the cold damp winters? Or that for a family of three the weekly food ration during the war consisted of "one egg per week, two ounces each of tea, sugar, meat, and margarine, and one ounce of butter?" Incidentally, as Furst observed, it was a diet "good for keeping your cholesterol down." Reading "The Rachel Chronicles" is like hearing Lilian Furst's voice: dry, full of humor, witty and extraordinarily intelligent.

\section{2. "The Rachel Chronicles: A Kind of Memoir" by Lilian Furst}

\subsection{Introducing Rachel and Her Memoir}

Who is Rachel? How did she come to spend the first half of her life in Europe and the second half in the US? And what is meant by "A Kind of Memoir"?

Perhaps this last question should be addressed first so as to explain the nature of this work. It is not an autobiography in the conventional sense, i.e., a first person narration of the events of the author's life. Under her own name, Lilian R. Furst, the persona here called Rachel has already published a partial autobiography centered on the most crucial phase of her life, her flight from Vienna with her parents in 1938 after the advent of the Nazis. Titled Home is Somewhere Else it chronicles the family's illegal crossing of the frontier from Germany into Belgium at Christmas 1938, their subsequent legal entry into Great Britain in March 1939, and their struggles to resettle and to fashion a new life. A brief closing section tells of her and her father's further emigration to the USA in 1971 following her mother's death in 1969. As an autobiography it is unusual, maybe even unique, in being cast in two voices. Lilian and her father each recall the stages of their moves in turn and quite separately. In fact the two accounts were written twenty years apart: her father's in the early 1970s when he had just retired, and her own in 1991. She recorded her memories without 
rereading his manuscript, only subsequently integrating the two in alternating chapters. The child and the adult are shown to perceive the same experiences from two different angles: the child merely seeing, hearing, and instinctively sensing the danger, while the adult grasps the political situation - and its implications. Readers of Rachel's memoir may want to look back to Lilian's and her father's book as a framework to Rachel's pieces, although it is not necessary to do so.

This "kind of memoir" follows sequentially some of the major episodes in Rachel's life: her early childhood in Vienna, her growing up in wartime England, her years as a graduate student at Girton College, Cambridge (England), her finding of her vocation and her field, her family's vacation travels in their small car, her search for a suitable position after coming to the USA. The order is chronological though not continuous. While the individual sections can be read as discrete entities, they coalesce to form a picture of her trajectory through life. It is a memoir in an absolutely literal sense in drawing exclusively on her own memories; she never kept a journal nor does she refer to outer sources.

Rachel's life is rather more complicated than the average partly owing to the political circumstances of the place and time (Central Europe in the 1930s) when she was born, and partly owing to the choices she herself made. Her early radically disruptive flights from Austria to Belgium and on to England were enforced; although her parents did not — could not - fully realize it, in retrospect they proved life-saving imperatives to escape the labor camps and the gas chambers. Her moves within Great Britain were also determined by necessity, either economic or in response to the ongoing war. So after an initial phase in London, Rachel was evacuated for a year to Chertsey, Surrey in 1939. When the family established a home in Bournemouth, an attractive resort on the south coast of England, she returned to her family. All too briefly, for her father was interned as an "enemy alien, a suspect holder of a German passport" in May 1940 when France fell despite the fact that it was the British Home Office that had directed them to Bournemouth. Rachel and her mother moved back to London, where they lived during the first months of the bombing. Without any reason to remain exposed to the city's increasing devastation and the frightening effects of the "Blitz," they selected Bedford, a small town about an hour north of London, as a relatively safe refuge. Finally, in 1942, they settled in Manchester, a major city in the north of England, the center of the cotton trade in which the family of Rachel's mother was engaged. There at age ten she began to go to school regularly after the many interruptions during their vagrant years. She graduated from Manchester University in 1952, did a Ph.D. in Cambridge, and got her first position in the German department of the Queen's University of Belfast in 1955. Her attraction to Comparative Literature took her back to Manchester University to try to build a department there in this fairly new discipline in 1967.

But Rachel gradually became disappointed at the resistance in Great Britain to an approach to literature that transcended national boundaries. Working on European Romanticism, how could she possibly ignore the impact of Shakespeare? The language departments in British universities, while strong, were entrenched each in its own traditions. At the same time, at international conferences, Rachel met American scholars who were far more open to innovation. So in 1971-72 she went "visiting" to Dartmouth College, a renowned Ivy League school in New Hampshire at the behest of a faculty member who had read her first book. She also taught at Harvard Summer School in 1971 and 1972. Before she came to the US she had already received an invitation to head the Graduate 
Program in Comparative Literature at the University of Oregon at Eugene. She knew nothing about this university except that it published Comparative Literature, the first English language journal in the field. She and her father went to the library to consult the Encyclopedia Britannica where they learned that rain and logging were the main features of Oregon. They were used to rain in Manchester; nevertheless the visit to Dartmouth offered them the opportunity to sound out a land of which they knew precious little and that only from movies and books.

Apart from the rain, which did indeed come down in buckets from September to June, Oregon was not what Rachel had been led to expect. While the Graduate Program had some 45 students on its books and many applicants, it had no budget whatsoever. Its funding had come from the NDEA (National Defense Agency), but that had dried up, and what little was left had been appropriated by the incoming editor of the journal together with the typewriter and the secretarial assistance. Rachel had no means to pay even for postage. Used to fighting for her department, she pleaded with the dean, the graduate dean, the provost, and would have gone to the university president had she not been told that he was too dumb to understand. She also felt very much out of it in Oregon's counterculture, where she could not get world news (in those days before CNN) on Sundays when only "the game" mattered. They had to call her uncle in New York to find out what was happening in the Middle East. After two years she got a research fellowship that allowed her to go back to the Boston area- and begin the search for another position.

This decision initiated the phase of their wandering about the US. It was motivated primarily by the quest for a congenial position in a good university that supported her discipline. She did not know at the outset how difficult-quixotic?- - her quest was in a period when the major expansion of American universities that had taken place in the 1970s was over. An immediate, if secondary benefit of their many moves was a vastly improved knowledge of the country's regions and academic traditions. From a base in a new branch of the University of Texas on the outskirts of Dallas, Rachel and her father embarked on a series of "visits" in every direction and to all sorts of schools: to Case Western Reserve University in Cleveland, to Stanford, to Harvard, to the College of William and Mary in Virginia. Now and then they would spend a year in Dallas to fix their house, but for seven years in a row they were at a different address every autumn. Strenuous though it was, it certainly enabled Rachel to learn a great deal about the American academic system. And she did eventually achieve her goal in 1986, a year after her father's death, by being appointed to an endowed chair in Comparative Literature at the University of North Carolina at Chapel Hill, which had the third oldest program in the field in the USA. She taught there for twenty years until her retirement, which has afforded her the time to write this kind of memoir.

Perhaps the trickiest question is: Who is Rachel? She is definitely not a fictitious figure in the sense of being invented any more than are any of her experiences told in this kind of memoir. The most precise characterization of her is as an alter ego of the author. Their relationship is indicated by their partially shared name for Rachel is one component of Lilian's Hebrew name (Rachelea). They overlap without being quite identical. They are separated by the many years - three-quarters of a century! - that have elapsed between "the little princess" of the opening and the currently scribbling persona. The passage of time inevitably results in a retrospective gaze that fosters a self-detachment conducive to both nostalgia and humor. Seen in hindsight, many of Rachel's adventures assume a tragicomic quality so that this kind of memoir is poised at the intersection of 
the sad and the humorous. Essentially a non-fiction, it is nonetheless written in the creative manner associated with fiction.

\section{2. "Growing Up in Wartime England"}

The day after she arrived in England on 1 March 1939 Rachel clamored to go to school. She was seven and a half, and she had not been to school for a year; in fact she had gone to school for just six months in her whole life - and she loved school. She had started in the first grade in Vienna in September 1937, but when the Nazis took over Austria in March 1938 she had been thrown out because she was Jewish. A segregated school for Jewish children was opened down the hill from the regular school. Her former classmates would taunt and jeer the Jewish children and then run down the hill throwing stones at them. Rachel's new school was out of the ordinary, to put it mildly. The teacher was an elderly professor of zoology who had been dismissed from his university post on account of his "racial impurity;" he had, of course, no idea how to teach first graders; he just tried to keep them quiet (they were pretty subdued anyway) by playing his violin and reading aloud to them. What was so eerie was that the class got smaller and smaller; children disappeared without a word. Had they been sent away (to prison? to some camp?) or had they left of their own free will? Where to? No one dared to reveal anything of their plans or movements. This school was a strange, temporary, tenuous arrangement.

Eventually Rachel too left, also without a word to her schoolfellows. She and her parents had already moved out of the apartment where she had lived all her life into one in a house owned by an uncle of hers where the janitor was trustworthy. Those late fall days of 1938 were dark in every sense. Rachel remembered one day in particular for it was foggy and smelled of smoke. When her father returned home from an errand at the post office, he told of the horrors he had witnessed: burning temples, looted stores, and Jews on hands and knees scrubbing the sidewalks with toothbrushes - it was Kristallnacht [the Night of Broken Glass]. Her parents whispered a lot, trying to protect her, but she had sharp hearing, and even if she did not understand the precise details, she gathered that something really bad was happening. Not long afterwards, under the cover of the Christmas travel rush, they left as inconspicuously as possible, walking out with just a couple of very small bags, as for a weekend trip. Rachel insisted on taking her school satchel with some paper and pencils for she really loved school.

However, she did not get to go to school in Brussels where they landed after various adventures and where they lived for two months, waiting for the promised visa to England. They had entered Belgium illegally on foot in the depths of winter, and were terrified of being picked up by the police and sent back to Germany to a concentration camp. So there was no question of school for Rachel; it would mean being put onto a register, and who knew what the consequences might be. She wrote letters to her mother, decorating them with little drawings. She had no toys, and knew that she must be good and not cause trouble for her parents had more than enough troubles without her being naughty.

No wonder though that she clamored to go to school immediately after they arrived in England as legal immigrants. They lived in Kilburn, a district of northwest London where the rent was low. Rachel's grandparents on her mother's side, several uncles and aunts and two cousins were already there, occupying the second floor of a small house on Brondesbury Road, a pleasant tree-lined road 
not far from a park. They were awfully crowded as it was and had to squeeze together to make a room available to Rachel and her family. If they were short of space, they had an overabundance of furniture for her parents had shipped all their things from their large apartment in Vienna to London. Some pieces - the dining-room table and a cupboard - were too big to go in through the door and had to be sold for a song at auction. The rest was crammed in, hardly leaving room for the inhabitants. But they were glad enough to have it or else they would have had to buy at least a minimum of furniture, and they had precious little money. A social worker, who came one day to inspect where Rachel was living, was bewildered: She was sleeping on a sort of settee in the one room that had been assigned to her family. The place was grossly overcrowded, but Rachel was obviously neither neglected nor abused, so she said nothing. In that part of London she must have seen much worse.

Her mother took her to an elementary school round the corner. She caused a great stir among the children. You might have taken her for retarded since she did not speak a word of English. Nor did she know the alphabet for the Nazis had taught her only the Gothic script. She could not even knit like all the others, so when she went home for lunch that first day, she asked her mother to teach her. Luckily she proved a quick learner, but her mother showed her the European way of knitting, which she went on using. In every respect she was different.

The children were kind to her. She had never seen children like this nor had they seen anyone like her. To them she was a sort of doll, unable to speak, and dressed in clothes such as they could hardly imagine. In this poor area of London they were almost in rags, with rough manners and speech, yet with Rachel they were gentle and considerate. They would escort her home and pick her up, finger the many bright dresses she had brought from Vienna, each with its matching hair ribbon, and matching socks and shoes. She was a curiosity, an almost magical figure who had appeared in their commonplace world. Best of all, they instinctively grasped how to help her learn English. Her mother, who knew a little, read with her every day from a book the school had lent her about an old woman and her dog. These lessons were a source of irritation to the other members of the family, already tense with their own worries, principally how to make a living. At school the children did "show and tell," holding up objects such as a pencil and scissors and saying the words. Once she had a big surprise when a boy brought a box and out jumped a frog as he triumphantly shouted: "frog." That was Colin, a tall handsome boy who had appointed himself her special protector. Rachel must have picked up the language rapidly for by the end of the school year in July, the children greeted her mother with excited cries of "She's top." Her mother could not understand what on earth she had been up to: "top" to her was associated with climbing a mountain, and there were none in this part of London. She was even more puzzled when Rachel's teacher assured her that she would get a "scholarship." She had not heard the word; when she mentioned it to their landlord, she gathered that it denoted something desirable.

Rachel picked up another language during those months in London: Yiddish. To speak German on the streets in 1939 did not meet with approval, so her grandparents were encouraged to speak Yiddish, which sounds a bit like Dutch. In their seventies, her grandmother was hard of hearing, and her grandfather frail. Rachel called Yiddish "old German" in the belief that at a certain age people switched to this dialect. This bizarre misconception proved to contain an element of truth, as she discovered many years later when she took a course in Middle High German and found it 
strangely familiar because of its affinity to Yiddish. Yiddish is in fact based on Middle High German, a version of the language of the time that the Jews took with them to Poland when they were driven out of Germany. It was subsequently enriched by loan words appropriated from whatever region the Jews lived so that it comprises Polish, Russian, and English terms, but its basic format remains Germanic.

On one occasion Rachel felt hurt and excluded. Her cousin, who was about the same age, had been invited to a birthday party. She went to a private school where her tuition was paid by some benefactor. As her mother was working, Rachel's mother was asked to take her to the party and bring her home. Rachel secretly hoped she would be invited in too, so she dressed in her party finery. But to her great disappointment she was left standing on the doorstep when her cousin was let in. She and her mother sat on a park bench until it was time to pick the party girl up. At least here in London Jews were permitted to sit on park benches. Yet Rachel was rather sad because she had been excluded.

In the summer of 1939 during the long school vacation Rachel's parents decided to give her a break from the family commune. It was an unusually hot summer, hot also in the metaphorical sense as London waited anxiously to see whether-or more likely when — war would break out. The headmistress of her school recommended a tiny boarding school in Chertsey, Surrey, about twenty-five miles southwest of London, run by a friend of hers. It could hardly be dignified by the name "boarding school" since there were no more than four boarders. In a big, gracious house with a beautiful garden, it was run by Miss Theakstone and her mother, who did the housekeeping. They had begun by taking in Miss T's nephew when his parents were posted to India; he was the only boy there. Rachel did not know how the three other girls, all older than her, got there, perhaps also for a vacation in the peace of the country. Rachel was terribly unhappy there; she had never been away from home, and during the perilous flight from Vienna she had come to put her trust in her parents. She missed them dreadfully and wrote to ask them to take her home. The Theakstones censored her letters and got her to write how happy she was. This made her most uncomfortable as she had been brought up always to tell the truth, however painful. Miss T tried to persuade her that she would cause her parents grief by admitting her unhappiness; they were making a sacrifice to send her there (it cost a pound a week). Later, on reflection, she thought that the greater sacrifice would have been on the part of the Theakstones who wanted that income.

Rachel did not mind sharing a bedroom with two or three other girls. It was a large room overlooking the garden, far more spacious than the cramped quarters she had recently shared with her parents in Kilburn. But she fell foul of Eva, the oldest one who was inclined to be bossy. She would read after "lights out" by pulling the drape back a little. When Rachel was asked whether Eva had done so, she answered without hesitation: "yes." Eva was told off, though not really punished, it was a minor disobedience. That was why Rachel could not understand Eva's extreme anger at her for "telling tales." At age eight, having had the imperative always to tell the truth drummed into her, she simply could not grasp the concept of "telling tales." Eva persecuted her; she instilled a terrible fear into Rachel by asserting that she would never be able to wear a skirt because she had no waist, she would forever have to have her skirt hang on a "bodice," as little girls did. Rachel had no idea that eight-year olds are not yet shapely enough to have a waist; she had no one in whom to confide (at home she would have asked her mother), so she nurtured this 
dread for years. By a curious coincidence she ran into Eva again when both of them were in their early teens and Eva was visiting relatives who happened to be neighbors in M. Then it was Eva who was rather plump and shapeless whereas Rachel had grown to have the neat waist she still has in her seventies.

Rachel's other recurrent source of trouble at Chertsey was the food. Truth to tell, she had been a picky eater since her childhood, favoring a small repertoire of familiar things. English food was strange to her; she liked some of it, especially the colorful fruit jellos ("jellies" as they were called in England). She was made to drink milk (which she never TOUCHES to this day) and she "took to" fish. That phrase, "took to," reported by Miss Theakstone to her parents, caused some confusion; without sufficient idiomatic English, her parents took it to mean that she was going fishing. Rachel drew the line absolutely at "brawn" ("head cheese" in American); it was an ugly beige-gray color with bits of unidentifiable things in it. She did not know what it was, but it looked so hideous that she refused even to taste it. No amount of persuasion could convince her; "granny" Theakstone argued that it was like the fruit jellos she loved, but they were pretty and this was ugly. She was sent to bed without supper, and made to face the brawn for lunch the next day. When she continued to stand her ground, they became alarmed and excused her from this dish permanently. She had won that round.

She learned all sorts of things at Chertsey. There were, of course, no lessons in summer. They played croquet on the lawn, did some gardening, and she learned to ride John's old bicycle. She also learned Church of England hymns for she went to church on Sundays with everyone else since she could not be left all alone in a country house at a time when there was talk of the possibility of German parachutists. Rachel knew that church was not her religion and she would recite to herself the Hebrew prayer she had been taught in infancy, but she enjoyed the hymns. She also had her first exposure, literally, to sex when John rounded the girls up in the bathroom and behind locked doors showed off his penis. Rachel was not much impressed and certainly did not feel deprived for not having that extra piece.

The most important and lasting thing she learned in Chertsey was English. At her school in Kilburn she had become fluent-in Cockney, the accent of working class Londoners. She would correct her parents who had taken English lessons in Vienna, assuring them that this was the authentic local pronunciation. What the genteel Theakstones must have thought she cannot imagine to this day. Miss T, who had been educated in Oxford, spoke beautifully. They were tactful enough not to say anything about the sounds Rachel made, merely correcting her until she spoke as they did, with an upper class south of England accent that she has retained to this day. Perhaps it was worth going through the brawn battle and the anxiety about her lack of waist in order to acquire the invaluable asset of good speech.

While Rachel was in Chertsey, war broke out. All children were to be evacuated from London to areas less likely to be bombed. Her parents decided to let her stay in Chertsey rather than make her deal with another new, unknown environment. In the belief that she was quite happy there, they preferred to spare her yet another dislocation, although evacuation was free and Chertsey had to be paid for. Rachel was too young to understand what was happening, so she ended by staying in Chertsey for some nine months. At the end of summer, lessons were instituted under the direction of an "Independent Schooling" system, similar perhaps to contemporary home schooling. Miss T 
did her best. John was lazy. Apart from English, croquet, gardening, and riding the bicycle, Rachel does not recall learning anything, but maybe that was enough. Actually she did acquire one other skill that has not proven so useful: that of undressing and dressing under the blankets because it was too cold to get out of bed in the unheated bedroom without clothing.

With the outbreak of war her parents became "enemy aliens" as they held German passports. Gradually all aliens were screened by special tribunals, no easy task since they still knew relatively little English. Both her parents were categorized as "friendly enemy aliens," i.e., not deemed to be any immediate danger to England, yet still subject to certain restrictions including no travel more than 5 miles from home without permission. This meant that they could not come to see her in Chertsey. Very kindly Miss $\mathrm{T}$ was arranging to bring Rachel nearer to Kilburn for a day when her father was granted permission to visit Chertsey. Rachel's excitement was intense; however, the visit was by no means a success. She spoke rapid idiomatic English with which he had difficulty, and she hurt him by her blunt comment: "how strange, a father who can't understand his daughter." For his part he was astonished at her appearance; from all that milk, not to mention the puddings, she had ballooned out to such an extent that even her underwear had had to be let out. At home she had been a small eater whereas at Chertsey she was made to "clean her plate." Her mother's visit some weeks later went much better. To begin with, she had been warned of Rachel's appearance so that it was not such a shock. Also she was more gifted at languages and therefore better able to understand her. They went for a walk together. That visit has remained a precious memory for Rachel; her mother was so elegantly dressed in black and white as if she were still in Vienna. Only one shadow darkened the visit: when Rachel inquired about her grandfather, who had been unwell for some time, her mother said he was doing better. But somehow Rachel sensed that this was not the case. Later she found out that he had died and her mother did not want to tell her because she had been very fond of him. But this breach of trust — and of truthfulness - actually hurt her more.

By May 1940 Rachel's father had succeeded in obtaining his British professional qualifications. On the advice of the Home Office they moved to Bournemouth, a lovely resort town on the south coast where there was said to be a shortage of dental practitioners. Although by then Rachel had more or less got used to Chertsey, she looked forward eagerly to being with her family again and going to a real school. But it was not to be. Reading the newspaper in the train from Chertsey to Bournemouth, her mother already muttered: "He won't be there." And her father had indeed disappeared. With the fall of France in May 1940 all enemy aliens, no matter how "friendly," were interned from the south coast. Arriving at an empty apartment they were bitterly disappointed. They had expected the Nazis to deal harshly with them, but they believed they had found a legal refuge in England. Now they lost everything a second time.

For three weeks they did not know where her father had gone, for the newspaper reports in those critical days of the war when it looked as though Hitler might invade England were more than cautious. What did "interned" mean and how long would he be held? Finally they had a letter from the Isle of Man where he had been taken; conditions, he wrote, were uncomfortable though not terrible. The worst thing for the internees was the uncertainty and the worry about the families they had left behind.

Rachel longed to go to school; it would be a way of getting away from the anxieties at home and of normalizing the situation. She got her mother to take her to the local school only to find it 
closed - full of soldiers who had escaped from Dunkirk. Most of the children were happy at the unexpected vacation; not so Rachel. The elderly headmaster consoled her with: "Maybe tomorrow," so every morning she and her mother turned up at the school, always to be sent away with the same illusory hopes. They would go for a walk and sit on the sandy beach-1940 was another sunny summer - but this was not what she wanted to do.

Settling back to "home" after Chertsey was at once difficult and easy. She had a hard time in getting back to the standard of absolute truthfulness. At her young age she had become curiously confused about the difference between "telling tales" and lying about trivial things. When asked, for instance, whether she had cleaned her teeth, she would casually give the most convenient answer: "yes" and then have to go back to make a correction. What was easy to revert to was the simple eating that had been customary in her family. Her mother, who could not cook, had got recipes from "granny" Theakstone in the belief that Rachel would have grown accustomed to English food. However, she was only too glad to be spared the milk and she never missed the puddings etc. She soon lost all that pudginess.

Her mother had bigger worries than cooking. They had nothing to live on. They had long ago exhausted the slender funds they had managed to convey to England as well as the yield from the diamond they had smuggled in a hollow tooth. They had lived on charity from the Jewish Refugees Committee in the full expectation of achieving independence again once her father could resume his profession. Rachel's reiterated phrase during that time was: "when Daddy earns some money again," and she was quite sure it would come to pass. Now their hopes were dashed indefinitely, and meanwhile they did not know what to live on. Their apartment in Bournemouth was in a nice part of town, half way up a hill with (almost) a view of the sea. Bournemouth was a "reception area," i.e., considered safe from bombing and therefore much sought after by those fleeing London. So they took in as sub-tenants the $\mathrm{C}$ family whom they had known in Vienna where Mr. C had been the representative of a major British firm and a patient of her father's. He would come from London to visit only at weekends, and though the apartment was smallish, they managed to squeeze in all together in rather closer proximity than they would have liked. In wartime England everyone became used to doubling up.

The arrangement fulfilled its purpose of covering their rent; otherwise it was trying. Mrs. C, an arrogant, uneducated woman, treated Rachel and her mother as her servants because they were now poor. The Cs' son, Peter, some three years younger than Rachel, was an utter pest, spoilt rotten, petulant, used to being king of the castle. Tensions arose particularly when Mr. C was there for he resented the fact that Rachel spoke so much better than his son, who had the annoying Cockney habit of punctuating every phrase with "eh?" Mr. C tried without success to eliminate this lower class interjection from Peter's vocabulary. He also tested Rachel's vocabulary by making her spell at meals: "rhododendron," and "hippopotamus." She would somehow get them right, thereby only intensifying his anger. Rachel was cast as Peter's nursemaid. Instead of herself going to school, she was supposed to be his teacher, a difficult task with a willful, cheeky little boy. When he lost his boat in the park, it was she who was blamed.

There was no reason for Rachel and her mother to stay on in Bournemouth. They feared her father might remain interned for the duration of the war, anyway he would not be allowed to return to the south coast. Sometimes they had no word from him for weeks, and once they were worried 
sick when a boat carrying internees to Canada, the Arandora Star, was sunk with massive loss of life. This was the time when Rachel became her mother's companion, sharing her anxieties and trying to mitigate them.

In September 1940 they went back to London. Why they did this was unclear; it was a time when all who could were leaving the city. Her mother's family, who had been in the cotton business in Vienna, had moved to Manchester where they had contacts. Probably Rachel's mother assumed, rightly, as it later proved, that her husband would come to London when - or if - he was released from the Isle of Man. Besides, rents were low in London so that they could live on the income from their apartment in Bournemouth where they left their furniture. It was a confusing time when life was so unpredictable that it was hard to make rational decisions.

There were, of course, no more schools in London; all the children had been evacuated. By September 1940 the blitz began in earnest, probably with the aim of demoralizing the population in preparation for a German invasion. While the British were sanguine, encouraged by Churchill's stirring speeches, the refugees from Europe were pessimistic and terrified, having once already experienced the Nazis' ruthless might and knowing that they would be the first targets for arrest and who knows what mistreatment. What did Rachel do all day? She knitted and read and went for walks in the park with her mother. Mainly, however, all day they waited for the night's air raids. Later raids occurred by day too, at first it was just at night, EVERY night without fail.

They would get into their shelter clothes, sturdy comfortable garments, and prepare their gear: a thermos bottle of hot tea, perhaps some sandwiches, and a large measure of hope that they would again be spared that night. They tried all types of shelters. The safest without doubt were the underground stations, which were kept open all night and crowded with people, who bedded down on newspapers, side by side like sardines. It was claustrophobic in that stuffy, not to say downright smelly atmosphere, and sleep was virtually impossible with the lights, the constant restless movement, and the almost perceptible undercurrent of fear: What would they find the next morning? Would they still have a home? Every day there were more piles of rubble, more devastation. The shops, however damaged, would hang out signs: "Business as usual." That indeed became the slogan in London, absurd though it was to pretend that anything was "as usual."

Their underground phase was of short duration. Next they tried the sub-basement of a big department store on Oxford Street. The sub-basements, deep enough to seem safe, were like the underground kept open all night, and they offered a more civilized environment. The countertops were cleared so that people could bed down on them as well as on the floor in the aisles. Rachel was asleep one night on a countertop when she felt herself lifted into the air and banging down again. She thought it was bad dream. It was a "direct hit" onto the building. Air raid wardens soon appeared to urge everyone to pack up and prepare for evacuation. There was no panic, quietly the orders were obeyed and they were led up the stairs out onto Oxford street. The sight that greeted them outside was one that Rachel will never forget. One store had been hit by an oil bomb, which fueled a fierce fire, and others had been struck by high explosives. It was as bright as daylight. The pavement was littered with broken glass and debris. And the noise was deafening, of the planes, the explosions, the anti-aircraft guns. The firemen worked as hard as they could but their task was hopeless. The air raid wardens led them to another store whose occupants were asked to move up 
and let them in. The calm was well nigh uncanny, bearing out the other slogan of the time: "we can take it." Miraculously no one was injured.

After that they stuck to the "Anderson shelter" in their back yard. Named after the Home Secretary who had devised it, the shelter was a small dug-out, three or four feet deep, covered by a piece of corrugated iron and with a few sandbags scattered around. It certainly would not protect anyone from a bomb; on the other hand, it was so small that the chances of its being hit by a bomb were very slim. Without a door, it was open to the rather damp, chilly night air even though it was only September. Here too sleep was very difficult because of the noise; in addition to the planes and the anti-aircraft guns you could hear the whistle of the bombs as they came down and the crash as a relief - so this one too had missed you. They shared this shelter with their landladies, three quarrelsome sisters who did not improve matters. They, the tenants, were barely tolerated as taking up some of their precious space.

One morning they came out of the shelter to find in the house the best surprise: her father fast asleep in bed. Released from internment, he had had a long journey from Liverpool to London, his train constantly stopped for air raids. He arrived at Euston Station in the middle of the night and the middle of a raid, but he wanted to get "home," so he walked miles in the blackout with his suitcase, and was so tired when he got home that he simply fell into bed and slept. He was altogether rather fatalistic about the bombing, saying that if a bomb had your name on it, it would find you, no matter where you hid. When he joined them in the little shelter, they became even more unpopular for being one more.

If they had had no reason to stay in Bouremouth, they now had even less to stay in London. So they evacuated ourselves. Rachel never found out how their location was chosen; there was talk of Hereford, but then they went to Bedford, a lively little market town about an hour by train northwest of London and an equal distance west of Cambridge. Since Bedford too was a "reception area," housing was extremely tight. They found one room in a row house owned by an old couple who had never taken in tenants but now thought they should do so as their contribution to the war effort. Ashburnham Road was hardly the safest spot in Bedford: alongside the railroad line, on the other side of which was a munitions factory. When the planes went over to bomb Coventry, they could hear the signal of the "spotter" on the factory roof although the sirens were not sounded so as not to alarm the population. On their way back the planes dropped a few spare bombs on Bedford without doing too much damage. Their second floor room was squalid, smaller even than that in Kilburn, gloomy, overlooking a desolate yard. There was a sink and a stove out in the corridor, no hot water of course, and a toilet down a long corridor. On top of a couch two mattresses were layered which were laid out side by side on the floor at night for them to sleep on. The room was heated by a tiny coal fireplace, on which a kettle could be perched to make tea. Water was also heated (occasionally) so that they could wash themselves and their clothes. Rachel and her mother would go out on her father's washing day. There was a saying among refugees, all of whom have vivid memories of the cold indoors, that people had been known to freeze to death but no one had yet "stunk" to death.

Despite the hardships of these early days in Bedford, things slowly began to look up for them. Rachel's father scoured the newspapers in the public library looking for a job. He was hired by a dentist, who had heart disease and could no longer work. The starting salary was six guineas 
(professional people and fancy stores dealt in "guineas," i.e., one pound and one shilling-a veritable fortune for them). Rachel's mother was alarmed on the first day when her husband came home at four p.m.; she thought he had already been fired - it was "tea time." Best of all, they also acquired superior accommodation in the house next to the dentist's where a doctor had his practice on the first floor. Since he did not want evacuees billeted in the vacant second floor, he offered it to Rachel's parents. There they had the luxury of TWO rooms, only one of which, admittedly, had a fireplace so that Rachel would go to sleep on the floor in front of the fire in the living-room rather than brave the iciness of the bedroom. A third small room served as a kitchen with an electric kettle and a gas ring, albeit no water. Water had to be brought in containers along a corridor some way from the back of the house. They were very glad to live in this relative comfort compared to their previous abode.

Best of all, Rachel now began to go to a proper school. Ten already, she had hardly been to school at all. Bedford was renowned for its schools, endowed by the Harper Trust so that they were all free. Since her parents knew nothing about the schools, they approached a police officer on the beat to inquire about girls' schools. English Bobbies were then famed for their helpfulness, so this one hardly turned a hair at this rather unusual question. He recommended the High School and the Modern School. Later it became a family joke that Rachel had been educated courtesy of the police. Her father went first to look at the High School, which he thought rather pompous as the headmistress received him wearing her academic gown. He liked the Modern School much better; not only was it less pretentious, it also had a lovely new building down by the River Ouse. He opted for the Modern School and was keen to send her as soon as possible to get her out of that squalid one room where they were still living. The headmistress suggested she should start after half-term; why not earlier? Next Monday? How about tomorrow?

So she started on a Thursday and "took to" it as she had done to fish in Chertsey. She excelled at English, was bad at drawing, and slow at needlework, working so long on a piece of cloth that her fingers rubbed a hole in it. But her real nemesis was gymnastics. The main drawback of the Modern School in her eyes was that it had a proper gym with all sorts of equipment she could not cope with. She managed to stand on her head but could never achieve a handstand, and as for climbing a rope or jumping over a "horse"-forget it. Although she could balance on a bar one foot from the floor, she could not or would not do it at three feet. She argued with the gym instructor about the dangers of what she was supposed to be doing and refused to be convinced even when Miss Delamare pointed out that there was a mat underneath and she would catch her. Rachel was adamant. She could not explain to Miss D that they were poor and could not afford to have her break an arm or leg. Only one thing was worse than the equipment: the ritual of being measured and weighed at the beginning of each term. Rachel was somehow the youngest in the class, the shortest, and if not quite the heaviest, not far off. She was truly mortified as the girls crowded round the scales and laughed at her. She was a blot on the gym class in another respect too; everyone except her wore a short blue tunic and matching pants. Her parents could not afford to buy the school uniform, let alone this gym outfit, which was useless outside the class. With clothing severely rationed during the war and only a very limited number of clothing "coupons" per person per year, they could pretend to be out of coupons, although they had plenty, just no money. In class Rachel could fade in with the others by wearing a white blouse and a navy blue jacket her 
mother had knitted for her. And they bought her a school hat with its distinctive hatband. Only in gym she stuck out like a sore thumb, and if at least she had been athletic Miss D might have forgiven her for spoiling the whole picture by appearing in her underwear. It was a lesson in learning to live with being different.

Rachel put a stop to one sort of difference by prevailing upon her father not to walk her to school carrying her school bag. She felt ashamed of this escort, although she realized it was well meant. Before he got the job with the local dentist, he had nothing to do, and her school was on the way to the library, where he spent part of every day. She weaned him slowly of his care-giving, first dismissing him at the corner of the road where the school stood, and then insisting that she could go alone all the way. The problem solved itself when he landed the job and so was himself busy.

Rachel went to school on Sunday morning too, to a Hebrew school that had been set up for the evacuees from London. Before the war, there had been virtually no Jews in Bedford, now there was a kosher butcher on Fridays and Hebrew classes on Sundays. The old couple in Ashburnham Road would ask approvingly every week to which church Rachel was going. When her parents explained that she was going to Hebrew class, that they were Jews, they absolutely refused to accept this explanation. Jews, they insisted, were people who came from London to the Saturday market and were liable to cheat you.

Rachel was happy in Bedford. Her father bought her an old bicycle at the cattle market, a very old "sit up and beg" model, the only sort available. As she perched up on the saddle, her father called her "Haile Selassie" after the Ethiopian emperor who would be carried about in a high litter. The bicycle gave her a certain freedom. There was very little traffic on the streets of Bedford other than bicycles because gas was so severely rationed as to almost nonexistent. Rachel would ride to the outskirts of the little town with a young refugee woman to her "allotment," a patch of kitchen garden where people patriotically grew vegetables.

Food too was of course rationed: one egg per week, two ounces each of tea, sugar, meat, and margarine, and one ounce of butter-good for keeping your cholesterol down. Besides the weekly rations each person had 20 points a month to be spent on discretionary items "subject to availability," a favorite wartime phrase. For points you could buy such things as cocoa, preserves, cereals, semolina (grits) - "subject to availability" which meant sometimes if you were lucky. Later, dried eggs could also be bought on points; they came in austere brown boxes from the United States and were an absolute godsend. Rachel's mother was a wizard with the dried eggs, smoothing out the lumps, making a paste with a little water, gradually adding more water, and cooking them like scrambled eggs, perhaps with a tomato mixed in-subject to availability. Rachel once asked her mother what they had eaten before the dried eggs came, and neither of them had an answer. Only vegetables and food grown in Great Britain were freely available: potatoes, carrots, turnips, swedes, apples and plums in season. Such things as bananas, oranges, and lemons that had to be imported simply disappeared. Why there was a shortage of onions was unfathomable; they heard of an onion being offered as a prize in a fund-raising raffle. They ate a lot of potatoes, and even invented a dish of their own: "Italian potatoes," i.e., boiled potatoes with an egg thrown over them, one egg for the three of them. The high point of that year and a half in Bedford was a visit from Rachel's grandmother from Manchester; she brought a small tin of Nescafé. Rachel's mother was a 
coffee lover; in the Viennese coffeehouses coffee could be ordered in all shades and varieties. In Bedford, she had had to make do with "Camp" coffee, a liquid essence out of a bottle diluted with hot water. Nescafé was a vast improvement. Once an American officer, who had consulted her father on a problematic tooth, sent his batman with a box of goodies: a cucumber, rice, chocolate, foods almost forgotten.

Altogether life got somewhat easier for them, at least in some respects. Her father's salary gradually increased from six to twelve guineas a week as the practice flourished. It had been badly run down when he took it over, but in the small town word spread of the presence of a good dentist so that people flocked to him. They were able to repay the loan from the Jewish Refugee organization and to begin to save a nest egg. Several patients urged her father to have her transferred to the High School, which was attended by the daughters of professional people, whereas the Modern School was for trades people. Ignorant of the class system in England, he would say that Rachel was happy at the Modern School and that is where she stayed.

Rachel loved going to the movies, the "pictures," as it was then known in England; to her mother's exasperation, she favored not just comedies but slapstick farce - the three stooges - that prompted hearty laughter. School rules forbade the cinema during the week; they were supposed to do their homework and go to bed early. The high point of their time in Bedford was the visit of the London Symphony Orchestra under Sir Malcolm Sargent. A special afternoon concert for schoolchildren was given in the Corn Exchange. Rachel proudly dressed up with a pair of white cotton gloves she still had from Vienna. Handel's "Water Music" was performed after the conductor had explained the occasion of its composition.

At the winter half-term holiday - it must have been in February - Rachel went by train with her mother to visit the family in Manchester. They lived in an apartment with central heating and constant running hot water-almost unimaginable comforts! But the weekend was overshadowed by new private anxieties sowed in Rachel's mind by the whisperings she overheard while her mother was out. Her mother's chronic cough was suspected as a symptom of TB. Rachel knew that her father was none too well either with his repeated gallstone attacks despite the removal of his gall bladder when she was just an infant. She could see herself left an orphan. To whom could she turn? Her mother's sister was a businesswoman, rather impatient and self-centered; she would not want Rachel hanging round. Her best bet, she decided, was her grandmother whom she loved. Yet the possible loss of the parents who had always protected her was a fearful thought, and one she could not mention to anyone.

The visit to Manchester was an exploratory expedition preparatory to their move. Although her father had been offered a partnership in the now prospering dental practice in Bedford, her mother's family urged them to move to Manchester. After the war, Bedford would revert to its former sleepy state when all the evacuees returned to London. There would be no Jews either. Besides, her mother missed her family. However, it was a difficult decision because of the risks it entailed. In Bedford they were financially secure. Starting up from scratch in Manchester would be a big risk; the hundred pounds they had saved would not go very far in meeting the rent in a big city as well as the costs of setting up in practice. After long deliberation instinct prevailed over reason; they wanted to live in a big city and to be with family. 
They moved to Manchester in the winter of 1942. It was then a large, ugly, dirty city. When Rachel first saw the city center, she wept that she could not live in a place so hideous. Its mills and slums were remnants of its growth out of nineteenth-century industrialization, although its southern suburbs, spreading into the farmlands of Cheshire, were pleasant enough. It suffered from incredibly dense "pea-soup" fogs that would totally immobilize traffic: buses moved in convoy led by a man holding a lantern, cars were abandoned, and the only sure way to get home was on foot. The soot-laden air was not only unhealthy; it also led to constant dirt indoors, and even settled on clothes. When Rachel came home from school, her mother would ask her whether she had been down a coal mine because of the soot on her blouse. After the switch to smokeless fuel, a radical change took place, with the fog much attenuated, and the air more salubrious. Yet Manchester had its glories too in its liberal tradition, its past as a leader in the free trade movement (its new post-war concert hall is called the Free Trade Hall), its outstanding public library in addition to the Rylands Library with its collection of manuscripts, the Hallé orchestra founded by a nineteenth-century German immigrant and brought to world fame under the baton of Sir John Barbirolli, its distinguished university, and its wealth of theatrical activity. It was certainly not Vienna, but intellectually and culturally it was a good place to live.

For Rachel's family it was a huge leap forward. They rented an apartment in the same complex as her grandmother and so had central heating and running hot water for the first time in six years. Admittedly, the heating in their apartment was nowhere near as cozy as in her grandmother's place, which was on the first floor while theirs was on the third floor and at the end of the heating line. Still it was incomparably preferable to the customary British little open fires that heated a radius of a few feet and left you fried on one side and frozen on the other. This was a proper apartment with a living room, dining room, kitchen, bathroom, and two bedrooms, one of which was Rachel's. She was so excited at having a room of her own again that she dragged all visitors in with the cry: "come and see MY room," to her parents' considerable embarrassment. Yet they understood and humored her.

Her father also took two rooms in the city center on the main square opposite the landmark public library to open his dental practice. Later they heard that their choice of location created almost a scandal as those rooms had been occupied by Manchester's leading surgeon, and it was considered impertinent for a refugee dentist to succeed him, as it were. The rooms were above a branch of the drugstore chain, Boots; they hoped that the pharmacists would refer patients with toothache. In the middle of the war there was a great shortage of dentists with most of the younger ones away in the forces. But despite the fine location, Rachel's father read Gone with the Wind and other long books while waiting for patients. The first one was a Norwegian sailor. They reckoned that their small savings would cover rent and expenses for three months at most. In order to have some income Rachel's father took a job two evenings a week and Sunday morning as assistant to a dentist in a far suburb on the other side of the city. He was having gallstone attacks and would sometimes have to give himself a shot of a potent painkiller before setting out for this second job. Rachel vividly recalls seeing her mother standing at the window behind the blackout curtain late at night waiting for him to come home in the blackout on the buses that ran rarely at night and weekends. It continued to be a precarious existence. 
In late 1942 or 1943 (Rachel does not recall the exact time), news began to percolate through of the atrocities perpetrated by the Nazis against Jews and others. They had known about concentration camps, beatings, every form of mistreatment before they left Vienna. But this was of a different dimension: organized extermination. Her parents did their best to protect Rachel from this news at that time. Yet she sensed from their whisperings and their deep gloom that something was radically amiss. All her father's family was in Hungary, and they had had no word from them for years. At first the Red Cross had transmitted occasional postcards of 25 words; then abruptly the messages stopped. They could only guess, and fear the worst. After the war, her father managed to find out that his younger sister, Ella, had been deported to Auschwitz and gassed on 6 June 1944 (ironically on D-Day), while his older sister, Irene, and her three children had been in Treblinka. Her husband, a furrier, was used to make caps for the German army in Russia, and when he was no longer needed, the family was exterminated.

The bright spot was that Rachel did get her wish of going to school fulfilled right away. Before they left Bedford, her mother had been to see the headmistress of her school to explain that they were moving. They intended to send Rachel to a convent school in their neighborhood. Miss Tonkin was very opposed to this and offered to write to Dr. Clarke, the headmistress of the Manchester High School for Girls, with whom she had been at Girton College, Cambridge. "And don't go to a policeman," she added. So Rachel was transferred without ever taking an entrance exam, much to the annoyance of neighbors who complained of her "walking" into the best girls school in Manchester, the sister institution of the famous Grammar School for boys. There really was not any room for her; a chair was brought into the classroom and she shared a desk. An independent school, run by a Board of governors, it was not free, as in Bedford. The embarrassing task of telling the headmistress that they could not afford the tuition fee fell to her mother; Dr. Clarke, unperturbed, said that the governors would be satisfied with two pounds per term, a quarter of the normal charge. Another difficulty was that at this highly academic school Latin was started at age eleven, followed by French at twelve. As Rachel had done no Latin, she was six months behind. Her mother taught her in daily lessons so that she caught up in six weeks, and even came "top" in Latin by the end of the year. Perhaps this success contributed to a certain resentment of Rachel on the part of some of her fellow pupils who were far from pleased that she had disrupted the pecking order. On the whole she found that the further up the social scale she went the less friendly the children were. She, who so loved school, would weep at breakfast at the memory of those sweet ragged kids in Kilburn.

On the other hand, the Manchester High School for Girls had one enormous advantage in her eyes. With its building recently bombed, it was housed in three old buildings, and had NO gym! No "equipment" to torture her! Physical education classes, held in a church hall, consisted of innocuous exercises, waving arms and legs about, running and jumping, without danger. Sports, too, were limited by lack of proper playing fields. They would go to a nearby park and play hockey on a muddy field in winter and tennis and cricket in summer. Even at these Rachel was no good. She played hockey just once and got a nasty bruise on the shin with a hockey stick; the same happened when she ran to catch a cricket ball, not knowing just how hard it was. After that she absconded between the school building and the park, easy to do. She would have loved to play tennis, and realized only years later that she had been too myopic to see the ball in time to get into 
position. Being "brainy" and non-athletic made for a bad situation; she was given a really excellent education by superb teachers at the Manchester High School, albeit at the cost of developing rather an inferiority complex on account of her unpopularity. In a class of 29 she was invariably the last to be "picked" for any team.

Rachel fared only a little better at Hebrew classes, which she enjoyed far more than school. In Manchester the classes were conducted at a temple and were for the children of members. Her parents could not at first afford the membership fee, so she went on her own one Sunday morning and asked the rabbi whether he would admit her for free. An enlightened, scholarly man and a brilliant teacher, he welcomed a pupil who actually wanted to learn. Most were there only to get through the bar mitzvah ritual. Rachel was the only girl in the top class together with a bunch of disinterested boys. As they read and translated stories from the Old Testament, the rabbi explained the rigorously logical structure of Hebrew in which every word can be reduced to a root of three letters and then constructed with various particles into nouns, adjectives, adverbs, different verb conjugations. As the vocabulary of Biblical stories is small and repetitive, it was not hard to translate them once the basic grammatical principles had been grasped. To Rachel this was an amazing revelation that came at the same time as her initiation into Latin, no doubt laying the foundation for her lasting fascination with language. The rabbi described her as having "a mind like blotting paper."

Rachel also liked going to Girl Guides (Scouts). Although the majority of troops were church affiliated, a friend of her mother's, who thought Rachel was lonely, found an independent troop where she became a member of the Daffodil patrol. Curiously at Guides she had the self-confidence to do things she could not do at school such as winning a three-legged race. One weekend she went camping only to be literally soaked to the skin - her first and last experience of camping. She worked hard to get all sorts of "badges," not just for reading and sewing (at which she had got better), but also cleaning her room, washing and ironing, though not cooking. Her mother could not cook either, having had a maid in Vienna, and during wartime there was not much to cook anyway. She once told Rachel to ask the other girls where they learned to cook, and when she heard "from their mothers," the subject was dropped forever. For her "First Class" at guides, Rachel had to cook outdoors. She cut the turf and folded it back neatly, and managed to light a little fire, helped by wax remnants from the candles they lit on Friday night. She had brought some half-cooked hamburger, and had just put it into the pan with some margarine when the examiner came around in the nick of time to see that the contents of the pan had caught fire! She passed all the same. It was the only time she cheated. With the Guides she also went to the top of the city library to turn paperback into hardbacks for the troops. They carefully detached the paper covers and stuck them onto cardboard, which was fixed round the books. They felt very important going up in the elevator behind the scenes in the library, and of course they came out covered in glue.

With her newly acquired cleaning skills Rachel helped her mother to clean her father's office. They would go while he was at his second job, and Rachel went along during school vacations to scrub and polish until everything glittered. Sometimes a patient would come to make an appointment (gradually there were a few patients). It seemed to cause more embarrassment to the patient than to them to recognize that the cleaning crew was the doctor's family. 
Rachel's ancient bicycle was a casualty of the move from Bedford. She mourned the loss intensely, especially as bicycles were, like most things, "in short supply" during the war, not to mention expensive. She saved her pocket money assiduously, and in due course her father was able to get a brand new bicycle through a patient. How she cherished it, fanatically polishing its chrome handlebars. One awful day, surely one of the worst days of her childhood, it was gone, stolen from the downstairs hallway where it had been firmly chained to a radiator. She was so upset that she called her father at his office, a thing she never did, and all she could do was weep into the telephone. Assuming that her mother had been injured, he was immensely relieved when at last she could stammer that it was her bicycle. "ONLY the bicycle," he replied. After a while he managed to get her another one, but Rachel never felt for it the affection she had had for its predecessor. To begin with, it had black handlebars, more practical to be sure than the shiny chrome, and then she hadn't "earned" it herself. Still she went out on it, sometimes with her one friend, Ruthy Macintyre, and later with her father. They would go off on Sunday afternoons to explore the environs of Manchester. On one occasion they skirted the airport, a training ground for paratroops. Her mother scolded them roundly for engaging in activities that might be deemed dangerous in enemy aliens.

Rachel became pretty self-reliant early on. Her mother spent a good deal of time in her father's office, keeping the records and assisting chairside. Later a series of girls were employed to answer the phone and open the door, but they were notoriously unreliable so that her mother would have to drop everything and rush into the office whenever the help did not turn up. After coming home from school Rachel would hastily do her homework, get a tomato sandwich for dinner, and go out to play in the parking area of the apartment complex throwing her precious ball against the wall. It had started life as a tennis ball, but its covering had long since worn off to reveal its black rubber interior. Because balls were rubber, they too were "in short supply," another phrase that meant you could not get them for they were, like almost everything, needed for "the war effort." Rachel had that one irreplaceable ball for years.

Sometimes during the school vacations she would accompany her grandmother on her shopping, acting as interpreter for the old lady who never learned English. In her late 80s she came to believe that there were just two languages, the Yiddish spoken by Jews, and "Goyish" ("goy" = stranger in Hebrew) spoken by all others. In the shops she would address the assistants in her best German. Her grandmother was to be her refuge in case of an air raid. She was instructed to grab a small pigskin suitcase in her parents' closet and go down to her grandmother's place if the siren went off when she was alone. She did not ask what valuables were in that suitcase, and was deeply disappointed to find out many, many years later that it contained nothing but documents: a copy of her birth certificate (the original had got lost), her parents' marriage certificate in Hebrew and German, her parents' medical degree certificates, etc. Under the Nazis without documents you were lost, a permanent non-person, so it was highly important to preserve all this evidence. There were few air raid attacks on Manchester after 1942. What frightened Rachel more, irrationally, was the fear of a parachutist, a lingering memory of the early days of the war. When she was alone in the apartment, especially after dark, she was afraid to go along the short corridor to the bathroom for fear that a Japanese parachutist would jump out of the closet.

In her early teens, Rachel experienced the usual friction with her mother over very minor matters. She would throw her raincoat down on her bed, when she came home from school, 
whereas her mother wanted her to hang it up and brush it. In time Rachel realized that she would have to hang it up when she went to bed, so she might as well do it immediately. Brushing it (it was navy blue and showed every speck) was another matter. Her mother also wanted her to brush her hair more, although Rachel insisted that would not help. She had her father's fine straight hair, not her mother's wavy sort. However, on the whole there was little real strife in the family; Rachel understood that her parents had enough troubles without her causing difficulties. They felt that she should fend for herself at school too, although her father helped her with drawing homework and patiently explained various mathematical concepts that had been poorly presented by her one bad teacher who was a gifted mathematician but inept at verbal explanations.

When Rachel was about thirteen, the school told her parents that she had a gift for languages. The headmistress made it her business to visit classes and to get to know each of the school's 300 pupils. Rachel had a wonderful French teacher, a French woman who made them not only read but actually speak the language from an early stage. Later Mrs. Herbert, like some of Rachel's other teachers at the Manchester High School, was recruited by university departments of education to teach how to teach. The news that languages were her forte was a bombshell to her parents; it was like hearing nowadays that your child is on drugs. They did not know how to handle this; they were stunned, for they, like she, had always assumed she would go to medical school. It was essential for a Jew to opt for an independent profession, they thought, where one would not have to seek employment by others. After their experiences in Vienna, the specter of antisemitism was never far from their minds. How can one support oneself with languages? That she needed to be selfsupporting was impressed on Rachel early on. The uncomfortable issue was temporarily shelved; in time it was to resolve itself.

VE (victory in Europe) day came in May 1945. The continuing war in the Far East was not of direct interest to the British population; as far as they were concerned, the war was over, and they had won. Immense spontaneous rejoicing occurred throughout the country.

Not so in Rachel's family where there was always more anxiety than celebration. Her father was in hospital, in desperate condition in those days before antibiotics, following another gall stone surgery after attacks for months on end that had often forced him to cancel appointments and had done his budding practice no good. Who wants to go to an unreliable dentist? There had been frightening talk of a tumor. Her father worried that he had no life insurance, he would have to rely on his brother-in -law to look after his wife and daughter. Rachel remembers well how terribly sick her father looked, curled up in bed, crouched in pain. A surgeon who was his patient and had an office in the same building insisted that it was not a tumor but further small stones coursing up and down the bile duct and causing terrific pain. He was right. He carried out the surgery under local anesthetic in a good but remote hospital in an extremely poor district (he was a socialist). After school Rachel would have to get two buses to go visiting. The people on the second bus literally smelled bad, yet they kept their tiny row houses immaculately clean, regularly scrubbing and whitening their front door steps. Owing to the shortage of nurses ("shortage" was of course another common wartime word), Rachel's mother would spend long hours in the hospital caring for her husband. She would come home at 11 p.m. sometimes. Fortunately it was May, and with the double summer time in operation in Britain during the war it remained light till very late. Rachel used to go to the bus stop to meet her until a man tried to molest her one evening, exposing himself 
and urging her to come and play with him. She turned tail, ran home, and never went to meet her mother again.

So on VE day Rachel was alone, not sharing the universal rejoicing. Her aunt, her mother's sister, rode round the city on the upper deck of a bus to see the crowds celebrating, but she did not think to take Rachel along. On the contrary, she caused her fright and grief by urging her sister to go back to Vienna now that the war was over to resume her profession, arguing that Rachel was old enough now at age 14 to look after herself, and her husband as good as dead. Knowing how much her mother loved both her profession and her sister, Rachel was truly afraid she might heed the advice. In these thoughts she did an injustice to her mother who was firmly committed to her family — not that she did not go on missing her profession. Apart from helping in the practice, she read the British Medical Journal and the Lancet with passion every week, only complaining sometimes that it was all biochemistry.

The war was far from over in 1945. Indeed, things got worse in the next few years because Britain was so depleted from the war effort. Bread was rationed briefly for the first time in 1946. Even in the early 1950s when Rachel went to Cambridge to graduate school, she had to take her ration book with her, although by then things were loosening up so that late on Saturday afternoon she might be able to scrounge an extra egg from a grocery store. Worst of all was the shortage of coal, particularly in the record-breaking cold of the winter of 1947. The central heating in their apartment gave out when the water froze in the underground pipes. The trains stopped running because the points were coated with ice. It seemed as if the entire country were immobilized, exhausted by the years of sacrifice that the war had entailed. The British resented the Marshall aid so liberally extended to the defeated Germans, while the victors were left to fend for themselves as best they could. The one bright event that year was the marriage of Princess Elizabeth to Philip Mountbatten.

Rachel experienced "peace time" for the first time when they went on vacation to Switzerland in 1948 after becoming naturalized as British citizens. They were keen to try out their British passports immediately! The contrast between war and peace was starkly impressed on her during that journey. After crossing by boat from Dover to Boulogne they went by train through the "Pas de Calais" area which had been heavily bombed in the closing months of the war when it had been the site for the launching pads for the unmanned V2 ("doodle-bug) bombs directed at London. Nothing was left but pile upon pile of rubble. The next morning, having crossed France overnight, they arrived into what seemed like a magically transformed world. They followed the advice they had been given to get off the train and have breakfast in the station restaurant in Basel. What a revelation! It was just a pretty ordinary continental breakfast but to Rachel it was full of wonders: freshly brewed coffee made from real coffee beans, crisply baked rolls, lashings of butter, two kinds of preserves, and to top it all, honey. Though she was no gourmet, she savored it. In Switzerland also they saw in the stores all sorts of things still unobtainable in England: Heinz baked beans, Dundee marmalade, British products that were for export only.

Growing up in wartime England left Rachel a legacy that was to prove utterly devastating later in her life. When she was fourteen, she got a bad sore throat with a high fever. Her mother looked at it and saw that her tonsils were all red and nasty looking, so she stayed in bed for a few days and drank lots of hot tea. There were very few doctors for the civilian population, and of course no 
antibiotics except those specially brought from the USA for Churchill when he got pneumonia. Several months later her parents noticed that her ankles were swollen and dragged her off to an old doctor who diagnosed that she had developed nephritis (inflammation of the kidneys) as a result of the strep throat. She was put to bed for months on end, cared for with great devotion by her mother. That is when she became a reader; she also knitted, sewed, and learned Italian from a course on the radio. Her classmates, who had hardly been friendly before, suddenly became amazingly kind; one of them would visit her on most days after school to bring the homework and to take her work back to school so that she was able to keep up with her class. Occasionally one or other of the teachers visited too. Apart from bed rest, the only other treatment at the time was a salt-free diet, which likely heightened her indifference to food. At the end of the school year, although she had missed six months of school attendance, she took the major public examination, the School Certificate. Her school made all the arrangements, sending a teacher who was on maternity leave to act as the official supervisor. Rachel was allowed to get out of bed long enough to sit at the table to write each of the eight three-hour exams. She got five "distinctions:" in English, French, Latin, German, and History, and three "credits:" in Geography, General Science, and Mathematics. Her illness and the exam results settled the question of her future direction. For the Higher School Certificate, which came two years later, she chose English, Latin, French, and German. It was obviously not feasible to pursue the scientific subjects without being in a lab, and anyway it had meanwhile become abundantly clear where her talents lay.

At the end of that summer a young doctor of German origin who had just been demobilized opened a practice in Manchester and quickly acquired a high reputation. He had newer ideas; he got Rachel out of bed. At first she was weak and very diffident, but by September she was able to go back to school half-time. Despite the kindness her classmates had shown her, her long absence made her detached from school, accustomed to doing things on her own. Resisting the school's wish that she should sit for the Oxford and Cambridge entrance competitions, she decided to go to the Victoria University of Manchester in order to stay at home in the central heating rather than brave the cold in the colleges. For she had been urged to avoid catching cold so as to prevent the nephritis from flaring up again.

So she got a 'flu shot in her mid-twenties; it seemed a prudent thing to do. By then she had got her Ph.D. at Cambridge and was in her first teaching job at the Queen's University of Belfast. Before the days of disposable needles, total sterilization was not possible; as among drug addicts today needles could spread infections. That is how Rachel came to be one of ten cases of B-hepatitis traced to the same needle by the public health authorities in Manchester. Most were either mild or even sub-clinical; hers alone was so virulent that her parents were told that she had no chance of survival. They should have doubted this verdict for Rachel sent her mother to buy some orange tinted nail varnish, which would look better with her deep yellow skin than her usual pink shade. As an experiment, since there seemed to be little to lose she was put onto high doses of steroids, which were gradually tapered off over five months. It cured her although she was off teaching for a year and was a physical mess with damage to her skin and the grotesque "moon" face characteristic of steroids. Yet she recovered from all this too, and seemed alright for thirty years until she began to experience a lot of pain in her joints. At first a male doctor diagnosed depression (it was eighteen months after her father's death) and put her onto an anti-depressant, which so knocked her out that 
she had to stay in the house for two days. A woman doctor sent her for x-rays, which showed that the steroids had cut off the blood supply to the cartilage so that bone was rubbing against bone. When she had hip replacement surgery, it was the joke of the hospital that she had been treated for this condition by an anti-depressant.

However, that surgery did not turn out well either. So now she sits and writes.

\section{Conclusion by Anabel Aliaga-Buchenau}

Today Lilian Furst does not write anymore but her voice remains. Working with Lilian Furst was a privilege in many ways. Her sharp mind and analytical skill were unmatched, and what is more her experiences and stories were a window into a lost world. The Rachel Chronicles tell her story from the early days in Vienna, to her life in war torn England, her education at Cambridge, her first academic job and then her immigration to and wanderings through the United States. Along the way, the reader learns about what it is like to be a woman graduate student in Cambridge in the 50s, about the Furst family furniture which made it from the apartment in Vienna, to London, then to Manchester, to Chapel Hill and finally to my home in Charlotte, Furst's collection of more then 100 bears, her books, and the deterioration of her eyes. Lilian Furst comes alive in Rachel's narrative.

\section{Bibliography of the Works of Lilian Renée Furst}

\subsection{Books}

Romanticism. New York: Barnes and Noble Publishers, 1969.

Naturalism. London: Methuen Publishers, 1971. Written in cooperation with Peter N. Skrine.

Counterparts: The Dynamics of Franco-German Literary Relationships, 1770-1895. Detroit: Wayne State University Press, 1977.

Romanticism in Perspective: A Comparative Study of Aspects of the Romantic Movements in England, France and Germany. London: Macmillan Publishing, 1979.

The Contours of European Romanticism. London: Macmillan Publishing, 1979.

European Romanticism: Self-Definition. London and New York: Methuen, 1980.

Fictions of Romantic Irony. Cambridge: Harvard University Press, 1984.

L'Assommoir: A Working Woman's Life. Boston: Twayne Publishers, 1990.

Through the Lens of the Reader: Explorations of European Narrative. Albany: State University of New York Press, 1992.

Realism. London: Longman Publishing, 1992. 
Home is Somewhere Else: Autobiography in Two Voices. Albany: State University of New York Press, 1994. Written in cooperation with Desider Furst.

All is True: The Claims and Strategies of Realist Fiction. Durham: Duke University Press, 1995.

Between Doctors and Patients: The Changing Balance of Power. Charlottesville: University Press of Virginia, 1998.

Just Talk: Narratives of Psychotherapy. Lexington: University Press of Kentucky, 1999.

Idioms of Distress: Psychosomatic Disorders in Medical and Imaginative Literature. Albany: State University of New York Press, 2003.

Random Destinations: Escaping the Holocaust and Starting Life Anew. New York: Palgrave Macmillan, 2005.

Before Freud: Hysteria and Hypnosis in Later Nineteenth-Century Psychiatric Cases. Lewisburg: Bucknell University Press, 2008.

\subsection{Articles}

“A Dead-End: Hermann Hesse's Haus der Träume." Neuphilologische Mitteilungen 59:4 (1958): $235-43$.

"Pete Gan und das grosse Trotzdem.” Deutsche Rundschau 85:2 (1959): 133-41.

“The Autobiography of an Extrovert: Fontane's Von Zwanzig bis Dreissig." German Life \& Letters 12:4 (1959): 287-94.

“Thomas Mann's Tonio Kröger" Revue des Langues Vivantes 27:3 (1960): 232-40.

"Madam Bovary and Effi Briest." Romantisches Jahrbuch 12 (1960): 124-35.

“Zu Feuchtwangers Romanwerk.” Revue des Langues Vivantes 30:2 (1963): 45-54.

“Benjamin Constant's Wallstein.” Romantisches Jahrbuch 15 (1964): 141-59.

"Romanticism in Historical Perspective." Comparative Literature Studies 5:2 (1968). Reprinted in Comparative Literature: Matter and Method, edited by A. Own Aldridge. Urbana: Illinois University Press, 1969, 115-43.

“Italo Svevo's La Coscienza Di Zeno and Thomas Mann's Der Zauberberg." Contemporary Literature 9:4 (Autumn 1968): 492-506.

“Agnon and Kafka.” European Judaism (1968). 
"Three Romantic Poems." Proceedings of the $5^{\text {th }}$ Congress of the International Comparative Literature Association. Amsterdam: Swets \& Zeitlinger, 1969, 209-14.

“Thomas Mann’s Interest in James Joyce.” The Modern Language Review 64:3 (July 1969): 60513.

"Novalis' Hymnen An die Nacht and Nerval's Aurélia." Comparative Literature 21:1 (Winter 1969): $31-46$.

"Two Versions of Schiller's Wallenstein." Modern Miscellany: Festschrift for Eugéne Vinaver, edited by T. E. Lawrenson, F. E. Sutcliffe and G. F. A. Gadoffre. Manchester: Manchester University Press and New York: Barnes and Nobles Press, 1969, 65-78.

"Kafka and the Romantic Imagination." Mosaic 3:4 (1970). Reprinted in Chaos and Form, edited by Kenneth McRobbie. Winnipeg: University of Manitoba Press, 1972, 81-9.

"Lessing and Mme. De Staël vis-á-vis the Literature of the Mediterranean." Journal of European Studies 1:1 (March 1971): 161-65.

“George Moore et Zola: une réévaluation.” Cahiers naturalistes 41 (1971): 42-57.

“Zola's Art Criticism.” In French Nineteenth Century Painting and Literature, edited by Ulrich Finke. Manchester: Manchester University Press, 1971, 164-81.

“The 'Relevance' of Romanticism.” The Critic 34:3 (1972).

“The Quest for Coherence.” The Times Higher Education Supplement, 4 August 1972.

“Zola’s Thérèse Raquin.” Mosaic 5:3 (1972): 190-202.

“Franz Kafka’s Quest.” Niv Hamidrashiah 10 (1972): 102-8.

"A Question of Choice in the Naturalist Novel." Proceedings of the Comparative Literature Symposium. Lubbock, TX: Interdepartmental Committee on Comparative Literature, 1972, 39-53.

“The Structure of Romantic Agony.” Comparative Literature Studies 10:2 (June 1973): 125-38.

“The Student-Teacher Team.” CEA Forum 4 (1974): 16.

“Stefan George's translation of Baudelaire's Fleurs de Mal." Revue de littérature comparée 48:2 (1974): 203-17.

“A Question of Influence.” Canadian Review of Comparative Literature 1:2 (1974): 138-55.

“Zola’s Motivation in the Dreyfus Affair.” Niv Manidrashiah 11 (1974): 134-43. 
“A Confusion of Romanticisms." The Critic 36 (1974): 39-42.

"Stephen Crane's Maggie, Girl of the Streets and Papa Hamlet by Arno Holz and Johannes Schlaf." Proceedings of the $7^{\text {th }}$ Congress of the International Comparative Literature Association. Budapest: Akadémiai Kiadó, 1979, 165-8.

"The Romantic Hero, or is he an Anti-Hero?" Studies in the Literary Imagination 9:1 (Spring 1976): 53-68.

“Mme. de Staël's De L'Allemagne: A Misleading Intermediary.” Orbis Litterarum 31 (1976): 4358.

"Innocent or Guilty? Problems in Reading and Filming Dreiser's An American Tragedy." Connecticut Review 9:2 (1976): 33-40.

“Flawed Greatness or Correct Mediocrity?” Mosaic 9:3 (1976): 139-45.

“Further Discriminations of Romanticism.” Neohelicon 3:3-4 (1975): 9-26.

"Bassani’s Portrayal of the Ferrara Community.” Niv Hamidrashiah 12 (1976-77): 136-54.

"The Dual Face of the Grotesque in Sterne's Tristram Shandy and Lenz's Der Waldbruder." Comparative Literature Studies 13:1 (March 1979): 15-21.

"The Concept of Mobility in Sterne's Tristram Shandy, Diderot's Le Neveu de Rameau and Goethe's Werther." Proceedings of the $8^{\text {th }}$ Congress of the International Comparative Literature Association. Budapest: Akadémiai Kiadó, 1981, 319-24.

“The Unity of the Arts." Yearbook of Comparative and General Literature 25 (1976): 13-4.

"Dostoyevsky's Notes from Underground and Salinger's Catcher in the Rye." Canadian Review of Comparative Literature (1978): 72-85.

“The Role of Food in Madame Bovary.” Orbis Litterarum 34:1 (1979): 53-65.

"Romantic Irony and Narrative Stance." In Romantic Irony, edited by Frederick Garber. Budapest: Akadémiai Kiadó, 1988, 293-309.

"Romanticism", "Naturalism", etc entries in American Academic Encyclopedia. Danbury, CT: Groller, 1980.

“Who Created 'Romantische Ironie'?” Pacific Coast Philology 16:1 (June 1981): 29-37.

"The Coherence of Les Soirées de Médan." In L'Héaurme Siécle: A Miscellany of Nineteenth Century French Essays, edited by William L. McLendon. Heidelberg: Carl Winter (1984): 125-34. 
"Romanticism: Revolution or Evolution?" In English and German Romanticism: Crosscurrents and Controversies, edited by James Pipkin. Heidelberg: Carl Winter (1985): 79-90.

"The Man of Sensibility and the Woman of Sense." Jahrbuch für Internationale Germanistik 14:1 (1983): 12-26.

"Irony and the 'Spirit of the Age'." Proceedings of the $9^{\text {th }}$ Congress of the International Comparative Literature Association. New York: Garland, 1984, 94-8.

"No Bed of Roses: The Women in Hofmannsthal's Der Rosenkavalier." Jahrbuch für Internationale Germanistik 16:1 (1985): 116-20.

"Shakespeare and the Formation of Romantic Drama in Germany and France." In Romantic Drama, edited by Gerald Gillespie. Amsterdam: Benjamins, 1994, 3-15.

"The 'Happiest Days of Your Life'." Colloquium Helveticum: Cahiers suisses de littérature générale et comparée 1 (1985): 37-49.

"Mythology into Psychology: Deus Ex Machina into God Within." Comparative Literature Studies 12:1 (Spring 1984): 1-15.

“The 'living enigma' of the Survivor.” Niv Hamidrashiah 18-19 (1984-1985): 85-93.

"Reading Kleist and Kafka." The Journal of English and Germanic Philology 84:3 (July 1985): 374-95.

"Letter to the Editor (Untitled).” New York Times (March 23 1986): SM94.

“Letter to the Editor regarding The Engaging Narrator.” PMLA 102:3 (May 1987): 351.

“Interpretation of What? Harman and Budick's 'Midrash and Literature'." The Journal of Religion 67:3 (July 1987): 348-52.

“Letter to the Editor regarding Social Reality.” PMLA 102:5 (October 1987): 842.

"Double-dealing: Ironies in Kleist's Die Marquise von O-." In Echoes and Influences of German Romanticism. Festschrift for Hans Eichner, edited by M. S. Batts, M. Riley, and H. Wetzel. New York and Bern: Peter Lang, 1987, 85-95.

“The Imprisoning Self.” In European Romanticism: Literary Cross-Currents, Modes, and Models, edited by Gerhart Hoffmeister. Detroit: Wayne State University Press, 1990.

"Autumn: An Exemplary Case of Paradigm Shift." In Romantic Poetry, edited by Angela Esterhammer. Comparative History of Literature Series, 17. Amsterdam; Philadelphia, PA: John Benjamins Pub. Co., 2002, 3-22. 
"Re-reading Realist Fiction." In Sensus Communis. Festschrift for Henry H. H. Remak, edited by Peter Boerner, János Riesz, and Bernhard Scholz. Tubingen: Günter Narr, 1986, 11-22.

“The Problem of Gretchen." In Approaches to Teaching Goethe's 'Faust.' New York: Modern Language Association of America, 1987, 48-54.

"Interpretation of What?" (review-article, jointly with Michael Goldberg.) The Journal of Religion 67:3 (1987).

"Realism and its 'Code of Accreditation'." Comparative Literature Studies 25:2 (1988): 101-26.

"Goethe's Italian Journey in its European Context." In Goethe in Italy 1786-1986, edited by Gerhart Hoffmeister. Amsterdam: Rodopi, 1988, 115-32.

“The Order of (Non)eating.” Medical Humanities Review 2:2 (1988): 14-22.

"In Other Voices: Wackenroder's Herzensergiessungen and the Creation of a Romantic Mythology." In The Romantic Imagination: Literature and Art in England and Germany, edited by Frederick Burwick and Jürgen Klein. Amsterdam; Atlanta, GA: Rodopi, 1996, 269285.

“Angel, Demon, Mother: Ibsen's Nora." In European Drama. Festschrift for Ronald Peacock, edited by Dorothy James. New York and Bern: Peter Lang, 1990, 137-49.

“The Ethics of Reading Death in Venice." LIT 1:4 (1990): 265-74.

"The Game of the Name." Proceedings of the $12^{\text {th }}$ Congress of the International Comparative Literature Association. Munich: iudicim 3 (1990): 25-31.

"Let's Pretend..." Yearbook of Interdisciplinary Studies in the Fine Arts 2. Lewiston: Mellen Press, 1990, 1-9.

“Ordeal by City." In Semper Aliquid Novi. Festschrift for Albert Gérard, edited by János Riesz, Bernhard Scholz and Alain Ricard. Tubingen: Günter Narr Verlag, 1990, 67-75.

“"Paris Change!': Image and Narration." In Essays in European Literature. Festschrift for Walter Strauss, edited by Alice N. Benston and Marshall C. Olds. Lincoln: University of Nebraska Press, 1990, 73-84.

"Volume 9- 'Fictive Ills: Literary Perspectives on Wounds and Diseases' Pairing Literature and Medicine." Literature and Medicine 10 (January 1991): 130-42.

"Reading Nasty Great Books." In The Hospitable Canon, edited by Virgil Nemoianou and Robert Royall. Amsterdam: Rodopi, 1991, 39-51.

"Re-reading Buddenbrooks." German Life \& Letters 44:4 (July 1991): 317-29. 
“Pairing Literature and Medicine." Literature and Medicine 10 (1991): 130-42.

"Begging an Answer: Kleist's The Beggarwoman of Locarno." In Countercurrents: On the Primacy of Texts in Literary Criticism, edited by Raymond A. Prier. Albany: SUNY Press, 1992, 98-111.

“Thomas Mann's Buddenbrooks: 'the first and only Naturalist novel in Germany'?" In Naturalism in the European Novel, edited by Brian Nelson. New York and Oxford: Berg, 1992, 226-44.

“A Medical Reading of Gervaise in L'Assommoir.” Symposium 46:3 (1992): 195-207.

"The Power of the Powerless: A Trio of French Nineteenth Century Disorderly Eaters." In Disorderly Eaters: Texts in Self-Empowerment, edited by Lilian R. Furst and Peter Graham. University Park: Penn State University Press, 1992, 153-66.

“Romanticism.” In The New Book of Knowledge. Danbury: Grolier, 1993, 302-4.

"Realism and Hypertrophy: A Study of Three Medico-Historical 'Cases'." Nineteenth-Century French Studies 22: 1 \& 2 (Fall-Winter 1993): 29-47.

"Realism" and "Naturalism" In The Mark Twain Encyclopedia, edited by J. R. Lemaistre and James D. Wilson. New York \& London: Garland, 1993, 302-4.

"Struggling for Medical Reform in Middlemarch." Nineteenth-Century Literature 48:3 (December 1993): 341-61.

"The Diary of a Young Girl." In Masterplots II: Juvenile and Young Adult Biography, edited by Frank N. Magill. Pasadena: Salem Press, 1993, 471-4.

"Two Irons in the Fire: Zola's L'Assommoir and Fontane's Irrungen Wirrungen." Connections, Festschrift for Eda Sagarra. Stuttgart: Akademischer Verlag (1993): 97-102.

"Born to Compare." for Building the Profession. Autobiographical Reflections on the Beginnings and Development of Comparative Literature, edited by Lionel Grossman and Mihai Spariosu. Albany: SUNY Press (1994): 107-24.

"Realism." In Women's Writing in the United States, edited by Linda Wagner-Martin and Cathy Davidson. New York: Oxford University Press, 1994, 749.

"Young Scholars Might Take Some Consolation From the 'Anti-Vitae' of Their Elders." Editorial for The Chronicle of Higher Education (January 13 1995): B3.

"Le Docteur Pascal: A Not Altogether Happy Ending." In The French Novel from Lafayette to Desvgnes, edited by Sharon D. Nell, Bernadette C. Lintz, and George Poe. Knoxville: New Paradigm Press, 1995, 233-42. 
"Emma Bovary: The Angel Gone Astray." In Teaching Flaubert's "Madame Bovary”, edited by Laurence M. Porter and Eugene F. Gray. New York: Modern Languages Association, 1995, $21-7$.

"On the Rim of the Holocaust: Anita Brookner's Latecomers." In Schein und Widerschein. Festschrift for Timothy J. Casey. Galway: Galway University Press, 1996, 370-7.

"Realistic Pathologies and Romantic Psychosomatics in Thomas Mann's Buddenbrooks." In Romanticism and Beyond. A Festschrift for John F. Fetzer, edited by Clifford A. Bernd, Ingeborg Henderson, \& Winder McConnell. New York: Peter Lang, 1996, 231-46.

“"Yes and no;' Thomas Mann's Lotte in Weimar." In Narrative Ironies, edited by Raymond A. Prier and Gerald Gillespie. Amsterdam: Rodopi, 1996, 75-89.

"Fictionalizing Fact." The Comparatist 21 (May 1997): 4-9.

"Halfway up the Hill: The 'Doctress' in Late Nineteenth Century American Fiction." In Women Healers and Physicians. Lexington: University of Kentucky Press, 1997, 221-38.

“Minding her Body: Kleist’s Marquise of O-." Synthesis 2:2 (Fall 1997): 17-25.

“Anxious Patients/Anxious Doctor: Telling Stories in Freud's Studies on Hysteria." LIT: Literature Interpretation Theory 8:3-4 (January 1998): 259-78.

"The Potential Deceptiveness of Reading in Death in Venice." In Death in Venice. Case Studies in Contemporary Criticism, edited by Naomi Ritter. Boston: Bedford Books, 1998, 158-70.

"The Salons of Mme. de Staël and Rahel Varnhagen." In Cultural Interactions in the Romantic Age, edited by Gregory Maertz. Albany: State University Press of New York, 1998, 95-103.

“'You Have Sprained Your Brain:' Margaret Cleaves' Autobiography of a Neurasthene." Nineteenth-Century Prose 25:1 (Spring 1998): 140-53.

"Between Yesterday and Tomorrow: Stefan Zweig's Die Welt von Gestern." Beyond Philology 2 (1999): 57-63.

“Daniel Hack Tuke Walking a Tight-Rope.” Nineteenth-Century Prose 27:2 (Spring 2000): 60-74.

"The Importance of Medical History to Literature." In History and Literature. Festschrift for Karl S. Guthke, edited by Scott Denham. Tübingen: Stauffenburg Verlag, 2000, 1-17.

"The Portrayal of Medical Progress in Nineteenth-Century German Literature." In Das schwierige Jahrhundert, edited by Jürgen Barkoff, Gilbert J. Carr, and Roger Paulin. Tübingen: Niemeyer, 2000, 337-44. 
"Medical History and Literary Texts." In Approaches to Teaching Literature and Medicine, edited by Anne Hunsaker Hawkins and Marilyn Chandler McEntyre. New York: MLA, 2000, 55-64.

“The Talk of the Town in George Eliot's Middlemarch and Leopold Alas' La Regenta." Letras Peninsulares 13/1 (2000): 209-20.

"'Hunting for the Real': Edith Wharton's Custom of the Country." Tennessee Studies in Literature 40: Twisted from the Ordinary: Essays on American Naturalism, edited by Mary E. Papke. Knoxville: University of Tennessee, 2003, 260-75.

"Class Ideology in Middlemarch.” PMLA 116:2 (March 2001): 429-30. Written in cooperation with Henry Staten.

“Freud and Vienna.”Virginia Quarterly Review 77:1 (Winter 2001): 49-63.

“Recognizing Mikhail Bulgakov's A Country Doctor’s Notebook.” Symposium 58:3 (Fall 2004): $167-77$.

“"The Ironic Little Dark Chasms of Life': Narrative Strategies in John Galsworthy's Forsythe Saga and Thomas Mann's Buddenbrooks." LIT: Literature Interpretation Theory 17:2 (April 2006): $157-77$.

"Memory's Fragile Power in Kazuo Ishiguro's Remains of the Day and W. G. Sebald's 'Max Ferber'." Contemporary Literature 48:4 (2007): 530-53.

“A Travel Rug for Graduate School Girton College in the 1950s." Sewanee Review 117:2 (Spring 2009): 248-67.

"A Personal Reminiscence of Hans Eichner." The Germanic Review: Literature, Culture, Theory 85:2 (2010): 120-4.

"Growing Up in Wartime England' from the 'Rachel Chronicles: A Kind of Memoir" with an introduction by Anabel Aliaga-Buchenau. Special Issue: "Between Religion and Ethnicity: Twentieth-Century Jewish Émigrés and the Shaping of Postwar Culture". Religions 3 (2012): 993-1024.

\subsection{Edited Volumes}

Editor. Disorderly Eaters: Texts in Self-Improvement. University Park: Pennsylvania State University Press, 1992

Editor. European Romanticism: Self Definition: An Anthology. London: Methuen Publishing, 1980.

Editor. Medical Progress and Social Reality: A Reader in Nineteenth-Century Medicine and Literature. Albany, State University of New York Press, 2000. 
Editor with James D. Wilson. "The Anti-Hero." Studies in the Literary Imagination, Vol. 9, No. 1. Atlanta: Georgia State University, 1976.

Editor. Woman Healers and Physicians: Climbing a Long Hill. Lexington: University Press of Kentucky, 1997.

\subsection{Unpublished Manuscripts}

"The Rachel Chronicles: A Kind of Memoir." In the Lilian R. Furst Archives at Girton College, Cambridge University, UK.

\section{Acknowledgment}

The editors' thanks go to Shaun Bennett, MA candidate of North Carolina State University for compiling the bibliography of Lilian Furst's works and for formatting many of the articles in this issue. 
MDPI AG

Klybeckstrasse 64

4057 Basel, Switzerland

Tel. +41616837734

Fax +41 613028918

http://www.mdpi.com/

Religions Editorial Office

E-mail: religions@mdpi.com

http://www.mdpi.com/journal/religions 


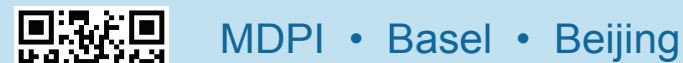

到 ISBN 978-3-906980-57-7

茴故 www.mdi.com 